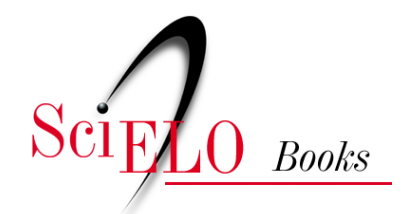

EDUFU

\title{
Cartografias do ensino do teatro
}

\author{
Adilson Florentino \\ Nasciso Telles \\ (orgs.)
}

FLORENTINO, A., and TELLES, N., eds. Cartografias do ensino do teatro [online]. Uberlândia: EDUFU, 2008, 326 p. ISBN 978-85-7078-518-3. https://doi.org/10.7476/9788570785183.

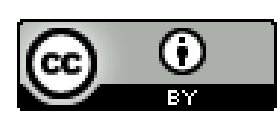

All the contents of this work, except where otherwise noted, is licensed under a Creative Commons Attribution 4.0 International license.

Todo o conteúdo deste trabalho, exceto quando houver ressalva, é publicado sob a licença Creative Commons Atribição $\underline{4.0}$.

Todo el contenido de esta obra, excepto donde se indique lo contrario, está bajo licencia de la licencia $\underline{\text { Creative Commons }}$ Reconocimento 4.0. 
Cartografias do ensino do teatro 


\begin{tabular}{|c|c|}
\hline Alfredo Júli & nandes Neto \\
\hline VICE-REITOR & DiREÇÃO EDUFU \\
\hline arizon Alves de Andrade & Humberto Guido \\
\hline
\end{tabular}

CONSElho Editorial

Daurea Abadia de Souza José Roberto Mineo

Décio Gatti Júnior Márcio Chaves-Tannús

Ernesto Sérgio Bertoldo Rejane Maria Ghisolfi da Silva Gina Maira Barbosa de Oliveira Roberto Rosa

João Carlos Gabrielli Biffi

\author{
Corpo Técnico Administrativo \\ Maria Amália Rocha \\ CoORdenaÇão Editorial \\ Maria Clara Tomaz Machado
}

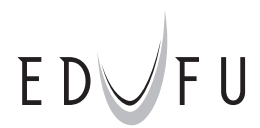

Editora da Universidade Federal de Uberlândia

Av. João Naves de Ávila, 2121 - Campus Santa Mônica - Bloco A - Sala 1A-01

Cep 38408-100 - Uberlândia - Minas Gerais

Tel: (34) 3239-4293

www.edufu.ufu.br

e-mail: livraria@ufu.br 
Adilson Florentino

Narciso Telles

organizadores

\title{
Cartografias do ensino do teatro
}

\author{
$E D \cup F U$
}




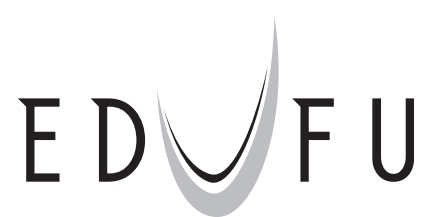

Editora da Universidade Federal de Uberlândia

Copyright (C) Edufu - Editora da Universidade Federal de Uberlândia/MG

Todos os direitos reservados. É proibida a reprodução parcial ou total sem permissão da editora.

Dados Internacionais de Catalogação na Publicação (CIP)

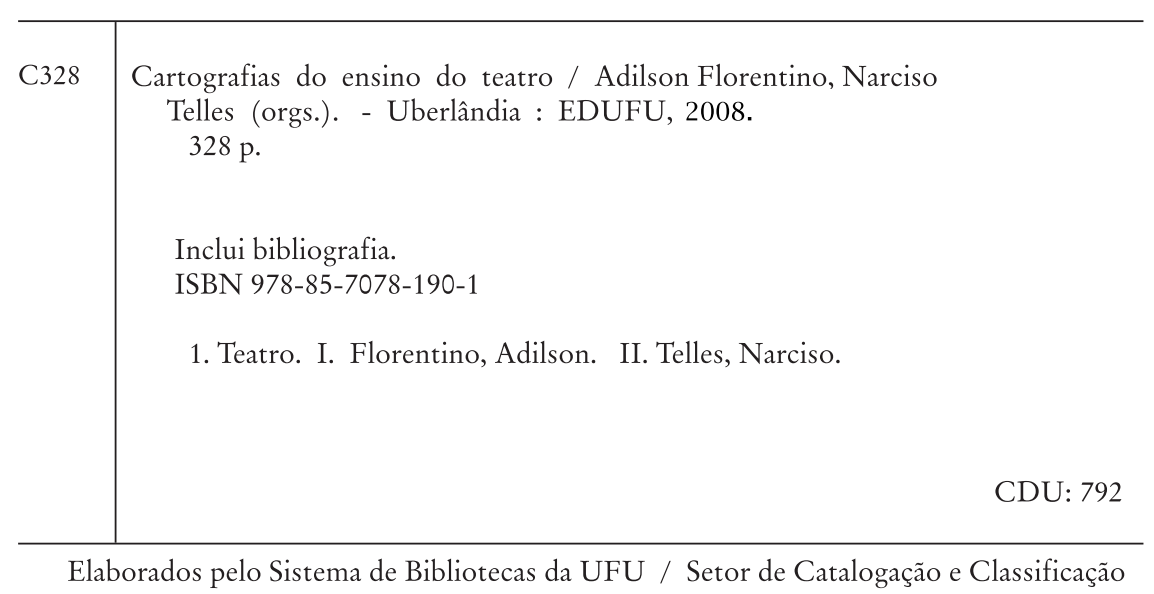

Equipe de realização

\begin{abstract}
Revisão gramatical Aline Coelho
\end{abstract}
Maria Cristina Gonçalves

Revisão ABNT Maira Nani França

Projeto gráfico e capa Ivan da Silva Lima

Diagramação Alexandre Carvalho 


\section{SUMÁRIO}

7 APRESENTAÇÃo

9 A PROBLEMATICIDADE EPISTEMOLÓGICA DO SABER TEATRAL

Adilson Florentino

17 TEATRo-Fórum: UMA PEDAGOGIA DA INTERVENÇÃo E OUTROS DiÁlogos POSSÍVEIS Antonia Pereira Bezerra

29 MetOdologias CONTEMPORÂNEAS DO ENSINO DO TEATRO - EM FOCO, A SALA DE AULA Arão Paranaguá de Santana

37 DOROTHY HEATHCOTE - MEDIAÇÃo E INTERVENÇÃO NA CONSTRUÇÃO DA NARRATIVA TEATRAL EM GRUPO

Beatriz Cabral (Biange)

49 Pedagogia do jogo teatral: uma poética do EFÊMero

Carmela Soares

61 PERFormanCE, TEATRO E ENSINO: POÉTICAS E POLÍTICAS DA INTERDISCIPLINARIDADE Eleonora Fabião

73 MECANISMOS DE COMICIDADE NO ENSINO DO TEATRO Elza de Andrade

85 A POSIÇÃO DO ESPECTADOR: PERSPECTIVAS PEDAGÓGICAS

Flavio Desgranges

95 IMPROVISAÇÃO: DA ESPONTANEIDADE ROMÂNTICA AO “MOMENTO PRESENTE” Gilberto Icle

103 CENOGRAFIA E INDUMENTÁRIA NA ARTE-EDUCAÇÃo Gilson Motta

113 Arts Education in Latin América and the Caribbean MeEting of Experts Ingrid Dormien Koudela

117 TEATRO CONTEMPORÂNEO: O SENTIDO EM DEBATE José da Costa

133 O TEATRO NA TERCEIRA IDADE José Luiz Ribeiro

145 DA APROPRIAÇÃO ESTÉTICA DAS ANOMALIAS José Tonezzi 
155 CRUZANDO ESPAÇOS: O TEATRO NO HOSPITAL

Lucia Helena de Freitas (Gyata)

165 ELEMENTOS DO TRÁGICO NO ESTUdO DO TEXTO TEATRAL

Luiz Humberto Martins Arantes

173 TeATro e COMUnidade

Marcia Pompeo Nogueira

185 FORMAR E FORMAR-SE EM TEATRO

Maria Beatriz Mendonça (Bya Braga)

193 Pesquisa Na LICENCIATURA EM ARTES CÊNICAS

Maria Lucia Souza de Barros Pupo

201 TEATRO, JOGO E BRINCADEIRA: UMA PROPOSTA DE REELABORAÇÃO DO CAVALO-MARINHO EM PROCEDIMENTOS PEDAGÓGICOS PARA O ATOR

Mariana Oliveira

209 CARACTERIZAÇÃO TEATRAL: UMA ARTE A SER DESVENDADA

Mona Magalbães

221 Jogos CORPORAIS EM SALA DE AULA

Nara Keiserman

233 As OFICINAS DE TEATRO E A PRÁTICA DO ARTISTA-DOCENTE

Narciso Telles

239 Jogo dramático SEgUndo JeAn-Pierre Ryngaert

Renan Tavares

249 GATO\&RATOS: ATIVIDADE TEATRAL NA PRÉ-ESCOLA

Ricardo Otoni Vaz Japiassu

271 SObRE A VOZ EM SUA FUNÇão POÉTICA

Sara Lopes

283 O ENSINO DO TEATRO DE ANIMAÇÃO

Valmor Nini Beltrame

299 JOGO TEATRAL E CRIAÇÃO LITERÁRIA

Vilma Campos dos Santos Leite

309 DOIS ECOS LONGÍNQUOS DE TAMBORES NA NOITE

Walder Gervasio Virgulino de Souza

323 SOBRE OS AUTORES 


\section{APRESENTAÇÃo}

De tempos em tempos surge a necessidade de nos embrenharmos no espesso bosque das idéias e práticas teatrais a fim de clarificar o lugar onde estamos e de vislumbrar o lugar para onde vamos. Hoje, esse trânsito pelo bosque, essa espécie de passeio, constitui uma empreitada difícil em um labirinto cuja saída não é fácil de ser encontrada. Isto porque as espécies se misturam, os caminhos se entrecruzam e os pontos de referência se tornam obscuros. O mundo do teatro, das idéias e das práticas, torna-se cada vez mais complexo e as classificações em eixos temáticos são essencialmente controvertidas.

Somos conscientes, portanto, dos riscos que uma leitura organizada, sob o domínio das classificações temáticas, poderia causar no enquadramento das questões postas pelo teatro. Ao invés disso, optamos por um desfile de textos e temas que pode orientar o leitor na livre escolha de onde se inicia e termina este livro. $\mathrm{O}$ eixo norteador de nossa proposta para o leitor é contribuir com o debate sobre as múltiplas possibilidades de entendimento das teorias e práticas teatrais que se têm ampliado nos últimos tempos nos contextos nacional e internacional. Desafiamos o leitor para a seguinte provocação: exercitar a crítica e a reconceptualização das tendências e perspectivas que atravessam os textos e temas aqui reunidos.

Os fios condutores que conectam o conjunto da obra têm como espaço de interseção a preocupação com o ensino de teatro e, mais diretamente, com a formação do professor de teatro no Brasil. Portanto, diante da diversidade temática que a produção do conhecimento teatral está submetida, atualmente, cabe-nos como pesquisadores, professores e profissionais de teatro a tentativa de elaborar um mapeamento, pelo menos provisório, das principais linhas de pesquisa desenvolvidas pelos "atores acadêmicos" que atuam no espaço das universidades, investigando o fenômeno teatral.

Nessa perspectiva, a racionalidade construída na organização dos temas e textos aqui problematizados é a do tipo estético-expressiva - no sentido weberiano - , fazendo emergir a dimensão polifônica, dialógica e plural no intercruzamento das vozes que remetem ao leitor. O princípio e o final desse itinerário assumem um sentido na medida em que desafiam, principalmente, o leitor em formação ao estabelecimento de uma profícua interlocução. 
A reunião de vinte e nove textos pretende oferecer ao estudante de Teatro e ao leitor de uma maneira geral a utilização de um caleidoscópio para o qual confluem diferentes teorias e práticas que têm como foco de análise o teatro em suas nuances e matizes. Todavia, a policromia que envolve a questão teatral não constitui a garantia de um brilho suave e harmonioso, mas a efusão de um brilho incandescente a deixar na margem a solidão das cores monocromáticas. Queremos evocar que as tensões e contradições colocadas pela questão teatral emergem no conjunto dos textos como um modo de situar o teatro como um campo de conhecimento perspectivado pelas lutas e disputas paradigmáticas. E no leitor o efeito deve ser o de exercitar a reflexividade e a criticidade, sem perder o entusiasmo e a paixão pelo teatro.

Os organizadores 


\section{A PROBLEMATICIDADE EPISTEMOLÓGICA DO SABER TEATRAL}

\section{Adilson Florentino}

As discussões analisadas neste artigo são frutos de alguns insights, de caráter reflexivo, produzidos no cerne da minha pesquisa de doutoramento cujo eixo investigativo tenta problematizar as perspectivas paradigmáticas do ensino do teatro a partir das condições históricas de produção do Teatro como um campo de conhecimento, tencionado nas relações entre o saber científico e o saber escolar. Assim sendo, o Teatro como um campo de conhecimento representa um terreno epistemologicamente conflitado, no qual diferentes teorias, tendências e práticas lutam pelo modo como a realidade teatral deve ser produzida, reproduzida, significada e, sobretudo, interpretada.

O objetivo aqui elaborado é o de refletir sobre o problema do conhecimento teatral a partir do pressuposto de que o conhecimento do teatro não tem sido examinado sempre do mesmo modo, pois existem diferentes padrões de análise que orientam o modo de compreensão dos estudos investigativos sobre o teatro. Defende-se o pressuposto de que o problema não se situa na diversidade de paradigmas, mas na possibilidade de estabelecer critérios homogêneos de análise a respeito do conhecimento teatral.

Falar do conhecimento do teatro é o mesmo que interrogar-se acerca do teatro como objeto de conhecimento, o que equivale a formular uma dupla indagação:

a) O que é necessário conhecer para entender e dominar o campo do teatro ou quais são os componentes constituidores do fenômeno teatral que têm de ser dominados para entender este fenômeno?

b) Como se dá o conhecimento desse campo ou que garantias de credibilidade se pode obter acerca do campo do teatro?

O objetivo, quando se analisa o conhecimento do teatro, é o de estabelecer um eixo de interpretação que nos permita, com critério lógico, compreender a distinta consideração que o conhecimento do teatro possui. Para isso, é preciso tentar descrever as propriedades que permitem caracterizar os diferentes momentos de constituição do teatro como objeto de conhecimento. O objetivo não é a produtivi- 
dade existente em cada um desses momentos; o que preocupa não é a quantidade de investigações realizadas, mas, sobretudo, saber como é considerado o teatro como objeto de conhecimento em diferentes investigações.

$\mathrm{O}$ interesse deve recair mais sobre as análises dos pressupostos que permitem entender, de certa perspectiva, o teatro como objeto de conhecimento. A fecundidade da hipótese que aqui está sendo colocada aponta para os conceitos e as precisões terminológicas que são, sucessivamente, estabelecidas. O que interessa, especificamente, é o entendimento da própria transformação do teatro como objeto de conhecimento e sua progressiva inserção no contexto estudado. Interessa saber, portanto, quais são as propriedades que definem, em diversos momentos, o teatro como objeto de conhecimento e como se dá a justificação de que determinada investigação é a que se deve proceder para a análise do objeto em questão.

Esse tipo de questão recebe a denominação, segundo Khun ${ }^{1}$ de paradigma de investigação. No trabalho de Khun acerca da estrutura das revoluções científicas, é possível detectar dezenas de usos diferenciados do termo paradigma. Os paradigmas podem ser entendidos como marcos de interpretação ou modos de pensar acerca de algo; em si mesmos, eles não constituem teorias, uma vez que o pesquisador se compromete ou assume um único marco ou modo específico, o que pode conduzir ao desenvolvimento de teorias.

A preocupação básica desta reflexão é a de estabelecer o marco de interpretação que permita compreender a distinta condição de possibilidade do conhecimento teatral. Nesse sentido, o ponto de partida está centrado na convicção de que não tem existido a mesma consideração para a função teatral, porque o conhecimento do teatro não possui sempre a mesma significação, entendida como a capacidade que esse conhecimento possui de responder aos problemas das práticas teatrais.

Assim sendo, os critérios estabelecidos para elaborar o marco de interpretação permitem, segundo o tipo de respostas, configurar uma concepção específica de teatro e, portanto, um modo peculiar de relacionar a teoria e a prática.

Em analogia com a historicidade de outros saberes, as práticas investigativas do teatro se distinguem em vários campos e tentam responder às seguintes questões:

1) a consideração do teatro como objeto de conhecimento;

2) o tipo de conhecimento a ser obtido pelo saber teatral;

3) o modo de resolver o ato de intervenção;

4) a possibilidade ou não do estudo "científico", das ciências do espetáculo ou da teatrologia.

Cada uma dessas questões cria um padrão de justificativa da ação teatral e estabelece os limites e as potencialidades de resolução da problemática do conhecimento teatral. Cada uma dessas questões elabora um tipo de discurso em que a relação teoria-prática se dá de um modo diferente. O discurso teatral, a função teatral e a prática teatral se relacionam de modos diferentes em cada uma das questões acima porque as respostas produzem distintas visões sobre o teatro, ou seja, produzem diferentes concepções de teatro.

\footnotetext{
${ }^{1}$ KHUN, Thomas. La estructura de las revoluciones cientificas. 2. ed. Madrid: Fondo de Cultura
} Económica, 1995. 320 p. 
As concepções podem funcionar como paradigmas, isto é, como marcos interpretativos assumidos pelo pesquisador e podem produzir teorias sobre a função teatral, o discurso e a prática teatrais. Como pressupostos de investigação, as concepções funcionam como uma antecipação daquilo que se deseja conseguir e orienta a observação do fenômeno teatral na perspectiva daquilo que adquire um sentido no interior de uma específica perspectiva.

Um ponto curioso dessa questão é que a perspectiva teatral, muitas vezes, não se encontra explicitada no exercício da investigação e, contraditoriamente, dela depende o sentido do que é afirmado e negado sobre o teatro. Talvez, por isso, cada concepção redefine o campo de conhecimento do teatro, produz novos valores e reformula os já existentes.

Cada concepção sobre o teatro deve exigir rigor lógico e significação. O rigor lógico se define como uma das características defendidas com exclusividade em uma dada concepção e, ao mesmo tempo, determina um modo distinto de entender o teatro como objeto de conhecimento. Por sua vez, a significação se define como a capacidade que tem a representação do conhecimento teatral, resultante de uma lógica, de organizar historicamente a produção desse conhecimento. A significação possibilita identificar a tendência do conhecimento teatral de uma determinada pesquisa, de um livro sobre o teatro ou até mesmo de uma prática teatral concreta. $\mathrm{O}$ fato de serem incluídos em uma tendência pressupõe a defesa de uma determinada concepção de teatro como objeto de conhecimento.

Cada tendência tem um marco referencial que permite uma resposta específica às questões de análise das investigações teatrais. Precisamente por isso, pode-se dizer que tudo o que afeta o tema de estudo (do teatro), desde que não contradiga àquelas respostas, cabe no território de uma dada tendência. Por esta razão, as tendências não se definem nem por um método nem por uma concepção de ciência, nem por uma filosofia de vida. Numa tendência, cabem todos esses elementos, desde que sejam compatíveis com o marco referencial estabelecido. O que há de variar em cada um dos elementos acima descritos são as finalidades que defendem sobre o teatro.

O teatro é um campo amplo e profundo para investigar; sua riqueza de situações, teorias, práticas e processos formam parte de um material que permite iniciar distintas investigações. Junto desse material encontramos a complexidade dos fenômenos teatrais que só podem ser captados mediante investigações realizadas em algumas perspectivas e, desse modo, o estudo heurístico do teatro possibilita uma ampla variedade de modos de investigação.

Não existe acordo na classificação dos métodos e variações de cada modo de investigação no campo teatral. O método pode ser colocado a serviço de variados tipos de objetivos, nos mais diferentes ramos do saber e, no seu interior, com diversas perspectivas e características. As diferenças entre os métodos de investigação não radicam no fato de que podem ser concebidos como vias alternativas para alcançar o mesmo fim ou responder de maneira diferente a mesma pergunta ou questão. $O$ que distingue radicalmente os métodos entre si não são os procedimentos que aplicam, mas sim, fundamentalmente, o tipo de questões que pretendem ou podem resolver, assim como pressupostos e postulados básicos que determinam e especificam os critérios de evidência e a interpretação das respostas obtidas. 
A diversidade metodológica da investigação teatral responde à existência de vários paradigmas que, por sua vez, estão enraizados em algumas tradições disciplinares, tais como a Semiologia. O espetáculo teatral está repleto de significação e se constitui numa constelação de signos complexos ${ }^{2}$. Na perspectiva da Semiótica, De Marinis assinala que esta área de estudos relaciona-se à dimensão central do objeto teórico do teatro que se revela tipicamente como sendo um fenômeno de significação e de comunicação. No cerne desse debate, mas a partir de uma outra vertente, merece consideração a análise que Ubersfeld empreende em relação à problematização da questão do signo no teatro, argumentando que a relação texto-representação se organiza partindo da hipótese que afirma que o fato teatral se constitui como relação entre dois conjuntos de signos: verbais ou não verbais ${ }^{3}$.

No entanto, é De Marinis que defende o que ele denomina de teatrologia ou ciências do teatro que se reveste de um caráter transdisciplinar, a fim de permitir estudar o complexo mundo do teatro. A complexidade dos fenômenos teatrais exige a operação de enfoques plurimetodológicos, conforme afirma Pavis, pois somente através de enfoques flexíveis pode ser possível captar e aprofundar a efetivação do objeto-espetáculo rumo ao objeto-teatro ${ }^{4}$.

Assim sendo, há possibilidade de se pensar na investigação teatral entendendo-a dentro do sistema aberto que as ciências do teatro formam. O teatro é um campo de estudos que contém fenômenos, problemas e processos que constituem em si mesmos o material para realizar investigações em diferentes perspectivas.

Todavia, o teatro não é uma ciência no sentido daquelas ciências discutidas por Feyerabend, Khun, Lakatos e Popper. Para Ubersfeld, o teatro é uma arte do paradoxo, cujos fios paradoxais se entrelaçam na relação entre texto e representação, a primeira contradição inscrita na arte do teatro ${ }^{5}$.

Nas considerações do debate em torno da arte, foi seguramente Adorno ${ }^{6}$ quem confrontou a análise da natureza dela como conhecimento, apontando o conteúdo de verdade que caracteriza e fundamenta, em seu aspecto mais essencial, toda a obra de arte. A partir da perspectiva que a sua teoria estética propõe, a característica da arte contemporânea não pode ser senão a impossibilidade de transparência. De fato, o caráter enigmático da obra de arte, sob o viés lingüístico, consiste naquilo que as obras dizem e não no que ocultam. A arte, como forma de ocultamento, atua através de seu aparente contrário: o jogo da hipervisibilidade, da hiperdemonstração. Esse procedimento consiste, segundo o próprio Adorno, que aquilo que a obra de arte tenta ocultar se manifesta, porque ao se manifestar se oculta. Daí que em todos os seus momentos mais ambiciosos a atuação artística se situa mediante um paradoxo desvelamento das convenções e recursos utilizados.

\footnotetext{
${ }^{2}$ GUINSBURG, Jaco; COELHO NETO, J. Teixeira; CARDOSO, Reni Chaves. Semiologia do teatro. 2. ed. São Paulo: Perspectiva, 2003. 380 p.

${ }^{3}$ MARINIS, Marco. Comprender el teatro: el lineamientos de una nueva teatrología. Buenos Aires: Galerna, 1997. 287 p.; UBERSFELD, Anne. Para ler o teatro. São Paulo: Perspectiva, 2006. 202 p.

${ }^{4}$ MARINIS, 1997; PAVIS, Patrice. A análise dos espetáculos. 2. ed. São Paulo: Perspectiva, 2003. $323 \mathrm{p}$.

${ }^{5}$ FEYERABEND, Paul. Contra o método. 2. ed. Lisboa: Relógio D’Água, 1997. 364 p.; KHUN, 1995; LAKATOS, Imre. Historia de las ciencias y sus reconstruciones racionales. 2. ed. Madrid: Tecnos, 1987. 188 p.; POPPER, Karl. A lógica da pesquisa científica. 2. ed. São Paulo: Cultrix, 1980. 256 p.; UBERSFELD, 2006.

${ }_{6}$ ADORNO, Theodor. Teoria estética. 2. ed. Lisboa: Edições 70, 2006. 294 p.
} 
Desse ponto de vista, o conhecimento que é arte não é discursivo, pois sua verdade não é reflexa de um objeto. Impõe-se ao artista mais que a exposição de resultados ou conclusões ao expor o próprio caráter problemático do pensar e do conhecer. A verdade da obra de arte não pode ser outra coisa do que a comunicação do incomunicável, a manifestação explosiva da consciência oprimida. Para Adorno, as obras de arte são evidências do inevidente, a compreensão do incompreensível, pois em nenhum momento cabe à tarefa da filosofia da arte elucidar o incompreensível, senão tratar de entender a própria incompreensibilidade.

A arte seria capaz, segundo Kant ${ }^{7}$ de servir de ponte de mediação entre dois eixos contrapostos: a natureza e a liberdade, entre as funções intelectuais e a atividade moral, a fim de garantir uma unidade harmônica no ser humano. A espontaneidade da razão é levada ao terreno da sensibilidade, cobrindo o imenso abismo existente entre ambas.

Schiller ${ }^{8}$, o fundador da educação estética como disciplina, considerava-a como o fundamento principal da educação humana, como a essência da própria educação ao entendê-la como mediação entre racionalidade e sensibilidade. Para Schiller, a arte constitui uma síntese de natureza e liberdade, realidade e identidade, entre matéria e forma.

No entanto, Habermas ${ }^{9}$ propõe que a experiência estética não deve ser capaz de renovar as interpretações das necessidades à luz do que percebemos do mundo, pois deverá ser capaz, também, de intervir na articulação cognitiva das experiências normativas, transformando o modo como os discursos estético, prático-moral e factual se referem uns aos outros. Habermas optou em considerar a obra de arte como uma possível função de mediação, sustentando que as experiências estéticas, as interpretações cognitivas e as regulações normativas não são independentes entre si. Isso significa pressupor que os discursos estético, prático-moral e factual não estão separados entre si por um abismo, mas estão relacionados de múltiplas formas.

Toda essa discussão de caráter filosófico está aqui apresentada para justificar a importância e o aprofundamento que a questão artística e, mais especificamente, a questão teatral evocam no que concerne à problemática do conhecimento. O que nos interessa neste trabalho é capturar os nexos existentes entre teatro e ciência, a fim de localizar uma possível epistemologia do saber teatral. O pressuposto fundamental por nós defendido é que a metodologia de investigação teatral possui um vínculo referencial com o conhecimento científico.

A teoria geral do teatro parte de uma teoria do texto dramático que desemboca na teoria do espaço cênico sob as perspectivas de diferentes propostas interdisciplinares. É exatamente essa disciplina do conhecimento científico-artístico que De Marinis denomina teatrologia. É nesse caráter epistemológico que a vinculação da ciência com a arte tem seus laços mais estreitos.

Assumir o estudo do teatro ou empreender uma investigação sobre o teatro é correr o risco de se deparar com a seguinte questão: como ciência, o estudo do teatro não é totalmente objetivo, pois o seu caráter é explicitamente subjetivo e tem

\footnotetext{
7 KANT, Immanuel. Observaciones acerca del sentimiento de lo bello y de lo sublime. 2. ed. Madrid: Alianza, 1990. 304 p.

${ }^{8}$ SCHILLER, Friedrich. A educação estética do bomem. São Paulo: Iluminuras, 1990. 164 p.

9 HABERMAS, Jürgen. O discurso filosófico da modernidade. São Paulo: M. Fontes, 2002. 540 p.
} 
uma amplíssima vantagem de ser uma ciência do espírito humano, mesmo que tal afirmativa possa correr o risco de sua radicalidade na medida em que se tece a indagação de qual ciência não é humana.

Para fundamentar esse desiderato, parto da premissa de que o teatro é uma manifestação cultural e artística, de caráter cênico e que possui especificidades próprias circunscritas nos planos sintático, semântico e pragmático. O estudo do teatro constitui um âmbito de realidade instalado numa esfera de conhecimento, contendo um objeto próprio e uma cientificidade específica que tentam definir um estatuto epistemológico para a construção de um discurso teórico e disciplinar que desenvolve o seu edifício acadêmico e institucional de modo a ser capaz de problematizar, formalizar e sistematizar aquilo que denominamos teatro.

É neste momento que a vinculação com a ciência se torna mais evidente, pois a investigação cria um amplo espectro de possibilidades para o nosso objeto de estudo que, necessariamente, requer um procedimento analítico e interpretativo. Tal procedimento exige, por sua vez, como critério para a produção do conhecimento, o uso da heurística, da epistemologia e da hermenêutica.

Sobretudo nas últimas décadas, o campo da investigação teatral tem crescido muito no Brasil. Houve diversificação das linhas de pesquisa em teatro, como também houve a ampliação dos paradigmas e da adoção de abordagens metodológicas que utilizam as técnicas de análise de dados, muito mais complexas e sofisticadas; para isso, recomendo a leitura do livro Metodologias de pesquisa em artes cênicas, organizado por Carreira e outros ${ }^{10}$.

Nesse sentido, devemos aglutinar esforços em relação à produção do conhecimento em teatro apontando uma alternativa de ação urgente e necessária: a formação de professores-pesquisadores de teatro. Entendemos que o professor-pesquisador de teatro deve estar atento ao contexto contemporâneo, observar os limites impostos pelas metodologias adotadas, produzir novas formas de aprofundar os conhecimentos sem sujeitar-se a esquemas preconcebidos; tudo isso com o objetivo de melhorar a teoria e a prática teatrais e de incidir na realidade histórico-social.

Por fim, gostaríamos de enfatizar que a noção do saber-fazer artístico comporta, em si, uma segunda premissa fundacional para este trabalho reflexivo: a reivindicação de uma epistemologia própria para a investigação levada a cabo por pesquisadores, professores e artistas de teatro. Muito mais que propor um rótulo de designação historicista, interessa questionar ativamente o território do teatro como lugar privilegiado de experimentação e interrogação que se alarga para âmbitos não estritamente reservados à pesquisa estética. Trata-se, portanto, de uma proposta de abordagem de amplitude alargada, uma opção pela inter/transdisciplinaridade que, ao ser capaz de gerar esta espécie de epistemologia para o lugar da interrogação teatral, terá a capacidade de refletir — não por inclusão, mas por alargamento - outras disciplinas, com particular ênfase naquelas que questionam diretamente o envolvimento das realidades com que o teatro se contextualiza para existir.

${ }^{10}$ CARREIRA, André et al. (Org.). Metodologias de pesquisa em artes cênicas. Rio de Janeiro: 7 Letras, 2006. $159 \mathrm{p}$. 


\section{REFERÊNCIAS}

ADORNO, Theodor. Teoria estética. 2. ed. Lisboa: Edições 70, 2006.

CARREIRA, André et al. Metodologias de pesquisa em artes cênicas. Rio de Janeiro: 7 Letras, 2006.

DE MARINIS, Marco. Comprender el teatro: el lineamientos de una nueva teatrología. Buenos Aires: Galerna, 1997.

FEYERABEND, Paul. Contra o método. 2. ed. Lisboa: Relógio D’Água, 1997.

GUINSBURG, Jaco; COELHO NETO, J. Teixeira; CARDOSO, Reni Chaves. Semiologia do teatro. 2. ed. São Paulo: Perspectiva, 2003.

HABERMAS, Jürgen. O discurso filosófico da modernidade. São Paulo: M. Fontes, 2002.

KANT, Immanuel. Observaciones acerca del sentimiento de lo bello y de lo sublime. 2. ed. Madrid: Alianza, 1990.

KHUN, Thomas. La estructura de las revoluciones cientificas. 2. ed. Madrid: Fondo de Cultura Económica, 1995.

LAKATOS, Imre. Historia de las ciencias y sus reconstruciones racionales. 2. ed. Madrid: Tecnos, 1987.

PAVIS, Patrice. A análise dos espetáculos. 2. ed. São Paulo: Perspectiva, 2003.

POPPER, Karl. A lógica da pesquisa científica. 2. ed. São Paulo: Cultrix, 1980.

SCHILLER, Friedrich. A educação estética do bomem. São Paulo: Iluminuras, 1990.

UBERSFELD, Anne. Para ler o teatro. São Paulo: Perspectiva, 2006. 


\section{TEATRO-FÓRUM: UMA PEDAGOGIA DA \\ INTERVENÇÃO E OUTROS DIÁLOGOS POSSÍVEIS}

Antonia Pereira Bezerra

Em julho de 2004, no âmbito do Programa Institucional de Bolsas de Iniciação Científica, Pibic/CNPQ, ficou em cartaz na Sala 5 da Escola de Teatro da Universidade Federal da Bahia, UFBA, o espetáculo teatral Um dia na vida de uma enfermeira ou o porquê dos animais domésticos?, texto de Armand Gatti (França, 1970 - tradução nossa). Este espetáculo constituía o resultado prático do projeto de pesquisa intitulado $O$ papel do espectador-ator, da pessoa e da personagem nas poéticas de Augusto Boal e Armand Gatti.

A metodologia da encenação consistia na elaboração de um espetáculo de teatro-fórum, técnica emblemática do Teatro do Oprimido, ancorando-se, dramaturgicamente, nas peças didáticas do Pequeno manual de guerrilha urbana ${ }^{1}$, projeto político-pedagógico de Armand Gatti, o qual comporta, entre outras, a peça supracitada. Nosso interesse principal concentrou-se no exame da inserção/participação do espectador no fenômeno da representação teatral, interrogando o papel/desempenho desse espectador-ator, dessa pessoa-personagem no espetáculo. Essa pesquisa compreendeu, a priori, três etapas estruturadas em torno de uma problemática que considerou:

- a relação ao engajamento político;

- a relação pedagógica: "educação e liberação do espectador-pessoa";

- e, finalmente, os questionamentos sobre as preocupações estéticas: teatro de ação, improvisação e perfeição artística são compatíveis? Toda palavra somente porque autêntica e portadora de uma reivindicação legítima, merece ser encenada?

Foi nesta perspectiva que escolhemos interrogar, no crivo da atualidade, uma técnica e um texto teatral oriundos de poéticas historicamente datadas: O Teatro-Fórum e $\mathrm{O}$ pequeno manual de guerrilha urbana. Antes de expor detalhadamente as bases de nossa hermenêutica e nossa problemática, convém efetuarmos uma breve apresentação dos autores e seus respectivos projetos.

\footnotetext{
1 Após os acontecimentos de maio de 1968, inspirando-se em Che Guevara, Gatti publica Le Petit manuel de guérilla urbaine.
} 


\section{Armand Gatti e Um dia na vida de uma enfermeira}

Para Armand Gatti², diretor de teatro, o mais importante é a relação ao espetáculo e não o espetáculo em si: a obra só passa a ter sentido na medida em que exerce uma ação. Gatti quer agitar o público, "levar aos espíritos um certo número de elementos susceptíveis de fomentar atitudes”. Seguindo essa lógica, após os eventos de maio de 68 e a exemplo de Che Guevara, Gatti publica em 1969 o Pequeno manual de guerrilha urbana ${ }^{4}$ composto de uma série de mini-peças, as quais compreendem um número reduzido de papéis (de um a sete), não necessitando nem do lugar teatral convencional nem de orçamento importante, sendo, por conseguinte, adaptáveis e transportáveis.

Assim, em 1970, a peça intitulada La journée d'une Infirmière ou les Animaux Domestiques (A jornada de uma enfermeira ou o porquê dos animais domésticos), é representada em "foyers", centros para jovens e em hospitais. Uma única atriz e uma equipe de apoio bastante reduzida são suficientes para a realização desse espetáculo que conta com a participação dos militantes do meio hospitalar, disseminados na platéia, durante cada sessão. Gatti define e resume o objetivo e a essência do espetáculo e da protagonista nestes termos: "para que Louise junte-se ao combate de seus camaradas, é necessário que a estrutura da peça tenha um «defeito», um esboço sabiamente sedimentado, aberto às imagens a serem recebidas e aceitas, com o objetivo de exorcizar a vida (sua vida) profunda que ela castrou”.

\section{Augusto Boal}

Augusto Boal, artista, militante ativo, presidente dos Centros de Teatro do Oprimido - CTO do Rio de Janeiro e Paris, pode variar seu projeto em função dos lugares, das circunstâncias, das pessoas e suas necessidades, mas preserva intactos os objetivos essenciais de sua poética: transformar o espectador, ser passivo e depositário, em ator, em protagonista da ação dramática; nunca se contentar em refletir sobre o passado, mas em preparar o futuro's. Na origem e considerando o contexto latino-americano, a Poética do oprimido investe no combate à dupla opressão (individual e coletiva) exercida no teatro e na sociedade: liberando o espectador da sua condição de espectador, ele poderá se libertar de outras opressões, acredita Boal. Desta premissa, nasce o conceito boaliano de espect-ator. A trajetória de Boal é desenhada pouco a pouco e obedece a uma lógica de criação teatral que se recusa a conceber a arte como isolada da vida. Numa atmosfera de experimentação e controvérsias, Boal cria gradativamente novas técnicas: Dramaturgia Simultânea,

\footnotetext{
2 Sobre a trajetória de Gatti e as peças do Pequeno Manual, remetemos o leitor ao artigo de nossa autoria, intitulado Armand Gatti: informando e formando espectadores-atores. BEZERRA, Antonia Pereira. Armand Gatti: informando e formando espectadores-atores. Sala Preta: Revista do Departamento de Artes Cênicas, São Paulo, n. 2, p. 293-299, 2002.

${ }^{3}$ GOZLAN, Gerard; PAYS, Jean-Louis. Gatti aujourd'bui. Paris: Seuil, 1970. p. 166.

${ }^{4} \mathrm{O}$ título foi voluntariamente escolhido em resposta à acusação do Comissário de polícia Sr. Grimaud que, no dia seguinte às manifestações do 10 de maio de 68, declarou: Nós tivemos que lidar com verdadeiros especialistas da guerrilha urbana (apud GONZLAN; PAYS, 1970, p. 252). ${ }^{5}$ BOAL, Augusto. Jogos para atores e não atores. Rio de Janeiro: Civilização Brasileira, 1998. p. 25.
} 
Teatro Invisivel e Teatro-Fórum ${ }^{6}$. Conhecida como a mais completa e espetacular das técnicas do arsenal, a fórmula/fórum, aliás, debate teatral, transformou-se no standarte do Teatro do oprimido?

\section{O Teatro-Fórum}

Um espetáculo de Teatro-Fórum se decompõe em três partes: um aquecimento para favorecer o contato e aproximação de atores e espectadores presentes, seguido da representação da peça denominada antimodelo e, finalmente, do fórum propriamente dito. Preliminarmente à montagem do espetáculo, a troupe deve efetuar uma pesquisa de campo (caso a opressão seja exterior aos membros do grupo), ou então ela organiza um estágio de sensibilização com o grupo implicado na opressão debatida. Após a representação do antimodelo, o Curinga ${ }^{8}$ expõe brevemente os mecanismos das ações/intervenções que se seguirão. Passando rapidamente da teoria à prática, ele convida os espectadores a "invadirem" a cena para se expressar com o corpo (assimilar algumas posturas, construir imagens a partir de outras), mas também para tomar consciência da sua profunda mecanização. Estes exercícios simples distendem a atmosfera e unem o público presente. A esse ritual segue-se a representação do Antimodelo, peça escrita sob um tema único, a opressão. Após a presentação, a troupe propõe-se a reapresentar a peça. Porém, desta vez, quando um espectador considerar que um dos personagens comete um erro, favorecendo a opressão, ele pode gritar Stop!, entrar em cena para substituir a personagem oprimida e os outros atores irão improvisar com ele a solução proposta. Mas, o jogo não é tão simples! Como na vida real, se a solução do espectador não é viável, ele perde e é devolvido à platéia pelo organizador do jogo, o Curinga.

\section{Nossa experiência}

Em nossa pesquisa, para viabilizar o jogo entre atores e espectadores, foi necessário inverter um pouco a ordem dos fatos. Tendo em vista que a base do nosso antimodelo era o texto Um dia na vida de uma enfermeira, primeiramente fizemos a presentação do espetáculo para, somente em seguida, aquecermos o público pelo viés da técnica do teatro-imagem. Em outras palavras, apenas no final da primeira presentação, construíamos três imagens, que capturavam e retratavam os momentos mais cruciais da opressão debatida e exibíamos ao espectador. Essas imagens eram a única ponte entre a sala e a cena, o único viés entre a ficção e o jogo, o motor da entrada do espectador em cena. $\mathrm{O}$ espectador poderia, se quisesse e quando quisesse, assumir uma ou todas as imagens, usando da palavra ou apenas de gestos, e propor uma solução à opressão de Louise, a enfermeira protagonista ${ }^{9}$.

\footnotetext{
6 Para saber mais sobre o Teatro do Oprimido ver nosso livro Le Théâtre de l'Opprimé et la notion du spectateur-acteur (Genèse personne, personnage, personnalité). BEZERRA, Antonia Pereira. Le théatre de l'opprimé et la notion du spectateur-acteur (Genèse personne, personnage, personnalité). Lille: ANRT, Presses Universitaires de Lille, 2002. 245 p.

7 O Teatro-Fórum nasce na periferia de Lima, Peru, em 1975, mas evolui na Europa.

${ }^{8}$ Inspirado nas técnicas brechtianas, este personagem aparece em Arena conta Tiradentes (Teatro Arena de São Paulo, 1968). Numa sessão de Teatro-Fórum, o Curinga desempenha o papel de mediador do jogo, exegeta e tem uma função maiêutica, pedagógica.

9 Para se ter uma idéia mais concreta e global dos dispositivos dramatúrgicos e técnicas de jogo
} 
No tocante à dramaturgia, em face das características eminentemente épicas do texto de Gatti, tivemos que efetuar uma série de modificações para torná-lo mais dramático e adaptável à técnica do Teatro-Fórum. La Journée d'une Infirmière, por exemplo, era um monólogo que comportava apenas a protagonista, Louise, e no qual acrescentamos mais dois antagonistas, conferindo à trama mais suspense e ação. Em outras palavras, fomos além de uma simples adaptação e reescrevemos a peça, pois para conferir uma dimensão mais dialética ao conflito de Louise, centrado na narração objetiva e crítica, inserimos na trama de Gatti, momentos de intensa subjetivação e objetivação, alternando a solidão de Louise com a invasão dos antagonistas, seus opressores que irrompiam no seu espaço, nas figuras da chefe do hospital (Sra. Kopalewski) e da colega do sindicato (Noune).

Quanto ao resultado final, é evidente que em um mês, e mais algumas apresentações, não encontramos respostas para todas as questões levantadas e que muitas das hipóteses avançadas necessitam, ainda, de um contato mais longo e intenso com o público. Não obstante, no que concerne à participação do espectador, algo nos interpelou profundamente: o espetáculo montado dentro de uma estética realista-naturalista (no que diz respeito à interpretação das atrizes), com uma abordagem épica para a narrativa, os cenários e demais acessórios, intimidava os espectadores. Acentuando deliberadamente o símbolo, a força da convenção teatral, evidenciando as fronteiras que separam o palco da platéia e sem prepararmos previamente o espectador para sua intervenção teatral, nos preocupávamos, essencialmente, em suscitar as intervenções sem abrir mão de uma técnica teatral elaborada, aliada a uma consciência política clara, a fim de evitar a manipulação e o sacrifício do rigor estético em detrimento da militância e do imediatismo que toda e qualquer encenação sobre opressão impõe. Esse foi um grande desafio, uma dimensão pensada ao longo de toda a pesquisa e em todas as apresentações.

Teoricamente, constatamos que o Teatro do Oprimido - a técnica do Teatro-Fórum em particular - aliado à dramaturgia de Gatti, precisamente às peças do Pequeno manual, amplia a problemática do espectador e sua implicação no jogo teatral. Ambos os projetos discutem a dificuldade de ser, ao mesmo tempo, pessoa e personagem, de ocupar, simultaneamente, um espaço de vida e ficção interrogando as poéticas teatrais, a natureza e os fins do jogo teatral. Entretanto, noite após noite, na prática, durante a construção das imagens e diante de um longo e pontual silêncio, como se ninguém pudesse ou quisesse intervir, até que uma mão timidamente se elevasse e uma silhueta saísse da penumbra da platéia e irrompesse o palco iluminado; diante da avalanche de intervenções que se sucediam, vencendo este primeiro momento de pudor, não mais nos colocávamos questões de ordem estética ou política, não mais pensávamos em oprimidos nem opressores strictu sensu. Por alguns instantes, impactados, diante do eterno encanto do teatro, perguntávamo-nos, apenas, como e onde, ao longo da história, já estariam prefiguradas poéticas nas quais o "ator social" desnuda o "ator teatral" e aponta o problema de seus destinos comuns. Remontando o fio da história, em quantos outros gêneros e formas

aplicadas ao espetáculo, ver nosso vídeo sobre ele que está disponível no acervo videográfico da Escola de Teatro/PPGAC da UFBA. 
teatrais os personagens já simularam algumas crises, abandonando a cena e invadindo a vida? Em outras palavras, para além dos objetivos políticos, terapêuticos, onde e como, no túnel do tempo, o Teatro-Fórum e sua ancestral e imanente pedagogia da intervenção já se prefiguravam?

\section{Outros diálogos possíveis ou a gênese do Teatro-Fórum}

Quando de sua chegada à Europa, perguntaram a Boal se era possível aplicar ali as técnicas concebidas e realizadas em resposta - estética e política - à intolerável repressão que se exercia na América Latina. Perplexo, ele hesitou em dizer sim. Atualmente, essa questão não se coloca mais. A prática reafirma que essas técnicas não foram inventadas por alguém, nem para um continente específico, como sempre proclamou o seu autor: o Teatro do Oprimido sempre existiu.

Inúmeras são as trupes e encenadores modernos que, no ocidente, tentaram reencontrar e reafirmar os vestígios das origens, resgatando a pedagogia da intervenção e do lúdico na representação. Se adotarmos o ponto de vista do historiador, nesse sobrevôo desprovido de rigor cronológico, poderíamos dizer que o Teatro-Fórum e sua pedagogia da intervenção já se prefiguravam a partir do momento em que o homem primitivo começou a "representar" seu medo, suas angústias e suas obsessões a fim de exorcizá-los. Quando evocamos o fenômeno da representação e sua “origem”, o que nos vem ao espírito é, indubitavelmente, a imagem do homem pré-histórico acreditando poder controlar, domar os animais recriando-os, representando-os, com sua mão pensante ${ }^{10}$. Remetemo-nos, igualmente, às danças xamânicas, aos jeux da Idade Média - os mistérios e milagres, os laudus - com suas incidências políticas e sociológicas consideráveis. Certamente, tal viagem no tempo ultrapassa o alcance deste trabalho, mas não nos impede de sobrevoar até a metade do século XVI ${ }^{11}$, até à Commedia dell'arte, por exemplo.

\section{A Commedia dell'arte}

Esse gênero teatral fecundou dois séculos de civilização européia e modelou as formas teatrais mais reconhecidas como o teatro de Shakespeare ou de Molière. Seus traços principais - a improvisação, os personagens fixos, a espontaneidade - privilegiam $\mathrm{o}$ ator e o texto e não a personagem. Assim, pela utilização que se faz, neste gênero, da espontaneidade a partir de cannovaccios preestabelecidos, ousamos aproximar o Teatro-Fórum da Commedia dell'arte. Com efeito, esta como aquele levantam e, de certa maneira, simplificam o paradoxo do comediante. Mas, ao contrário do Teatro-Fórum, se a Commedia dell'arte permite a $a b$-reação ${ }^{12}$, paralelamente ela não conduz o espectador ao distanciamento; se ela oferece ao público um espelho, não o autoriza, todavia, a

${ }^{10}$ Claude Lévi-Strauss, Michel Leiris, Roger Bastide e Sigmund Freud, entre outros, contribuíram para o esclarecimento desta questão.

${ }_{11}$ Mesmo se ousamos infringir a cronologia da "história do fenômeno da representação, em geral, e da representação teatral, em particular”.

${ }_{12}$ Psicanálise: descarga emocional mais ou menos intensa, em que o indivíduo revive um acontecimento traumático que o libera da repressão à qual estava submetido e que pode ser espontânea ou manifestar-se no curso de certos processos psicoterápicos, por ação deles. PSICANÁLISE. In: FERREIRA, Aurélio Buarque de Holanda. Novo dicionário Aurélio de língua portuguesa. 2. ed. rev. e ampl. Rio de Janeiro: Nova Fronteira, 1986. p. 13. 
tornar-se o outro - o personagem ativo (o ator), mas apenas ele mesmo, a pessoa passiva (o espectador). A Commedia dell'arte se contenta em oferecer um rico e "belo arsenal" de máscaras, de espelhos e disfarces. Se quatro séculos mais tarde a representação se pretende o duplo da vida, como desejou Artaud em seu projeto visionário, atualmente, no Teatro do Oprimido, ela pretende desfazer-se de todo um revestimento anacrônico para tornar-se a própria vida. Boal sustenta, com efeito, que o Teatro-Fórum, em particular, é um meio "muito mais rico que uma assembléia" onde acontece, freqüentemente, que se digam coisas como se diriam muitas outras.

\section{O teatro shakespeariano: Hamlet (v. 1600)}

As representações do Antimodelo e seus aspectos pedagógicos comportam, igualmente, algumas analogias com o teatro shakespeariano. Em Hamlet, por exemplo, é feita uma magistral utilização da ab-reacção, pelos jogos de reflexos e de espelhos. O desejo de "desalienar-se" desencadeia não somente uma busca pela verdade, mas também por alternativas de comportamento face à situação conflituosa que se representa. Sem querer reforçar o clima "freudiano", que muitos críticos acreditam discernir nas grandes tragédias shakespearianas, pensamos que Hamlet é mais que "teatro no teatro". A exemplo de Sonbo de uma noite de verão (v. 1595), essa peça recria uma atmosfera atravessada pela agulha das paixões humanas, portadora de todas as possibilidades de interpretação, de esclarecimento e, até mesmo, de (re)utilizações. Não é por acaso se cada época soube encontrar em Hamlet referências a sua própria história. A peça dentro da peça poderia ser lida como um Teatro-Fórum onde o "Curinga Hamlet" vigia e dirige o jogo, sob os traços de um espectador dissimulado na sala, inquirindo, "jogando verde para colber maduro".

O personagem de Hamlet aborda a questão da primazia do papel, onde a catarse do espectador religa-se a do ator. Mas, notemos que a catarse que se opera aqui, a da "grande peça", distancia-se da noção boaliana do termo para aproximar-se, a priori, da concepção aristotélica, pois, embora nesta peça uma metalinguagem tenha lugar, além de Claudius, da rainha Gertrude e de Hamlet, os outros espectadores, ignorantes da "situação", permanecem passivos: eco desconcertante com o Teatro-Invisível que Boal, atualmente, hesita em praticar. Além disso, o papel de Hamlet é um papel imposto. Hamlet aceita a situação mesmo revoltando-se contra ela. Tal qual os oprimidos, é constrangido e forçado que desempenha o seu papel. Hamlet busca liberar-se da opressão porque ele é outro além da personagem, ele a ultrapassa. O Teatro-Fórum não reivindica esse desenvolvimento do indivíduo pelo viés do personagem que se realiza na direção que lhe é própria? Reavaliar-se no Teatro-Fórum significa tornar-se a si mesmo, confrontar-se à sua identidade humana profunda pela mediação do drama, da opressão vivida e representada.

Essa peça dentro da peça poderia ser um fórum onde Hamlet, o Curinga, vigiaria as verdadeiras ações de seu tio, o rei fratricida, incapaz de suportar a representação de seu crime. Um fórum onde, graças ao teatro, procura-se a verdade e a liberação. Se Hamlet está dividido entre ser e não ser, os protagonistas do Antimodelo, esses “personagens” com “personalidades” diferentes, podem 
- uma vez que a representação e diante das alternativas a suas questões - decidir fugir, acomodar-se ou lutar. Não é depois da representação, pela voz do real e não pela voz, talvez enganadora, de um fantasma, que Hamlet sabe onde se encontra a verdade? Por outro lado, é preciso admitir que ele cai numa nova armadilha; a partir daí, ele se impõe um outro papel: o do justiceiro, para quem é tarde demais para renunciar. Mas, toda pedagogia da intervenção não pressupõe uma implicação?

\section{Luigi Pirandello (1867 - 1936)}

Sempre nesse espírito de busca por uma "prefiguração" do Teatro-Fórum e sua pedagogia da intervenção, como não pensar em Luigi Pirandello, em seu teatro de máscaras e reflexos? Como não pensar nessa exploração das profundezas de identidades telescopicamente examinadas e nesse questionamento não somente da noção de barreira entre o palco e a platéia, mas também das noções de realidade e ficção? Seis personagens a procura de um autor nos parece mostrar que o teatro é que é verdade e o travestimento, nudez; que a máscara, no sentido etimológico do termo, é que é real. Pirandello nos mostra que os verdadeiros vivos de sua peça são personagens aparentemente irreais, que questionam a identidade e a presença carnal dos chamados vivos. Entretanto, ao examinar mais de perto, esses personagens recusam o monopólio dos atores de carne e sangue que representam a peça de um certo Pirandello, num certo teatro, diante de um certo público. Eles reivindicam, assim, o direito à existência. Isso nos remete, de certa maneira, às disputas (estéticas e políticas) entre oprimidos-artistas e atores profissionais.

Moderamos, pois, a comparação, uma vez que o teatro de Pirandello, se não aborda a questão da "loucura" diretamente, no mínimo, alude com freqüência aos jogos de espelhos da loucura. É provável que o drama familiar de Pirandello, a "doença” de sua mulher Antonietta esteja na origem do lugar atribuído à loucura em suas obras. $\mathrm{O}$ jogo constante entre o real e a aparência impregna suas peças de uma dialética cortante e patética do ser e do parecer. Isso é, particularmente, impactante em Henrique IV (representada pela primeira vez em 1925). Ressalte-se, também, que a maior parte das peças de Pirandello foi concebida para ser representada de maneira convencional, mesmo se, às vezes, os atores invadem a sala e convidam os espectadores a subir no palco, a exemplo de Assim (Assado), representada pela primeira vez em $1926^{13}$. Enfim, sua trajetória de homem não testemunha de nenhuma rejeição à instituição teatral.

Em Seis personagens a procura de um autor, quando o Pai reage contra a intolerância do Diretor, o qual se recusa a acreditar que está, realmente, diante de personagens, cujos dramas da vida imaginária permanecem inacabados, confissões em aparência patéticas, mas, na verdade profundas, jorram:

\footnotetext{
${ }_{13}$ Nessa peça, uma trupe representa o drama verdadeiro de uma atriz decadente (La Mareno, a qual se encontra na sala). Indignada, ela ameaça entrar em cena, mas seu marido a contém. No entreato, ela decide ir às coxias invectivar a trupe e, particularmente, a atriz que representa seu papel. Isso lembra um Fórum relatado por Boal, em Jogos para atores e não atores, ocorrido em 1980, em Grodano (povoado da Sicília), onde o prefeito, tomado de cólera diante do ator que representa seu papel (é um opressor, se é preciso esclarecer) e, não se contendo, mais grita Stop!, entra em cena e representa ele próprio.
} 
[...] o senhor diz que não tem tempo a perder com loucos e, no entanto, ninguém melhor que o senhor pode saber que a natureza se serve da imaginação humana para continuar num plano mais elevado seu trabalho de criação ${ }^{14}$.

Apesar da sinceridade desses propósitos, o Diretor e a trupe dos "verdadeiros atores" não consegue escapar de julgar a situação absurda e inverossímil. Numerosas são as sessões do Teatro-Fórum em que, quando o Curinga (duplo de Boal) grita Stop é mágico!, os espec(atores), indignados, recusam-se a deixar a cena, persuadidos de que suas proposições, julgadas "ilusórias" pelo diretor do jogo, são perfeitamente realistas e aplicáveis.

Também os cannovaccios do Antimodelo, qualificados de inferiores em relação à “dramaturgia clássica e dominante”, remetem à cena em que o Diretor pergunta aos seis personagens onde está o manuscrito de suas vidas. O Pai (duplo de Pirandello), vítima das zombarias dos "verdadeiros atores", replica: "Ele está em nós, senhor Diretor. O drama está em nós; nós somos o drama e estamos impacientes para representá-lo, como nos impele a paixão que ferve em nós!”. Assim, eles reivindicam que seus papéis sejam representados por eles e não pela trupe profissional que se "recusa" a deixar o palco. Não poderíamos encontrar eco mais justo para (re) evocar os desacertos dos espect(atores), em suas improvisações na cena "sagrada" do teatro. E, mais particularmente, no que concerne à intensidade emotiva que revira toda sessão do Teatro do Oprimido. Como Pirandello com seus "personagens", Boal não cessa de clamar às "pessoas": "Deixemos os oprimidos se exprimir, porque somente eles podem nos mostrar onde está a opressão"15. Esse descomprometido sobrevôo nos leva a uma outra interrogação importante.

\section{A representação e o sagrado: outra vez o lúdico, outra vez a pedagógica da intervenção}

Há uma idéia muito difundida de que a noção de sagrado, na representação em geral, está estritamente ligada à história do homem, posto que ela aparece nas danças xamânicas (ou ainda nas danças rituais dos Orixás no Brasil), mas também nas pinturas rupestres ${ }^{16}$. Do mesmo modo, a reencontramos na teatralidade dos cultos de possessão ou da representação - o que é dado em espetáculo, o que reatualiza o mito permitindo o exorcismo e sucessivo estabelecimento e quebra da magia. Quer consideremos as danças xamânicas, o vodu haitiano, as danças de possessão dos Sonrhais do Niger e mesmo os Mestres loucos, do filme etnográfico de Jean Rouch ${ }^{17}$ - do qual Jean Genet tiraria sua obra prima Les Nègres, em 1958 - o tempo parece ter sofrido uma espécie de curto-circuito; ou, talvez, seja a prova da unicidade do homem, idêntico a si mesmo para além dos milênios. Tanto no homem da pré-história, quanto em nossos contemporâneos,

\footnotetext{
${ }_{14}$ PIRANDELLO, Luigi. Six personnages en quête d'auteur (suivi de Chacun sa vérité, Henri IV, Comme ci (ou comme ça). Paris: Gallimard, 1950. p. 17.

${ }^{15}$ BOAL, Augusto. Stop! C'est magique. Paris: L'Échappée Belle/Hachette Littérature, 1980. p. 22.

${ }_{16}$ Sobre o tema, consultar MARINGE, Jean. L'homme préhistorique et es Dieux. Paris: Arthaud, 1958.

17 Filmado em 1955 no subúrbio de Accra, em Gana (que se chamava, então, Gold Coast), esse filme recebeu o primeiro prêmio entre os filmes etnográficos, geográficos, turísticos e folclóricos, no "Festival Internacional de Veneza", em 1957. Falaremos mais tarde de sua temática.
} 
submetidos à aceleração aparente da história, reencontramos as mesmas preocupações essenciais, a mesma tentativa de dominar as situações pela representação, seja com relação a Deus - pelo viés do sagrado -, seja com relação à condição de dependência aos fatos.

E em quaisquer das situações, o lúdico e a pedagogia da intervenção se configuram como uma via privilegiada para se atingir os fins, de sorte que, também nesse domínio, a busca por "controle”, que passa pela representação, poderia ser vista como uma sorte de eco longínquo da Poética do Oprimido, do Teatro-Fórum, notadamente em seu drama/debate que, pretendendo liberar o homem de uma opressão vivida, incita a pessoa a "transgredir" os limites de sua personalidade, pela metamorfose do espectador em personagem. Não obstante, precisamos relativizar a noção de rito e levar em consideração o conteúdo diferencial, ainda que o mimetismo identificado nos "rituais de possessão" como uma constante - "posto que posso me tornar você, eu te domino" - é, de certa maneira, uma das buscas do teatro. Um dos postulados fundamentais da Poética do Oprimido não é a "ficção antes da realidade", ou seja: "posto que posso representar minha libertação, posso realizá-la em seguida na vida?”

\section{Os mestres loucos}

Para aprofundar essa questão, evocaremos Os mestres loucos, filme que nos mostra uma cerimônia sacrificial entre os africanos do subúrbio de Accra (capital de Gana). Habitantes do vilarejo da etnia Haouka transformam-se em possuídos: um cão é degolado (nesse momento, os iniciados bebem seu sangue), depois esquartejado e comido. Além da dança e do transe, podemos interrogar-nos como o cineasta, por que comer um cão? Posto que se trata de uma carne totalmente proibida, os Haoukas pensam que ao ingeri-la serão mais poderosos que todos os outros homens, negros ou brancos.

O filme de Jean Rouch remete não somente aos rituais do sacrifício grego do bode, mas também à refeição totêmica freudiana, o mito dos irmãos cassados que matam e comem o pai, o ancestral do grupo, o espírito protetor. Transgredindo a ordem das coisas, do sagrado consagrado, eles se tornam tabus. Ora “ [...] o tabu é um ato proibido, em cuja direção o inconsciente inclina-se com uma tendência muito forte"18. Essa questão concerne não somente o teatro, mas também todo um ramo médico e político. Em Magia e religião, Claude Lévi-Strauss parte do princípio que "eficácia simbólica, cura xamânica e cura psicanalítica são reorganizações estruturais entre corpo e psiquismo". A esse respeito basta escutar a voz em off de J. Rouch para se convencer:

[...] quando o sacrifício é cometido, o inconsciente é liberado; os mitos podem entrar em ação. E desses OPRIMIDOS, livres dos limites, a chaga do medo jorra à luz dia: o mais constrangedor de seus mitos, a imagem de seus OPRESSORES, eles encarnam a imagem incoerente, incompreensível, que se fazem dos branco, poderosos e diferentes até parecerem desumanos.

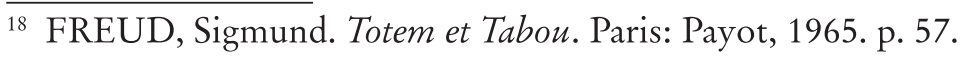


Não se trata aqui de procurar saber se os "possuídos" fingem ou, ainda, de diagnosticar a possessão. Se é verdade que o possuído alcança um estado que põe em jogo a totalidade de seu ser, poderíamos, então, perguntar-nos se o teatro, como a possessão, não seria uma busca por "remédios" para "curar a vida"? Ora, na manhã seguinte ao ritual, Jean Rouch vai reencontrar os Haoukas - com sua câmera - não mais na floresta, mas na cidade, cada um em seu papel, sua função social habitual. Diante de seus rostos sorridentes e seus comportamentos "pacíficos", o autor se pergunta "se esses homens da África não conhecem certos remédios que lhes permitem, por uma via incomum, integrarem-se perfeitamente a seu meio [...] Remédios que nós os ocidentais não conhecemos ainda”.

\section{Antonin Artaud}

Em busca de remédios para curar a vida, a exemplo de Freud, mas ao contrário de Brecht que concebia o poder ideológico apenas como uma potência "exteriora", Artaud, em sua inquietante trajetória, também sabia que o nosso "ser profundo" é infectado por monstros, por todo um conjunto de pulsões destruidoras acumuladas em nós desde a infância. Porém, Artaud jamais pôde praticar seu teatro. Suas aplicações teóricas conheceram o fracasso, suas peças não tiveram repercussão nem na França nem alhures ${ }^{19}$. Les Cenci foi "um desastre financeiro" (somente dezessete representações), ainda que, para ele, tenha sido "um sucesso no absoluto"20. A breve aventura do teatro Alfred Jarry $(1926$ - 1930) faz nascer no plano teórico - e com furor - aquela do teatro e seu duplo: poesia, loucura, filosofia e profecias dialogam de maneira extraordinária. Em 1935, o autor parte para o México, país dos Tarahumaras, em busca do mana. Mas, as montanhas mexicanas, gravadas com corpos de homens esculpidos como sinais na rocha, já rondavam o imaginário de Artaud desde 1933, ano em que inicia suas pesquisas sobre Héliogabale ou o anarquista coroado. Em 1934, ele publica um primeiro ensaio, El Gabal - encarnação do mito hermafrodita adorador do sol e da pedra negra ELAGABALE: "Esse Deus ELAGABALUS, ou saído da montanha, cume brilhante, vem de muito longe"21.

\section{Considerações conclusivas: o fim do começo}

Se as noções de jogo, de opressão e de intervenção concernem tanto o teatro, a psicologia, quanto a política e a educação, a necessidade de diálogos como estes que estabelecemos ao longo deste ensaio torna-se imprescindível, sobretudo pelo fato da técnica aqui analisada trabalhar, dialeticamente, com todas essas noções. Ora o Teatro-Fórum é uma pedagogia da e pela intervenção teatral. Assim, interrogamo-nos, ainda, enquanto professora e pesquisadora: o que ensejamos precisamente? Fazer dos estudantes melhores espectadores, amadores esclarecidos e mais exigentes ou transformá-los igualmente em «atores»? Será necessário então iniciá-los numa arte concebida como separada da vida? Teremos que engajá-los em montagens de espetáculos, levando-os a preservar, paralelamente, a ruptura entre

19 Notadamente Ventre brulé ou la mére folle (1926), Les Cenci (1930) adaptada de Shelley, dirigida e representada pelo próprio Artaud.

${ }^{20}$ ARTAUD, Antonin. Le théatre et son double. Paris: Payot, 1960. p. 10.

21 ARTAUD, Antonin. Héliogabale ou l'anarchiste couronné. Paris: Gallimard, 1979. p. 17. 
mimesis e criação nos seus comportamentos sociais? Ou será questão de ensinar-lhes, de uma só vez, que o teatro é uma dimensão substancial do ser humano, o Solar e o Lunar, Apolo e Dionísio, a clareza de espírito e as profundezas noturnas do ser? Não se trata, aqui, de estabelecer um equilíbrio estático entre Apolo e Dionisio ou, para retomar as oposições binárias, de colocar um pouco de "papel» e um pouco de "personalidade", um pouco de Brecht, um pouco de Artaud, sob pena de confundir dois enfoques absolutamente distintos: o da arte e o da vida cotidiana. Seguir quem acredita que "o homem-espectador" pode ser o criador e mestre do destino do "homem-personagem", quem clama como Boal "Não digam! Venham em cena e mostrem-nos suas visões do mundo"22, ou quem prefere, como Gatti, ir ao encontro dos "atores da realidade" e reapropriar-se com eles do "poder da linguagem teatral" para se tornarem "criadores" seria uma opção eficaz? A dimensão prática desse projeto respondeu a muitas dessas importantes questões.

$\overline{22}$ BOAL, 1980, p. 50. 


\section{REFERÊNCIAS}

ARTAUD, Antonin. Héliogabale ou l'anarchiste couronné. Paris: Gallimard, 1979.

ARTAUD, Antonin. Le théâtre et son double. Paris: Payot, 1960.

BEZERRA, Antonia Pereira. Armand Gatti: informando e formando espectadores-atores. Sala Preta: Revista do Departamento de Artes Cênicas, São Paulo, n. 2, p. 293-299, 2002.

BEZERRA, Antonia Pereira. Le théâtre de l'opprimé et la notion du spectateur-acteur (Genèse personne, personnage, personnalité). Lille: ANRT, Presses Universitaires de Lille, 2002.

BOAL, Augusto. Jogos para atores e não atores. Rio de Janeiro: Civilização Brasileira, 1998.

BOAL, Augusto. Stop! C'est magique. Paris: L’Échappée Belle/Hachette Littérature, 1980.

BOAL, Augusto. Teatro do oprimido e outras poéticas políticas, Rio de Janeiro: Civilização Brasileira, 1988.

FREUD, Sigmund. Totem et Tabou. Paris: Payot, 1965.

GATTI, Armand. Théâtre complet. Paris: Verdier Lagrasse, 1970. 3 t.

GOZLAN, Gerard; PAYS, Jean-Louis. Gatti aujourd'bui. Paris: Seuil, 1970.

LÉVI-STRAUSS, Claude. Antropologia estrutural. Paris: Plon, 1958.

MARINGE, Jean. L’homme préhistorique et es Dieux. Paris: Arthaud, 1958.

MANNONI, Octave. Les clefs pour l'imaginaire. Paris: Seuil, 1980.

PIRANDELLO, Luigi. Six personnages en quête d'auteur (suivi de Chacun sa vérité, Henri IV, Comme ci (ou comme ça). Paris: Gallimard, 1950.

PSICANÁLISE. In: FERREIRA, Aurélio Buarque de Holanda. Novo dicionário Aurélio de lingua portuguesa. 2. ed. rev. e ampl. Rio de Janeiro: Nova Fronteira, 1986.

ROUCH, Jean. Lês maîtres fous. Paris: Cinémathèque, 1953. 


\section{METODOLOGIAS CONTEMPORÂNEAS DO ENSINO DE TEATRO: EM FOCO A SALA DE AULA}

Arão N. Paranaguá de Santana

Na virada do milênio, as concepções culturais emergentes germinaram no campo da educação valores como respeito ao receptor, intertextualidade, fragmentação de um discurso anteriormente linear, pluralismo, utilização de meios tecnológicos inovadores, dentre outros fenômenos que vislumbram, a um só tempo, ruptura e crise, face ao convívio com procedimentos desgastados, embora recorrentes - didáticas autoritárias, práticas repetitivas, o novo que se acha belo porque desconhece memória e tradição.

Perplexidades como essas têm motivado o debate em encontros de especialistas, pesquisas e publicações, fazendo-se presente, sobretudo no trabalho cotidiano dos docentes. Nesse esteio surgem estudos consubstanciados na nova sociologia da educação, na psicopedagogia, na teoria crítica, na pedagogia dos conteúdos, no multiculturalismo e noutras vertentes que compõem o imenso arquipélago da teoria social da atualidade.

Esses trabalhos têm contribuído para o avanço de propostas teóricas e metodológicas relativas ao ensino e ao aprendizado, possibilitando aos educadores certo distanciamento para que possam relativizar as diferenças entre os estágios de desenvolvimento material e cultural dos alunos, concedendo-lhes, também, as estratégias para compreensão dos percursos de entrada e saída numa modernidade alcançada apenas por pequena parcela da população mundial ${ }^{1}$.

Em face desses fenômenos estampados no tecido social e suas implicações na escolarização, creio que o ensino de Arte, ou pelo menos uma parcela significativa de seus praticantes, tem procurado fundamentar-se em obras e conceitos revelados na arte contemporânea, no fazer dos artistas, no pensar dos críticos, nas práticas culturais comunitárias, nas propostas de museus e instituições culturais, sem ignorar, contudo, a realidade da sala de aula. Creio, também, que essa jornada ruma para a superação do fazer que caracterizou o sentido da formação em arte predominante durante séculos, bem como do sentir enquanto esfera da liberdade expressiva de fundo psicológico que alude à imanência estética, mas que, na verdade, não penetra na essência da arte, retomando a questão da reflexão como estatuto de um pensar que existe para tecer conexões entre esses três componentes da ação artística e pedagógica - fazer, sentir, pensar.

${ }^{1}$ Canclini, N. G. Culturas híbridas: estratégias para entrar e sair da modernidade. São Paulo: EDUSP, 1998. p. 17-30. 
Com o objetivo de contextualizar essa argumentação perante às indagações deste VI Seminário de Linguagens Artísticas, sou levado a guiar-me a partir de alguns pontos: i) em que bases metodológicas constituiu-se a área de Teatro-Educação? ii) como adaptar as proposições mais interessantes à realidade da sala de aula? iii) qual o perfil e o que pensam os professores, já que são eles os responsáveis diretos pela produção de conhecimentos e práticas escolares?

Considerando o quadro complexo que se apresenta para a compreensão de questões tão abertas, tentarei verificar, a partir de uma perspectiva histórica, se no caso das didáticas do Teatro é possível - ou não - assumir um discurso vanguardista, como nas Artes Visuais, por exemplo, campo onde florescem metodologias pós-modernas.

\section{Significados do teatro na escolarização}

Desde Aristóteles, tem-se pensado muito sobre o potencial reflexivo que permeia o fazer e o fruir, o pensar e o sentir contidos na arte dramática. A palavra drama vem de dromenon, referindo-se à ação, ao passo que teatro, vocábulo que também veio do grego, significa lugar donde se vê. Essa capacidade de ver-se em ação, criticando e apreciando os próprios gestos e atitudes, constituiu-se num recurso vital para o processo de humanização da natureza e, sendo inerente à atividade artística, tem implicações ontológicas no campo da educação.

Os nexos epistemológicos originários do Teatro-Educação remontam a um passado longínquo, embora sua vertente no ensino formal tenha sido consolidada somente nesse século, em resposta às necessidades do teatro moderno e aos reclames da sociedade em prol de uma consciência cidadã plenamente democrática.

Assim, no âmago de sua própria historicidade, criou-se uma cultura compreendendo os fins do Teatro na escolarização, suas metas pedagógicas e estéticas, conteúdos, atividades facilitadoras do aprendizado e procedimentos de avaliação. Ao longo desse processo de tornar-se disciplina foram sendo configurados métodos e teorias, visando-se superar os obstáculos suscitados através da ação.

Não consigo pensar em desenvolvimento curricular sem visualizar a imagem dos sujeitos que, na prática, são os deflagradores do processo de ensino e, como motivadores do aprendizado, escolhem os caminhos da ação pedagógica.

Para Gisèle Barret, o especialista em Teatro-Educação é um personagem estranho entre-deux, considerando-se a ambigüidade de sua atuação no limiar do teatro e da educação. A autora entende que essa área carece de definições no âmbito dos fundamentos, apesar de sua história importante no cenário acadêmico e escolar, propondo as seguintes reflexões:

Somos generalistas, especialistas, generalistas-especialistas ou especialistas-generalistas? Nós jogamos ou criamos arte? Fazemos teatro, teatro na educação, teatro improvisacional ou educação através do teatro? Usamos arte, ensinamos arte ou fazemos arte? ${ }^{2}$

\footnotetext{
2 BARRET, G. Le spécialiste en théâtre éducation: une personnage étrange entre-deux. IDEA Journal: Polyphonic voices, rainbow worlds: one destiny, v. 1, n. 1, p. 6, 1997. Tradução livre do autor em parceria com Ulisses Ferraz de Oliveira.
} 
Acirrando esse debate, Charles Combs observa que para realizar bem sua função o especialista em ensino de Teatro estabelece metas, objetivos e procedimentos, atribuindo, porém, propósitos bem mais específicos para sua conduta:

Nós queremos que o estudante aprenda, transforme-se e busque desenvolver-se; nós ensinamos, agimos, encenamos, criamos performances cotidianamente e interferimos mediando ações dentro das escolas, em contextos formais ou informais; usamos métodos de ensino, formas artísticas e valores culturais no nosso trabalho; trabalhamos como artistas, professores e mediadores - nós desejamos que o estudante ou pessoa continue a aprender e a desenvolver-se através da vida sem a nossa intervenção ${ }^{3}$.

Citei os pontos de vista desses dois especialistas internacionais com a intenção de atualizar o debate sobre os alicerces do Teatro-Educação e, assim, compreender melhor o perfil atribuído aos docentes, alimentando a reflexão acerca de um dilema sempre recorrente - estar entre dois. Para a superação desse entrave, Combs estabelece conexões entre quem e onde são produzidas as teorias e as propostas didáticas, assegurando que há uma fusão entre o que as lideranças intelectuais realizam e a ação das instituições; como corolário dessa argumentação, cita exemplos de parcerias que se revestiram de sucesso acadêmico em seu país ${ }^{4}$.

No caso brasileiro, pode ser comprovada uma situação semelhante, considerando-se a atuação decisiva de algumas universidades na pós-graduação, de seus professores na pesquisa e publicação de livros, além dos personagens pioneiros e outros mestres do presente que, com sua ação, vêm dando notoriedade ao ensino de Teatro ${ }^{5}$.

\section{Breve historiografia da didática do teatro na realidade escolar brasileira}

Até aqui busquei situar a disciplina Teatro frente ao estado atual da cultura, como pano de fundo para entender sua prática escolar numa época "de tecnologia avançada, iluminismo científico e iluminação estética", ao tempo em que propus uma reflexão sobre algumas questões pontuais. Tentarei agora discutir a insurgência dos métodos a partir de contribuições historicamente situadas, dando ênfase às influências absorvidas pela educação brasileira.

${ }^{3}$ ComBs, C. E. The drama/theatre/artist/teacher/educator/scholar matrix. IDEA Journal: Polyphonic voices, rainbow worlds: one destiny, v. 1, n. 1, p. 10, 1997. Tradução livre do autor em parceria com Geraldo Salvador de Araújo.

${ }^{4}$ Combs registra a seguinte relação de personagens e instituições: Winifred Ward / Northwestern University; Kenneth Graham / The University of Minnesota; Geraldine Silks / The University of Washington; Jed Davis / The University of Kansas (COMBS, 1997, p. 11).

${ }^{5}$ Mesmo correndo o risco de esquecer nomes importantíssimos para a história do Teatro-Educação nacional, cito os seguintes: Aladir Santos Lopes, Amicy Santos, Antonio Januzelli, Augusto Boal, Beatriz Ângela Vaz, B. de Paiva, Clóvis Garcia, Dilza Délia Dutra, Fanny Abramovitch, Flávio Império, Helena Barcelos, Hilton Carlos de Araújo, Ilo Krugli, Ingrid Dormien Koudela, Joana Lopes, Laís Aderne, Lúcia Benedetti, Luiza Barreto Leite, Luiz Paulo de Freitas, Maria Alice Vergueiro, Maria Clara Machado, Maria Lúcia Pupo, Paschoal Carlos Magno, Olga Reverbel, Santa Rosa, Yan Michalski, Yara Silveira e muitos outros (a relação foi elaborada, originalmente, por Marcos Bulhões).

${ }^{6}$ Nunes, B. Educação artística e filosofia da arte. Rio de Janeiro: MEC: FUNARTE, 1986. p. 3. 
O aprendizado cênico secularizou-se através do fazer e, sobretudo, fundamentado na instrução do mestre, procedimento que assegurou a existência de troupes e famílias de artistas, inclusive nos momentos em que o teatro era uma atividade proibida pelo poder instituído.

Na perspectiva da educação, Rousseau, Pestalozzi e Froebel observaram que o jogo proporcionado pelo teatro era um poderoso estímulo para o desenvolvimento da criança, sugerindo pistas para a investigação de pensadores como Dewey, Piaget e Wygotsky. Esse legado conceitual possibilitou aos educadores do presente século a formulação de idéias e métodos de ensino, calcados no movimento conhecido mundialmente por escola nova. Foram muitas as tendências teatrais representativas desse momento da pedagogia ocidental, destacando-se o play way, de Caldwell Cook; jogo dramático infantil, de Peter Slade; creative dramatics, de Winifred Ward e Brian Way; dança moderna educacional, de Rudolf Laban, Alan Garrard e Lise Ullman; linguagem criativa, de Marjorie Hourd; psicodrama, de Jacob Moreno.

Apesar dos avanços teóricos e metodológicos que vieram à tona com esses movimentos, predominou na escola uma visão espontaneísta que velava a essência da arte dando ênfase à livre-expressão, ao invés de instaurar experimentos geradores de saberes, práticas e fruição de obras. Educadores e artistas desfraldaram bandeiras alardeando a importância do processo educativo em detrimento do produto estético, seja nas escolas ou nos movimentos políticos de conscientização popular.

Era esse o pensamento praticado na escola brasileira quando a Educação Artística foi implantada, salvo raríssimas experiências isoladas. Nas aulas de Artes Cênicas, os professores limitavam-se a propor temas e distribuir material, deixando os alunos livres para improvisar à vontade. Somente aqueles mais tradicionais incorporavam o texto dramático, sendo muito comum a montagem de pecinhas em datas comemorativas. Nesse cenário, desenvolveu-se uma pseudoteoria que separava o que era arte do que poderia ser educação, mapeando em categorias estanques o teatro formal e o teatro educativo.

Durante anos de 1980, o quadro da Educação Artística polivalente - e, portanto, das Artes Cênicas - transfigurou-se aos poucos. Foram implantados cursos superiores em proporção geométrica, os professores tomaram as rédeas de sua própria história, ao tempo em que surgiram pesquisas sobre o Teatro na educação fundamental, dando início a uma profusão de idéias e práticas que hoje em dia vêm sendo avaliadas.

Além das experiências que se avolumaram no interior de escolas e instituições culturais, outros fatores contribuíram para esse salto qualitativo do Teatro-Educação, ressaltando-se os seguintes: i) o intercâmbio com o estrangeiro, seja através da divulgação de livros ou da vinda de especialistas renomados para ministrar cursos, participar de seminários e dar consultoria; ii) a larga difusão de obras como Improvisação para o teatro, de Viola Spolin, indicativa de caminhos para o ensino da linguagem cênica para crianças, adolescentes e adultos; iii) o surgimento tímido, mas eficiente de cursos de pós-graduação específicos em Arte, bem como a abertura de linhas de pesquisa sobre ensino de Teatro nos mestrados de áreas afins; iv) o agrupamento de profissionais em entidades para-acadêmicas, federações e sindicatos, o

\footnotetext{
7 O ideário dos movimentos de conscientização popular dos anos 60 - a exemplo dos CPCs da União Nacional dos Estudantes -UNE aproximava-se ao difundido pela escola nova e muitos deles baseavam-se no culto à livre-expressão, embora seu objetivo fosse a resistência cultural. Ver CANCLINI, 1998, p. 139-140.
} 
que propiciou a realização de simpósios regulares.

No bojo desse movimento, emergiram experiências de pessoas interessadas em contemporizar as idéias de Stanislavski, Brecht, Artaud, Grotowski, Barba e Peter Brook, dentre outros autores que referenciam a inovação metodológica contemporânea. Em meio a essas tendências, as mais relevantes privilegiam o jogo e a improvisação, e não se cercam, como no passado, de receios quanto ao uso do texto e à instrução enquanto regra didática. Considerando-se a diversidade de enfoques e procedimentos pedagógicos disseminados por escolas, instituições culturais, mestres e grupos teatrais, torna-se extremamente salutar o estudo dessas diferentes propostas, embora seja complicado analisar, sistematicamente, seus resultados ${ }^{8}$.

Com a configuração dos fenômenos anunciados até aqui, a discussão de práticas e a divulgação de pesquisas nas várias linguagens artísticas - marcas dos anos 90 -, percebe-se agora um cintilar alvissareiro no espaço do Teatro-Educação, muito embora, no plano prático da escolarização, tudo isso seja ainda uma incógnita.

$\mathrm{Na}$ grande maioria dos Estados brasileiros são raras as redes de ensino dotadas de professores devidamente preparados e, até mesmo nas escolas públicas das capitais, a realidade insiste em ofuscar o brilho das conquistas. Dentre os fatores que sobrevivem como fantasmas atormentando o ensino de Arte, sobressaem-se: turmas abarrotadas de alunos; espaço inadequado para a prática teatral; tempo insuficiente para preparação e desenvolvimento das aulas; má qualidade do material didático; diálogo truncado e falta de parcerias, mesmo entre docentes; inexistência ou descontinuidade no aperfeiçoamento profissional; mentalidade servil e avessa à ousadia; e baixa remuneração dos trabalhadores da educação.

Tendo em vista o enfrentamento dessas questões o poder público vem anunciando uma série de medidas, a exemplo dos Parâmetros Curriculares Nacionais - PCN. Essa estratégia representa uma novidade substantiva para a área da Arte, pois, pela primeira vez, o Ministério da Educação e Cultura - MEC presta orientação formal para o planejamento curricular da Música, das Artes Visuais, da Dança e do Teatro. Muito já se disse sobre o assunto e, pessoalmente, acho que os PCNs só deixarão de ser mais uma ação burocrática e prescritiva caso seja possível superar...

[...] a visão reducionista da escola, inserindo-se uma noção de currículo como tecido articulador no qual a formação de professores, as práticas pedagógicas e os processos de ensino, aprendizagem e avaliação se relacionem mutuamente. No momento, esses vínculos não existem?!

Fundamentando-se na Psicopedagogia e na Proposta Triangular, os PCNs não se limitam apenas a filosofar sobre os conceitos que sustentam as quatro áreas da disciplina Arte e a relacionar os respectivos objetivos e conteúdos; propõem também encaminhamentos didáticos e critérios de avaliação. A orientação metodológi-

\footnotetext{
${ }^{8}$ Ainda não existe no Brasil um estudo sistematizado sobre as metodologias praticadas no ensino do Teatro. A bibliografia estrangeira também não é muito extensa, excetuando-se trabalhos como o de SOMERs, J. Drama and theatre in education: contemporary research. Ontario: Captus University Publications, 1996.

9 SANTANA, A. N. P. Reconsiderando o ensino de artes cênicas. In: CONGRESSO NACIONAL DA FEDERAÇÃO DE ARTE EDUCADORES DO BRASIL, 11., 1998, Brasília. Anais... Brasília, DF: FAEB, 1998. p. 9-10.
} 
ca apresentada aos docentes sugere organização do espaço, do tempo, instrumentos de registro e documentação, como forma de organizar as atividades e as intervenções do professor junto ao aluno.

A ação de planejar um curso requer do educador uma atitude criadora, a seleção de conhecimentos e práticas que tornem possíveis descobertas e construção de saberes, desconsiderando o método enquanto modelo pronto. Essa é uma tarefa essencial ao ato de ensinar, pois "os encaminhamentos didáticos expressam a seriação dos conteúdos da área e as teorias da arte e da educação selecionadas pelo docente ${ }^{10 ”}$. Contudo, como este precisa conhecer referenciais e utilizá-los na prática pedagógica, é recomendável que se aproxime de experiências sistematizadas, teorias, pesquisas e, sobretudo, que participe de oficinas práticas no seu campo de saber ${ }^{11}$.

\section{Formação de professores e prática docente}

Para que as teorias e metodologias traduzam-se em avanços concretos na sala de aula, é essencial que se leve a sério a formação de professores. E, como as demais áreas que compõem o currículo, o Teatro precisa de profissionais com conhecimentos adequados para a tarefa da escolarização - não o professor faz de conta que atua improvisadamente e torna tudo superficial, nem tampouco o profissional deus ex machina que tudo sabe da linguagem artística e que, a cada situação, lança mão de seus poderes miraculosos. Num momento de crise na educação, faz-se necessário redirecionar a formação inicial e o aperfeiçoamento contínuo dos docentes, tendo em vista a grandeza da missão que cabe a esses profissionais.

A tarefa de preparar educadores é de toda a sociedade, cabendo às universidades e aos órgãos executores do ensino empreender ações objetivas, visando traduzir o estado do conhecimento que se tem acerca do assunto frente às perplexidades instauradas no processo da escolarização.

Pensando-se na sala de aula, não é mais possível conceber uma formação tradicionalmente dicotômica; não tem mais lugar também a abordagem polivalente que, por ser vazia de conteúdo, concebe um profissional cujo perfil assemelha-se à imagem pejorativa do pato - nada sem mergulhar, tem asas mas não voa e anda desengonçado. Na condição humana que se apresenta nesse fim de século, seria mais interessante considerar a metáfora sugerida por Leonardo Boff:

Cada um hospeda dentro de si uma águia. Sente-se portador de um projeto infinito. Quer romper os limites apertados de seu arranjo existencial. Há movimentos na política, na educação e no processo de mundialização que pretendem reduzir-nos a simples galinhas, confinadas aos limites do terreiro. Como vamos dar asas à águia,

\footnotetext{
${ }_{10}$ BRASIL. Ministério da Educação. Parâmetros curriculares nacionais da área de arte: I e II ciclos. Brasília, DF: 1997. p. 105.

${ }^{11}$ Refiro-me aqui ao trabalho de professores que construíram teorias a partir de suas práticas institucionais, a exemplo de Ingrid Dormien Koudela/USP e Helena Barcelos/UnB (in memorian), dentre outros. Refiro-me também a livros como os de Viola Spolin, especialmente Theatre game file (SPOLIN, Viola. Theatre game file. Evanston: Northwestern University Press, 1989), que detalham com precisão métodos de ensino em Teatro. Não existem muitas obras publicadas no Brasil a esse respeito - mesmo esta nunca foi traduzida -, embora um número considerável de relatórios de pesquisa, dissertações e teses comprovem a existência de boas referências.
} 
ganhar altura, integrar também a galinha e sermos heróis de nossa própria saga ${ }^{12}$ ? REFERÊNCIAS

BARBOSA, A. M. A imagem no ensino da arte. São Paulo: Perspectiva/Iochepe, 1991.

BARRET, G. Le spécialiste en théâtre éducation: une personnage étrange entre-deux. IDEA Journal: Polyphonic voices, rainbow worlds: one destiny, v. 1, n. 1, p. 6-8, 1997.

BOFF, L. A águia e a galinha: uma metáfora da condição humana. São Paulo: Vozes, 1997.

BRASIL. Ministério da Educação. Parâmetros curriculares nacionais da área de arte: I e II ciclos. Brasília, DF: 1997.

CANCLINI, N. G. Culturas híbridas: estratégias para entrar e sair da modernidade. São Paulo: EDUSP, 1998.

COLL, C. Psicologia e currículo: uma aproximação psicopedagógica à elaboração do currículo escolar. São Paulo: Ática, 1996.

COMBS, C. E. The drama/theatre/artist/teacher/educator/scholar matrix. IDEA Journal: Polyphonic voices, rainbow worlds: one destiny, v. 1, n. 1, p. 10-13, 1997.

NUNES, B. Educação artística e filosofia da arte. Rio de Janeiro: MEC: FUNARTE, 1986.

SANTANA, A. N. P. Reconsiderando o ensino de artes cênicas. In: CONGRESSO NACIONAL DA FEDERAÇÃO DE ARTE EDUCADORES DO BRASIL, 11., 1998, Brasília. Anais... Brasília, DF: FAEB, 1998.

SOMERS, J. Drama and theatre in education: contemporary research. Ontario: Captus University Publications, 1996.

SPOLIN, Viola. Theatre game file. Evanston: Northwestern University Press, 1989.

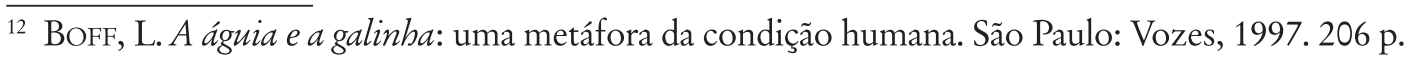




\section{DOROTHY HEATHCOTE: MEDIAÇÃO E INTERVENÇÃO NA CONSTRUÇÃO DA NARRATIVA TEATRAL EM GRUPO}

Beatriz Cabral (Biange)

Este estudo focaliza as similaridades entre as abordagens de Dorothy Heathcote ${ }^{1}$, Augusto Boal e Bertolt Brecht, chamando atenção, particularmente, para o potencial da forma de "intervenção", usada por Heathcote para intensificar a dimensão crítica na prática usualmente fragmentada do teatro no contexto curricular. A partir destas similaridades é possível observar mais claramente o 'particular' do estilo da autora - a forma pela qual ela, continuamente, amplia e ressalta a qualidade da contribuição do aluno.

Heathcote promove experiências de drama a partir de materiais históricos: fatos, documentos, objetos, fragmentos de texto de autores diversos. Sua abordagem é totalmente oposta à representação. Caracteriza-se como intervenção. Como resultado, desenvolve uma narrativa coletiva similar a uma colagem, e os elementos desta colagem podem ser reorganizados novamente em qualquer direção e a partir de outra perspectiva. A intervenção se dá ao nível da estrutura e do questionamento - os significados são produzidos pelos participantes e por eles transformados; não há assim uma 'verdade' autoral estabelecida pelo professor. No drama, e em especial na abordagem de Heathcote, o material oferecido aos alunos (imagens ou textos) é desconstruído; torna-se uma pista para mediar as interações.

Tal como Boal e Brecht, Heathcote manifesta uma preocupação com a forma: confrontos espaciais, signos visuais de linguagem (cartões, posters, banners, rótulos, manchetes), atuação dialética através de uma troca de enquadramentos e papéis, foco no gesto (identidade a partir de um código de relações sociais).

Os três teatrólogos, na esfera da pedagogia, usam intencionalmente a lógica e a linguagem para trazer à tona as contradições dos personagens e sua história. Neste sentido, a dialética é sua piéce de rèsistance. Associar a dialética ao pós-modernismo pode parecer contraditório; entretanto, a dialética hoje é reconhecida como parte da natureza da comunicação humana. De acordo com Elizabeth Wright, "a dialética é

${ }^{1}$ Dorothy Heathcote é considerada a criadora do process drama, forma teatral inglesa, desenvolvida no contexto escolar, e equivalente ao Teatro-Educação brasileiro. 
o padrão de mudança de qualquer conceito ou significado que resulta da colocação da fonte de referência em um novo contexto de relevância, uma nova perspectiva intencional"'.

Os críticos de Brecht apontaram para o fato de que "o foco na forma reduz o elemento dialético das peças em tal grau que nada resta lá a não ser a dialética ${ }^{3 "}$. Porém, não apenas Brecht, mas também Boal e Heathcote, em diferentes culturas e através de métodos distintos, usam a forma para desafiar os códigos de representação aceitos e estabelecidos. É jogando com a forma que eles interrompem, congelam e marcam a ação, a fim de salientar as contradições da ordem social.

\section{Brecht e Boal na perspectiva do drama inglês}

Dois artigos são referenciais para se considerar a influência de Brecht e Boal na prática do teatro na escola nos países de língua inglesa: "Ways of seeing"4 e "Dra-

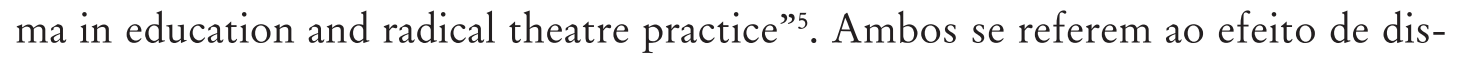
tanciamento e ao lugar do espectador na aula de drama.

O’Neill observou em 1989:

[...] a única experiência de platéia que os participantes deveriam ter durante uma aula de drama seria quando 'apresentações em pequenos grupos' ou improvisações 'polidas'fossem compartilhadas com o restante da turma, usualmente como conclusão de um trabalho. Esta é talvez o tipo de platéia menos útil para interpretar ou ser parte do processo. Tal platéia pode ser egoísta, crítica ou mesmo destrutiva em suas respostas $[\ldots]^{6}$.

Alternativamente, ela chama atenção para a dupla realidade de ser participante e espectador ao mesmo tempo, e lembra que Boal esclareceu a natureza desta dupla realidade, desenvolvendo um método onde os espectadores não só recebem idéias, mas também sobem ao palco e as praticam, criando uma dupla consciência, por ele denominada 'metaxis'.

Mas, se para Boal os espectadores são observadores ativos que supostamente intervém na ação como indivíduos, o 'espectador consciente’ de O’Neill implica um grupo com 'unicidade de resposta':

O contágio social opera para criar pressão em direção a uma conformidade do grupo, acordo e aceitação [...] o professor de drama pode controlar esta energia do grupo, ampliar seu efeito e forçar o acordo, especialmente nas etapas iniciais do trabalho, para estabelecer o contexto dramático'.

${ }^{2}$ WRIGHT, Elizabeth. Post-modern Brecht. Londres: Routledge, 1984. p. 14.

3 WRIGHT, 1984, p. 15.

${ }^{4}$ O’NEILL, Cecily. Ways of seeing: audience function in drama and theatre. 2D, n. 8, p. 17-29, 1989.

${ }^{5}$ LACEY, Stephan; WOOLLAND, Brian. Drama in education and radical theatre practice. New Theatre Quarterly, v. 8, p. 4-15, 1992.

6 O'NEILL, 1989.

7 O’NEILL, 1989. 
É possível atingir este estado mental através do 'professor-personagem' (teacher-in-role) e O'Neill comenta sobre a habilidade de Heathcote para tornar o grupo espectador de seu papel. Esta uniformidade de resposta é atingida, ela argumenta, quando a ambivalência de sentimentos é a resposta individual predominante. Esta ambivalência é algo que Heathcote explora de forma positiva, diz O’Neill, trabalhando papéis com potencial para provocar hostilidade (comandante militar, guardião de prisão, etc.), os quais unem o grupo contra ela e, conseqüentemente, reforçam e fortalecem os papéis dos alunos.

Além dessa unicidade de resposta ao professor-personagem, a ambivalência de operar em dois níveis ao mesmo tempo estimula os alunos a trabalhar, segundo Ken Robinson", "com um forte sentido de ser espectador de si mesmos e de suas próprias ações". É a partir desta combinação de participante e espectador que Gavin Bolton constrói a idéia de "percipiente", para designar o participante ativamente engajado naquilo que ele observa e responsável por criar a cena ou apresentação em primeira mão. De acordo com O'Neill, o "percipiente" resulta do entendimento de Bolton de que a luta dos professores para promover a reflexão dentro do processo dramático tem sido inimiga da forma, uma vez que seria necessário interromper a atividade para conseguir um tempo para reflexão. O conceito de percipiente introduz a idéia de que a observação é possível em ação, isto é, sem interromper o processo dramático.

Para O'Neill, o percipiente ou a mente de espectador (o estado mental de ser espectador) deve estar presente no fazer teatral, "pois, se sairmos completamente da ação para iniciar a reflexão, podemos descobrir que não há nada lá para ser refletido". Como um exemplo de "observar" enquanto um princípio estrutural no drama, a autora cita as estratégias de enquadramento de Heathcote, as quais estabelecem a observação e o julgamento a partir do início da atividade, através dos papéis escolhidos para os alunos (vide na frente).

\section{O relacionamento espectador-ator}

Para Lacey e Woolland ${ }^{10}$, "o Drama Educação não apenas se entrelaça com o teatro por caminhos marginais, mas é em si uma forma de prática teatral”. Eles ilustram seu argumento discorrendo sobre aspectos do modernismo pós-Brechtiano na Inglaterra, principalmente sobre a influência de Augusto Boal e Paulo Freire na prática do drama. Em vez de focalizar o percipiente, eles analisam a troca de funções durante a atividade - os participantes como platéia, uns dos outros.

Os autores enfatizam que para Brecht, a forma não é apenas o que é dado aos participantes para ser interpretado, mas é também o que deve ser negociado. A decorrência foi colocar o espectador no centro do debate e a criação da Lebrstuck ${ }^{11}$. As lehrstücke, segundo Lacy e Woolland, foram criadas, inicialmente, para uso com um

\footnotetext{
${ }_{8}^{8}$ ROBINSON, Ken. Exploring theatre and education. Londres: Heinemann, 1980. 185 p.

9 O'NEILL, 1989.

${ }^{10}$ LACEY; WOOLLAND, 1992.

${ }^{11}$ Brecht traduziu Lehrtuck como 'learning play' (peça de aprendizagem) em seu ensaio "Das deutsche Theatrer der Awanziger Jahre", Arquivo Bertolt Brecht 147/33-36. Referência de Reiner Steinweg em KOUDELA, Ingrid. Brecht: um jogo de aprendizagem. São Paulo: Perspectiva, 1991. p. 98.
} 
grupo de participantes sem a presença de um público além dos próprios atores. $\mathrm{O}$ objetivo era transformar a arte numa prática social através de um processo de observação e ação, trabalhar e re-trabalhar o texto, o qual estaria sempre aberto a mudanças.

Boal baseou seu método em Brecht e na pedagogia radical de Paulo Freire. Ambos focalizam o conceito de "práxis" e enfatizam que nós podemos compreender e transformar o mundo através da associação entre teoria e prática, isto é, através da reflexão e da ação. No âmbito da metodologia, esta perspectiva propõe um experimentar de alternativas baseadas na escolha do espectador, e abre espaço para tomadas de decisão, o que oferece meios de controle significativos ao observador-participante. Segundo Boal, o espectador "delega poder ao ator, que então age em seu lugar”. Lacey e Woolland exemplificam sua prática com esta atuação de expectativas através da descrição de uma aula onde os personagens não são apenas vistos ser construídos, são também propositalmente criados por espectadores ativos.

\section{O espectador de si mesmo (self-spectator)}

Os ensaios comentados acima se referem às influências de Brecht e Boal no Drama, mas suas abordagens ao papel do espectador no desenvolvimento do texto coletivo são bem distintas.

Em Ways of seeing, O’Neill ${ }^{12}$ enfatiza o espectador implícito como a contribuição mais útil para manter o envolvimento com o processo dramático e evitar a separação entre ação e reflexão. O conceito de "metaxis" é observado em sua dimensão temporal - como uma dupla consciência de pertencer a dois mundos ao mesmo tempo.

Para Lacey e Woolland, observar e atuar são atitudes distintas quanto às dimensões formais e temporais. Metaxis, para eles, significa a possibilidade do ator manter ambos os papéis, observador e ator, em diferentes momentos. Como observadores, eles são capazes de sugerir alternativas para aquilo que lhes foi apresentado.

Entretanto, as duas abordagens são mais similares do que parecem. A similaridade reside no fato de que não há platéia além do próprio grupo. Quando este se subdivide em pequenos grupos ou equipes, todos estão envolvidos no mesmo evento e suas alternativas respondem ao mesmo contexto de ficção.

Qual a origem pedagógica desta perspectiva metodológica?

A partir de 1930, Brecht passou a insistir em uma "regra básica" para diferenciar o jogo de aprendizagem da peça épica: "atuar para si próprio é o pressuposto para a realização do jogo de aprendizagem como um ato artístico ${ }^{13}$ ”. Segundo Walter Benjamin, "o jogo de aprendizagem figura como uma situação específica devido à sua pobreza de aparato, simplificando o relacionamento entre ator e espectador. Cada espectador é, ao mesmo tempo, um observador e um ator ${ }^{14 "}$. A influência de Brecht na prática do Drama se refere principalmente a este aspecto de sua teoria da aprendizagem: não sendo platéia das apresentações de outras pessoas, os participantes tornam-se espectadores de si mesmos ${ }^{15}$, de seus próprios argumentos e atitudes.

\footnotetext{
12 O’NEILL, 1989.

13 STEINWEG, Reiner. Das lebrstuck. Stuttgart: Metzler, 1972. p. 87.

14 BENJAMIN, Walter. Versuche über Brecht. Frankfurt: Sührkamp, 1981. p. 36.

15 Dorothy Heathcote cunhou a expressão "self-spectator" (auto-espectador) para identificar a situação aqui descrita como "espectador de si mesmo".
} 


\section{Implicações da influência de Brecht e Boal no Drama}

O trabalho didático de Brecht estava baseado não apenas em textos, mas em bons textos. As Lehrstücke contêm um teor desafiante (quanto à forma e ao assunto) e de grande dramaticidade, que chamam por diferentes atitudes e permitem desvelar vieses ideológicos.

Boal re-trabalhou os critérios de Brecht e introduziu novas convenções para aumentar o distanciamento entre o observador e o personagem, por exemplo, o "sistema coringa", através do qual os atores se alternam para representar a mesma personagem. Boal não usa texto, mas trabalha com um grupo de atores com habilidades para aceitar as sugestões da platéia e experimentá-las para checar possíveis alternativas para o problema ${ }^{16}$. Para traduzir estas experiências para o Drama, em sala de aula, sem um texto dramático ou atores que interpretem as contribuições dos espectadores, a ampliação do campo de referências e do conceitual dependerá do input do professor. Isto se refere tanto à qualidade da atuação do professor (pedagógica ou artística), quanto ao(s) texto(s) usado(s) para engajar os participantes com a construção verbal (falada, escrita ou cantada) e visual (física, espacial e cênica) do processo do Drama. Um procedimento que assegura ao professor a delimitação de um campo de atuação, onde poderá ampliar, gradualmente, a introdução de referências, problemas a serem resolvidos, e desafios (confrontos), sem perder a coerência interna da narrativa em construção, tem sido o uso de um texto como pré-texto.

O texto, como pré-texto, segundo Cecily O’Neill, “opera em diferentes momentos como uma espécie de 'forma-suporte' para os demais significados a serem explorados ${ }^{17}$ ". Como pano de fundo, o texto torna-se uma referência para alternativas de ações, e subsidia o professor na seleção e orientação dos jogos teatrais na identificação do contexto e na busca de coerência interna para a narrativa em processo.

A noção de pré-texto indica a necessidade de desconstruir o texto dramático a fim de adaptá-lo às condições e motivações do grupo, ou introduzir parâmetros artísticos de estrutura e linguagem a fim de transgredir os limites do cotidiano e do “já visto”. Trata-se de um procedimento metodológico que permite, por um lado, delimitar as interações dos participantes a partir do cruzamento de fragmentos do texto com histórias de vida, e, por outro lado, ampliar as formas de olhar e entender o texto e a cena através do jogo teatral. Entretanto, a re-construção do texto dramático ou a criação coletiva a partir de fragmentos do texto, exige a habilidade de um dramaturgista. No contexto escolar, esta constatação exige uma investigação metodológica contínua.

A preocupação com o que os alunos aprendem ao participar do Drama tem sido expressa e analisada por David Hornbrook, o qual sugere que devemos investigar métodos que possibilitem aos alunos seu desenvolvimento como leitores do Drama, como espectadores das histórias de outras pessoas, tornando-se assim "al-

\footnotetext{
$\overline{16}$ Não estou incluindo aqui o "teatro de imagens", por considerá-lo uma estratégia e não uma forma teatral que introduza elementos da linguagem cênica - estes podem ser trabalhados se o professor acrescentar outras estratégias de leitura ou construção da cena.

${ }_{17}$ O’NEILL, Cecily. Dram worlds: a framework for process drama. Londres: Heinemann, 1995. p. 22.
} 
fabetizados nas questões do palco ${ }^{18}$.

Em princípio, pode-se argumentar que "alfabetizar em teatro" depende mais da habilidade do professor para estruturar a atividade, selecionar as convenções apropriadas e apontar as múltiplas faces do texto teatral durante seu processo de criação do que da seleção de um texto, gênero ou tema.

$\mathrm{O}$ fato de que muitos professores se eximem de trabalhar com montagens no contexto escolar é tão verdade quanto aquele dos professores que costumam envolver os alunos com uma peça simplesmente pedindo que distribuam os personagens entre si, memorizem e apresentem o texto. Parâmetros curriculares, semana de planejamento e coordenação de área ajudam apenas em parte, se o professor não tiver habilidade, conhecimento específico e experiência para estruturar e seqüenciar o trabalho, de maneira a possibilitar que os alunos percebam e compreendam as regras e convenções teatrais durante o desenvolvimento do processo dramático enquanto as usam. É esta compreensão que irá permitir que eles se tornem leitores críticos tanto de espetáculos teatrais quanto de outros meios de comunicação. $\mathrm{O}$ importante aqui é que o drama, quer desenvolvido como construção coletiva com base na escolha temática dos alunos, quer a partir de um texto dramático, exige um considerável input do professor durante o processo de descoberta gradual do texto e de seus subtextos potenciais. Em ambos os casos, o papel do leitor e o espaço da leitura são fundamentais.

\section{Dorothy Heathcote - significação em processo}

Muito tem sido escrito a respeito da influência de Dorothy Heathcote sobre os professores de Drama e o alto grau de intervenção de seu modo de ensino. $\mathrm{O}$ argumento, aqui, é que este consiste em um método dialético, no qual a intervenção funciona como um quebra-cabeça que oscila constantemente entre os níveis metodológico e ideológico. No seu aspecto externo, a intervenção reside na esfera da metodologia - ao estruturar e seqüenciar o trabalho - cada tarefa proposta por Heathcote põe em cheque a criação anterior e traz à tona as implicações das atitudes tomadas pelos alunos na tarefa precedente. Quanto ao nível ideológico, a intervenção de Heathcote tem como foco o "leitor"19 - ela aceita todas as contribuições dos alunos e interage com eles através de desafios postos pelas tarefas que vai introduzindo a seguir. Pode-se dizer que ao selecionar as convenções e estratégias e em dar prosseguimento à narrativa, Heathcote administra a percepção dos participantes sobre a situação em pauta e, desta forma, intervém ideologicamente no processo.

Entretanto, embora ela determine o material de trabalho ${ }^{20}$, ao introduzi-lo e propor as tarefas para sua exploração, os alunos o lêem e o usam à vontade. Sua intervenção não é explícita; ocorre indiretamente, através de tarefas que tornam evidente as implicações das ações tomadas anteriormente. A cada novo

\footnotetext{
${ }_{18}$ HORNBROOK, David. Education in drama. Londres: Falmer Press, 1991. p. 6.

${ }_{19}$ O conceito de leitor, que nas recentes teorias de produção e recepção adquiriu um forte sentido de "produtor de significados", mantém aqui as noções de espectador e percipiente; e tem sido comumente usado para afirmar a autoria do aluno sobre o texto que está sendo produzido. ${ }^{20}$ Material de trabalho refere-se aqui a tudo o que o professor introduzir para iniciar o Drama ou durante seu processo - texto ou fragmentos de texto, objetos de cena, fotos e outros impressos, figurino, etc.
} 
episódio, Heathcote leva em consideração as decisões e ritmo dos alunos, tal como observados na etapa anterior - isto torna possível dizer que são os alunos que, em última instância, definem a seqüência e a estrutura do trabalho, e que sua abordagem dialética leva a um processo contínuo de ampliar e aperfeiçoar as formas de recepção dos participantes.

Trata-se assim de um método de trabalho onde o professor amplia e aperfeiçoa o conteúdo (o quê está sendo investigado cenicamente) através da forma (o como está sendo trabalhado).

A participação em processos de Drama coordenados por Heathcote, entre os anos de 1990 e $1994^{21}$, permitiu-me observar um padrão comum às diferentes experiências:

- o professor "lê" tanto o contexto quanto a atitude dos participantes, e questiona o conhecimento destes sobre o assunto a ser investigado através do Drama;

- o professor amplia e realça a contribuição do aluno, reformulando-a ou salien tando aspectos que possam representar boas oportunidades de aprendizagem;

- o professor pinça no Drama em andamento um problema com potencial dramático, introduz uma nova convenção e direciona o processo nesta direção;

- o professor desafia a leitura que os participantes fazem das circunstâncias que estão sendo exploradas, principalmente através da introdução de novas convenções que promovam uma troca entre expressões verbais e visuais;

- o ponto de vista ou perspectiva predominante no desenvolvimento de um episódio será o ponto de partida do próximo.

\section{O bom samaritano}

"Um homem caminhava de Jerusalém para Jericó quando caiu nas mãos de assaltantes. Os ladrões tiraram tudo o que ele tinha, bateram nele e o deixaram semimorto à beira da estrada. Aconteceu que um padre seguia pela mesma estrada; mas quando ele o viu, passou para a outra margem. Assim, também um Levita chegou ao local e quando o viu passou para o outro lado. Mas um samaritano que estava fazendo a mesma jornada, chegou até ele e ao vê-lo foi tomado pela piedade. Ele o levantou e fez uma bandagem em seus ferimentos, banhando-os com óleo e vinho. Então, ele o colocou em seu próprio animal e o levou consigo para uma estalagem, cuidando dele ao chegar. No dia seguinte, ele deu duas moedas de prata ao estalajadeiro e disse, 'cuide dele; se você gastar mais, eu lhe re-embolsarei em meu caminho de volta"'22.

Dorothy Heathcote, ao propor o uso de O bom samaritano como pré-texto em um seminário do curso de Mestrado em Drama Educação, na Politécnica de Birmingham em 1992, salientou a importância de o professor lembrar dois procedimentos básicos para se iniciar qualquer processo de drama:

1. achar o elemento de tensão em cada episódio, sempre lembrando que lidar

\footnotetext{
${ }^{21}$ Neste período, participei dos seguintes trabalhos: "Mary Morgan", "O bom samaritano", "Dr Knox", "Vivendo sob uma ditadura", "Channel Islands durante a ocupação nazista", "O projeto de pesquisa Oxfam", todos disponíveis em vídeo no Centro de Estudos em Drama na Educação, da University of Central England, em Birmingham.

${ }_{22}$ Lucas 10, 29-35
} 
com limitações evita que nos fixemos nas circunstâncias. Por exemplo, o homem não poderá evitar a viagem, mesmo sabendo ser ela perigosa;

2. a tarefa escolhida não deve ser negociada, pois o tipo de aprendizagem gerado relaciona-se com ela. Cabe ao professor determiná-la.

De acordo com Heathcote, o professor deve definir os elementos de tensão e tarefas para cada episódio a partir do enquadramento e perspectiva da cena. Com a parábola do samaritano, ela pretende levar os participantes a considerar a natureza de correr riscos, aqui decorrentes da ajuda a inimigos moribundos. Assim, seja qual for o enquadramento escolhido, o objetivo da escolha é se aproximar deste entendimento sobre a natureza dos riscos. Os diferentes enquadramentos vão determinar o relacionamento do grupo com a parábola e seu olhar sobre as situações propostas em cada episódio. Como ressalta Heathcote, em sua prática, se as crianças querem uma "batalha”, rememorá-la, compreendê-la e entender suas estratégias é de diferente ordem do que interpretá-la.

Perspectivas de Enquadramento - alternativas para O bom samaritano:

Agente: como argumento é proposto um programa de TV, onde um comerciante aleijado (juntamente com seu libertador) está relembrando o momento em que foi atacado. O programa dará a seu salvador uma medalha de bravura. O contexto requer uma imagem acurada e detalhada - repórteres, câmera, som, tribunal. A violência seria demonstrada e não interpretada - não haveria o fazer de conta.

Observação: a linguagem gerada é a de um quadro sobre como "as coisas eram” na época em que ocorreram. Há distanciamento e os papéis são de intermediários - os agentes que construirão a imagem do passado.

Guia: pastores encontraram evidências de que pessoas andam usando seu abrigo - sinais de cavalos, lixo. À distância, observam um encontro entre ladrões e um comerciante. Ficam com medo de interferir, mas foram vistos pelos ladrões. $\mathrm{Na}$ vila, suas mulheres esperam ansiosas, vão ao seu encontro e os descobrem amarrados e bastante machucados.

Observação: a linguagem gerada é a dos que contam - eles viram - eles estavam lá. É importante que a violência haja ocorrido no passado, e que a tensão do momento presente esteja concentrada na impossibilidade de revidar. É fundamental que os alunos não sejam solicitados a fazer de conta que estão lutando, porque isto seria inverossímil e, portanto, ridículo.

Autoridade: os participantes, como os pastores e suas mulheres, são conduzidos ao templo para fornecer detalhes sobre rumores de que haviam sido atacados após um roubo, e que um padre e um Levita deixaram de socorrer o homem que fora ferido, passando com indiferença pelo local. Os pastores e as mulheres são pressionados a mudar de opinião e admitir que estavam enganados. A cena estará centrada na força da autoridade e na pressão. A classe representará as autoridades, o professor será o pastor que estará representando todo o grupo de pastores. O contrário seria problemático, pois o professor ao assumir um personagem de autoridade corrupto estaria ensinando posturas e linguagem equivalentes.

Observação: a linguagem gerada é a do questionamento sobre o assunto - exigir esclarecimentos, definições, explicações, de tal maneira que o registro seja útil 
para as investigações.

Repórter: os pastores já se incomodaram o suficiente com este evento e com o samaritano e não querem mais problemas. Eles se sentem ameaçados pela atitude de seus interlocutores. Formas distintas de entrevistas podem ser exploradas: direcioná-la para agradar as autoridades e considerar "o caso encerrado"; para realizar uma reportagem sensacionalista e mostrar "um mundo cão"; para estabelecer a ordem, identificando os responsáveis.

Observação: a linguagem gerada é de dois tipos: diálogo, durante a entrevista, e forma escrita ou narrada para veicular a notícia.

Pesquisador: um hospital a ser inaugurado pretende utilizar a parábola "O bom samaritano" como símbolo para divulgar que: a) eles dão assistência a todos que precisam de ajuda; b) dar assistência requer recursos financeiros, lugar seguro e tempo integral; c) todos podem ser bons samaritanos - basta querer.

Observação: a linguagem gerada é a da busca de como este evento será visto à luz das questões mais amplas. O grupo deverá incluir a história na logomarca e na divulgação do hospital. É necessário considerar que: a) o hospital precisa de alguma forma mostrar que existe; b) o planejamento do apelo - a forma, o estilo, os meios; c) a autorização daqueles que planejam.

Crítico: uma empresa de marketing preparou um programa referente à campanha do hospital e despertou tanto interesse que está concorrendo a um prêmio jornalístico. O material está sendo examinado por críticos que darão seu parecer posteriormente.

Observação: a linguagem gerada é a de pessoas que analisam e interpretam o evento a fim de expressar sua opinião sobre o assunto. $\mathrm{O}$ professor deve considerar que: a) o programa deve ser percebido como se realmente existisse; b) deve haver evidências comuns disponíveis a todos os participantes; c) deve haver meios de examinar estas evidências; d) é necessário tempo para absorver as evidências; e) é necessário tempo para comentar o estilo, a forma e o conteúdo; f) é necessário um público convidado pelos críticos.

As perspectivas de enquadramento apresentadas acima vão requerer papéis e funções distintas por parte dos participantes. Em decorrência, estes usarão linguagem e atitudes de acordo com sua função e status. Ao propor "O bom samaritano" como pré-texto, Heathcote conduziu um processo de Drama estruturado através de episódios, e indicou a alternativa de alterar a perspectiva de enquadramento da situação e do grupo em cada episódio, ou em grande parte deles. Neste sentido, foi possível observar e vivenciar a parábola sob perspectivas distintas. Ao fazer isso, os participantes percebem as implicações das atitudes tomadas, ou não tomadas, e usam jogos de linguagem próprios de cada contexto.

\section{Episódios: decomposição e significação}

Heathcote conduz processos de Drama caracterizados como uma seqüência de episódios delimitados pelo mesmo pré-texto. Cada episódio significa - em - si, isto é, focaliza um aspecto do pré-texto que é apresentado e apreciado independente do que o antecedeu. Trata-se de um processo de decomposição - de uma peça, um 
texto, um problema ético, de paradoxos e metáforas de ordem pessoal ou social que já possui um percurso traçado na área da pedagogia do teatro.

Ao analisar as cenas Brechtianas, Barthes parte da estética de Diderot e sua identificação entre cena teatral e pintura: "a peça perfeita é uma sucessão de quadros, isto é, uma galeria, uma exposição: a cena oferece ao espectador tantos quadros reais, quantos momentos há na ação, favoráveis ao pintor” ${ }^{23}$. No teatro épico de Brecht (que procede por quadros sucessivos), diz Barthes,

[...] toda a carga significante e aprazível incide sobre cada cena, não sobre o conjunto; ao nível da peça, não há desenvolvimento, não há amadurecimento, há um sentido conceptual, certamente (até mesmo em cada quadro), mas não há um sentido final, são apenas recortes, cada um com suficiente força demonstrativa ${ }^{24}$.

Esta carga significante e aprazível que incide sobre cada cena foi considerada posteriormente por Lessing como instantes plenos. O teatro de Brecht e o cinema de Eisenstein, diz Barthes, são seqüências de instantes plenos. $\mathrm{O}$ cinema de Eisenstein inclui todas as ausências (lembranças, lições, promessas), que tornam a história simultaneamente inteligível e desejável. Em Brecht, é o gestus social que retoma a idéia do instante pleno. Este:

[...] é um gesto, ou um conjunto de gestos (mas nunca uma gesticulação) onde se pode ler toda uma situação social [...] nem todos os gestus são sociais: não há nada de social no gesto que faz um homem para espantar uma mosca; mas se esse mesmo homem, mal vestido, debate-se contra cães de guarda, esse gestus torna-se social $[\ldots]^{25}$.

Para Brecht o gesto social pode ser observado até mesmo na língua. Uma linguagem pode ser gestual, ele afirma, quando ela indica certas atitudes que o orador adota em relação aos outros. Assim como a linguagem, as atitudes são socialmente construídas, e determinam a forma com que percebemos o mundo. Desvendar estas atitudes, e perceber o que Wittgenstein considera como "o poder enganador da linguagem" é o desafio da educação contemporânea. Segundo o filósofo, as formas de falar não são elementos isolados e sim uma parte profundamente arraigada de nosso estilo de pensar e expressar, que nos mantém sob controle ${ }^{26}$. Ele esclarece que não podemos forçar o pensamento, mas para se chegar a uma atitude pensante é necessário que se produza um corte. Ao longo de seu trabalho, fez algumas observações sobre a maneira pela qual podemos chegar a observações esclarecedoras ao abordar um fenômeno (ou problema) por uma perspectiva diferente: memórias, descrições, chistes, metáforas e ironia. Acima de tudo, buscar clareza e compreensão através da linguagem.

O trabalho de Heathcote revela um método de ensino centrado em diferentes níveis de intervenção do professor nas formas de ver o mundo e interagir em grupos, em torno de conflitos e solução de conflitos. Ao propor formas distintas de enquadra-

\footnotetext{
${ }^{23}$ BARTHES, Roland. O óbvio e o obtuso. 4. ed. Rio de Janeiro: Nova Fronteira, 1990. p. 86.

24 BARTHES, 1990, p. 87.

${ }_{25}$ BARTHES, 1990, p. 88.

26 HEATON, John M. Wittgenstein y el psicoanálisis. Barcelona: Gedisa, 2004. p. 14.
} 
mento para um mesmo texto ou pré-texto, ela está mudando perspectivas e priorizando a linguagem como forma de intervir na ação do grupo e levá-lo a interagir entre si e em relação ao texto e contexto. Segundo Heathcote, Drama não é um recontar de histórias; ao alterar perspectiva e função na investigação de atitudes e ações, o sujeito começa a notar novos aspectos da situação sendo explorados e os conflitos se dissolvem com a compreensão decorrente do que se diz e se faz no novo contexto. A situação de investigar um problema no decorrer de distintos episódios permite, assim, compreender e dar nome às confusões de linguagem e pensamento, esclarecendo as relações que se encontram em estado de confusão.

As diferentes formas de focalizar e analisar uma narrativa desenvolvida através de episódios têm em comum a identificação e acentuação de um foco de atenção para tornar cada momento significante em si. Em termos estruturais, é possível ter uma história, e dividi-la em episódios, a fim de explorar diferentes perspectivas ou enfatizar detalhes (processo de segmentação), ou ter um episódio inicial que irá gerar situações ou questões para novos episódios que deverão ser conectados posteriormente para formar a narrativa (processo de composição).

A importância de se considerar as formas de estruturar a narrativa em Teatro/ Drama-Educação está associada ao fato de que o crescimento e reconhecimento desta área do fazer teatral passa pela necessidade de estabelecer similaridades e diferenças com fazeres afins, condição esta que delimitará seu espaço entre as artes contemporâneas. 


\section{REFERÊNCIAS}

BARTHES, Roland. O óbvio e o obtuso. 4. ed. Rio de Janeiro: Nova Fronteira, 1990.

BENJAMIN, Walter. Versuche über Brecht. Frankfurt: Sührkamp, 1981.

CABRAL, Beatriz. Signs of a post-modern, yet dialectic, practice. Research in Drama Education, Oxford, v. 1, n. 2, p. 215-220, 1996.

HEATON, John M. Wittgenstein y el psicoanálisis. Barcelona: Gedisa, 2004.

HORNBROOK, David. Education in drama. Londres: Falmer Press, 1991.

KOUDELA, Ingrid. Brecht: um jogo de aprendizagem. São Paulo: Perspectiva, 1991.

LACEY, Stephan; WOOLLAND, Brian. Drama in education and radical theatre practice. New Theatre Quarterly, Cambridge, v. 8, p. 4-15, 1992.

O’NEILL, Cecily. Dram worlds: a framework for process drama. Londres: Heinemann, 1995.

O'NEILL, Cecily. Ways of seeing: audience function in drama and theatre. 2D, n. 8, p. 1729, 1989.

ROBINSON, Ken. Exploring theatre and education. Londres: Heinemann, 1980.

STEINWEG, Reiner. Das lehrstuck. Stuttgart: Metzler, 1972. 284 p.

TAYLOR, Philip (Ed.) Pre-text and storydrama: the artistry of Cecily O'Neill and David Booth. Austrália: NADIE, 1995. 55 p. (Research monograph series, n. 1).

WRIGHT, Elizabeth. Post-modern Brecht. Londres: Routledge, 1984. 


\section{Pedagogia do jogo teAtral: UMA POÉTICA do EFÊMERO ${ }^{1}$}

Carmela Soares

Como professora de teatro do sistema municipal e estadual do ensino público do Rio de Janeiro, procuro refletir, neste estudo, sobre as possibilidades de se realizar na prática, especificamente dentro da grade curricular, uma ação pedagógica condizente com os princípios da linguagem teatral. Neste sentido, atribuo ao jogo teatral, papel central na formulação de uma pedagogia, que se propõe a desenvolver e estimular a educação estética do aluno.

A grande questão que se coloca em evidência é que função o jogo teatral ocupa na práxis pedagógica?

E ainda, como o jogo teatral permite ao aluno encontrar o gancho do prazer e reconhecer a natureza e o valor estético do conhecimento?

Portanto, de que maneira, dentro do caos da sociedade contemporânea e dentro do contexto escolar, o aluno ainda pode encontrar e dar significado à sua vida e às ações humanas? Segundo Carlos Byington ${ }^{2}$, o aprendizado escolar e o desenvolvimento do ser humano devem passar pela capacidade do indivíduo e da escola de criar símbolos e imagens significativas ou "estruturantes do self" - de si mesmo - como ele denomina.

A função principal destas imagens é a de apoiar (no sentido de sustentar) a formação de uma personalidade integrada com o todo, a partir da visão de unidade, e não de fragmentação, que tem prevalecido no mundo contemporâneo. Certamente, proporcionar aos alunos uma educação estética é um dos grandes desafios da sociedade atual, uma vez que ela está sofrendo, em escala gigantesca, os clichês, as imagens e os símbolos de memória curta que os meios de comunicação de massa multiplica e reproduz.

Encontramos, assim, no ato de levar o jogo teatral para a escola, um meio valioso de proporcionar ao aluno uma educação estética, fundada na experimentação, na relação sensível e direta com o espaço e com o outro, na produção e apreciação de formas e imagens teatrais, que lhe permitam experimentar e criar novos universos simbólicos, dotados de maior significação para sua vida.

\footnotetext{
${ }^{1}$ Este artigo teve origem a partir de minha dissertação de mestrado, intitulada Pedagogia do jogo teatral. SOARES, Carmela. Pedagogia do jogo teatral: uma poética do efêmero. O ensino do Teatro na Escola Pública. 2003. Dissertação (Mestrado) - Centro de Letras e Artes, Universidade Federal do Estado do Rio de Janeiro, Rio de Janeiro, 2003.

2 BYINGTON, Carlos Amadeu Botelho. Pedagogia simbólica: a construção amorosa do conhecimento do ser. Rio de Janeiro: Record: Rosa dos Tempos, 1996.
} 
Em sua natureza, o jogo teatral pressupõe a invenção e a reinvenção, a partir do vazio; dos jogos de corpos e do uso do espaço, nas condições em que se apresenta. E até mesmo da falta. Da falta de interesse dos alunos, da falta de escuta, da falta de comunicação, da falta de auto-estima e, principalmente, da falta de otimismo que caracteriza os jovens de nosso país, muitas vezes massacrados por uma realidade social, familiar e escolar, que os distancia de si mesmos e de seu poder e direito de expressão.

Partindo-se desta perspectiva, o jogo teatral é elevado à categoria de objeto estético, ou seja, possui uma elaboração formal e, enquanto tal, é produtor de uma teatralidade em sala de aula, que poderá ser reconhecida e apreciada à medida que o olhar do aluno, como também do professor, for trabalhado nesta direção.

Esta teatralidade, no entanto, tem características particulares ao contexto escolar e está sujeita a inúmeras variáveis. Seu aspecto é tênue, impreciso e manifesta-se em meio à profusão de corpos, gestos, sons, ruídos, num movimento de ordem e desordem, característico da sala de aula. Ela não se define como no teatro profissional, por seu alto grau de acabamento formal, mas, mesmo assim, pode ser reconhecida, enquanto forma expressiva dotada de qualidades estéticas.

Enquanto objeto estético, o jogo teatral comporta, em sua análise, dois elementos distintos e complementares: um elemento material e outro não material. Isto significa que, se por um lado, o jogo teatral pode ser reconhecido por suas características formais, isto é, por seu aspecto concreto, visível e sensível, possui também uma dimensão simbólica, ou seja, é da ordem do vivido, da experiência e, enquanto tal, é capaz de colocar o aluno em contato com o dentro e o fora de si mesmo. Assim, através de um substrato material próprio da linguagem teatral, podemos ver surgir, em sala de aula, imagens poéticas de grande significação para os alunos. Traduzidas em sensações, sentimentos, pensamentos e percepções interiores, estas imagens nascem da relação de troca entre o sujeito - jogadores e espectadores - e o objeto, ou seja, as formas sensíveis geradas no decorrer do próprio jogo.

Assim, a noção do objeto estético permite-nos reconhecer que o jogo teatral praticado em sala de aula comporta um sentido que pertence à própria esfera da experiência do teatro, compreendida como um acontecimento único, realizado no momento presente e dotado de uma carga expressiva capaz de despertar, no aluno, o conhecimento de si mesmo e do mundo.

Portanto, onde reside a beleza do jogo teatral realizado em sala de aula?

Segundo Duarte ${ }^{3}$, a beleza não é atributo ou propriedade que pertença ao sujeito ou ao objeto, mas se localiza nesta zona de encontro entre um e outro.

A beleza habita a relação. A relação onde os sentimentos entram em consonância com as formas que lhes tocam, vindas do exterior. O prazer estético reside na vivência da harmonia descoberta entre as formas dinâmicas dos sentimentos e as formas da $\operatorname{arte}^{4}$.

${ }^{3}$ DUARTE JÚNIOR, João Francisco. Fundamentos estéticos da educação. 2. ed. Campinas, SP: Papirus, 2000.

${ }^{4}$ DUARTE, 2000, p. 93. 
Da mesma maneira, a beleza do jogo teatral reside neste espaço intermediário entre sujeito e objeto, que Winnicott ${ }^{5}$ denomina de "espaço em potencial”. Segundo este autor, o jogo tem localização particular, ocorre num entre dois, não está nem dentro e nem fora do sujeito, mas se dá nesta relação de troca, de intercâmbio, entre sujeito e objeto, entre realidade e fantasia. É então, por meio do jogo, que o homem assume, em relação à realidade, uma postura ativa e dinâmica de transformação da mesma. Por conseguinte, é jogando que o homem atribui sentido e significado à vida. A realidade é, desta maneira, uma criação do indivíduo que joga. Aqueles que têm prejudicada sua "capacidade jogo" ou interação lúdica com a realidade, encontram-se num estado de total "submissão", de indiferenciação em relação a si mesmo e ao outro, o que termina por acarretar no indivíduo problemas de ordem psicológica.

O "espaço intermediário" característico do jogo, como define Winniccott ${ }^{6}$, é também o espaço da experiência estética, "o playground”, ou mais especificamente, "o campo de experimentação criativa da realidade", que permitirá ao bebê e, mais tarde, ao homem, em relação a este mundo, desenvolver um sentimento de pertencimento, de integração, de totalidade e, ao mesmo tempo, descobrir sua própria singularidade.

$\mathrm{Na}$ experiência estética com o jogo teatral, a consciência do aluno é lançada neste espaço intermediário, onde a percepção do objeto passa a ocorrer a partir de uma consciência mais expandida em que cabe aos sentimentos e às sensações, diferentemente, da consciência prática (no sentido de apenas conceitual, racional), orientar a relação sujeito-objeto, agora dentro de uma perspectiva de totalidade.

Ao conceber a noção de "espaço-vazio", inspirado no pensamento de diversas culturas, verificamos que Brook ${ }^{7}$ também nos remete à idéia do terceiro espaço, ou seja, do "espaço em potencial", definido por Winnicott. No "espaço-vazio", o sentimento de dualidade, provocado pela vivência de separação sujeito-mundo, é superado. O jogador, através de uma atitude lúdica, que comporta o inesperado, entrega-a ao momento presente, alcançaria uma área de silêncio que corresponderia à experiência do sagrado, do absoluto ou da totalidade, em que sujeito e mundo são percebidos como partes integrantes e, ao mesmo tempo, diferenciadas de uma mesma realidade.

Pela concepção do "espaço vazio", as ações cênicas não estariam restritas ou limitadas a construções mentais, mas surgiriam de dentro de um espaço interior amplo, aberto, enraizado. A partir deste espaço, não é preciso "fazer nada”, não é necessário "pensar em nada": toda ação nasce espontaneamente da completa presença e disponibilidade do ator em cena. Quando o ator alcança este espaço, ele está totalmente imerso num estado criativo. Não recorre a clichês ou a ações mecânicas como forma de expressão, mas é capaz de se colocar aberto e sem medo, diante das incertezas que este lugar provoca.

Para $\mathrm{Brook}^{8}$, no teatro, a intensa atividade mental que dirige as ações humanas, principalmente do homem ocidental, a partir do espaço-vazio, cede lugar à vivência de uma experiência sensível e direta com a realidade cênica e, portanto, mais

\footnotetext{
${ }_{5}$ WINNICOTT, Donald Woods. O brincar e a realidade. Rio de Janeiro: Imago, 1975. p. 71.

6 WINICOTT, 1975.

7 BROOK, Peter. A porta aberta: reflexões sobre a interpretação e o teatro. Tradução Antônio

Mercado. 2. ed. Rio de Janeiro: Civilização Brasileira, 2000. p. 19.

${ }^{8}$ BROOK, 2000.
} 
autêntica e viva. Por isso, mais do que um espaço físico despojado, "o espaço-vazio" consiste numa disponibilidade interna de se dar ao jogo, que gera, por sua vez, a capacidade de reconhecer a beleza que permeia as relações e as formas.

$\mathrm{Na}$ escola pública, podemos perceber que grande parte dos alunos vive o desafio de existir verdadeiramente, ou seja, de superar o estado de "submissão" ou esquecimento a que muitos estão sujeitos. Encontramos, pois, no jogo teatral uma possibilidade de despertar o aluno para este "espaço-vazio", para este "espaço em potencial”, autêntico, criativo em cada um.

Para compreendermos a experiência de beleza proporcionada pelo jogo teatral em sala de aula, é importante recorrermos também às idéias de Huizinga a a respeito do jogo. Huizinga aproxima o jogo do domínio da estética ao esclarecer que ele produz ordem e é ordem. "Os laços que unem o jogo e a beleza são muitos e bem íntimos. Em suas formas mais complexas, o jogo está saturado de ritmo e harmonia, que são os mais nobres dons de percepção estética de que o homem dispõe". Descrevendo as qualidades formais do jogo, ele destaca: a intensidade, a tensão ou a incerteza, o prazer, o divertimento, a atividade voluntária, o caráter desinteressado do jogo, sua delimitação em limites de espaço e tempo, a criação de uma realidade paralela diferente da vida habitual, o caráter fictício ou representativo, a sujeição do jogo a certas regras.

Da mesma maneira, o jogo teatral na escola pode ter sua beleza reconhecida, quando realizado dentro de um clima de alegria, intensidade, prazer e tensão; quando obedece às regras propostas pelo professor ou pelo grupo ou, ainda, quando reinventa outras; quando tem caráter livre e não é imposto; quando instaura uma realidade cênica diferente da vida cotidiana; quando tem sua área de jogo delimitada ou enquadrada e quando, pela imaginação, cria inúmeras imagens e metáforas decorrentes de um processo contínuo de simbolização.

De acordo com o conceito de jogo proposto por Huizinga ${ }^{10}$, podemos afirmar que o jogo teatral, enquanto objeto estético, possui uma estrutura ou realidade independente, autônoma, portadora de sentido próprio, configurada no decorrer do próprio jogo, pela manipulação de uma materialidade específica ao fazer teatral. Isto significa que, por meio do jogo, os elementos materiais do teatro como texto, espaço, personagem, gesto, som, movimento, corpo, serão organizados, ativa e dinamicamente, dentro de uma linguagem, de uma estrutura significante que garantirá à cena a criação de uma forma expressiva, ou seja, de uma teatralidade.

Dessa maneira, o jogo teatral deixa de ser um simples exercício, a ilustração de um tema ou mesmo um mero momento de brincadeira e se define como uma experiência estética. Experiência que surge pela interação imediata do sujeito com o objeto confeccionado no momento presente e que é, portanto, dinâmico e efêmero, mas sobretudo vivo e pulsante.

Por este motivo, encontramos na textura viva do jogo teatral, a própria essência e característica fundamental do objeto estético. Na sua intensidade, o jogo teatral realizado em sala de aula apresenta um sentido de ordenação, ritmo e harmonia e, enquanto tal, resulta num todo orgânico, vivo, expressivo, capaz de lan-

\footnotetext{
${ }_{9}$ HUIZINGA, Johan. Homo Ludens: o jogo como elemento da cultura. 4. ed. São Paulo: Perspectiva, 1996. p. 10.

${ }^{10}$ HUIZINGA, 1996. 
çar jogador e espectador numa experiência de troca e de partilha. Nesse momento, podemos perceber, em meio ao movimento de corpos, ruídos e sons característicos da aula de teatro no ensino público, o traçado de pequenos desenhos cênicos, isto é, de "pequenas formas", pequenos momentos de criação. Estas pequenas formas estão fortemente determinadas pelos valores expressivos da contemporaneidade, uma vez que a falta de sentido do mundo atual e o aspecto desarmônico das estruturas sociais resultaram na criação de uma linguagem teatral em que o fragmento e a descontinuidade predominam, enquanto qualidades estéticas e formais.

Por conseguinte, as imagens criadas no decorrer da aula de teatro nem sempre são nítidas ou totalmente delineadas. Podemos compará-las a um borrão no papel, onde as formas se esboçam, mas não se desprendem totalmente, imagens trançadas num tempo ínfimo, num segundo, mas, assim mesmo, com poderes de encantamento e formadoras de memória.

À semelhança com o teatro contemporâneo, podemos verificar que o jogo teatral realizado em sala de aula produz imagens independentes, flashes, superposições, que um olhar atento e bem treinado poderá captar. Deste modo, basta trabalhar sobre esta forma expressiva, dar-lhe dimensão, acentuar seu aparecimento e desaparecimento, mostrar sua existência e as maneiras como dela podemos dispor, intencionalmente, no ato da comunicação teatral.

A comunicação dentro da escola ocorre nesta dimensão múltipla do olhar, característica do teatro e do mundo contemporâneo. Um olhar que já não abarca o todo como no teatro renascentista, época em que o homem é colocado no centro do espaço e, a partir daí, relaciona-se com a natureza e com o mundo ao seu redor. O olhar contemporâneo tem a visão dos fragmentos que compõem este todo, a sua superfície, virtualidade e desdobramentos, como nos lembra Fayga Ostrower ${ }^{11}$.

A ocupação desordenada do espaço feita pelos alunos ao entrarem em sala de aula, a profusão de movimentos, uma guerra de papel, o repicar do sino da igreja ao lado, o chão cobertos de folhas de amendoeiras podem transformar-se em motivo de jogo. Tudo pode ser usado para aprender a linguagem do teatro: seus elementos, climas, tons, a importância de um objeto no espaço, a força expressiva do silêncio, o significado do "espaço-vazio" que comporta o gesto, o olhar e suas inúmeras representações. Trata-se, portanto, de identificar, no cotidiano da escola e da vida, a presença de uma materialidade específica ao fazer teatral, que não está restrita apenas ao domínio do texto e do diálogo. Deste modo, antes mesmo de qualquer tentativa de teatralização da cena, que muito freqüentemente leva à aplicação mecânica dos códigos teatrais, é importante direcionar o olhar do aluno, como nos faz recordar Ryngaert $^{12}$, para os elementos de teatralidade, involuntários, advindos do lugar real.

A perspectiva é de que os alunos possam identificar os elementos de teatralidade manifestos espontaneamente, como também sejam capazes de incorporá-los, progressivamente, dentro do campo da ação cênica propriamente dita. Assim, um espaço, um gesto, um balançar de árvores, uma mudança de luminosidade, o barulho repentino da chuva, tudo pode ser tomado pelos alunos, durante o jogo teatral, como signos concretos de uma teatralidade. Dessa maneira, o aluno aprende,

${ }_{11}$ OSTROWER, Fayga. Criatividade e processo de criação. Petrópolis: Vozes, 1999.

12 RYNGAERT, Jean-Pierre. Jouer, représenter: pratiques dramatiques et formation. Paris: Cedic, 1985. p. 60. 
paulatinamente, que o jogo é um campo aberto, enriquecido pelos signos, que se constituem no decorrer da própria ação e não um campo fechado, determinado por convenções rígidas e transpostas mecanicamente para o seu interior.

$\mathrm{Na}$ sala de aula, buscamos estimular a entrada do aluno no jogo, como também refletir e analisar a dinâmica de criação das imagens: sua organização formal, suas cores, intensidade, movimento ou a maneira como se desenham no espaço. $\mathrm{O}$ objetivo é desenvolver o olhar intencionado, o olhar consciente sobre as formas dimensionadas no espaço, ampliando a experiência sensível dos alunos em torno das qualidades estéticas do jogo teatral e, por conseguinte, tornando possível o desdobramento do seu campo de significação.

Dentro do contexto rude e antiestético, característico da escola pública, pensar uma "poética do efêmero", como proposta metodológica para o ensino do teatro, torna-se fundamental. Por meio do jogo teatral, procuramos articular, dentro de um todo significativo para os alunos, as imagens que se esboçam, ainda que de maneira fragmentada e inacabada, no cotidiano escolar e da vida.

Assim, mesmo que as condições do ensino público não sejam as mais adequadas, tentamos superar as dificuldades tirando partido da situação concreta que se apresenta em sala de aula, através do reconhecimento e da exploração dos signos e da materialidade dos códigos teatrais.

Por este motivo, a noção do jogo teatral, enquanto objeto estético, permite-nos reconhecer na escola, em meio à sua rotina diária, a confecção e a leitura de uma teatralidade que, mesmo marcada por uma tessitura efêmera, está carregada de beleza e poesia. A partir desta perspectiva, encontramos na formulação de uma pedagogia do jogo teatral como poética do efêmero, a possibilidade concreta de ensinar e de aprender teatro na escola pública, segundo os princípios da linguagem teatral.

Consideramos fundamental, no entanto, destacar e analisar a função de dois elementos pedagógicos importantes para a realização deste objetivo. São eles: o olhar e o espaço. Estes dois elementos estão inter-relacionados. Neste sentido, o olhar é trabalhado em função de um espaço enquadrado, ou seja, à medida que um determinado espaço é delimitado, o olhar sobre este espaço é intensificado. Isto é, torna-se mais consciente, focado, interessado sobre as formas, movimentos, objetos e sentimentos estruturados no decorrer do próprio jogo. O olhar ganha, então, uma qualidade nova: deixa de ser um olhar prático e utilitário, para, agora, assumir uma dimensão estética. Desta maneira, pelo enquadramento do espaço, o olhar, sobre este mesmo espaço, modifica-se, passando a ser percebido ou vivenciado no seu elemento de beleza. Esta é, portanto, a magia do jogo teatral na sala de aula. Por seu intermédio, os alunos transformam o espaço institucional em espaço lúdico, em espaço poético.

Segundo Stanislavski13, o olhar está na base do jogo teatral: "É essencial nos reeducarmos para olhar e ver no palco, para escutar e ouvir".

Diante deste princípio, Stanislavski ${ }^{14}$ desenvolveu um recurso didático, cuja função é auxiliar o aluno a concentrar a atenção no espaço da cena, isto é, na-

13 STANISLAVSKI, Constantin. A preparação do ator. Tradução Pontes de Paula Lima. 17. ed. Rio de Janeiro: Civilização Brasileira, 2001. p. 112.

14 STANISLAVSKI, 2001. 
quilo que acontece na esfera do jogo teatral. Ao trabalhar sobre os "círculos de atenção", que correspondem a enquadramentos espaciais diferenciados, pequeno, médio e grande, o aluno estabelece um foco de atenção em relação aos objetos colocados mais próximos ou mais distantes dele. Ao realizar tal objetivo, ao se colocar de forma atenta na relação com o espaço do jogo, o desconforto de atuar diante de uma platéia é superado, ampliando-se a consciência do aluno em relação aos elementos necessários à criação da realidade cênica.

Neste estado de atenção concentrada, o aluno, de acordo com Stanislavski ${ }^{15}$ tem sua percepção estética ampliada, pois intensifica a relação com o espaço ao redor e com os elementos necessários à criação da realidade cênica. Desta forma, percebe os objetos nos seus detalhes mais intricados e, ao mesmo tempo, entra em contato com as variações e os matizes dos seus sentimentos e pensamentos.

Outro aspecto importante da teoria dos “círculos de atenção" é a perspectiva de que o olhar, direcionado dentro de um espaço delimitado, leva o aluno à ação. Ao entrar na relação com o objeto, através da observação, o aluno é movido a agir e agindo descobre novos aspectos do mesmo objeto, expandindo o seu campo de percepção, como se pode verificar através das palavras de Stanislavski:

A observação intensiva de um objeto naturalmente desperta o desejo de fazer com ele alguma coisa. Fazer qualquer coisa com ele intensifica, por sua vez, a observação do mesmo. Essa inter-relação mútua estabelece um contato mais forte com o objeto da atenção de vocês ${ }^{16}$.

Partindo deste princípio, o espaço pode ser considerado o elemento fundador do jogo teatral. $\mathrm{Na}$ escola, podemos verificar que o procedimento prático de enquadrar os espaços ajuda o aluno a vencer a resistência inicial de se colocar em jogo. O espaço funciona, assim, como um elemento concreto que estimula a ação e a exploração sensível. Desta maneira, o espaço apresenta-se como um convite de entrada ou como um elemento facilitador do jogo.

O procedimento metodológico de diferenciar o "espaço do jogo" do "espaço do não jogo" possibilita também aos alunos irem fazendo, de modo progressivo, a passagem entre a simples brincadeirinha e a experiência teatral. Ao entrar e sair de um espaço definido, aos poucos, eles começam a perceber que a ação no teatro se dá segundo regras e convenções específicas, diferentes da realidade. Nesse momento, o jogo deixa de ser sinônimo de "bagunça”, "maluquice” e a simples diversão em sala de aula ganha um novo estatuto, o jogo passa, então, a ser chamado de improvisação, cena, teatro.

Por conseguinte, a delimitação de uma área de jogo coloca o olhar dos alunos sob perspectivas diferentes, ora assumindo o lugar dos jogadores, ora dos espectadores. É, pois, através deste jogo de olhares, que o fenômeno teatral passa a existir, como nos revela Pavis, ao definir o significado da palavra grega theatron:

A origem grega da palavra teatro, o theatron, revela uma propriedade esquecida, porém fundamental, desta arte: é o local de onde o público olha uma ação que lhe é

${ }^{15}$ STANISLAVSKI, 2001.

16 STANISLAVSKI, 2001, p. 111. 
apresentada em outro lugar. O teatro é mesmo, na verdade, um ponto de vista sobre um acontecimento: um olhar, um ângulo de visão e raios ópticos o constituem. Tão somente pelo deslocamento do olhar e objeto olhado é que ocorre a construção onde tem lugar a representação ${ }^{17}$.

Por esse motivo, Ryngaert ${ }^{18}$ ressalta que a prática do jogo no ensino do teatro deve levar em consideração o lugar de onde se vê e o lugar de onde se é visto. Neste sentido, é importante colocar o olhar dos alunos em relação ao espaço do jogo, levá-los a observar e a perceber o espaço, antes, durante e depois do jogo; levá-los a compreender e a analisar as imagens que dali surgiram, a sua textura e a maneira como foram elaboradas.

$\mathrm{Na}$ prática, observamos, portanto, que o enquadramento do espaço estimula o aluno a enfrentar os riscos inerentes ao "espaço-vazio", intensifica a atenção do grupo e prepara internamente os jogadores para apreender o espaço em suas possíveis relações estéticas. Marca, portanto, a entrada do aluno num círculo mágico, diferente do habitual. Lembremos, também, que para Huizinga ${ }^{19}$, a criação de um círculo mágico é um dos elementos formais do jogo, que nos permite reconhecê-lo no seu caráter estético. Dessa maneira, o jogo ocorre dentro de um espaço-tempo, que lhe é específico. Por sua vez, Oberlé20 chama nossa atenção para o fato de o espaço ser um elemento estruturante do próprio jogo, propondo o seguinte paradoxo: "Jogar implica a existência de um espaço, um espaço diferente da realidade; mas é apenas jogando que este espaço se constitui. ${ }^{21}$ "

Assim, se por um lado, o espaço permite o surgimento do próprio jogo, por outro lado, é também um elemento significante e, enquanto tal, está repleto de sentido. Neste aspecto, Ryngaert ${ }^{22}$ esclarece: "Os espaços institucionais onde circulamos estão carregados de sentido pelos que neles vivem ou trabalham. É bem interessante esvaziar esse sentido e ter o prazer em todos os cruzamentos de sentido que aparecem. O jogo é um meio de recarregar os espaços”.

Por meio do jogo teatral, podemos desdobrar o significado original de um mesmo espaço, e propor inúmeras imagens e leituras. Os alunos se surpreendem e se divertem ao perceberem as possibilidades de invenção e reinvenção de um mesmo espaço, a partir de sua própria imaginação. Desta maneira, iniciamos o trabalho prático, delimitando uma área de jogo, depois explorando com o corpo sua geografia, volumes, distâncias, aberturas, reentrâncias, luminosidade, criando a partir daí novas metáforas. Assim, de um mesmo espaço, surge um confessionário, uma casa de detenção, uma cadeira de rodas, uma carruagem e, portanto, deste modo, o aluno percorre um trajeto pedagógico que vai do plano real, físico, para o plano imaginário, estabelecendo o "espaço poético", que pode ser definido, segundo Lessa ${ }^{23}$, como o encontro destes dois espaços: o real e o imaginário.

Buscando descobrir espaços de aprendizagem e do fazer teatral "não-convencionais" ou "não-tradicionais", percorremos com os alunos os diversos espaços da

\footnotetext{
17 PAVIS, 1999, p. 372.

1 RYNGAERT, 1985.

19 HUIZINGA, 1996.

20 OBERLÉ DOMINIQUE. Jeu dramatique et développement personnel. Paris: Retz, 1989. p. 49.

21 Tradução livre.

22 RYNGAERT, 1985, p. 71.

23 Cf.: LESSA, Bia (Org.). Conbecimento teatral. 1985. Apostila mimeografada.
} 
sala de aula, da escola, do bairro e de outras localidades, conferindo-lhes maior sentido e humanidade. Encontramos na perspectiva de jogar, em espaços "não-tradicionais” (a sala de aula) uma ação pedagógica de extrema riqueza e importância. Esta ação auxilia a romper com uma condição de confinamento, a que estão submetidos os alunos na escola; propõe uma atitude dinâmica e ativa diante do conhecimento; aumenta a proximidade entre professor e aluno; questiona as relações de saber e poder, características do ensino tradicional; suscita uma experiência de prazer e de liberdade junto ao espaço e nos permite superar o espaço atravancado de carteiras.

O jogo teatral está dotado de grande significação para o ensino do teatro na escola pública, principalmente nos grandes centros urbanos, onde a falta se faz presente em todos os sentidos, seja na carência de condições físicas, seja no crescente empobrecimento humano, social e político com que nos deparamos constantemente.

Uma outra questão que se levanta ao analisar o elemento espaço para a construção de uma pedagogia do jogo é que ele nos permite aproximar o ensino do teatro na escola aos princípios do jogo teatral contemporâneo, de modo diferente de um teatro tradicional, em que há o predomínio do texto e do diálogo. O jogo teatral na atualidade privilegia o espaço como substrato concreto, onde se articulam todos os demais signos da linguagem teatral. Assim, a teatralidade é construída no espaço direto da cena e, desta maneira, a palavra passa a ser mais um dos elementos significantes da linguagem e não o único. O teatro é, portanto, a linguagem do espaço, é "poesia no espaço", como nos recorda Artaud"2.

Sendo assim, é preciso, na sala de aula, "penetrar o espaço", ocupá-lo dinamicamente para a criação da realidade cênica. É o que Spolin ${ }^{25}$ chama de "físicalização", ou seja, é pela experimentação sensível e orgânica do corpo no espaço que o aluno irá apreender os diversos signos da linguagem teatral e suas possíveis relações. Neste sentido, podemos dizer que a teatralidade enquanto forma expressiva, contemporânea, inscreve-se no espaço. Ela emerge das relações que os alunos estabelecem no espaço, física e concretamente, a partir da relação direta com os colegas e com o ambiente no próprio momento do jogo.

Podemos verificar que por meio das brincadeiras do corpo no espaço, do correr, do saltar, do esconder, a criança começa, desde bem pequena, a organizar seus primeiros desenhos ou composições cênicas. Segundo Slade ${ }^{26}$, o aprendizado do teatro tem início com "o jogo pessoal”, através do qual a criança se lança no espaço, percebendo-o em sua tridimensionalidade, geografia e distâncias e, ainda, inventando personagens e consequentemente espaços de representação. Ela vai, aos poucos, adquirindo noções de profundidade, tamanho, volume e eqüidistância, ou seja, começa a estabelecer relações formais a partir do próprio espaço. O objetivo do jogo teatral na escola é, portanto, retomar esta primeira experiência de liberdade da criança no espaço, agora apreendida e elaborada de uma maneira consciente e expressiva. Deste modo, a construção da teatralidade na escola consiste em desenvolver, no aluno, este olhar progressivamente consciente, tornando cada gesto e

${ }^{24}$ ARTAUD, Antonin. O teatro e seu duplo. Tradução Teixeira Coelho. 2. ed. São Paulo: M. Fontes, 1999. p. 37.

${ }^{25}$ SPOLIN, Viola. Improvisação para o teatro. Tradução Ingrid Dormien Koudela. São Paulo: Perspectiva, 1982. p. 15.

26 SLADE, Peter. O jogo dramático infantil. Tradução Tatiana Belinky. São Paulo: Summus, 1978. p. 17. 
cada ação no espaço, intencional.

É também pela ocupação e exploração do espaço que o aluno progressivamente descobre e conquista o seu próprio espaço pessoal. Assim, no início do curso de teatro, aquele espaço que se mostrava ameaçador, "grande" (como se refere um dos alunos), torna-se paulatinamente "pequeno", acolhedor; ele é enfim conquistado. O espaço do jogo não é mais fonte de medo, mas de prazer. A timidez dá lugar ao enorme desejo de jogar. As tendências exibicionistas do jogador são substituídas pelo sentido do coletivo, pelo reconhecimento da troca e da parceria mútua. O espaço passa, então, a ser "lugar" de identidade e de relação do sujeito com o mundo, a partir do qual se constrói uma história, como define Augée ${ }^{27}$.

Por sua vez, a questão da valorização do espaço no teatro contemporâneo coloca o ator num lugar de importância dentro do processo criativo, uma vez que há uma retomada da improvisação e do jogo. Neste momento, segundo Ryngaert ${ }^{28}$, “o corpo do ator passa a ser encarado como fonte de invenção". O ator não fica mais preso apenas às indicações do diretor, mas tem autonomia, experimenta, pesquisa, faz valer suas idéias e percepções da cena.

Da mesma maneira, a prática do jogo teatral permite ao aluno realizar seu potencial criativo e reafirmar seu lugar de sujeito dentro da escola e do mundo. Ao assumir uma postura ativa e dinâmica, a realidade deixa de ser apreendida como um dado acabado, imutável e passa a ser construída e transformada pela ação particular e coletiva dos próprios alunos que, cada vez mais, apropriam-se de suas ações e palavras. Esta atitude lúdica estimula, nos alunos, o conhecimento sensível e, portanto, estético da vida. Encontram, deste modo, em meio a um cotidiano árido, uma tessitura delicada e poética, capaz de conferir novo sentido às suas vidas.

Portanto, a noção do jogo teatral, enquanto objeto estético, permite-nos colocar no centro do processo de ensino-aprendizagem do teatro a questão da teatralidade, sua criação e leitura, no cotidiano da escola. Desta maneira, podemos afirmar que é através da linguagem, de sua materialidade, que o aluno poderá alcançar, de maneira mais profunda, o sentimento de transcendência, de integração, de harmonia, de forma e beleza, que deveria reger a educação e a vida, em todos os seus momentos.

27 AUGÉ, Marc. Não lugares: introdução a uma antropologia da supermodernidade. Tradução Maria Lúcia Pereira. 2. ed. Campinas, SP: Papirus, 2001. p. 50.

${ }^{28}$ RYNGAERT, 1985, p. 46. 


\section{REFERÊNCIAS}

ARTAUD, Antonin. O teatro e seu duplo. Tradução Teixeira Coelho. 2. ed. São Paulo: M. Fontes, 1999.

AUGÉ, Marc. Não lugares: introdução a uma antropologia da supermodernidade. Tradução Maria Lúcia Pereira. 2. ed. Campinas, SP: Papirus, 2001.

BROOK, Peter. A porta aberta: reflexões sobre a interpretação e o teatro. Tradução Antônio Mercado. 2. ed. Rio de Janeiro: Civilização Brasileira, 2000.

BYNGTON, Carlos Amadeu Botelho. Pedagogia simbólica: a construção amorosa do conhecimento do ser. Rio de Janeiro: Record: Rosa dos Tempos, 1996.

DUARTE JÚNIOR, João Francisco. Fundamentos estéticos da educação. 2. ed. Campinas, SP: Papirus, 2000.

HUIZINGA, Johan. Homo Ludens: o jogo como elemento da cultura. 4. ed. São Paulo: Perspectiva, 1996.

OBERLÉ DOMINIQUE. Jeu dramatique et développement personnel. Paris: Retz, 1989.

OSTROWER, Fayga. Criatividade e processo de criação. Petrópolis: Vozes, 1999.

PAVIS, Patrice. Dicionário de teatro. São Paulo: Perspectiva, 1999.

RYNGAERT, Jean-Pierre. Joner, représenter: pratiques dramatiques et formation. Paris: Cedic, 1985.

SLADE, Peter. O jogo dramático infantil. Tradução Tatiana Belinky. São Paulo: Summus, 1978.

SOARES, Carmela. Pedagogia do jogo teatral: uma poética do efêmero. O ensino do Teatro na Escola Pública. 2003. Dissertação (Mestrado) - Centro de Letras e Artes, Universidade Federal do Estado do Rio de Janeiro, Rio de Janeiro, 2003.

SPOLIN, Viola. Improvisação para o teatro. Tradução Ingrid Dormien Koudela. São Paulo: Perspectiva, 1982.

STANISLAVSKI, Constantin. A preparação do ator. Tradução Pontes de Paula Lima. 17. ed. Rio de Janeiro: Civilização Brasileira, 2001.

WINNICOTT, Donald Woods. O brincar e a realidade. Rio de Janeiro: Imago, 1975. 


\section{Performance, teatro e ensino: POÉTICAS E POLÍTICAS DA INTERDISCIPLINARIDADE}

Eleonora Fabião

Abordarei aqui aspectos relativos à performance e ao teatro no âmbito da criação e do ensino. Na primeira parte do artigo, introduzo o tema "performance" e na segunda defendo a importância da inserção teórica e prática da performance em contextos de ensino superior de teatro.

Esta reflexão se baseia na minha experiência como performer, atriz, pesquisadora e professora. Assim como as vivencio, as atividades artística, crítico-filosófica e pedagógica são momentos distintos de uma mesma experimentação corporal, política e poética que proponho como performer. A sala de aula, o palco, a rua, a folha de papel, o corpo são dimensões de uma mesma busca: fundar espaços de reflexão e criação onde proponho que nos perguntemos não apenas o que seja "arte contemporânea”, mas o que queremos, contemporaneamente, que a arte seja.

\section{Performance}

Ao longo dos últimos anos coleciono histórias verídicas baseadas nas práticas de artistas que se auto-definem performers. A história do homem que arrastou um bloco de gelo pelas ruas da Cidade do México até seu derretimento completo. A história da mulher que se submeteu a nove cirurgias plásticas combinando em seu rosto traços de nove beldades da pintura ocidental. Do homem que introduziu uma boneca Barbie no ânus e, com controle absoluto de sua musculatura abdominal, expeliu-a lentamente na frente de uma audiência. Ou do homem que se trancou numa cela por um ano e não leu, não falou, não escutou música, não se comunicou com nada nem com ninguém. Este mesmo homem propôs-se a ficar um ano sem adentrar qualquer tipo de espaço coberto, ou seja, passou 365 dias "sem-teto". Este mesmo homem levou a cabo o seguinte projeto: clicar um auto-retrato a cada hora certa, ou seja, 24 vezes por dia, ao lado do mesmo relógio de ponto e no mesmo lugar, ao longo de 12 meses. A história de outro homem que raspou a cabeça, cobriu-a com mel e folhas de ouro, tomou uma lebre morta nos braços e explicou-lhe, silenciosamente, os quadros de sua exibição. E outro que se trancou por 5 dias consecutivos num escaninho $(60 \mathrm{~cm}$ de altura $\times 60 \mathrm{~cm}$ de comprimento $\times 90 \mathrm{~cm}$ de 
profundidade) recebendo água por um tubo e expelindo urina por outro. E outro que convidou amigos para mastigar páginas do célebre Art and Culture, de Clement Greenberg, juntou à polpa ácido sulfúrico, açúcar e bicarbonato de sódio, depositou a mistura num pote que etiquetou com os dizeres "Art and Culture" e retornou o objeto para a biblioteca (perdendo, nesta ocasião, seu emprego como professor na San Martin's School of Art). A mulher que tomou o metrô sábado à noite e foi a uma livraria movimentada vestida com roupas que havia deixado de molho por uma semana num caldo de vinagre, leite, óleo de rícino de bacalhau e ovos. Uma mulher que construiu uma miniatura de palco Italiano, tapou os seios nus com a maquete e convidou os passantes na rua a tocar-lhe os peitos através das cortinas do pequeno palco. A mulher que subiu com os pés descalços uma escada cujos degraus eram feitos de lâminas cortantes. O homem que comemorou seu aniversário na rua, partilhou seu bolo, trocou abraços e recebeu votos de felicidade dos amigos desconhecidos. A mulher que girou uma longa volta (cerca de uma hora de duração) numa praça do Rio de Janeiro. A dupla (um homem e uma mulher) que, por um ano, manteve-se atada pela cintura por uma corda de cerca de dois metros e meio sem tocarem-se. A mulher que convidou os espectadores a usarem nela, enquanto se manteve passiva e parada por seis horas, inúmeros objetos, dentre eles uma rosa, uma pistola, uma bala, tesoura, mel, correntes, caneta, baton, uma câmera Polaroid, faca, chicote e vários outros "instrumentos de prazer e de dor" (os objetos puderam ser utilizados livremente e a performer assumiu plena responsabilidade pelos atos dos espectadores). O homem negro que se sentou numa calçada cinza, exibiu três vidros de maionese branca, e tentou vendê-los por 100 dólares cada. A mulher que, trajando camisolão branco, usou terços para realizar desenhos de pênis no chão. A mulher que perguntou a seus compatriotas palestinos exilados: "Se eu pudesse fazer algo para você, em qualquer lugar na Palestina, o que seria?” E, graças a seu passaporte Americano, cruzou a fronteira inúmeras vezes e atendeu aos pedidos que lhe foram feitos: regar uma planta, pagar uma conta, comer doces, visitar um túmulo, tirar fotografias, jogar futebol com meninos, cheirar o mar ${ }^{1}$.

Estas e muitas outras histórias descrevem programas concebidos e performados por artistas interessados em relacionar corpo, estética e política através de ações intensas e extremas. Gosto de passar estas histórias adiante, de articulá-las em frases curtas, de lançá-las como dardos de adrenalina, sem detalhá-las, sem adjetivá-las, para que cravem secas; estilhaços de mitologia contemporânea. Penso que estas práticas alargam, que estes programas oxigenam e dinamizam nossas maneiras mesmas de agir e de pensar ação e arte contemporaneamente. Esta é, a meu ver, a força da performance: des-automatizar a relação do cidadão com a polis; do agente histórico com seu contexto; do vivente com o tempo, o espaço, o corpo, o outro e consigo mesmo. Esta é a potência da performance: não se trata de operações bizarras e provocativas promovidas por um punhado de sadomasoquistas e idiossincráticos para chocar o "senso-comum" (que aturdido pergunta-se "o que é isso?" "para que isso?" "afinal, o

\footnotetext{
${ }^{1}$ Estas ações foram respectivamente criadas pelos seguintes artistas: Francis Alys (2000), Orlan (anos 90), Denis O'Connor (1999), Theching Hsieh (1978/79, 1981/82 e 1980/81), Joseph Beuys (1965), Chris Burden (1971), John Lathan (1966), Adrian Piper (1970), Valie Export (1968), Gina Pane (1971), Eduardo Flores (2002), Eleonora Fabião (2003), Linda Montano e Theching Hsieh (1983/84), Marina Abramovic (1974), William Pope.L (1991), Márcia X (200003), Emily Jacir (2003).
} 
que eles querem dizer com isso?" "então isso é arte contemporânea?"), mas da expansão da noção de dramaturgia, ou seja, da idéia do que seja ação e "artisticidade" da ação, corpo e "politicidade" do corpo.

Chamo as ações performativas de programas $^{2}$, pois esta me parece a palavra mais apropriada para descrever um tipo de ação metodicamente calculada, conceitualmente polida, que exige extrema tenacidade para ser levada a cabo, e que se aproxima do improvisacional única e exclusivamente na medida em que não será previamente ensaiada. $O$ performer não improvisa uma idéia: ele cria um programa e programa-se para realizá-lo. Ao agir seu programa, necessariamente, des-programa seu organismo e seu meio. Tratam-se de experimentações, de ações "extracotidianas”, da vivência de estados psicofísicos alterados que disseminam dissonâncias diversas: dissonâncias de ordem econômica, política, emocional, orgânica, ideológica, psicológica, espiritual, identitária, sensorial, sexual, social, racial... Programas criam corpos naqueles que os performam e naqueles que são afetados pela performance. Programas anunciam que "corpos" são sistemas relacionais abertos, altamente suscetíveis e cambiantes. Programas geram corpos com proporções que ultrapassam em muito os limites da pele. O performer é um criador de corpos individuais e coletivos, públicos e privados. Se o performer potencializa a relação com seu corpo é para disseminar uma reflexão e uma experimentação sobre a corporeidade do mundo, das relações, do pensamento.

Sugiro que programas performativos baseiam-se em elementos dramatúrgicos discerníveis. Destaco alguns: 1) o deslocamento de referências e signos de seus habitats naturais; 2) a aproximação e fricção de elementos de distintas espécies, naturezas e esferas ontológicas; 3) acumulações, exageros e exuberâncias de todos os tipos; 4) aguda simplificação da forma e condensação de materiais e idéias; 5) a aceleração ou des-aceleração da experiência de sentido até seu colapso; 6) a aceleração ou des-aceleração da noção de identidade até seu colapso; 7) a recusa de performar personagens fictícios e o interesse em explorar características próprias (etnia, nacionalidade, gênero, especificidades corporais), em exibir seu tipo ou estereótipo social; 8) o investimento em dramaturgias pessoais, por vezes biográficas, onde posicionamentos e reivindicações pessoais são publicamente performados; 9) o curto-circuito entre arte e não-arte; 10) o estreitamento entre política e estética; 11) agudez conceitual; 12) o encurtamento ou a distensão da duração até limites extremos; e 13) a ampliação dos limites psicofísicos do performer e de sua audiência;

Porém, veja bem, restrinjo-me a apontar tendências dramatúrgicas genéricas, pois considero vão e mesmo equivocado qualquer esforço no sentido de definir o que seja "performance". Trata-se de uma forma de expressão tão híbrida e flexível que dribla definições rígidas de "arte”, “artista”, “espectador” ou "cena”. Neste sentido, proponho, ao invés de uma investigação sobre o que significa a performance, uma reflexão sobre o que move a performance e o que a performance é capaz de mover. Estrategicamente, a performance escapa a qualquer formatação, tanto em termos das mídias empregadas quanto dos materiais ou espaços utilizados. Como sugere Eduardo Flores numa assertiva propositadamente generalizante, "a matéria

${ }^{2}$ A inspiração para a escolha deste vocábulo vem do texto "Como criar para si um corpo sem órgãos” (DELEUZE, Gilles; GUATTARI, Félix. A thousand plateaus. Minneapolis: University of Minnesota Press, 1987. 107 p.) onde se propõe que o programa é motor de experimentação. 
da performance é a vida, seja do espectador, do artista, ou ambas"3. Flores sugere que a arte opera sempre no sentido de transformar algo, seja matéria em objeto, ou movimento, som, palavra em composição. No caso da performance, a matéria a ser trabalhada é a própria vida. O ofício do performer seria o de "transformar a vida" como sugere Flores, ou ainda, o modo como a vida pode ser vivida. O performer é aquele que evidencia e potencializa a mutabilidade do vivo.

A performance desafia definições, pois ativa dinâmicas paradoxais que complicam estatutos tradicionais tanto do fazer quanto da fruição artística: trata-se da fundação de uma cena-não-cena equiparável ao teatro-não-representacional vislumbrado por Antonin Artaud. É trans-real, pois que move e move-se por múltiplas camadas de sentido sem deixar-se fixar. Artaud preconiza um "teatro da crueldade" sendo que, como explica, "crueldade não é sinônimo de sangue, martírio e inimigos crucificados. Essa identificação de crueldade com vítimas torturadas é um aspecto menor da questão" 4 . Ele esclarece: "Eu disse 'crueldade' como poderia ter dito 'vida' ou 'necessidade"' 5 . O projeto artaudiano, assim como a performance, não visa tampouco a formação de um teatro inconsciente. "Quase o oposto", argumenta Jacques Derrida: "Crueldade é consciência, é lucidez exposta" . A performance, assim como o teatro artaudiano, é cruel na medida em que ativa fluxos paradoxais, ou seja, lógicas que escapam à regulamentação da doxa (senso comum e bom senso); é cruel na medida em que ativa consciência crítica atrelada à consciência corporal, ou seja, ativa consciência como "coisa corpórea". A performance, assim como o teatro de Artaud, é cruel ao minar fundamentos determinantes da cultura ocidental: logocentrismo e tirania teológica. Fundamentos estes que silenciam, anestesiam, minguam nossos corpos; forças de subjetivação que descorporalizam nossas maneiras de nos relacionarmos e criarmos mundo. Como propõe Artaud, o julgamento de Deus precisa ser erradicado para o nascimento do Corpo (self corpóreo); a fúria logocêntrica precisa ser acalmada para o nascimento do Corpo (self corpóreo). Como propóem os performers com seus programas cáusticos, o tipo de conhecimento de que precisamos no presente momento se faz nos Corpos, através dos Corpos, com Corpos, como criação de Corpos. Ou como convoca Gilles Deleuze: "É preciso que estiquemos nossa pele como um tambor para que uma nova política comece".

A partir de uma perspectiva histórica, destaco ainda a (in) definição da "origem” deste gênero. Alguns pesquisadores associam a origem da performance ao teatro de vanguarda europeu do início do século XX - especificamente às práticas cênicas futuristas e dadaístas e ao "Teatro do Absurdo", como sugere RoseLee Gol$\mathrm{dberg}^{8}$. Diferentemente, outros historiadores e teóricos propõem que a origem da

\footnotetext{
${ }^{3}$ Notas tomadas na visita do artista mexicano Eduardo Flores a uma aula do curso "Performance!" que ministrei no primeiro semestre de 2005 como disciplina opcional para alunos de sexto, sétimo e oitavo períodos do curso de Direção Teatral, Universidade Federal do Rio de Janeiro. ${ }^{4}$ ARTAUD, Antonin. Theater and its doublé. New York: Grove Press, 1958. p. 102. Traduzido do inglês.

${ }^{5}$ ARTAUD, 1958, p.114.

${ }^{6}$ DERRIDA, Jacques. A escritura e a diferença. São Paulo: Perspectiva, 1995. p. 165.

7 DELEUZE, Gilles. The logic of sense. New York: Columbia University Press, 1990. p. 72. Traduzido do inglês.

${ }_{8}$ GOLDBERG, RoseLee. Performance art, from futurism to the present. New York: Thames and Hudson, 2001.
} 
performance está relacionada não ao teatro ou à dança, não às artes cênicas, mas a transformações ocorridas nas artes plásticas em meados do século; especificamente à inserção do movimento como elemento da composição plástica e à decorrente e gradual des-materialização do objeto de arte. Fato é que a valorização da ação resultou num encontro do artista com seu próprio corpo, num confronto com a materialidade de sua presença que se tornou material de trabalho. $\mathrm{Ou}$, como se convencionou dizer, o artista tornou-se sujeito e objeto de sua obra. De acordo com esta perspectiva, o marco de origem das práticas performativas teria sido a action painting norte-americana e experimentos correlatos acontecendo em outros países protagonistas da Segunda Guerra Mundial, especificamente na Ásia e na Europa como sugere Paul Schimmel' . De fato, enquanto gênero, a performance começa a adquirir feições mais definidas depois da Segunda Guerra Mundial e suas catástrofes correlatas. A experiência de morte massiva e, significativamente, a experiência da explosão atômica, foram referências determinantes para um certo entendimento de "corpo", "comunicação" e "experiência” investigado por performers. A partir de então, começaram a espocar pelo mundo afora séries de práticas difíceis de classificar, a maioria delas envolvendo o corpo do artista de forma inédita e radical, baseadas em aguda materialidade e força conceitual.

Entretanto, seja afirmando que a performance originou-se a partir ou de práticas cênicas ou de práticas plásticas, muito pouco muda em relação ao estatuto artístico da performance e sua inserção na tradição cultural ocidental. Este é o argumento de Thomas McEvilley em "Stages of Energy: Performance Art Ground Zero?" 10 . Neste artigo, o autor defende a idéia de que a performance é uma forma de recusa aos valores e procedimentos da arte ocidental, ou, mais enfaticamente, uma ruptura e um afastamento desta tradição. McEvilley sugere que o "novo gênero" se originou em manifestações rituais antiqüíssimas, práticas que o autor define como "pré” ou "extra" civilizatórias.

Pessoalmente penso que uma discussão sobre a "origem" da performance é interessante apenas na medida em que se mantém aberta. Se consideramos o caráter eminentemente híbrido do fato performativo, ter de optar se foi a pintura, a dança, o teatro ou qualquer gênero artístico o berço da performance, soa redutor. Diferentemente de McEvilley, não penso que a performance represente uma refuta mas uma contrapartida a valores predominantes da cultura ocidental contemporânea - nomeadamente: reprodutibilidade, eficiência, eficácia, efetividade, durabilidade, segurança identitária e material, conforto e solidez - sem contudo deixar de ser um componente cada vez mais importante da nossa cultura. A performance atualmente é referência contundente, ainda que marginal; é prática marginal, ainda que contundente ${ }^{11}$.

\footnotetext{
9 SCHIMMEL, Paul (Org.) Out of actions: between performance and the object 1949-1979. Los Angeles: Tharus and Hudson, The Museum of Contemporary Art, 1998.

10 McEVILLEY, Thomas. Stages of energy: performance art ground zero? In: Artist's body. Milano: Charta, 1998.

${ }^{11}$ Não percebo, por exemplo, uma rejeição, mas uma relação conturbada com valores de mercado. A performance participa, ainda que como crítica e recusa, da economia reprodutiva e do mercado de arte. Basta pensarmos no frisson editorial, na quantidade de catálogos, livros, exposições de documentos e relíquias de performances, na quantidade de souvenirs, postais, canecas decoradas e DVDs dedicados à "mais efêmera das artes".
} 


\section{Performance e ensino de teatro}

A pergunta é direta: por que considero fundamental, contemporaneamente, ensinar, ou ainda, instigar o debate e a prática da performance em contextos de ensino superior de teatro? E de que maneira uma aproximação pedagógica entre performance e teatro pode beneficiar estudantes de teatro ${ }^{12}$ ?

Fato é que entrecruzamentos entre teatro e performance são moeda corrente nos palcos contemporâneos. Grupos de teatro experimental como o britânico Forced Entertainment, os norte-americanos Wooster Group e Goat Island, ou os brasileiros Teatro da vertigem e Companbia dos atores ${ }^{13}$, bem como Denise Stoklos e seu Teatro essencial, para citar alguns casos, desenvolvem trabalhos influenciados e/ou consonantes com estéticas e éticas performativas. Em nível pedagógico, porém, o ensino da performance em cursos de teatro no Brasil ainda é prática embrionária e precisa ser cuidadosamente discutido.

Considero a inserção da prática e da teoria da performance no circuito pedagógico teatral estimulante por vários motivos e destaco alguns dos principais: 1) sofisticação de pesquisas corporais; 2) ampliação do repertório de métodos composicionais; 3 ) investigação de linguagens e dramaturgias não-convencionais e hibridação de gêneros artísticos; 4) discussão de questões cênicas através de outro viés que não os da teoria do drama ou das histórias e poéticas espetaculares; 5) aprofundamento de debates e práticas teatrais focados em políticas de identidade e em políticas de produção e recepção cada vez mais articuladas e acutilantes; 6) valorização da investigação sobre dramaturgias do espectador. Estes serão os temas abordados ao longo das próximas páginas.

Para o aluno de teatro em geral (não apenas futuros atores, mas também futuros diretores, professores e teóricos) penso ser de extrema valia confrontar-se com experiências psicofísicas baseadas na tradição da performance. Tais vivências (para usar o termo cunhado por Lygia Clark e Hélio Oiticica nas fases de seus trabalhos voltadas para a expansão da sensorialidade do espectador) visam à desconstrução de hábitos cotidianos (e automatismos teatrais). A proposta consiste em operar mudanças radicais nas dinâmicas espaços-temporais habituais para que outros estados psicofísicos possam aflorar. Trata-se de uma oportunidade para o aluno abrir horizontes perceptivos insuspeitados, aprofundar autoconhecimento e questionar-se a respeito de padrões culturais e sociais.

\footnotetext{
12 Nos últimos anos leciono cursos e workshops em performance para fazedores de teatro e dança em diversas instituições e países, em nível de graduação e pós-graduação. Ser professora é parte do meu projeto artístico. Considero estes cursos performances em si, programas que realizo com grupos de alunos através de uma pedagogia relacional. Como ensinadora da performance, proponho diversas experiências psicofísicas bem como a leitura e debate de textos históricos e filosóficos, e aponto técnicas de composição para que os participantes criem peças. Não trabalho propondo exercícios em performance ou conduzindo ensaios para a realização de futuras peças. Sou uma propositora de experiências. Como professora-performer, meu trabalho é propor e vivenciar experiências. Tais experiências visam o desenvolvimento e a integração das capacidades orgânicas, criativas e comunicacionais do atuante (performer, cidadão, sujeito histórico, vivente) e visam seu fortalecimento através do aumento de agilidade, flexibilidade e disponibilidade. Considero a sala de aula um dos mais interessantes espaços performativos, pois que estabelecemos, de antemão, um pacto colaborativo. Trata-se de um espaço de criação e experimentação, um microcosmo político a ser poeticamente e pedagogicamente explorado.

13 No caso da carioca Cia. dos atores, percebo este tônus performativo especificamente numa montagem recente: Ensaio. Hamlet.
} 
Não se trata de focar na criação de personagens ou na exploração de técnicas interpretativas ou jogos improvisacionais, mas de acessar algo que antecede, que enerva atuação e atuante. Trata-se de um confronto do fazedor de teatro com sua psicofisicalidade, com sua metafisicalidade, com seu Corpo e história; confronto este que, penso, sofisticará enormemente a relação com personagens, parceiros de equipe, espaços, objetos, espectadores, conceitos. Como propôs Grotowski "O Performer, com maiúscula, é o homem de ação. Não é o homem que faz o papel do outro. É o dançante, o sacerdote, o guerreiro: está fora dos gêneros estéticos. [...] Pode compreender apenas se faz. Faz ou não faz. O conhecimento é um problema de fazer" ${ }^{14}$.

Aqui, interessa evocar as formas de conbecimento ativo do grupo paulista Teatro da Vertigem. Interessa como o Vertigem investe em mecanismos dramatúrgicos de alta voltagem performativa para a criação de seus espetáculos ${ }^{15}$. $O$ grupo privilegia o que chamo dramaturgia do ator, ou seja, processos criativos onde o ator não é exclusivamente um intérprete, mas um co-autor do espetáculo assim como o diretor, o cenógrafo, o iluminador, o figurinista e todos os demais membros da equipe que, geralmente coordenados por um diretor, colaboram para a criação da dramaturgia do espetáculo. Ou, como os atores do Vertigem definem sua função, o ator "é simultaneamente autor e performer" ${ }^{16}$. No artigo "O que fazemos na sala de ensaio" os atores-autores-performers do Vertigem destacam a importância do que chamam "depoimento pessoal": "Depoimento pessoal é sua colocação como ser humano, como cidadão e artista. [...] É deixar que sua experiência vire arte, seja manipulada"17, esclarece Mariana Lima. Como dizem, não estão interessados em “camuflar características, mas ampliá-las"18.

Quanto aos métodos de ensaio, composição de cena e personagens, o grupo destaca quatro modalidades de práticas: a vivência (método que se aproxima do laboratório teatral, sempre pontuado com atividade de escrita automática), a improvisação (improvisações sem preparo prévio a partir de materiais diversos relacionados com o tema pesquisado), os workshops (cena-resposta a uma questão lançada, composição a ser preparada de um dia para outro utilizando qualquer tipo de mídia) e as visitas (pesquisa de campo, sempre em espaços públicos, a partir da qual o ator elabora cenas e/ou personagens).

Atrelada à pesquisa dramatúrgica em sala de ensaio há outro elemento determinante: o interesse em ocupar espaços não convencionais ${ }^{19}$. "A apresentação em lugares impróprios para o aconchego do público ou para o conforto dos atores abre outras possibilidades, que reinventam o teatro não apenas como entretenimento, mas como experiência" ${ }^{20}$. Refletindo sobre a relevância destes espaços ativos para o desenvolvimento de suas práticas teatro-performativas afirmam: "A relação

${ }^{14}$ REVISTA MÁSCARA. Cidade do México: Fondo de Cultura del México, [19--] p. 78. Número especial em homenagem à Jerzy Grotowski.

${ }^{15}$ Refiro-me à criação e encenação da Trilogia bíblica composta pelas peças $O$ paraíso perdido (1992), O livro de Jó (1995) e Apocalipse 1,11 (2000). NESTROVSKI, Arthur (Org.). Trilogia bíblica: teatro da vertigem. São Paulo: Publifolha, 2002. 359 p.

16 "O que fazemos na sala de ensaio" em NESTROVSKI, 2002, p. 45.

17 NESTROVSKI, 2002, p. 46.

${ }_{18}$ NESTROVSKI, 2002,

19 No caso da Trilogia bíblica, respectivamente, igreja, hospital e presídio.

20 NESTROVSKI, 2002, p. 48, destaque nosso. 
com o público é conseqüência de uma situação híbrida em que representação e realidade se confundem" ${ }^{21}$. A criação de uma cena híbrida onde elementos fictícios e não-fictícios são justapostos, a ativação política provocada por tal justaposição, a ocupação de espaços "extracênicos" (para que possam circular outras dinâmicas relacionais), a ampliação de características pessoais (em busca de uma dramaturgia pessoal, por vezes biográfica), a valorização da experiência e da experimentação psicofísica através dos métodos criativos utilizados, a valorização do ator-dramaturgo e do artista-etnógrafo, são elementos marcadamente performativos explorados pelo Teatro da Vertigem. Grupo que, como o próprio nome diz, não pretende um teatro de estabilidade ou uma relação confortável com a "cena".

Da mesma forma, a performance. Sua inserção no âmbito de ensino do teatro causará algum desconforto e desassossego, mas, seguramente, proporcionará fricções interdisciplinares de enorme valia. Por posicionar-se como uma prática "antiteatral" - ou seja, desinteressada nos espaços teatrais, métodos criativos, funções especializadas, possíveis hierarquias nas equipes, poéticas e economias de ensaio e repetição - a performance representa um referencial dialógico fascinante (no mínimo uma pedra no sapato que nos faz parar, descalçar, sacudir, e voltar a caminhar com novas percepções do pé, do terreno em que se pisa, do calçado que se escolhe usar, ou seja, das relações entre corpo, objeto e meio). Um performer não apenas coloca propositadamente pedras em seu sapato, mas usa sapatos de pedra para que os fluxos ditos "naturais" sejam interrompidos e outras maneiras de percepção e relação possam se desenvolver. Muito me interesso pelo valor crítico-pedagógico de atos que suspeitam dos "padrões de normalidade".

Penso que o aluno de teatro se beneficia não apenas no contato prático, mas no estudo da teoria da performance através do qual poderá refletir sobre aspectos centrais do teatro do século XX. Interesssa por exemplo, à luz da performance, abordar temas como o ilusionismo (construção e demolição) e a narrativa ficcional (adesão e desconstrução). A performance, em sua aguda materialidade, des-narrativização, antificcionalidade e instantaneidade, ou seja, por operar em extrema oposição ao ilusionismo e ao narrativismo, torna-se uma referência importante para um certo teatro contemporâneo interessado em discutir seus espaços de atuação, políticas de produção e recepção, noções de corporeidade e dramaturgia.

Este é o caso do grupo de teatro Forced Entertainment (Entretenimento Forçado), especificamente em suas peças de longa duração. O grupo expõe o projeto:

Depois de anos fazendo teatro, em que uma parte do trabalho consistia em ensaiar e fixar coisas - fazer a mesma peça funcionar da mesma maneira repetidas vezes - nós resolvemos fazer algo diferente, algo mais extremado. As peças longas foram um passo nessa direção: trabalhos entre seis e vinte e quatro horas de duração nos quais os atores improvisam dentro de um sistema pré-definido de regras. [...] Considere cada peça como uma tarefa ou um jogo [...] e considere que cada jogo tem regras, estratégias, movimentos conhecidos e também limites ${ }^{22}$.

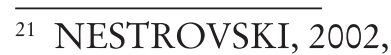

22 "Notas sobre as peças de longa duração" em * HEATHFIELD, Adrian. (Ed.). Live art. Mustang: Tate Publishing, 2004. p. 101. Traduzido do inglês.
} 
Um destes trabalhos - Quizoola!, um jogo de perguntas e respostas para dois participantes - tem a duração de seis horas. O público está livre para entrar e sair quando e quanto quiser. Três atores da companhia explorando as três combinações de dupla possíveis, revezam-se por períodos de duas horas. Os atores interrogam-se mutuamente baseados num questionário com duas mil perguntas sobre os mais variados temas - esportes, história, amor, filosofia, fatos... Como explicam, as respostas podem ser verdadeiras, falsas, longas, curtas, confessionais, abstratas, de acordo com decisões imediatas. O design da cena é extremamente simples. Lâmpadas elétricas ligadas em série formam um círculo no chão que delimita o espaço do jogo. Os atores estão vestidos com roupas cotidianas e maquiados como palhaços. Duas cadeiras, as folhas de papel com as perguntas e algumas garrafas d'água pontuam o quadro.

Em Quizoola! não há vestígio de narrativa, ficção, personagem ou qualquer espécie de mediação dramática. O "fechamento" da cena circunscrito pelas lâmpadas no chão é meramente alegórico: a cena chega aos espectadores de forma direta através de interpretações abertas (ou seja, através de atores não apenas cientes da presença dos espectadores, mas capazes de transformá-los em elementos da ação se assim desejado). A dramaturgia da peça é outro elemento de abertura: cada vez que uma pergunta é lançada abre-se um vácuo que é imediatamente ocupado mentalmente pelos espectadores. A cada interrogação suspensa, um salto mental. A longa duração da peça tanto exaure como exalta atores e espectadores fazendo daquela cena uma experiência psicofísica única. Por vezes, a argüição é cômica e amigável; em outros momentos, transforma-se numa forma de tortura; noutros, adentra-se um espaço desarticulado, demente, vazio, disléxico, mole. Os semblantes de palhaço oscilam significação de acordo com a atmosfera da cena. Quizoola! é um jogo de perguntas e respostas a partir de uma interrogação essencial: quais os limites da cena teatral?

Esta é uma interrogação fundamental para o aluno interessado tanto em aprender técnicas e tradições quanto em posicionar-se crítica e criativamente em relação à tradição e seu arcabouço técnico e teórico. A performance sugere que parte do aprendizado é inserir-se na tradição e dialogar com ela, e parte do aprendizado é forçar limites preestabelecidos e criar ruídos. Ou, em outras palavras, parte do estudo é conhecer o teatro e parte do estudo é perguntar-se sobre o que seja "teatro".

Penso que interessa particularmente ao aluno de teatro - num momento histórico em que outras mídias dramáticas (industriais, eletrônicas, digitais) exigem um investimento nas especificidades da cena da presença compartilhada - uma reflexão diretamente voltada para a dramaturgia do espectador como aquela proposta pela performance. Se o espetáculo teatral é único em cada apresentação, e de fato é, a performance acirra ainda mais a efemeridade da presença e a precariedade do evento: a performance é radicalmente irrepetível. O imediatismo da performance deve-se justamente à falta de elementos de mediação, seja o enredo, o personagem ou o palco. Conforme dito anteriormente, a performance funda uma cena com características muito particulares uma vez que propõe a realização de ações não-fictícias em tempo "real". Ou ainda, a performance distende a idéia de "cena" propriamente dita: do drama do palco passamos ao drama da sala, da rua, da cidade. A "cena” performativa trata da execução de programas psicofísicos e da vivência das relações que estes 
programas deflagram (relações consigo, com o outro, com o objeto, com o meio). $E$ É determinante o fato de que o decréscimo ficcional, ilusionista e narrativo implica num acréscimo de presença e participação do espectador. $\mathrm{O}$ espectador torna-se um elemento fundamental na trama performativa, um agente direto ou indireto, uma testemunha, ou, por vezes, um co-autor da ação proposta pelo performer. Comemorar o aniversário de um desconhecido na rua, abraçá-lo, desejar-lhe sinceros ou insinceros votos de felicidade e comer do seu bolo; ver uma pessoa cortar-se e não impedi-la; interferir com objetos que provocam dor ou prazer no corpo de um alguém desconhecido e passivo; comprar ou não um vidro de maionese por 100 dólares; divertir-se ou chocar-se com o fato de que uma pessoa transforma seu próprio rosto, a cirurgia plástica e o set cirúrgico num circo macabro; indignar-se ou não com um cidadão que decide, não por falta de recursos, transformar-se temporariamente num sem-teto e chamar isso "arte"; revoltar-se ou rir com outro que esculpe caralhos com terços; optar por tocar ou não nos seios de uma mulher através das cortininhas de um teatro à italiana são provocações que implicam não num ensaio psicológico de posicionamento, mas em tomadas de posição imediatas. $\mathrm{O}$ chamado da performance é justamente este: posicione-se já, aqui e agora. Chamado este que instiga no aluno de teatro um posicionamento político consciente e ativo e aponta para a importância da dramaturgia do espectador, ou seja, para as maneiras como o teatro ativa seu público.

Entretanto, é preciso esclarecer: mesmo abolindo a ficção, não escapamos da narrativa, visto que o processo de cognição humana é fortemente narrativo. A desaceleração narrativa tampouco elimina por completo a dimensão representacional, pois como ressaltado anteriormente, estamos tratando de cenas, ainda que imediatas e cruas. Porém, ao esvaziarmos ao máximo a narratividade de um evento, sua condição de decifração através de um ato de "leitura" será minimizada em favor de uma experiência relacional com o mesmo. Conforme proposto na primeira parte deste ensaio, não penso que a melhor maneira de acessar o evento seja definindo o significado ou significados da ação performada, mas buscando perceber qual seja sua força motriz e que novas forças daí se repercutem. (Definir o que significa um sujeito arrastando um bloco de gelo pela Cidade do México ou alguém rodando por um longo período de tempo numa praça pública do Rio de Janeiro me parece menos importante e interessante do que atentar para as motivações dramatúrgicas e políticas de seus agentes e para as ações e reflexões que se derivam nos que experimentam tais programas - seja assistindo, performando ou ouvindo falar).

E neste ponto adentramos, talvez, a maior zona de turbulência ativada pela performance: sua maneira de operar "comunicação". Como sabemos, o conceito de comunicação sofreu significativas alterações quando se flexibilizaram as noções de sujeito, objeto, linguagem, meio, corpo... (com Einstein, Freud, Heisenberg, Merleau-Ponty, Beckett e tantos outros que demonstraram como o relativismo, a inconsciência, a indeterminação, o paradoxo e o vazio são forças constitutivas da experiência comunicacional). A ilusão da comunicação como transmissão mecânica de uma mensagem - que trafega invariável entre emissores e receptores de forma transparente e inequívoca -espatifou-se. O temido 
"ruído" tornou-se elemento paradoxicalmente comunicacional, elemento incluído por vários artistas em seus discursos. O performer não pretende exatamente comunicar um determinado conteúdo ao espectador, mas, acima de tudo, promover uma experiência através da qual conteúdos serão elaborados. Em geral, o foco não está na transmissão de determinado conteúdo, mas na potência relacional promovida pela experiência proposta (no caso do espectador, na experiência que este estabelece com o performer, consigo, com os outros da audiência, com o espaço onde a operação se dá e seu contexto histórico). É sobretudo neste conteúdo relacional que reside a força política do ato performativo. Para os estudantes de teatro, o desafio lançado pela performance (e todas as práticas que provocam distúrbios comunicacionais) é direto: como o teatro vem tratando destas questões e quais as conseqüências éticas e estéticas destas manobras? Trata-se igualmente de uma pergunta-chave para professores de teatro, ocupados em liderar cenas comunicacionais abertas a tantas correntes interdisciplinares como a sala de aula de teatro.

Por fim, penso que especificamente em nosso país, um país marcado tão profundamente por atos de violência e de irresponsabilidade política, a aproximação entre performance e teatro indica caminhos prolíficos para uma renovação da discussão política da e na cena brasileira. Como, depois do apogeu da era Bertolt Brecht, estamos articulando nossas poéticas políticas? Como a cena contemporânea responde às políticas da globalização "pós-colonial”? Ao refletir sobre a verve política da arte contemporânea, Lucy Lippard esclarece:

Está claro que hoje em dia até a arte existe como parte de uma situação política. O que não quer dizer que a arte tem de ser vista em termos políticos ou ser explicitamente engajada, mas a maneira como os artistas tratam sua arte, onde eles a fazem, as chances que se tem de fazê-la, como ela será veiculada e para quem - é tudo parte de um estilo de vida e de uma situação política ${ }^{23}$.

Ou seja, tratar-se ou não de militância política, não é o ponto nevrálgico do problema. O chamado é por uma ativação da consciência política, a noção de que participamos de um contexto histórico e, sobretudo, de que nossos atos formam tal contexto. A performance é a arte da negociação.

Espero que ao fim deste artigo estejam claros alguns dos principais motivos pelos quais penso que a performance deva ser incluída nos currículos de teatro em nível superior de ensino. Espero que esta discussão se fortaleça na academia assim como vem fortificando-se nos palcos e festivais de teatro pelo mundo afora. A interdisciplinaridade não é um modismo, mas um caminho contemporâneo de potencialização política e poética.

${ }^{23}$ LIPPARD, Lucy R. Six years: the dematerialization of the art object. Berkley: University of California Press, 1973. p. 8-9. Traduzido do inglês. 


\section{REFERÊNCIAS}

ARTAUD, Antonin. Theater and its doublé. New York: Grove Press, 1958.

DELEUZE, Gilles. The logic of sense. New York: Columbia University Press, 1990.

DELEUZE, Gilles; GUATTARI, Félix. A thousand plateaus. Minneapolis: University of Minnesota Press, 1987.

DERRIDA, Jacques. A escritura e a diferença. São Paulo: Perspectiva, 1995.

GOLDBERG, RoseLee. Performance art, from futurism to the present. New York: Thames and Hudson, 2001.

HEATHFIELD, Adrian. (Ed.). Live art. Mustang: Tate Publishing, 2004.

LIPPARD, Lucy R. Six years: the dematerialization of the art object. Berkley: University of California Press, 1973.

McEVILLEY, Thomas. Stages of energy: performance art ground zero? In: Artist's body. Milano: Charta, 1998.

NESTROVSKI, Arthur (Org.). Trilogia bíblica: teatro da vertigem. São Paulo: Publifolha, 2002.

REVISTA MÁSCARA. Cidade do México: Fondo de Cultura del México, [19--]. Número especial em homenagem à Jerzy Grotowski.

SCHIMMEL, Paul (Org.) Out of actions: between performance and the object 1949-1979. Los Angeles: Tharus and Hudson, The Museum of Contemporary Art, 1998. 


\section{MeCANismos DE COMICIDADE NO ENSINO DO TEATRO}

Elza de Andrade

Os diversos escritos sobre construção do personagem não fazem distinção entre o sério e o cômico. Quem, entretanto, vive a prática da cena (e do magistério) sabe que efetivamente existe uma diferença entre seus processos de construção. E que, na maioria das vezes, o desconhecimento desse processo em relação aos personagens de comédia leva-nos a atribuir sua representação a um talento particular; ou, então, a tentar encontrar algumas justificativas equivocadas e preconceituosas que acreditam na inviabilidade de a comédia ser ensinada, negando qualquer possibilidade ao ator de representá-la por meio de estudo e técnica.

Já há alguns anos, portanto, como professora e diretora de teatro, estudo alguns conceitos do cômico e da comédia, procurando transformá-los em prática cênica, no sentido de oferecer ao aluno-ator uma estrutura técnica, por meio da qual ele possa caminhar para construir seus personagens, sem depender exclusivamente de um dom particular. $\mathrm{Na}$ minha opinião, é equivocado acreditar que "comédia não se aprende na escola", procedimento que me parece demonstrar a negação do gênero.

$\mathrm{Na}$ tentativa de escapar do procedimento comum que é compreender o cômico apenas partir do texto dramatúrgico, isto é, propondo a leitura e montagem de cenas de diversos comediógrafos, minha pesquisa tem caminhado no sentido de elaborar um conjunto de exercícios práticos, pensados a partir de conceitos teóricos sobre o cômico. O objetivo principal desses exercícios é oferecer ao aluno e ao ator a consciência e o domínio daquilo que chamo de mecanismos de comicidade, ou seja, um acervo técnico de procedimentos atoriais.

\section{Modelo de atuação do ator cômico - Marco De Marinis}

Marco De Marinis é um dos mais importantes teóricos teatrais contemporâneos, professor da Universidade de Bologna e autor de diversas obras sobre teoria e prática do teatro. Sua obra propõe uma revisão profunda tanto do método como do objeto dos estudos teatrais, oferecendo novas ferramentas, cujo enfoque histórico é completado substancialmente por outros aportes das novas ciências do espetáculo, e para tanto propõe uma nova "teatrologia". Superando o conceito "textocêntrico", que durante muito tempo reduziu a história do teatro à história da literatura dramática, De Marinis investe numa história do teatro global, isto é, numa nova perspectiva 
teatrológica não mais parcial, e sim orgânica e integradora. Uma perspectiva capaz de enfatizar uma visão global e unitária do fato teatral, baseada em seus elementos fundantes - o ator e o espectador - e, mais precisamente, na relação que os une, que ele denomina simplesmente relação teatral.

De Marinis ${ }^{1}$, analisando o ator cômico no teatro italiano do século XX, constrói um modelo de atuação, do qual utilizo alguns procedimentos na organização da metodologia de estudo dos mecanismos de comicidade. Escolhi esse texto como uma das principais referências de uma parte de minha pesquisa por encontrar nele elementos de uma estrutura mais ampla, que pode ser a do ator de teatro em geral, e não apenas do cômico italiano do século XX. Além disso, esse modelo apresenta procedimentos ligados diretamente à cena, ao trabalho do ator e à recepção da comicidade, sendo, portanto, muito apropriado para o entendimento da essência da representação cômica, encarada como uma tensão entre atuação (gesto, voz, palavra, emoção) e o público. Tensão que só pode ser compreendida e testada a partir do olhar do outro, que é o espectador. Estudar a comicidade sem considerar a presença do público é perder um personagem fundamental, que serve de guia e estímulo para o ator.

Trabalho também com as análises conceituais de Northorp Frye (19121991), Vladimir Propp (1895-1970) e Henri Bergson (1859-1941) sobre o fenômeno cômico. Estas análises têm caráter eminentemente teórico, a partir de referências literárias, folclóricas, dramatúrgicas e filosóficas. Procurei destacar da obra de cada um deles alguns princípios que procuro compreender e utilizar como "matrizes de comicidade", com o intuito de servir de referência à realização dos exercícios práticos para o ator, posto que trazem implícito caráter dramático, teatral e cênico.

\section{Vocação para o solo}

Segundo De Marinis, esta é a primeira e principal característica que diferencia o ator cômico do ator burguês (ou dramático): ser, por vocação, um solista. Uma forte característica do ator burguês é a de se limitar a interpretar aquilo que está escrito pelo autor, em rigoroso respeito à palavra do dramaturgo, enquanto o cômico é aquele que inventa partes de seu próprio texto, num procedimento, muitas vezes, co-autoral.

Sua vocação para o solo refere-se a diferentes aspectos do trabalho teatral. Um deles pode ser a ausência do texto dramático, uma espécie de solidão dramatúrgica, que não diminui significativamente quando existe o texto a priori. Há também a solidão cênica: o ator geralmente está sozinho no palco, diante de seu público. Ele só tem a si próprio, sua pessoa, sua técnica. Além disso, dispõe de um tempo curto para convencer o espectador. Daí a necessidade de uma inteligência imediata, rápida, ágil e sintética, alimentada por um arcabouço técnico, um conjunto de acervos textuais, das mais variadas procedências, que protegem o ator em seu solo, e que podem vir a ser aprendidos e elaborados.

\footnotetext{
1 DE MARINIS, Marco. Comprender el teatro: lineamientos de una nova teatralogía. Buenos
} Aires: Galerna, 1997. p. 158-170. 


\section{Autotradição: bricolage; bricoleur}

O ator cômico vive em uma solidão histórica. Não é possível fazer referência a um modelo único de tradição atorial cômica. Encontramos uma série de "tradições" individuais ou, melhor, de "autotradições". Essa autotradição não nega a existência de mestres nem de paradigmas; apenas não concebe a atuação como algo já preexistente, e sim como invenção de algo novo - portanto, como reconstrução do próprio mecanismo de atuação.

A autotradição deve ser considerada necessidade vital para o ator cômico, fonte de reorganização de seu próprio acervo, por meio da relação livre com o pensamento. Ela pode ser construída por meio de um trabalho minucioso e complexo de bricolage: seleção, desmontagem, recomposição, assimilação e reelaboração.

O antropólogo francês Claude Lévi-Strauss, em sua obra $O$ pensamento selvagem (1962), explora as noções de "bricolage e bricoleur" como conceitos fundantes para o campo da antropologia que trabalha com mitos, arte e ciência. Para ele, esses conceitos referem-se à reflexão mitopoética das culturas primitivas em que bricoleur é aquele que "executa um trabalho usando meios e expedientes que denunciam a ausência de um plano preconcebido e se afastam dos processos e normas adotados pela técnica. Caracteriza-o especialmente o fato de operar com materiais fragmentários já elaborados, ao contrário, por exemplo, do 'engenheiro' que, para dar execução ao seu trabalho, necessita da matéria-prima" 2 .

A regra do jogo para o bricoleur é arranjar-se com os "meios-limites", isto é, um conjunto sempre finito de utensílios e de materiais bastante singulares (heteróclitos). Esses elementos são recolhidos segundo o princípio de que "isso pode servir para alguma coisa”, e não em função de algum projeto. Os materiais do bricoleur já foram usados antes para outros fins ou em outros contextos, sendo agora adaptados a outras funções, de acordo com as necessidades. Ele constrói com restos/fragmentos algo novo e pessoal, a que ele soma seu próprio modelo e lhe dá uso diferente daquele que tiveram suas partes componentes. Sua forma de trabalhar supõe a capacidade de criar, trazendo implícita a necessidade de adaptar-se às circunstâncias e ao inesperado.

Lévi-Strauss chama atenção para as decisões que o bricoleur toma em face dos elementos predeterminados que entram na construção de sua bricolage; são escolhas e permutas que se entrelaçam, criando uma nova estrutura.

Aproximando o conceito de bricoleur do universo do ator cômico, podemos perceber que a autotradição a que De Marinis se refere está relacionada à maneira pela qual o ator opera suas referências/fragmentos. Sua assinatura bem como sua competência, seu virtuosismo - traduz-se na maneira pela qual ele as reúne e reelabora, criando, a partir de materiais já conhecidos, um novo modelo, uma nova estrutura.

Podemos observar que, muitas vezes, a comicidade é conseqüência dessa nova arrumação. $\mathrm{O}$ espectador ri ao identificar as partes componentes colocadas em um novo padrão.

${ }^{2}$ LÉVI-STRAUSS, Claude. O pensamento selvagem. 3. ed. Campinas, SP: Papirus, 2002. p. 32. 


\section{Variedade de linguagens teatrais}

O ator cômico não trabalha dentro numa única forma espetacular, mas circula em meio a grande variedade de linguagens teatrais:

Aqui nasce o tão celebrado ecletismo do ator cômico (algumas vezes um pouco mediatizado) que sabe recitar, cantar, dançar, representar uma farsa ou uma comédia séria e muitas outras coisas. Daqui nascem a amplitude, a variedade e também a precisão de seu saber-fazer, em comparação aos limites técnicos (e por outro lado também culturais) do ator burguês, que é, essencialmente, um ator de vozes, um declamador, bem mais desajeitado no manejo corporal ${ }^{3}$.

São muitas as descendências do ator cômico popular, e muito antiga é a sua origem; nesse longo percurso ele foi aperfeiçoando seu saber-fazer na soma de tantas artes e técnicas da cena. Sua tradição engloba quase toda a história da arte cênica, se considerarmos que ele estava lá nas procissões dionisíacas, nas praças medievais, nas tavernas, no circo, nos cabarés, nos pavilhões, no boulevard e, agora, está também nas telinhas e nos telões. Os que sobreviveram, fizeram-no independentemente dos estilos ou das idades históricas, entendendo a tradição como repertório de acervos que devem ser utilizados a partir de uma assinatura própria.

Nos dias de hoje, portanto, precisamos pensar no ecletismo do ator cômico como uma meta a ser atingida. $O$ ator contemporâneo deve alargar suas possibilidades cênicas para estar apto a enfrentar diferentes linguagens e concepções, postura fundamental ao exercício da profissão. Conhecer alguns mecanismos de comicidade utilizados pelo ator cômico/popular é ampliar sua técnica e seu espaço de atuação na cena do teatro contemporâneo. A obra de alguns de nossos principais encenadores, assim como as pesquisas atoriais das últimas décadas do teatro brasileiro, aponta para a necessidade de formação do profissional capaz de dominar diferentes acervos técnicos em busca de uma atuação múltipla e, principalmente, autoral.

\section{Metatuação carnavalesca}

Para De Marinis, a atuação do ator cômico deve ser entendida como uma metatuação, isto é, como uma atuação sobre a atuação, um teatro sobre o teatro, na qual a comicidade se aplica mais à realidade teatral do que à realidade cotidiana; mais exatamente, à interpretação proposta pelo teatro sério do final do século IXX, ou seja, o ator cômico satiriza e caricatura a representação sentimental, cheia de dor e ênfases sublimes, do grande ator burguês.

Pensando o teatro sério como a forma canônica de representação, podemos perceber aqui uma analogia com o conceito de "carnavalização" apresentado por Bakhtin. Segundo o autor, "as formas da cultura cômica da Idade Média tinham uma relação capital com o tempo, a mudança, o devir. Elas destronavam e renovavam o poder dirigente e a verdade oficial. Faziam triunfar o retorno de tempos melhores, da abundância universal e da justiça. A nova consciência his-

\footnotetext{
${ }^{3}$ DE MARINIS, 1997, p. 162.
} 
tórica se preparava nelas também. Por esse motivo, essa consciência encontrou sua expressão mais radical no riso" ${ }^{4}$.

Todas as imagens da festa popular estavam dialogando com essa nova sensação histórica, produzindo uma despedida cômica e popular do velho poder e da velha verdade:

Naquela época, era absolutamente necessário estar armado do riso não oficial para aproximar-se do povo que desconfiava de tudo que era sério, que tinha o hábito de estabelecer um parentesco entre a verdade livre e sem véus e o riso ${ }^{5}$.

O jogo de contrastes entre rebaixamento e elevação também remete ao conceito bakhtiniano de carnavalização. Segundo Bakhtin, uma das características dos festejos carnavalescos na Idade Média e no Renascimento é a inversão da hierarquia vigente: personalidades elevadas, como o Rei, ganham sua versão rebaixada, normalmente representada de maneira grotesca, como, por exemplo, o Rei Momo; por outro lado, o povo permite-se imitar os trajes e as maneiras fidalgas. Nesse sentido, o carnaval transmite a impressão de "mundo às avessas"; além disso, estimula os exageros relacionados com o baixo corporal, e a presença de uma multidão de pessoas provoca a mistura de corpos, característica do grotesco. No carnaval, o grotesco, associado ao riso alegre, adquire um sentido positivo.

$\mathrm{O}$ verdadeiro riso, ambivalente e universal, não recusa o sério, ele purifica-o e completa-o. Purifica-o do dogmatismo, do caráter unilateral, da esclerose, do fanatismo e do espírito categórico, dos elementos de medo ou intimidação, do didatismo, da ingenuidade e das ilusões, de uma nefasta fixação sobre um plano único, do esgotamento estúpido. O riso impede que o sério se fixe e se isole da integridade inacabada da existência cotidiana. Ele restabelece essa integridade ambivalente ${ }^{6}$.

\section{A relação com o espectador}

O teatro ilusionista preserva seus atores ao fechá-los dentro da caixa preta, porém o ator cômico incorpora o espectador no centro de sua atenção, convertendo-o em sujeito e objeto de seu espetáculo. O espectador é arrancado de seu voyeurismo quando o ator derruba a quarta parede e fala diretamente com ele, atribuindo-lhe uma dupla função ao transformá-lo em confidente e parceiro de cena.

Invadindo a intimidade do público, o ator torna-se também vulnerável a uma reação imprevisível, pois não tem certeza da resposta do espectador. $\mathrm{O}$ ator cômico fica exposto a sofrer diretamente todas as conseqüências de sua atuação: indiferença, agressividade, fascinação ou, então, uma reação totalmente inesperada e imprevisível. E precisa saber incorporar essas reações a sua atuação, transformando-as em possibilidade de diálogo, de texto na cena, o que exige o domínio de técnica específica.

4 BAKHTIN, Mikhail. A cultura popular na Idade Média e no Renascimento: o contexto de François Rabelais. 2. ed. São Paulo: Hucitec, 1993. p. 85.

${ }^{5}$ BAKTHIN, 1993, p. 87.

${ }^{6}$ BAKTHIN, 1993, p. 105. 


\section{Matrizes de comicidade - Frye, Propp e Bergson}

O teórico canadense Northrop Frye ${ }^{7}$ observa que Aristóteles, no segundo capítulo da Poética, refere-se às diferentes posições dos personagens, que podem ser: melhores, piores e iguais a nós. Em conseqüência, as ficções podem ser classificadas pela força da ação do herói: se maior do que a nossa, ele é um ser divino, e a sua história será um mito. Nessa categoria estão também a lenda e os contos maravilhosos, em que o herói é um ser humano cujas ações são extraordinárias, porque algumas leis da natureza foram momentaneamente suspensas. Temos também o herói do modo imitativo elevado, da maior parte da epopéia e da tragédia.

O herói do modo imitativo baixo, da maior parte da comédia e da ficção realística, apresenta-nos a categoria de personagens que não são superiores aos outros homens. Nesse plano, há dificuldade em manter a palavra herói. Se de poder ou inteligência inferiores aos nossos, de modo que temos a sensação de olhar de cima (mesmo quando o leitor sente que está ou poderia estar na mesma situação), o personagem pertence ao modo irônico. Frye acrescenta ainda que "examinando esse rol, podemos ver que a ficção européia, durante os últimos quinze séculos, desceu constantemente seu centro de gravidade, lista abaixo"8.

Para o teórico canadense, o tema do cômico é a integração da sociedade. Portanto, a ação da comédia move-se no sentindo de incorporar o personagem à sociedade a qual ele naturalmente se ajusta; isso quer dizer que o movimento da comédia é de mudança de uma classe social para outra. Os obstáculos aos desejos do herói constituem-se na ação da comédia e sua superação no desenlace cômico. Em geral, os obstáculos vêm representados pelos desejos de um segmento mais velho ou mais poderoso, o que faz com que se atribua à comédia um movimento de subversão da ordem constituída. A tendência é incluir o maior número de personagens na sociedade final, mediante a reconciliação ou a conversão das partes. Para os personagens, cuja principal função é o divertimento do público, o princípio da conversão torna-se mais claro, pois a tendência da sociedade cômica é incluir e não excluir.

$\mathrm{Na}$ comédia, os personagens obstrutores são mais absurdos do que maus, podendo-se dizer que o absurdo está perto de uma norma cômica. Mas, afinal, o que torna absurdo o personagem obstrutor? Uma possibilidade encontra-se na obsessão. O princípio da idéia fixa é o de que é engraçada a repetição sem clímax.

Para Vladímir Propp, filólogo soviético, a contraposição do cômico ao trágico e ao sublime não revela a natureza da comicidade em sua especificidade. É preciso definir o cômico como tal, e não comparativa ou negativamente, pois seria negar a especificidade do gênero.

Pode-se rir do homem em quase todas as suas manifestações, podendo ser encontrados aspectos ridículos em sua vida física, moral e intelectual. A única exceção coloca-se nas manifestações de dor e sofrimento que, instantaneamente, bloqueiam os impulsos do riso.

Propp e Bergson concordam que a natureza não é ridícula - não existem florestas, estrelas, montanhas engraçadas. No entanto, o animal pode ser ridículo quando nos lembra o ser humano e seus movimentos. Podemos concluir, então, que

\footnotetext{
${ }_{7}$ FRYE, Northrop. Anatomia da crítica. São Paulo: Cultrix, 1973. p. 39-40.

${ }^{8}$ FRYE, 1973, p. 40.
} 
o cômico sempre, direta ou indiretamente, remete-nos ao humano.

O extraordinário ator Charles Chaplin (1889-1977) declara que na base de toda a comicidade "não há senão um conhecimento da natureza humana. A circunstância de um chapéu voar não é por si só cômica, mas sim o ver-se o seu proprietário a correr, com os cabelos no vento [...]. Os filmes cômicos tiveram um sucesso imediato porque a maior parte apresentava policiais que caíam em buracos de esgoto"

Um dos princípios que percorrem quase toda a obra de Propp afirma que o riso só é provocado quando o físico revela uma falha oculta do espiritual. Por exemplo, em geral as pessoas gordas (ou muito magras, altas, baixas, com nariz avantajado, carecas, etc.) costumam parecer ridículas. No entanto, existem gordos que não fazem rir, porque um princípio espiritual prevalece sobre o físico, sobrepondo-se a ele. Dentro dessa mesma idéia, encontramos algumas ações e funções corporais que também provocam a comicidade. Por exemplo, a embriaguez. A embriaguez exagerada, no entanto, o vício, não é ridícula, mas lamentável, porque se aproxima da idéia de doença e sofrimento. São também quase sempre ridículas as funções fisiológicas involuntárias do corpo: arrotos, gazes, soluços, cheiros.

Charles Chaplin acrescenta a essa idéia a questão da tentativa de manutenção da dignidade por parte daqueles que infringem o padrão "normal", colocando nessa pretensão, o núcleo da comicidade.

Ainda mais divertida é a pessoa ridicularizada que, apesar disso, se recusa a admitir que lhe aconteceu alguma coisa de extraordinário e teima em defender a sua dignidade. O melhor exemplo nos é dado pelo homem ébrio, que denunciado pela sua fala e pelo seu andar, nos quer convencer bastante dignamente de que está em jejum. A bebedeira no cinema é geralmente ligada a uma tentativa de se manter a dignidade, pois os realizadores aprenderam que esta pretensão é divertida ${ }^{10}$.

O cômico é um mecanismo de subversão e destruição: ele revela e assim destrói a falsa autoridade e o falso poder daqueles que são submetidos ao ridículo. A comicidade, portanto, é provocada pela descoberta de algum defeito oculto.

O ser humano, em geral, possui um conjunto de idéias que considera a norma, o padrão. Essas normas referem-se tanto ao aspecto exterior do homem quanto à vida moral e intelectual. Provocam a comicidade os desvios, as quebras da norma ou do padrão.

É possível parodiar tudo: os movimentos e as ações de uma pessoa, seus gestos, o andar, a mímica, a fala, os hábitos de sua profissão e o jargão profissional. A paródia busca demonstrar que por trás das formas exteriores de uma manifestação espiritual não há nada, que por trás delas existe o vazio. A paródia é cômica quando revela a fragilidade interior do que é parodiado. Para Propp ${ }^{11}$ :

A paródia consiste na imitação das características exteriores (a forma), de um fenômeno qualquer de vida, de modo a ocultar ou negar o sentido interior daquilo que é

${ }^{9}$ CHAPLIN et al. Chaplin: cadernos de cinema. Lisboa: Dom Quixote, 1969. n. 3, p. $109-110$.

${ }^{10}$ CHAPLIN et al., 1969, p. 110.

${ }^{11}$ PROPP, Vladímir. Comicidade e riso. São Paulo: Ática, 1992. p. 84 -85. 
submetido à parodização. Desse modo, a paródia representa um meio de desvendamento da inconsistência interior do que é parodiado.

Segundo Pavis ${ }^{12}$, em seu Dicionário de teatro, a paródia é "uma peça ou fragmento que transforma ironicamente um texto preexistente, zombando dele por toda espécie de efeito cômico". O texto parodiante nunca pode esquecer o alvo parodiado; caso contrário, desaparecerá a força crítica, pois ele cita o texto original deformando-o. A paródia é, ao mesmo tempo, citação e criação original. A inversão dos signos substitui o elevado pelo vulgar. A inversão, em geral, é feita com o objetivo de degradar, mas é possível também que um texto vulgar possa ser substituído por um texto nobre. Nesse caso, o contraste e seu efeito cômico parecerão ainda mais surpreendentes.

Pavis ${ }^{13}$ acrescenta que a paródia de uma peça não se restringe a uma técnica cômica. "Ela institui um jogo de comparações e comentários com a obra parodiada e com a tradição literária ou teatral. Constitui um metadiscurso crítico sobre a peça de origem".

Linda Hutcheon ${ }^{14}$ comenta que a paródia é também uma forma de imitação que se caracteriza por uma inversão irônica que nem sempre acontece à custa do texto parodiado. É uma repetição com distância crítica, que marca a diferença em vez da semelhança. Portanto, a inversão irônica está presente em toda paródia.

A comicidade está sempre muito próxima do exagero, no entanto, o exagero só é cômico quando revela um defeito. São três as formas fundamentais de exagero: a caricatura, a hipérbole e o grotesco. A caricatura consiste em tomar-se qualquer particularidade e aumentá-la até que ela se torne visível para todos. A hipérbole é uma variação da caricatura. Na caricatura ocorre o exagero de um pormenor; na hipérbole, o do todo. O grau mais elevado e extremo do exagero é o grotesco, no qual, o exagero atinge tais dimensões, que extrapola os limites da realidade e penetra o domínio do fantástico. $\mathrm{O}$ grotesco é a forma de comicidade preferida pela arte popular desde a Antigüidade.

Para Pavis ${ }^{15}$, o grotesco é uma deformação significativa de uma forma conhecida ou aceita como norma e aparece estreitamente associado ao tragicômico, mantendo instável equilíbrio entre o risível e o trágico.

Bakhtin ${ }^{16}$, por sua vez, afirma que a verdadeira natureza do grotesco é inseparável do mundo da cultura cômica popular e da visão carnavalesca do mundo, pois elas destroem a seriedade e as pretensões de significação incondicional, liberando o pensamento e a imaginação humanas para novas possibilidades.

Chaplin ${ }^{17}$, porém, chama atenção para o exagero excessivo, que também pode matar a comicidade. "Poderei mais facilmente matar o riso por exagero que por qualquer outro meio". É preciso, portanto, saber o que exagerar e qual sua medida adequada.

A descoberta dos defeitos das pessoas e outras descobertas semelhantes só levam à comicidade quando são inesperadas. Uma piada nos faz rir por seu

\footnotetext{
${ }_{12}$ PAVIS, Patrice. Dicionário de teatro. São Paulo: Perspectiva, 1999. p. 278.

13 PAVIS, 1999, p. 279.

${ }^{14}$ HUTCHEON, Linda. Uma teoria da paródia. Lisboa: Edições 70, 1989. p. 17.

${ }_{15}$ PAVIS, 1999, p. 188-189.

16 BAKTHIN, 1993, p. 41-43.

17 CHAPLIN et al., 1969 , p. 121.
} 
final espirituoso e surpreendente. A essência da piada é a inesperada e rápida aproximação de dois objetos que por sua natureza pertencem a duas categorias diferentes.

Henri Bergson ${ }^{18}$, filósofo francês, vencedor do Prêmio Nobel de literatura de 1927, apresenta uma visão metafísica do riso. Para ele, rimos sempre do humano que deixou de ser, circunstancialmente, humano para se tornar mecânico, autômato, envolvido na repetição e na caricatura. Bergson propõe a existência de mecanismos que interrompem, desarranjando a vida espontânea, criativa, livre. Uma de suas idéias principais demonstra que o cômico é o mecânico que se sobrepõe ao vivo. Para Bergson, o riso é uma espécie de gesto social:

[...] uma certa rigidez do corpo, do espírito e do caráter, que a sociedade gostaria de eliminar para obter de seus membros a maior elasticidade e a mais elevada sociabilidade possíveis. Essa rigidez é a comicidade, e o riso é seu castigo ${ }^{19}$.

Automatismo, rigidez, hábito adquirido e conservado são alguns traços físicos que provocam o cômico e que ganham mais intensidade quando lhes somamos uma causa profunda, que os relacionam a um desvio de caráter. No cômico das formas e dos gestos, Bergson propõe que a comicidade surge quando o corpo nos leva a pensar num simples mecanismo, perdendo sua humanidade. Nesse princípio, encaixam-se muitos dos artifícios usuais da comédia, como a repetição de gestos, expressões e movimentos.

O outro mecanismo de comicidade ocorre quando se dá uma transferência de atenção da alma para o corpo. A corporalidade do personagem e suas necessidades físicas e fisiológicas nos remetem ao cômico. Segundo Bergson ${ }^{20}$, essa é a razão pela qual o poeta trágico evita "tudo o que possa chamar a nossa atenção para a materialidade de seus heróis".

Esse princípio pode ter vários desdobramentos, como, por exemplo, a forma que se impõe ao conteúdo, o ridículo físico e o ridículo profissional.

Dentro da comicidade de situação e de palavras, Bergson destaca a inversão, que pode ser entendida também como o contraste, um dos mecanismos mais tradicionais, sempre presente nas comédias antigas.

Chaplin confirma a tendência do público para gostar dos contrastes e das surpresas, e do conflito entre o bem e o mal, o rico e o pobre, o bobo e o esperto. Por isso, na maioria de seus filmes, quando seu personagem é perseguido por policiais, esses são pesados e desajeitados, enquanto ele, pequeno e ágil, escapa por entre as pernas de seu perseguidor:

É evidentemente uma sorte que seja pequeno e possa assim fazer estes contrastes sem custo. Sabendo desta inclinação pelo fraco, arranjo sempre uma maneira de acentuar a minha fraqueza encurvando as costas fazendo uma cara medrosa e tomando um ar assustado. Tudo isto, naturalmente, é a arte da pantomima; mas se eu fosse um pouco

${ }_{18}$ BERGSON, Henri. O riso. São Paulo: M. Fontes, 2001. 152 p.

${ }^{19}$ BERGSON, 2001, p. 15.

20 BERGSON, 2001, p. 39. 
maior teria mais dificuldade em ser simpático ${ }^{21}$.

O contraste é um dos mecanismos mais presentes na comicidade de todos os tempos da história do ator e do teatro. Existe uma lógica nas oposições que se pode manifestar de várias formas: na própria linguagem (na fala do personagem), em seu corpo (diferenças no andar, na dimensão, no gesto), na pulsação rítmica e temporal, no temperamento e na moral, no figurino e na caracterização, ou seja, em quase todas as possibilidades de composição externa e interna dos personagens.

Por contraste, podemos pensar em vários níveis de oposição, como, por exemplo, na cena da commedia dell'arte, em que encontramos dois planos de ação: um "sério", com a presença dos enamorados, e outro "ridículo", dos criados e dos velhos, representantes de tradições e códigos atoriais diferentes. O contraste, tão nitidamente característico da cena da commedia dell'arte, apresenta-se em vários outros momentos da história do teatro, também como um recurso de complementaridade entre os personagens; e, ampliando seu sentido, podemos localizá-lo na base fundante do teatro e da dramaturgia se entendermos o conflito também como um jogo de contrastes.

\section{Mecanismos de comicidade - arte ou técnica?}

O grande legislador ateniense, Sólon, empreendeu uma reforma estrutural da polis grega a partir de 594 a.C. Um dos pontos dessa reforma foi o estímulo ao desenvolvimento e ao enriquecimento dos artesãos, patrocinando as técnicas e criando honrarias para os ofícios, sendo esse um dos motivos do declínio do poder das famílias aristocráticas. Segundo Chaui ${ }^{22}$, a polis democrática humanizou as técnicas ao desfazer a concepção mítica de que elas haviam sido dadas aos homens pelos deuses, como, por exemplo, o gesto heróico de Prometeu roubando o fogo sagrado de Zeus, trazendo-o para os homens. Essa humanização das técnicas significa também a valorização de uma classe social não aristocrática cujo valor não vem do sangue. Em resumo, a polis democrática enfatiza e destaca o valor da ação humana na natureza e na cidade. O humano em sua relação com o mundo, a experiência e a ação são, portanto, os temas da técnica.

Segundo Platão, a técnica é um saber especializado capaz de concretizar algo que existia apenas potencialmente. Na cultura greco-latina não havia distinção para os conceitos de técnica e arte. Segundo Chaui, na sociedade greco-romana "técnica ou arte é toda ação humana que fabrica alguma coisa que não existia na natureza, submetida a regras, portanto ordenada, em oposição ao acaso, ao espontâneo e ao natural”.

Porém, em nosso contexto histórico, a palavra técnica adquiriu um sentido afastado do conceito de arte, que provoca um empobrecimento de sua ação. Em geral, compreende-se a técnica como algo frio, burocrático, automatizado, que não respeita o espaço individual, muito próximo da máquina e distante do universo da criação.

Em nossa sociedade, fomos acostumados a distinguir técnica e arte. Técnica é a apli-

${ }^{21}$ CHAPLIN et al., 1969 , p. 117.

22 CHAUI, Marilena. Introdução à história da filosofia: dos pré-socráticos a Aristóteles. 2. ed. São Paulo: Brasiliense, 1994. v.1, p. 116. 
cação de um conhecimento com finalidade prática e instrumental. Arte é a criação desinteressada de coisas belas pela fantasia e imaginação. Para os antigos gregos e romanos arte e técnica eram a mesma coisa, tanto assim que a palavra latina "ars" é a tradução da palavra grega "téchne"23.

No âmbito do ensino do teatro, deve-se trabalhar pensando nessa parceria antiga entre técnica (o processo) e arte (um momento do processo). É acreditando nessa conjugação de conceitos que proponho o estudo de mecanismos de comicidade na formação do ator.

A divisão clássica - aristotélica - dos gêneros perdeu sua validade; portanto, o cômico não se restringe apenas ao gênero da comédia. É um fenômeno que age em vários campos distintos, ligados à história do homem e à sua capacidade de representar aspectos insólitos, ridículos e humanos de sua realidade externa, interna, pessoal e coletiva.

A cena brasileira tem evidenciado, em suas últimas décadas, grande complexidade e a necessidade de atores mais preparados tecnicamente - entendendo "técnica" como sinônimo de "arte" - para enfrentar seus desafios; portanto, essa é uma demanda efetiva. Acredito que o estudo de alguns mecanismos de comicidade pode fornecer elementos para a construção e o enriquecimento do acervo técnico do ator contemporâneo.

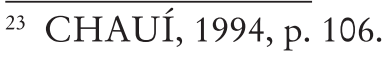




\section{REFERÊNCIAS}

ANDRADE, Elza de. Mecanismos de comicidade na construção do personagem: propostas metodológicas para o trabalho do ator. 2005. 272 p. Tese (Doutorado em Teatro) - Programa de Pós-Graduação em Teatro, Universidade Federal do Estado do Rio de Janeiro, 2005.

BAKHTIN, Mikhail. A cultura popular na Idade Média e no Renascimento: o contexto de François Rabelais. 2. ed. São Paulo: Hucitec, 1993.

BERGSON, Henri. O riso. São Paulo: M. Fontes, 2001.

CHAPLIN et al. Chaplin: cadernos de cinema. Lisboa: Dom Quixote, 1969. n. 3,

CHAUI, Marilena. Introdução à história da filosofia: dos pré-socráticos a Aristóteles. 2. ed. São Paulo: Brasiliense, 1994. v.1,

DE MARINIS, Marco. Comprender el teatro: lineamientos de una nova teatralogía. Buenos Aires: Galerna, 1997.

FRYE, Northrop. Anatomia da crítica. São Paulo: Cultrix, 1973.

HUTCHEON, Linda. Uma teoria da paródia. Lisboa: Edições 70, 1989.

LÉVI-STRAUSS, Claude. O pensamento selvagem. 3. ed. Campinas, SP: Papirus, 2002.

PAVIS, Patrice. Dicionário de teatro. São Paulo: Perspectiva, 1999.

PROPP, Vladímir. Comicidade e riso. São Paulo: Ática, 1992. 


\section{A POSIÇÃO DO ESPECTADOR: PERSPECTIVAS PEDAGÓGICAS}

Flávio Desgranges

O pensamento a respeito da posição do espectador em sua relação com a obra teatral permite que se apontem enfoques diversos e, quem sabe, complementares acerca das perspectivas pedagógicas que podem ser traçadas a partir deste encontro entre aquele que age em cena e aquele que observa da sala. Alguns aspectos podem ser destacados com vistas ao desdobramento da questão, tomando por diferentes ângulos esta pedagogia do espectador: 1) pode-se tomar a atividade proposta ao espectador como sendo por si pedagógica, apoiando-se, por exemplo, na máxima benjaminiana ${ }^{1}$, que aponta que na própria experiência artística reside seu potencial educacional, pois este lhe é inerente; 2) um outro feixe reflexivo se descortina ampliando a questão, ao se reconhecer o jogo de linguagem formulado pelo artista nas provocações estéticas que faz ao espectador, como proposições pedagógicas; 3 ) pode-se ainda abordar esta relação entre palco e platéia sob o âmbito da formação de espectadores apontando a relevância de um público teatral especializado, além dos procedimentos pedagógicos que podem ser adotados tendo em vista a dinamização da recepção teatral e a criação do gosto por esta arte.

Trataremos, aqui, o assunto tendo em vista especialmente o último dos aspectos ressaltados, traçando possíveis desdobramentos para a formulação de uma pedagogia do espectador ressaltando a pertinência da questão e os procedimentos pedagógicos a serem adotados no âmbito da formação de espectadores teatrais. Contudo, ao enfocarmos o teatro épico de Bertolt Brecht, serão abordados também alguns dos aspectos citados no item dois, dando conta, ainda que de maneira breve, de como as proposições estéticas formuladas pelo artista teatral podem ser tomadas como propostas pedagógicas.

\section{A formação de espectadores}

As pesquisas acerca da importância da formação de espectadores vêm tendo grande desenvolvimento nos últimos anos em todo o mundo. São dois os fatores preponderantes que sustentam estas investigações, e apontam para a necessidade

\footnotetext{
1 "A arte é educadora enquanto arte, não enquanto arte educadora", Walter Benjamin [1892-
} 1940], filósofo alemão. 
cada vez maior de implementação de práticas de formação: a necessária participação dos espectadores no desenvolvimento da arte teatral, o que sugere a efetiva atuação de um público teatral interessado nos próprios rumos desta arte; e a formação crítica do indivíduo contemporâneo que, numa sociedade espetacularizada, vê-se exposto cotidianamente a uma enxurrada de signos, diante dos os quais precisa encontrar-se apto para dialogar e produzir sentidos próprios.

Assim, o primeiro dos aspectos citados diz respeito à importância de que haja espectadores interessados em ver e debater teatro, já que não há desenvolvimento da arte teatral que possa se dar sem a efetiva participação dos espectadores. Não existe teatro sem platéia e a importância da presença do espectador nele precisa ser vista não somente por uma razão econômica, de sustentação financeira das produções. É evidente que o fator econômico é vital e não pode ser esquecido, até porque o preço do ingresso torna o acesso inviável, excluindo das salas uma parcela do público que talvez fosse a mais interessada. Como um livro que só existe quando alguém o abre, o teatro não existe sem a presença deste outro com o qual ele dialoga sobre o mundo e sobre si mesmo. Sem espectadores interessados neste debate, o teatro perde conexão com a realidade a que se propõe refletir e, sem a referência deste outro, o seu discurso se torna ensimesmado, desencontrado, estéril. Não há evolução ou transformação do teatro que se dê, portanto, sem a efetiva participação dos espectadores.

O olhar do observador sobre o espetáculo sustenta o próprio jogo do teatro. A necessidade de companheiros de jogo, companheiros de criação, anima o movimento de formação de espectadores. Uma pedagogia do espectador se justifica, assim, pela necessária presença de um outro que exija diálogo, pela fundamental participação criativa deste jogador no evento teatral; participação que se efetiva na sua resposta às proposições cênicas, na sua capacidade de elaborar os signos trazidos à cena e de formular um juízo próprio dos sentidos.

O público participativo é aquele que, durante o ato da representação, exige que cada instante do espetáculo não seja gratuito, o que não significa que seja necessário, pois, se manifestar ou intervir diretamente para participar do evento. A sua presença se efetiva na cumplicidade que ele estabelece com o palco, na vontade de compactuar com o evento, na atenção às proposições cênicas, na atitude desperta, no olhar aceso. Este espectador crítico, exigente e participativo é aliado fundamental nos diálogos travados acerca dos rumos da arte teatral.

O outro fator relevante para se pensar uma pedagogia do espectador, em nossos dias, diz respeito à espetacularização da sociedade, ocasionada pela proliferação de meios de comunicação de massa. Esses meios condicionam a sensibilidade e a percepção dos indivíduos contemporâneos, e indicam a necessidade de uma formação reflexiva do observador, visando a sua aptidão tanto para perceber os recursos espetaculares utilizados, quanto para analisar a produção de sentidos veiculada por estes canais de comunicação.

Em uma sociedade baseada na espetacularidade dos acontecimentos e apoiada na indústria moderna, que "não é fortuitamente ou superficialmente espetacular, ela é fundamentalmente 'espetacularista”, em que o espetáculo é “o sol que não se esconde

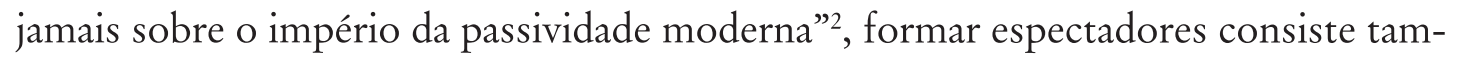

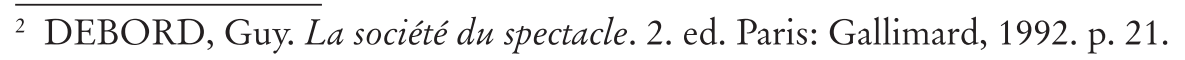


bém em estimular os indivíduos (de todas as idades) a ocupar o seu lugar não somente no teatro, mas no mundo. Educar o espectador para que não se contente em ser apenas o receptáculo de um discurso que lhe proponha um silêncio passivo. A formação do olhar e a aquisição de instrumentos lingüísticos sensibilizam o espectador para o diálogo que se estabelece nas salas de espetáculo, além de estimulá-lo para enfrentar o duelo que se trava no dia-a-dia. O olhar armado busca uma interpretação aguda dos signos utilizados nos espetáculos diários, na propaganda, nos noticiários, nos programas eleitorais, ou mesmo nas produções da cultura de massa. Com um senso crítico apurado, este consumidor-espectador, eleitor-espectador, cidadão-espectador procura estabelecer novas relações com o entorno e com as diferentes manifestações espetaculares que buscam retratá-lo.

Se nesta sociedade "a linguagem do espetáculo é constituída pelos signos da produção reinante" ${ }^{\text {, }}$ tomar conhecimento dos mecanismos que envolvem uma encenação, desvendar e apreender a lógica da teatralidade significa conquistar instrumentos que viabilizem a reflexão acerca dos procedimentos utilizados nas diferentes produções espetaculares. $\mathrm{O}$ espectador especialista se encontra em condições de decodificar os signos e de questionar os significados produzidos, seja no palco ou fora dele.

A formação de espectadores se justifica também pela urgência de uma tomada de posição crítica frente às representações dominantes, pela necessária aptidão do indivíduo-espectador para questionar os procedimentos e desmistificar os códigos espetaculares hegemônicos.

\section{Viabilizar o acesso do espectador ao teatro. Duplo acesso}

O despertar do interesse do espectador não pode acontecer sem a implementação de medidas e procedimentos que tornem viáveis o seu acesso ao teatro. $\mathrm{Na}$ verdade, duplo acesso: o físico e o lingüístico. Ou seja, tanto a possibilidade do indivíduo freqüentar os espetáculos quanto a sua aptidão para a leitura das obras teatrais. Antes disso, é fato, torna-se necessário que tenhamos boas condições de produção para um oferecimento quantitativo e qualitativo de espetáculos teatrais. No entanto, não é suficiente ter oferta de peças em cartaz, é preciso mediar este encontro entre palco e platéia. Primeiramente, é preciso criar condições para o espectador ir ao teatro, o que envolve uma série de medidas para favorecer a freqüentação, tais como: divulgação competente das peças em cartaz, que atinja públicos de diversas regiões e classes sociais; promoções e incentivos que viabilizem financeiramente o acesso das diferentes faixas de público; condições de segurança; rede de transportes eficiente; e tantas outras atitudes de apoio e incentivo que visem, em última instância, a colocar o espectador diante do espetáculo (ou vice-versa). O acesso ao teatro, porém, não se resume a possibilitar a ida às salas (ou a levar espetáculos itinerantes a regiões menos favorecidas). Formar espectadores não se restringe a apoiar e estimular a freqüentação, é preciso preparar e estimular o espectador para um rico e intenso diálogo com a obra, criando, assim, o desejo pela experiência artística.

Portanto, a pedagogia do espectador, no âmbito da formação, está calcada fundamentalmente nos procedimentos adotados para criar o gosto pelo debate es-

${ }^{3}$ DEBORD, 1992, p. 18. 
tético, para estimular no espectador o desejo de lançar um olhar particular à peça teatral, de empreender uma pesquisa pessoal na interpretação que se faz da obra, despertando o seu interesse para uma batalha que se trava nos campos da linguagem. Assim, contribui-se para formar espectadores que estejam aptos para decifrar os signos propostos, para elaborar um percurso próprio no ato de leitura da encenação, colocando em jogo sua subjetividade, seu ponto de vista, partindo de suas experiências, da posição, do lugar que ocupa na sociedade. A experiência teatral é única e cada espectador descobrirá a sua forma de abordar a obra e de estar disponível para o evento.

Figura chave nas reflexões traçadas entre teatro e educação, Brecht afirmava que a leitura crítica, a capacidade de compreensão de uma obra de arte, no entanto, pode e precisa ser trabalhada. A capacidade de elaboração estética é uma conquista e não somente um talento natural.

É uma opinião antiga e fundamental que uma obra de arte deve influenciar todas as pessoas, independente da idade, status ou educação [...]. Todas as pessoas podem entender e sentir prazer com uma obra de arte porque todas têm algo artístico dentro de si [...]. Existem muitos artistas dispostos a não fazer arte apenas para um pequeno círculo de iniciados, que querem criar para o povo. Isso soa democrático, mas, na minha opinião, não é totalmente democrático. Democrático é transformar o pequeno círculo de iniciados em um grande círculo de iniciados. Pois a arte necessita de conhecimentos. A observação da arte só poderá levar a um prazer verdadeiro, se houver uma arte da observação. Assim como é verdade que em todo homem existe um artista, que o homem é o mais artista dentre todos os animais, também é certo que essa inclinação pode ser desenvolvida ou perecer. Subjaz à arte um saber que é um saber conquistado através do trabalho ${ }^{4}$.

A especialização do espectador se efetiva na sua aquisição de conhecimentos de teatro, o prazer que ele experimenta em uma encenação se intensifica com a sua apreensão da linguagem teatral. O prazer estético, portanto, solicita aprendizado. A arte do espectador é um saber que se conquista com trabalho.

Familiarizado com os códigos teatrais, este espectador iniciado descobre pistas próprias de como se relacionar com a obra, percebendo-se no ato da recepção capaz de dar unidade ao conjunto de signos utilizados na encenação e de estabelecer conexões entre os elementos apresentados e a realidade exterior. A conquista da linguagem teatral propicia ao espectador uma atitude não submissa diante do fato narrado e das opções cênicas propostas. Conhecendo os signos que vêm sendo estabelecidos ao longo da história do teatro, bem como o funcionamento dos mecanismos utilizados em uma encenação, e os efeitos que produzem, o espectador ganha distância para melhor apreciar como estes elementos de significação podem ser apresentados em um espetáculo. A aquisição destes conhecimentos permite que o observador esteja em melhores condições para traçar linhas de reflexão a respeito da obra e elaborar um juízo de valor da mesma.

\footnotetext{
${ }^{4}$ BRECHT apud KOUDELA, Ingrid Dormien. Brecht: um jogo de aprendizagem. São Paulo: Perspectiva, 1991. p. 110.
} 
A distância possibilita que o espectador problematize a encenação, faça perguntas à cena, tais como: Que temas este espetáculo aborda? De que maneira isto se relaciona com a vida lá fora? Que signos e símbolos o artista se utiliza para apresentá-las? Eu já vi algo parecido? Como eu faria? De que outras maneiras esta mesma idéia poderia ser encenada? O prazer de assistir a espetáculos teatrais advém justamente do domínio da linguagem que amplia o interesse pelo teatro na medida em que possibilita uma compreensão mais aguda, uma percepção cada vez mais apurada das encenações.

\section{Procedimentos pedagógicos}

Os procedimentos visando à especialização de espectadores podem ser divididos em: espetaculares e extra-espetaculares. Os primeiros dizem respeito à própria constituição do espetáculo teatral, ou seja, espetáculos criados especialmente com o intuito de formar espectadores especialistas; e aí iremos nos aproximar necessariamente da teoria de teatro épico, criada por Bertolt Brecht. Os procedimentos extra-espetaculares constituem-se, em suma, no fornecimento de material didático sobre a encenação (biografia do autor, proposta de encenação, histórico do grupo, etc.) ou na proposição de jogos e exercícios dramáticos, antes e/ou depois dos espetáculos, com o objetivo de dinamizar a recepção dos espectadores. A seguir, abordaremos mais detalhadamente cada um destes procedimentos pedagógicos.

\section{O teatro épico como prática de formação de espectadores}

Neste breve comentário acerca do caráter formador do teatro épico, em sua vontade de proporcionar a apreensão da linguagem teatral pelos espectadores, será enfatizado especialmente o aspecto narrativo deste teatro brechtiano.

Em suas formulações teóricas com referência a arte teatral, na primeira metade do século XX, Brecht clamava por um teatro que se contrapusesse ao teatro da burguesia, o qual classificava como ilusionista, pois este se valia de algumas técnicas de representação - bem como de algumas inovações científicas da época, em especial a iluminação elétrica. Seu intuito era suscitar, no espectador, a ilusão de estar diante da realidade, como se o artista pretendesse trazer para o palco uma fatia da vida. Impossibilitado de se colocar enquanto sujeito que assiste a uma peça de teatro, o espectador deste teatro burguês, segundo Brecht, seria conduzido emocionalmente pela trama, o que diminuiria a sua capacidade reflexiva.

Os recursos cênicos utilizados pelo teatro épico brechtiano têm, assim, o intuito de afastar o espectador da ação dramática, interrompendo a corrente hipnótica e possibilitando a sua atitude crítica. "O espectador não deve viver o que vivem os personagens, e sim questioná-los"5. O encenador alemão propõe, em seus espetáculos, que o espectador se distancie e reflita sobre o que vê, ao invés de entregar-se a um envolvimento emocional que inviabilizaria o raciocínio. Este efeito de distanciamento é a viga mestra do teatro brechtiano.

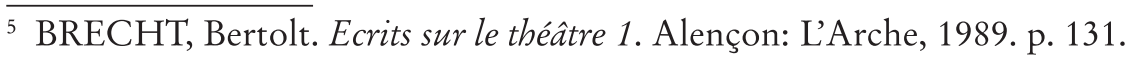


O distanciamento proposto pelo teatro épico brechtiano ao espectador tem nos elementos narrativos trazidos para a encenação seus principais recursos artísticos e pedagógicos.

O épico é um gênero literário em que a história é contada tanto por um narrador, em sua descrição dos acontecimentos, quanto pelos personagens, nos diálogos que interrompem a narrativa. $\mathrm{O}$ épico tem, portanto, um caráter fortemente narrativo, ao contrário do gênero dramático, em que a história vai sendo contada somente por meio do diálogo dos personagens entre si, sem a interferência direta de um narrador (autor).

No gênero épico, o autor relata uma história já ocorrida e, em geral, uma história que aconteceu com uma outra pessoa. Portanto, o narrador fala no pretérito (a história foi assim) e na terceira pessoa do singular (aconteceu com ele). "Isto cria uma certa distância entre o narrador e o mundo narrado" ${ }^{6}$, pois, se a história já aconteceu e aquele que a conta conhece bem todo o seu desenrolar, este narrador não tem o mesmo envolvimento emocional com o fato ocorrido que tem o autor do texto dramático, já que este apresenta o fato no tempo presente, como se o estivesse conhecendo pela primeira vez. Da mesma maneira, o leitor que entra em contato com um texto épico, com uma história já ocorrida, história que lhe é narrada, mantém certa distância do fato e não tem o mesmo envolvimento que o leitor do texto dramático, ao qual os fatos, mesmo quando se trata de um acontecimento histórico, são apresentados como se estivessem acontecendo naquele momento.

O texto no teatro épico, portanto, procura apresentar as situações de forma narrativa, tratando os fatos como históricos - fatos já ocorridos e que têm relevância histórica. Esta distância que se estabelece entre o espectador que assiste no presente a um fato ocorrido no passado permite que ele mantenha uma atitude reflexiva acerca do assunto narrado. No texto do teatro dramático, o autor se ausenta da história, que parece ganhar vida própria; o espectador vivencia a história que acontece diante dele no tempo presente. Vinculado emocionalmente à trama, o espectador do drama teria diminuída a sua capacidade de refletir sobre a mesma.

Como o texto, os elementos cênicos do teatro épico também têm um caráter narrativo. Embora a fábula seja considerada o coração do teatro épico, pois é ela que revela as vicissitudes sociais que enredam os personagens, na concepção brechtiana, no entanto, não apenas o texto, mas a encenação como um todo assume o papel narrativo; o palco conta de maneira crítica a história. Todos os recursos cênicos - a luz, o cenário, os figurinos e adereços - podem desempenhar função narrativa, comentando a ação, tomando posição em face dos acontecimentos. $\mathrm{O}$ palco assume uma função narrativa.

Um dos recursos épicos utilizados por Brecht em suas encenações era, por exemplo, a colocação de grandes telas, em que se projetavam documentos com cifras concretas, ou fotos ou citações, e que permitiam trazer à memória outros processos que se desenrolavam simultaneamente em outros lugares e que contradiziam ou comentavam as palavras e atitudes de alguns personagens.

Esta postura narrativa do palco diante dos fatos trazidos à cena, ressalte-se, somente se tornou viável devido a certas conquistas técnicas do período. A partir de então, para efetivar esta postura, podia-se contar com as projeções de slides e com

\footnotetext{
${ }^{6}$ ROSENFELD, Anatol. O teatro épico. 3. ed. São Paulo: Perspectiva, 1985. p. 25.
} 
os recursos cinematográficos, além de um maquinário motorizado que aumentou as possibilidades de transformação do palco. Estas inovações permitiram ao teatro incorporar estes elementos cenográficos, que davam à encenação um caráter quase literário, com a inclusão na peça de críticas e comentários do autor que, por vezes, assemelhavam-se a notas de pé de página.

A cena começa, assim, a exercer uma função pedagógica. Distante da ação dramática, o espectador do teatro épico pode deparar-se com questões que lhe digam respeito. Assim, o petróleo, a inflação, as lutas sociais, a família, a religião, a manteiga, o pão e o comércio de carnes passam a ser objetos de representação teatral. A intenção era trazer o pano de fundo social para a cena, afirmando a dimensão histórica do acontecimento apresentado por meio dos elementos narrativos que a golpeiam, interrompendo a corrente dramática e afirmando a atitude crítica do espectador. Brecht elaborou uma série de técnicas e recursos cênicos com esta finalidade, entre eles se destacam, por exemplo: jornaleiros que percorrem a sala, anunciando manchetes que caracterizam o clima social, ou slides com fotos históricas, ou ainda canções (songs) e cartazes com dizeres que propunham uma visão crítica sobre o fato representado.

Outro importante aspecto pedagógico deste teatro brechtiano está no fato de que cada elemento da encenação (cenário, figurino, iluminação, etc.) ser apresentado separadamente, e manifestar-se com voz própria em face dos acontecimentos. Assim, ao observarem os elementos da encenação, os espectadores podem perceber a existência, o funcionamento, e a utilização de cada um deles. Isto porque a encenação deixa claro como o artista teatral (diretor, cenógrafo, figurinista, ator, etc.) os está utilizando, possibilitando que o espectador perceba que, se a cena é assim apresentada, ela poderia também ser concebida de outras maneiras; e que as construções da encenação são sempre opções do artista, que se apresenta enquanto autor do espetáculo e assume uma posição em face da história que apresenta. Ao se tornar conhecedor da utilização dos diversos elementos que compõem uma encenação, e atento para a dimensão histórica dos fatos, o espectador do teatro épico se torna um especialista, apto a compreender criticamente as cenas apresentadas no palco, e estimulado a produzir sentidos próprios para os acontecimentos históricos.

\section{Dinamizando a recepção teatral}

A expansão das práticas extra-espetaculares de formação de espectadores se dá especialmente nos anos 1960, na esteira dos movimentos contraculturais que clamavam pela democratização da arte teatral, e que, entre outras tantas conquistas, propuseram o estreitamento das relações entre teatro e escola. Artistas e educadores passam, a partir de então, a propor às escolas, com maior freqüência, diversas atividades de expressão dramática, com o objetivo de sensibilizar crianças e jovens para o teatro. Dentre estas práticas, que passaram a ser conceituadas como animações teatrais, estão as que se organizavam em torno de um espetáculo teatral, dinamizando a compreensão da encenação vista pelos alunos.

Estas práticas de formação de espectadores podem dividir-se em dois aspectos, principalmente: os procedimentos pedagógicos de integração escolar e os procedimentos pedagógicos de leitura. 
Os procedimentos pedagógicos de integração escolar, como o próprio termo sugere, buscam integrar a obra teatral ao processo de aprendizagem escolar. O espetáculo motiva atividades variadas, torna-se o pivô de um estudo que pode interligar diversas disciplinas do currículo escolar, sendo utilizado como atividade de reforço. A peça propicia, assim, a aplicação de exercícios, visando a uma dinamização do aprendizado em múltiplas áreas do conhecimento.

Os procedimentos pedagógicos de integração escolar acontecem, por via de regra, após o espetáculo e estabelecem relações entre a encenação vista pelos alunos e as diversas áreas do conhecimento. As atividades de desdobramento da peça enfocam, por exemplo: noções de matemática (exercícios de conjunto, os personagens são em grupos); abordagens históricas; exercícios de expressão escrita (redações sobre a peça ou aplicação de ditados); atividades de artes plásticas (a criação de cartazes para a peça ou de desenhos animados que retratassem a história contada). Entre outras tantas atividades que variavam em função das possíveis abordagens suscitadas pelo espetáculo e da faixa etária dos alunos.

Estas práticas de prolongamento de um espetáculo, visando à integração da arte ao currículo da escola, têm sido muito criticadas, acusadas de "pedagogizar" o teatro pelo fato do espetáculo ser utilizado como instrumento de aprendizagem de determinadas disciplinas da grade curricular ou como mero pretexto para atividades normalmente aplicadas no cotidiano escolar. A arte teatral acaba, deste modo, por ser "fagocitada" pelo sistema de ensino. Considera-se que a utilização do teatro como ferramenta para a apreensão de conteúdos disciplinares empobrece o diálogo do aluno-espectador (e os desdobramentos deste diálogo) com a peça, e torna a experiência estética padronizada, ao atrelar a recepção às necessidades imediatas da escola.

Os procedimentos pedagógicos de leitura podem ser divididos em borizontal e transversal. Nos procedimentos de leitura horizontal, o conteúdo da peça é prioritariamente abordado nos exercícios propostos. Os artistas e educadores estimulam o grupo de alunos a debater o assunto em questão e a improvisar cenas que se relacionem com o tema da peça. Estas práticas chamam a atenção dos participantes para o discurso da obra, para a atualidade dos temas tratados, além de provocar a observação dos espectadores para como a encenação lida com tais questões e que técnicas teatrais são utilizadas nesta abordagem.

Estes prolongamentos, que enfocam primordialmente a temática da peça, podem, por exemplo, ser estruturados a partir das seguintes atividades: 1) exposição prévia sobre a vida do autor, de seu tempo (em se tratando de uma peça de época) e do conteúdo do texto; 2 ) debates posteriores ao espetáculo abordando a atualidade das situações encenadas; 3) proposição de exercícios dramáticos em que os alunos transpõem cenas da peça para acontecimentos contemporâneos ou mesmo para situações outras que, de algum modo, estejam relacionadas àquelas apresentadas pelos atores.

Nos procedimentos pedagógicos de leitura transversal, que têm como objetivo estimular os alunos-espectadores para o reconhecimento, a decodificação, a interpretação dos signos do espetáculo e o enfoque dado às atividades propostas reduzem a importância da percepção imediata provocando o espectador a empreender uma análise detalhada da encenação, estimulando-o a efetivar a sua compreensão 
dos significados contidos nas concepções dramatúrgicas, nas intenções gestuais, nas opções cenográficas e nas demais criações dos realizadores do espetáculo. Propiciar aos alunos a compreensão do espetáculo não se reduz, assim, à trama, mas se constitui de uma totalidade de signos, pois se possibilita a percepção da especificidade da arte teatral e a elaboração dos elementos semióticos presentes na encenação. Estas práticas são fundamentalmente implementadas a partir de companhias teatrais que constroem os seus espetáculos tendo em vista a busca de uma escritura cênica provocativa, nem sempre evidente, que valoriza a atitude do espectador diante da obra, incitando-o a engendrar uma leitura própria, inventiva dos signos propostos.

Partindo do princípio de que a capacidade de ler os signos não é um fenômeno natural, mas uma conquista cultural, estes procedimentos pedagógicos de leitura teatral têm o intuito de estimular e sensibilizar os espectadores para a decifração dos códigos e a efetivação de uma leitura plural do espetáculo. 


\section{REFERÊNCIAS}

BAKHTIN, Mikhail. Estética da criação verbal. São Paulo: M. Fontes, 1992.

BENJAMIN, Walter. Obras escolbidas: magia e técnica, arte e política. 2. ed. São Paulo: Brasiliense, 1993.

BORNHEIM, Gerd. Brecht, a estética do teatro. Rio de Janeiro: Graal. 1992.

BRECHT, Bertolt. Ecrits sur le théâtre 1. Alençon: L'Arche, 1989.

DEBORD, Guy. La société du spectacle. 2. ed. Paris: Gallimard, 1992.

DELDIME, Roger; PIGEON, Jeane. La mémoire du jeune spectateur. Bruxelas: De Boeck, 1988.

DESGRANGES, Flávio. A pedagogia do espectador. São Paulo: Hucitec, 2003.

DESGRANGES, Flávio. Pedagogia do Teatro: provocação e dialogismo. São Paulo: Hucitec, 2006.

KOUDELA, Ingrid Dormien. Brecht: um jogo de aprendizagem. São Paulo: Perspectiva, 1991.

ROSENFELD, Anatol. O teatro épico. 3. ed. São Paulo: Perspectiva, 1985. 


\section{IMPROVISAÇÃO: DA ESPONTANEIDADE ROMÂNTICA AO "MOMENTO PRESENTE"}

Gilberto Icle

Este texto pretende abordar de maneira introdutória o tema da improvisação teatral como natureza e procedimento do trabalho do ator. É preciso iniciar esclarecendo que o termo ator, aqui, pode ser generalizado para todos os âmbitos nos quais seres humanos se dão a ver em situações espetaculares organizadas. Assim, podemos incluir crianças em situação de jogo, atores profissionais num palco à italiana ou oficiantes de um ritual religioso. Contudo, neste texto, vou ocupar-me da atividade sistematizada na qual os praticantes jogam em situação de como se. $\mathrm{Ou}$ seja, trata-se de atividades nas quais os jogadores se transportam para uma situação fictícia, brincando, fazendo de conta ou atuando teatralmente.

O senso comum, freqüentemente, acredita que a improvisação é fruto de um talento espontâneo, de um jogo que inicia e se completa apenas no momento em que é revelado. No entanto, como veremos a seguir, a idéia de improvisação é muito mais complexa e envolve um movimento entre o passado, a projeção de futuro e o momento presente.

A idéia de improvisação perpassa o próprio cerne do trabalho do ator, pois tudo o que o ator faz diante do público consiste numa improvisação, contudo, não se trata de pensar a improvisação como uma revelação, pois embora o ator faça parecer que suas ações são realizadas naquele instante, elas são fruto de um trabalho ou de uma construção anterior.

Por outro lado, principalmente no século XX, a improvisação teatral foi tida como um procedimento para alcançar êxito na atuação. Ela passou a constituir métodos e modalidades que ajudam o ator a construir um personagem, a edificar sua presença cênica, a acessar uma determinada linguagem cênica, a ligar diferentes atores na constituição de um ensemble teatral ou, ainda, a auxiliar diretores e atores na investigação de processos poético-pedagógicos.

\section{A commedia dell'arte como arte da improvisação}

A commedia dell'arte consiste num marco histórico para a improvisação teatral, pois antes dos ideais modernos de originalidade, que fizeram com que a improvisação teatral atingisse o status de procedimento privilegiado para a pedagogia teatral, os atores desse tipo de teatro mascarado, improvisado e popular levaram a cabo, com impressionante profundidade, a idéia de improvisação. 
O primeiro aspecto que é interessante reter da experiência da Commedia dell'arte, principalmente nos séculos XVI e XVII, é o fato de que a noção de improvisação tem pouco a ver com espontaneidade. Ao contrário, os atores desse tipo de teatro europeu, principalmente italiano, eram especialistas em uma única máscara por toda sua vida. Os documentos da época revelam que em pouquíssimos casos um mesmo ator jogava mais de uma máscara. Isso, aliado ao fato de se tratar de exímios cantores, instrumentistas, acrobatas, oradores, mímicos entre tantas outras habilidades, oportunizava a esse ator um jogo bastante rebuscado. Trata-se de uma intervenção de temas e assuntos do presente, de cada lugarejo no qual a trupe estivesse, no repertório de histórias, gags, piadas e roteiros já conhecidos.

O canovaccio era um instrumento precioso a esses atores. Tratava-se de um roteiro que os atores tinham de memória, com o qual era possível atuar de forma improvisada, pois ele era constituído de forma aberta, delimitando apenas as entradas e saídas e algumas situações básicas, para se poder introduzir a imitação de um político corrupto daquele local ou uma piada sobre um adultério conhecido dos moradores, por exemplo. Esse roteiro passava de geração a geração, mas o que o público via em cena era a dialética sempre renovada entre essa tradição, essa história roteirizada e quase arquetípica - que muitas vezes envolvia a figura do Arlecchino (criado faminto e atrapalhado) - em confusões com seus patrões e o momento presente.

Taviani ${ }^{1}$ afirma que a idéia de espontaneidade associada à improvisação é fruto do romantismo, pois até o século XVIII a improvisação era um exercício comum em academias e escolas e consistia em saber muitos poemas de memória, para se poder improvisar uma poesia, por exemplo. Tratava-se de um exercício de memória, de reorganização do conhecimento constituído, de mostra de saberes. Mostrava-se o domínio de um determinado campo de saber e não um dom espontâneo. $\mathrm{Na}$ Commedia dell'arte não era diferente.

\section{A improvisação como procedimento do ator: os marcos históricos}

Os principais marcos históricos instauradores da improvisação como procedimento de preparação dos atores, construção de personagem e processo de montagem de um espetáculo tiveram lugar no Sistema de Stanislavski (1863-1938), no início do século XX, na Rússia, e no trabalho de Jacques Copeau (1879-1949), na França, quase ao mesmo tempo. Ambos foram muito importantes para a instauração da idéia de improvisação nas tradições pedagógicas teatrais, numa perspectiva parecida, mas com pontos distintos.

Copeau chegou a propor um retorno da improvisação, numa atualização da Commedia dell'arte, na qual máscaras de tipos contemporâneos a ele serviriam de base para a reconstrução de um teatro improvisado.

Contudo, Copeau legou a improvisação como procedimento de preparação do ator e essa tradição instaurada por ele se desenvolveu em muitas escolas na França, como no trabalho de Dorcy, Dastè, Decroux, esse último, por sua vez, foi mestre de professores influentes como Thomas Leabhart, Luiz Otávio Burnier e Jacques Lecoq.

1 TAVIANI, Ferdinando. Once puntos para entender la improvisacion em la Commedia dell'arte. Máscara: Cuaderno Iberoamericano de Reflexion sobre Escenologia, México, ano 4, n. 21-22, p. 4-23, jan. 1997. 
Na trilha de Copeau encontramos noções fundamentais para a improvisação. Uma das mais importantes talvez seja a noção de neutralidade. Com o uso das máscaras, ele promoveu uma verdadeira revolução no trabalho do ator, pois instaurou a necessidade dele desconstruir seu corpo cotidiano, eliminar os obstáculos físicos e emocionais e neutralizar o rosto, minimizando a expressão facial em prol de uma revelação mais contundente do corpo como suporte e natureza da expressão artística do ator. Esse processo de eliminação, de tentativa de neutralização, de descontrução do corpo cotidiano foi chamado de via negativa.

A máscara subsidiou as tentavas de Copeau, pois permitia, ao mesmo tempo, mostrar e revelar o universo interior do ator, na medida em que escondia seu rosto. Esse ocultamento e sua correspondente revelação, proporcionados pela experiência primitiva da máscara, constitui um modo de trabalho com a improvisação que perpassou a prática de muitos homens de teatro no decorrer do século XX.

Da mesma forma, o Sistema de Stanislavski constitui um modo de operar com a improvisação teatral amplamente difundido, recriado e desenvolvido durante o século XX. Ao contrário dos herdeiros de Copeau, os quais se abrigaram muito mais em estúdios, pequenas escolas, grupos de teatro; o Sistema stanslaviskiano ocupou muitas das escolas oficiais e dos discursos hegemônicos sobre a pedagogia do ator.

Embora o trabalho inicial de Stanislavski, resumido no que se tornou conhecido como a Psicotécnica, tenha sido mais difundido em nosso meio, foi seu trabalho ulterior, resumido no Método das ações físicas, que consiste na contribuição inaugural da improvisação como forma e processo de criação para o ator.

Trata-se de um conjunto de improvisação que visa fazer o ator se aproximar do universo do texto dramático, construir um personagem em coerência com as indicações que o dramaturgo apresenta, formar uma pauta, ou linha, ou partitura de ações físicas capaz de traduzir em expressão física, e não somente mental ou emocional, as atitudes e motivações do personagem e, por fim, constituir com verdade cênica as respectivas cenas do espetáculo.

A proposição de Stanislavski constituía-se de uma seqüência de improvisações. Nessa fase, ao contrário do trabalho anterior, ele aboliu praticamente por completo o trabalho de mesa, ou seja, as leituras coletivas, interpretações e análises do texto previamente às improvisações práticas.

Nessas improvisações, o ator deveria reconhecer a fábula e os fatos motores; colocar-se como se estivesse dentro das circunstâncias mínimas dadas pelo texto; com a ajuda do diretor, improvisar todas as circunstâncias dadas pelo texto; improvisar circunstâncias imaginárias que completariam o universo do texto; improvisar o universo completo do ator e os acontecimentos da peça.

Enfim, Stanislavski propõe e, consequentemente instaura, a tradição da improvisação como caminho para a criação do ator.

\section{As modalidades de improvisação}

Existem muitas modalidades de improvisação. Se nos ocuparmos da improvisação como procedimento podemos elencar diversos tipos, mas se nos ocuparmos da improvisação como natureza do trabalho do ator, quase tudo o que um ator faz para se preparar ou atuar pode ser considerado como improvisação. 
Os procedimentos mais gerais podemos classificar como processos de composição. Esse procedimento é muito comum nas tradições codificadas das artes cênicas, consiste em agrupar elementos já conhecidos por uma tradição codificada e lhe conferir vida, èlan, corpo. Um exemplo fácil de compreender é o aprendizado de danças clássicas, como o Ballet europeu, o Odissi, ou Bharata Natyam hindu. Nessas tradições, o aprendiz deve memorizar por imitação uma seqüência de movimentos já estabelecidos pela tradição e torná-los orgânicos, ou seja, torná-los seus, fazer parecer que executa, sem esforço, movimentos e ações que exigem uma deformação do corpo e da voz.

Um outro procedimento, muito popular em escolas de educação básica, é a dramatização. Nesse caso, trata-se de tornar dramático algo que não é em sua origem preparado para isso. Assim, podemos incluir aí a construção de espetáculos partindo-se de um conto, uma história, uma imagem. A improvisação serve como elemento para a construção temática, para se dar a ver, da melhor forma possível, a narrativa. São secundárias, freqüentemente, as preocupações com a linguagem teatral. A ênfase está na fábula e no enredo e não nos aspectos da formalidade da linguagem.

A dramatização lembra muitos procedimentos livres, nos quais grupos de jogadores, sem a orientação de um diretor ou professor, buscam produzir um espetáculo sem preocupações que ultrapassem a comunicação de uma mensagem. Contudo, o procedimento de dramatização tem sido usado por grupos de teatro importantes no panorama brasileiro, como recurso para a construção dramatúrgica.

Dos procedimentos e modalidades de improvisação teatral mais comuns entre nós podemos destacar dois: o jogo dramático e o jogo teatral.

Esses dois tipos de improvisação se caracterizam por propor aos jogadores situações em que esses devem atuar como se. O princípio dramático de personificação ou de atuação estará sempre presente, ou seja, o jogador se reportará, com o corpo e não apenas como tarefa mental, a uma ação que envolve a imaginação na expressão de uma circunstância, de um tempo ou de uma pessoa que estão ausentes e que serão presentificados pela ação.

Segundo Pupo ${ }^{2}$,

[...] jogo teatral e jogo dramático, fundamentam-se na idéia de que a depuração estética da comunicação teatral é indissociável do crescimento pessoal do jogador. Ambos têm na platéia - interna ao grupo de jogadores - um elemento essencial para a avaliação dos avanços conquistados pelos participantes. Prescindem da noção de talento ou de qualquer pré-requisito anterior ao próprio ato de jogar e apresentam propostas de caráter estrutural, derivadas da linguagem do teatro, que permitem a formulação, pelo próprio grupo, das situações, temas, desejos, que quer trazer à tona.

O jogo teatral - theater game - foi sistematizado por Viola Spolin, nos Estados Unidos, e se diferencia do jogo dramático, principalmente porque no primeiro há a necessidade de se estabelecer regras precisas que envolvam os princípios teatrais, dentre as quais o estabelecimento da relação palco/platéia, ou seja, jogado-

${ }^{2}$ PUPO, Maria Lúcia de Souza Barros. O lúdico e a construção do sentido. Sala Preta, São Paulo, v. 1, n. 1, p. 181-187, 2001. 
res que atuam e jogadores que assistem. Além disso, Spolin ${ }^{3}$ propõe um Ponto de Concentração para cada jogo, pautando a atuação dos jogadores em regras pontuais a serem observadas durante a atuação e a serem discutidas na avaliação. A idéia de Instrução também é uma característica diferenciadora do Jogo Teatral, pois o orientador do jogo pode instruir os participantes durante o próprio jogo a fim de garantir o andamento do mesmo e o melhor cumprimento das regras.

Os exercícios de Viola Spolin se agrupam principalmente na investigação e proposição de circunstâncias - ao gosto da tradição instaurada por Stanislavski resumidas, principalmente, em grupos de exercícios de Onde, O que e Quem.

Para Ryngaert ${ }^{4}$, o jogo dramático pode ser caracterizado por sete elementos: 1) análise da realidade traduzida em linguagem não naturalista; 2) trabalho coletivo; 3 ) não subordinação a um texto como ponto de partida, mas poderá existir um texto improvisado; 4) discussão sobre o que se fez no jogo, avaliação do processo; 5) negação do virtuosismo ou de habilidades, todos se colocam como jogadores, não como atores profissionais; 6) descarte de cenografia e indumentária, tudo é produzido pelo próprio jogo, no corpo e com o corpo; 7) prazer como elemento indispensável.

O jogo dramático não necessita de grupos distintos de jogadores, embora possa utilizá-los, como no jogo teatral no qual deve haver atuadores e assistentes, mesmo que esses papéis sejam constantemente trocados entre os jogadores, embora ambas as modalidades de jogo trabalhem com os princípios do drama.

\section{O momento presente}

Ao mesmo tempo em que o trabalho do ator é fruto de um complexo e contínuo processo de construção de conhecimento que o faz estruturar conhecimentos precisos e diferentes do mundo cotidiano, o grande desafio do jogo da atuação é conseguir estar no momento presente.

Quando falamos em improvisação, estamos pretendendo evocar um duplo procedimento: estar no aqui-agora e, ao mesmo tempo, refazer o processo que nos conduziu a esse momento. Vejamos que paradoxo complicado: estar no presente recuperando o passado.

Para Brook", "o teatro não tem a ver com edifícios, nem com textos, atores, estilos ou formas. A essência do teatro reside num mistério chamado 'o momento presente”. Mas como é possível ao ator estar de corpo e mente no momento presente?

Pode parecer fácil, mas unir mente e corpo numa única ação é o grande desafio do ator. No mundo cotidiano nos acostumamos a automatizar nosso comportamento. Fazemos ações, movimentos e gestos automaticamente. Podemos dirigir um carro e pensar no que faremos a noite; fazer compras e programar mentalmente uma viagem; caminhar e relembrar um acontecimento. $\mathrm{O}$ ator não pode deixar sua mente viajar além da ação do presente. É esse conhecimento que caracteriza o que chamamos teatro e define a diferença entre cotidiano e extracotidiano ${ }^{6}$.

\footnotetext{
${ }_{3}^{3}$ SPOLIN, Viola. Improvisação para o teatro. São Paulo: Perspectiva, 1987. 349 p.

${ }^{4}$ RYNGAERT, Jean-Pierre. O jogo dramático no meio escolar. Coimbra: Centelha, 1981. 230 p.

${ }_{5}^{5}$ BROOK, Peter. A porta aberta: reflexões sobre a interpretação e o teatro. Rio de Janeiro: Civilização Brasileira, 2002. 145 p.

6 ICLE, Gilberto. O ator como xamã: configurações da consciência no sujeito extracotidiano.
} 
Ao permanecer no momento presente, o ator cria um comportamento que se diferencia do comportamento cotidiano. Chamo extracotidiano o comportamento que se caracteriza pela sistematização de ações, objetivando se dar a ver de modo distinto do cotidiano. Nesse momento, opera-se um salto ou uma transcendência do cotidiano a um estado no qual corpo, mente e espírito se unem numa função superlativa. O corpo parece maior, o tempo parece suspenso e quem assiste é tocado e conduzido ao illud tempus.

É esse comportamento extracotidiano que a improvisação visa atingir. Assim, a idéia de uma improvisação teatral como procedimento permite pensar que a improvisação é também a natureza do trabalho do ator.

Mas como o ator logra acionar essa união mente/corpo no momento presente? Da mesma forma que os atores da Commedia dell'arte conseguiam improvisar, porque possuíam de memória um repertório de textos, cenas, gags, entre outros, um ator qualquer atinge a capacidade de improvisar no momento presente porque improvisou muitas situações e acumulou um repertório de ações, textos, gags, cenas, efeitos que podem ser utilizadas agora, no entanto, produzidas no passado.

Essa dialética entre passado e momento presente é bastante complexa, pois ao mesmo tempo em que o ator usa esse repertório de ações do passado, essa utilização não pode ser planejada. Ela flui no momento presente sem que o ator deva (nem precise) pensar de antemão nas soluções cênicas. $O$ que, de fato, caracteriza o ato de improvisar é essa dialética quase impossível de recuperar o passado e fazer dele momento presente. Tão presente que parece ser realizado de forma espontânea, como se nada houvesse sido planejado, como se nada fosse organizado, como se tudo estivesse sendo realizado ao acaso, pela primeira vez.

Mas só parece. Alguns poucos minutos do trabalho do ator podem ser tão impressionantes e tocantes quanto os anos de trabalho que eles escondem.

O exercício dessa dialética em recuperar o passado e convertê-lo em momento presente permite ao ator a incorporação do que acontece no momento presente. Converter em momento presente o passado é, também, incorporar os dados do aqui-agora: as reações ou a falta de reação do público, um imprevisto com algum equipamento, as reações dos outros atores, entre outros.

Esse jogo entre passado e presente faz transcender as ações e, de certa forma, faz o ator prever o futuro. $O$ ator seria, então, um vidente? Não é bem assim, contudo, a improvisação, como natureza e procedimento, faz o ator oferecer respostas antecipadas aos problemas cênicos, fazendo parecer que se antecipa aos acontecimentos. $\mathrm{O}$ momento presente é, também, futuro.

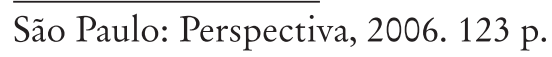




\section{REFERÊNCIAS}

BROOK, Peter. A porta aberta: reflexões sobre a interpretação e o teatro. Rio de Janeiro: Civilização Brasileira, 2002.

CHACRA, Sandra. Natureza e sentido da improvisação teatral. São Paulo: Perspectiva, 1991.

GUINSBURG, Jacó. Stanislavski, Meierhold E Cia. São Paulo: Perspectiva, 2001.

HODGSON, John; RICHARDS, Ernest. Improvisation. New York: Grove Press, 1979.

ICLE, Gilberto. O ator como xamã: configurações da consciência no sujeito extracotidiano. São Paulo: Perspectiva, 2006.

ICLE, Gilberto. Teatro e construção de conhecimento. Porto Alegre: Mercado Aberto-Fundarte, 2002.

LA IMPROVISACION. Máscara, México, v. 4, p. 21-22, jan. 1997.

JOHNSTONE, Keith. IMPRO: la improvisacion y el teatro. 4. ed. Santiago: Cuatro Vientos, 1990.

KOUDELA, Ingrid Dormien. Jogos teatrais. São Paulo: Perspectiva, 1984.

MOORE, Sonia. The Stanislavski System. 2. ed. New York: Penguin, 1984.

PUPO, Maria Lúcia de Souza Barros. O lúdico e a construção do sentido. Sala Preta, São Paulo, v. 1, n. 1, p. 181-187, 2001.

RYNGAERT, Jean-Pierre. O jogo dramático no meio escolar. Coimbra: Centelha, 1981. 230 p.

SPOLIN, Viola. Improvisação para o teatro. São Paulo: Perspectiva, 1987.

TAVIANI, Ferdinando. Once puntos para entender la improvisacion em la Commedia dell'arte. Máscara: Cuaderno Iberoamericano de Reflexion sobre Escenologia, México, ano 4, n. 21-22, p. 4-23, jan. 1997. 


\section{Cenografia e indumentária na Arte-Educação}

Gilson Motta

O tema deste ensaio - a Cenografia e a indumentária na Arte-Educação - foi sugerido pelos organizadores deste periódico visando desenvolver o debate em torno da reforma curricular no âmbito das licenciaturas. Neste texto, tento contribuir para este debate fazendo uma reflexão sobre os fundamentos destas atividades, pensadas aqui de modo indiferenciado. O elemento que se antepõe de modo não explícito é a própria idéia do teatro, isto é, as características básicas do fenômeno teatral enquanto elemento configurador da plasticidade. Pensar no sentido de cenografia e indumentária no contexto da formação do arte-educador implica, antes, um pensar crítico sobre o sistema de produção teatral. Esta reflexão pode conduzir, de um lado, à ratificação dos procedimentos criativos herdados pela tradição, mas, por outro, ela pode apontar para metodologias diferenciadas voltadas para a uma autêntica formação estética do aluno. Num primeiro momento, farei uma caracterização geral destas disciplinas, valorizando sua natureza teórico-prática; num segundo, situarei estas disciplinas no âmbito do ensino destacando aspectos que considero relevantes para a formação do arte-educador.

\section{Cenografia e indumentária como artes visuais}

Cenografia, indumentária, iluminação e maquiagem são chamados de elementos visuais do espetáculo. Em sua interação e integração no espetáculo, eles transmitem mensagens visuais, construindo um efeito visual. Embora os atores também possam ser vistos como elementos transmissores de mensagens visuais de acordo com sua posição e deslocamento no espaço, só os elementos acima contêm uma linguagem visual, isto é, um conjunto de signos visuais articuladores de um sentido.

Codificada pela psicologia da Gestalt e pela Bauhaus, a linguagem visual manifesta sua presença nas obras, sobre a plasticidade do teatro, produzidas na Europa e nos Estados Unidos a partir da década de 1950. Assim, a modernidade no teatro é construída com os estudos sobre a linguagem visual e com as experiências formais desenvolvidas entre o final do século XIX e as vanguardas artísticas. Por um lado, as experiências formais geram novas relações entre os elementos da linguagem visual; por outro, tais elementos tornam legíveis os estilos e formas teatrais. Este fato tornou possível - em especial nos textos norte-americanos - a presença de classifi- 
cações de cenários, por tipos ou estilos ${ }^{1}$. Embora esta classificação não tenha mais efeito na cena contemporânea, ela é importante por permitir realizar na esfera da composição visual do teatro aquilo que Donis A. Dondis chama de "alfabetização visual" ": o entendimento das mensagens visuais presentes em cada estilo ou forma teatral. Este entendimento da cultura visual é o ponto de partida para o desenvolvimento do gesto criativo do aluno.

Em suma, enquanto pertencentes ao universo da visualidade e da plasticidade, os elementos visuais do espetáculo são regidos pela linguagem visual, sendo idênticos em seus fundamentos. Daí a interdependência dos mesmos, quando da criação de um espetáculo teatral. Portanto, um primeiro aspecto a ser considerado na Indumentária e na Cenografia é que ambas são atividades artísticas cuja criação e recepção funda-se na linguagem visual.

\section{O invisível na cenografia e na indumentária}

No capítulo anterior, indiquei o vínculo entre a linguagem visual e os elementos visuais do espetáculo. Subentende-se que, numa relação de ensino-aprendizagem, é essencial caracterizar cenografia e indumentária como artes visuais. Apresentarei agora a relação da cenografia e da indumentária com um elemento não visual: a palavra.

O sistema de produção teatral vigente sustenta-se, por via de regra, na relação diretor-autor. Nesta relação, o diretor propõe uma interpretação do texto, determinando um conceito ou temática básica de encenação, que informará as demais atividades criadoras. O texto constitui-se, portanto, como um elemento de origem, que contém uma antecedência e uma autonomia em relação à cena. E, embora, na atualidade, o texto já não ocupe um lugar privilegiado na estética teatral, ele continua exercendo a função de elemento de referência, articulador do sentido do espetáculo. Enfim, a criação visual no teatro é informada pelo drama.

A palavra ou texto pertence ao elemento temporal, sonoro e, portanto, ao invisível. Em "A exibição das palavras", Denis Guénoun afirma que o fenômeno teatral se constrói a partir da tentativa de tornar visíveis as palavras. A teatralidade relaciona-se à visibilidade. "A teatralidade não está no texto. Ela é a vinda do texto ao olhar. Ela é este processo pelo qual as palavras saem de si mesmas para produzir o visível. A teatralidade é o próprio pôr/em/cena" ${ }^{3}$. A encenação seria a arte da passagem do elemento lingüístico ao visual e vice-versa.

Estas observações são importantes para se pensar a dimensão interpretativa da cenografia e da indumentária teatrais, pois ambas transformam o que é conceito em imagem, de modo a configurar a linguagem do espetáculo. Esta dupla interpretação envolve o conhecimento das artes visuais, mas, sobretudo, um conhecimento da dramaturgia, mais precisamente, da teatralidade do drama, de sua visualidade virtual.

\footnotetext{
${ }_{1}$ Esta classificação apresenta-se em várias obras. Ver, por exemplo: SELDEN, Samuel; SELLMAN, Hunton. Stage scenery and lighting: a handbook for non-professionals. New York: Appleton-Centry-Crofts, [19--]; PARKER, Oren; SMITH, Harvey K. Scene design and stage lighting, New York: Holt, Rinehard and Winston, 1966; NELMS, Hennig. Scene design: a guide to the stage. New York: Dover Publicatons, 1975. 96 p.

${ }^{2}$ Cf. DONDIS, Donis A. Sintaxe da linguagem visual. São Paulo: M. Fontes, 2000. 236 p.

${ }^{3}$ GUÉNOUN, Denis. A exibição das palavras: uma idéia (política) do teatro. Rio de Janeiro: Teatro do Pequeno Gesto, 2003. p. 55.
} 
Ora, por ser uma arte integrada, o teatro possui uma linguagem extremamente complexa. Além de fundarem-se na linguagem visual, cenografia e indumentária são parte de um sistema semiológico amplo que envolve a interação das artes do espaço e das artes do tempo. Esta interação atribui ao signo teatral uma intensa mobilidade: a escrita cênica é uma configuração de sentido originada do dinamismo entre o ator, os elementos visuais e os elementos sonoros do espetáculo. Assim, no teatro, as relações formais possuem um campo de abrangência muito extenso, já que os elementos móveis e temporais estão aí contidos.

Enfim, cenografia e indumentária são artes visuais que conservam uma relação com o invisível: o teatro comporta uma visualidade diferenciada, porquanto informada por elementos dinâmicos visíveis (ator e luz) e invisíveis (palavra, música). Entender a articulação entre o visível e o invisivel é essencial para a criação visual no teatro. Por conseguinte, no âmbito do ensino do teatro, é fundamental valorizar este aspecto.

\section{Apresentação de um problema: formação técnica e formação estética}

Cenografia e indumentária são atividades que envolvem conteúdos teóricos e práticos. Os capítulos anteriores apontaram para duas dimensões nas atividades dos criadores visuais do espetáculo. Uma relaciona-se à exterioridade num sentido amplo, pois os próprios instrumentos e aparelhos do palco, por exemplo, são apreendidos como elementos de construção da plasticidade do espetáculo. A outra diz respeito a uma dimensão introspectiva, a uma constante ação que o artista exerce sobre si mesmo. Juntas, as duas determinam o estilo, enquanto escrita absolutamente pessoal. Portanto, estas duas dimensões são inseparáveis, como nota José Dias:

O êxito do cenógrafo não depende apenas de um bom texto, de uma boa proposta da direção ou de uma inspiração genial, mas de todos esses fatores. Se os primeiros, o texto e a direção, como fatores externos, dependem às vezes de sorte, de oportunidade, os fatores internos, a inspiração e a capacidade do artista, dependem do talento e da formação profissional; da chamada alma de artista, bem como de paciência e calma para desenvolvê-la ${ }^{4}$.

Uma dimensão é estética no sentido de um trabalho com as formas (a composição, o significado do objeto artístico). Outra é estética por se referir ao processo dinâmico da sensibilidade. A presença simultânea destes fatores externos e internos é um fator problemático na formação do arte-educador, pois os elementos técnicos e expressivos nem sempre podem ser contemplados nos cursos de formação.

Cenógrafo e figurinista são profissionais que devem dominar técnicas de projeção gráfica, técnicas de construção, devem saber dialogar com profissionais diversos, devem ter o conhecimento de diversos materiais expressivos. O oficio do figurinista e do cenógrafo envolve uma grande gama de conhecimentos (históricos, teóricos, artísticos, técnicos, culturais), mas é somente na prática artística que a razão de ser destes conhecimentos é posta à prova. O fundamental nestes dois ofícios é, portanto, o domínio técnico, um saber instrumental que possa vir a fornecer soluções para problemas tópicos. Se

\footnotetext{
${ }^{4}$ DIAS, José. A importância da cenografia. O Percevejo, Rio de Janeiro, ano 7, n. 7, p. 29, 1999.
} 
este fato dá a tônica do trabalho do criador visual no teatro, ocorre então que ele entra em conflito com o próprio oficio do arte-educador, já que o aluno de licenciatura possui uma abordagem mais generalizada dos aspectos da arte teatral. Ele não é um especialista do fazer teatral. Contudo, em seu ofício, o arte-educador deve estar apto a responder às questões gerais relativas a áreas como direção, interpretação, iluminação, figurinos, cenografia. Esta solicitação de respostas imediatas ocorre, por exemplo, quando são feitas montagens teatrais com alunos. Ora, a especificidade da formação do arte-educador está menos na capacidade de propor soluções técnicas do que na capacidade de formar sensibilidades e potencialidades. Cenografia e indumentária devem ser apenas meios para que o arte-educador possa vir a desenvolver nos alunos outras qualidades de sensibilidade, outras formas de inteligência e outros comportamentos criativos.

Os aspectos destacados aqui - a linguagem visual, a interpretação, a fusão da estética e da técnica visam determinar as características essenciais da cenografia e da indumentária. É a partir destes traços essenciais que podemos pensar no modo como elas devem ser abordadas no contexto do ensino.

\section{Cenografia e indumentária na formação e na prática profissional do arte-educador}

A formação do cenógrafo e do figurinista envolve conhecimentos teóricos e de conhecimentos técnicos. A matriz curricular do curso de Cenografia e de Indumentária da Universidade Federal do Rio de Janeiro - UNIRIO, por exemplo, consta de uma extensa carga horária voltada para o desenvolvimento da expressão plástica (desenho, geometria, perspectiva, modelo vivo, perspectiva e sombra, entre outros) e para os conhecimentos técnicos (corte e montagem, modelagem, adereços, entre outros).

Quando oferecidas a outros cursos - direção, interpretação, teoria, licenciatura - Cenografia e Indumentária têm seu enfoque transformado, já que elas tornam-se mais condensadas em função da reduzida carga horária, a qual, na maioria das escolas de teatro (UNIRIO, UFMG, ECA-USP, UFOP, UFRGS, UDESC, entre outras) tende a variar entre 60 e 120 horas. De minha parte, quando ministro estas disciplinas para cursos como Direção Teatral, Interpretação e Licenciatura, evito valorizar os aspectos relativos à cenotécnica, preferindo destacar os elementos da construção estética do espetáculo: relação diretor-cenógrafo ou figurinista, semiologia, linguagem visual do espetáculo, tipologia do espaço cênico, luz-cena, ator-espaço, etc. Na Licenciatura, em particular, há ainda uma outra mudança de enfoque, pois o fundamental aqui é mostrar como o professor-orientador pode usar dos elementos visuais do teatro para poder formar a sensibilidade do aluno. Neste sentido, estão em jogo questões relativas à percepção do espaço, ao entendimento dos valores e qualidades espaciais, à apreensão dos elementos visuais que tornam expressivo o espaço, entre outros.

Contudo, esta mudança tem sido mais difícil e problemática devido justamente às referidas solicitações técnicas, as quais trazem muitos problemas para o professor orientador. Dentre os problemas que considero mais freqüentes e mais interessantes, podemos listar os seguintes: 
1) O professor-orientador tem poucos recursos de expressão gráfica ou plástica, mas precisa elaborar um cenário para cenas criadas pelos alunos.

2) O professor-orientador elaborou junto com seus alunos os figurinos e cenários para um espetáculo, mas não sabe como elaborar os planos de custo para a execução da montagem.

3) A instituição e/ou comunidade dispõe de um espaço para criar uma espécie de centro cultural, onde haverá um pequeno teatro e solicita ao professor de teatro a elaboração de um projeto para o espaço.

4) Uma montagem teatral está sendo realizada com trajes recuperados, mas a diversidade das peças dificulta o estabelecimento da unidade do figurino.

Esta lista foi construída a partir de situações concretas vivenciadas ou por mim ou por meus alunos, cada item diz respeito a um aspecto específico do fazer teatral. As situações 1 e 4 estão relacionadas à linguagem do espetáculo teatral, envolvendo questões de ordem técnica e estética. A situação 2 relaciona-se à produção e à técnica. Já a situação 3 diz respeito à arquitetura cênica. Aquilo que todas estas situações têm em comum é o fato de elas exigirem a presença de um profissional especializado, já que não podem ser resolvidas por um professor de teatro. Isto é, o licenciado em teatro não tem a menor obrigação de dominar estes conteúdos. E, o fato dele desconhecer tais procedimentos não constitui uma falha em sua formação.

Mas é justamente neste ponto que tem início o problema: por força de sua formação específica, o professor de teatro desconhece os aspectos técnicos envolvidos na indumentária e na cenografia, mas seu ofício lhe exige constantemente a necessidade de propor soluções técnicas para problemas concretos. Considerando que, nem sempre, ou quase nunca, a instituição tem condições de contratar profissionais especializados para executar tais serviços, devemos nos perguntar se existe uma maneira de atenuar este problema, durante a formação do arte-educador.

\section{Desenvolvimento da expressão gráfica: o desenho}

Como vimos, quando transpostos para o universo da Licenciatura, cenografia e indumentária sofrem uma condensação de seu conteúdo. Assim, num curso de 120 horas, divididas em dois semestres, o aluno lida com uma multiplicidade de informações complexas que abrangem todos os elementos necessários para a elaboração de um projeto cenográfico para um texto (teoria, história, expressão, técnica). Os conteúdos teóricos são de mais fácil manipulação, visto dependerem exclusivamente da análise das obras; já os conteúdos de mais difícil transmissão são os que envolvem elementos técnicos e expressivos, em especial, o desenho. Em sua grande maioria, os professores de teatro possuem mais conhecimentos nas áreas de interpretação e de direção teatral, pois, em geral, são atores que manifestam interesse pelo ensino. Raramente encontramos cenógrafos ou figurinistas que optaram também pela licenciatura. 
As experiências de sala de aula têm me mostrado que, em sua grande maioria, os alunos têm grandes dificuldades de realizar um projeto cenográfico, pois isto implica vários conhecimentos técnicos fundados na expressão gráfica e plástica. Ao serem solicitados a elaborar projetos de cenografia para um texto teatral, eles tendem a resistir à dimensão técnica (o que envolveria croquis, perspectivas, plantas baixas, cortes, planta de construção, maquete) e aos elementos práticos, como elaboração de plano de custos, orçamentos, quantitativo de materiais. Se, por um lado, esta resistência não afeta o objetivo central da disciplina, por outro, ocorria que a maior parte dos alunos nunca sabia como uma determinada idéia seria executada: a técnica, enquanto meio para se chegar a um fim, permanecia alijada do processo. Um projeto cenográfico se limitava a uma boa idéia (entenda-se, um bom discurso) e a alguns desenhos mal feitos. Em suma, a cenografia era traída em sua natureza. De minha parte, eu traía os ensinamentos do professor Anísio Medeiros, que repudiava a idéia de uma "cenografia falada". O desenho se fazia, portanto, necessário.

Ora, assim como qualquer forma de expressão artística, a arte de desenhar implica a existência de uma capacidade prévia e de um tempo de exercício para seu desenvolvimento. Mas, num curso de 30 aulas, são reservadas 5 aulas - no máximo - para o desenho, o que considero absolutamente improdutivo. Assim, a possibilidade de desenvolver o potencial expressivo do aluno é tolhida em função do tempo.

Deste modo, um procedimento acadêmico que considero importante é propiciar ao aluno de Licenciatura em Teatro o contato com aulas de desenho: livre, artístico, técnico, de moda. Estas aulas devem se configurar como disciplinas optativas ou como oficinas, sendo oferecidas no mesmo período ou no período anterior ao das disciplinas em questão. O objetivo destas aulas não deve ser o de gerar desenhistas: mais importante é fazer o aluno entender o desenho como uma ferramenta básica para ele expor suas idéias. Igualmente importante é preparar o olhar do aluno para os tratamentos gráficos específicos, isto é, fazer o aluno compreender a representação de tecidos, de caimentos, de volumes, entre outros. Com isso, ele poderá manter um diálogo mais fluido com os profissionais que executam seu projeto, evitando erros de interpretação. O que se nota assim é que o conhecimento básico do desenho pode contribuir para que o futuro professor de teatro possa resolver alguns dos problemas listados acima: a visão do conjunto de personagens possibilita a correção da falta de unidade; o desenho permite ainda uma primeira projeção ou materialização das idéias, possibilita ainda a projeção do espaço.

\section{Laboratórios de criação: dos materiais expressivos à cena}

Iniciemos com as palavras de Gianni Ratto:

O material de desenho é importante para poder traduzir em linha, cores ou sombras nossas idéias, mas acho que se pensarmos em materiais nossa tarefa ficará potencializada: quer dizer, deixar que a matéria aceite ou não ser utilizada por nossa imaginação ${ }^{5}$.

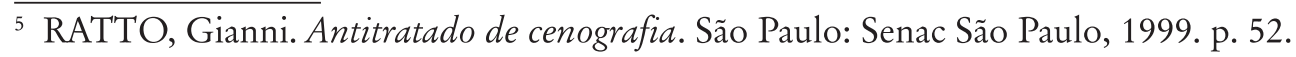


O tempo reduzido conduz também a uma desvalorização de um elemento específico das disciplinas de Indumentária e de Cenografia: o conhecimento das potencialidades expressivas dos materiais e, por conseguinte, com as técnicas de confecção e montagem. Na matriz curricular do curso de Licenciatura em Artes Cênicas da Universidade Federal de Ouro Preto há uma disciplina chamada "Materiais expressivos", cujo objetivo é possibilitar aos alunos um contato com os diversos materiais utilizados na criação teatral (madeiras, papéis, tecidos, metais, plásticos, etc.), e com as diversas técnicas de transformação destes materiais. Assim, de acordo com a abordagem do professor, a disciplina pode conter elementos de cenotécnica, de adereços, de figurinos e de confecção em geral.

Feito a partir de visitas a espaços de produção (oficinas de bonecos, cenotécnicas, carpintarias, oficinas de costura, etc.) ou a espaços culturais (teatros, museus, edifícios históricos, festas, manifestações folclóricas, entre outros), este contato permite ao aluno dois tipos de aprendizado. Num nível mais imediato, eles tomam conhecimento das técnicas e soluções plásticas empregadas por artistas e técnicos teatrais, ou seja, eles assimilam procedimentos para empregá-los em outro contexto. No caso da indumentária, uma visita ao guarda-roupa do Centro Técnico do Palácio das Artes, por exemplo, possibilita uma assimilação de soluções de acabamento do traje, tratamento das peças, materiais alternativos usados para a confecção do traje, entre outros. Na cenografia, uma visita a este mesmo espaço permite assimilar as diversas possibilidades formais de um único material, as diferentes técnicas de tratamento dos materiais, assim como os "macetes" dos cenotécnicos. Este contato com os materiais e com os profissionais pode auxiliar o aluno a elaborar planos de custo, orçamentos e especificar quantidades de materiais.

Num nível mais amplo, visitas desta natureza estabelecem um contato com o fazer coletivo. Os grandes espetáculos envolvem imenso número de artistas, artesãos e técnicos e, conseqüentemente, uma diversidade de ofícios e uma variedade de modos de fazer. Os alunos são lançados no ambiente do fazer teatral, numa cultura viva, onde teoria e prática não se distinguem, onde o conhecimento é transmitido ainda sob outros moldes, tais como, a relação mestre e aprendiz. Assim, a observação dos materiais conduz aos produtores e ao sistema de produção e, por fim, ao fenômeno cultural cuja natureza é essencialmente política. Em suma, ao se pensar nos materiais expressivos, pensa-se também nas práticas culturais, num conjunto de procedimentos técnicos e nos agentes da criação.

Concluindo, no que se refere à formação do arte-educador, ao me referir aos materiais e às oficinas de criação, aponto para a necessidade de as escolas de teatro possuírem laboratórios onde o aluno possa fazer experiências cênicas sistemáticas com os diversos materiais, explorando os elementos da linguagem visual. Laboratórios não somente de criação plástica, mas de experimentação cênica, que permitam o desenvolvimento de pesquisas com o ator, o espaço, a luz, o objeto, o traje. Por outro lado, tendo em vista o aspecto social e político, convém destacar que o professor de teatro ou o aluno de licenciatura encontra nestas práticas culturais um grande material de exploração para o desenvolvimento de uma série de atividades, as quais envolverão outros conteúdos didáticos e outras disciplinas. 


\section{Metodologia da criação visual no teatro: entre o mesmo e o diferente}

Vimos que a criação visual no teatro funda-se numa articulação entre os elementos visuais e os não visuais, na interpretação do conceito de encenação e do texto dramático, e, por fim, na capacidade técnica. Acredito que, para atender ao mercado teatral, a metodologia presente nas obras didáticas ou técnicas sobre cenografia e indumentária são suficientes.

O modo pelo qual um cenógrafo ou um figurinista chega a uma idéia envolve vários fatores subjetivos, de forma que tentar estabelecer um "método" comum a todos é um contra-senso, já que, por sua natureza, este processo resiste à transmissão ou à reprodução. Contudo o sistema de produção teatral determina um modo de criação semelhante para todos os artistas. Por conseguinte, apesar da dimensão subjetiva, é possível se identificar fatores gerais, sujeitos a um registro objetivo, logo, passíveis de transmissão. São estes “fatores gerais" que aparecem nas obras didáticas ou técnicas. Para orientar e estimular o processo criativo, algumas obras apresentam questões que o figurinista ou cenógrafo deve colocar na ocasião em que elaboram projetos. Qual o sentido do texto (análise dramatúrgica)? Qual o conceito da encenação? Que tipo de espaço cênico é mais apropriado para a encenação? Qual o estilo da representação? Que abordagem de figurinos deve ser adotada (realistas, estilizados, abstratos)? Quais as necessidades do ator em relação aos figurinos? Qual a dinâmica do movimento dos atores? Que materiais iconográficos serão necessários para a definição formal? Que cores e formas podem traduzir melhor uma idéia?

Estas perguntas constituem um estímulo válido para o aluno apreender o modo como o drama informa a cenografia e a indumentária. Mas, deve-se entender que, o processo de criação visual no teatro envolve uma experimentação contínua. Isto é, estas perguntas não são respondidas conceitualmente, mas sim plasticamente. A idéia gera formas que, por sua vez, esclarecem a idéia dando-lhe materialidade. É neste ponto que a confecção de maquetes tem se afirmado como um elemento fundamental do estudo e da criação: nela, os materiais são potencializados, de modo a superar as próprias dificuldades de expressão gráfica. Na maquete, as massas, as cores e os volumes são postos em cena, são visualizados concretamente, possibilitando uma antevisão do fenômeno cênico.

Aqui, mais uma vez, sugere-se que as escolas de teatro possuam oficinas necessárias para tais experimentos. Mas, além disso, sugere-se também que haja uma inter-relação das disciplinas: Direção Teatral e Dramaturgia, por exemplo, podem ser disciplinas geradoras de materiais para a experimentação plástica. $\mathrm{O}$ mesmo pode se dar com as disciplinas de Interpretação em relação à prática do figurinista. Enfim, o que se vislumbra aqui - no interior da metodologia tradicional - é que os cursos de teatro sejam mais centrados na prática ou experimentação cênica, envolvendo atividades interdisciplinares. Isto porque Cenografia e Indumentária são disciplinas teórico-práticas que contêm elementos conceituais e elementos referentes à ordem do fazer. Um termo não existe sem o outro, eles se alimentam e se interpenetram, num movimento circular, onde a teoria gera o fazer e o fazer gera a teoria.

Mas, devemos pensar ainda que o licenciado em teatro atuará, em boa parte dos casos, em circuitos alheios a este grande mercado. Devemos pensar também que, por natureza, o gesto criador é sempre transformacional. Ele é agente 
e paciente de uma infinidade de forças. De tal modo que nem sempre as soluções e procedimentos presentes nos livros didáticos são as mais apropriadas, não devendo, portanto, constituírem o único objeto de interesse do arte-educador. É necessário pensar em outros caminhos para a criatividade, caminhos diferentes da "técnica" tradicional e da cultura visual a ela aliada. É necessário ter em vista que as novas tecnologias da imagem e os caminhos da arte contemporânea propõem novas sensibilidades, determinando outras metodologias. De minha parte, tenho experimentado inversões do processo tradicional: gerar a cenografia e o traje não a partir do texto, mas a partir de outras espacialidades (pinturas, fotos, elementos arquitetônicos, entre outros).

Paradoxalmente, o que estes caminhos revelam ao aluno e a nós mesmos é sempre o mesmo: um espaço de visão onde se dá o encontro (neste caso, virtual) do ator e do público, um espaço da metamorfose do ator, do jogo das máscaras, da fusão do real e do irreal. Trata-se nada mais do que formas diferentes de se ver o mesmo fenômeno. 


\section{REFERÊNCIAS}

DIAS, José. A importância da cenografia. O Percevejo, Rio de Janeiro, ano 7, n. 7, p. 11-17, 1999.

DONDIS, Donis A. Sintaxe da linguagem visual. São Paulo: M. Fontes, 2000.

GUÉNOUN, Denis. A exibição das palauras: uma idéia (política) do teatro. Rio de Janeiro: Teatro do Pequeno Gesto, 2003.

HOLT, Michael. Phaidon Theatre manual: costume and make-up. London: Phaidon Press, 1993.

NELMS, Hennig, Scene design: a guide to the stage. New York: Dover Publicatons, 1975.

PARKER, Oren; SMITH, Harvey K. Scene design and stage lighting, New York: Holt, Rinehard and Winston, 1966.

RATTO, Gianni. Antitratado de cenografia. São Paulo: Senac São Paulo, 1999.

SELDEN, Samuel; SELLMAN, Hunton. Stage scenery and lighting: a handbook for non-professionals. New York: Appleton-Centry-Crofts, [19--]. 


\section{ARTS EDUCATION IN LATIN AMERICA \\ AND THE CARIBBEAN MEETING OF EXPERTS}

Ingrid Dormien Koudela

O "Encontro de Especialistas de Educação Artística da América Latina e Caribe”, realizado na Universidade de Uberaba, de 16 a 19 de outubro de 2001, com apoio da Organização das Nações Unidas para a Educação, a Ciência e a Cultura - Unesco -, teve por objetivo discutir o currículo do ensino de arte. Pelo fato de a América Latina e o Caribe já possuírem currículos nacionais estruturados, passou-se à discussão das recomendações a serem feitas pelos diversos grupos, assim constituídos: Teatro, Dança, Música e Artes Visuais.

O grupo de Teatro chegou à conclusão de que essa área é importante para o desenvolvimento da criatividade e da capacidade simbólica de crianças, jovens e adultos, sendo também uma forma de abrir as portas da escola para a entrada dos valores da comunidade e suas tradições artísticas e culturais.

A ponte entre a sala de aula e instituições comunitárias artísticas e culturais cria relações entre crianças, artistas e produtores culturais.

A Unesco se propõe incentivar a promoção de um ensino/aprendizagem em Arte e Teatro visando ao desenvolvimento da criatividade das crianças, jovens e adultos, e à apreciação de bens artísticos e culturais.

As seguintes recomendações foram feitas pelo grupo de especialistas de Teatro, formado por Ingrid Dormien Koudela e Arão Paranaguá de Santana do Brasil; Nolma Coley-Agard da Jamaica, Lílian Galván do Peru, com a colaboração dos observadores, Larry O’Farrell do Canadá e Tintti Karppinen da Finlândia.

\section{Teatro na Educação Básica}

Em uma perspectiva pedagógica, Teatro e Drama são utilizados em diferentes culturas com diferentes concepções e significados. O Teatro é uma área de aquisição e construção de conhecimento na escola. Deveria estar presente no currículo escolar, sendo-lhe atribuída a mesma importância que as outras áreas de conhecimento.

Na Educação Básica (infantil, fundamental e média), o Teatro deveria ser parte da área de conhecimento denominada Arte, ao lado da Dança, da Música e das Artes Visuais, dentro de um programa integrado e interdisciplinar. 
Nas últimas séries do Ensino Fundamental e ao longo do Ensino Médio, o Teatro deveria ser considerado como uma disciplina autônoma, de forma articulada com as outras linguagens artísticas.

As quatro linguagens artísticas (Teatro, Música, Dança e Artes Visuais) deveriam estar presentes no currículo escolar, tanto individualmente como através de programas interdisciplinares. O Teatro deveria estar presente todas as vezes que for concebido um programa multidisciplinar.

O Teatro deve ser considerado como uma metodologia de ensino na Educação Básica.

\section{Formação de professores de teatro}

Para desenvolver atividades de ensino em Teatro, recomendam-se dois modelos de formação, um com caráter generalista, voltado para a Educação Infantil e primeiras séries do Ensino Fundamental, e o outro com caráter de especialização, para as últimas séries do Ensino Fundamental e Ensino Médio.

A educação de professores de Teatro deveria acontecer em dois estágios:

- Pré-serviço ou formação inicial antes da profissionalização;

- Em serviço ou formação continuada a acontecer em qualquer momento da carreira.

Os programas formativos deveriam enfatizar a relação entre a teoria e prática, o estudo de metodologias específicas e a relação entre ensino e pesquisa.

Artistas de teatro que atuam nas escolas deveriam participar de programas de educação continuada.

\section{Formação pré-serviço}

$\mathrm{Na}$ formação do professor generalista, a área de Teatro deve compor o currículo em conjunto com as outras linguagens artísticas (Dança, Música e Artes Visuais) reservando-se como um mínimo de 60 horas para cada uma delas. Recomenda-se que, depois de cumpridas essas quatro disciplinas, sejam reservadas mais 60 horas para o desenvolvimento de projetos interdisciplinares. Os professores que atuam na Educação Infantil e primeiras séries do Ensino Fundamental que não tenham recebido essa fundamentação em cada uma das linguagens artísticas deveriam participar de cursos equivalentes.

\section{Formação em serviço}

Todos os professores que atuam na Educação Infantil e nas primeiras séries do Ensino Fundamental (incluindo aqueles que tenham recebido a fundamentação em cada uma das linguagens artísticas) deveriam ser incentivados a participar em cursos de formação continuada, nas várias artes. Modelos específicos de desenvolvimento profissional podem incluir o seguinte:

- oficinas, conferências e seminários, para dar ao professor as habilidades básicas para trabalhar nos termos do presente programa;

- participação de professores especialistas em Teatro para coordenar oficinas e ministrar cursos; 
- participação de artistas de teatro em oficinas;

- inclusão de programas culturais, sobretudo na área de teatro.

\section{Estratégias para implementação}

Os modelos para a implementação do currículo de Teatro podem incluir:

- o convite a professores especialistas para coordenar oficinas de Teatro;

- o convite a artistas de teatro para ensinarem Teatro na escola, bem como orga nizar oficinas para professores;

- o convite aos pais e membros da comunidade com habilidades em Teatro;

- a inclusão de políticas culturais integradas às atividades das escolas, universi dades, conservatórios, museus etc., com o objetivo de ampliar as oportunidades para a aprendizagem do Teatro.

Os professores deveriam colaborar com os museus que utilizam o Teatro para tornar viva a história e a cultura. Eles deveriam cooperar com o teatro profissional, proporcionando aos alunos o acompanhamento do processo de produção de uma encenação teatral, a discussão com atores e diretor, incluindo esse tema nas aulas de teatro. Deveriam incentivar seus alunos a participar de festivais de teatro de alta qualidade, desde que tenham uma orientação educacional; deveriam incentivar seus alunos a se apresentarem em hospitais, asilos, fábricas e outros locais comunitários; e incentivar seus alunos a desenvolver e apresentar cenas e peças sobre eventos locais, acontecimentos históricos e outros. Por exemplo, os alunos podem pesquisar um tema entrevistando pessoas com conhecimento e desenvolver uma peça de teatro que envolva todas as formas de arte. Por fim, os professores deveriam convidar os pais a se engajarem nas atividades de teatro, fazendo figurinos, cenários etc.

\section{Elementos do currículo de teatro para a educação infantil e o ensino fundamental}

\section{Objetivos}

Ao final do programa, os alunos devem estar aptos a:

- Usar estórias e jogos tradicionais para criar teatro

- Iniciar suas próprias atividades cênicas

- Realizar atividades de mímica usando a experiência pessoal

- Usar a narração nas apresentações teatrais

- Usar bonecos e objetos animados nas suas apresentações

- Usar adereços e figurinos para criar personagens

- Improvisar diálogos

- Escrever e gravar diálogos a partir de improvisações

- Interagir com outras personagens em cenas improvisadas e escritas

- Experimentar várias formas de apresentação do teatro

- Conhecer formas através das quais o teatro afeta a vida

- Apreciar e criticar sua apresentação dramática e aquela de seus pares

- Apresentar diante de funções da escola, da comunidade e em festivais

- Entender e apreciar várias formas culturais 
- Apreciar a contribuição de praticantes de teatro e o desenvolvimento dessa for ma de arte.

\section{Propostas metodológicas}

- Pesquisa e exploração de jogos tradicionais, jogos teatrais, canções, provér bios, gestos e linguagem corporal nas oficinas pedagógicas de teatro.

- Pesquisa e exploração de exercícios sensório-corporais, com a voz e o espaço cênico.

- Pesquisa e desenvolvimento da concentração (foco), instrução e avaliação no jogo teatral.

- Pesquisa e experimentação com as várias formas poéticas na exploração do corpo e da voz (narrativa, texto dramático, poemas, contos).

- Criação e animação de adereços, figurinos e cenários.

- Pesquisa e exploração de vários espaços nas oficinas pedagógicas de teatro e nos espetáculos teatrais realizados com os alunos.

- Pesquisa e criação de cenas e episódios a partir de estímulos oriundos das "cem linguagens da criança”, através da integração entre as linguagens artís ticas.

- Seqüência de cenas e episódios na demonstração e no espetáculo teatral.

- Pesquisa e experimentação do receptor: a relação palco (atuante) e platéia (apreciador da obra de arte).

- Visita a teatros, circos, eventos musicais e de dança, museus e outros centros artísticos e culturais.

- Entrevistas com produtores e artistas de teatro.

- Experimento com várias formas de publicidade sobre espetáculos de teatro em cartaz.

- Experimentos com projetos multiculturais e interculturais nas oficinas pedagó gicas de teatro. 


\section{TEATRO CONTEMPORÂNEO: O SENTIDO EM DEBATE}

José da Costa

Segundo Nelson de Sá, Nova velha estória, espetáculo que Antunes Filho realizou a partir do conto de Chapeuzinho vermelho dos irmãos Grimm, era uma espécie de panfleto contra o teatro visual: "O diretor, com 40 anos de teatro, chutou glórias passadas e saiu a campo contra o teatro ininteligível, de imagens e gelo seco”. Com essas palavras, o crítico paulista se referia aos procedimentos cênicos utilizados por Gerald Thomas. Nelson de Sá justifica o caráter de obviedade que enxerga nos signos e na dramaturgia de Nova velha estória como uma maneira pela qual Antunes Filho estaria contrapondo-se à rarefação do significado em certo teatro brasileiro contemporâneo e como uma reação ao chamado teatro visual. A referência a Gerald Thomas, no comentário à peça de Antunes, explicita-se sem ambigüidade:

Nova velha história é, por assim dizer, o fundo do poço. Depois de cinco anos de Gerald Thomas, era preciso uma "terra arrasada" para mudar. O próprio Thomas tentou isso com Morte, espetáculo contido, apesar do título. A peça de Antunes Filho é um novo passo nessa direção. Um espetáculo mais para destruir do que para apontar alternativas ${ }^{1}$.

Mas não é só Nelson de Sá que se inquieta com o crescimento do suposto teatro visual no Brasil durante os anos 80 e 90 . Em edição da Revista da Universidade de São Paulo - USP -, dedicada ao teatro brasileiro contemporâneo, a pesquisadora Tânia Brandão discute o panorama teatral do Rio de Janeiro naquele momento ${ }^{2}$. Preocupavam, então, à ensaísta a automatização dos intérpretes em decorrência da primazia dada à "materialidade plástica que os envolve" no teatro de Gerald Thomas, mas também no de Bia Lessa, em cujo trabalho "a direção de ator e os problemas de interpretação não são valorizados”. Essa espécie de redução do papel criativo desempenhado pelo ator atingia também, conforme as avaliações de Tânia Brandão, as produções lideradas por Moacyr Góes e por Márcio Vianna à época em que o ensaio foi escrito. Nas peças desses dois últimos diretores, a exacerbação da intensidade corporal, a qual os intérpretes eram levados, acarretaria o prejuízo da capacidade de modulação da emoção e da enunciação do texto na visão de Tânia.

\footnotetext{
${ }^{1}$ SÁ, Nelson de. Divers/Idade: um guia para o teatro dos anos 90. São Paulo: Hucitec, 1997. p. 49.

2 BRANDÃO, Tânia. Visionários ou alienados. Revista da USP, São Paulo, n. 14, p. 28-33, jun./ ago. 1992.
} 
No trabalho dos quatro diretores tomados como representantes das tendências dominantes no teatro carioca no final dos anos 80 e início dos 90 , a ensaísta verifica outro traço comum. Trata-se de uma segunda redução, aquela imposta à função do texto verbal, levando a uma espécie de "morte da palavra", que teria a ver com razões diversas interligadas entre si. A rejeição por vários daqueles diretores de encenarem textos disponibilizados pelo repertório da literatura dramática ocidental seria uma das causas do sacrifício da palavra diagnosticado pela pesquisadora carioca. A única exceção seria Moacyr Góes, que lançou mão de obras de Brecht, Büchner, Marlowe, Guelderode, Sakespeare e Sófocles em sua trajetória de encenador. Entretanto, na visão de Tânia Brandão, a ênfase dada à corporeidade (em uma orientação mecânica ou automatizada) reduzia a importância do texto nos empreendimentos teatrais realizados por Moacyr.

Entre as razões da dupla redução da palavra e do ator, a ensaísta menciona a tendência a se priorizarem narrativas de ficção livremente teatralizadas a partir das exigências dos projetos cênico-visuais dos diretores (Thomas em relação a obras de Kafka, Bia Lessa em relação à de Virgínia Wolf etc.); bem como uma tendência aparentada à primeira, qual seja, a de os próprios encenadores escreverem textos "em geral, bem pouco densos, desprovidos de relevância enquanto dramaturgia e até de importância secundária na dinâmica da montagem”’. Para Tânia Brandão:

\begin{abstract}
Não há dúvida de que as tendências teatrais cariocas mais recentes e de maior repercussão acontecem tendo como pano de fundo o processo de diluição da linguagem teatral moderna, cuja institucionalização não ocorreu plenamente. Por isso, parece preocupante que essas novas tendências reúnam produtores que, dedicados à livre criação e à expressão pessoal de seu ideário, não tenham um cálculo nítido de diálogo ou atrito com os temas da modernidade histórica. Não há como não sentir um sabor amargo quando se constata que certos temas, onipresentes e cruciais para o teatro do século XX, não são trabalhados ou são descartados com razoável facilidade. Pode ser que aí esteja o teatro do futuro, o rascunho da cena do século XXI - a distância frente ao problema do sentido, o abandono do conceito tradicional de ação dramática, a ênfase na plasticidade e na construção visual, o desprezo ou a indiferença diante da hipótese da palavra, a automatização do ator seriam indícios de uma cena-de-um-outro-tempo-que-virát.
\end{abstract}

Tânia Brandão tem desenvolvido em vários trabalhos a visão de que o viés dominante no teatro brasileiro atual, centrado em certo tipo de estrelismo dos diretores (no teatro mais experimental) e dos atores (no teatro mais comercial), implica uma espécie de desvio ou degeneração do movimento modernizante da cena nos anos 40 e 50. Movimento esse que não teria, como demonstra a estudiosa, apenas focalizado a construção de uma poética da encenação, mas teria também realizado esforços de transformação do mercado profissional e da inserção institucional do teatro, ainda que esses esforços não tivessem atingido, conforme a avaliação de Tânia Brandão, suficiente consistência ou continuidade ${ }^{5}$.

\footnotetext{
BRANDÃO, 1992, p. 32.

BRANDÃO, 1992, p. 33.

5 Um exemplo de trabalho em que Tânia Brandão aborda essas questões é o brilhante ensaio
} 
O movimento modernizante do teatro no Brasil se iniciou no Rio de Janeiro pelos amadores (Teatro Brasileiro do Estudante e Os Comediantes, fundamentalmente) e, profissionalmente, foi empreendido pelo TBC e pelas companhias dele procedentes ou a ele aparentadas em termos de projeto artístico-cultural, como, por exemplo, o Teatro Popular de Arte de Sandro Polonio e Maria Della Costa, surgido, como o TBC, no ano de 1948. É, aliás, ao Teatro Popular de Arte (que surge no Rio de Janeiro e só depois se transfere para São Paulo) que Tânia dá a primazia em termos de profissionalização de uma prática teatral moderna no Brasil ${ }^{6}$.

$\mathrm{O}$ afastamento com relação ao moderno detectado por Tânia no palco contemporâneo começaria, segundo sua avaliação, na fase nacional-popular do Teatro de Arena de Boal, Vianinha e Guarnieri, no final dos anos 50; atingiria, ainda em São Paulo, o Teatro Oficina de José Celso Martinez Correia, a partir de seu momento tropicalista com a encenação de $O$ rei da vela, de Oswald de Andrade, em 67; instalando-se também, no Rio de Janeiro, em uma companhia como o Teatro Ipanema de Ivan de Albuquerque e de Rubens Correia no início dos anos $70^{7}$. O resultado do desvio de rota ou desagregação do teatro moderno seria um teatro que se aproxima da prática pré-moderna - segundo os termos da própria autora ${ }^{8}$-, experiência de tipo voluntarista, dos grandes atores dos anos 30 e 40, a exemplo de um Procópio Ferreira e de um Jaime Costa ${ }^{9}$ e tradição iniciada no contexto romântico oitocentista de João Caetano ${ }^{10}$. $\mathrm{Na}$ densa e complexa discussão da noção de moderno, em sua tese de doutoramento, a autora tem o cuidado de evitar dualismos como, por exemplo, o do binômio avançado-atrasado como correspondente da dicotomia moderno versus não-moderno ${ }^{11}$. Esse cuidado aponta para a percepção de que esses dualismos acabam por desqualificar um dos termos da oposição, como desqualificam também todas as alternativas que escapam à versão priorizada hierarquicamente, podendo gerar, como conseqüência, raciocínios históricos unilaterais ou unívocos.

Mas de modo crucial, o que parece à pesquisadora estar na base do subjetivismo voluntarista que vê nos trabalhos dos diretores, no final dos anos 80 e início dos 90 no Rio de Janeiro, é o desprezo "frente ao problema do sentido" e o "abandono do conceito tradicional de ação dramática”. São esses os fatores que reduziriam a um papel secundário tanto as palavras, quanto os intérpretes no teatro carioca do período comentado no texto da Revista da USP.

Nesse ensaio, Tânia Brandão explicita a posição de que a co-habitação de referências a contextos histórico-culturais muito díspares em uma mesma obra seria, em sua

Teatro brasileiro do século $X X-$ As oscilações vertiginosas. BRANDÃO, Tânia. $\mathrm{O}$ teatro brasileiro do século 20. Revista do IPHAN, Brasília, DF, n. 29, p. 300-335, 2001b. Mas também na tese de doutoramento da pesquisadora, Peripécias modernas: companbia Maria Della Costa (19481974), aparece o tema da extinção da experiência do teatro moderno no Brasil a partir da década de 60 e principalmente de 70. BRANDÂO, Tânia. Peripécias modernas: Companhia Maria Della Costa (1948-1974). 1998. p. 323, 332. Tese (Doutorado) - Instituto de Filosofia e Ciência Sociais, Universidade Federal do Rio de Janeiro, Rio de Janeiro, 1998. Não publicada. O interesse da historiadora pelo percurso de um certo teatro moderno profissional aparece ainda no livro em que estuda a trajetória da companhia carioca Teatro dos Sete. BRANDÃO, Tânia. A máquina de repetir e a fábrica de estrelas: Teatro dos Sete. Rio de Janeiro: 7 Letras, 2002. 330 p.

6 BRANDÃO, 2001b, p. 320

7 BRANDÃO, 2001b, p. 325-326, 329.

8 BRANDÃO, 1992, p. 33.

9 BRANDÃO, 2001b, p. 315, 324.

${ }^{10}$ BRANDÃO, 2001b, p. 303-305, 309.

${ }^{11}$ BRANDÃO, 1998, p. 1-69. 
opinião, um dos exemplos da atitude voluntarista dos diretores. Trata-se de um trecho em que a ensaísta se refere a Gerald Thomas como sendo, dentre os diretores citados (Moacyr Góes, Bia Lessa e Márcio Vianna, além do próprio Thomas), aquele:

[...] cujos trabalhos estão mais estreitamente ligados à própria personalidade e aos maneirismos do criador, inclusive devido às citações gratuitas, episódicas ou anedóticas de outras obras de arte (o caso mais grave, aqui [no Rio de Janeiro] foi a montagem da ópera $O$ navio fantasma, de Wagner, em que o diretor se deu ao luxo de se referir à Documenta de Kassel e a obras de artes plásticas do século XX ${ }^{12}$.

Em suma, os procedimentos de aglutinação de referências díspares, as técnicas de colagem e de montagem, associando aspectos relativos a contextos históricos e culturais heterogêneos, foram vistos pela pesquisadora em certo momento como sintoma de uma espécie de subjetivismo gratuito e, por isso, reprovável.

Sábato Magaldi, em seu ensaio de abertura da mesma publicação ${ }^{13}$, compartilha, de certo modo, o tipo de visão expressa por Tânia Brandão sobre o teatro do início dos anos 90, afirmando ser recomendável:

Que os encenadores-criadores admitam um pouco mais de modéstia, reflitam que não são deuses todo-poderosos e acolham a colaboração de dramaturgos e intérpretes, já que o bom senso diz que não se faz bom teatro sem boa literatura ${ }^{14}$.

Já Alberto Guzik ${ }^{15}$ não reproduz esse apelo ao "bom senso", naturalizado nas palavras de Magaldi, que opta por recorrer às noções de "bom teatro" e de "boa literatura", como se elas fossem auto-evidentes e não necessitassem maiores especificações de critérios ou de perspectivas segundo as quais se possa aludir às mesmas. Apesar de não recorrer à expressão tão singela quanto "boa literatura", Guzik também lida com a dicotomia teatro da palavra versus teatro da imagem, a que se refere como "dramaturgia do espaço", exercida, segundo ele, por encenadores como Bia Lessa, Ulysses Cruz e Gerald Thomas.

Estamos em um determinado campo de apreciação do teatro contemporâneo que, apesar de diferenças em vários níveis, considerando os distintos perfis intelectuais, profissionais e geracionais dos críticos mencionados, compartilha certa perspectiva comum no que diz respeito ao modo de entender determinados aspectos do teatro atual. De fato é, por exemplo, bastante habitual, em vários setores da crítica jornalística e acadêmica, uma visão razoavelmente pessimista (expressa, muitas vezes, também em depoimentos de artistas) em relação à tendência do teatro contemporâneo de priorizar adaptações de textos originalmente não escritos para a cena; a encenação integral de narrativas de ficção razoavelmente longas; e, ainda, a ênfase dada nas composições dramatúrgicas empreendidas pelos próprios encenadores (e/ou por dramaturgos ou dramaturgistas integrados às companhias), às técnicas de colagem, de montagem literária, de bricolagem e de livre manipulação de referências artísticas

\footnotetext{
12 BRANDÃO, 1992, p. 32.

${ }_{13}$ MAGALDI, Onde está o teatro. Revista da USP, São Paulo, n. 14, p. 6-9, jun./ago. 1992.

${ }^{14}$ MAGALDI, 1992, p. 8.

${ }^{15}$ GUZIK, Alberto. Um exercício de memória: dramaturgia brasileira anos 80. Revista da USP, São Paulo, n. 14, p. 10-15, jun./ago. 1992.
} 
e culturais. Esses procedimentos de criação escapam ao que, do ponto de vista do drama tradicional e do play-writing mais atual, é considerado o domínio da chamada carpintaria dramatúrgica, da eficiência no ofício especializado da composição do texto dramático, entendido dentro das pautas particulares de um gênero definido ou de certa expectativa de comunicabilidade com o público médio.

Entre as ressalvas de Bárbara Heliodora em relação ao espetáculo $A$ paixão segundo G.H., com adaptação teatral do romance de Clarice Lispector assinada por Fauzi Arap e direção de Enrique Diaz, o aspecto dramatúrgico foi especialmente destacado e serviu a uma avaliação mais geral de certa tendência do teatro brasileiro atual.

Trata-se, portanto, de mais um exemplo da síndrome da literatura que vem atacando o teatro nacional nesses últimos tempos. Se fazer teatro não é fácil, não chega a ser muito compreensível esse insistente acréscimo nos obstáculos a serem superados até a hora do espetáculo, pelo uso de textos que não foram criados para o palco ${ }^{16}$.

$$
* * *
$$

Patrice Pavis, não partilhando da sensação de incompreensibilidade a que alude Bárbara Heliodora, apresenta uma outra visão do mesmo fenômeno no contexto francês:

Ninguém (exceto os teóricos do drama) acredita mais na especificidade do texto dramático, na existência de regras e de leis do diálogo, do personagem, da estrutura dramática, etc. Por prova, esta pesquisa de textos não escritos inicialmente para a cena e que permitiram as experiências do teatro-relato. [...] Trata-se de tomar o texto romanesco não como substrato para uma fábula e personagens, mas de fazer uma leitura cênica daquele texto mais ou menos dramatizada pelas improvisações de seus diversos leitores ${ }^{17}$.

Jacó Guinsburg, em texto que focalizava um outro aspecto, incluído na mesma publicação da USP a que venho recorrendo aqui, questionava a recepção crítica de certo teatro contemporâneo:

O fato de o teatro dos anos 80 distinguir-se por ser em grande parte criação de diretores, e muito menor escala de dramaturgos, suscitou na literatura especializada uma sucessão de especulações sobre a impotência teatral da escritura dramatúrgica como sinal de fenecimento da arte dramática. Nem o surgimento de autores como Heiner Müller, Botho Strauss e outros é considerado como uma demonstração de poder criativo de textualização, sendo apontado como confirmação do processo de decadência, pelas características de suas peças. As colagens, as citações, as montagens de fragmentos, as transposições do épico para o dramático, os enredos soltos, as estruturas abertas e a

${ }_{16}$ HELIODORA, Bárbara. Cuidados e carinhos com Clarice. O Globo, Rio de Janeiro, 4 dez. 2002. Segundo Caderno, p. 4.

17 PAVIS, Patrice. Le théâtre au croisement des cultures. Paris: Librairie José Corti, 1990. p. 74. Tradução nossa. 
própria potencialização dos recursos e das intervenções cênico-diretoriais tornam-se outros tantos argumentos em favor da desvitalização da força do teatro, de seus componentes essenciais e constitutivos, e não são tidos como elementos de uma linguagem que faz da montagem de teatro um teatro de montagem ${ }^{18}$.

No mesmo número da Revista da USP em que aparecem os ensaios de Tânia Brandão, Sábato Magaldi, Alberto Guzik e Jacó Guinsburg, dentre outros autores e autoras, chama a atenção a posição expressa por Sílvia Fernandes:

Para desobstruir o palco dos rótulos ou, pelo menos, observá-lo sob nova luz, é preciso enxergar no trabalho autoral de (Gerald) Thomas uma das matrizes de análise da encenação nos anos 80. [...] As peças musicais de Hamilton Vaz Pereira, as experiências plásticas e espaciais de Bia Lessa, o Corpo de baile de Ulysses Cruz ou o $A$ bao a qu de Enrique Diaz afirmam-se, tanto quanto a ópera seca de Thomas, como concretizações de um discurso da encenação ${ }^{19}$.

Sílvia Fernandes se aproxima de Guzik, uma vez que a idéia de um "discurso da encenação" se associa a de uma "dramaturgia do espaço", a que alude o crítico paulista. Em seu livro sobre o teatro de Thomas, Sílvia dedica um dos capítulos ao estudo da construção cênico-dramatúrgica a partir da análise do espaço, do tipo de sintaxe livre ou aberta que ali é proposta por meio de repetições, de citações e de variações de quadros cênicos e cenográficos. Sílvia Fernandes também se une a Tânia Brandão, uma vez que, como Tânia, ela enxerga, nos anos 80, uma espécie de retorno a uma autoria individualizada e centralizada nas mãos do encenador. Para Sílvia, essa tendência marca uma diferenciação em relação tanto às experiências de criação coletiva dos anos 70, quanto à concepção da encenação teatral como criação espetacular que se dá a partir de um texto dramático prévio ${ }^{20}$.

Apesar da aproximação sob certos aspectos, Sílvia Fernandes apresenta uma perspectiva claramente diferenciada em relação àqueles que fazem do trabalho cênico de Thomas o paradigma de um teatro semanticamente estéril:

18 GUINSBURG, Jacó. O lugar do teatro no contexto da comunicação de massa. Revista da USP, São Paulo, n. 14, p. 92-96, jun./ago. 1992b. A posição de Jacó Guinsburg mais aberta a certas práticas criativas contemporâneas aparece igualmente em texto da Revista Sala Preta (GUINSBURG, Jacó. Texto ou pretexto. Sala Preta: Revista de Artes Cênicas, São Paulo, ano 1 , n. 1, p. 87-88, 2001), como pode também ser pressuposta a partir de pelo menos alguns dos ensaios escritos a quatro mãos reunidos no livro Diálogos sobre teatro. GUINSBURG, Jacó. Diálogos sobre teatro. Organização de Armando Sérgio da Silva. São Paulo: Edusp, 1992a. 262 p. Lembre-se ainda que o autor é um dos organizadores do livro coletivo Um encenador de si mesmo: Gerald Thomas. FERNANDES, Sílvia; GUINSBURG, Jacó (Org.). Um encenador de si mesmo: Gerald Thomas. São Paulo: Perspectiva, 1996. 295 p.

${ }_{19}$ FERNANDES, Sílvia. O espectador emancipado. Revista da USP, São Paulo, n. 14, p. 70-71, jun./ago. 1992.

${ }_{20}$ Sílvia Fernandes - que se dedicara aos grupos de teatro dos anos 70 em estudo realizado antes da pesquisa sobre a obra de Thomas, ainda que publicado posteriormente (FERNANDES, Sílvia. Grupos teatrais: anos 70. São Paulo: UNICAMP, 2000a. 268 p.) - enxerga hoje, no Teatro da Vertigem de Antônio Araújo, o exemplo de uma mentalidade (a da prática colaborativa de criação cênica e dramatúrgica) que não se coaduna nem com o espírito da criação coletiva da década de 70 e nem com o domínio do encenador verificado nos anos 80 (FERNANDES em NESTROVSKI, Arthur (Org.). Trilogia bíblica: teatro da vertigem. São Paulo: Publifolha, 2002. p. 35-40). Para a pesquisadora, o Teatro da Vertigem aponta um outro modo de criação participativa, envolvendo simultaneamente encenador, atores e dramaturgo. 
Muitas críticas começaram a alvejar o teatro de Thomas. Estetização, hermetismo, auto-referência, simulacro, eram alguns dos conceitos que rotulavam o palco do encenador. Subjacente a elas, o que estava em jogo era um determinado conceito de teatro, construído pacientemente desde Aristóteles. Teatro de verdade tinha de ter conflito, texto dialogado, ator identificado (ou, quando muito, distanciado) e se possível, nó dramático. E no caso de Thomas, o jogo da teatralidade se desenrolava através das imagens em cena ${ }^{21}$.

A pesquisadora se refere aqui às críticas que Thomas começou a receber no Brasil a partir da exibição dos primeiros espetáculos realizados como composições inteiramente escritas pelo próprio Thomas, como Electra com Creta (Rio de Janeiro, 1985) e Carmen com filtro (São Paulo, 1986) e não como encenações de textos de outros autores, a exemplo de Quatro vezes Beckett (Rio de Janeiro, 1985), com textos curtos de Samuel Beckett, e de Quartet, de Heiner Müller (Rio de Janeiro, 1986).

Sílvia Fernandes havia antecipado, em seu ensaio da Revista da USP, aspectos que viriam a ter um desdobramento mais extenso na tese sobre o teatro de Gerald Thomas, que veio a defender e publicar alguns anos depois. Estudo em que dedica um dos capítulos à discussão da construção da personagem pelo encenador-dramaturgo Gerald Thomas e pela atriz Bete Coelho no espetáculo Carmen com filtro. Nesse capítulo, a pesquisadora chama a atenção para a composição por procedimentos de acumulação de referências literárias e histórico-culturais muito variadas e mesmo díspares sobre o suporte da figura de Carmen, destacando ainda a importância da colaboração criativa de Bete Coelho no espetáculo.

No ensaio da Revista da USP, a ensaísta confronta o fechamento do palco por uma cortina de filó (colocada no proscênio em algumas das encenações de Gerald Thomas) com a teorização da quarta parede na perspectiva naturalista de André Antoine. A pesquisadora, ao contrário de Tânia Brandão, apreende, assim, um diálogo (com diferenciação) do trabalho de Thomas com certas experiências fundantes do teatro moderno do início do século passado.

O fechamento do palco contemporâneo não parece obedecer a essa necessidade (refere-se à demanda de ilusão teatral, que marcara a produção de André Antoine no início do século XX). Em primeiro lugar porque aquilo que vemos em cena (no caso do teatro de Thomas) é ficção elevada à última potência, ou melhor, é desestabilização dos mecanismos de preservação da ficção. Em segundo, porque a representação não pretende entregar ao público um sentido, uma visão de realidade, uma mensagem ou qualquer outro elemento exterior a ela ${ }^{22}$.

Sílvia Fernandes enxerga no teatro de Gerald Thomas o "esboço de uma nova concepção de representação”, que não opera a partir da unificação dos elementos de cena, com a redução de sua possível heterogeneidade, visando à construção unitária de um sentido comum. Como lembra a pesquisadora, esse modo de operar - com aplainamento do heterogêneo - está na base das práticas do modernismo teatral

${ }^{21}$ FERNANDES, Sílvia. Memória e invenção: Gerald Thomas em cena. São Paulo: Perspectiva, 1996. p. X.

${ }^{22}$ FERNANDES, 1992, p. 72. 
desde suas primeiras teorizações em Wagner, em Craig ou em Adolph Appia.

Segundo Patrice Pavis, o sentido no teatro pós-moderno é marcado pela mobilidade ou provisoriedade num grau que não se via no teatro moderno da primeira metade do século $\mathrm{XX}^{23}$. Nesse último, as operações de harmonização dos elementos sígnicos e semânticos tenderiam, conforme o pensamento do teórico francês, a produzir certas sínteses significacionais após todas as dispersões (temporais, espaciais etc.) que tenham por ventura sido admitidas e todas as contradições dialéticas que tenham sido acionadas ao longo da peça, ou seja, tenderiam a constituir uma univocidade e uma estabilidade controladora das possíveis derivas do sentido. De fato, são as operações harmonizadoras e estabilizadoras do sentido que parecem ser colocadas fortemente em questão por certo teatro dos dias atuais.

No Brasil, não é apenas a voz de jornalistas ou de estudiosos que se levanta em defesa de um princípio de causalidade e de certo tipo de narratividade linear ou de base referencial mais estável. Muitos criadores, em depoimentos públicos e em textos de reflexão, apegam-se a essa perspectiva. Adere-se a ela, várias vezes, como um modo de recuperar platéias perdidas para outras formas de lazer e distração. $\mathrm{O}$ dramaturgo Luiz Alberto Abreu ${ }^{24}$, por exemplo, defende, em dois artigos publicados recentemente em revistas acadêmicas de teatro, tanto a retomada de eixos narrativos razoavelmente unificados e harmônicos - mesmo mencionando, contraditoriamente, exemplos de autores que não trabalham nessa perspectiva como Heiner Müller e Bernard-Marie Koltés ${ }^{25}$-, quanto de personagens estáveis e contínuos, capazes de ter uma consciência de si e do mundo ${ }^{26}$.

Para Abreu, a revalorização da dimensão narrativa seria fundamental para a reaproximação do teatro em relação ao público, que ter-se-ia distanciado, em decorrência da perda da capacidade dos criadores de falarem "a mesma língua" que os espectadores, de veicularem "imagens extraídas de um imaginário comum”27. A recuperação dessa capacidade, fazendo o teatro voltar a tocar no que o dramaturgo chama de "imaginário coletivo" e levando à superação dos "guetos com suas diminutas platéias"28 poderá contribuir, na opinião do dramaturgo, para a criação ou reconstituição de laços mais gerais entre as pessoas, laços de tipo comunitário ou nacional.

Penso que a defesa do aspecto narrativo, no texto da Revista O Percevejo, faz Luiz Alberto Abreu confundir os traços formais de um teatro narrativizado (a presença de coros, narradores etc.) com algo que é distinto disso que é o eixo narrativo-diegético (fabular) do texto teatral, tenha esse texto um formato dramático mais fechado ou rompa ele o caráter absoluto da ação, por meio da utilização de traços épico-líricos. De fato, o que o dramaturgo, nos ensaios mencionados, está defendendo (talvez sem maior

\footnotetext{
${ }^{23}$ PAVIS, 1990, p. 65-87, 89-108; PAVIS, Patrice. Vers une théorie de la pratique théâtrale: voix et images de la scène. Septentrion: Presses universitaires de Septentrion, 2000. p. 193-206.

${ }^{24}$ Luiz Alberto Abreu é autor de peças como Foi bom, meu bem?, Bella Ciao, Lima Barreto ao terceiro dia e guerra santa dentre outras, tendo diversas vezes trabalhado como dramaturgo no interior de projetos de certos grupos de teatro como, por exemplo, o Grupo Galpão e Teatro da Vertigem.

${ }_{25}$ ABREU, Luiz Alberto. A restauração da narrativa. O Percevejo: Revista de Teatro, Crítica e Estética, Rio de Janeiro, ano 8, n. 9, p. 115-125, 2000.

26 ABREU, Luís Alberto. A personagem contemporânea: uma hipótese. Sala Preta: Revista de Artes Cênicas, São Paulo, ano 1, n. 1, p. 61-68, 2001.

${ }^{27}$ ABREU, 2000, p. 121.

${ }^{28}$ ABREU, 2000, p. 121.
} 
consciência desse fato) parece ser a retomada de determinados valores de caráter bastante tradicional na história da arte e da literatura ocidentais, valores que tiveram uma configuração mais objetiva nos séculos XVIII e XIX e que dizem respeito a funções pedagógicas da ficção (narrativa ou dramática) e da lírica para a construção de identidades coletivas, das bases da nacionalidade e mesmo da formação do indivíduo burguês.

A ruptura da forma dramática pode levar a uma narrativização do teatro mais ou menos problematizadora da noção de verdade, da realidade como algo estável e disponível à apreensão cognoscitiva e à reconstituição pelo discurso narrativo. Luiz Alberto recorre de maneira nostálgica à complexa noção de intercâmbio de experiências extraída do conhecido ensaio de Walter Benjamin sobre o narrador ${ }^{29}$. O que Benjamin demonstrou foi a inviabilidade do que chama de transmissibilidade de experiências no contexto histórico em que se desenvolve o romance moderno. A ruptura é constatada como definitiva dentro de um novo quadro sócio-histórico e cultural. $\mathrm{O}$ crítico alemão afirma que é a inviabilidade daquele intercâmbio de experiências que afasta radicalmente o romance como o conhecemos modernamente (gênero ligado fundamentalmente ao campo da vivência individual) do quadro das narrativas tradicionais, cuja função era precisamente promover as trocas capazes de solidificar ou de reforçar os elos e valores coletivos.

Luiz Alberto Abreu fala em "conteúdos narrativos”, para aludir tanto a aspectos referenciais, quanto a traços formais ou de gênero. Mas o que realiza, no texto da Revista $\mathrm{O}$ percevejo, é, em suma, a defesa de um teatro de conteúdos temáticos definidos e de significados comunicáveis, de um reforço do funcionamento cognoscitivo ou formativo e do caráter referencial tradicional da arte teatral. A reflexão que o dramaturgo realiza no texto que publicou na Revista Sala Preta a propósito do personagem, ainda que tenha relação com as questões que ele levanta sobre a narrativa no texto de $\mathrm{O}$ Percevejo, parece mais concentrada e específica, enquanto no texto de $\mathrm{O}$ Percevejo a discussão assume um teor meta-histórico (ontológico e axiológico) sobre a narrativa. De fato, o texto sobre o personagem tem caráter mais técnico-dramatúrgico (de análise de problemas sobre procedimentos composicionais) e se mostra mais delimitado, enquanto levantamento de questões sobre caminhos possíveis de construção do personagem pelos autores no contexto da contemporaneidade. Desse modo, o texto se apresenta como a exposição das inquietações de um dramaturgo inserido em seu tempo e não ganha ares de uma teorização supra-histórica e nostálgica no grau em que isso ocorre no texto de $\mathrm{O}$ percevejo.

$* * *$

Em outro diapasão, Mariângela Alves de Lima, em pequeno artigo incluído em publicação do início dos anos $80^{30}$, postula outros horizontes de análise. Ela tenta, nesse trabalho, entender o desapontamento que os críticos e os produtores teatrais pareciam sentir no momento da atenuação dos mecanismos repressivos e da censura no final da década de 70 . Esse desapontamento, ampla-

29 BENJAMIN, Walter. O narrador. Considerações sobre a obra de Nicolas Leskov. In: Magia e técnica, arte e política. Tradução de Sérgio Paulo Rouanet. São Paulo: Brasiliense, $\overline{1987 . ~ p}$. 197-221. (Obras escolhidas, v. 1).

30 LIMA, Mariângela Alves de. O caos é muito grande. Revista Ensaio Teatro, Rio de Janeiro, p. 7-12, 1983 
mente referido (Yan Michaski, Sábato Magaldi, Guzik e outros), relacionava-se à frustração da expectativa de que, com o fim da vigência do Ato Institucional - AI-5 e com uma retomada (ainda que muito parcial) de certa liberdade de expressão na fase final da ditadura militar, viessem à luz numerosos textos dramáticos construídos a partir de perspectivas formais e políticas variadas, mas tendo sempre uma capacidade de debater as questões político-sociais ou de corresponder aos amplos anseios de discussão acumulados nos anos anteriores e reprimidos pelo poder ditatorial no Brasil.

Ao tratar da situação de certos dramaturgos nos anos 70 e início dos 80, Yan Michaski cunhou a expressão premiados inéditos para se referir a autores que eram reiteradamente premiados em concursos de dramaturgia do extinto Serviço Nacional de Teatro e que não eram encenados (como Wilson Sayão), seja porque a montagem de seus textos era impedida pela censura, seja porque eles não eram absorvidos pelo mercado teatral. Os diretores mais experientes priorizavam outras temáticas, distintas das abordadas nas obras desses autores premiados ou preferiam peças de mais fácil sucesso junto ao público. Já as equipes mais jovens estavam envolvidas em processos como os da criação coletiva e se mostravam ansiosas por falarem de seu cotidiano e das questões que surgiam no seio da sua convivência artística ${ }^{31}$.

A expectativa de que o teatro revelasse, com o fim da ditadura, a força de uma dramaturgia até então reprimida era alimentada, por um lado, pelo conhecimento da enorme quantidade de peças que eram escritas e que reiteradamente eram impedidas de serem encenadas durante o período mais duro da ditadura militar. Por outro lado, o aparecimento de autores de grande vigor no começo do período repressivo - como Leilah Assumpção, Isabel Câmara, Consuelo de Castro, José Vicente, Antônio Bivar e outros - levava a crer que a capacidade de produção no campo da dramaturgia tinha tudo, uma vez desmantelados os mecanismos da repressão e da censura, para gerar um verdadeiro boom, que, entretanto, não se verificou na prática, quando o rigor do aparato autoritário da ditadura começou a se atenuar.

A análise que Mariângela Alves de Lima empreende começa por colocar em questão o conceito de obra no teatro.

Autores e teóricos pensam o texto dramático como alguma coisa a que a encenação dá vida, reinterpreta e amplia. Entretanto, como obra do autor, ele já está completo. A encenação seria o afluente dessa sobredeterminação ${ }^{32}$.

Referindo-se ao período da ditadura e ao momento em que se enseja a abertura gradual da vida política, momento no interior do qual escreve seu artigo da Revista Ensaio Teatro, Mariângela afirma ainda que:

Durante todos esses anos foi impossível para o dramaturgo expressar com clareza as opiniões e as deliberações de consciência sobre o que percebia. Agora é igualmente

${ }_{31}$ MICHALSKI, Yan. Uma categoria paradoxal: os premiados inéditos. Revista Ensaio Teatro, Rio de Janeiro, p. 21-30, 1983.

${ }^{32}$ LIMA, 1983, p. 8. 
difícil compreender-se dentro de um processo cultural que deliberadamente rejeita a autoridade da consciência. Aparentemente o cotidiano se encarrega de provar a desimportância do discurso para organizar qualquer forma de resistência ${ }^{33}$.

Mariângela aqui está fazendo uma menção direta à sensação contemporânea de impossibilidade (por meio de narrativas ordenadas e causais) de sintetizar-se ou de explicar-se (mesmo metaforicamente) a complexidade do mundo social e histórico em que se vive ${ }^{34}$. A sustentação de discursos de ordenamento e de explicação pressupõe, de fato, a existência de horizontes compartilhados como, por exemplo, os de identidade de classe ou de aversão ao autoritarismo político. Como Mariângela explica, os elos que eram favorecidos durante a ditadura tornavam viável a identificação do espectador com todo tipo de personagem rebelde ou marginal, com todo tipo de discurso metafórico da "loucura", selando uma espécie de pacto que envolvia dramaturgos, criadores da cena e receptores.

O que a autora indica é que, no novo contexto dos anos 80 (com o início da diluição da imagem de um inimigo comum), a autoridade da consciência discursivamente organizada, assim como o peso da voz autoral (entendido o autor como sujeito capaz de expressar um sentimento coletivo ou comunitário) perdem o alcance que tiveram na cultura ou no teatro brasileiro nos anos imediatamente anteriores. Agora, nem o engajamento de personagens de peças políticas do início dos anos 60 e nem os desbundados, loucos ou marginais que figuram em textos afinados à contracultura ou à tropicália nos anos 70 dão conta de mobilizar o interesse da platéia. Interesse esse que o teatro, entretanto, angariou amplamente em momentos anteriores (em que a imprensa estava calada, a universidade reprimida e todos os meios de comunicação extremamente controlados).

Podemos, assim, dizer que, nesse contexto, foi bastante viável a continuidade não problemática de certa concepção moderna do espetáculo teatral canonizada no ocidente $^{35}$. Concepção essa que compreende o espetáculo como uma produção que reúne artistas distintos, que se dispõem a fazer ressoar o discurso de uma obra determinada escrita por um autor e coletivamente assimilada pelo elenco e pelos criadores da cena (cenógrafos, iluminadores etc.), sob a liderança ou a regência do encenador. Com efeito, o centramento e a unificação do sentido teatral, como projeto intencional ou deliberado, datam do início do teatro moderno e da afirmação da encenação como linguagem artística, no final do século XIX e nas primeiras décadas do século XX. Podemos, com Mariângela Alves de Lima, afirmar que o mesmo projeto de centramento e de unificação do sentido foram a base da resistência no teatro brasileiro dos anos 60 e 70, tanto da resistência inspirada por um pensamento materialista de esquerda (mais diretamente reprimida), quanto daquela de caráter contracultural (conectada com o que

33 LIMA, 1983, p. 9.

34 Mariângela não se refere a Jean-François Lyotard, mas sua reflexão tem evidentes pontos de conexão com o livro já clássico que Lyotard publica na França em 1979, praticamente no mesmo momento em que a pesquisadora estava escrevendo seu ensaio, produzido em 1980. Lyotard, como é sabido, discorre sobre o contexto cultural do pós-modernismo como sendo o do naufrágio do que chama de as grandes meta-narrativas da modernidade e de sua autoridade para fornecerem explicações e ordenamentos conceituais definitivos sobre o real. LYOTARD, Jean-François. O pós-moderno. Rio de Janeiro: J. Olimpio, 1986. 123 p.

${ }_{35}$ Em uma orientação realista-naturalista (Stanislavski, Antoine) ou com inspiração simbolista (Jacques Copeau). 
ficou conhecido no Brasil como o tropicalismo e a marginália, que também sofreram os constrangimentos da censura e do governo militar).

Para concluir, gostaria ainda de recorrer brevemente a um texto em que Flora Süssekind analisa o trabalho teatral de Gerald Thomas e o de Bia Lessa ${ }^{36}$, destacando em especial um modo complexo de figuração do tempo e uma ênfase na voz narrativa ou na instância organizadora do discurso cênico-dramatúrgico nos espetáculos dos dois encenadores. Para a autora, um dos elementos mais significativos na construção das peças de Bia Lessa e de Gerald Thomas diz respeito à convivência ou à interação entre tempos distintos na estrutura de cada espetáculo. Exemplo dessa imagem de um tempo múltiplo ou bipartido é dado pelas duas Elas, personagens de The flash and crash days, de Thomas. As duas Elas foram interpretadas por atrizes bastante conhecidas, que são mãe e filha - Fernanda Montenegro e Fernanda Torres - e que representavam ficcionalmente as relações de poder e os conflitos geracionais de uma mãe e uma filha.

No que diz respeito à voz narrativa - ou àquilo a que no título do ensaio a autora designa como a "imaginação monológica" -, o texto se refere aos vários modos de auto-representação ficcionalizada dos dois encenadores no interior de seus espetáculos. Um desses modos de auto-representação dos organizadores do discurso são as vozes off, que podem ser ou não as dos próprios encenadores (no caso de Thomas a utilização de sua voz em off é, como se sabe, freqüente) referencialmente associadas aos criadores das peças. As personagens também podem ser meras representações mais ou menos episódicas e irônicas do sujeito enunciador do discurso teatral. É nessa condição que as duas Elas de The flash and crash days são vistas pela ensaísta.

Esses modos de auto-representação da voz ou da instância organizadora do discurso são submetidos, entretanto, a procedimentos diversos de divisão (como é o caso das duas Elas), de auto-ironia e de desautorização. Assim, a ênfase em um sujeito do discurso que preside, de algum modo, ao que se vê e ao que se ouve no espaço da cena, colabora, conforme o raciocínio da ensaísta, para atenuação paradoxal da unidade e da centralidade desse sujeito. Retira-se da voz qualquer função de autolegitimação e de autorização dos conteúdos discursivos possivelmente veiculados. De fato, podemos dizer a respeito dos espetáculos dos dois criadores que tudo o que aparece neles e tudo que é dito ali pode ser igualmente verdadeiro ou falso, pois se associa a um sujeito que pode dizer indiferentemente a verdade ou a mentira, estar brincando ou falando sério, sem oferecer nunca quaisquer garantias de legitimidade confiáveis.

O núcleo reflexivo da leitura realizada por Flora Süssekind constitui-se pelo tema da impossibilidade contemporânea de reconstituição narrativa segura do mundo como objeto, tema que se associa ao da fragmentação do sujeito individual e de sua auto-

\footnotetext{
${ }^{36}$ SÜSSEKIND, Flora. A voz e a série. Rio de Janeiro: Sette Letras; Belo Horizonte: UFMG, 1998. 297 p. Publicado originalmente no mesmo número da Revista da USP em que apareceram os ensaios de Tânia Brandão, Alberto Guzik Sábato Magaldi e Sílvia Fernandes, anteriormente mencionados (SÜSSEKIND, Flora. A imaginação monológica. Revista da USP, São Paulo, n. 14, p. 43-49, jun./ago. 1992), o ensaio de Flora passou a ser referência importante nos estudos voltados para o teatro contemporâneo, como, por exemplo, os de Renato Cohen e de Luiz Fernando Ramos, além da própria Sílvia Fernandes. O texto aparece também em Um encenador de si mesmo: Gerald Thomas (FERNANDES; GUINSBURG, 1996).
} 
-imagem como fonte de um saber racionalmente sustentado e sustentável. Creio que por trás de várias das análises do teatro contemporâneo mais ou menos centradas em dicotomias hierarquizadoras como "teatro de texto" versus "teatro visual" ou "teatro do ator" versus "teatro da imagem" revelam-se as dificuldades de se confrontar (sem pura negação ou ânsia de retorno a uma estabilidade perdida) com o problema crucial que é o das derivas ou do nomadismo do sentido no teatro e na arte contemporânea. É para a necessidade dessa reflexão que apontam certos posicionamentos como os de Flora Süssekind e de outros dos críticos aqui comentados, a exemplo de Mariângela Alves de Lima, no seu texto do início dos anos 80. 


\section{REFERÊNCIAS}

ABREU, Luís Alberto. A personagem contemporânea: uma hipótese. Sala Preta: Revista de Artes Cênicas, São Paulo, ano 1, n. 1, p. 61-68, 2001.

ABREU, Luiz Alberto. A restauração da narrativa. O Percevejo: Revista de Teatro, Crítica e Estética, Rio de Janeiro, ano 8, n. 9, p. 115-125, 2000.

BENJAMIN, Walter. O narrador. Considerações sobre a obra de Nicolas Leskov. In: . Magia e técnica, arte e política. Tradução de Sérgio Paulo Rouanet. São Paulo: Brasiliense, 1987. p. 197-221. (Obras escolhidas, v. 1).

BRANDÃO, Tânia. A estática da palavra. Revista Ensaio Teatro, Rio de Janeiro, p. 13-20, 1983.

BRANDÃO, Tânia. A máquina de repetir e a fábrica de estrelas: Teatro dos Sete. Rio de Janeiro: 7 Letras, 2002.

BRANDÃO, Tânia. Ora direis ouvir estrelas: historiografia e história do teatro brasileiro. Sala Preta: Revista de Artes Cênicas, São Paulo, ano 1, n. 1, p. 169-217, 2001 a.

BRANDÃO, Tânia. Peripécias modernas: Companhia Maria Della Costa (1948-1974). 1998. 2v. Tese (Doutorado) - Instituto de Filosofia e Ciência Sociais, Universidade Federal do Rio de Janeiro, Rio de Janeiro, 1998. Não publicada.

BRANDÃO, Tânia. O teatro brasileiro do século 20. Revista do IPHAN, Brasília, DF, n. 29 , p. 300-335, 2001b.

BRANDÃO, Tânia. Visionários ou alienados. Revista da USP, São Paulo, n. 14, p. 28-33, jun./ago. 1992.

FERNANDES, Sílvia. O espectador emancipado. Revista da USP, São Paulo, n. 14, p. 7073, jun./ago. 1992.

FERNANDES, Sílvia. Grupos teatrais: anos 70. São Paulo: UNICAMP, 2000a.

FERNANDES, Sílvia. Memória e invenção: Gerald Thomas em cena. São Paulo: Perspectiva, 1996.

FERNANDES, Sílvia. Notas sobre dramaturgia contemporânea. O Percevejo: Revista de Teatro, Crítica e Estética, Rio de Janeiro, ano 8, n. 9, p. 25-38, 2000 b.

FERNANDES, Sílvia; GUINSBURG, Jacó (Org.). Um encenador de si mesmo: Gerald Thomas. São Paulo: Perspectiva, 1996. 
GUINSBURG, Jacó. Diálogos sobre teatro. Organização de Armando Sérgio da Silva. São Paulo: Edusp, 1992a.

GUINSBURG, Jacó. O lugar do teatro no contexto da comunicação de massa. Revista da USP, São Paulo, n. 14, p. 92-96, jun./ago. 1992b.

GUINSBURG, Jacó. Texto ou pretexto. Sala Preta: Revista de Artes Cênicas, São Paulo, ano 1, n. 1, p. 87-88, 2001.

GUZIK, Alberto. Um exercício de memória: dramaturgia brasileira anos 80. Revista da USP, São Paulo, n. 14, p. 10-15, jun./ago. 1992.

HELIODORA, Bárbara. Cuidados e carinhos com Clarice. O Globo, Rio de Janeiro, 4 dez. 2002. Segundo Caderno, p. 4.

LIMA, Mariângela Alves de. O caos é muito grande. Revista Ensaio Teatro, Rio de Janeiro, p. 7-12, 1983.

LIMA, Mariângela Alves de. Tendências atuais do teatro. Revista da USP, São Paulo, n. 14, p. 16-21, jun./ago. 1992.

LYOTARD, Jean-François. O pós-moderno. Rio de Janeiro: J. Olimpio, 1986.

MAGALDI, Onde está o teatro. Revista da USP, São Paulo, n. 14, p. 6-9, jun./ago. 1992.

MICHALSKI, Yan. Uma categoria paradoxal: os premiados inéditos. Revista Ensaio Teatro. Rio de Janeiro, p. 21-30, 1983.

NESTROVSKI, Arthur (Org.). Trilogia bíblica: teatro da vertigem. São Paulo: Publifolha, 2002.

PAVIS, Patrice. Le théâtre au croisement des cultures. Paris: Librairie José Corti, 1990. p. 229

PAVIS, Patrice. Vers une théorie de la pratique théâtrale: voix et images de la scène. Septentrion: Presses universitaires de Septentrion, 2000.

SÁ, Nelson de. Divers/Idade: um guia para o teatro dos anos 90. São Paulo: Hucitec, 1997.

SÜSSEKIND, Flora. A imaginação monológica. Revista da USP, São Paulo, n. 14, p. 43-49, jun./ago. 1992

SÜSSEKIND, Flora. A voz e a série. Rio de Janeiro: Sette Letras; Belo Horizonte: UFMG, 1998. 


\section{O TEATRO NA TERCEIRA IDADE}

José Luiz Ribeiro

A sociedade contemporânea, fragmentada e especializada, gerou um novo segmento do fazer teatral: o grupo da terceira idade. Aparecendo como uma faixa de consumidor ideal, esse segmento encontrou no teatro um motivo de satisfação. No outono, as folhas caem, porém esta preparação para o inverno é um estágio que, com o passar das estações, apresenta um movimento de eterno retorno. É justamente nesse desprendimento que vamos encontrar, na terceira idade, a oportunidade de um reencontro com desejos íntimos.

Uma larga faixa de opções é estendida ao antigo "ancião". Um verdadeiro supermercado de produtos surge estimulando tanto as ações físicas como os cuidados com a saúde, com a higiene corporal e mental. Turmas especiais de aulas de dança de salão, grupos de viagem, bingos beneficentes, ou não, cursos de atualização e aulas de computação lhes são oferecidos.

Percebendo esse vigor, várias empresas, de olho na potencialidade econômica dessa faixa de mercado, começam a contratar atores idosos para criar uma imagem simpática de velhinhos incríveis que anunciam viagens, esportes radicais, aconselham planos de saúde maravilhosos e uma infinidade de produtos dirigidos ao bem-estar do idoso.

Dentro dessa gama de ofertas, o teatro se apresenta como uma atividade saudável que amplia a potencialidade da qualidade de vida, restaura o fazer da cidadania e alimenta o campo emocional com atividades físicas, ações emotivas, desenvolvimento da personalidade e exercício da memória. Assim, o preparo do profissional que se dedica ao trabalho com a terceira idade necessita de juntar conhecimentos cênicos, um certo lastro de saberes e uma prática de valores humanos.

\section{Por que fazer teatro na terceira idade?}

A cada atividade que se realiza buscando o fazer teatral, é necessário um mapeamento do público-alvo. Não apenas levando em conta a idade, mas o nível socioeconômico, a procedência regional e os hábitos de entretenimento. O lastro memorial é de grande importância para se definir objetos e objetivos.

O teatro para a faixa de terceira idade tem uma força muito grande no imaginário da memória coletiva. A força do rádio e o mito de atores que percorriam 
o interior em apresentações mambembes integram-se à cultura popular. Os melodramas apresentados como complemento de funções circenses, acrescentam-se também a esse patrimônio.

No interior, companhias itinerantes levavam atores como Procópio Ferreira, Dulcina, Henriette Morineau, Jaime Costa, Rodolfo Mayer, dentre outros, para apresentações que marcavam o evento dos jovens de outrora. O teatro foi, para essa geração, um encontro com a emoção, com o riso e com histórias que caracterizavam ou se acrescentavam ao universo cultural local do brasileiro.

Existe, ainda, um resquício do teatro escolar. A glória de um talento abortado pela vida fica reprimida como um sonho irrealizado. A recuperação de momentos felizes são os principais instrumentos que proporcionam, aos grupos de terceira idade, o encontro de motivações para buscar no teatro um momento de realização pessoal.

Muitos dos que procuram um grupo de apoio encontram aí uma forma de sociabilização que supre carências afetivas, devolve a segurança perdida e possibilita a criação de novo círculo de amizades. Recuperando a voz, abafada pelo cotidiano de tarefas domésticas ou burocráticas desenvolvidas mecanicamente, eles buscam, na atividade teatral, uma forma de rever conceitos e assumir novas atitudes. A magia, o jogo e o poder de transformação são caminhos a percorrer.

\section{A identidade do grupo}

O teatro é uma arte de contágio. Realizando-se a partir da inclusão dos atores num jogo em que a platéia atua como parceira, necessita de um preparo de inclusão social para atingir seus objetivos. O primeiro passo é o da identificação dos componentes de um grupo. Esse princípio básico, que caracteriza qualquer metodologia do fazer teatral, é necessário em grupos diversos, mas exige um cuidado especial quando se trata de um grupo de terceira idade.

Estabelecer parcerias é um bom passo para sua formação, e isso vai ser feito através da fixação das regras do jogo. A construção do ator ativa o afloramento das alteridades. Um grupo de terceira idade possui muitas certezas e opiniões solidificadas, e para eliminar os conflitos deve-se aparar as arestas, evitar desentendimentos ou incentivar a evasão de individualismos aflorados durante essa nova experiência de resgate identitário. $\mathrm{O}$ encontro de motivações comuns estabelece os objetivos para o mapeamento do grupo.

O primeiro encontro é cerimonioso. As apresentações tornam-se necessárias para enfrentar os dois instintos básicos: o de platéia e o de representação. O jogo tem início com um seminário de revelações pessoais. Cada participante, mostrando-se, torna-se um ator de si mesmo, vivendo uma personalidade delineada pelos interditos e cuidadosamente dosada.

Nesse primeiro encontro é necessário perceber a divisão dos caracteres, das posturas e da forma de exposição. É comum que pessoas de terceira idade, extremamente tímidas, procurem fazer parte de um grupo de teatro como forma de vencer esse traço incômodo de personalidade. O teatro é uma forma de dar voz a esses incluídos. Mas o embate com outros membros, extrovertidos e falantes, gera o primeiro estremecimento, mas também a fresta do entendimento. Para se 
equilibrar através dessas primeiras revelações, passamos para o entrosamento das identidades variadas.

\section{Jogos de outono}

O teatro é um ato de comunicação estética e natureza lúdica. $\mathrm{O}$ jogo busca libertar o homem de suas tensões cotidianas e isso acontece na representação. $O$ primeiro estágio para conseguir a integração do grupo é deixar claro que a coletividade solidária é a principal regra desse jogo. Não é difícil para uma pessoa madura percorrer caminhos de volta através da rememoração. Para vencer a inibição dos primeiros instantes, gerada pela postura de observador crítico, muitas vezes tímido, podemos recorrer às apresentações protocolares.

O primeiro jogo se organiza quando o grupo se despersonaliza para se contar individualmente. Pedimos aos participantes que falem de si como se fosse de um outro. Conta-se, então, uma história na terceira pessoa. Ao eliminar o eu, transformado em ele ou ela, inicia-se a narrativa de fatos cotidianos.

A edição de uma vida, buscando fatos marcantes a partir dos insignificantes, permite uma diagnose de máscaras sociais. Rever a vida para o idoso é como percorrer o mito de Fausto, um julgamento de perdas e danos. É recontar fatos encadeados de forma emocionada, despertando empatias, risos e lágrimas.

Os primeiros encontros decantam as personalidades e manifestam comportamentos. O grande impacto está, agora, na organização de uma comunidade dotada de massa crítica. O jogo teatral terá grande importância para formar essa comunidade, criando objetivos que serão alcançados e dificuldades que serão vencidas.

A cada passo dessas apresentações distanciadas encontramos a quebra do gelo inicial. Revelações sempre geram interesse para uma comunidade que pretende tornar-se um grupo teatral. Contar e recontar é uma forma de ritualizar bons e maus momentos.

\section{Riso com muito siso}

Um grupo que se reúne para fazer teatro na terceira idade busca o prazer. Mas a alegria de participar de um espetáculo inclui também um investimento no método. É importante que se trace uma linha de objetivos a serem alcançados: que tipo de espetáculo que se quer produzir, qual o trabalho a ser desenvolvido e a potencialidade de crescimento do elenco.

A ética será o principal caminho a percorrer. A disciplina dos encontros deve ser mantida ferreamente e cada participante conscientizado de que um grupo que se forma para fazer teatro deve ter plena consciência de que, como nos diz Pirandello, em Seis personagens à procura de um autor, "o palco é um lugar onde se brinca a sério". As normas de comportamento precisam ter linhas preestabelecidas quanto à pontualidade e a assiduidade de cada participante.

Um dos grandes empecilhos para a atividade da terceira idade está no processo de vitimização. Como nos afirma a sabedoria popular, "O diabo é sábio porque é velho" e por isso não podemos nos esquecer de que existem alguns comporta-

\footnotetext{
${ }^{1}$ PIRANDELLO, Luigi. Seis personagens à procura de um autor. São Paulo: Abril, 1977. p. 134.
} 
mentos que escamoteiam a verdade diante do grupo. O idoso, por tradição social, é encarregado pela família de cumprir tarefas "por amor": ficar com os netos ou buscá-los na escola; somando-se a isso ainda tem a série interminável de exames e consultas médicas nos horários dos ensaios.

Há que se exigir o "arrebatamento dos jogadores para se chegar à imaginação criadora" 2 . Ao integrar um grupo teatral, deve-se ter um compromisso com o "sacro ofício" e doar-se de forma integral ao empreendimento: respeitar o ingresso no tempo mítico do teatro de forma ortodoxa. $O$ jogo teatral tem suas regras e, para que aconteça, é preciso que sejam respeitadas. Cada participante será seu fiscal e deverá zelar para que a ordem reine soberana em busca da concretude dos objetivos.

\section{Movimentos dialógicos}

As atividades tribais incluem sempre um rito. Um grupo deve, aos poucos, criar nos ritos o fator de integração. Para isso é importante notar que cada indivíduo traz dentro de si um campo de experiências vividas. Essa formação envolve uma filosofia vivencial, cadenciada pela sociedade e pelo campo de aspiração que dimensiona carências e sonhos. Diante desses fatores, um grupo de terceira idade busca acertar as contas com a vida. A busca do lucro, depois de tantas pequenas perdas, é um instrumento de sobrevivência. O conflito social, que alijou o velho do poder familiar, elegeu novas estratégias para recomposição do estar no mundo de um grupo que se nega à imobilidade dos condenados à morte.

Assim, detectar os campos de experiência comum a cada participante importa em criar um lastro não só para a vivência teatral, mas também para a preservação identitária das nações, possibilitando a presença da diversidade em convivência com o global. Ao estabelecer tópicos para a discussão, pode-se criar um vasto arsenal de reminiscências. O encadeamento destas memórias vai despertar momentos de recuo temporal em que as lembranças atuam na esfera da memória afetiva exorcizando antigos recalques.

Buscar respostas em sentimentos vividos vai permitir o desenvolvimento da atuação dramática acordando a memória de emoção tão praticada pela herança do Método Stanislavski. Reviver é viver de forma crítica, assim como rever é ver com outros olhos. Nas raízes da espontaneidade vamos encontrar um processo de ações e reações que motivam o jogo dramático, conferindo certa "verdade cênica" ao trabalho. Esse modelo de representação, que busca convencer a si mesmo de suas potencialidades, é a primeira resposta a ser procurada para uma atuação segura.

\section{As ações corpóreas}

A fisiologia de um grupo de idosos é variável. Qualquer um que pretenda fazer parte da atividade teatral é movido por um vigor adolescente. Ao encontrar identificação, as relações tornam-se afetivas. Rapidamente passamos a deixar de lado o protocolo para, através de atividades dirigidas, eliminarmos conceitos e preconceitos.

2 HUIZINGA, Johan. Homo Ludens: o jogo como elemento da cultura. São Paulo: Perspectiva,1971. p. 20. 
Recorrer aos folguedos populares é um bom princípio. Cirandas, cantigas de trabalho ou modinhas são importantes por dois motivos: o primeiro é o reencontro com a infância, com as lembranças de brincadeiras infantis; o segundo é a formação de um repertório de atos vividos em passado não muito próximo, mas que a sabedoria da natureza se encarrega de privilegiar na memória.

As rodas de energia são um bom começo para vencer a barreira do contato físico. Iniciando com apertos de mão e terminando com abraços calorosos, o grupo começa por se tocar, vencendo barreiras culturais e étnicas. A dinâmica do corpo é importante para recuperar eixos e posturas.

O uso de música, aliado a exercícios respiratórios, pode permitir, nos jogos de leveza, um momento de descontração com balões que flutuam a um suave toque. A busca do movimento e a harmonização do gesto podem ser conseguidas e utilizadas como instrumentos para os jogos de integração.

O lúdico deve ser adotado. Músicas folclóricas ou de raízes populares são, então, utilizadas como marcação rítmica em que as palmas criam a relação grupal, através da mecânica rítmica. Dessas manifestações surgem risos pelos erros cometidos e estaremos preparados para o próximo passo: os exercícios de alongamento, deslocamentos com a utilização de relaxamento e tensão. Cantar e se movimentar é uma etapa importante para elaborar a planilha de atividades para a terceira idade.

\section{Passos e compassos}

A idade faz com que o ser humano perca, aos poucos, a intensidade do exercício de seus sentidos. O treinamento da atenção é um princípio básico para a recuperação dessas atividades. E como motivação, o teatro fornece muitos impulsos para que as pessoas recuperem, de forma lúdica, qualidades para uma boa atuação: saber ouvir para melhor responder.

A dança é o primeiro passo do treinamento. Recordar o tempo em que dançar reproduzia normas comportamentais entre damas e cavaleiros, em que a dança de salão era organizada em direção às relações prazerosas do lazer, sem as exigências performáticas imprimidas pelos modernos cursos do gênero, onde os pares se enlaçam com a matemática dos volteios exibicionistas, é uma tarefa divertida.

Ao se tocar na dança, ao acertar os passos, temos o início de uma atividade corporal que se automatiza impulsionada pelo ritmo. A atenção passa a fazer parte dos exercícios, criando espírito crítico diante de acertos e erros. A preocupação com os passos e a execução das propostas consegue um aprimoramento para futuras execuções de marcas coreográficas.

Das lembranças dos antigos bailes, passamos a exercícios mais elaborados com jogos dramáticos incentivando a atenção rumo à execução de coreografias grupais. Passos coreografados, ou criados pelo grupo, podem sofrer alterações e encadeamentos gerando formas diferentes de treinamento.

Temos, agora, um grupo que canta, dança e executa marcas coreográficas. Cada acerto é gratificado com a alegria de ter vencido mais uma etapa e se cada erro é mostrado como uma nova dificuldade a ser vencida, os acertos são vitórias comemoradas e que imprimem segurança a cada participante e afirmação no grupo. A integração se dá através da dinâmica corporal. 


\section{Do cantar ao falar}

A intercessão do teatro com literatura confere ao texto uma importância documental. Se o texto é a semente do espetáculo, sua interpretação é a forma de torná-lo vivo e próximo ao tempo em que vivemos. Dizer um texto confere ao intérprete uma responsabilidade que necessita de treinamento e abertura dos poros sensíveis.

Para o ator de terceira idade o contato com a literatura se fez, muitas vezes, nos bancos da escola. Talvez essa seja uma das grandes dificuldades para quem se propõe a fazer teatro na terceira idade. É preciso demonstrar, em primeiro lugar, que falar de cor é falar de coração. O rumor da língua envolve uma musicalidade conferida pela retórica.

Durante muito tempo, a declamação possuía um maneirismo, como quando o teatro brasileiro, relembrando Bandeira, de "Recife", "macaqueava a sintaxe lusíada”. Para o ator de terceira idade a declamação com trinados na voz ainda é o modelo. A primeira dificuldade é aproximar este aspirante a ator de um discurso coloquial contemporâneo. Tornar a fala natural, mas sensível e colorida, torna-se outro desafio a vencer.

A invenção da dimensão simbólica e a musicalidade da entonação tornam-se um bom mote para o exercício nas leituras de mesa, com entendimento prévio das intenções das falas. Dependendo do nível de escolaridade do grupo, esta fase deve merecer cuidado especial. Partir da poesia lírica, interpretar crônicas, passar por contos e textos dialogados são itinerários a percorrer.

É necessário criar uma noção do ritmo da frase em prosa. Perceber a pontuação como sinalização de intenções, as pausas respiratórias, buscar intenções nas palavras é saber usar sua força. A musicalidade da fala permite traçar imagens na mente dos espectadores. Entender, falar e convencer são passos para que um ator viabilize a sua interpretação. Libertar-se da leitura mecânica, fixa e sem colorido é a meta a atingir.

\section{O drama do esquecimento}

A questão da memorização talvez seja o maior pesadelo para um grupo de terceira idade que começa a fazer teatro. A preocupação com palavras deve ser, de imediato, substituída pela lógica de ação, através do exercício criativo de sucessão de imagens. A dispersão da atenção, gerada pela preocupação em reter automaticamente o texto, deve ser combatida.

O homem pensa por imagens. Associá-las é um bom exercício para a memorização das falas. Mas o mais importante, quando se trata de um texto dialogado, é saber ouvir como personagem. Dividir cada réplica de maneira minuciosa e proceder ao estudo das intenções da personagem, aliado à diagnose do papel, poderá fazer nascer grandes discussões sobre o procedimento de cada papel conforme a configuração da personalidade a ser representada.

A fixação de palavras-chave que determinam a ação propositiva de cada fala pode resultar em uma reelaboração textual. A palavra torna-se, então, marca para o treinamento mnemônico. A absorção da qualificação como primeiridade do signo poderá fornecer o desenvolvimento orgânico da interpretação. Esse procedimento vai eliminar a fala dura, sem colorido e artificial. 
Certamente o idioleto do ator é um fator de predominância quando tratamos de um grupo que pretende montar um espetáculo. As características pessoais devem ser aproveitadas no momento da distribuição dos papéis, mas um bom exercício de aprimoramento é também a imitação, pelos membros do elenco, dos idioletos grupais mais marcantes. Nesse jogo de divertimento, cria-se o distanciamento que, através do riso, possibilita a improvisação. A resposta rápida e o estado de prontidão poderão levar um bom rendimento ao desempenho dos atores e vencer problemas da memória.

\section{$\mathrm{O}$ ator médium}

A criação da personagem no grupo de terceira idade passa por um processo de transferência de vivências. Um segundo momento é o de alertá-lo sobre a diferença entre palco e vida. Muitas vezes a escalação do papel pode ser prejudicada pelo narcisismo, que será vencido na medida em que nasça a consciência do fazer teatral.

$\mathrm{Um}$ ator re-apresenta o mundo. Em alguns casos é muito difícil convencer a um iniciante de terceira idade de que o papel que lhe foi atribuído não está ligado a sua vida pessoal. O convencimento de que teatro é um jogo é o primeiro estágio para vencer conflitos que perpassam os mais diversos grupos: o triunfo da vaidade.

O conflito entre o real e o imaginário percorre a história do teatro desde que Théspis, o primeiro ator, foi severamente advertido por Sólon. Para o ator de terceira idade, numa experiência amadora, o objetivo pessoal pode superar a humildade necessária ao aprendizado e aprimoramento. Existe um elemento que perturba a ordem espetacular: a existência da competição originada dentro do próprio grupo.

Entretanto, a competição natural, gerada pela vontade de participar, tem que ser colocada como um princípio de afirmação da alteridade. Para que isso aconteça é preciso fortalecer o sentimento de grupo e isso se faz diante do resultado final. A cumplicidade é um fator primordial a ser desenvolvido num grupo que se propõe a fazer teatro.

Viver a personagem não é ser a personagem. A consciência de um ator em ser médium sem, no entanto, perder o senso de representação nasce da utilização de saber ouvir para melhor responder. Essa sintonia só se dá quando ele amadurece sua criação. Esse passo é primordial num grupo maduro que procura ter voz ativa numa atividade artística. Ouvir para responder com lógica a cada situação é fazer aflorar a denúncia cidadã na sensibilidade e canalizar a expressão da atuação.

\section{A relação espetacular}

A rede expressiva da polifonia teatral é um fato. Conhecer as etapas da estrutura de produção de um espetáculo é respeitar o todo da criação artística e não abastardar qualquer fase de composição da mensagem espetacular. $\mathrm{O}$ respeito ao fazer teatral deve ser despertado no grupo para assegurar um bom produto final.

O mecanismo cênico move-se na instância grupal. A superposição das individualidades sobre o objetivo do grupo pode gerar desgastes relacionais que têm que ser resolvidos. Para isso, a clareza de objetivos, a solidariedade do jogador e a generosidade da doação são propostas a serem exercitadas a cada dia, num compromisso constante com a renovação dos valores da humanidade. 
Uma casa dividida, não se sustenta. Assim, cada ponto de apoio deverá ser contemplado, e o reconhecimento da importância de cada detalhe fazer parte do projeto comum. Isso vai possibilitar ao ator melhor desempenho no palco e no grupo. A percepção de que o cenário, o figurino, a luz, a música e a coreografia estão a serviço de uma causa comum amplia a qualificação do ator e sua consciência do fenômeno teatral.

Ao reconhecer o universo espetacular e identificar sua importância, o ator saberá entender que figurino é mais do que uma fantasia carnavalesca, que a cor utilizada nem sempre é a de sua preferência ou a que mais lhe favoreça esteticamente mas, com certeza, é a mais apropriada ao espetáculo. Aumentando o conhecimento, eliminamos a fogueira das vaidades.

O prazer da representação está no ato da transformação. As representações revestem-se de maior autenticidade quando o ator se liberta do real para atingir o universo dramático. O distanciamento, através do cômico, substitui a atração narcisista pela epifania do ator suporte e essência da criação dramática.

\section{Ritual de troca}

Depois do treino, chega a hora do jogo. A criação do espetáculo culmina no momento mágico da apresentação. Dividir com um público especial o seu trabalho é para este ator, também especial, que procura o teatro na terceira idade, um momento de afirmação social e familiar. Ao vencer a barreira que parecia instransponível, ao eliminar medos e temores chega à vitória final.

Se, como nos diz Mc Luhan, "a função da arte na sociedade tribal não é orientar a população para a novidade, mas fundi-la com o cosmo", a interligação entre o palco e a platéia cria um rito de celebração no qual se penetra como numa experiência catártica. Não existe nesta celebração lugar para a ratio, apenas o pathos triunfa, através da comunhão dos pertencentes.

Observa-se, então, o fenômeno da transfiguração, quando filhos, esposos e esposas descobrem um artista em suas famílias. O público amigável deixa o espaço da consciência crítica para ingressar na comunhão dionisíaca na qual, como nos fala Stanislavski:

[...] muitos sentimentos incomunicáveis superconscientes, invisíveis, que nem o equipamento físico mais perfeito pode transmitir. São passados diretamente de alma para alma. As pessoas comungam umas com as outras por meio de correntes interiores invisíveis, radiações de seu espírito, compulsão de sua vontade $[\ldots]^{4}$.

A grande caracterização do espetáculo de grupos de terceira idade está no seu público. Esse espectador tem como ponto referencial os laços afetivos. É um público que não vai apenas assistir a uma peça teatral, vai reverenciar um ente querido.

${ }^{3}$ McLUHAN, Marshall; WATSON, Wilfred. Do clichê ao arquétipo. Rio de Janeiro: Record, 1973. p. 208.

4 STANISLAVSKI, Constantin. A preparação do ator. Rio de Janeiro: Civilização Brasileira, 1964. p. 102. 
Tudo isso gera uma corrente de energia positiva através da atenção comprometida. A espera ansiosa pela entrada do representante familiar na apresentação e os aplausos encantados a cada cena, marcam o tempo mítico da festa que se instaura soberano na casa de espetáculos.

\section{Colhendo os frutos}

Eis o momento de listar os benefícios para o idoso que participa de um grupo teatral. O primeiro deles é a restauração de envolvimento num rito social dentro de uma cultura cada vez mais tecnológica e distanciadora do contato humano. Quanto maior a tecnologia, maior a necessidade de magia. E o teatro fornece o círculo mágico onde o ser se reestrutura numa ligação cosmogônica.

A relação social gera o respeito pela alteridade e nessa contrapartida o autoconhecimento passa a ser um ponto de desbloqueamento de preconceitos. A visão de mundo, sem sentimento de autopiedade, proporciona maior segurança para enfrentar a realidade. Desenvolve-se, a partir de então, a consciência cidadã plena de reivindicações.

O aprimoramento do discurso permite o uso de uma retórica segura que dialoga e defende pontos de vista; a saúde corporal é beneficiada pelos procedimentos de aquecimento, postura e reavaliação de potencialidades; a saúde mental desenvolve-se com treinamentos de atenção e memorização; a sensibilidade amplia-se com uma visão mais acurada do mundo sensorial. A realidade passa a ser vista de maneira mais racional: aprendem-se estratégias comunicativas que permitem abordagens de novas políticas sociais, culturais e educacionais.

E, por fim, encontramos um processo de reabastecimento da sensibilidade e da organização psicológica diante do mundo. Como num incêndio na floresta, em que os animais fogem juntos em busca de preservação, os idosos se juntam num mundo juvenilizado pela sociedade de consumo, mas mantêm sua identidade através valores preservados, mas renovados. A decantação do cotidiano reorganiza a tribo e a afirmação de identidade adquirida pelos atores da terceira idade é prova da existência daqueles que se recusam a capitular e se reinventam com nova máscara.

\section{Conclusão: a arte de empinar pipas}

O profissional que se destinar a desenvolver um trabalho teatral com um grupo de terceira idade deverá, antes de tudo, saber empinar pipas. Saber medir a força do vento, puxar a linha em pequenos arrancos e liberar, com segurança, para que a pipa voe mais alto.

Um grupo de terceira idade, ao contrário de um grupo jovem, organiza-se com um passado e um campo de aspirações próprio. Ao buscar uma atividade artística em que o suporte é o homem, o aspirante a ator tem desejos recônditos de reencontrar um sonho interditado, viver uma experiência juvenil ou rumar em direção a um mundo mágico desconhecido que o atrai.

Exige-se do condutor desta tribo uma grande dose de paciência, carisma e senso analítico capaz de criar novas estratégias diante de novas propostas. A carência que envolve o idoso o faz buscar um ouvinte atento e alguém que lhe dedique atenção e afetividade. Porém, é importante perceber que o avanço da humanidade se 
faz diante de novos desafios. Assim, seria interessante notar que só o temor constrói. Ele modifica o ser humano, cria novas estratégias e engendra novas soluções para velhos problemas.

Existe em grupos de idosos um comportamento juvenil. Há necessidade do riso, da festa e, em especial, a carência de comemorações de datas festivas. As celebrações rituais com pequenas lembranças, atividades de entretenimento, demonstraçóes de afeto fazem parte de qualquer grupo humano, mas em se tratando de um grupo que faz teatro isso é marcante.

O teatro é um instrumento de transformação social que permite, a quem o pratica, uma revisão constante de sua natureza e uma visão renovadora do mundo. Para quem se prepara para viver grandes emoções, ainda que tardiamente, o teatro é o portal do prazer, da festa e da alegria. 


\section{REFERÊNCIAS}

HUIZINGA, Johan. Homo Ludens: o jogo como elemento da cultura. São Paulo: Perspectiva, 1971.

McLUHAN, Marshall; WATSON, Wilfred. Do clichê ao arquétipo. Rio de Janeiro: Record, 1973.

PIRANDELLO, Luigi. Seis personagens à procura de um autor. São Paulo: Abril, 1977.

SOEIRO, Alfredo Correia. O instinto de platéia. Porto: Edições Afrontamento, 1990.

STANISLAVSKI, Constantin. A preparação do ator. Rio de Janeiro: Civilização Brasileira, 1964. 


\section{DA APROPRIAÇÃO ESTÉTICA DAS ANOMALIAS}

José Tonezzi

Refletir sobre o ensino do teatro e a formação do ator já se apresenta comumente como algo de extrema complexidade. $\mathrm{O}$ que dizer então sobre as condições dadas para esse debate num regime de exceção, como é o caso de atores ou candidatos a atores que apresentem algum tipo de disfunções, sejam elas de caráter físico, sensitivo ou neurológico? Assim, cumpre esclarecer que, embora o presente estudo tenha por objeto o trabalho cênico envolvendo anomalias, o envolvimento deve ocorrer no âmbito da competência estética, daí a importância de que a abordagem não considere projetos necessariamente concebidos para deficientes ou que tenham como premissa a participação deles.

Quando se destaca o termo apropriação estética se quer significar o apossar-se das disfunções pelo fazer artístico, de maneira a adequá-las e tornar a elas ou aos seus sintomas instrumentos para o exercício e a experiência estética, no caso, da arte do teatro. Assim, diferentemente de um caráter terapêutico ou pedagógico, o ensejo é pensar o procedimento artístico que desconsidere possíveis anormalidades como empecilho ou impedimento mas, ao contrário, perceba-os como matéria de efetiva criação e experiência estética, sendo correto afirmar que se trata de uma abordagem sobre a acepção cênica das disfunções. Mesmo assim, na parte final do texto, tenta-se uma referência mais específica ao ensino teatral nesse âmbito.

De início, vale uma breve alusão à própria evolução da cena ocorrida no século XX, quando o espetáculo teatral passa a ser tido cada vez mais como um objeto distinto e independente do texto dramático. Este, em geral valorizava a composição de personagens previamente concebidas, quase sempre requerendo e estimulando o trabalho de atores com biótipos semelhantes. As exceções ficavam por conta de eventuais personagens exóticos ou estereotipados, levados à cena pela camuflagem corporal e pela maquiagem desses mesmos atores. O que se pode afirmar é que, até então, as anomalias eram vistas comumente como bizarrices, admitidas apenas no seio de determinados espetáculos e atividades de entretenimento, como o circo, onde eram apreciadas como objeto de curiosidade.

Com a autonomia da cena em relação ao texto, novos procedimentos começam a ser percebidos, dentre os quais, uma criação com base na dinâmica e nas características corporais do artista. Essa transformação se dá de forma gradual e se mostra muito mais como estratégia necessária à sobrevivência e evolução de ambos, texto e cena, dando conta de uma nova realidade que parece impor-se ao papel 
desempenhado pelo próprio teatro. O desafio começa na complexidade cada vez maior com que o mundo e a vida moderna passam a se apresentar e, aos poucos, mesmo os mecanismos de um drama absoluto calcado em questões intersubjetivas dos personagens não darão conta das intricadas relações sociais modernas.

$\mathrm{O}$ aparecimento da performance ou body art, em princípio restrita às artes plásticas, logo influenciará nas diversas outras formas de expressão, dentre as quais o teatro. Surgida como resultado de manifestações artísticas ocorridas desde o final dos novecentos, a performance terá importância capital para a incorporação cênica das anomalias, já que nela são enfatizadas justamente a efemeridade e a falta de acabamento da produção. Novas alternativas serão simbolicamente detonadas e inéditas perspectivas serão abertas para a concepção do corpo como matéria significante, o que altera e desestabiliza as relações até então perenes entre a obra e o observador:

O processo comunicacional a nível corporal inclui pressupostos - os códigos culturais compartilhados - e seu valor ilocutório se estende além da zona de consciência do receptor: afeta núcleos profundos, sobretudo no caso de experiências traumáticas como as amputações ou a presença de corpos marcados, tatuados, feridos ${ }^{1}$.

O conceito ganha novos contornos e acaba incorporado por áreas diversas. Para o sociólogo Erving Goffman ${ }^{2}$, performance é toda atividade desenvolvida por um participante em dada ocasião que sirva para influenciar de alguma maneira outros participantes. Interessando-se pela estrutura da experiência individual em todos os momentos da vida social, ele ampliaria ao extremo a concepção para o termo ator, assim denominando todo e qualquer indivíduo a desempenhar "papéis/personagens" que seguem uma trama previamente estabelecida.

A partir dessa premissa, passa a ser possível perceber o elemento performático numa simples intervenção pública de algo inusitado, o que incute o status de performer sobretudo àqueles indivíduos que apresentem condições alteradas de expressão ou comportamento. Pode-se afirmar, inclusive, que as condições pré-estabelecidas de aparência ou conduta que o alçam do meio comum favorecem no indivíduo fora de padrão a criação de um estado de surpresa, muitas vezes só alcançável pelo ator não deficiente através de um efetivo trabalho de preparação. E é justamente o que se denota como surpreendente que, na performance, normalmente atrai o interesse e a conseqüente atenção do espectador:

[...] in order to attract and direct the spectator's attention, the performance must first manage to surprise or amaze; that is, the performance must put into effect disruptive or manipulative strategies which will unsettle the spectator's expectation both short and long term - and, in particular, her/his perceptive habits ${ }^{3}$.

\footnotetext{
${ }^{1}$ GLUSBERG, Jorge. A arte da performance. São Paulo: Perspectiva, 2003. p. 98.

${ }_{2}^{2}$ GOFFMAN, Erving. A representação do eu na vida cotidiana. Petrópolis: Vozes, 1996. p. 191-217.

${ }^{3}$ DE MARINIS, Mario. Dramaturgy of the Spectator. The Theatre Drama Review, New York, v. 31, n. 2 (T114), p. 100-114, Summer, 1987. Tradução nossa. "[...] a fim de atrair e dirigir a atenção do espectador, a performance deve antes conseguir surpreender ou assombrar; isto é, a performance deve fazer uso de estratégias manipuladoras ou destruidoras de maneira a perturbar a expectativa do espectador - ambas a curto e longo prazo - e, em particular, a sua percepção habitual”.
} 
Portanto, as reações e comportamentos previsíveis, inesperados ou mesmo inoportunos que as chamadas disfunções e distúrbios do corpo e da mente ocasionam passam a mostrar-se como fatores que, se eficientemente trabalhados, serão capazes de mobilizar a assistência e mover o exercício da cena. Isso faz com que diretores e dramaturgos se apercebam cada vez mais das anomalias, para extrair-lhes o que de mais performático eles possam ter.

A apropriação estética das condições e particularidades, em si, decorrentes das disfunções que acometem o indivíduo, poderá se dar tanto por parte dele próprio como ser ocasionada e estimulada por quem o orienta ou o dirige cenicamente. Ambos os casos, no entanto, estariam invariavelmente vinculados a uma experiência vivida e compartilhada, pressupondo uma relação de mútua confiabilidade, em que o sujeito esteja inserido num contexto de significação. Fala-se, então, em competência poética para a constituição da cena quando se mune tais pessoas de condições mínimas para que atuem e se desenvolvam. E isto, a partir de um maior ou menor conhecimento e apropriação dos elementos que compreendem a composição e a estruturação dramática.

\section{A experiência de Robert Wilson}

Sem dúvida, diversas iniciativas poderiam ser citadas no que tange ao uso cênico das disfunções, algumas até bem mais recentes, mas o processo de criação desenvolvido por Robert Wilson, sobretudo em seus trabalhos iniciais como diretor, permanece emblemático. É o que acaba, efetivamente, por determinar a própria trajetória de sua arte e abre um novo campo de visão para o teatro ocidental contemporâneo.

Atuando, na juventude, como arquiteto e interior designer, além de pintor, Wilson terá boa parte de sua obra no teatro realizada a partir do contato e cooperação com dois artistas deficientes: os meninos Raymond Andrews e Cristopher Knowles. Coincidentemente, as dificuldades de ambos incidem sobre a linguagem, já que o primeiro é surdo-mudo e o segundo, autista. E é justamente isto que chamaria a atenção do diretor, que vê nessas características a chance de exploração de novas possibilidades de expressão.

Na verdade, ele havia participado de trabalhos dessa natureza já na universidade onde, sob orientação da bailarina Byrd Hoffman, desenvolvia atividades teatrais com crianças cérebro-lesadas. Esse contato, ao que parece, além de ajudá-lo a superar um problema de fala de infância, permitiu-lhe o acesso a uma série de exercícios por ela criados com base nos primeiros estágios da atividade física, cujo intuito seria ativar determinadas células cerebrais daquelas crianças. Neste sentido, Galizia é enfático: "O contato de Wilson com a Sra. Hoffman estimulou seu interesse por terapia com surdos, retardados, autistas, senis e deficientes; porém, mais do que isso, abriu para ele as portas de uma nova visão das artes teatrais"”.

Assim, uma das maiores características de Wilson será justamente sua visão não autoritária do processo criativo. Ao buscar uma forma de acesso ao universo pessoal e ao imaginário, ele está muito mais interessado em aproveitar a expressão

${ }^{4}$ GALIZIA, Luiz Roberto. Os processos criativos de Robert Wilson. São Paulo: Perspectiva, 1986. p. XXI-XXII. 
de cada indivíduo de maneira particular. Ao contrário de um processo tradicional de criação, em que uma nova estrutura de linguagem é normalmente aprendida, o seu performer deve na verdade familiarizar-se e aprofundar o seu próprio vocabulário.

Em Nova Iorque, ele forma e dirige uma companhia que denomina Byrd Hoffman School of Byrds, numa homenagem a sua antiga professora. Todos, exceto um dos integrantes do grupo, eram amadores sendo que alguns, inclusive, foram tirados da rua por Wilson. O trabalho deles, conseqüentemente, era livre de modelos pré-estabelecidos, apresentando modos de comportamento e tipos de fala bastante distintos entre si. Nos workshops experimentais que realiza com o grupo, o diretor estimulava-os a uma criação sem preconcepções estéticas, evitando trabalhar nos moldes do teatro convencional.

Sem dúvida, a colaboração com artistas amadores, diversos deles tidos como deficientes sensorial ou intelectualmente, será um dos meios mais bem sucedidos utilizados por Wilson em sua busca por uma expressão que se pode dizer idiossincrática. $\mathrm{O}$ primeiro deles a contribuir para o seu teatro foi o pintor Raymond Andrews, menino surdo e sem fala que, até conhecer Robert Wilson, nunca havia ido à escola. Excluído do mundo e de suas conseqüentes idéias e normas, Andrews desenvolveu uma genuína e rica vida interior:

He was not only an accomplished visual artist, possessing an extraordinary sense of colour and spacial composition, his paintings also provided Wilson with an entirely original iconography, a network of images that was unique to his imagination ${ }^{5}$.

O principal fruto desta cooperação será o espetáculo "O olhar do surdo", que durava três horas, contava com cerca de cem atores e apresentava cenários gigantescos. Era excepcional não apenas por sua grandiosidade e pelas imagens criadas, mas, sobretudo, pela aparente ausência de lógica, cujo sentido era inacessível ao público. Baseando-se em grande parte nos desenhos e visões de Andrews, que também aparecia em cena, eram trazidas à cena imagens oníricas e figuras tão diversas quanto belas e desconexas, como anões, ossos e animais diversos. Essa multiplicidade de sons e formas era, na verdade, reflexo do mundo e das referências internas de seus criadores, não compartilháveis culturalmente.

Recursos como movimentos em câmera lenta, atividades simultâneas e repetição foram gradativamente tornando-se uma marca do trabalho de Wilson no teatro. É nos limites do dizer que Bob Wilson produzirá, nesse período, espetáculos em que a palavra será minimamente utilizada, passando as imagens e as atividades não-verbais a impor-se sem, no entanto, significar algo específico e pré-determinado, mas, ao contrário, abrindo possibilidades diversas de significação - ou não. Isto, é certo, empresta um sentido polissêmico à cena, pois que a possibilidade do múltiplo, base da polissemia, se constitui justamente pela incompletude.

\footnotetext{
${ }^{5}$ COUNSELL, Colin. Signs of performance: an introduction to twentieth-century theatre. London: Routledge, 1996. p. 182. Tradução nossa. "Ele era não apenas um talentoso artista visual, possuindo um extraordinário sentido de cor e composição espacial, suas pinturas muniram Wilson com uma iconografia inteiramente original, um sistema de imagens que era extraordinário para sua imaginação."

${ }^{6}$ DEAFMAN glance. Criação e direção de Robert Wilson. New York: Byrd Hoffman Foundation, 1970.
} 
Entretanto, a partir de sua colaboração com Christopher Knowles, iniciada em 1973, a palavra passa a ocupar um espaço cada vez maior na obra do diretor norte-americano. Buscando um resultado cênico, Wilson tentará descobrir qual estrutura de linguagem era capaz de permitir a Knowles, um menino considerado autista, expressar-se. Percebe então que sua habilidade no manejo da palavra era de ordem matemática:

O bom da poesia de Christopher é que se trata de matemática e geometria, mas tem a ver com imagens poéticas. Há um sentido de construção e matemática no modo com que as coisas se juntam. Essa é a sua maneira de pensar: Chris tem quase uma obsessão por ordem

Assim, o material verbal utilizado em algumas de suas performances com Knowles baseia-se, sobretudo, nas estruturas lingüísticas geométricas por ele desenvolvidas, em que fragmentos de uma palavra podem ser ditos muito depressa e repetidos de maneira normal ou de trás para frente, o que acaba por criar um padrão visual na mente daquele que ouve:

In using language in anti-sensical ways - breaking the usual ties between a sound/ image and its meaning, or between one word and those which follow it grammatically - Knowles and Wilson elude the formulations of the exterior screen. In doing so, however, they reduce word to raw phonetic or visual material which can then be used to create patterns of a different kind. Knowles and Wilson do not structure their words to generate new meanings; rather, they strip words of their usual meaning in order to build new structures."

A fim de estimular criativamente Knowles, levando-o a travar consigo um diálogo composto de jogos verbais, Wilson fará uso de um procedimento que se repete em diversas das performances que criaram. O recurso seria a evocação de estágios primários do relacionamento entre eles, como se a reativação daqueles momentos bem-sucedidos de comunicação pudesse funcionar como meio de abertura para novas possibilidades de interação e de criação. Assim, na peça longamente intitulada "Um homem louco, um gigante louco, Um cachorro louco, uma urgência louca, um rosto louco", estreada em maio de 1974, a frase "Emily likes the TV", por exemplo, excerto de um diálogo gravado ocorrido entre ambos, servirá como estímulo à improvisação de Knowles, gerando fragmentos de frase, fonemas e sons diversos e repetitivos, como explica Wilson:

Quando dizemos uma palavra há muitas outras coisas acontecendo. No segundo que utilizamos para dizer essa palavra muitos outros pensamentos já passaram por nossas mentes: pudemos experimentar através dos outros sentidos, muitas outras coisas. Eu

\footnotetext{
7 DE LA FALAISE, M. Einstein at the met (an operatic interview). Feb. 1977. Interview. Disponível em: <http://www.robertwilson.com>. Acesso em: 19 jul. 2008.

${ }^{8}$ COUNSELL, 1996, p. 192, tradução nossa. "Usando a linguagem de maneira anti-sensitiva rompendo os laços habituais entre um som/imagem e o seu significado, ou entre uma Palavra e o que a complementa gramaticalmente, Knowles e Wilson transcendem as formulações do mundo exterior. Entretanto, ao fazer isso eles reduzem a palavra a um material fonético ou visual bruto, que então pode ser usado para criar padrões de diferentes tipos. Knowles e Wilson não estruturam suas palavras de modo a gerar novos significados; para além disto, eles despojam as palavras do seu significado habitual para construir novas estruturas."
} 
queria saber como poderia transcrever todas essas outras coisas que se passam, ao mesmo tempo, para o som das palavras. Parecia-me que muitas das coisas que Chris estava fazendo relacionavam-se diretamente com o que ele estava vivenciando?.

Acreditando que há, na linguagem, uma espécie de energia, um elemento que precede o significado tornando possível a comunicação, Wilson observa semelhantes reações entre Knowles e Andrews, percebendo que antes de aprendermos o significado de uma palavra, nós respondemos ao seu som. Conclui que algo muito básico e universal existe na linguagem, tornando-a possível de ser compreendida em qualquer lugar. Para ele, a comunicação pode perfeitamente ocorrer nesse nível e o teatro pode ser a instância privilegiada para esse processo.

\section{Conclusão}

Ampliando-se a discussão para o âmbito do ensino teatral e da formação do ator, é preciso entender que num regime de exceção, como é o caso, o assunto se torna tão importante quanto difícil. Vale, porém, a lembrança de que a arte do ator quase sempre se colocou à margem do que se convencionou chamar "mainstream" vigente. Num passado não tão distante, eram comuns as intervenções da Igreja ou de autoridades civis que impediam as trupes teatrais de se instalar por muito tempo numa mesma cidade. Isso para não falar do tratamento em geral dado à categoria, classificada no mesmo rol de atividades tidas como impuras, ilícitas e imorais. Dono de um modo de vida peculiar e normalmente muito diferente da maioria dos seus contemporâneos, o ator acabava excluído, fosse por inveja, rejeição ou reprovação, tido como um herético aos olhos dos seus contemporâneos. E ainda que o seu estatuto social tenha se modificado e ele já não seja banido como ocorria no século XVII, o comediante ganha uma nova conformidade:

Il est un marginal de societé globale et néanmoins membre d'une communauté réelle [...] A quelques exceptions près, il est en rupture avec son milieu d'origine. Non seulement la precarité financière de l'avenir effraie la famille, mais le 'desordre' de moeurs, conséquence de la profession est encore plus inquiétant. Les préjugés moreax à l'égard des jeunes gens et des jeunes filles qui choisissent une 'vie libre' persitent aujourd'hui sans que l'Eglise ait besoin d'excommunier ${ }^{10}$.

É essa tradicional condição que lhe foi destinada pela sociedade que permite ao teatro mostrar-se como um fértil reduto para a preservação e exercício das diferenças. Isso, no entanto, não exime os seus profissionais de preconceitos ou de desinformação quando o assunto é a diferença no sentido das limitações impostas por disfunções e distúrbios do corpo e da mente.

\footnotetext{
${ }_{9}$ GALIZIA, 1986, p. 79.

10 MOUNIER, Catherine. Devenir comédien. Les Voies de la Création Théatrale, Paris, n. 9, p. 17, 1983. Tradução nossa. «É um marginal da sociedade global e, contudo, membro de uma sociedade real. [...] Salvo exceções, ele está sempre em ruptura com o seu meio de origem. Não apenas a precariedade financeira do futuro assusta a família, mas a desordem dos costumes, conseqüência da profissão, é ainda inquietante. Os prejuízos morais com respeito aos jovens que escolheram uma 'vida livre' persistem ainda hoje, sem que a Igreja tenha a necessidade de excomungá-los.»
} 
Neste sentido, bastante útil e esclarecedor é o conceito implementado pela Organização Mundial da Saúde (OMS), que conceitua distintamente as deficiências, as incapacidades e os impedimentos, comumente tidos sob um único entendimento. Segundo esse critério, uma situação pode decorrer em outra e em ordens diferentes. Uma deficiência visual profunda e precoce, por exemplo, decorrerá em certas incapacidades, dentre as quais a de identificar à distância a forma e a dimensão das coisas, o que por sua vez acarreta como desvantagem a restrição de trânsito do indivíduo pelo mundo e o seu impedimento na realização de determinadas tarefas. Num sentido inverso, algumas desvantagens ou impedimentos (a miséria, por exemplo) podem decorrer em incapacidades (a de domínio da expressão simbólica e manipulação do pensamento hipotético) que, por sua vez, podem levar um observador menos atento de testes a concluir por certa «deficiência» das funções cognitivas do indivíduo.

A partir dessa percepção, tem se buscado reduzir ou remediar as incapacidades com base nas capacidades da pessoa: "Isso implica transformar o olhar dirigido em sua direção: não se trata mais apenas de determinar seus limites e sim, além disso, de ressaltar aquilo de que de fato é capaz"11. Portanto, quando se fala em limitação pode se estar falando também em potencialidades e alternativas, sendo a questão muito mais de atitude diante do fato do que uma simples concessão.

Isso torna fundamental que o indivíduo seja aceito no interior de um grupo de atores considerados "normais" e que o programa tenha em conta e promova as diferenças, realçando justamente as singularidades de cada um, avivadas pela presença de alguém tão distinto. $\mathrm{O}$ fato pode, inclusive, constituir-se como diferencial para um exercício cênico inovador e instigante. Não se trata, porém, de se admitir uma pessoa pela simples razão de possuir algum tipo de anomalia, e sim de promover uma concreta integração daquelas que demonstrem sensibilidade e disponibilidade para a expressão dramática, características perceptíveis a partir de uma sessão de jogos e exercícios.

Em geral, duas ações distintas e complementares se apresentam, sendo a primeira delas a que diz respeito ao reconhecimento e apropriação, em si, das condições e particularidades do individuo, já abordadas anteriormente. A segunda está relacionada à identificação e uso das habilidades por ele adquiridas, graças a uma formação anterior e específica, junto a instituições ou profissionais especializados. Essa condição pressupõe uma cultura assimilada e compartilhada, em geral, no seio de um coletivo, perpetrada por práticas reconhecidas de ensino para deficientes, especialmente os auditivos e visuais. Tais habilidades se valem, em geral, de alternativas que compensem impedimentos relacionados ao uso da linguagem e da comunicação. São códigos e procedimentos técnicos criados de maneira a facilitar a relação e trânsito da pessoa no mundo. Aqui, podem mostrar-se útil ao orientador o acesso e o reconhecimento dos elementos que compõem esse universo, a fim de promover um efetivo intercâmbio de possibilidades e de interesses, a serem transportados para o exercício cênico. Servem de exemplo a linguagem de sinais utilizada pela comunidade de surdos e os procedimentos levados a efeito para a integração social de cegos, como os meios e instrumentos de identificação sonora e tátil.

Para cada caso haverá uma configuração bastante particular, em que a pes- 
soa tem o direito e será capaz, se assim estimulada, de valer-se de meios criativos e originais para uma expressão cênica. Portanto, um efetivo trabalho de reconhecimento, exploração e reorganização esquemática do corpo-voz mostra-se importante para sua restituição como espaço primeiro de automanifestação e relação com o mundo. As práticas devem ser capazes de levá-la a uma (re) descoberta das habilidades intrínsecas à expressão e à comunicação humana, incorporando de maneira dinâmica as suas condições e limitações, o que incorre numa afirmação da capacidade singular de manifestação que cada um possui. Para tanto, importante será reconhecer a validade dos recursos epilingüísticos e metonímicos na expressão e na comunicação, o que recolocará o indivíduo com dificuldade de fala ou de expressão na condição de um interlocutor efetivo, autorizado a processar as informações, reconstituindo-as de acordo com as suas experiências próprias e contextualizando-as de acordo com as suas condições. Portanto, através de simulacros verbais e corporais o sujeito torna-se capaz de ampliar sua capacidade de comunicação, ainda que fora dos padrões normatizados e socialmente tidos como corretos. A produção e uso de gestos e de sons, a articulação de palavras próximas ou similares, que semanticamente contextualizem o enunciado devem, pois, ser estimulados de maneira a integrar o repertório expressivo do indivíduo.

Reinventar formas de dizer, compartilhar e produzir sentidos deve, pois, ser o propósito maior das atividades teatrais numa situação que envolva as anomalias. É nesse âmbito que o poder do teatro como jogo e, sobretudo, a partir de seu inegável valor como espaço de criatividade e improvisação pode atuar de maneira inestimável e, com isso, estimular um novo olhar, que não apenas indulgente ou inclusivista, às potencialidades e características de pessoas consideradas incapazes seja pela deformidade corporal ou por suas condições incomuns de expressão e de comunicação. 


\section{REFERÊNCIAS}

COUNSELL, Colin. Signs of performance: an introduction to twentieth-century theatre. London: Routledge, 1996.

DE LA FALAISE, M. Einstein at the met (an operatic interview). Feb. 1977. Interview. Disponível em: < http://www.robertwilson.com>. Acesso em: 19 jul. 2008.

DE MARINIS, Mario. Dramaturgy of the Spectator. The Theatre Drama Review, New York, v. 31, n. 2 (T114), p. 100-114, Summer, 1987.

DEAFMAN glance. Criação e direção de Robert Wilson. New York: Byrd Hoffman Foundation, 1970.

GALIZIA, Luiz Roberto. Os processos criativos de Robert Wilson. São Paulo: Perspectiva, 1986.

GLUSBERG, Jorge. A arte da performance. São Paulo: Perspectiva, 2003.

GOFFMAN, Erving. A representação do eu na vida cotidiana. Petrópolis: Vozes, 1996. p. 191-217.

LEPOT-FROMENT, Christiane. Introdução. In: Educação especializada: pesquisas e indicações para a ação. Bauru: EDUSC, 1999. p. 9-22.

LULKIN, Sérgio Andrés. Atividades dramáticas com estudantes surdos. Cadernos de Autoria, Porto Alegre, n. 2, p. 51-65, 2000.

MOUNIER, Catherine. Devenir comédien. Les Voies de la Création Théatrale, Paris, n. 9, p. 15-31, 1983.

PAVIS, Patrice. Dicionário de teatro. São Paulo: Perspectiva, 2001.

SCHECHNER, Richard. O que é performance. O Percevejo, Rio de Janeiro, ano 11, n. 12, p. 25-50, 2003. 


\section{CRUZANDO ESPAÇOS: O TEATRO NO HOSPITAL}

Lucia Helena de Freitas (Gyata)

Este artigo é parte de uma pesquisa de doutoramento ${ }^{1}$ que analisa modos e efeitos da inserção do jogo teatral no espaço hospitalar público a partir do enfoque de trabalhos experimentais realizados, sob minha orientação, por alunos da Licenciatura em Artes Cênicas da Escola de Teatro da Unirio, desde 1999 até 2005.

Estas intervenções teatrais fazem parte do projeto de extensão "O hospital como universo cênico”, uma parceria entre a Unirio e o Hospital da Lagoa, e foram solicitadas pela instituição hospitalar visando auxiliá-la a tornar o atendimento de seus pacientes mais humanizado.

Diversos fatores que caracterizam os serviços hospitalares foram apontados pelos profissionais de saúde como elementos de desumanização - a enorme quantidade de doentes atendida pelos profissionais diariamente, o alto grau de estresse desses profissionais que lidam continuamente com o sofrimento e a morte sem receberem um treinamento especializado; a priorização de cuidados somente com o corpo físico do paciente em detrimento dos aspectos afetivos e, principalmente, a dificuldade de comunicação entre o médico e o paciente. A proposta, por parte da instituição hospitalar, de intervenção teatral visava estabelecer outras relações de comunicação naquele espaço que facilitassem o diálogo e amenizassem o estresse, tanto o dos profissionais quanto o dos pacientes.

Tratava-se, portanto, uma vez aceito o desafio de realizar essas intervenções teatrais, da apropriação teatral de um espaço não tradicionalmente destinado à prática cênica, o que abriu perspectivas novas para o professor de teatro, para além da instituição escolar. Foi a oportunidade de mostrar a pertinência e viabilidade da criação de espaço para a atuação desse profissional na instituição hospitalar.

Por outro lado, a realização de experiências teatrais no espaço hospitalar permitia, do ponto de vista da formação artística dos alunos engajados neste projeto, que fosse experimentada a prática teatral em espaços a princípio não destinados a ela, indo ao encontro da chamada explosão do espaço teatral, que aconteceu no século $\mathrm{XX}^{2}$.

\footnotetext{
${ }^{1}$ Cruzando espaços e olhares: o teatro no hospital de Lucia Helena de Freitas (Gyata) - tese de doutoramento - Programa de Pós-graduação em Teatro - Unirio.

2 Este século, segundo Jean-Jacques Roubine em A linguagem da encenação teatral, foi marcado por formas diversas de recusa do teatro burguês e de sua estrutura cênica mais típica: o palco
} 
O Hospital da Lagoa é um hospital público, situado no Jardim Botânico, às margens da Lagoa Rodrigo de Freitas. Seus pacientes são originários de favelas próximas e da Baixada Fluminense. Como hospital público, insere-se numa sociedade de desigualdades econômicas, sociais e culturais. Seus pacientes são indivíduos destituídos de bens materiais e sociais e que, em geral, encontram-se privados de poder político para falar de sua condição e de lutar por possíveis transformações.

A inserção educativa do teatro no hospital vai dar-se pela possibilidade de trazer novas formas de sensibilização que desperte estes indivíduos, que desvele outras possibilidades de pensar e sentir, que provoque imagens não-usuais nos espaços já embotados, que abra espaços de diálogo em que suas histórias possam se materializar por alguns instantes ou que, em frações mínimas de tempo, eles identifiquem afetos e possam experimentá-los com intensidade.

Aceitar, portanto, a solicitação do Hospital da Lagoa para desenvolver um projeto teatral naquele espaço oportunizou um desafio ao curso de licenciatura: o de sair de seu âmbito tradicional de atuação, ou seja, a escola, e poder pensar e experimentar formas teatrais para um espaço diverso e desconhecido. Isso suscitou, imediatamente, algumas perguntas e alguns temas para reflexão. Reflexão importante para alavancar as ações que, ali, começamos a empreender. A primeira pergunta se referiu à importância desta intervenção para a formação dos alunos de licenciatura em teatro. Poderiam eles atualizar metodologias específicas do ensino do teatro naquele espaço? A segunda pergunta dizia respeito ao modo como a intervenção teatral poderia auxiliar o hospital em seu projeto de humanizar suas práticas. A terceira pergunta incidiu sobre as relações entre estas duas áreas de conhecimento: teatro e medicina. Como seria esta convivência simultânea num mesmo espaço?

Uma abordagem em que sobressai a reflexão crítica sobre a realidade hospitalar, seu espaço político-social, sua organização e as relações interpessoais ali existentes fez-se fundamental para o desenvolvimento de uma práxis que, igualmente, se voltou para a importância da construção de um espaço de teatralidade, cuidando em pesquisar e desenvolver formas teatrais.

Este espaço de construção teatral, onde o aluno de licenciatura foi inserido, abriu para ele duas perspectivas dentro da mesma experiência: a primeira se refere à sua preparação como futuro professor de ensino do teatro, para a qual ele deve desenvolver a capacidade de jogar, como um pré-requisito para o trabalho no campo, e, assim, ao mesmo tempo, apropriar-se dos fundamentos do ensino do teatro. A segunda perspectiva é a experiência peculiar vivida no hospital: pensar e produzir intervenções para aquele espaço, sentir e perceber suas necessidades, desenvolver um olhar sensível aos espaços escolhidos para as intervenções, interagir com sua população e com as relações várias que ali estão constituídas. Ao licenciando caberia articular seu aprendizado teórico e prático para pensar, elaborar e experimentar formas de intervenções teatrais no espaço hospitalar, analisando sua interferência nesse espaço e verificando a pertinência ou não das formas de intervenção escolhidas em relação aos objetivos propostos.

italiano e a representação ilusionista. Diversos encenadores como Grotowski, Brook, Artaud, entre outros, buscaram, para a atividade teatral, espaços não convencionais, como grandes galpões, pátios de mosteiros, hospitais etc., ao mesmo tempo em que propunham concepções inovadoras da linguagem teatral. 
As intervenções teatrais que vieram a se realizar no hospital mostraram a impossibilidade de possuir um objetivo único. Desta forma, integrar as demandas do hospital - seu desejo de humanizar os serviços - com as demandas do teatro - a produção de formas teatrais conseguidas por meio de jogos improvisacionais - foi o nosso propósito ao partir para as intervenções.

Em relação ao licenciando, o conhecimento conquistado junto ao conjunto de disciplinas teóricas e práticas que fazem parte de sua formação tornou-se a bagagem pessoal, artística e pedagógica que ele traria para o trabalho no hospital. Canalizar estes conhecimentos teóricos e habilidades práticas, acrescentando a eles leituras específicas sobre a área da saúde, foi o que se procurou realizar, fazendo com que cada licenciando pudesse explorar, ao máximo, suas possibilidades criativas, desenvolver suas técnicas, aperfeiçoar seus sentidos, sua sensibilidade, num trabalho de construção coletiva das intervenções.

Um ponto nodal do trabalho referiu-se, precisamente, às formas teatrais de intervenção e ao processo de jogo escolhido para sua construção. É fato que, assim como no teatro em geral, o ensino do teatro é fortemente marcado por um apego ao ilusionismo e à relação frontal, própria do palco italiano. Jean Pierre Ryngaert, em Jouer, représenter, referindo-se aos jogos de improvisação realizados na escola com alunos ou em outros locais como colônias de férias, clubes etc., praticado por não-atores, constata que:

As primeiras improvisações em geral pouco levam em conta o espaço. Nossa educação limita o teatro a uma relação frontal, nem sempre claramente percebida, nem verdadeiramente assumida como tal. As idéias recebidas sobre o teatro remetem a um "estrado" ou a um "palco", sem que o espaço seja levado em conta como um elemento do jogo. A forte tradição literária de nosso teatro considera o espaço sob a dimensão plástica, ou em última instância pela vaga noção de cenário. A relação entre o lugar de onde se vê e o lugar de onde se é visto não é perceptível neste tipo de abordagem do fenômeno teatral. Velhos hábitos, originários do naturalismo, fazem o resto e, sem a preocupação com as convenções, os jogadores escolhem os espaços reais para neles jogar 'como que de verdade's.

Tornar o espaço um elemento indutor do jogo teatral, provocando uma educação do olhar por intermédio de proposições que incitem a enquadrar os elementos da realidade ${ }^{4}$, passou a ser uma de nossas propostas.

Afetar o espaço e ser afetado por ele seria a primeira proposta a ser trabalhada nas intervenções. Adentrar o hospital, interagir com doentes, acompanhantes, médicos e funcionários e criar um atrito, naquele espaço específico, que provocasse o ato criativo foi o objetivo dessa proposta. Atrito que o teatro, no seu fazer provocativo, pretendia explorar, criando tensões que, de certa forma, acabaram por desvelar, também, tensões que já ali existiam. Tensões essas provocadas, pôde-se constatar nas experiências realizadas, pelos confrontos entre concepções antagônicas a respeito da medicina. Tensões que vieram intensificar aquelas advindas do atrito entre o ritual medico estabelecido e o jogo teatral.

${ }^{3}$ RYNGAERT, Jean-Pierre. Jouer, représenter. Paris: Cedic, 1985. p. 69.

4 RYNGAERT, 1985. 
Consideramos que o teatro no hospital não deveria ficar confinado a um espaço determinado, caracterizado como único local possível para sua prática. Pelo contrário, deveria surgir onde não se esperasse jogar com o imprevisto, com o acaso. Aparecer no meio dos atos cotidianos e causar um estranhamento, propor uma atividade incomum que pudesse gerar reflexões e afetos diversos.

Para que o atrito ocasionado pela atividade do jogo teatral que "desarrumava" de certa forma os espaços e os tempos hospitalares pudesse acontecer seria preciso que o teatro percorresse diversos espaços do hospital: o saguão, os corredores, as enfermarias. Espaços não apropriados integralmente pelo poder institucional da saúde, espaços intervalares, onde toda a população do hospital circula e, também, alguns espaços mais restritos, as salas de atendimento médico e as enfermarias, ocupadas pelos doentes e acompanhantes.

A apropriação destes diversos espaços, com suas diferenças de tamanho, forma e função, provocaram problemas específicos para cada jogo teatral ali realizado. Os espaços que denominamos intervalares caracterizam-se por um público móvel, um público que se desloca de um lugar a outro. Ali o público se torna imprevisível porque pode levantar-se a qualquer momento e sair do espaço destinado ao jogo. Apesar disso, nos espaços intervalares toda a população do hospital, em algum momento, encontra-se, independente de sua posição na hierarquia hospitalar e, por isso, consideramos importante a sua apropriação. Ali pudemos perceber e analisar as principais tensões próprias da instituição e aquelas que o teatro viria provocar. Já os espaços restritos - as enfermarias - levavam a uma aproximação maior com os pacientes e seus dramas, gerando a necessidade de criar intervenções mais intimistas ou de adaptar aquelas realizadas nos espaços intervalares para esse outro espaço, levando em conta sua redução e características próprias.

Jogar com e nesses espaços que se apresentavam sempre imprevistos: as arrumações de mobiliário são diferentes em cada enfermaria, o hall das escadas, às vezes, está livre, outras vezes, guarda macas e caixotes; invasões constantes no espaço são realizadas por carrinhos com material hospitalar, aparelhos médicos e pessoas, tudo isso se tornou parte integrante de nossa proposta de jogo, fazendo da flexibilidade e da constante mudança características de cada intervenção. O espaço era componente provocativo do jogo, o qual era modelado em cena, em cada apresentação.

A apropriação dos espaços do hospital pelo teatro se fez inicialmente pela criação de algumas oficinas de jogo teatral e por intervenções interativas para pacientes, acompanhantes e funcionários. A proposta era a de levar o não-ator (os profissionais e pacientes) a participar do jogo teatral ou como jogador ou como observador ativo. A intenção era transformar os espaços materiais do hospital em espaços de imaginação. Transformar os elementos conhecidos e os espaços já impregnados de sentidos e, assim, criar outros espaços foi este o objetivo desta ação ${ }^{5}$.

As intervenções teatrais aconteceram nos espaços intervalares e nas enfermarias, tendo o espaço se tornado um dos indutores do jogo pela variedade de formas

\footnotetext{
${ }^{5}$ Uma oficina infantil, por exemplo, realizada na salinha de recreação do setor pediátrico, trabalhou com a confecção de dedoches (bonecos de dedo) feitos com gaze gessada e, posteriormente, com a criação de improvisações com os bonecos. O emprego de um material característico do tratamento hospitalar - a gaze -, como elemento do jogo, demonstrou a possibilidade de flexibilizar, por meio de processos de imaginação, o significado cristalizado de um determinado elemento, dando-lhe novos sentidos.
} 
físicas que o caracterizavam e, também, por suas qualidades psicossociais - lugar de dor, sofrimento, miséria, morte, mas, também de cura e de possibilidade de riso, de alegria.

O esboço dessas intervenções foi construído em sala de aula, na Escola de Teatro, por mim e pelo grupo de alunos participantes do projeto, e a proposta foi a de encenar textos, em princípio narrativos, que seriam dramatizados nos corredores do hospital por alunos-atores e por não-atores convidados - os pacientes que aguardavam as consultas.

Utilizar o exíguo espaço do corredor, as disposições espaciais dos pacientes, as portas de consultórios que se abriam e se fechavam a cada momento como elementos do jogo teatral foi o desafio que o grupo se dispôs a enfrentar. Os pacientes, às vezes, eram assumidos como elementos que compunham o ambiente - por exemplo, árvores numa floresta - ou, ainda, sua disposição podia estabelecer caminhos por onde os atores se deslocavam. As histórias, no início das intervenções, eram conduzidas por um narrador principal que funcionava também como um diretor, pois indicava situações aos atores a serem realizadas cenicamente. A proposta do grupo era jogar com o imprevisto, estabelecendo vínculos e cumplicidade com a platéia.

A escolha de textos para as intervenções recaiu sobre textos literários, não dramatúrgicos, que pudessem estabelecer relações com o universo hospitalar.

Os processos de trabalho para a realização de intervenções, em determinado momento, diversificaram-se. Havia a proposta de um trabalho de improvisação mais livre, em que os atores tinham mais liberdade de criar, e outros em que essa liberdade se tornou mais restrita, em razão da encenação escolhida. Apesar disso, o processo de construção do segundo tipo de intervenção se caracterizou sempre pelos jogos de improvisação e direção compartilhada pelo grupo.

Para desenvolver estímulos nos alunos-atores, partia-se de um levantamento dos efeitos sensoriais (imagens, cores, sonoridades) que eles experimentavam logo nas primeiras leituras do texto e que resultavam na criação, por eles, de formas sonoras e visuais. Estas formas se relacionavam com os outros elementos que iam sendo criados a partir das improvisações. O texto inicial induzia a descoberta de uma dramaturgia em cena pela fisicalização das ações selecionadas pelos atores e pela realização de um texto oral. A condução do olhar do espectador era realizada pelo movimento corporal dos atores que desenhavam o espaço cênico, modificando-o de acordo com a necessidade de encontrar lugar para as ações. Ao texto cinético escrito pelos atores no espaço, ligava-se o texto verbal e os outros elementos sonoros não-verbais, formando o enunciado que, a cada manifestação concreta, ganhava um sentido.

Por exemplo, a encenação de $A$ bistória de uma folha, de Leo Buscagglia, uma adaptação de um texto não-dramático, apresentado no corredor para adultos e crianças, foi conduzida pelos atores que se transformavam em árvores, velhos, crianças, vento, a partir do jogo de transformação de objetos, no caso, lenços coloridos, que eram movimentados por eles, às vezes representando folhas, outras vezes vento, e, em outras, indicando o personagem (transformado em fita indicava uma criança, enrolado na cabeça indicava uma velha). Havia a coexistência de narração e diálogos na cena, sendo que os atores desempenhavam as duas funções, narrar e dialogar, podendo a função 
de narrador passar de um para outro ator dentro da mesma cena. Procurou-se quebrar um possível caráter ilusionista do jogo, pois o ator somente indicava o personagem por meio do objeto lenço, dando-lhe voz e gestual e, em determinados momentos passava, também, a ser o narrador que conduzia a ação.

Muitas vezes, com as crianças, usamos formas animadas: objetos e bonecos para criar personagens. Os bonecos se mostraram importantes para o jogo pela sua capacidade de criar um espaço lúdico quase que instantâneo.

A escolha de estímulos visuais e sonoros marcantes ocorria pelo desejo de sensibilizar o espaço hospitalar com cores, formas e sons diversos dos convencionais. Esses estímulos agiram como agentes mobilizadores para a criação de estados de sensibilidade que puderam abrir, no público, espaços possíveis de imaginação.

Quando se trabalha com o ensino do teatro na escola, um dos objetivos é desenvolver a apreciação artística com as crianças e adolescentes, porque é importante aprender a ver. E ver não é somente a apreensão das formas que impressionam nosso sentido da visão. Duarte Jr. diz que há duas maneiras de perceber as coisas: uma prática e a outra estética. A primeira buscaria a utilidade dos objetos, indagaria sobre seu valor e as vantagens a serem obtidas, enquanto a outra percebe, com prazer e sensibilidade, suas formas e maneiras de aparecer, quer dizer - o olhar estético deixa fluir, deixa ocorrer o encontro entre uma sensibilidade e as formas que lhe configuram emoções, recordações e promessas de felicidadé. É tarefa, portanto do professor de teatro ensejar as oportunidades para que a sensibilidade estética possa ser trabalhada, ao longo da trajetória do aluno, no meio escolar. Deveria ser assim, mas sabemos das deficiências que as escolas, de um modo geral, apresentam na formação de seus alunos. No Hospital da Lagoa, porém, estamos diante de uma realidade mais precária, pois lidamos com crianças provenientes de um meio social muito pobre, onde as escolas, em geral, não proporcionam um trabalho produtivo de desenvolvimento artístico, nem no âmbito do fazer, nem do apreciar e muito menos no contextualizar. Crianças, como já dissemos, que nunca foram ao teatro, nunca fizeram teatro. E, para agravar, nosso encontro com elas, na maioria das vezes, é único. Que fazer então, se não temos tempo nem espaço significativo em suas vidas para fazer criar o gosto e a necessidade pelo teatro?

Com nossas pequenas formas teatrais, o que procuramos foi intensificar o contato, o prazer e o diálogo, mostrando que é possível falar, é possível discordar, é possível brincar. Talvez seja isso - mostrar um possível diferente daquilo que elas conhecem.

Constatei, à medida que as intervenções foram sendo realizadas no hospital, várias tensões recorrentes, tais como: as dificuldades de diálogo dos médicos com os pacientes, a incompreensão do projeto por alguns médicos e funcionários, a dificuldade com os espaços e tempos hospitalares para as encenações, a apatia dos pacientes, o mal-estar vivido por alguns licenciandos diante de quadros de dor, entre outros. Estas tensões levaram-me à necessidade de empreender a pesquisa sobre a instituição hospitalar. Era importante, dentro daquele espaço, perceber que lugar era oferecido ao teatro, onde ele se encaixava, onde era rechaçado e por que estas tensões e contradições aconteciam. Que fatores levaram médicos a acenar ao teatro, propondo sua interferência e que fatores faziam com que outros médicos e

\footnotetext{
${ }^{6}$ DUARTE JÚNIOR, João-Francisco. O sentido dos sentidos. Curitiba: Criar, 2001. p. 98.
} 
funcionários manifestassem uma reação, às vezes, expressamente contrária e, outras vezes, de neutralidade apática.

Tornou-se, portanto, necessário empreender o levantamento do espaço hospitalar em todos os seus aspectos relevantes: o aspecto físico, o aspecto institucional, o aspecto discursivo. E então confrontá-lo com o espaço teatral: seu aspecto conceitual, as formas de experiência que ele provoca e sua capacidade de organizar signos numa linguagem própria.

Nas intervenções hospitalares priorizamos o jogo por sua flexibilidade em tirar partido dos espaços, não importa de que natureza e forma eles se apresentassem. Ao iniciar o projeto no Hospital da Lagoa escolhemos trabalhar nos corredores, saguão e quartos porque decidimos por uma proposta agressiva em relação ao espaço no sentido de realizar intervenções na rotina e no ritual hospitalares. Não usamos o auditório do hospital como espaço para as apresentações, não preparamos encenações para serem representadas ali, descartando, assim, a arquitetura que sublinha a divisão palco e platéia. Não ficamos aguardando um público para nos assistir, pelo contrário, fomos ao encontro dele e realizamos o jogo teatral em cada brecha de espaço possível.

Os pacientes vão ao Hospital da Lagoa em busca de cura para suas enfermidades. A grande maioria nunca foi ao teatro. Estes dados me levam a crer que o teatro se encontra distante destas pessoas. Não é uma necessidade percebida por esta população. Desta forma, o sentido da intervenção foi mostrar como o teatro, e num sentido mais amplo, a arte é necessária. E tão necessária quanto a droga ou a intervenção cirúrgica, porque opera em todas as instâncias do indivíduo.

A criação de um espaço teatral não é somente o corte espacial que se faz em um determinado espaço físico, é bem mais do que isto. É sobretudo um espaço diverso de relação. Relação que se estabelece entre os que atuam e os que assistem. Relação que se faz pelo olhar, pelo contato físico. Esse contato é mediado por um conjunto de signos que se espacializa na apresentação teatral.

Pode-se creditar à noção de espaço teatral um fechamento em relação àquilo que se encontra exterior a ele. No momento, por exemplo, em que se institui o espaço teatral e a apresentação se processa, haveria um corte espaço-temporal em relação ao espaço maior, neste caso, o hospital. Isto, porém, não acontece. Ocorrem cortes e interpenetrações dos tempos e espaços hospitalares no espaço-tempo do jogo e são aproveitados no próprio jogo, e é isto que almejamos: transformar, em alguns momentos, o ritual do hospital em jogo, mostrar que é possível uma certa leveza..

Ryngaert, em Jouer, Représenter, ao analisar as relações que se estabelecem entre o teatro e os locais diversos, não teatrais, usados por encenadores contemporâneos, aponta para o fato de que:

Os espaços institucionais onde circulamos são muitas vezes carregados de sentido pelos que neles vivem ou trabalham. É bem interessante esvaziar esse sentido e ter prazer em todos os cruzamentos de sentido que aparecem. O jogo é um meio de 'recarregar' os espaços'.

\footnotetext{
7 RYNGAERT, 1985, p. 71.
} 
Ubersfeld diz que teatro é espaço ${ }^{8}$. Ryngaert diz que o espaço é fundador do jogo teatral ${ }^{9}$.Trabalhar com o espaço como um dos indutores do jogo é um processo que demanda uma educação do olhar para que este possa, partindo do referencial deste espaço, fazer instalar, ali, uma dimensão artística.

A questão, no hospital, não era modificar fisicamente o espaço, cobri-lo ou maquiá-lo para estabelecer um espaço ilusório. Nada do espaço real era mudado: as camas desocupadas no saguão serviam para sentar, as latas de lixo dividiam áreas de jogo, das escadas surgiam- personagens, as cabeceiras das camas serviam para a movimentação dos bonecos e assim por diante. Quer dizer, criava-se um espaço de jogo que transformava o espaço real por meio de novos modos de utilizá-lo. Este espaço de jogo se caracterizou por estabelecer uma continuidade entre o ator e o espectador, o que propiciou um contato muito intenso. A comunicação e o diálogo se estabeleceram efetivamente em cada intervenção realizada por grande parte dos pacientes e acompanhantes, apesar da apatia de alguns e hostilidade de alguns funcionários.

A escolha do jogo recaiu na possibilidade, nunca descartada, apesar de todas as dificuldades, de que todos pudessem se converter em jogadores. Portanto, não houve uma preocupação da minha parte com virtuosismos, nem com encenações muito elaboradas. Havia, em nossa proposta, esta característica de não acabamento proposital. Eram necessários a flexibilidade e o espaço aberto para, a cada instante, estabelecer relação, contato e respostas que mantivessem ativo o canal de comunicação através do qual o teatro acontecia, fazendo surgir olhares e discursos diversos dos habituais.

A ênfase no ato de jogar apostava em sua capacidade de mostrar a possibilidade criativa própria dos indivíduos e que, mesmo embotada e reprimida pelas injunções sociais, poderia ser resgatada. Estes indivíduos se encontram de tal forma destituídos de auto-estima, tão fragilizados pela indigência econômica e cultural, que disso resulta a carência de um olhar que os individualize e que perceba a sua importância como indivíduos e cidadãos. São crianças e adultos que desde muito cedo vivenciam a vida como um drama de experiências dolorosas. A dor psicológica e moral, em certos casos, é muitas vezes maior do que a dor física.

Se, para o adulto, estar doente e ser hospitalizado é algo perturbador, para a criança a angústia e o medo, diante do desconhecido, intensificam-se. A internação hospitalar, dependendo do tempo de permanência, da gravidade da doença, do apoio familiar e da faixa etária da criança, pode vir a ser especialmente traumática, trazendo danos psicológicos irreversíveis.

Para a criança em idade escolar que tenha que passar por período demorado de internação, o afastamento da escola pode prejudicá-la em dois importantes aspectos: a escolaridade e as inter-relações que são travadas na sala de aula.

Para responder a esta demanda, foram criadas as classes hospitalares, funcionando dentro dos hospitais e tendo como objetivo principal suprir a escolaridade das crianças e dos jovens internados.

Estas classes são um direito obrigatório, reconhecido pela legislação brasileira, constando da Declaração dos Direitos da Criança e do Adolescente Hospitaliza-

\footnotetext{
${ }^{8}$ UBERSFELD, Anne. Lire le théâtre II. Paris: Gallimard, 1996. p. 49.

9 RYNGAERT, 1985, p. 69.
} 
dos, emitida em 1995, mas já prevista pelo MEC, através da publicação da Política Nacional de Educação Especial ${ }^{10}$. É um espaço que o licenciado em Teatro tem legalmente o direito de ocupar, restando somente que se empreenda uma luta política para que isto se torne possível.

Uma pedagogia hospitalar na qual a arte estivesse presente provocaria o aflorar de outras relações humanas.

A experiência do teatro no hospital busca, portanto, por meio da linguagem artístico-teatral, apontar para uma vida em que a sensibilidade e a percepção de existir sejam intensificadas. Brook explica que, no teatro, a vida é mais compreensível e intensa porque é mais concentrada. A limitação do espaço e a compressão do tempo criam essa concentração ${ }^{11}$.

Ao realizar os jogos dramáticos em nosso trabalho no hospital, o intuito foi o de conseguir a participação da platéia, tornando-a também jogadora, ou, como diz Brook, a cúmplice da ação $o^{12}$.

O ritual do hospital, que separa os pacientes, seleciona-os em filas, divide-os em consultórios, ambulatórios, examina-os e lhes prescreve medicamentos, choca-se com o jogo teatral, pois este institui um outro ritual que integra os participantes, promove sua expressão, faz com que se tornem também agentes do processo de criação. O jogo é uma atividade livre, como afirma Huizinga em Homo Ludens (1996), que se distingue da vida habitual, realizada num recorte de espaço e tempo - como um intervalo em nossa vida cotidiana - e que se caracteriza por absorver de forma intensa os jogadores. Logo, a realização do jogo teatral quebra a rotina hospitalar e pode levar os pacientes a encontrar, em seu espaço, possibilidades de criar novas realidades.

Dentro desse jogo de espaço-tempo, o teatro faz com que espectadores e atores se encontrem, favorecendo a cada indivíduo perceber sua capacidade criativa. Capacidade que poderá ser usada, talvez, para recriar sua própria vida. Criar um outro presente é a possibilidade que o teatro pode abrir no espaço do hospital. Criar e projetar, neste espaço de dor e morte, espaços livres e diferenciados de diálogo e imaginação.

\footnotetext{
${ }^{10}$ BRASIL. Ministério da Educação. Secretaria de Educação Especial. Política Nacional de Educação Especial. Brasília, DF, 1994.

${ }_{11}$ BROOK, Peter. A porta aberta. Rio de Janeiro: Civilização Brasileira, 2000. p. 8.

12 BROOK, 2000, p. 23.
} 


\section{REFERÊNCIAS}

BRASIL. Ministério da Educação. Secretaria de Educação Especial. Política Nacional de Educação Especial. Brasília, DF, 1994.

BROOK, Peter. O ponto de mudança. Rio de Janeiro: Civilização Brasileira, 1995.

BROOK, Peter. A porta aberta. Rio de Janeiro: Civilização Brasileira, 2000.

BROOK, Peter. O teatro e seu espaço. Petrópolis: Vozes, 1970.

BUSCAGLIA, Leo. A história de uma folha. Rio de Janeiro: Record, 2002.

DUARTE JÚNIOR, João-Francisco. O sentido dos sentidos. Curitiba: Criar, 2001.

HUIZINGA, Johan. Homo ludens. São Paulo: Perspectiva, 1982.

RYNGAERT, Jean-Pierre. O jogo dramático no meio escolar. Coimbra: Centelha, 1981.

RYNGAERT, Jean-Pierre. Jouer, représenter. Paris: Cedic, 1985.

ROUBINE, Jean-Jacques. A linguagem da encenação teatral. Rio de Janeiro: J. Zahar, 1996.

UBERSFELD, Anne. Lire le théâtre II. Paris: Gallimard, 1996. 


\section{ELEMENTOS DO TRÁGICO NO ESTUDO DO TEXTO TEATRAL}

Escrever é uma certa maneira de desejar a liberdade; tendo começado de bom grado ou à força, você estará engajado ${ }^{1}$.

Se alguém me pedisse para dizer a principal crença da juventude de minha geração, eu diria sem titubear: a atribuição à arte de uma função transformadora da sociedade ${ }^{2}$.

Por uma questão de tempo e espaço, as metodologias de pesquisa e estudo do texto de teatro existentes não poderiam ser resumidas neste artigo, tamanha a quantidade e complexidade das mesmas ao longo de mais de dois mil anos de cultura teatral e criação literária ${ }^{3}$. Isto, considerando a tradição ocidental, que tem como marco a Poética aristotélica ${ }^{4}$.

No decorrer destes quase dois milênios e meio se alternaram, e se conjugaram, análises que privilegiaram ora a abordagem estrutural ora a perspectiva temática, coincidindo momentos em que ambas tinham importância aos olhos dos estudiosos. Assim, pode-se entender que a primeira foca estudos em torno da personagem, dos diálogos, do enredo, enfim, dos procedimentos que fazem funcionar a textualidade; enquanto a segunda procura olhar os elementos psicológicos, históricos e sociológicos que regulam o funcionamento da narrativa teatral, permitindo que a mesma libere as marcas de um tempo, o tempo que a tornou possível.

Pensando assim, o inglês Raymond Willians é um dos estudiosos da literatura e do texto teatral que mais se destacou no decorrer do século XX, fez amplo uso de análises que combinaram a análise do texto na sua relação com o contexto e vice-

${ }^{1}$ SARTRE, Jean-Paul. Que é a literatura? Tradução de Carlos Felipe Moisés. São Paulo: Ática, 1989. p. 53.

2 MACIEL, Luiz Carlos. Geração em transe: memórias do tropicalismo. Rio de Janeiro: Nova Fronteira, 1996. p. 73.

${ }^{3}$ Contribuíram para este artigo os processos e resultados adquiridos com o trabalho de pesquisa e ensino no Curso de Teatro na Universidade Federal de Uberlândia, ao qual estão vinculados os projetos de Pesquisa: Estudos do Texto Teatral: história, criação e temas e Biblioteca Digital de Peças Teatrais, ambos realizados com apoio e financiamento institucional da Universidade Federal de Uberlândia (UFU) e da Fundação de Amparo à Pesquisa do Estado de Minas Gerais (Fapemig).

${ }^{4}$ ARISTÓTELES. Arte poética. São Paulo: M. Claret, 2003. p. 26. 
-versa, não deixando de ressaltar a importância da aproximação entre o literário e o performático, ou seja, as possibilidades de cena que são inerentes a todo texto teatral.

Em suas pesquisas a respeito de gêneros e história do texto teatral, Willians sempre se incomodou com certos determinismos literários, um exemplo foi o debate que travou com o crítico literário George Steiner a respeito da questão do trágico e sua historicidade, pois Steiner acreditava na "[...] impossibilidade da experiência trágica nos tempos modernos [...]. Acidentes de automóvel não podiam ser chamados de trágico"s.

Deste debate, surge a idéia de que não se deve negar a tragédia como tradição, mas que se deve sim reconhecer a pertinência de se falar em 'elementos trágicos' presentes numa obra literária, teatral e até mesmo nas nossas experiências contemporâneas. Mas, para isso, acreditou ser necessário enfrentar os princípios da teoria da tragédia, tais como ordem e acidente, a destruição do herói, a ação irreparável e a morte e a ênfase sobre o mal'.

Em recente entrevista jornalística, o crítico literário britânico Terry Eagleton, ao ser indagado se não estaríamos fadados a 'viver atualmente' uma tragédia grega, o Eagleton respondeu que sim, pois indícios e elementos trágicos estão muito presentes nos tempos atuais, principalmente quando se toca na questão dos recentes atos terroristas:

[...] Os mitos da Grécia Antiga contam histórias de limitações humanas, de barreiras que não podem ser ultrapassadas e sobre o alto preço que pagamos ao transgredir esses limites. Para o Ocidente, principalmente no tocante à cultura americana, o problema existe no desejo infinito. O Ocidente vive um mito faustiano de ganância perpétua, que nunca se contenta. E isso certamente nos levará à autodestruição ${ }^{7}$.

Pensando na atualização destes elementos trágicos no âmbito do literário/teatral e do real é que um importante dramaturgo brasileiro merece ser recuperado, pois também transitou pelas fronteiras dos gêneros, qual seja: o dramaturgo Jorge Andrade (1922-1984). É o que acontece ao se analisar textos como A Moratória (1954) e Rastro Atrás (1965), obras em que tenciona elementos formais como o drama e características do épico. Com perspectiva semelhante é o que o autor irá também realizar em Pedreira das Almas (1957), obra em que articula um enredo tecido a partir das proximidades e distanciamentos entre o drama e o trágico, ou melhor, elementos do trágico.

Os textos teatrais de Jorge Andrade foram escritos entre o início dos anos 1950 e meados da década de 1960. Dentre todas as características desse período, sempre se lembra a intensa democratização que marcou tal intervalo de tempo. Momento em que se debatiam os resultados do período Vargas, avaliava-se seu retorno ao poder e pesavam-se os impactos da abertura do país ao capital automobilístico estrangeiro. Também um período de expectativa com a prosperidade projetada pelo governo Kubitschek, assim como de endividamento, visando à realização de grandes projetos, como foi o caso da construção de Brasília.

\footnotetext{
${ }^{5}$ WILLIANS, Raymond. Tragédia moderna. São Paulo: Cosac \& Naify, 2002. p. 14.

6 WILLIANS, 2002, p. 70.

7 EAGLETON, Terry. Duelo de Titãs. Folha de S. Paulo, São Paulo, 04 jan. 2006. Caderno Mais!, p. 4.
} 
Ao lado disso, também foi um período em que se "respirou aliviado", com a saída de um momento marcado por guerras e ditaduras. Numa conjuntura mais ampla, pensando a América Latina em sua totalidade, a tensão acerca da ocupação do poder estava solta, haja vista que a Guerra Fria entre capitalistas e comunistas informava o debate ao sul do Equador.

Diante de tudo isso, algo pareceu evidente no debate público, a discussão em torno do tema da liberdade. Fora debatido em suas várias nuances: negação da ditadura anterior, liberdade para construir a nacionalidade e liberdade para evitar outras experiências ditatoriais.

É possível perceber que o debate sobre a questão da liberdade perpassou a aparente conotação política, alcançando também o meio artístico e estético dos anos 1950 e 1960. Para restringir-se apenas ao meio teatral, basta lembrar a evidência que o tema recebeu com o Teatro de Arena, o Teatro Oficina e o Teatro Opinião, especificamente, com a crescente pressão das forças conservadoras para a efetivação do golpe de 1964.

$\mathrm{O}$ dramaturgo Jorge Andrade viveu esse contexto em toda a sua intensidade. Estudou e formou-se em teatro, dialogou com referências teatrais e historiográficas do momento e, com a publicação e encenação de suas peças, procurou interferir no debate público que então se realizava em torno da questão da liberdade, fosse respirando democracia fosse receando a proximidade do golpe militar.

Diante da necessidade de enfrentar presente, Jorge Andrade não escreveu apenas uma peça, pois a riqueza da temática e a urgência do momento levaram-no a tecer tramas e personagens que dialogavam com importantes bandeiras de luta política da década de 1960, o que pode ser observado em As Confrarias (1968), Pedreira das Almas (1957), A Escada (1960), Rastro Atrás (1966) e O Sumidouro (1967).

Se há um tema em Jorge Andrade no qual se vislumbra a presença de 'elementos trágicos' em sua obra, sem dúvida é a forma como ele processa a busca da liberdade e, principalmente, como o dramaturgo tece suas personagens diante desta clássica 'bandeira' de luta política.

Assim, pode-se perceber que o tema da liberdade em Jorge Andrade não é propriamente inaugurado na década de 1960, pois, já em 1957, o texto Pedreira das Almas apontava para a presença do tema em sua dramaturgia. Nesta peça, o dramaturgo articula uma tripla temporalidade, visto que é escrita no final de década de 1950, mas possui um enredo que remete à Revolta Liberal de 1842. No entanto, ela é publicada, ao lado do conjunto da obra, em 1970, quando o país atravessava os momentos mais truculentos da ditadura militar.

A busca da liberdade é sustentada por tensões que também aparecem em outras peças, tais como a relação passado/presente, tradicionais/progressistas, no conflito entre aqueles que desejam partir e aqueles que precisam ficar.

Diante dessa polarização, a personagem Urbana destaca-se, pois ela viu a vila de Pedreira surgir, crescer e, frente à sua decadência, não quer deixá-la. A sua verdade é permanecer junto aos mortos de seu passado. Ela é a continuidade de uma tradição construída na 'rocha':

Urbana: Encontraram sinais estranhos na rocha, e uma imagem de São Tomé no nicho de pedras. "Este é o lugar para a cidade. São Tomé nos protegerá, como nos protegeu da tormenta!” Descobriram ouro na gruta. Abriram galerias que foram sair 
em dez pontos diferentes do morro, como se fossem dez portas de Pedreira. Mais tarde, partindo daqui, abriram lavras por todo o vale e fundaram novos lugarejos ${ }^{8}$.

A firme opinião de Urbana irá contrastar com o espírito novidadeiro dos mais jovens, entre eles, aparece Gabriel, que vê na partida para outras terras o único caminho de busca da prosperidade. Para cumprir seu objetivo, Gabriel procura aliciar Mariana a Martiniano, ambos de filhos de Urbana.

Esse conflito, que tem como pano de fundo o embate político entre liberais e conservadores, em 1842, prevalece até a chegada, em Pedreira, de um batalhão de policiais comandados pelo delegado Vasconcelos, que traz, algemado, o ‘subversivo' Martiniano.

Logo na sua entrada à cidade, Vasconcelos propõe trocar a liberdade de Martiniano pela delação de Gabriel. Inconformado com a possibilidade da troca, Martiniano - mártir? - se solta dos soldados e sai correndo. Aos gritos, a mãe e toda a vila vêem o jovem cair fuzilado. Após a morte, um novo conflito se apresenta, pois já não há mais lugar no cemitério, ninguém pode sair da vila para buscar terra para se construir novos túmulos. Como desafio à autoridade e às atrocidades do poder de Vasconcelos, Mariana sugere que o corpo fique exposto como exemplo.

Mariana: Leis! Leis! Não aceitamos, nem o povo de Pedreira das Almas aceitará suas leis.

Vasconcelos: (Áspero) Falo com dona Urbana.

Mariana: Respondo por ela e por Pedreira. Todas as leis que o senhor representa, não nos poderão arrancar nenhuma palavra, nem um gesto de acatamento às suas ordens. Abra as suas portas das prisões, traga os instrumentos de tortura, revolva e destrua a cidade, derrube as torres de nossa igreja...! Mas de nossas bocas jamais sairá uma única palavra de delação Os mortos sairão das lajes e os impiedosos serão destruídos! (Os soldados entreolham-se, admirados) Que um anátema caia sobre suas cabeças! Que o corpo de meu irmão fique exposto... será uma lembrança viva do seu pecado, da sua indignidade!

Vasconcelos: Veremos mais tarde, minha senhora, se não falam.

Mariana: O senhor tem as espadas... nós, aquilo que assassinos de sua espécie desconhecem: respeito à liberdade. É o que Gabriel representa para nós. Pagaremos, por ele, qualquer preço9!

Mais uma vez, retorna a imagem do corpo que permanecerá insepulto, o que reforça novamente a tensão entre as leis naturais e as leis do Estado. Diante do fuzilamento do irmão e a iminente prisão do namorado, a jovem Mariana assume a defesa da liberdade, pois se, anteriormente, seu direito de ir e vir era ameaçado pela força da tradição da mãe, no momento seguinte, a situação transforma-se, já que a questão da busca da liberdade ganha uma conotação política.

Após a perda do irmão e a fuga do revolucionário Gabriel, coube a Mariana o enfrentamento da opressão, no caso, representado na figura do delegado Vasconcelos.

\footnotetext{
${ }^{8}$ ANDRADE, Jorge. Pedreira das almas. In: p. 81-82 . Marta, a árvore e o relógio. São Paulo: 1970.

9 ANDRADE, 1970, p. 97.
} 
Mariana: Entre na igreja, diante de seus soldados, e prove que suas leis não são ímpias. Onde está sua justiça para ajudá-lo a transpor esta porta? Onde o poder que o levará até aqueles corpos? Não passam de mortos, disse o senhor! Então, deve ter coragem para insultá-los com sua presença. [...] Se o senhor não suporta, por que suportarão eles? O senhor nos prometeu um túmulo, se revelássemos onde está Gabriel. Gabriel está lá, como minha mãe, caído sobre Martiniano. O senhor nos impôs, como condição da sua opressão, o corpo exposto de Martiniano. Nós só lhe impomos, para a nossa delação, a sua entrada na igreja. Entre e veja o que suas leis fizeram dos homens, depois de terem feito à província, empobrecendo a terra com seus tributos e toda sorte de impiedades ${ }^{10}$ !

As leis do Estado parecem chegar àquela localidade pelas vias da força e da imposição, o que justifica as reações de Mariana e das demais mulheres. Considerando que esse texto perpassou os anos 1960 e só veio a ser publicado em 1970, há que se observar que ele estabelece um íntimo diálogo com a idéia de engajamento do período. A narrativa aponta claramente para os poderes opressivos e até mesmo para os métodos de tortura exercidos pelo Estado ditatorial.

Vasconcelos: Será processada e responderá pelo crime de Gabriel.

Mariana: Já estou com as mãos amarradas. Faça cumprir suas leis! Martiniano também estava, como está o povo da Província desde os dias da Bela Cruz. Desde que nossa montanha passou de sesmaria de ouro a pedra para os mortos. Onde está Gabriel? Onde os mortos estão expostos, e os vivos presos nas rochas, sonham com uma terra mais justa. Gabriel é a única saída deste túmulo imenso que seu Governo fez de Pedreira das Almas. Faça cumprir suas leis, já que não pode fazer os mortos reviverem. Este é o nosso preço, senhor. $\mathrm{O}$ meu e o seu. $\mathrm{O}$ senhor não terá nunca Gabriel, porque matou Martiniano... e eu... porque deixei Martiniano e minha mãe morrerem! Chame seus soldados e entre na igreja! Prove a eles que não teme os mortos. Que pode encarar seus crimes. (Silêncio. Vasconcelos continua imóvel) Governos como o seu, senhor, só executam leis ímpias, mas com braços subordinados ou mãos escravas. Não presenciam nunca a verdadeira imagem de suas vítimas. Se o senhor entrar... (Vacila, fazendo um grande esforço)... naquele rosto desfigurado... que era a própria imagem do nosso sonho... verá a que ficou reduzida a Província sob sua justiça! Só aí poderá saber o que Gabriel representa para nós. Entre!... e Gabriel será seu! Eu também prometo ${ }^{11}$ !

Aceitando o desafio, o delegado resolve entrar na igreja, e o que o leitor percebe é a indicação do dramaturgo que descreve a expressão de horror que domina o rosto de Vasconcelos. O que ele teria visto? Os corpos amontoados? Desfigurados? As indicações do autor não são diretas, deixando no subtexto o que o delegado teria presenciado dentro da igreja. Com toda certeza, estavam lá os corpos de Martiniano e Urbana, mas o estado em que estavam não é descrito claramente, cabe ao leitor/ diretor/espectador a construção do sentido.

Sabe-se, ainda, que o acontecido foi o suficiente para os soldados fugirem e 
o delegado desistir de Gabriel. Em seguida, Mariana entra para a igreja e proíbe as outras mulheres de contarem a Gabriel os fatos ocorridos. Ninguém deve comentar ou lembrar a imagem que se viu de Martiniano.

Ao fim, a vila apresenta sinais de abandono, empoeirada e com papel sendo levado pelo vento aos quatro cantos. Mariana, cada vez mais parecida com a mãe, é observada por Padre Gonçalo, dando indícios de que não vai partir com o restante da vila, nem mesmo para acompanhar Gabriel.

O diálogo final é entre Gabriel e Mariana, também é a última tentativa de demovê-la da idéia fixa de não partir para outras terras.

Mariana: Mais forte do que as promessas é a morte que nos liga à terra. Sinto tudo dentro do meu corpo, como se fizesse parte do meu sangue. As rochas... a igreja... o adro!

Gabriel: Mariana! Não podemos passar a vida venerando mortos. Foi para escapar a isso que sonhamos partir. É preciso saber escolher, Mariana. (...)

Mariana: Gabriel! Duas pessoas perderam a vida. Não compreendes? Duas pessoas que eram a minha família. Como queres que seja a mesma?

Gabriel: Também perdi a minha.

Mariana: Há muito tempo. Viveste sem ela.

Gabriel: Prometeste uma para mim. Não te lembras.

Mariana: Não a este preço.

Gabriel: Mas que preço? Foi o próprio mundo de Pedreira que matou Martiniano, como matou minha família.

Mariana: Nossos mortos não podem ser abandonados ${ }^{12}$.

A jovem Mariana assume todo o apego da mãe à vila de Pedreira. Não bastando, quer também estar junto aos mortos. Tal como a mãe quer valorizar o passado em detrimento do presente, o qual é representado pelo personagem Gabriel. $\mathrm{Na}$ despedida do jovem casal, é marcante a emoção construída:

Gabriel: Pedreira! Vista de longe, perdida entre as nuvens, parece uma estrela branca de mármore! (consigo mesmo) O passado é um monstro... que nos acompanha para onde vamos ${ }^{13}$ !

A personagem Urbana simboliza uma tradição consolidada, que valoriza o passado e os mortos da vila. Diante da 'velha senhora', Gabriel precisa satisfazer às necessidades históricas do presente, por isso, precisa do rompimento, deseja partir para outras terras e construir o novo. No início, Mariana acredita na urgência da partida, mas, diante do passado, que pode ser esquecido, resolve ficar e defender o direito à lembrança. Ela será uma inventora de tradições, a sua atitude de ficar irá provocar uma nova coesão na coletividade, não a mesma da mãe, mas sim, novas definições de comunidade e de pertencimento a um grupo ${ }^{14}$.

${ }_{12}$ ANDRADE, 1970, p. 112.

13 ANDRADE, 1970, p. 114.

${ }_{14}$ PINTO, Júlio Pimentel. Uma memória do mundo: ficção, memória e história em Jorge Luis Borges. São Paulo: Estação da Liberdade, 1998. p. 57. 
Essa peça de Jorge Andrade traz a defesa da liberdade, mas como uma bandeira daqueles que acreditam que as mudanças são possíveis, mesmo sacrificando vidas. Martiniano pagou este preço. Gabriel partiu para construir o novo, e Mariana articulou a novidade e o arcaico, o passado e o presente, rebelou-se contra as leis artificiais do Estado, entretanto, ao fim, apostou na conservação da tradição deixada pela mãe e seus antepassados.

Esses três personagens de Pedreira das Almas, mais uma vez, reforçam a idéia de que Jorge Andrade construía seus textos com os olhos no passado, mas com os pés no presente. Por ser escrita em 1957 e divulgada neste contexto auxiliou o dramaturgo a participar do debate do momento, qual seja: o processo de construção do 'homem novo'15.

A partir da década de 1950, vários setores da sociedade brasileira passaram a refletir a construção desse novo homem. Havia, assim, uma valorização da vontade de transformação, da ação humana capaz de mudar o curso da história. As raízes deste homem brasileiro deviam, portanto, ser buscadas no passado, no 'autêntico homem do povo', ainda com características rurais e sem a contaminação da urbanidade capitalista $^{16}$.

Pensando assim, Jorge Andrade aproxima-se das influências de esquerda, dos comunistas ou trabalhistas do final da década de 1950. Mas esta aproximação temática não é tranqüila no universo ficcional. Se as idéias da 'utopia revolucionária' propunham a ruptura, Jorge Andrade diferencia-se e lança um olhar singular sobre esse homem novo.

O dramaturgo mostra a coragem de Gabriel para romper com a tradição de Urbana. Mas, ao mesmo tempo, apresenta as agruras de Mariana com uma consciência que se divide entre o ficar e o partir. Se o dramaturgo ressalta a força do rompimento, não deixa de ser verdade que este se realizou com perdas, pois Gabriel teve de partir sem a noiva Mariana.

Se o homem novo das 'utopias revolucionárias' é decidido e está pronto para, se necessário, pegar em armas, o de Jorge Andrade titubeia entre passado e presente, ao duvidar da tradição e não vislumbrar que o novo que se aproxima deixa florescer toda sua humanidade, o que o faz pensar e pesar as perdas de suas decisões.

Por fim, a imagem do corpo insepulto em praça pública, tecida por Jorge Andrade, não caracteriza o texto como tragédia, tal como ocorre em Antígona de Sófocles, mas é uma intertextualidade que aponta para o que Raymond Willians descreve como a presença de 'elementos trágicos' nos textos da modernidade.

15 O final da década de 1950 reforçou, no campo das esquerdas, a procura deste homem novo, aquele "[...] a que se referia o jovem Marx, termo recuperado com entusiasmo na época pela revolução cubana - e pelos escritos daquele que é chamado romanticamente em Cuba de 'guerrilheiro heróico', Che Guevara”. RIDENTI, Marcelo. Em busca do povo brasileiro: artistas da revolução, do CPC à era da TV. São Paulo: Record, 2000. p. 120.

${ }^{16}$ RIDENTI, 2000, p. 24. 


\section{REFERÊNCIAS}

ANDRADE, Jorge. Pedreira das almas. In: . Marta, a árvore e o relógio. São Paulo:

Perspectiva, 1970. p. 71-116.

ARANTES, Luiz Humberto M. Do passado ao presente: história, textos e cenas na dramaturgia de Jorge Andrade. 223 p. Tese (Doutorado) - Pontifícia Universidade Católica de São Paulo, São Paulo, 2003.

ARANTES, Luiz Humberto M. Teatro da memória: história e ficção na dramaturgia de Jorge Andrade. São Paulo: Annablume: Fapesp, 2001.

ARISTÓTELES. Arte poética. São Paulo: M. Claret, 2003.

EAGLETON, Terry. Duelo de Titãs. Folha de S. Paulo, São Paulo, 04 jan. 2006. Caderno Mais!, p. 4-5.

MACIEL, Luiz Carlos. Geração em transe: memórias do tropicalismo. Rio de Janeiro: Nova Fronteira, 1996.

PINTO, Júlio Pimentel. Uma memória do mundo: ficção, memória e história em Jorge Luis Borges. São Paulo: Estação da Liberdade, 1998.

RIDENTI, Marcelo. Em busca do povo brasileiro: artistas da revolução, do CPC à era da TV. São Paulo: Record, 2000.

SARTRE, Jean-Paul. Que é a literatura? Tradução de Carlos Felipe Moisés. São Paulo: Ática, 1989.

WILLIANS, Raymond. Tragédia moderna. São Paulo: Cosac \& Naify, 2002. 


\section{TEATRo E COMUnidAde}

\section{Marcia Pompeo Nogueira}

Teatro na Comunidade é um fenômeno que se manifesta de diversas formas, assumindo diferentes nomes em diferentes países: teatro popular, teatro para o desenvolvimento, teatro radical do povo, teatro para a libertação, etc. Assim como nomes diferentes podem significar a mesma coisa, nomes iguais podem significar coisas diferentes. Nos Estados Unidos, por exemplo, o Teatro Comunitário é o nome dado para o que chamamos no Brasil de Teatro Amador. Trata-se de uma modalidade teatral difícil de definir, já que adquire diferentes formatos, ligada a diferentes instituições e finalidades. Baz Kershaw propõe a seguinte definição:

Sempre que o ponto de partida [de uma prática teatral] for a natureza de seu público e sua comunidade. Que a estética de suas performances for talhada pela cultura da comunidade de sua audiência. Neste sentido estas práticas podem ser categorizadas enquanto Teatro na Comunidade ${ }^{1}$.

O autor chama atenção para a natureza política deste tipo de teatro direcionado a platéias "cuidadosamente selecionadas". Mas antes de aprofundarmos nosso entendimento desta modalidade teatral, precisamos ter claro o que vem a ser comunidade. Ainda se pode falar de comunidade nos dias de hoje?

\section{O conceito de comunidade}

Quando falamos de comunidade a primeira imagem que geralmente se faz é de uma comunidade rural, pequena, estável, isolada geograficamente.

Pessoas interagiam umas com as outras enquanto seres sociais "totais" informados por um amplo conhecimento de cada um, cujos relacionamentos são freqüentemente formados por ligações de afinidade e consangüinidade ${ }^{3}$.

\footnotetext{
${ }^{1}$ KERSHAW, Baz The politics of performance: radical theatre as social intervention. Londes: Routledge, 1992. p. 5.

2 KERSHAW, 1992, p. 5.

${ }^{3}$ COHEN, Anthony. The symbolic construction of community. Londres: Routledge, 1985. p. 25.
} 
Esta perspectiva seria completamente distinta da comunidade urbana, caracterizada pela multiplicidade de contextos, no qual as pessoas:

Vivem em um [lugar] e trabalham em outro, viajam para ainda outros, indo talvez para outro lugar no seu tempo de lazer. Esta pluralidade de contextos é reproduzida estruturalmente na própria ecologia da cidade, dividida em zonas, claramente distinguível pela população e função. Os vestígios da comunidade seriam somente encontrados no nível das vizinhanças ${ }^{4}$.

Diante desta fragmentação e diferenças internas, pode-se até concluir que a comunidade não poderia sobreviver à industrialização e urbanização. Entretanto, Cohen chama atenção de que a unicidade aparente das comunidades rurais são simplificações, escondem diversidades, hierarquias, baseadas em diferentes bases: idade, posição social etc. O que daria a aparência de unicidade seria, segundo este autor, a aceitação de símbolos comuns sobre o significado da comunidade. A aceitação dos mesmos símbolos identifica uma comunidade, mesmo quando cada indivíduo o interpreta a sua maneira. Comunidade implicaria, portanto, em semelhanças e diferenças.

Qualquer comunidade - rural ou urbana - ou formas de associações, teriam a função estrutural e ideológica, segundo Raymond Willians, de mediar os indivíduos e a sociedade mais ampla 5 .

Para Kershaw, toda comunidade é parecida no que diz respeito às diferenças internas que abriga e ao papel de mediação que assume entre o indivíduo e a sociedade. Ele cita dois tipos de comunidade:

'Comunidade de local' é criada por uma rede de relacionamentos formados por interações face a face, numa área delimitada geograficamente.

'Comunidade de interesse', como a frase sugere, são formadas por uma rede de associações que são predominantemente caracterizadas por seu comprometimento em relação a um interesse comum. Quer dizer que estas comunidades podem não estar delimitadas por uma área geográfica particular. Quer dizer também que comunidades de interesse tendem a ser explicitas ideologicamente, de forma a que mesmo se seus membros venham de áreas geográficas diferentes, eles podem de forma relativamente fácil reconhecer sua identidade comum ${ }^{6}$.

No primeiro sentido, acredita-se que pessoas que vivem e/ou trabalham numa mesma região possuem determinadas vivências e problemas comuns, enquanto o segundo indica que algumas pessoas comungam idéias, se identificam por um olhar preconceituoso com que são vistas, ou sofrem uma mesma exclusão, como por exemplo: mulheres, homossexuais, negros, meninos de rua, domésticas, entre outros. Boal chama esses grupos de "temáticos - formados por participantes que, por alguma razão, ou idéia, algum forte objetivo se uniram [...]”7.

\footnotetext{
${ }^{4}$ SPENGLER apud COHEN, 1985, p. 25 -26.

5 WILLIAMS, Raymond. The long revolution. Harmondsworth: Pelican, 1965. p. 95.

${ }^{6}$ KERSHAW, 1992, p. 31.

7 BOAL, Augusto. Teatro legislativo. Rio de Janeiro: Civilização Brasileira, 1996b. p. 70.
} 
Desta forma, assumimos a conceituação de Anthony Cohen em relação ao entendimento do que é comunidade:

Comunidade não se define apenas em termos de localidade. [...] É a entidade à qual as pessoas pertencem, maior que as relações de parentesco, mas mais imediata do que a abstração a que chamamos de "sociedade". É a arena onde as pessoas adquirem suas experiências mais fundamentais e substanciais da vida social, fora dos limites do lar ${ }^{8}$.

\section{Origens do teatro na comunidade}

A origem deste teatro pode ser associada à própria origem do teatro, quando não havia separação entre quem faz e quem assiste o teatro. Ou como diz Boal, à festa popular:

"Teatro" era o povo cantando livremente ao ar livre: o povo era o criador e o destinatário do espetáculo teatral, que se podia então chamar "canto ditirâmbico". Era uma festa em que podiam todos livremente participar?.

Neste sentido, são consideradas raízes desse teatro as tradições populares pré-coloniais e greco-romanas. Já as raízes mais imediatas dessa modalidade podem ser associadas a movimentos mais recentes de reaproximação do teatro de seu público.

De forma bastante resumida ${ }^{10}$, pode-se dizer que o ponto de partida desta reaproximação do teatro com a comunidade foi o seu movimento de disseminação, cujo objetivo inicial era ampliar seu acesso para além do público burguês, que podia pagar os ingressos. Como, por exemplo ${ }^{11}$, o Movimento Socialista, especialmente durante a segunda internacional (1890 - 1914), entendia-se como mensageiro da cultura, com a função de levar educação e conhecimento para as massas. Baseado inicialmente em dramaturgia alheia aos interesses específicos da classe trabalhadora, envolvendo uma gama de peças que iam do melodrama ao naturalismo, o teatro era ainda limitado ao uso de estilos tradicionais. A proposta era oferecer alta cultura, evitando qualquer tentativa de instrumentalização.

Arte podia levar uma mensagem social, mas era senso comum, entre seus ideólogos e críticos [do movimento socialista], que ela serviria melhor ao movimento se fosse verdadeira para si mesma, absorvendo idéias emancipatórias, mas expressas, em primeiro lugar, artisticamente ${ }^{12}$.

\footnotetext{
8 COHEN, 1985, p. 15.

9 BOAL, Augusto. Teatro do oprimido: e outras poéticas políticas. Rio de Janeiro: Civilização Brasileira, 1983. p. 14.

${ }^{10}$ Para mais detalhes, ver NOGUEIRA, Marcia Pompeo. Towards a poetically correct theatre for development: a dialogical approach. 2002. 224 p. Tese (Doutorado) - Universidade de Exeter, 2002. Não publicada.

${ }^{11}$ Existem outros exemplos de práticas que integram este movimento de disseminação do teatro. Ver, entre outros, GARCIA, Silvana. Teatro de militância. São Paulo: Perspectiva, 1990. 208 p.

${ }^{12}$ SAMUEL, Raphael; MACCOLL, Ewan; COSGROVE, Stuart. Theatre of the left, 1880-

1935: workers' theatre movements in Britain and America. London: Routledge \& Kegan Paul, 1985. p. XVII.
} 
Contribuiu para este movimento de disseminação do teatro o novo entendimento do papel da classe trabalhadora na sociedade. Segundo a filosofia marxista, o proletariado passou a ser visto como classe revolucionária, que poderia guiar a sociedade na luta pela superação do capitalismo. Atingir este público passou a ser um objetivo de várias iniciativas.

A origem deste percurso também está associada a espetáculos teatrais que, a partir do início do século XX, passaram a assumir uma perspectiva política de transformação da realidade, e enfrentaram os limites da dependência econômica do teatro profissional. Montagens com objetivos políticos explícitos, apresentadas em teatros de regiões centrais, evidenciavam, na verdade, uma contradição: o conteúdo político, objetivo deste teatro, era apresentado apenas para um público burguês que podia pagar o ingresso. Esta contradição impulsionou dois movimentos: de um lado diversas iniciativas de atingir um novo público se efetivam através de turnês para os lugares mais remotos do globo; de outro experiências em que o público se transforma em ator ganham espaço ${ }^{13}$.

O percurso do Teatro de Arena, no Brasil, inclui um exemplo de questionamento da contradição vivida por grupos que tinham uma prática de teatro político e atuavam em casas de espetáculo situadas em regiões centrais. Como expresso por Vianinha:

O Teatro de Arena trazia dentro de sua estrutura um estrangulamento que aparecia na medida mesmo em que se cumprisse sua tarefa. O Arena era porta-voz das massas populares num teatro de cento e cinqüenta lugares ${ }^{14}$.

Essa contradição mobilizou o Arena e muitos outros grupos, em diversos países, para buscar um novo público, para sair das casas de espetáculo, ganhar a estrada, e levar o teatro para o povo.

Finalmente, indentificamos como raízes imediatas do Tearo na Comunidade as rupturas formais das convenções teatrais, fruto de diversos movimentos de vanguarda artística, que revolucionaram as práticas teatrais no século XX: o cenário havia deixado de ser necessário, e até mesmo o palco; teatro poderia ser feito em qualquer lugar. O fazer teatral passou a ser visto, por alguns artistas, como acessível a todos, os métodos de trabalho se democratizaram e processos de criação coletiva se multiplicaram.

\section{Formas do teatro na comunidade}

Segundo Van Erven, os diferentes estilos do Teatro na Comunidade se unem por "sua ênfase em histórias pessoais e locais (em vez de peças prontas) que são trabalhadas inicialmente através de improvisações e ganham forma teatral coletivamente" 15 . Seus materiais e formas sempre emergem diretamente (se não exclusivamente) da comunidade, cujos interesses se tenta expressar.

\footnotetext{
13 O próprio Teatro Didático de Bertold Brecht, onde não havia necessidade de expectadores, era fruto do enfrentamento dessa contradição.

${ }_{14}$ VIANINHA apud BERLINK, Manoel. O centro popular de cultura da UNE. Campinas: Papirus, 1984. p. 20.

${ }_{15}$ VAN ERVEN, Eugene. Community theatre: global perspectives. Londres: Routledge, 2001. p. 2.
} 
No percurso assumido pela prática de Teatro na Comunidade, identificamos basicamente três modelos, frutos de uma evolução histórica. Pode-se dizer que esses modelos partem de práticas decididas de cima para baixo, para práticas cujo objetivo e métodos são decididos pelas pessoas que participam dos projetos teatrais. Entretanto, este percurso não é o único, pois todas essas etapas podem ser encontradas ainda hoje. O que existe de comum entre todos esses modelos é que "são representados fora dos holofotes metropolitanos"16. Os três modelos seriam:

\section{Teatro para comunidades}

Este modelo inclui o teatro feito por artistas para comunidades periféricas, desconhecendo de antemão sua realidade. Caracteriza-se por ser uma abordagem "de cima pra baixo", um teatro de mensagem. Como nos diz Boal:

Usávamos nossa arte para dizer verdades, para ensinar soluções: ensinávamos os camponeses a lutarem por suas terras, porém nós éramos gente da cidade grande; ensinávamos aos negros a lutarem contra o preconceito racial, mas éramos quase todos alvíssimos; ensinávamos às mulheres a lutarem contra os seus opressores. Quais? Nós mesmos, pois éramos feministas-homens, quase todos. Valia a intenção ${ }^{17}$.

\section{Teatro com Comunidades}

Este modelo, em geral, parte de uma crítica do modelo anterior em termos da fragilidade dos resultados atingidos. Aqui, o trabalho teatral parte de uma investigação de uma determinada comunidade para a criação de um espetáculo. Tanto a linguagem, o conteúdo - assuntos específicos que se quer questionar - ou a forma - manifestações populares típicas - são incorporados ao espetáculo.

A idéia de vinculação a uma comunidade específica estaria ligada à ampliação da eficácia política do trabalho.

Os anos de contato com públicos específicos e comunidades específicas ensinaram uma importante lição aos trabalhadores do teatro radical: cada tipo de comunidade, cada tipo de grupo requer uma abordagem sob medida - de forma a se tornar eficaz culturalmente e, talvez social e politicamente ${ }^{18}$.

\section{Teatro por Comunidades}

O terceiro modelo tem grande influência de Augusto Boal. Inclui as próprias pessoas da comunidade no processo de criação teatral. Partindo de uma perspectiva crítica ao teatro de mensagem, Boal enfrenta um outro tipo de contradição do teatro com objetivos políticos. Esta proposta é relatada por Boal no formato de uma história sobre a reação de um camponês nordestino, das ligas camponesas. Ela expressa os fundamentos da evolução do teatro de mensagem em relação ao teatro participativo.

\footnotetext{
${ }^{16}$ VAN ERVEN, 2001, p. 243.

17 BOAL, Augusto. O arco-íris do desejo: método Boal de teatro e terapia. Rio de Janeiro: Civilização Brasileira, 1996a. p. 17-18.

${ }_{18}$ KERSHAW, 1992, p. 165.
} 
A história narrada por Boal começa quando, ao final de um espetáculo, os atores emocionados diziam: "Derramemos nosso sangue!". Após o espetáculo, o Sr. Virgílio veio conversar com os atores, emocionado, quase chorando: “- É uma beleza ver vocês, gente moça da cidade, que pensa igualzinho que nem a gente. A gente também acha isso, que tem que dar o sangue pela terra"19

Boal revela a alegria dos atores por sentirem que a mensagem tinha atingido o público, mas Virgílio, um homem descrito como alto e forte, continuou:

- E já que vocês pensam igualzinho que nem a gente, vamos fazer assim: primeiro a gente almoça (era meio dia), depois vamos todos juntos, vocês com estes fuzis de vocês, e nós com os nossos, vamos desalojar os jagunços do coronel que invadiram a roça de um companheiro nosso $[\ldots]^{20}$.

Assustados, responderam, com muito cuidado, que os fuzis eram adereços, que não eram armas de verdade. Mas Sr. Virgílio continuou:

— Se os fuzis são de mentira, pode jogar fora, mas vocês são gente de verdade, eu vi vocês cantando pra derramar o sangue, sou testemunha. "Vocês são de verdade, então venham com a gente assim mesmo porque nós temos fuzis para todo mundo"21.

Boal diz que "o medo fez-se pânico"22. E, com muito custo, explicou que eles eram artistas e que nem sabiam atirar. Então Sr. Virgílio concluiu: “-Então aquele sangue que vocês acham que a gente deve derramar é o nosso, não o de vocês...?”23.

Esta história marca a origem do Teatro do Fórum. Boal cita Che Guevara para explicitar a aprendizagem que esta vivência lhes proporcionou: "Ser solidário significa correr os mesmos riscos" 24 . Marca a crítica ao teatro de mensagem e uma abertura para uma nova perspectiva de teatro na comunidade. Em vez de fazer peças dizendo o que os outros devem fazer, passou-se a perguntar ao povo o conteúdo do teatro, ou dar ao povo os meios de produção teatral. Transformar o povo de espectador em ator.

Esta evolução proposta por Boal influenciou muitos trabalhos de teatro e comunidade no mundo todo. Ganhou forma um novo Teatro na Comunidade, cuja função seria fortalecer a comunidade. $O$ Teatro passou a ser a arena privilegiada para se refletir sobre questões de identidade de comunidades específicas, contribuindo para o aprofundamento das relações entre os diferentes segmentos da comunidade que podem, através da improvisação, do jogo teatral, explicitar suas semelhanças e diferenças. O teatro seria, neste sentido, porta-voz de assuntos locais, o que poderia contribuir para expressão de vozes silenciosas ou silenciadas da comunidade. Como dizem alguns autores, o teatro feito pela comunidade contribuiria para a "contínua regeneração do espírito de comunidade" 25 .

19 BOAL, 1996a, p. 18.

${ }^{20}$ BOAL, 1996a, p. 18.

${ }^{21}$ BOAL, 1996a, p. 18.

${ }^{22}$ BOAL, 1996a, p. 18.

${ }^{23}$ BOAL, 1996a, p. 19.

${ }^{24}$ BOAL, 1996a, p. 19.

${ }^{25}$ KERSHAW, 1992, p. 60. Referência de Baz Kershaw aos resultados de uma conferência sobre 


\section{Um exemplo de teatro comunidade africano}

A evolução de um teatro preocupado em trazer mensagens para o povo, para um teatro feito pelas pessoas teve também, na história do Kamiriithu, no Quênia, um modelo.

Ngugi wa Thiong'o e outros artistas do Departamento de Literatura da Universidade de Nairobi, que já assumiam uma postura política crítica através de suas peças teatrais nacionalistas radicais e antiimperialistas. Além da perspectiva crítica do conteúdo dessas peças, buscavam também quebrar os limites de um teatro formal e, ao mesmo tempo, buscavam ampliar o acesso a suas peças.

Ngugi wa Thiong'o foi procurado, em 1976, por uma moradora do Kamiriithu, vilarejo próximo a sua casa, para apoiar as atividades de um centro comunitário que estava passando por dificuldades. Como resposta a esta solicitação e pela insistência da senhora, ele resolveu contribuir. O resultado foi um projeto fantástico. Trabalhadores, camponeses, professores, desempregados e empresários construíram, com suas próprias mãos, um teatro ao ar livre de 2.000 lugares, que integrava o centro cultural, o qual passou a abrigar um curso de alfabetização e teatro.

A peça Ngaabika Ndeenda (Me Caso Quando Quiser), escrita por Ngugi wa Thiong'o e Ngugi wa Miiri, para a comunidade do Kamiriithu, bebeu nas fontes da luta por terra e liberdade, parte das lutas pela independência do Quênia, na qual muitos dos trabalhadores e camponeses da comunidade participaram, seja de forma ativa ou passiva. "Muitos viram suas casas serem queimadas; suas filhas estupradas pelos Ingleses; suas terras roubadas; seus parentes mortos"26.

A peça celebrava esta história e ao mesmo tempo mostrava como a independência, pela qual muitos quenianos morreram, estava sendo expropriada pelo poder neocolonial, ainda dominado pelos interesses britânicos. A peça também retratava as condições sociais contemporâneas dos trabalhadores, tanto nas multinacionais como nas plantações ${ }^{27}$.

A escolha da língua falada na peça foi crucial. Muitas peças revolucionárias da época eram representadas em inglês - língua duramente imposta pelos colonizadores e ensinada nas escolas - mas os camponeses não podiam entendê-la bem. A escolha do Gikuyu, língua local, ampliou a participação. Esta foi a primeira vez que Ngugi wa Thiong'o escreveu em Gikuyu. Educado em inglês, teve que aprender novamente sua língua mãe.

A experiência do Kamiriithu representou um enorme processo de aprendizagem para os professores universitários. Eles aprenderam com os atores e com a platéia, que contribuíram com elementos de suas experiências de vida, e até em relação às idéias gerais apresentadas na peça, que foi re-escrita durante o processo de criação:

O processo, particularmente para Ngugi wa Miiri, Kimani Gecau, e para mim foi de aprendizagem contínua. Aprendemos nossa história. Aprendemos o que acontece

Teatro na Comunidade, em 1983, no Dartington College, Inglaterra.

${ }^{26}$ THIONG'O, Ngugi Wa. Decolonising the mind: the politics of language in African literature. London: James Currey; Nairobi: EAEP; Portsmouth: Heinemann, 1986. p. 45.

27 THIONG'O, 1986, p. 44. 
nas fábricas. Aprendemos nossa língua, já que os camponeses eram essencialmente os guardiões da língua por anos de uso. Aprendemos também uma nova forma de Teatro Africano ${ }^{28}$.

A aprendizagem da forma veio do reconhecimento de como as músicas e as danças eram centrais para a vida das pessoas no Quênia, presente nas celebrações especiais como nas conversas cotidianas.

Em Ngaahika Ndeenda tentamos incorporar músicas e danças, como parte da estrutura e do movimento dos atores. A música vinha do que estava acontecendo em cena e liderava a cena que se seguia. A música e a dança viravam a continuidade da conversa e da ação ${ }^{29}$.

A montagem durou nove meses: de janeiro a setembro de 1977. Os ensaios aconteciam aos finais de semana e eram assistidos por cerca de 300 pessoas da comunidade, que contribuíam para o processo discutindo a forma como sua história vivida era apresentada, sugerindo detalhes sobre as danças e músicas, ajudando a reconstruir os rituais, encontrando a linguagem correta para personagens específicos em relação a sua idade e ocupação. Debates acalorados aconteceram durante todo o processo em relação à forma e ao conteúdo da peça. Mesmo o processo de representação era parte do processo educacional compartilhado e das contribuições coletivas:

A prática do Kamiriithu foi parte de um processo educacional, enquanto um processo de desmistificação do conhecimento e portanto da realidade. As pessoas podiam ver como os atores evoluíam do momento em que mal conseguiam mover suas pernas e dizer suas falas para o momento em que conseguiam conversar e se movimentar no palco como se tivessem nascido lá dizendo estas falas. Algumas pessoas eram recrutadas para o elenco depois de uma intervenção em que mostravam como este ou aquele personagem deveria ser mostrado. A platéia os aplaudia para que continuassem fazendo o papel. Perfeição foi assim mostrada como sendo um processo, um processo histórico social, mas era mesmo assim admirada. Pelo contrário se identificavam ainda mais com esta perfeição porque era um produto deles e de sua contribuição. Era uma elevação deles mesmos enquanto uma comunidade ${ }^{30}$.

A peça foi um sucesso enorme. Veio gente de todos os lugares para assistir. Isto assustou o governo, que agiu violentamente. Em 16 de novembro de 1977, o governo do Quênia baniu qualquer outra apresentação do espetáculo. Ngugi wa Thiong’o foi preso em 31 de dezembro de 1977 e passou todo o ano de 1978 em prisão de segurança máxima.

O espaço aberto que ajudou a comunidade queniana a reconectar-se com suas raízes rompidas representou uma ameaça maior para o governo do que as peças políticas feitas anteriormente por Ngugi wa Thiong'o, apesar das últimas terem um

${ }^{28}$ THIONG'O, 1986, p. 45.

29 THIONG'O, 1986, p. 45.

30 THIONG'O, 1986, p. 57. 
conteúdo revolucionário mais explícito. Lendo, por exemplo, a peça de Ngugi wa Thiongo's, The Trial of Dedan Kimathi (O Julgamento de Dedan Kimathi), seu conteúdo revolucionário é bem mais evidente do que em Vou me Casar Quando Quiser. Mesmo assim, o efeito político foi muito mais ameaçador para o governo, e provocou uma pressão política muito maior. A relevância política deste teatro na comunidade ia além de seu conteúdo, que incluía a participação da comunidade no processo criativo. A participação da comunidade em torno de seus próprios interesses representou um novo tipo de desenvolvimento.

Outras experiências em muitos outros países africanos guiaram-se nesta direção de uma arena dramática da comunidade, inspiradas pelo modelo do Kamiriithu, bem como nas idéias de Augusto Boal e Paulo Freire. O método evoluiu de acordo com a experiência em outros contextos, especialmente durante os anos 1980.

\section{Aspectos estéticos e éticos do teatro na comunidade}

Os processos de criação nesta área envolvem freqüentemente a interação de artistas classe média com pessoas de comunidades periféricas. Em termos metodológicos, esta interação exige o enfrentamento de muitas questões: como evitar uma relação de invasão cultural? Como criar uma relação dialógica? Como pode se dar a interação de culturas diferentes? Qual o papel do facilitador? Paulo Freire ${ }^{31}$ fornece as bases de muitos trabalhos que enfrentam este tipo de desafio. Seu método fundado no diálogo, no respeito pelo diferente, exige períodos preparatórios de conhecimento mútuo, em que ambos, comunidade e facilitadores, pesquisam a comunidade na busca de temas significativos que podem estar na base de processos teatrais conjuntos.

Freqüentemente, em trabalhos de Teatro na Comunidade, os objetivos são definidos em termos dos conteúdos:

O trabalho de teatro na comunidade é de criar uma dialética entre o estado presente e as possibilidades futuras de uma comunidade particular, moderada pelo conhecimento sobre e a identificação com estas comunidades ${ }^{32}$.

Mesmo não sendo o principal foco explícito de muitos trabalhos de Teatro na Comunidade, a questão estética também está presente. Como dissemos anteriormente, a produção de teatro, nesta área, é talhada pela cultura da comunidade. Trata-se de uma estética com padrões particulares que não pode ser julgada segundo parâmetros estranhos a ela:

O status de toda arte legítima e da alta cultura é confirmado por uma elite burguesa que promove seu próprio gosto social e culturalmente determinado enquanto naturalmente superior e relega a arte comunitária para uma categoria decididamente inferior de expressão cultural ${ }^{33}$.

${ }^{31}$ FREIRE, Paulo. Pedagogia do oprimido. Rio de Janeiro: Paz e Terra, 1977. 204 p

${ }^{32}$ KERSHAW, 1978 apud KERSHAW, 1992, p. 61.

${ }^{33}$ HAWKINS apud VAN ERVEN, 2001, p. 252. 
A superação desta perspectiva pode contribuir para enfocar um novo entendimento da estética do Teatro na Comunidade, de modo a superar a forma como esta área artística vem sendo marginalizada: “[...] não são somente os participantes considerados 'periféricos' [da periferia], teatro na comunidade enquanto uma forma artística também o é" ${ }^{34}$. Esta marginalização, que se reflete na falta de publicações a respeito, na falta de debate sobre seus resultados e da especificidade de sua estética, precisa ser superada para que possamos nos informar mais sobre as práticas existentes, para que estas práticas possam ser aprimoradas e que revertam em mais benefícios para as comunidades.

$\overline{{ }^{4} \text { VAN ERVEN, 2001, p. } 2 .}$ 


\section{REFERÊNCIAS}

BERLINK, Manoel. O centro popular de cultura da UNE. Campinas: Papirus, 1984.

BOAL, Augusto. O arco-íris do desejo: método Boal de teatro e terapia. Rio de Janeiro: Civilização Brasileira, 1996a.

BOAL, Augusto. Teatro do oprimido: e outras poéticas políticas. Rio de Janeiro: Civilização Brasileira, 1983.

BOAL, Augusto. Teatro legislativo. Rio de Janeiro: Civilização Brasileira, $1996 \mathrm{~b}$.

COHEN, Anthony. The symbolic construction of community. Londres: Routledge, 1985.

FREIRE, Paulo. Pedagogia do oprimido. Rio de Janeiro: Paz e Terra, 1977.

GARCIA, Silvana. Teatro de militância. São Paulo: Perspectiva, 1990.

KERSHAW, Baz The politics of performance: radical theatre as social intervention. Londes: Routledge, 1992.

NOGUEIRA, Marcia Pompeo. Towards a poetically correct theatre for development: a dialogical approach. 2002. 224 p. Tese (Doutorado) - Universidade de Exeter, 2002. Não publicada.

SAMUEL, Raphael; MACCOLL, Ewan; COSGROVE, Stuart. Theatre of the left, 18801935: workers' theatre movements in Britain and America. London: Routledge \& Kegan Paul, 1985.

THIONG'O, Ngugi Wa. Decolonising the mind: the politics of language in African literature. London: James Currey; Nairobi: EAEP; Portsmouth: Heinemann, 1986.

VAN ERVEN, Eugene. Community theatre: global perspectives. Londres: Routledge, 2001.

WILLIAMS, Raymond. The long revolution. Harmondsworth: Pelican, 1965. 


\section{FORMAR E FORMAR-SE EM TEATRO}

Maria Beatriz Mendonça (Bya Braga)

O presente texto trata de alguns aspectos da redescoberta do corpo no teatro do século XX e como a repercussão deste fato é evidente na formação do ator desde este período, qualificando este ato de formar.

Isto se revela não somente na prática de formação técnica em si, por meio das escolas formais de atuação, dos teatros-escola, teatros-laboratório, ou mesmo em grupos artísticos, como também pela difusão da ação-física como unidade mínima da atuação teatral, fruto da organização e codificação de seu próprio material-corpo, numa composição expressiva autoral. Também, nota-se tal valorização do corpo na experimentação cênica de um "teatro teatral", uma teatralidade da forma revelada ao logo do século XX.

Jacques Copeau foi um dos protagonistas do fenômeno da reteatralização do teatro na França, valorizando o estudo corporal nas suas práticas pedagógicas, em sua Escola Vieux-Colombier na Paris de 1920. Em busca de uma poética nova para o ator, Copeau propôs um modo diferenciado de educação teatral existente, que era fundada na tradição dos chamados "Conservatórios de Arte Dramática", comuns na Europa desde o século XIX.

A escola deve servir (na proposta de Copeau) para 'ultrapassar o ator'. Se por um lado, Copeau se distancia dos 'cabotinos do músculo' e da 'afetação' produzida por certos métodos novos (a referência à Rítmica de Dalcroze é explícita), ao mesmo tempo, por outro lado, ele estabelece no 'conhecimento e experiência do corpo humano' uma das tarefas prioritárias da formação do ator e elogia a 'ação real' no palco'.

O conhecimento de técnicas corporais, das disciplinas físicas que envolviam movimentos ginásticos, rítmicos, estudos das máscaras da Commedia dell 'Arte e de neutralidade, estudos de dramatização mímica, danças e improvisações corporais, é um valor priorizado na formação do artista cênico, no Vieux Colombier, com a intenção de "fazer com que o ator adquirisse consciência das possibilidades expressivas, em grande maioria inexploradas, e que estavam à sua disposição, pondo-o, assim, nas condições de poder transformar-se de intérprete-executante em criador"2.

${ }^{1}$ MARINIS, Marco de. Copeau, Decroux e o nascimento do mimo corporal. Tradução de J. R. Faleiro. Revista O Teatro Transcende, Blumenau, p. 46, 2004.

${ }^{2}$ MARINIS, 2004, p. 48. 
O valor do trabalho corporal também é difundido nas experiências de encenadores e pedagogos teatrais como C. Stanislavski, V. Meyerhold, E. Decroux, J. Grotowski, J. Lecoq, E. Barba e T. Suzuki, ou mesmo nas proposições de G. Craig, A. Appia e C. Dullin. A preocupação destes teatrólogos era (e é) com a "formação técnica do ator”. Para uma conceituação desta formação destaca-se, por exemplo, o pensamento de que a condução do exercício do ofício deve ser realizada, especialmente, por poucos professores, ou mesmo por um só mestre que pudesse proporcionar um desenvolvimento harmonioso entre o corpo do ator e seu próprio caráter.

Entretanto, "este modo de formação segundo o qual os atores elegem um mestre do mesmo modo em que este último os elege é um modelo pouco freqüente nas escolas institucionais" 3 . Por outro lado, percebe-se que as escolas formais de teatro no Brasil, cursos de formação de atores em nível médio ou os bacharelados de interpretação teatral, têm buscado, na medida do possível, se inspirar nas práticas difundidas pelos referidos teatrólogos, resguardando-se, evidentemente, os objetivos de cada proposta de ensino e prática nos referidos contextos. Mas, é evidente que as visões de atuação exercitadas nos teatros-laboratório e teatros-escola repercutem sobremaneira no dia-a-dia da escola institucional de teatro contemporâneo. Se isto não se dá na própria atitude do artista-professor e na sua prática de ensino, se revela em projetos de pesquisa-prática que valorizam o teatro de grupo e os processos de preparação técnica continuada de ator. Fortalecer na escola formal modos alternativos de aprendizagem associados a pesquisas-práticas é difundir uma idéia de atuação que está agregada ao exercício diário de treinamento técnico, bem como ao trabalho da interioridade do ator. Um trabalho como este, orientado por um artista-professor, pode se inspirar na ética de trabalho dos mestres ocidentais. Além disso, tais práticas, por estarem menos sujeitas às leis do mercado profissional do teatro, podem e devem sustentar o aprofundamento do trabalho técnico na busca de composições realmente experimentais. Portanto, na escola formal, há espaço para um exercício de atuação diferenciado em "Laboratórios de Atuação".

Ao lado da prática de ensino na escola institucional pode-se observar no Brasil processos de aprendizagem em meio ao trabalho de grupos e companhias teatrais - teatros-laboratório -, ou ao redor da prática de alguns encenadores que possuem também uma visão pedagógica.

Talvez o que esteja de fato na base de todas estas experiências e tentativas de aprofundamento técnico de ator é a aquisição e o exercício continuado de uma "ciência da ação". Para isso, em qualquer contexto, é necessário reconhecer o corpo, expandi-lo, sensibilizá-lo, isto é, "refazer o corpo", mas buscando-se o sentido profundo do fazer teatral e sua relação com a sociedade.

Neste momento, é importante lembrar que a necessidade do ator "refazer o corpo" foi marcada de modo radical em Antonin Artaud. Sua escritura teatral, poética fundamental, revelou a importância do ator dar forma à sua vida interior, isto é, diminuir uma defasagem que há entre o sentir e o expressar. Apesar dele não ter, na verdade, valorizado a técnica-prática corporal como meio de diminuir esta fenda, ele elaborou em seus escritos que o ator deveria experimentar a revelação de si na

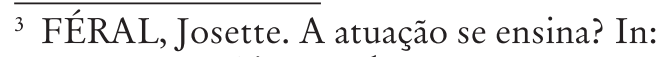
teras. Buenos Aires: Galerna, 2003a. p. 211. . Teatro, teoria y práctica: más allá de las fron- 
experiência física e sensorial. Mas, quando Artaud entra em contato com o teatro de Bali, bastante codificado corporalmente, um teatro de tradição cultural, ele pareceu compreender, então, a idéia da organicidade da forma. E, portanto, percebeu que a eficácia técnica não destrói a espontaneidade, o sentir, mas o faz durar no tempo por meio da ação. A técnica não é, porém, algo simples, frágil, ou mesmo sem utilidade na prática do ator. Pelo contrário. Nos escritos de Artaud pode-se perceber a valorização do ato de "refazer o corpo" como ato complexo, forte e até violento. Transformação essencialmente necessária ao ator. $\mathrm{E}$ em qualquer âmbito de formação.

Falar em transformação do corpo, estado físico numa natureza diferenciada, "extracotidiana", é pedir que a aquisição deste outro corpo passe por um processo de decomposição. Decompor para recompor. A decomposição, do ponto de vista técnico corporal, pode ser revelada no trabalho de consciência, segmentação e flexibilidade, em busca de movimentos plásticos que exteriorizem também o trabalho com a interioridade, num ato de escuta interna e externa para a composição de uma expressão orgânica. Dos teatrólogos citados neste texto, cada um, à sua maneira, experimentou ou ainda experimenta isso em diálogo com outras culturas e outros campos do conhecimento.

Refazer o corpo trata, portanto, do ato de re-elaboração física e mental que é "criação de si mesmo". Ou "alquimia, ciência da arte, recriação, metamorfose".

Faço agora um comentário específico, a título de curiosidade, que nos apontam valores do ato de refazer o corpo e podem fortalecer a idéia de formação tratada aqui. Falo da sociedade indígena e seus mitos, que entendo possuir conexão com o assunto deste texto.

Segundo Eduardo Viveiros de Castro ${ }^{4}$, a mitologia indígena entende que é pela corporalidade que nos enraizamos no cosmos e nos diferenciamos. No Xingu, a reclusão pubertária tem o objetivo de mudar o corpo do índio. Mas, porque fazem isso se o corpo irá "mudar" mesmo no processo da adolescência? O índio adolescente, nesta "clausura", faz uma dieta complexa, exercita aprendizagem artesã, toma remédios vegetais na busca de uma espécie de purgação e de criação de uma forma corporal estética desejável na tribo. A passagem do índio por esse processo o torna "bem-educado". Há uma ligação da evolução física com a evolução moral. Nesta sociedade educar significa "transformar o corpo". Certas atividades que consideramos simbólicas, transcendentes, para os índios são atividades corporais. A atividade do Xamã, por exemplo, exige uma condição corporal apta ao seu trabalho. Sua eficácia de ação relaciona-se diretamente à sua condição de preparo pessoal. Outro aspecto curioso da relação com o corpo é que a noção de parentesco, na visão ameríndia, pode-se dar pós-natalmente, e não só pré-natalmente. Esta é uma concepção que se relaciona às aquisições adquiridas na convivência. Pode-se, assim, "assimilar" o corpo do outro pela convivência. A corporalidade comum se dá pela troca estabelecida pelo grupo. O corpo é, então, visto como um "organismo aberto". E, com isso, pode-se, de fato, "fazer corpos". Tal fazer relaciona-se diretamente com a abertura do corpo às trocas possíveis, mas reconhecendo também a responsabilidade com o outro.

Da exposição acima, destaco a questão da "metamorfose", pois no universo

${ }^{4}$ O antropólogo Eduardo V. de Castro (UFRJ) proferiu palestra na UFMG, no Curso de Artes Cênicas, em 16/05/05, a qual assisti, contribuindo, então, para algumas reflexões expostas aqui. 
ameríndio o corpo é o lugar da diferença, e não o da semelhança, do comum a todos, como muitas vezes acreditamos.

Volto, então, ao pensamento sobre o ator criador, o ator "metamorfoseador", aquele que forma e se forma com a arte do teatro, e que precisa de uma técnica para isso.

$\mathrm{Na}$ preparação para esta metamorfose, que pode gerar uma composição no sentido de uma teatralidade da forma, elabora-se uma estruturação por meio de princípios que podem ser traduzidos aqui pelo o que diz Fayga Ostrower:

Formar importa em transformar. Todo processo de elaboração e desenvolvimento abrange um processo dinâmico de transformação, em que a matéria, que orienta a ação criativa, é transformada pela mesma ação. Transformando-se, a matéria não é destituída de seu caráter. Pelo contrário, ela é mais diferenciada e, ao mesmo tempo, é definida como um modo de ser. Transformando-se e adquirindo forma nova, a matéria adquire unicidade e é reafirmada em sua essência. Ela se torna matéria-configurada, matéria-e-forma, e nessa síntese entre o geral e único é impregnada de significações ${ }^{5}$.

A percepção sobre a forma na exposição de Ostrower é importante para que valorizemos o ato criador do artista cênico na busca de sua própria recriação de identidade.

A forma é algo em si delimitado - mas não no sentido de uma área demarcada por fronteiras. Nem, aliás, nas artes plásticas a forma se resume a configurações de superfície, a uma espécie de silhuetas. A forma é o modo por que se relacionam os fenômenos, é o modo como se configuram certas relações dentro de um contexto. [...] A forma será sempre compreendida como a estrutura das relações, como o modo por que as relações se ordenam e se configuram 6 .

Talvez sejam nestas relações que mais nos formamos, nos construímos, elaboramos e nos expressamos. No ato de formar, exercitando o formar-se, trabalhamos sobre nós mesmos. Exercitamos uma primeira configuração por meio de técnicas apreendidas e de princípios de ordem filosófica, sociológica, entre outros.

Mas, considerando-nos à parte do pensamento ameríndio citado, localizando-nos no mundo urbano contemporâneo, em muitas vezes dissociado de tradições culturais e históricas, como despertar este "trabalho sobre nós mesmos"? Ou, ainda, como aprofundá-lo, mantê-lo, transmiti-lo?

Fundamentalmente, faz-se necessário conhecer as experiências realizadas na formação de atores do século XX e refletir sobre suas bases ideológicas e estéticas. É imprescindível também possuir um diagnóstico claro sobre o momento histórico atual da aprendizagem cênica no Brasil, e nos locais que será exercitada, bem como sua relação com a profissionalização, isto é, com o aspecto econômico do fomento e manutenção da arte teatral. Também, é necessário o desenvolvimento de uma preparação técnica artística específica, mais difundida como treinamento de ator, em bases técnicas cor-

OSTROWER, Fayga. Criatividade e processos de criação. Petrópolis: Vozes, 1987. p. 51.

${ }^{6}$ OSTROWER, 1987, p. 79. 
porais consoantes com o momento cultural e histórico (de cada um ou cada grupo), que promova a vivência do aprendizado sobre o próprio corpo do atuante, seus limites e bloqueios. A partir do trabalho de sensibilização corporal e consciência, que podem ser fundamentados nos trabalhos da Educação Somática, pode-se elaborar um programa de vivências corporais e exercícios físicos de acordo com o perfil dos participantes. Começa-se, então, um trabalho na direção de um treinamento continuado de ator, mas que sempre deverá estar apto a transformações.

Para que o treinamento seja o percurso de uma vida, deve inscrever-se na duração. [...] É preciso concebê-lo como uma 'formação contínua' para que permita realmente que o ator, como o músico ou o bailarino, mantenha seu instrumento (físico e psíquico) em condições, quer dizer em estado de criação${ }^{7}$.

O treinamento pode se realizar de modo coletivo e individual. No modo individual há a possibilidade de se investigar as próprias resistências para o ato da metamorfose necessária, e de modo mais adequado às possibilidades físicas e mentais de cada um. Mas, o jogo do treinamento não deve se distanciar da busca de esboços de estruturas, do ato de configuração. "Como lembra Grotowski, todos esses movimentos não devem ser produzidos inutilmente. A pesquisa da forma é importante, pois é unicamente através dela que escapamos do treinamento repetitivo para entrar na arte"

Se o treinamento de ator é uma proposição para uma formação humana, de recriação e metamorfose, podemos dizer que este é um sentido importante do ensino da atuação.

Para Copeau, o ensino teatral em si é também uma arte. Isto porque seu princípio deve ser o de elevação do ser humano, não algo exclusivamente técnico. Trata-se de um projeto de formação que prevê espaço de escutas internas, externas, bem como espaço de exposição extrema. Se é técnica psicofísica, esta prevê o exercício do humano, das relações interpessoais, da reflexão de valores éticos e estéticos da atualidade. A prática de orientação deste caminho necessita não só de sabedoria conteudística. Necessita vivência, tolerância, rigor, clareza, cuidado, humor, escuta e olhar refinados, responsabilidade extrema e desejo de convivência com um outro em todas as suas complexidades.

Trata-se, portanto, de uma liderança difícil e que exige constante aprimoramento. É tentador concordar com G. Craig quando ele diz que "atuar não se ensina”, ou mesmo apoiar certo pensamento bastante difundido de que ator não se faz, nasce. $\mathrm{E}$, ainda, de defender que o treinamento é somente um meio pelo qual há o despertar da inspiração, o estabelecimento do estado de criatividade e que não estabelece a configuração. "Estas convicções diversas sobre a natureza da atuação remetem, de fato, a uma questão muito mais pragmática e muito mais complexa sobre a pertinência do ensinamento teatral. Que é o que se pode ensinar verdadeiramente ao ator? Que formação pode ser dada a ele?"”.

Esta questão, às vezes, se apresenta a mim por estudantes-atores em período

7 FÉRAL, Josette. Você disse training? In: teras. Buenos Aires: Galerna, 2003b. p. 174.

${ }^{8}$ FÉRAL, 2003b, p. 176.

9 FÉRAL, 2003a, p. 204.

. Teatro, teoria y práctica: más allá de las fron- 
de iniciação de sua formação. Existe uma ansiedade e uma necessidade de afirmação das pessoalidades que revelam, de fato, pressões sofridas com a questão da formação artística, sobre o que é isso de fato, e o que conseguirão conquistar num curso de atuação. Somado a isso existe uma crítica pública de artistas importantes, como Eugênio Barba, às escolas formais (como os cursos de graduação em artes cênicas, por exemplo) que, segundo ele, mesmo possuindo profissionais eficazes estão sujeitos a contextos estruturais ou ideológicos complexos, que interferem diretamente em sua prática influenciando negativamente na formação nos aspirantes a ator.

Já tratei desta questão mais acima e o que posso ainda dizer é que percebo a formação do ator como algo móvel entre arte e ciência.

Certamente, a ciência de que se trata aqui não é uma ciência pura cujos preceitos são claros, unívocos e normativos. Trata-se mais de métodos diversos criados de maneira pragmática por meio de experimentações diversas. Eles permitem escapar de uma aprendizagem intuitiva da atuação ${ }^{10}$.

Se o teatro pode ser ensinado, pode-se aprender de diversas maneiras, mesmo porque existem variados teatros, mesmo que eu defenda aqui técnicas corporais como técnicas fundamentais para o ator. Há pessoas que necessitam aprendê-las por meio de artistas-professores, mestres únicos ou orientadores profissionais. Há aqueles que diante de uma vivência pessoal artística continuada, em grupos ou não, conseguem estabelecer as próprias orientações, organizando, inclusive, proposições técnicas de formação para si e para outros. Talvez não exista uma regra única de formação de ator. O que de fato está implícito na convivência com os artistas-formadores talvez seja, em si, a idéia do trabalho continuado, o exercício permanente do atuante, sob uma orientação experiente e sensível, que conduza trabalhos de revisão técnica, experimentações práticas e composições autorais. Mas, ainda penso que o que está mesmo no cerne da questão da formação é a busca do formar-se. E para isso é preciso uma rigorosa metamorfose.

\section{REFERENCIAS}

$\overline{10}$ FÉRAL, 2003a, p. 206. 
FÉRAL, Josette. A atuação se ensina? In: Teatro, teoria y práctica: más allá de las fronteras. Buenos Aires: Galerna, 2003a. p. 203-218.

FÉRAL, Josette. Você disse training? In: Teatro, teoria y práctica: más allá de las fronteras. Buenos Aires: Galerna, 2003b. p. 165-180.

MARINIS, Marco de. Copeau, Decroux e o nascimento do mimo corporal. Tradução de J. R. Faleiro. Revista O Teatro Transcende, Blumenau, p. 45-56, 2004.

OSTROWER, Fayga. Criatividade e processos de criação. Petrópolis: Vozes, 1987. 


\title{
Pesquisa na licenciatura em Artes CÊnicas
}

\author{
Maria Lúcia de Souza Barros Pupo
}

Entre as atribuições do professor universitário, a atividade de ensino, paradoxalmente, não goza entre nós do mesmo prestígio proporcionado pela atuação em pesquisa. $O$ fato, por exemplo, de o ensino ser menos sujeito a avaliações e a modalidades de controle por parte da instituição ilustra bem essa constatação. Se a autonomia do professor é uma prerrogativa incontestável de seu trabalho, a observação indica que o relativo isolamento do docente acaba não favorecendo o debate sobre questões de ensino/aprendizagem, centrais em seu cotidiano. Raramente ensino e pesquisa são encarados como dimensões que se alimentam reciprocamente, no conjunto das funções docentes; a segunda delas tende a ganhar proeminência em detrimento da primeira.

Nos limites restritos deste artigo, nossa intenção é levantar questões acerca da relação entre a formação e a pesquisa dentro da Licenciatura em Artes Cênicas, de modo a indicar caminhos, tendo em vista a superação da dicotomia entre essas duas esferas da atuação docente.

A referência da qual nos valemos é a Licenciatura em Artes Cênicas oferecida pela Escola de Comunicações e Artes da Universidade de São Paulo. Em seu âmago, o que se propõe é uma reflexão sobre as finalidades, as condições, os métodos e os procedimentos relativos a processos de ensino/aprendizagem dentro de manifestações da cena contemporânea.

A meta é formar um profissional capaz de coordenar processos artísticos efetivamente sintonizados com os desafios das manifestações cênicas de nosso tempo, seja em termos da educação formal - escolas de educação infantil, ensino fundamental e ensino médio - seja no âmbito da ação sócio-cultural - no quadro das políticas públicas, em organizações não-governamentais, centros culturais, associações, prisões, hospitais e outros contextos.

Assim sendo, fazemos nosso o enunciado formulado pela Comissão Permanente de Licenciaturas da USP que, em 2004, trabalhou em prol da valorização e redimensionamento das licenciaturas oferecidas por aquela universidade. $\mathrm{O}$ que se pretende é a "formação de um profissional competente, socialmente crítico e responsável pelos destinos de uma sociedade que se deseja justa, democrática e auto- 
-sustentável”" Nosso desafio, portanto, é traduzir essas metas em termos artísticos, mais precisamente, cênicos.

O recrutamento dos estudantes da Licenciatura em Artes Cênicas é feito já há cerca de 15 anos, de modo específico. Ao se inscrever para o concurso vestibular, o candidato já é levado a optar entre o Bacharelado - que compreende as habilitações de Interpretação, Direção Teatral, Teoria e Crítica e Cenografia - e a Licenciatura. As provas específicas do concurso vestibular para a Licenciatura ocorrem na segunda e última fase da seleção e têm como objetivo avaliar a disponibilidade de jogo do candidato, sua capacidade de reflexão crítica a partir de leituras específicas, assim como suas condições de analisar criticamente uma prática artística na área.

À primeira vista pode parecer estranha a solicitação de tal escolha a jovens recém saídos do ensino médio, antes mesmo de serem admitidos na universidade. Separar assim de modo categórico Bacharelado e Licenciatura, dimensões do conhecimento teatral tão entrelaçadas entre si, pode parecer, de imediato, incoerente. Tal medida, no entanto, tem uma razão de ser: ela busca enfatizar a importância do papel da universidade na formação de docentes. Consideramos de primordial importância que a USP destine anualmente dez vagas no vestibular para a formação de professores de Artes Cênicas, na perspectiva de assegurar para essa área - nem sempre suficientemente conhecida pelo grande público - a relevância que caracteriza as relações entre as artes da cena e a tarefa educacional.

A posição de destaque atribuída pela USP à formação de docentes em Artes Cênicas apresenta sem dúvida repercussões favoráveis em todo o território nacional e contribui para que a Pedagogia do Teatro se desenvolva entre nós. A organização curricular em pauta foge à fórmula indesejável "conhecimentos específicos da área + disciplinas didáticas". Desde o início da escolaridade, estudantes da Licenciatura e do Bacharelado, juntos, problematizam as complexas questões vinculadas às funções sociais do teatro em nossa sociedade. Dentro de disciplinas como "Teatro e Educação I e II" e "Prática de Ensino I a III", centrais dentro da habilitação Licenciatura e oferecidas dentro do próprio Departamento de Artes Cênicas, são trazidas à tona teorias, experiências, indagações, que configuram o corpo de conhecimentos na área.

Destacaremos a partir de agora dois dispositivos de trabalho nos quais se dá de modo tangível a articulação entre formação e pesquisa à qual nos referimos há pouco. Graças em grande parte a eles é que nosso curso vai além da simples transmissão de conteúdos tidos como desejáveis, mas se propõe a gerar novos conhecimentos sobre a Pedagogia do Teatro. O primeiro desses dispositivos diz respeito à integração entre a graduação e a pós-graduação; o segundo está vinculado à prática de ensino.

\section{Graduação e Pós-graduação, uma via de mão dupla}

Desde os anos noventa, a USP abriga o Programa de Aperfeiçoamento de Ensino - PAE, destinado a alunos de pós-graduação de mestrado e doutorado nela matriculados, cujo objetivo é o de aprimorar a formação do pós-graduando para a atividade didática de graduação. Com exceção dos estudantes beneficiados com a

${ }^{1}$ UNIVERSIDADE DE SÃO PAULO. Pró-Reitoria de Graduação. Comissão Permanente de Licenciaturas. Programa de formação de professores. São Paulo, 2004. p. 7. 
Bolsa Demanda Social da Fundação Coordenação de Aperfeiçoamento de Pessoal de Nível Superior - Capes, para os quais o estágio é obrigatório, o PAE é opcional para os alunos de pós-graduação da Universidade.

Os professores de graduação desejosos de receber um estudante PAE em sua sala de aula apresentam um programa de atividades destinado a um estagiário a ser posteriormente determinado. Os estudantes interessados em desempenhar esse papel passam por uma preparação pedagógica em forma de conjunto de conferências com especialistas das áreas de Educação e de Arte, tendo como tema questões vinculadas ao ensino superior. Uma vez acertada a dupla docente-discente que vai trabalhar de modo associado, iniciam-se as atividades, que normalmente se estendem por um ou dois semestres letivos.

A título de ilustração, apresentamos em rápidas palavras um exemplo de estágio PAE, dentro da disciplina "Prática de Ensino III", por nós assegurada. Duas vertentes complementares caracterizam o domínio dessa disciplina: por um lado, os estudantes observam situações de aprendizagem teatral em diferentes locais, fora dos muros da Universidade; por outro, nos encontros que correspondem às aulas propriamente ditas, os processos observados são objeto de exame pelo conjunto dos alunos, à luz da bibliografia especializada e de discussões de caráter pedagógico, assumidas coletivamente.

No contexto das aulas de "Prática de Ensino I, II e III", de fato, os estudantes se defrontam com as mais variadas questões envolvidas em processos educacionais. Aspectos de caráter artístico, institucional, e, naturalmente, de caráter especificamente didático se entrecruzam dentro de situações concretas de aprendizagem do teatro, configurando, por si só, a complexidade e a relevância da disciplina.

No caso em pauta, propusemos ao estagiário um esquema de atuação de seis horas semanais, distribuídas entre diferentes tipos de ação pedagógica:

Organização do cronograma de estágio dos estudantes da turma, a partir do elenco de instituições e entidades proposto pela professora responsável;

- Apresentação e discussão do projeto de pesquisa de mestrado ou doutorado Em curso;

— Levantamento de bibliografia específica relacionada às questões suscitadas pelos estudantes nos contextos observados;

- Contribuição no trabalho coletivo de elaboração de instrumentos de observação a serem utilizados pelos estudantes;

- Coordenação de seminários de reflexão sobre a prática;

— Orientação relativa à elaboração dos relatórios finais de estágio.

Essa aproximação entre a graduação e a pós-graduação strictu sensu, sem dúvida, constitui um avanço palpável para o estreitamento das relações entre a transmissão do conhecimento já adquirido e a formulação de novos saberes, missão precípua do ensino superior. 
Muitos são os benefícios do projeto do ponto de vista do pós-graduando. $\mathrm{O}$ contato direto com a problemática do ensino do teatro em diferentes esferas pode ser de grande valia para o desenvolvimento de sua pesquisa, caso seu tema tenha correlações com essa diversidade. Sem dúvida, o interesse por questões de ensino será ampliado, assim como as habilidades de cunho propriamente didático. Tomar conhecimento do conteúdo da disciplina de graduação, assim como reunir elementos que permitam uma visão mais abrangente das relações humanas dentro da sala de aula são, certamente, outras conquistas efetivadas.

$\mathrm{Na}$ ótica dos estudantes de graduação as vantagens também são nítidas. Eles passam a contar com a colaboração sistemática de um pesquisador envolvido com investigação acadêmica dentro do próprio campo para o qual estão sendo formados, o que, certamente, passará a constituir fonte de novos questionamentos e reflexões. Ao entrarem em contato com os embates e desafios da pesquisa através da experiência do estagiário PAE, sua visão sobre o ensino será dinamizada e enriquecida, pois pesquisa implica, inevitavelmente, capacidade de fazer perguntas, de colocar em xeque o já instituído, a capacidade de inventar. Os futuros professores nesse momento em formação inicial são, assim, incentivados a levantar questões sobre sua própria prática como regentes de classe ou coordenadores de oficina, prática essa que, aliás, não raro se inicia bem antes do momento previsto dentro da chamada "grade curricular".

Um terceiro ponto de vista que cabe levar em conta é o do docente responsável pela disciplina de graduação. As repercussões advindas do diálogo sistemático com o estagiário se fazem sentir em termos de um estímulo à contínua reformulação, tanto do conteúdo proposto, quanto das modalidades escolhidas para trabalhá-lo. Os riscos de cristalização do desempenho do professor universitário ficam, assim, significativamente reduzidos.

\section{Processos de aprendizagem teatral na berlinda}

Gradativamente, ao longo das disciplinas "Prática de Ensino I a III" e, na seqüência, dentro do chamado "Trabalho de Concluso de Curso (TCC)", os estudantes passam da observação de situações de aprendizagem de teatro, para a coordenação de situações dessa natureza.

Ao longo dos estágios de observação - em educação formal e informal - os estudantes aprendem a problematizar as situações objeto de sua atenção. O que se dá, em última análise, é uma investigação sobre as práticas; eles são convidados a interrogar a ação pedagógica que se desenrola diante de sua presença, aprendendo a valer-se das referências teóricas - oriundas tanto dos estudos teatrais quanto da pedagogia - como instrumento para abrir férteis perspectivas de análise.

O TCC, que se sucede àqueles estágios, é um momento-chave na formação, ocasião em que o estudante é convocado a se valer dos diferentes conhecimentos elaborados ao longo da escolaridade universitária, tendo em vista a formulação de um projeto de aprendizagem teatral a ser por ele coordenado.

Como já se pode vislumbrar, estamos diante de uma perspectiva de formação profissional fundada na reflexão sobre a própria prática, nos moldes de trabalhos já bastante difundidos, como é o caso, entre outros, de autores como Giroux e 
Perrenoud. Parte-se de problemas ligados a processos de ensino-aprendizagem, que se tornam objeto de exame por parte do estudante. Na seqüência, se dá o caminho inverso: a partir da investigação sobre a própria ação pedagógica, ele é novamente remetido à prática, agora em um novo patamar, ao qual foi integrada a análise crítica.

Nessa medida, espera-se que o estudante da Licenciatura, uma vez formado, esteja em condições de produzir novos conhecimentos, sendo capaz de:

— Formular com precisão questões sobre o significado, a natureza e as modalidades da sua intervenção;

- Prever procedimentos sistemáticos e rigorosos que possam ser colocados a serviço da busca de resposta a essas questões;

— Proceder à apresentação e divulgação dos resultados obtidos.

A elaboração do chamado TCC se inicia, portanto, com um projeto teatral preciso, envolvendo a coordenação de um processo de aprendizagem em teatro dentro de um contexto escolhido pelo aluno. No bojo desse projeto, nosso estudante é convidado a levantar uma ou mais perguntas sobre sua própria prática, de modo a poder refletir sobre suas opções, sua conduta e/ou demais aspectos de sua intervenção.

Subjaz a esse encaminhamento um ponto de vista singular sobre a subjetividade do pesquisador; longe de ser encarada como um obstáculo, ela é incorporada como parcela relevante para a produção de conhecimento em arte.

Ao longo do semestre letivo no qual se dão os encontros de trabalho sobre os passos do TCC dentro da universidade, os estudantes apresentam seus projetos em forma de seminário. Cada um desses textos é colocado na berlinda, de modo a receber contribuições dos demais membros da turma, estimulados a examinar sua formulação, ainda em processo. Percebe-se sem dificuldade a riqueza de tal dispositivo, no qual cada um aprende com as aspirações e as dificuldades do outro.

Dois ou três meses mais tarde, no final do cronograma previsto para a duração do processo teatral, dispositivo semelhante é instaurado, tendo agora como meta colocar em pauta a redação da monografia correspondente ao TCC propriamente dito.

As hesitações e impasses característicos do desafio representado pelo ato da escrita em circunstâncias dessa ordem foram por nós analisados em artigo recente ${ }^{2} \mathrm{e}$ constituem, sem dúvida, tema para caudalosas considerações. Por ora, vale lembrar que se trata de um momento delicado na perspectiva do estudante, que deve organizar seu pensamento e registrá-lo, de modo a partilhá-lo com leitores estrangeiros ao seu percurso.

O procedimento ao qual acabamos de fazer referência é o da discussão coletiva a partir do sumário de cada um dos textos de TCC, em fase de elaboração. Promover o debate em torno do sumário do texto final apresenta a vantagem de focalizar o âmago da organização do pensamento do autor; a estruturação entre as partes é reveladora de conquistas e de fragilidades no plano da exposição das idéias.

Cada um dos sumários, uma vez colocado na berlinda, engendra comentários, críticas, sugestões cuja manifestação constitui, em si mesma, outro aprendizado.

${ }^{2}$ PUPO, Maria Lúcia de Souza Barros. Rituais de iniciação. Revista da FUNDARTE, Montenegro, ano 4, v. 4, n. 8, p. 42-44, jul./dez. 2004. 
Entre as contribuições verificadas, salientam-se:

— Indicações bibliográficas;

- Apontamentos que contribuem para a explicitação mais clara de motivações, intenções, dificuldades;

— Indicações relativas à precisão de referências teóricas, temas e conceitos;

— Sugestões relativas à documentação da pesquisa;

— Propostas referentes à organização dos tópicos, visando a articulações mais coerentes, produtivas e originais entre eles.

É em relação a este último item que se revela de modo mais nítido a riqueza do procedimento. O exame do sumário do colega pode ser especialmente revelador das fragilidades do seu próprio. Envolvidos com o desafio de conceber uma estruturação satisfatória para as considerações pretendidas, os estudantes se mostram particularmente sensíveis às soluções encontradas pelos companheiros. Examinar o sumário do outro constitui, simultaneamente, um eficaz exercício de autocrítica.

Há um aspecto que chama a atenção dentro dessas considerações, por seu caráter recorrente nas diferentes turmas: a desejável tessitura entre o referencial teórico e a experiência empírica. Advertidos ao longo de vários semestres sobre a necessária alimentação recíproca entre essas esferas e colocados diante do desafio de mostrar essa articulação no cerne do texto em processo, os alunos se dão conta, quase sempre pela primeira vez, da complexidade da tarefa. Nesse sentido, multiplicam-se as proposições tendo em vista a elaboração de uma tessitura que possa responder, pelo menos provisoriamente, a esse difícil requisito.

O trabalho de conclusão de curso vem sendo tornado público por ocasião de uma mostra anual organizada pelos licenciandos, que reúne também a apresentação das manifestações teatrais por eles coordenadas. Grupos de diferentes pontos da capital e municípios vizinhos, trabalhados pelos formandos, comparecem à universidade para mostrar as realizações que, direta ou indiretamente, estão na base dos TCC. A variação do formato dessas apresentações é o coração mesmo da proposta; de aulas abertas a encenações já buriladas, passando por performances e formas breves, um significativo leque de modalidades evidencia para o público a multiplicidade da cena contemporânea.

A monografia, por sua vez, é objeto de uma sessão também pública, na qual intervêm pelo menos dois docentes: um professor convidado e o professor responsável pela disciplina "TCC”, além de a palavra ser estendida ao público presente.

Estamos novamente diante de uma rica situação de aprendizagem: na berlinda, a produção de cada um dos alunos gera descobertas relevantes para o conjunto da turma.

O leitor destas páginas certamente sabe que os caminhos aqui descritos não são tão regulares quanto podem levar a crer, como tampouco são isentos dos recuos e hesitações que costumam estar no cerne da tarefa de formação.

Ao destacar, por um lado, a articulação entre a graduação e a pós-graduação e, por outro, o questionamento da própria prática teatral como fonte de pesquisa, nossa intenção é apontar pistas que conduzam à progressiva autonomia do estudante em sua busca de construção de conhecimento. 


\section{REFERÊNCIAS}

PUPO, Maria Lúcia de Souza Barros. Rituais de iniciação. Revista da FUNDARTE, Montenegro, ano 4, v. 4, n. 8, p. 42-44, jul./dez. 2004.

UNIVERSIDADE DE SÃO PAULO. Pró-Reitoria de Graduação. Comissão Permanente de Licenciaturas. Programa de formação de professores. São Paulo, 2004. 


\section{TEATRO, JOGO E BRINCADEIRA: \\ UMA PROPOSTA DE REELABORAÇÃO do CAVALO MARINHO \\ EM PROCEDIMENTOS PEDAGÓGICOS PARA O ATOR}

\section{Mariana Oliveira}

Este artigo apresenta parte dos resultados da pesquisa de mestrado $O$ jogo da cena do Cavalo Marinho: diálogos entre teatro e brincadeira, desenvolvida no âmbito do projeto integrado Um estudo sobre o cômico: o teatro popular no Brasil entre ritos e festas, sob orientação da Profa. Beti Rabetti (Maria de Lourdes Rabetti), no Programa de Pós-Graduação em Teatro da Uni-Rio. Através de trabalho de campo com observação participante na zona da mata norte pernambucana, especialmente na cidade de Condado, e de laboratório experimental realizado na Escola de Teatro da Uni-Rio, procurou-se discutir o lugar, no teatro, da brincadeira, categoria adotada pelos realizadores do Cavalo Marinho ao designá-lo. Manifestação espetacular de múltiplas origens, das quais aquela localizada entre os escravos nas senzalas dos engenhos canavieiros costuma ser a mais referida pelos brincadores, apresenta-se hoje principalmente por contrato nas festas de rua municipais por ocasião do Natal, do Ano Novo e das homenagens aos santos padroeiros nos meses de dezembro e janeiro.

Os diálogos travados entre os dois fenômenos, tanto no plano teórico, analítico e conceitual quanto no da experimentação prática, que em verdade ocorrem não dissociados, mas entrelaçados e de maneira orgânica, são atravessados pela noção de jogo: primeiro porque participa das essências de ambos, sendo o "próprio modo de ser da obra de arte" ${ }^{1 \text { ", }}$ e, segundo, porque se tem mostrado recorrente nas reflexões acerca do teatro contemporâneo.

As idéias gerais da brincadeira e do teatro aproximam-se em pontos que constituem também características lúdicas: faz-de-conta, universo imaginativo, estado diferenciado de presença, ambiente instável, estabelecimento de relação, harmonia, ritmo, absorção, encantamento, circunscrição espaço-temporal, capacidade agregadora, regramento, repetição, acaso, atenção, relaxamento, liberdade, ordem, crença, consciênciaª .

\footnotetext{
${ }^{1}$ GADAMER, Hans-Georg. A ontologia da obra de arte e seu significado hermenêutico. In: Verdade e método. Petrópolis: Vozes, 1997. p. 174-201.

${ }^{2}$ HUIZINGA, Johan. Homo ludens. 5. ed. São Paulo: Perspectiva, 2004. 243 p.
} 
Alguns desses fatores evidenciam-se quando o teatro funciona plenamente, quando se diz que "o jogo acontece". Um último elemento que participa tanto do ser jogo, quanto do ser teatro e do ser brincadeira é a “diversão”, isto é, uma "volta ou 'versão' de nosso ser para o ultravital ou irreal", para um mundo "diferente", termo usado pelos brincadores para designar com positividade a autonomia da brincadeira em relação às leis da realidade cotidiana. Acerca disso, vale o comentário feito por mestre Mariano Teles durante entrevista dada à autora em 31/12/04, em Chã de Camará, zona rural do município de Aliança/PE, sobre a confecção das máscaras do Cavalo Marinho:

A máscara [...] pode sair até um pouco parecida com a gente, mas ela pode sair uma coisa mais divulgada, diferente, ela pode não ficar mesmo a feição de uma pessoa $[. .$.$] a gente tem que fazer ela mais estranha [. .$.$] tem que fazer a máscara$ diferente e a gente nunca faz que nem uma obra da natureza [...] só é bonita porque é feia, que se fosse bonita, a gente não queria nem olhar.

A instauração de um ambiente especial e de um universo imaginativo faz da “cena em jogo" uma realidade autônoma, livre da preocupação de representar fielmente o que está além dela e que trabalha com o que se dá no ato, no presente. Para jogar em teatro, além de saber repetir, é necessário estar aberto para o inesperado e lidar com ele de forma não mecanizada, mas com disponibilidade e escuta. Executar opõe-se a jogar, ação que se dá consigo mesmo, com o ambiente, com o outro ator e com o público.

Após essa série de aproximações, é necessário atentar para a não identidade absoluta entre jogo, teatro e brincadeira. Se no jogo em geral todos são jogadores, no representativo, no teatro ou na instância espetacular, como a brincadeira, a ação se dá em relação a alguém:

O jogo não é mais, aqui, um mero representar-se de um movimento ordenado, nem mesmo um mero representar, no qual se revela a criança que brinca, mas é, "representando para...”. Essa indicação, própria a todo representar, também será resgatada aqui, tornando-se constitutiva para o ser da arte ${ }^{4}$.

Assim, dá-se a transformação do jogo em configuração, isto é, sua consumação em ser arte. A separação palco/platéia marca o limite entre o princípio lúdico e o jogo teatral ${ }^{5}$.

No que tange às práticas teatrais contemporâneas, incluindo as performances, percebe-se que ganham espaço reflexivo questões tais como as da presença, do imprevisto, da escuta (atores/atores, atores/espectadores, atores/ambiente) e das dualidades lúdicas evidenciadas em experiências que exploram os limites entre tempos, espaços e sujeitos reais e ficcionais.

A análise de alguns aspectos fundamentais da brincadeira do Cavalo Marinho estreita os diálogos com o fazer teatral contemporâneo:

${ }^{3}$ ORTEGA Y GASSET, José. A idéia do teatro. São Paulo: Perspectiva, 1991. p. 51

${ }^{4}$ GADAMER, 1997, p. 184, destaques da autora.

${ }^{5}$ PAVIS, Patrice. Dicionário de teatro. 2. ed. São Paulo: Perspectiva, 1999. 512 p. 
1) a abertura e a fragmentação da dinâmica de apresentação, com dissolução do encadeamento causal, mistura de gêneros e valorização do estilo épico-narrativo, remetem diretamente à estrutura não aristotélica, mas feita por colagens, justa e sobreposições, sem necessária sucessão lógica ou coerente de ações bem definidas, também encontrada nas performances e em outros exemplos da cena contemporânea;

2) a aprendizagem não sistemática, mas por bricolagem, observando a diver sidade de saberes e fontes, relaciona-se à maneira de se estudar teatro hoje, em meio a uma enormidade de estilos, escolas e tradições;

3) a configuração espacial da roda coloca atuantes e espectadores em relação diversa daquela que define espaços distintos de atividade versus pura passividade, contribuindo para a investigação contemporânea acerca das possíveis formas de relação entre atuação e recepção;

4) o modo de "colocar figura" reporta à interpretação citacional ou ilustrativa vista em muitas experiências teatrais contemporâneas nas quais não se constitui exatamente nem o personagem dramático nem o narrador, mas algo entre eles, numa função enunciativa, como a que cumpre a figura de mestre Ambrósio no Cavalo Marinho. Numa espécie de prólogo e através de mímicas e danças específicas, ele apresenta as demais figuras. Essas, próximas dos personagens-tipo, são colocadas por um pequeno número de "figureiros" ao longo de uma brincadeira, em episódios curtos, verdadeiras passagens. Mantêm-se num plano bastante superficial, não tridimensional e sem profundidade, e questionam a representação pela ambigüidade estabelecida em relação à própria pessoa do figureiro;

5) o destaque da dimensão do significante sobre a do significado constitui aspecto também verificável no teatro contemporâneo. Na brincadeira, o modo de construção poética e a repetição de trechos dialogados fazem esmaecer o sentido profundo do texto falado e chamam a atenção para sua sonoridade.

As experiências teatrais contemporâneas, como "práticas significantes"” que não visam à revelação de um sentido preexistente, mas geram uma polifonia de significados, são ainda marcadas por recorrências: paródia, citação, linguagem lírico-narrativa, tendência miscelânica, indecisão quanto ao gênero de manifestação artística, multiplicidade de referências culturais, mobilidade ou ambigüidade de sentidos (o signo perde a relação estável entre o significante e o significado), auto-ironia, tensão entre atualidade cênica e relato, problematização da representação do sujeito e da estrutura tradicional do personagem $^{8}$. Dentre elas, algumas claramente dialogam com os aspectos da brincadeira acima citados.

6 Figura é o termo utilizado no Cavalo Marinho para designar espécies de personagens-tipo, elaborados principalmente a partir de um nome enunciativo e de um roteiro de ações na roda da brincadeira. Ex.: o Soldado da Gurita vem prender os negos Mateus e Bastião, para que dêem a licença para o Capitão "dar o baile na cidade"; a Véia do Bambu vem atrás de seu pássaro perdido, a Ema, e demonstra ser muito "fogosa" diante dos homens presentes, colocando-os debaixo de sua saia.

7 PAVIS, Patrice. La herencia clásica del teatro postmoderno. In: . El teatro y su recepción, semiologia, cruce de culturas y postmodernismo. Cuba: UNEAC, $\overline{1994 . ~ p . ~ 207-223 . ~}$

${ }^{8}$ DA COSTA, José. Narração e representação do sujeito no teatro contemporâneo. O Percevejo: Revista de Teatro, Crítica e Estética, Rio de Janeiro, ano 8, n. 9, p. 3-24, 2000. 
As artes da performance também constituem espaço de releitura e rediscussão dos conceitos estruturais da cena, rompendo com a representação e aproximando-se da vida. São alguns de seus traços característicos: estrutura não aristotélica, ambigüidade entre personagem e a própria pessoa do artista, caráter de evento, de rito, dialética entre tempos e espaços ficcionais e reais, que convivem sobrepostos, relação mais mítica ou ritualística que estética entre espectador e objeto artístico, com possibilidade de maior grau de atividade daquele". Aqui, também se verificam coincidências em relação ao observado na análise da brincadeira.

Estabelecidos esses assuntos comuns, propõe-se estender os diálogos entre teatro e brincadeira para o campo da experimentação prática. Para tanto, é preciso refletir acerca da maneira de enfrentar o objeto do Cavalo Marinho:

\begin{abstract}
No que se refere à possibilidade de percepção de acervos técnicos, talvez devêssemos suspender o encantamento aflorado pela visão de uma natureza característica, e, então, indagar por um sistema de códigos, tão singulares quanto longamente elaborados. E, acredito, será através do cuidadoso exercício de compreensão e recuperação destes códigos, e através de sua precisa reelaboração em métodos e técnicas adequados à arte da cena, que um teatro popular pode vir a se articular de maneira mais efetiva, isto é, como expressão artística e criadora autônoma $[\ldots . .]^{10}$.
\end{abstract}

Ou seja, os "códigos da brincadeira" podem se oferecer para "reelaboração" no âmbito teatral, sem se deixar de atentar para o fato de que esse processo constitui “[...] não uma absorção cênica estreita e simplista de persistentes manifestações populares encontradas nas correntes artísticas ou festivas de culturas tradicionais [...]" ${ }^{11}$. Não se trata de reprodução, mas de um "diálogo forte" com a tradição, de maneira que sejam percebidos "códigos (persistências) e variáveis (aptas para adequações a novos tempos ou a novos sentidos)" capazes de gerar "combinações inovadoras"12. Essa experiência materializou-se no âmbito do laboratório experimental O jogo da cena do Cavalo Marinho: experimentando teatro e brincadeira.

Aqui a noção de jogo volta a ser importante, mais especificamente no modo de trabalho com os atores-pesquisadores do laboratório, que lançaram mão de diversos exercícios lúdicos reelaborados a partir do universo temático, do repertório técnico e de momentos especiais do Cavalo Marinho.

Ao longo do tempo, os jogos dramáticos e teatrais passam a desempenhar atraente função pedagógica no ensino do teatro: na década 1940, encenadores franceses criam a Educação pelo jogo dramático, estabelecendo tradição verificável nas propostas de Jean-Pierre Ryngaert ${ }^{13}$; na década de 1950, Viola Spolin constrói um sistema de jogos teatrais e improvisacionais amplamente difundido no teatro-educação; no Brasil, os exemplos d'O Tablado de Maria Clara Machado e de Augusto Boal confirmam a tendência para o recurso do jogo no ensino da linguagem teatral. O laboratório seguiu

\footnotetext{
${ }_{9}$ COHEN, Renato. Performance como linguagem. São Paulo: Perspectiva, 2002. 176 p.

${ }^{10}$ RABETTI, Beti. Memória e culturas do "popular" no teatro: o típico e as técnicas. O Percevejo: Revista de Teatro, Crítica e Estética. Rio de Janeiro, ano 8, n. 8, p. 7-8, $2000 .$.

11 RABETTI, 2000, p. 11.

12 RABETTI, 2000, p. 11-12.

${ }_{13}$ MARTINS, Marcos Bulhões. Encenação em jogo: experimento de aprendizagem e criação do teatro. São Paulo: Hucitec, 2004. 245 p.
} 
esse caminho.

Assim, redimensionou-se a noção de brincadeira, não mais exclusivamente a categoria usada pelos praticantes do Cavalo Marinho para designá-lo, mas também a própria definição para determinada maneira de se pesquisar e trabalhar em teatro. Nesta nova concepção, outros dois conceitos são fundamentais: o "estado da brincadeira" e o "corpo-que-brinca". O primeiro traduz-se por um estado de concentração relaxada ou de atenção sem tensão que ocorre em corpos conectados, trabalhando em conjunto, e o segundo refere-se ao corpo que experimenta tal estado, pronto, preciso, em escuta, e que se organiza com soltura articular, oposições segmentares e agilidade de movimentação.

O “corpo-que-brinca” avizinha-se da imediata resposta à excitação dos reflexos preconizada por Meyerhold, em 1969 e do "corpo decidido" de Barba ${ }^{14}$. Evidencia-se no trabalho energético promotor de disponibilidade física e mental para a criação, construído a partir da dança do Cavalo Marinho e, ainda, numa série de jogos úteis para o treino de habilidades específicas para um ator presente, ativo e ágil, e para o estímulo à sua capacidade imaginativa.

O trabalho energético desenvolveu-se através do treinamento na dança do Cavalo Marinho, feito livremente no espaço a partir da célula rítmica usada no "Tombo do marguio", espécie de jogo-dança em roda. No centro da roda, duplas de participantes se alternam, estabelecendo instigantes diálogos corporais, e dos "passos soltos", maneira encontrada para designar os passos de dança que constituem o repertório geral da brincadeira. Caminhando e marcando a pulsação da música, os alunos-pesquisadores acrescentavam, aos poucos, contratempos, pausas, quedas, suspensões e aproximações com colegas. Esse exercício gerou um estado de disponibilidade, tanto física, pela mobilização do corpo todo, como também de jogo, isto é, de estabelecimento de relação com o outro, através do olhar e do diálogo corporal. Desenvolveu a ampliação do campo de visão, além de um refinamento dos sentidos e da percepção, e revelou-se um jogo de presença ao requerer atenção múltipla, distribuída entre ritmo, espaço, olhar, encontro. Neste jogo de conjunto, todos marcam o tempo juntos e vigorosamente, estabelecendo conexão com a terra. A pulsação, a exaustão e o desafio diante dos limites relacionam-se à geração daquele "estado de brincadeira" comparável à diversão e ao prazer da brincadeira de criança. Em determinado momento, o corpo, impulsionado pelo diálogo com o outro e pela força coletiva, ultrapassa o estágio do cansaço para alcançar uma espécie de leveza.

Entre os outros jogos experimentados, vale comentar, especialmente, o "Tombo do marguio", o "Não pague não, Capitão!”, o "Sinhá véia, sinhá moça”, o "Capitão viu?", o "Roda de figuras” e o "Capitão mandou chamar?”. O primeiro, realizado tal qual no Cavalo Marinho, revela códigos estruturantes da brincadeira. Nele, importa não tanto o desempenho individual, mas o aspecto coletivo, como no próprio sentido de jogo:

Se considerarmos o uso da palavra jogo [...] sempre está implícito o vaivém de um movimento, o qual não está fixado em nenhum alvo, no qual termine. A isso corres-

${ }_{14}$ MEYERHOLD, V. O ator e sua atuação. In: CONRADO, Aldomar (Org.). O teatro de Meyerhold. Rio de Janeiro: Civilização Brasileira, 1969. p. 173-174; BARBA, Eugenio. A canoa de papel: tratado de antropologia teatral. São Paulo: Hucitec, 1994. p. 54. 
ponde também o originário significado da palavra jogo como dança, que sobrevive em múltiplas formas de palavras [...]. O movimento, que é jogo, não possui nenhum alvo em que termine, mas renova-se em permanente repetição. $\mathrm{O}$ movimento de vaivém é obviamente tão central para a determinação da natureza do jogo que chega a ser indiferente quem ou o que executa esse movimento. [...] $\mathrm{O}$ jogo é a consumação do movimento como tal ${ }^{15}$.

No "Tombo do marguio", jogo-dança, o vaivém do movimento é experimentado praticamente nos corpos dos jogadores-dançarinos que dispõem de uma estrutura básica de passo dentro da qual lhes é permitido o improviso. Asseguradas a continuidade e a fluência do jogo, o aspecto pessoal pode e deve inserir-se no conjunto.

O “Não pague não, Capitão!", reelaborado a partir das chamadas "cobranças" do Cavalo Marinho, realiza-se em roda ao som de música. Em determinado momento, um jogador, de "corpo decidido", entra na roda desafiando outro com o olhar. O primeiro "cobra" o segundo, ameaçando-o com rasteiras, pernadas, giros ou outros movimentos até imobilizá-lo através de uma "chave de pernas". A intenção de prender o outro gera tensão lúdica, constituindo uma das tarefas do jogo, mas não o seu único objetivo: “[...] o verdadeiro fim do jogo não é, de forma alguma, a solução dessas tarefas, mas a regulamentação e a configuração do próprio movimento do jogo" 16 .

Isto é, os jogadores devem preocupar-se com o que fazem na trajetória em direção aos fins. Assim, a alternância de dinâmicas de movimentação (rápidas ou lentas, curvilíneas ou retas), o seu uso criterioso (para distrair ou ameaçar, por exemplo), o olhar concentrado no outro, a manha, a malícia, o enfrentamento, o corpo tático, que joga para desfazer o jogo do outro, encontrando brechas para escapar quando encurralado, fazem daquele momento um acontecimento vivo e interessante.

O "Sinhá véia, sinhá moça” utiliza uma curta passagem do episódio da Véia do Bambu, figura do Cavalo Marinho, para estabelecer um jogo em roda. Uma pessoa entra e coloca uma máscara de Véia; os demais cantam anunciando a chegada de seu marido que lhe traz um presente. A Véia escolhe alguém e pergunta de que presente se trata. Repetindo-se essa dinâmica uma série de vezes, configura-se um jogo cumulativo em que o jogador que cumpre a função da Véia tem que lembrar a cada vez todos os presentes trazidos pelo marido. Além disso, porém, importa fundamentalmente que o aluno-ator construa aos poucos, na ação e na relação com os demais, a sua Véia, sem ter estabelecido a priori composição de voz ou de postura.

No “Capitão viu?” uma célula textual do diálogo entre mestre Ambrósio e Capitão, figuras do Cavalo Marinho, é reutilizada, objetivando desenvolver uma "palavra que brinca", isto é, uma palavra que segue uma estrutura pré-definida, mas que tem liberdade de variar, de improvisar, desde que de maneira precisa e sem perder de vista o roteiro. A repetição também faz com que o foco não esteja na obediência ao tempo psicológico de ação, reflexão e reação coerentes, mas na própria sonoridade gerada, na forma de se dizer. Em roda, ao som da música, um voluntário 
entra e realiza a dança de uma figura. Em seguida, pergunta ao Capitão se a reconheceu, desencadeando o diálogo pré-definido. Ao final, deve realizar a dança de outra figura e assim por diante. $\mathrm{O}$ jogador tem que ter atitude e decisão.

Os dois últimos jogos, mais propriamente de reelaboração, "Roda de figuras" e "Capitão mandou chamar?", visam à criação de novas figuras, inspiradas no repertório técnico e temático do Cavalo Marinho. No primeiro, em roda e ao som de música, uma pessoa entra realizando uma dança que revele o estado de sua figura. Os demais participantes propõem um nome significativo para aquela figura. No segundo, alguém assume a função de Capitão, dizendo para que mandou chamar aquela figura e, assim, auxiliando na definição de sua ação específica.

Além dessas atividades, exercícios improvisacionais calcados nas idéias de roteiro, repertório e figuras, à semelhança da dinâmica estudada na brincadeira do Cavalo Marinho, constituem interessante engrenagem cênica teatral que, a partir de estrutura mais ou menos fixa, oferece espaço para inúmeras novas combinações. Essa noção de improvisação como espaço combinatório assemelha-se àquela da Commedia dell'arte, cuja imagem da liberdade e da espontaneidade constitui uma falsa idéia do que, na verdade, está relacionado a uma habilidade derivada de intensa prática geradora da possibilidade de uma "composição veloz"17. Como diz mestre Antônio Teles, irmão de Mariano, deve-se "criar pela memória”, ou seja, não se trata nem de jogo totalmente livre, no qual se improvisa acerca de um tema mais ou menos definido, nem de texto ou partitura absolutamente fixos e imutáveis; trata-se de um jogar entre o roteiro e o improviso.

Assim, o modo de trabalho constituído, passível de aproveitamento em pesquisas ulteriores para elaboração de eficaz treinamento para atores, caracteriza-se, de maneira geral, pelas discussões diárias acerca do fazer, pelo trabalho coletivo, do qual a configuração dos exercícios em roda é emblemática e, ainda, pela atividade prazerosa perpassada por divertimento e comicidade.

Os elementos estéticos, o recurso da máscara, a metalinguagem, o estilo épico-narrativo integram, ainda, o "sistema de códigos" 18 da brincadeira colocado à disposição para direta utilização na cena com vistas a potencializar sua força expressiva. Os materiais do Cavalo Marinho oferecem-se, assim, como poderoso acervo "indutor", isto é, "propulsor da criação em arte"19, enriquecendo os diálogos entre brincadeira e teatro e, de maneira efetiva, as próprias práticas teatrais contemporâneas.

17 TAVIANI, Ferdinando. Once puntos para entender la improvisacion em la Commedia dell'arte. Máscara: Cuaderno Iberoamericano de Reflexion sobre Escenologia, México, ano 4, n. 21-22, p. 5, jan. 1997.

${ }_{18}$ RABETTI, 2000, p. 7.

19 RABETTI, 2000, p. 4. 


\section{REFERÊNCIAS}

BARBA, Eugenio. A canoa de papel: tratado de antropologia teatral. São Paulo: Hucitec, 1994.

COHEN, Renato. Performance como linguagem. São Paulo: Perspectiva, 2002.

DA COSTA, José. Narração e representação do sujeito no teatro contemporâneo. O Percevejo: Revista de Teatro, Crítica e Estética, Rio de Janeiro, ano 8, n. 9, p. 3-24, 2000.

GADAMER, Hans-Georg. A ontologia da obra de arte e seu significado hermenêutico. In: . Verdade e método. Petrópolis: Vozes, 1997. p. 174-201.

HUIZINGA, Johan. Homo ludens. 5. ed. São Paulo: Perspectiva, 2004.

MARTINS, Marcos Bulhões. Encenação em jogo: experimento de aprendizagem e criação do teatro. São Paulo: Hucitec, 2004.

MEYERHOLD, V. O ator e sua atuação. In: CONRADO, Aldomar (Org.). O teatro de Meyerhold. Rio de Janeiro: Civilização Brasileira, 1969. p. 173-174.

ORTEGA Y GASSET, José. A idéia do teatro. São Paulo: Perspectiva, 1991.

PAVIS, Patrice. Dicionário de teatro. 2. ed. São Paulo: Perspectiva, 1999.

PAVIS, Patrice. La herencia clásica del teatro postmoderno. In: . El teatro y su recepción, semiologia, cruce de culturas y postmodernismo. Cuba: UNEAC, 1994. p. 207-223.

RABETTI, Beti. Memória e culturas do "popular" no teatro: o típico e as técnicas. O Percevejo: Revista de Teatro, Crítica e Estética. Rio de Janeiro, ano 8, n. 8, p. 3-18, 2000.

TAVIANI, Ferdinando. Once puntos para entender la improvisacion em la Commedia dell'arte. Máscara: Cuaderno Iberoamericano de Reflexion sobre Escenologia, México, ano 4, n. 21-22, p. 4-23, jan. 1997. 


\section{CARACTERIZAÇÃO TEATRAL: UMA ARTE A SER DESVENDADA}

Mona Magalhães

Este texto tem como objetivo ressaltar pontos para o estudo da caracterização e, em particular, da maquiagem cênica, nas escolas, e sua utilização prática nos espetáculos teatrais. São muitos os fatores relevantes dentro deste tema. De início, enfrenta-se uma barreira pela escassez de literatura específica, de informações e de profissionais capacitados nessa área. As poucas obras encontradas, normalmente em outros idiomas, enfocam principalmente o uso de técnicas. Os livros que privilegiam um pensamento sobre a criação da caracterização ainda estão aquém da demanda em relação ao ensino e à prática, que vêm se fazendo cada vez mais presentes nas escolas, festivais de teatro e mercado de trabalho. Tal lacuna foi o que me incentivou a pesquisar este tema, sobre o qual foi feita a minha dissertação de mestrado, intitulada $U m$ rosto para a personagem: o processo criativo das maquiagens do espetáculo teatral 'Partido', do Grupo Galpão. Deste modo, destacarei neste artigo alguns pontos em caráter introdutório, que se encontram mais aprofundados na minha dissertação.

Primeiramente, há a necessidade de definir o conceito de caracterização, para depois discutir as suas funções no teatro. A caracterização, em um sentido lato, significa desde a construção dos atributos físicos e características psicológicas da personagem pelos escritores até a sua materialização no palco ou nas telas (cinema ou televisão). A maneira que o escritor encontra para apresentar a personagem ao leitor se dá por meio da caracterização. As personagens, seres fictícios, reproduzidos ou inventados, saídos da memória, da observação ou da imaginação dos autores são dispostas no romance de uma maneira fragmentária, para que, assim como acontece na vida real, o leitor possa conhecê-las aos poucos, porém de uma forma mais lógica, com uma "linha de coerência fixada para sempre, delimitando a curva de sua existência e a natureza do seu modo-de-ser”. Para um estudo mais detalhado a respeito das técnicas de caracterização das personagens utilizadas pelos escritores, podem ser verificadas as seguintes obras:

${ }^{1}$ CANDIDO, Antonio et al. A personagem de ficção. São Paulo: Perspectiva, 2000. p. 59. 


\section{Decupagem das características da personagem}

Como um modo de identificação dos atributos das personagens e futura utilização na materialização cênica, utilizo um quadro de análise baseado nos estudos de Renata Pallotini (1989):

Quanto ao espetáculo: Estilo: Proposta texto/montagem.

Época em que se passa a história, ou época em que foi escrita.

Com relação às personagens são verificados os seguintes itens:

Posição sócio-cultural; Sexo; Idade (Cronológica/aparência); Raça;

Estado físico do momento;

a) Interferência por uma atividade física (sujeira, suor etc.);

b) Influência climática (chuva, sol, vento etc.);

c) Sinais particulares/defeitos físicos (cicatrizes, anomalias, queimaduras etc.);

d) Conformação especial (beleza/aparência grotesca).

\section{A materialização da personagem}

No cinema, na televisão e no teatro, a personagem é encarnada pelo ator, o que possibilita, desse modo, a sua passagem do estado virtual (palavra escrita) para o estado real construído. Mediante o ator, ela ganha consistência, alterando, assim, a percepção imaginária do papel, que era de posse do leitor, e introduz uma perspectiva que não é imaginada e, sim, determinada pela encenação.

Robert Abirached observa que o caminho percorrido pela personagem escrita até a personagem na cena passa pelo imaginário do ator, e esse imaginário é a dimensão humana do papel que "a torna legítima aos olhos daqueles que a apreciam [os espectadores]"2. Conforme pensa Abirached, o ator se submete aos elementos fornecidos pelo escritor como: algumas características físicas ou os chamados atributos, no romance (altura, voz, vestuário, forma de andar) e de algumas coordenadas históricas ou sociais (meio, educação, profissão etc.). Por meio de sua experiência e sensibilidade, o ator constrói sua personagem, objetivando-a, dirigindo-a, desfazendo, por conseguinte, a fronteira atribuída ao real. Sendo assim, a transformação visual do ator na personagem passa a ser de grande importância tanto para ele próprio quanto para o espectador. Verifica-se, então, a real importância da caracterização para a construção facial das criaturas ficcionais, tanto pela necessidade do ator de se desvincular de sua imagem quanto para a concepção estética e visual do espetáculo.

\section{A caracterização do ator}

É a partir da caracterização que se fará com que a personagem, criada por um autor, possa ser verossímil ao ser humano, ou seja, como pensa Renata Pallotini: “[...] seja ela vista pelo ângulo físico, psicológico ou social - ou outros -, a carac-

\footnotetext{
2 ABIRACHED, Robert. La crisis del personaje em el teatro moderno. Madrid: Asociacion de Directores de Escena de España, 1994. p. 217.
} 
terização é um conjunto de traços organizados, que visam a pôr de pé um esquema de ser humano" . Para o ator, no teatro, a caracterização é um conjunto de técnicas que lhe possibilitam a construção da personagem criada anteriormente pelo autor.

$\mathrm{Na}$ encenação, a construção do rosto da personagem está inserida na caracterização que o ator utiliza para compô-la de uma forma geral, e também os recursos que ele utiliza para criar suas personagens, como corpo e voz. No entanto, trata-se aqui, da construção visual dos seres fictícios, especificamente da construção do rosto por meio da maquiagem. Lembrando, ainda, que o figurino faz parte da caracterização visual da personagem.

Para o arquiteto e fotógrafo Cláudio Araújo Kubrusly, o rosto é a verdadeira identidade do ser humano, que mesmo com o passar dos anos é possível o seu reconhecimento. Ele seria como páginas de um livro que contam uma história que pode ser lida por seus semelhantes. "O rosto identifica uma única pessoa e evoca seu modo de ser, sua personalidade e, eventualmente, suas idéias"4.

A arte que possibilitará a criação desse rosto para a personagem é a maquiagem. Para Pavis, ela pode ser considerada o figurino vivo que se inscreve na pele do ator, que "faz o rosto passar do animado ao inanimado, flerta com a máscara" ${ }^{5}$.

A maquiagem não é, no entanto, uma extensão do corpo como podem ser a máscara, o figurino ou o acessório. Não é tampouco uma 'técnica do corpo', uma 'maneira com a qual os homens sabem utilizar seu corpo'. É, melhor dizendo, um filtro, uma película, uma fina membrana colada no rosto: nada está mais perto do corpo do ator, nada melhor para servi-lo ou traí-lo que esse filme tênue ${ }^{6}$.

Constantin Stanislavski relata sobre a vinculação natural e estreita que se procede entre um ator e sua personagem, como privilegia a atuação realista do final do século XIX, abordando a relevância da caracterização para a transformação do intérprete em personagem, e, de uma mesma forma, preservá-lo para que ele possa se transformar por completo em sua personagem. "Assim, a caracterização é a máscara que esconde o indivíduo-ator. Protegido por ela, [ele] pode despir a alma até o último, o mais íntimo detalhe. Este é um importante atributo ou traço da transformação"”.

A caracterização como um todo, e a maquiagem em particular, é um recurso importantíssimo para o ator, pois irá ajudá-lo a revelar a sua personagem para si mesmo, durante o seu processo de construção e, mais adiante, no desvelar que irá proceder em relação ao público que o assistirá. Tal pensamento é corroborado por Richard Corson, que diz que a maquiagem irá iluminar a personagem tanto para o ator quanto para o público, provendo seu verdadeiro retrato para ambos. E, posso dizer que a ma-

\footnotetext{
3 PALLOTTINI, Renata. Dramaturgia: a construção do personagem. São Paulo: Ática, 1989. p. 67.

4 KUBRUSLY, Cláudio Araújo. O que é fotografia. São Paulo: Brasiliense, 1991. p. 35.

5 PAVIS, Patrice. Dicionário de teatro. São Paulo: Perspectiva, 1999. p. 232.

6 PAVIS, Patrice. A análise dos espetáculos: teatro, mímica, dança, dança-teatro, cinema. São Paulo: Perspectiva, 2003. p. 170.

7 STANISLAVSKI, Constantin. A construção da personagem. Rio de Janeiro: Civilização Brasileira, 1986. p. 53.
} 
quiagem irá tornar a personagem palpável para seu intérprete, o que antes era, como define Pallottini, "um fantasma sem forma", a partir do momento em que o ator a vê sobre seu rosto este se torna mais vivo, é como se fosse o seu real nascimento.

A maquiagem cênica também é um importante preparo para o ator oriental ou ocidental, como é relatado por Pronko. Em seu livro é encontrado um depoimento de um ator do Kabuki em excursão aos Estados Unidos, em 1960: "Quando você vai ao teatro cedo, você começa fazendo sua maquilagem vagarosa e calmamente, e, na hora em que você está pronto, então você está olhando a personagem no espelho. Você está preparado"”.

\section{Máscara x Maquiagem}

Para Roubine, o rosto do ator numa caracterização pode estar nu, maquiado ou mascarado ${ }^{10}$. Para Jean-Louis Barrault, "a máscara e a maquiagem apesar de serem um caso extremo se aproximam em algumas estéticas teatrais" ${ }^{11}$, com isso, faço algumas observações acerca da primeira, já que a segunda será vista com mais atenção. Para Amleto Sartori e Abirached, a máscara nasceu da necessidade de se anular as características do ator para que ele pudesse se descobrir um indivíduo com vida independente, permitindo desenvolver diferentes caracteres morais sem se preocupar com o julgamento sobre sua conduta, pensamento análogo ao de Stanislavski ${ }^{12}$.

A máscara, segundo Roubine, “[...] se distingue da maquiagem pelo fato de anular, com uma superfície rígida, a mobilidade expressiva do rosto ${ }^{13}$. Para Pavis, esta mesma "[...] máscara desrealiza a personagem, ao introduzir um corpo estranho na relação de identificação do espectador com o ator" ${ }^{14}$, motivo pelo qual, para Roubine, “[...] o código mimético dominante a baniu do palco moderno"15, cujo objetivo é o da ilusão sobre o real.

\section{A maquiagem e suas funções}

"Um rosto no meio do palco. Uma platéia inteira na frente". Zeca Camargo começa com esta frase o capítulo relativo à maquiagem das artes cênicas, do livro $A$ maquiagem através dos tempos ${ }^{16}$. Com certeza, uma das funções da maquiagem cênica é a de tornar o rosto do ator perceptível ao público. No entanto, ela não se reduz apenas a valorizar e a ressaltar traços verossímeis e realistas, do ator ou da personagem. Segundo Pavis, ela "[...] assume um relevo particular, visto ser o último toque dos preparativos do rosto do ator e porque contém uma série de informações” ${ }^{17}$. Seguindo esse pensamento, Corson acredita que assim como a expressão vocal e corporal, "a maquiagem

\footnotetext{
8 PALLOTINI, 1989, p. 63.

9 UTEMON apud PRONKO, Leonard C. Teatro: leste \& oeste. São Paulo: Perspectiva, 1986. p.181.

${ }_{10}$ ROUBINE, Jean-Jacques. A arte do ator. Rio de Janeiro: J. Zahar, 1987. p. 56.

11 BARRAULT, Jean-Louis. Préfase. In: BAISSE, Guy; ROBIN, Jean. Maquillages et perruques au théatre. Paris: Librairie Théatrale, 1954. p. 6.

12 STANISLAVSKI, 1986

13 ROUBINE, 1987, p. 59.

14 PAVIS, 1999, p. 235.

15 ROUBINE, 1987, p. 59.

16 CAMARGO, 1987, p. 80.

17 PAVIS, 1999, p. 231.
} 
faz parte do ofício do ator” ${ }^{18}$, e a negligência neste campo poderá levar ao fracasso o projeto visual preciso e cuidadoso da maquiagem. Para Corson, o corpo do ator é seu canal de comunicação visual com o público e o descuido com esse aspecto, certamente, diminuirá o possível impacto de sua performance. Sem dúvida, “[...] a maquiagem veste tanto o corpo como a alma daquele que a usa, daí sua importância estratégica tanto para a sedutora, na vida, como para o ator, no palco"19.

São encontrados vários estilos e funções da maquiagem teatral. Pavis destaca cinco funções: embelezar, acentuar ou reforçar os traços, codificar o rosto, teatralizar a fisionomia e estender a maquiagem.

\section{A maquiagem como meio de embelezar o rosto}

A maquiagem independente de sua natureza, ou seja, social, cinematográfica, de sociedades orientais ou ocidentais, tradicionais ou não tradicionais, das diversas civilizações, possui diferentes significados culturais, sociais e espirituais, contudo, não perde o sentido estético.

Não se pretende aqui julgar o gosto ou costume de cada civilização, sociedade ou época, e sim, verificar como ela é vista cenicamente. No teatro ela é valorizada pela capacidade de camuflar pequenos defeitos da pele e do rosto do ator: "[...] como retirar bolsas dos olhos, disfarçar um queixo duplo, eliminar uma espinha” 20 . Tais cuidados podem ser tratados com certa ironia para os que desconhecem as necessidades teatrais, porém, para Barrault, mesmo no embelezamento para se estar no palco, assim como fazem as mulheres e, em alguns casos, os homens, para a sociedade em que vivem, "está embutido uma magia"21.

\section{A maquiagem para acentuar os traços do rosto}

Numa outra função, a maquiagem teatral é usada devido à necessidade de se aumentar os traços expressivos do ator para suportar o excesso de luz e para compensar a distância existente entre a platéia e o palco, neste caso refiro-me à arquitetura do palco italiano, visto que os palcos de arena e de câmara proporcionam uma certa proximidade da platéia com o palco, fazendo com que a intensidade da maquiagem usada no primeiro deva ser diminuída. A luz artificial tende a empalidecer e achatar a fisionomia do ator, além de levar a perda de $30 \%$ da intensidade da maquiagem e a distância, quando muito grande, faz com que o espectador não consiga ter uma definição da expressão facial do ator. Desse modo, como pensa Pavis, "os traços expressivos devem ser aumentados de maneira a aparecerem naturais, mesmo longe do palco"22, inclusive o detalhe sutil deve ser visto. Jean-Jacques Roubine a define como um rosto nu, ou seja, tecnicamente o rosto estará maquiado, porém será uma maquiagem invisível ao espectador, dissimulando, desta maneira, a natureza de artifício. É uma maquiagem que evita que "o ator pareça pálido sob a luz dos refletores"23.

${ }^{18}$ CORSON, Richard. Stage makeup. New Jersey: Prentice-Hall, 1975. p. 3.

19 PAVIS, 2003, p. 170.

20 PAVIS, 1999, p. 231.

${ }^{21}$ BARRAULT, 1954, p. 6.

22 PAVIS, 2003, p. 171.

${ }^{23}$ ROUBINE, 1987, p. 57. 
Roubine ${ }^{24}$, ao contrário de Pavis, considera a acentuação dos traços apenas uma necessidade técnica e não um instrumento de teatralidade, assim, ele acrescenta outras necessidades além dessa acima descrita, ou seja, a utilização de um determinado artifício para atender uma solicitação de um autor ou de um encenador. Relata, ainda, a exigência histórica para as produções de época. A maquiagem propriamente dita, ele considera como sendo o uso de pinturas de cores e traços sem o compromisso mimético, como as do Extremo Oriente.

A maquiagem técnica seria, para Roubine, aquela usada por um ator branco que representaria Otelo, de Shakespeare, necessitando, desta maneira, aplicar sobre o rosto uma base mais escura que permita uma verossimilhança com o real. Posso adotar aqui, diante da questão do rosto nu (Roubine), ou seja, da aceitação da maquiagem em um espetáculo realista/naturalista, a mesma pergunta feita pelo dramaturgo japonês, Chikamatsu: "será que negamos a maquilagem do ator simplesmente porque a personagem por ele retratada jamais iria usar maquilagem na vida diária”25?

\section{A maquiagem proporcionando a codificação do rosto}

A codificação do rosto no teatro acontece em algumas tradições teatrais orientais, como na Ópera de Pequim (China), no Kathakali (Índia) e no Kabuki (Japão) . Fundamentam-se "num sistema puramente simbólico de correspondências entre cores e características sociais" ${ }^{26}$.

$\mathrm{Na}$ Ópera de Pequim, a maquiagem é considerada "um espelho da alma"27, por toda simbologia e pela fácil comunicação com o público. O rosto do ator é transformado em uma máscara, cujas cores, formato de linhas e desenhos são códigos que permitem aos espectadores decifrarem as características de cada personagem.

Já no teatro japonês Kabuki o código social também é evidente inclusive na pintura dos dentes. O Onnagata, "ator que representa papéis femininos"28, segue uma "cartografia" do rosto, que não deve apenas transformar o ator, mas, como diz Barba e Savarese, "realçar a sensualidade dos olhos". Ele é, portanto, segundo Pronko, "um símbolo profundo da metamorfose, que é o mistério do teatro" 29 , ele participaria de dois mundos distintos, além da dupla identidade ator e personagem, mas também da dualidade mulher-homem.

Deve-se ressaltar uma importante diferença entre a maquiagem da Ópera chinesa, que "oblitera a feições", e a maquiagem do Kabuki, que as acentua. ${ }^{30}$. Outro ponto que diferencia o Kabuki dos outros dois estilos orientais de teatro é a posição que ele ocupa, ou seja, segundo Pronko, ele está a "meio caminho entre o realismo e a estilização, torna-o um ponto de encontro acessível e proveitoso para os teatros do Oriente e do Ocidente" ${ }^{31}$.

\footnotetext{
${ }_{24}$ ROUBINE, 1987, p. 59.

25 PRONKO, 1986, p. 183.

26 PAVIS, 1999, p. 232.

27 MENGLIN, Zhao; JIQING, Yan. Peking opera painted faces. Beijing: Morning Glory Publishers, 1996. p. 11.

28 BARBA, Eugenio; SAVARESE, Nicola. A arte secreta do ator: dicionário de antropologia teatral. Campinas, SP: UNICAMP, 1995. p. 117.

29 PRONKO, 1986, p. 185.

30 PRONKO, 1986, p. 147.

31 PRONKO, 1986, p. 147.
} 
No teatro de dança indiano - o Kathakali - a maquiagem também não busca relação com a cor natural da pele, assim como nas outras duas tradições orientais acima citadas, as cores são simbólicas e significam a expressão da emoção das personagens. "A aplicação da maquiagem é um longo e lento processo que é realizado por especialistas enquanto o dançarino relaxa, gradualmente vai se transformando em uma figura fortemente caracterizada que ele irá interpretar" ${ }^{\prime 2}$.

Mais detalhes podem ser encontrados nos livros:

\section{A maquiagem como elemento de teatralização da fisionomia}

A maquiagem [...] se torna uma máscara mais ou menos opaca e flexível que às vezes utiliza a mobilidade do rosto. $\mathrm{O}$ ator às vezes produz caretas que ela mantém ${ }^{33}$. [...] $\mathrm{Na}$ arte do semblante, a maquiagem pode, ao mesmo tempo, acentuar a teatralidade, a maquinária facial [...] e dar novamente impressão de vida, renaturalizar e 'interiorizar' a expressão mímica. Ela joga com a ambigüidade constitutiva da representação teatral: mescla de natural e artificial, de coisa e de signo ${ }^{34}$.

Não se pode negar que a maquiagem cênica é fundamental para o teatro de perspectiva psicológica (realista, naturalista), a qual, segundo Pavis ${ }^{35}$, em geral, fornece o maior número de informações acerca da personagem. No entanto, desde os primórdios do séc. XX várias teorias estéticas ocidentais colaboraram para novas formas da representação facial não psicológica. Como destaca Roubine: o "expressionismo e o teatro brechtiano, a teoria artaudiana e, em tempos mais recentes, a experiência de Jerzy Grotowski na Polônia. [...] Será preciso também evocar as contribuições de Gordon Craig, [...] ou de Alfred Jarry"36, e mais tarde, se destacariam Samuel Beckett e Genet ${ }^{37}$.

Cabe ressaltar, neste momento, conforme pensa Roubine, que as experiências desses encenadores vêm confirmar uma característica comum entre eles, ou seja, "com ou sem ajuda da maquiagem, a prática de uma representação facial não psicológica leva sempre a fazer o rosto trabalhar como uma máscara polivalente, ao mesmo tempo capaz de expressões múltiplas e deliberadamente limitada em sua abundância" ${ }^{38}$. Assim, desta maneira, percebe-se que houve uma fuga da maquiagem comprometida com mimetismo. Para esse grupo tudo o que pudesse quebrar a ilusão cênica era bem vindo.

O que se percebe é que a utilização do rosto, maquiado ou não, nas diferentes estéticas teatrais acompanha as transformações sofridas pela personagem, seja ela narrativa ou teatral. Enfim, o rosto se torna um cenário ambulante, com seus músculos sendo trabalhados de maneira controlável ou não. Ele é, como diz Pavis, "o lugar onde o sentido desenha signos na carne" 39 , no entanto, pode-se dizer que não se pode negar

32 GRÖNING, Karl. Body decoration: a world survey of body-art. New York: Vendome Press, 1998. p. 184.

${ }^{33}$ GROTOWSKI, 1971, p. 64 apud PAVIS, 1999, p. 232.

${ }^{34}$ PAVIS, 1999, p. 232.

35 PAVIS, 1999, p. 234.

${ }^{36}$ ROUBINE, 1987, p. 64.

${ }^{37}$ ROUBINE, 1987, p. 66.

${ }^{38}$ ROUBINE, 1987, p. 66.

39 PAVIS, 1999, p. 243. 
a importância da maquiagem para a construção da personagem de cunho realista / naturalista ou para a criação das personagens nas demais tendências teatrais.

Sobre esta questão da teatralização do rosto do ator podem ser consultadas as seguintes obras:

\section{A maquiagem saindo dos limites do rosto}

Nesta função, discriminada por Pavis, a maquiagem é que assumirá a função de cenário, antes limitada somente ao rosto. Ela, agora, se expande para o resto do corpo. Um cenário também ambulante, "estranhamente simbólico" que "não mais caracteriza de maneira psicológica e, sim, contribui para a elaboração de formas teatrais do mesmo modo que os outros objetos da representação (máscara, iluminação, figurino)" ${ }^{40}$.

A pintura corporal, muito utilizada pelos povos de cultura tradicional, promove a valorização da multidimensionalidade dos corpos assegurando assim a conexão da cabeça ao corpo, deixando de consagrar apenas o rosto, como ocorre na cultura moderna, de acordo com o pensamento de Deleuze ${ }^{41}$. Essa valorização do corpo é denominada de corporalidade, de acordo com o que é relatado por Lux Vidal e Aracy Lopes da Silva, e a pintura corporal, de uma forma mais ampla a body art "faz do corpo uma matriz de símbolos e um objeto de pensamento"42, cujos temas são mitológicos, cerimoniais e refletem também uma organização social, assim como o corpo do ator é transformado em cenário por meio da maquiagem cênica.

Cenicamente, a maquiagem deixa de apenas acentuar os traços de expressão ou os aspectos psicológicos, como prima o uso realista, para salientar sua própria conduta e se tornar body art, como pensa Pavis, passando, a não servir aos outros signos, mas chamando atenção para "sua própria prática autônoma" po humano, por meio da body art, passa-se a vivê-lo, retirando o fetiche, "eliminando toda a exaltação à beleza a que ele foi elevado durante séculos pela literatura, pintura e escultura - para trazê-lo à sua verdadeira função: a de instrumento do homem, do qual, por sua vez, depende o homem" ${ }^{44}$. Sendo este o princípio que rege o movimento que teve seu auge nos anos 1970, fazendo com que desde os primórdios os seres humanos decorem as suas peles de infinitas maneiras e por variadas razões, como pensa o autor de Body Decoration, Karl Gröning.

Carregados com mensagens culturais, e imbuídos com experiências estéticas, a decoração corporal é o princípio fundamental da própria expressão em que o artista cria para si mesmo, uma segunda pele como um testemunho para a sociedade em que vivem, como um espelho de sua própria individualidade e como uma reflexão do sobrenatural ${ }^{45}$.

\footnotetext{
40 PAVIS, 1999, p. 232.

${ }^{41}$ DELEUZE, Gilles; GUATTARI, Félix. Mil platôs: capitalismo e esquizofrenia. Rio de Janeiro: Ed. 34, 1996. v. 3, 120 p.

${ }^{42}$ VIDAL, Lux; SILVA, Aracy. Grafismo indígena. São Paulo: EDUSP, 1992. p. 283.

${ }^{43}$ PAVIS, 1999, p. 172.

${ }^{44}$ GLUSBERG, Jorge. A arte da performance. São Paulo: Perspectiva, 2003. p. 42-43.

${ }^{45}$ GRÖNING, 1998, p. 09.
} 
Ao sair dos limites do rosto, a maquiagem cênica formará, então, "um sistema estético que obedece apenas às suas próprias regras”, correndo o risco de "abandonar a federação das artes que constitui representação para fundar sua própria república" ${ }^{46}$.

\section{Considerações finais}

Acredito que antes de se pensar em desenvolver uma maquiagem para quaisquer personagens e espetáculos, deve-se ter claro em mente os princípios acima mencionados. Não é apenas uma técnica sem fundamento que deve reger a criação de um rosto para a personagem. Como também de nada adianta uma técnica sem a prática, assim como uma bela maquiagem sem um bom ator. $O$ treino para se maquiar bem é tão essencial quanto os ensaios para a construção das personagens e das cenas. De preferência devem vir juntos, ensaiar maquiados e vestidos, só assim é possível sair da realidade do ator para entrar na realidade da personagem, uma vez que enquanto se está no palco se vive a realidade e o que está fora dele é pura fantasia.

Tanto o ensino quanto a prática da maquiagem partem de uma intuição, que é inato ao ser humano e que não deve ser abandonada. A técnica da maquiagem vem para apurar essa intuição. Em um processo de criação não existe uma lei, "só há a inventividade e a originalidade do artista" ${ }^{47}$. E, continuando a parafrasear Luigi Pareyson, “[...] o verdadeiro artista é aquele que encontra sempre insights em torno de si, não precisa procurá-los: basta olhar em torno de si para logo ser assediado por sugestões não solicitadas" ${ }^{48}$.

Um método, talvez o único, pelo que eu saiba, que ensina didaticamente a maquiagem, é o de Richard Corson. Este método faz com que se pense em cada área do rosto e, conseqüentemente, para cada personagem que se cria, de forma a não deixar escapar qualquer detalhe. O método da reprodução de uma outra obra é limitador, pois a cópia impede a originalidade. Em breve, publicarei um livro que versa sobre os métodos de ensino da maquiagem, que utilizo nas disciplinas de caracterização I e II, da escola de teatro, da Uni-Rio. O que me fez pensar nessa possibilidade foi a carência de literaturas nacionais na área da maquiagem cênica. Espero poder preencher essa lacuna, difundir o ensino e, com isso, valorizar um detalhe precioso da criação da personagem e do espetáculo teatral.

${ }_{46}$ PAVIS, 2003, p. 172.

47 PAREYSON, Luigi. Os problemas da estética. São Paulo: M. Fontes, 1997. p. 182

${ }^{48}$ PAREYSON, Luigi. Estética: teoria da formatividade. Petrópolis: Vozes, 1993. p. 80. 


\section{REFERÊNCIAS}

ABIRACHED, Robert. La crisis del personaje em el teatro moderno. Madrid: Asociacion de Directores de Escena de España, 1994.

BAEKE, Viviane. Pintar o corpo. O Correio da UNESCO, Rio de Janeiro, ano 25, n. 2, p. 19-21, fev. 1997.

BARBA, Eugenio; SAVARESE, Nicola. A arte secreta do ator: dicionário de antropologia teatral. Campinas, SP: UNICAMP, 1995.

BARRAULT, Jean-Louis. Préfase. In: BAISSE, Guy; ROBIN, Jean. Maquillages et perruques au théatre. Paris: Librairie Théatrale, 1954. p. 5-7.

BECKET, Samuel. End game. London: Faber and Faber, 1958.

BONFITTO, Matteo. O ator-compositor: as ações físicas como eixo de Stanislavski a Barba. São Paulo: Perspectiva, 2002.

BORIE, Monique; ROUGEMONT, Martine de; SCHERER, Jacques. Estética teatral: textos de Platão a Brecht. Lisboa: Fundação Calouste Gulbenkian, 1996.

BRUSAK, Karel. Signos do teatro chinês. In: GUINSBURG, Jaco; COELHO NETO, J. Teixeira; CARDOSO, Reni Chaves (Org.). Semiologia do teatro. São Paulo: Perspectiva, 1988.

CAMARGO, Zeca. A maquiagem através dos tempos. In: III Prêmio Avon Color de maquiagem. São Paulo: MD, 1997.

CANDIDO, Antonio et al. A personagem de ficção. São Paulo: Perspectiva, 2000.

CORSON, Richard. Stage makeup. New Jersey: Prentice-Hall, 1975.

DELEUZE, Gilles; GUATTARI, Félix. Mil platôs: capitalismo e esquizofrenia. Rio de Janeiro: Ed. 34, 1996. v. 3,

GLUSBERG, Jorge. A arte da performance. São Paulo: Perspectiva, 2003.

GRÖNING, Karl. Body decoration: a world survey of body-art. New York: Vendome Press, 1998.

GROTOWSKI, Jerzy. Em busca de um teatro pobre. Rio de Janeiro: Civilização Brasileira, 1987.

GUINSBURG, Jaco; COELHO NETO, J. Teixeira; CARDOSO, Reni Chaves (Org.). Semiologia do teatro. São Paulo: Perspectiva, 1988. 
JANSEN, José. Caracterização: histórico e importância. Rio de Janeiro: Gráfica Haroldo de D’ Alvear Gomes, [19--].

KUBRUSLY, Cláudio Araújo. O que é fotografia. São Paulo: Brasiliense, 1991.

KURY, Lorelai; HARGREAVES, Lourdes; VALENÇA, Máslova Teixeira. Ritos do corpo. Rio de Janeiro: SENAC, 2000.

LINS, Daniel. Antonin Artaud: o artesão do corpo sem órgãos. Rio de Janeiro: Relume Dumará, 1999.

MENGLIN, Zhao; JIQING, Yan. Peking opera painted faces. Beijing: Morning Glory Publishers, 1996.

PALLOTTINI, Renata. Dramaturgia: a construção do personagem. São Paulo: Ática, 1989.

PAREYSON, Luigi. Estética: teoria da formatividade. Petrópolis: Vozes, 1993.

PAREYSON, Luigi. Os problemas da estética. São Paulo: M. Fontes, 1997.

PAVIS, Patrice. $A$ análise dos espetáculos: teatro, mímica, dança, dança-teatro, cinema. São Paulo: Perspectiva, 2003.

PAVIS, Patrice. Dicionário de teatro. São Paulo: Perspectiva, 1999.

PERAZZO, Luiz Fernando. Elementos da forma. Rio de Janeiro: SENAC, 2002.

PRONKO, Leonard C. Teatro: leste \& oeste. São Paulo: Perspectiva, 1986.

ROCHA FILHO, Rubem. A personagem dramática. Rio de Janeiro: INACEN, 1986.

ROUBINE, Jean-Jacques. A arte do ator. Rio de Janeiro: J. Zahar, 1987.

SEGOLIN, Fernando. Personagem e antipersonagem. São Paulo: Cortez \& Moraes, 1978.

STANISLAVSKI, Constantin. A construção da personagem. Rio de Janeiro: Civilização Brasileira, 1986.

STANISLAVSKI, Constantin. A preparação do ator. Rio de Janeiro: Civilização Brasileira, 1984.

VIDAL, Lux; SILVA, Aracy. Grafismo indígena. São Paulo: EDUSP, 1992. 


\section{JOGOS CORPORAIS EM SALA DE AULA}

Nara Keiserman

Dentro do imenso repertório de Jogos Teatrais, há aqueles em que o Movimento é usado pelo aluno como principal meio de expressão, em que se pode dizer que é o corpo que fala. Estes jogos favorecem a aquisição e/ou aprimoramento de diferentes qualidades, referentes tanto a aspectos propriamente físicos, como outras de caráter social e mesmo psicológico.

Pensando a Educação como instrumento efetivo para o desenvolvimento harmonioso da pessoa por inteiro e acompanhando o pensamento de Moshe Feldenkrais, em seu livro Consciência pelo Movimento, credito ao Movimento um importante papel neste contexto educacional. Segundo o autor, quando estamos acordados lançamos mão dos quatro componentes da vigília, que são as sensações, os sentimentos, o pensamento e o movimento. De acordo com a tarefa praticada, estes componentes estão mais ou menos ativados, mas a falta total de um deles é sintoma garantido de doença ou desequilíbrio. Feldenkrais chama de ATENÇÃO* (escrito assim, com maiúscula e asterisco) o estado almejado em que os componentes da vigília estão em perfeito equilíbrio, possibilitando ações efetivas e harmoniosas - em outras palavras, o estado de componentes que favorece uma vida feliz e saudável. No caso do adulto, o objetivo do trabalho é restabelecer o fluxo de comunicação entre aqueles quatro componentes. Quando se trata da criança, o objetivo é oferecer oportunidades de Jogo para que ela se mantenha em contato pleno com suas sensações (advindas dos cinco sentidos), seus sentimentos (que não podem ser bloqueados), seu pensamento (fértil, espontâneo, inteligente), por meio da ativação e expressão através do Movimento.

Para que haja um bom aproveitamento das propostas de Jogos Corporais listados abaixo, é preciso algumas palavras sobre o professor que vai propô-los e o modo como isso será feito.

\section{O professor e a aula}

O professor é um guia, um orientador. É um parceiro dos jogos que vai propor, em que exerce a função de dar indicações e sugerir caminhos. Não aponta modelos a 
serem seguidos, mas oferece oportunidades de encontro de cada um consigo mesmo. Esse professor é um parceiro de seus alunos e deve, mais do que tudo, amar e respeitar os seus corpos e o seu próprio, para poder observar atentamente as suas expressões, manifestas ou escamoteadas, ao mesmo tempo em que sente o seu próprio corpo, que certamente também fala uma língua que os alunos entendem e com a qual dialogam mesmo no silêncio. Se o professor pretende que os alunos joguem espontaneamente, que sejam capazes de exercer plenamente suas percepções, ele próprio deve ser capaz de fazê-lo. Isso é muito claro em outras matérias, mas no Teatro, às vezes, se esquece que é preciso saber fazer para saber ensinar.

O professor é aquele que vê todos os alunos, que sabe ler as suas mensagens corporais, que sabe ouvir, que sabe tocar nos seus corpos nos momentos necessários, que reconhece quando deve falar ou silenciar. O professor é aquele que sente.

Há alguns aspectos ou princípios que organizam a prática dos Jogos Corporais, que serão alterados pelo professor de acordo com as circunstâncias em que trabalha, e que convém que os alunos conheçam logo na primeira aula. São eles: dar preferência ao uso de roupas confortáveis, que não impeçam os movimentos e que possam sujar e aos pés descalços, para um melhor contato com o chão e a libertação dos pés do domínio torturante dos sapatos - isso vale também para o professor. Não há um jeito certo de realizar os jogos propostos, já que cada um deles possibilita muitos e muitos modos de execução possíveis, criativos, originais, o que significa que de nada serve espiar os colegas e que a avaliação do professor não vai se guiar por critérios de certo ou errado. As dúvidas quanto à compreensão da proposta do Jogo devem ser feitas antes de se iniciar a jogar e o professor só vai responder aquilo que considerar imprescindível para que o aluno dê início ao seu movimento. Uma idéia vaga do que é para fazer é suficiente para começar. As instruções dadas durante o jogo vão suprindo as dúvidas que possam gerar insegurança, ao mesmo tempo em que ajudam o aluno a manter-se no jogo, ou seja, a pensar no que faz enquanto faz - uma das principais metas do trabalho com os Jogos Corporais. Os alunos não devem olhar para o professor durante o Jogo, de que este participa apenas como voz e isso porque há um estado almejado de imaginação ficcional que o próprio aluno estabelece e de que o professor não faz parte.

Cabe, portanto, ao professor, ser econômico no enunciado da proposta, de modo a não antecipar ou dar pistas sobre como realizá-la; nas instruções dadas durante a sua realização, orientar os alunos no sentido de encaminhar o seu percurso em direção ao objetivo da proposta e a descoberta de uma linguagem pessoal de expressão pelo movimento; ter como critério para a avaliação os objetivos (que para isso devem ser claros, tanto para o professor quanto para os alunos) e o que vai avaliar é em que medida o grupo os alcançou, tendo o cuidado de não expor as fraquezas ou dificuldades individuais, mas sempre salientando os aspectos positivos do que foi realizado.

\section{Jogos corporais}

A seguir, uma listagem de propostas de Jogos Corporais que admitem muitas variações, a serem selecionados pelo professor de acordo com as necessidades de seus alunos e condições em que trabalha, como dimensões da sala, duração da aula, 
organização curricular, faixa etária, número e experiência dos alunos, entre outras. Certamente, todos estes aspectos interferem no resultado obtido.

Os Jogos, pontos de partida para a elaboração de muitos outros, estão organizados de acordo com o foco principal das propostas e assim denominados: Percepção Sensorial, Partes do Corpo, Locomoção e Espaço - sem esquecer que, em todos eles, o Movimento é o canal privilegiado de expressão e realização pessoal.

\section{Percepção Sensorial}

Aqui se trabalham os Sentidos e sua relação com movimento em duas direções: com que movimentos se podem apreender as sensações e que movimentos esta apreensão vai gerar.

\section{Audição}

Esta proposta não deve ser anunciada previamente. Os alunos devem estar numa posição confortável, em atitude aquietada, serena, de olhos fechados. O professor deve saber o que propor para colocar os alunos neste estado, de atenção serena, de disposição sem alarido. Ir indicando cada etapa, dando o tempo necessário para a sua realização - é preciso que o professor tenha essa percepção do grupo. Pedir que os alunos abram os olhos quando começarem a se deslocar no espaço caso isso não ocorra espontaneamente, o professor poderá indicar.

1) Ouvir o som que vem de mais longe. 2) Imaginar quem ou o que produz este som (a imagem do som, a fonte sonora). 3) Ouvir o som que vem de mais perto, mas fora da sala de aula. Visualizar a fonte. 4) Há algum som vindo de um ponto intermediário, entre o mais distante e o mais próximo? Ouvir e imaginar a fonte. 5) Para cada um dos sons imaginar mais de uma fonte. 6) Movimentar-se conforme um dos sons que vem de fora. 7) Cantar uma música mentalmente e imaginar que ela percorre o corpo por dentro. 8) Ir movimentando cada parte do corpo por onde a música passa. Como se fosse o movimento que produzisse o som. 9) Alternar (por indicação do professor ou a critério do aluno) as duas atitudes de resposta ao som de fora e música de dentro, sempre com movimentos - que podem ser muito pequenos. 10) Reagir com movimento aos sons da sala, que podem ser produzidos por CDs, instrumentos musicais ou outros. 11) Alternar: quando há som dentro da sala, movimentar-se; quando há silêncio, movimentar-se de acordo com a música interna; por indicação ou não, ouvir os sons de fora, sem movimento.

Como na proposta anterior, os alunos devem estar aquietados fisicamente e com o pensamento vivo. Não há necessidade de explicações prévias e a posição inicial é deitada.

1) Pedir aos alunos que observem os únicos movimentos existentes no seu corpo no momento em que eles não estão se movimentando, que são os da respiração. 2) Nela, observar: a) o contato do corpo com o chão se modifica na inspiração e na expiração? b) onde, no corpo, sente que chega o movimento da respiração? c) existe pausa entre os movimentos de inspiração / expiração? d) qual o tempo de cada movimento e da pausa? e) perceber que o peito, na inspiração, alarga-se lateralmente, sobe na direção do teto, e a pélvis como que pressiona o chão, a cintura afasta-se levemente do chão e o retorno destas partes do corpo, trazendo uma sensação de relaxamento, na expiração. 3) Imaginar um termômetro colocado dentro do peito, começando no 
pescoço e indo até a altura do umbigo. Imaginar que ao inspirar o mercúrio desce e na expiração sobe; e depois ao contrário, ao inspirar sobe e ao expirar desce. 4) Colocar movimento na respiração: ao inspirar, elevar qualquer parte do corpo, na expiração executar movimentos descendentes e, nas pausas, não se movimentar. A duração de cada movimento e das pausas deve corresponder exatamente aos tempos da respiração. 5) Ao expirar, deixar que produza um som, que poderá ser de S ou F. 6) Substituir este som pelos sons dos fonemas que compóem o seu nome. Criar movimentos para cada som, sem mais a preocupação com o seu desenho no espaço (ascendente ou descendente). Buscar variedade na emissão dos sons (duração, força, altura, timbre) e que os movimentos tenham alguma relação com eles. Compor a seqüência de sons e movimentos até o nome todo. 7) Alternar: realizar apenas os sons, visualizando os movimentos; realizar apenas os movimentos, ouvindo os sons mentalmente. Decorar as duas seqüências, de sons e movimentos. 8) Andar pela sala, parando a cada pessoa que encontrar e se apresentar com este seu novo nome (sem o movimento). "Falar" e ouvir e só então andar, para um novo encontro. Repetir até que cada um tenha passado por todos. 9) Em roda, em pé. Cada um faz o seu movimento, ouvindo o som mentalmente. Os outros observam tentando associar com o som que ouviram. Em seguida, repetir o movimento observado, todos juntos. É o que se chama de imitação eco. 10) Retomar a sua própria seqüência, modificando-a em função do que viu, ouviu e realizou. 11) Novamente na roda, cada um realiza a sua seqüência de sons e movimentos, com imitação eco.

\section{Visão}

Dividir os alunos em dois grupos. Um observa e o outro joga. Os jogadores ficam de costas para o local do jogo.

1) O primeiro aluno se coloca no espaço e faz uma pose. 2) O próximo, do grupo de jogadores observa-o com a intenção de reproduzir a pose com o máximo de fidelidade. Depois de um certo tempo, que deverá ser curto, o primeiro aluno desfaz a pose e o segundo a reproduz. 3) Vem o terceiro, observa a pose do segundo. Este desfaz e aquele a executa. E assim por diante. Quando o último aluno do grupo de jogadores a fizer, todos se colocam em linha e cada um faz a sua pose. 4) O grupo de observadores vai apontar as alterações que foram feitas na pose original. Trocar as funções.

É importante que o aluno que observa o faça sem imitar, de modo que sua capacidade de ver e reter o que viu possa ser exercitada.

\section{Tato}

Anunciar aos alunos que será feito um trabalho de percepção sensorial através do tato - sentido que só é ativado quando tocamos um objeto ou uma pessoa; quando milhares de células que entram em ação para nos informar se algo é quente ou frio, áspero ou macio, seco ou úmido. Assim, é nisto que estará a sua atenção, de modo que ao tocar o objeto deve ser evitado o pensamento comumente imediato de pensar na sua utilidade. O pensamento que acompanhará todos os movimentos se dá em função das sensações que ele desperta. Deve ser evitado a todo custo agir com uma caneta na mão como quem escreve no ar - por exemplo. Os movimentos que a caneta vai trazer para o aluno se dão devido a sua forma, textura, densidade. 
O jogo:

Todos estarão sentados em roda enquanto o professor conversa sobre o que foi explicitado acima. Cada aluno vai lembrar dos objetos que tem na sua bolsa e selecionar um deles para o Jogo. De maneira tranqüila e sem comentários verbais cada um vai apanhar este objeto ou outro que chame mais sua atenção.

1) Colocar o objeto no centro da roda e voltar a sentar. 2) Observar os objetos à medida que vão sendo colocados, observando suas características, e evitando pensar neles por seu nome. Voltando ao mesmo exemplo, não pensar "caneta”, mas sim objeto fino, transparente etc. $O$ professor chama a atenção do aluno para o quanto a visão e a experiência podem suprir o próprio toque. Basta olhar um objeto para que se saiba se ele é flexível ou não, áspero ou não, e até mesmo para sentir o seu aroma e paladar. 3) Fechar os olhos e colocar as mãos em concha, à frente do corpo. O professor vai distribuir os objetos, colocando-o nas mãos de cada aluno. 4) Assim que o sentir nas mãos, iniciar a pesquisa sensorial do objeto, conferindo pelo tato aquilo que a visão já havia informado. Experimentar o objeto em várias partes do corpo, observando as diferentes percepções. Experimentar equilibrar o objeto em diferentes partes do corpo, de modo a prescindir das mãos. 5) Colocar o objeto bem perto dos olhos e abri-los. Movimentar-se a partir das indicações de ter o objeto no corpo, perto do corpo, longe do corpo - sem e com deslocamento no espaço. 6) Seguir a instrução: eu movimento o objeto / o objeto me movimenta. 7) Trocar de objeto com a pessoa que estiver mais próxima, fazendo deste momento um acontecimento de troca efetiva. 8) Movimentar-se com o novo objeto. 9) Nova troca, nova movimentação. Instruir o aluno para que permita que cada novo objeto traga novos movimentos. 10) Colocar-se em duplas e comunicar-se através dos objetos. Indicar que se trata de um jogo entre quatro parceiros, em que dois são objetos. 11) A dupla seleciona um dos objetos e segue seu diálogo através deste objeto. 12) Trocar o objeto, apanhando o que havia sido deixado de lado. 13) Separar-se do par, seguindo com o objeto que era inicialmente do outro. 14) Nova dupla, mesmo procedimento. 15) Trocar de objeto até que tenha nas mãos o seu objeto, aquele que apanhou na sua bolsa. Instruir para a diferença entre olhar aberto para o jogo enquanto não encontrou o seu objeto e, ao contrário, o olhar com foco definido no objeto quando tiver encontrado o seu. 16) Assim que tiver o seu objeto nas mãos, movimentar-se em função dele. 17) Para finalizar, pode-se pedir que simplesmente devolvam o objeto na bolsa, ou que o coloquem no centro, voltando para a roda. Neste caso: olhar todos os objetos, identificando aqueles com que trabalhou e observar o novo olhar que pode ter para estes objetos e eventualmente até mesmo para os outros. O que mudou não foi o objeto, evidentemente, mas sim o olhar.

\section{Paladar e Olfato}

Cada aluno traz um objeto de comer, devidamente embalado (já que vai ser jogado, manuseado etc.), e outro que tenha um cheiro que considere especial. O ponto de partida é o mesmo usado nas propostas para o aprimoramento do Tato com foco nos objetos. Pode-se fazer em duas etapas, sendo a primeira com os objetos de cheiro, de modo que este determine os movimentos executados. Para o objeto de comer, a partir do momento em que cada um está com o seu objeto nas mãos, os alunos vão ser orientados para: 
1) Visualizar o objeto por dentro da embalagem. 2) Sentir seu gosto só de o ter nas mãos e olhar. 3) Colocá-lo muito perto dos olhos e ir, lentamente, abrindo a embalagem, ouvindo o barulho que isto produz, apreciando cada movimento que faz para isso. 4) Cheirar o objeto. 5) Sentir seu gosto só de o ter nas mãos, olhar e cheirar. 6) Finalmente, quando não agüentar mais, colocá-lo na boca. 6) Andar pela sala, mostrando o seu objeto e partilhando-o com os outros. 7) Devolver o objeto, ou o que sobrou dele, ao centro da sala. 8) Olhar para cada objeto sentindo seu sabor e aroma e dançar a sensação. 9) Sem olhar para os objetos, dançar a sensação.

\section{Partes do Corpo:}

O objetivo principal é dar oportunidade ao aluno de mobilizar as diferentes partes do corpo, numa idéia de isolamento (o aluno ser capaz de movimentá-las de forma independente) assim como de composição, em que o movimento de uma parte determina as posições ou movimentos de outras. Entram no jogo os conceitos de repercussão e fluência. O aluno é orientado para permitir que o movimento iniciado numa parte do corpo repercuta no corpo inteiro e ainda que observe o modo como o movimento se espalha, fluindo pelo corpo inteiro.

É claro que a percepção e a consciência do corpo aparecem aqui como causa e conseqüência, ou seja, elas são simultaneamente favorecedoras do resultado alcançado na execução da proposta, como se beneficiam dela.

Estes Jogos permitem que se faça analogias entre as partes do corpo, favorecendo uma compreensão de sua estrutura. É fácil para os alunos perceberem seu corpo como formado por três volumes empilhados: a cabeça (uma espécie de aquário), o peito (caixa torácica) e a pélvis (bacia), os três unidos por um fio que é a coluna. Do volume de cima saem dois "penduricalhos", os braços, e do volume de baixo outros dois, as pernas. Há duas cinturas: a de cima une o aquário à caixa, e a de baixo, a caixa à bacia. Os volumes não se partem ao meio, seus movimentos são compactos: vão inteiros para cima, para baixo, para frente, para trás, para a direita e para a esquerda, enquanto os penduricalhos podem ser revirados em todas as direções de forma independente uns dos outros.

As propostas seguem o seguinte padrão:

Movimentar-se com o foco em tal parte do corpo, iniciando pela posição deitada até chegar a ficar em pé, seguindo com deslocamentos no espaço. A realização é de início individual, seguindo em duplas. Os dois alunos podem estar colocados à distância, ou próximos um do outro, por muito pouco tempo, trocando de par constantemente - o que obriga a rápidas adaptações de resposta corporal - ou permanecendo por um tempo maior, de modo a aprofundar a relação. Esta deve ser de diálogo entre as partes do corpo, de comunicação efetiva. A cada troca de par deve haver uma mudança nas qualidades dos movimentos, considerando que há um estímulo vindo do par, a quem a resposta corporal será sempre única.

A parte do corpo que está com o foco pode ser determinada pelo professor ou selecionada pelo aluno. Nas duplas, os dois podem ou não estar se comunicando com a mesma parte do corpo. Pode ser feito em grupos maiores. Pode-se ter mais de um foco, por exemplo: um na parte alta e outro na parte baixa do corpo, considerando a cintura a linha média, ou um para cada lado do corpo, direita e esquerda. 


\section{Locomoção}

A base para os Jogos Corporais de Locomoção pode ser encontrada no livro La expresión corporal y el niño, de Patrícia Stokoe. Ali, ela se refere aos Movimentos Fundamentais de Locomoção, identificando cinco deles, ordenados de acordo com a sua circunscrição espacial: arrastar-se, em que o corpo está todo na linha do chão; engatinhar, em que o tronco está fora do chão, englobando as locomoções sobre joelhos e sobre os glúteos; andar, quando nos encontramos sobre os dois pés; correr, em que se alternam sucessivamente pé e outro sobre o chão; e saltar, em que a ênfase está em sair do chão, em ganhar o espaço aéreo. Cada um destes movimentos de Locomoção admite muitas variações, de acordo com: a postura de base, ou seja, o modo como o corpo se coloca o espaço para iniciar o movimento, e que será mantida durante sua realização; a parte do corpo que conduz o movimento; o modo como as partes do corpo vão se movimentando de forma simultânea ou sucessiva; os graus de energia empregados nas diferentes partes do corpo; o desenho no espaço; o andamento adotado, por exemplo.

Os movimentos podem ser sugeridos aos alunos na sua ordenação espacial, do chão para o ar ou vice-versa, ou indicar a sua realização por contraste, fazendo com que o corpo tenha que se organizar para fazer mudanças bruscas e repentinas, como em: arrastar-se e andar; engatinhar e correr; andar e saltar. Pode-se ainda propor uma realização em que cabe aos alunos organizar a sua seqüência, selecionando a ordem e o tempo de permanência em cada movimento, de acordo com sua imaginação e impulso corporal.

Convém conversar com os alunos sobre os movimentos de Locomoção, o que diferencia uns dos outros, antes de propor os Jogos.

O movimento de andar pode ser assim trabalhado: 1) $O$ professor vai indicando uma por uma as partes do corpo envolvidas no andar, solicitando dos alunos uma atitude de percepção em relação ao seu modo de atuação. Por exemplo: o que fazem os dedos dos pés? Movimentam-se juntos ou separados? Qual o tamanho do passo? Para onde apontam os pés? Quando e como se dá a transferência de peso de um pé para o outro? 2) O professor vai indicando uma por uma as articulações envolvidas no andar, pedindo aos alunos que exagerem no seu movimento e depois que as anulem. Ao chegar à articulação que une a coxa ao quadril, o aluno descobrirá que é impossível andar. 3) O professor sugere variações nas dimensões e no andamento do passo, do movimento dos braços, da cabeça, da pélvis, do tronco. 4) Cada aluno observa atentamente seu modo de andar até descobrir qual o seu traço mais forte e evidente. Vai aos poucos exagerando nisso até ter uma caricatura do seu próprio andar. 5) Observar o andar de um colega, sem que ele perceba e sem modificar o seu próprio, que possivelmente está sendo observado por outro. Ao sinal do professor, transformar imediatamente o seu andar, reproduzindo o do colega observado. Descobrir aí, então, a sua marca mais forte e ir, aos poucos, exagerando até a caricatura. Cada um vai observando os demais, sem modificar o que está fazendo, tentando reconhecer-se no andar do outro. Isto não deve ser revelado ou apontado, a não ser pelo próprio aluno imitado que assim o desejar, manifestando-se espontaneamente a respeito. 


\section{Espaço:}

É considerado nas categorias de Espaço Interno ou Pessoal, Espaço Parcial e Espaço Total ou Global.

Espaço Interno ou Pessoal é aquele que se ocupa pelo simples fato de existir. Convém conversar com os alunos sobre isso, sobre o ar que se desloca para que se possa, simplesmente, estar aqui, ali, acolá. É uma ótima oportunidade para se conversar também sobre a pele, lembrando que ela é o maior órgão do corpo humano e responsável pela sensibilidade tátil, realizando várias e complicadas funções como proteção, manutenção da temperatura, defesa imunológica. É a pele que possibilita a troca entre o mundo interno e o externo, definindo o desenho de cada pessoa, seu perfil, sua silhueta.

Espaço Parcial é o que ocupamos sem locomoção, sem deslocamento. Neste caso, predominam os gestos, que são os movimentos que executamos no ar, ocupando o espaço à nossa volta. Seu desenho é basicamente retilíneo ou arredondado. Conforme Rudolf Laban, em seu livro Domínio do Movimento, significa o uso do espaço direto ou indireto, de sua ocupação em linhas retas ou sinuosas.

Espaço Total ou Global é aquele para o qual não há limites, e sua ocupação pode ser também considerada como direta ou indireta. Pensando a ocupação ou deslocamento do espaço em relação a um objetivo (objeto ou pessoa), as possibilidades são as de aproximar-se, afastar-se ou rodeá-lo.

Como no caso dos Jogos de Locomoção, convém aqui esclarecer os alunos sobre o que vai ser trabalhado. A proposta pode ser indicada já com os alunos na posição inicial.

Jogos:

Espaço Interno

1) Posição inicial: deitados no chão, com as pernas estendidas e afastadas naturalmente, os braços também estendidos ao longo do corpo. Visualizar o contorno do corpo, percebendo o seu desenho, o quanto de ar foi deslocado para dar espaço a ele, a marca deixada no chão se este fosse de areia. Visualizar o corpo conforme a estrutura já mencionada: três volumes unidos e seus penduricalhos, as duas cinturas. 2) Dobrar os joelhos, colocando os pés no chão e repetir a visualização, observando o que se modificou: quais as partes que encostam agora no chão, como algumas afundam mais do que antes e do que outras. 3) Tirar os pés do chão, levando as coxas em direção ao peito e repetir a visualização, com os mesmos pontos de observação. 4) Cada um vai elaborando outras posições, e em cada uma delas, repetir o exercício de visualização e percepção, respondendo-se: como está o desenho do meu corpo? Como ele está apoiado: no chão, no ar, sobre si mesmo? Estão próximos ou afastados os volumes e seus apêndices? Os movimentos que levam de uma posição a outra devem ser simples e contínuos, só interrompidos quando a posição parecer, ao aluno, interessante. 5) Organizar a seqüência de posições e movimentos de modo que cada vez vá ficando com um número menor de apoios sobre o chão, até finalmente ficar em pé. Cada posição ou pose pode ser associada a uma atitude de expansão ou recolhimento; de espalhar ou recolher; de dar ou tomar; de adesão ou resistência. Pedir aos alunos que identifiquem a sua atitude. 6) Andando, e ao sinal do professor, formar duplas ou grupos ao acaso. Apoiar-se um no outro formando uma pose, em que se permanece para realizar a mesma pesquisa anterior: 
o desenho dos dois corpos juntos, sua silhueta, o recorte que fazem no espaço, como estão apoiados, um no outro, no próprio corpo, no ar e a atitude. Importante ajudar o aluno a perceber a diferença entre encostar e apoiar, e que nenhuma das duas ações é a de empurrar. 7) Em grupos de quatro ou cinco. Um aluno se coloca numa pose. Outro se apóia nele, servindo de apoio para o próximo e assim por diante. Realizar a mesma pesquisa. $\mathrm{O}$ primeiro sai do seu lugar, sem que a pose já formada se altere e vai se apoiar no último. O que foi o segundo sai do seu lugar e se apóia sobre o primeiro e assim por diante até que todos estejam numa nova posição. Nova pesquisa. E assim por diante.

\section{Espaço Parcial}

Considera-se a possibilidade de movimentos em que o desenho do corpo todo adquire diferentes formas, quais sejam: uma forma arredondada, a "bola", em que as partes afastadas do corpo quando estamos na posição ereta se aproximam; a "seta", em que predominam as linhas retas e as partes do corpo se afastam, e o "parafuso", em que as partes do corpo apontam para várias direções de forma sucessiva ou simultânea. Todos esses são desenhos trabalhados no Espaço Parcial, ou seja, sem locomoção, de forma individual, em dupla ou em grupos maiores. É necessário explicar aos alunos do que se tratam esses desenhos antes de pedir que se coloquem na posição deitada.

\section{O jogo:}

1) Levantar descrevendo um parafuso, que vai de baixo para cima, até que fique na posição de pé. 2) Movimentar-se em bola. 3) Movimentar-se em seta. 4) Movimentar-se em parafuso. 5) Colocar-se rapidamente em poses com a forma que o professor vai solicitando. 6) Colocar-se numa pose em parafuso, movimentar-se em bola até chegar à outra pose em parafuso. 7) Colocar-se numa pose em seta, movimentar-se em bola até chegar à outra pose em seta. E assim por diante, até que se tenha proposto todas as combinações possíveis.

Quando feito em duplas ou grupos maiores, instruir os alunos para a idéia de, ao realizar a forma, ir dando espaço para o movimento do outro, ao mesmo tempo em que, com seus movimentos, interfere no espaço oferecido.

\section{Espaço Total}

1) Em grupos de quatro, os alunos se colocam numa formação espacial em losango, todos voltados para a mesma direção. Os movimentos que executam, com locomoção, são liderados pelo que está à frente. Quando este mudar a direção, executando um quarto de volta ou meia volta, o que passará a estar na frente vai guiar os movimentos. $\mathrm{O}$ importante é que se mantenham as distâncias iniciais estabelecidas entre eles de que não se perca o desenho do losango.

2) Locomover-se em espiral, ao redor de um ponto imaginário, do eixo menor para o maior, até abarcar a sala toda, e voltando na direção inversa até retornar ao ponto de partida. É a própria trajetória que vai determinar o movimento de locomoção, o andamento, a parte do corpo que lidera, o modo como o movimento flui pelo corpo etc. Pode ser feito em duplas, em que um tem a função de eixo, ou em grupos maiores, em que um faz o eixo ou todos se locomovem simultaneamente, ao redor uns dos outros. 
3) Estabelecer um ponto de atração, imaginário ou real. Ir até ele em linha reta. Ao chegar lá, alguma coisa estabelece um impulso de repulsão, que faz a pessoa afastar-se em linha sinuosa até um outro ponto qualquer do espaço. Mesma coisa, com atração e repulsão em linha reta; em linha sinuosa; atração em linha sinuosa e repulsão em linha reta.

\section{Considerações finais}

Meu objetivo foi o de oferecer uma pequena amostragem, entre as inúmeras possibilidades de propostas de jogos corporais que podem ser feitos em sala de aula. A seleção destas categorias, Percepção, Locomoção, Partes do Corpo e Espaço, foi por considerar que elas oferecem uma base sólida para a iniciação dos alunos na linguagem do Movimento.

Os jogos listados podem ser propostos de diferentes maneiras, como já foi dito. Cada professor saberá de suas necessidades, podendo eliminar etapas sugeridas ou acrescentar outras, ocupar mais de um encontro para cada um deles, encontrar pontos de contato e juntar mais de um numa única proposta, torná-los mais simples ou sofisticados, usar música ou outro estímulo sonoro.

A intenção é provocar no professor o desejo de inventar seu próprio trabalho com os Jogos Corporais.

Lembrar de: dar o tempo necessário para que os alunos possam compreender e responder corporalmente às propostas de jogo; instruir, durante o jogo, para a elaboração de imagens que acompanhem os movimentos, enfatizando a necessidade de pensar no que faz enquanto faz. Por exemplo: ao se locomover, o aluno deve imaginar para aonde está indo. E se está indo para um lugar é porque está em um lugar e então: que lugar é esse? O que o faz se locomover? Está indo para aonde? Por quê?

Aliás, essa é uma boa pergunta para o professor de Teatro na Educação: você está indo para aonde? Por quê?

Seja para aonde for, você não está sozinho. 


\section{REFERÊNCIAS}

BRIKMAN, Lola. A linguagem do movimento corporal. 2. ed. Tradução de Beatriz A. Cannabrava. São Paulo: Summus, 1989.

CALAZANS, Julieta; CASTILHO, Jacyan; GOMES, Simone (Coord.). Dança e educação em movimento. São Paulo: Cortez, 2003.

FELDENKRAIS, Moshe. Consciência pelo movimento. Tradução de Daisy A. C. Souza. São Paulo: Summus, 1977.

LABAN, Rudolf. Dominio do movimento. Tradução de Anna Maria Barros de Vecchi e Maria Sílvia Mourão Netto. São Paulo: Summus, 1978.

STOKOE, Patricia. La expresión corporal y el adolescente. 2. ed. Buenos Aires: Barry, 1976.

STOKOE, Patricia. La expresión corporal y el niño. Buenos Aires: Ricordi, 1972. 


\section{As OFICINAS DE TEATRO E A PRÁTICA DO ARTISTA-DOCENTE}

Narciso Telles

Os cursos de licenciatura em teatro, muitos originados dos "antigos" cursos de Educação Artística, habilitação em Artes Cênicas, formam, basicamente, professores de teatro para atuarem, prioritariamente, nas salas de aula das escolas de educação básica. Pouco pensamos na formação deste licenciando e sua atuação em espaços estritamente de formação teatral, como as escolas técnicas e profissionalizantes ou ainda no bacharel em teoria, interpretação, direção ou cenografia que, por uma demanda, acaba trabalhando como professor. Assim, este texto apresenta reflexões sobre os processos de ensino-aprendizagem desenvolvidos por grupos teatrais brasileiros, na perspectiva de apontar novos caminhos de atuação profissional para os bacharéis e licenciados em teatro que desenvolvem atividades em espaços formais e informais de ensino.

Para tanto, escolhemos o campo da pedagogia do teatro como nosso ponto de vista. Segundo Ingrid Koudela:

[...] o termo pedagogia do teatro visou não apenas ampliar o espectro da pesquisa na área, trazendo para a discussão os Mestres do Teatro - dramaturgos, teóricos e encenadores, como também, fundamentar a epistemologia e os processos de trabalho em teatro, inserindo-os na história da cultura ${ }^{1}$.

Conduzir nosso olhar pelo campo pedagógico teatral significa traçar diálogos com educadores, artistas, alunos e demais envolvidos, percebendo seus pontos de intersecção na construção do fenômeno teatral e sua assimilação pelas instituições formadoras de atores, professores de teatro, diretores, cenógrafos e teóricos. Assim, focalizaremos as oficinas de teatro utilizadas pelos grupos na formação de atores e em projetos sociais.

Decifrar o cotidiano não é tarefa fácil para o pesquisador interessado em traduzir a dinâmica e a riqueza de um determinado processo pedagógico. Tal aventura implica numa disposição por parte do pesquisador em ampliar sua percepção de

${ }_{1}^{1}$ KOUDELA apud SANTANA, Arão Paranaguá (Coord.). Visões da Ilha: apontamentos em teatro e educação. São Luís: Grupo de Pesquisa em Ensino do Teatro \& Pedagogia Teatral, 2003. p. 17. 
uma determinada realidade "buscando referências de sons, sendo capaz de engolir sentindo a variedade de gostos, caminhar tocando as coisas e pessoas e [se] deixando tocar por elas, cheirando os odores que a realidade coloca em cada ponto do caminho diário" ". A apreensão dos modos de fazer e ensinar dos espaços cotidianos necessita de uma "parceria" entre os sujeitos da pesquisa, de forma a possibilitar a compreensão dos elementos presentes nestes modos, suas articulações, seus conteúdos e formas.

Como, então, poderemos compreender os procedimentos cotidianos em uso nas oficinas de teatro? Neste sentido, apoiamo-nos nos estudos de Michel de Certeau sobre as práticas cotidianas.

Certeau desenvolve as noções de estratégias e táticas:

[...] as estratégias são, portanto, ações que, graças ao postulado de um lugar de poder (a propriedade de um próprio), elaboram lugares teóricos (sistemas e discursos totalizantes), capazes de articular um conjunto de lugares físicos onde as forças se distribuem. Elas combinam esses três tipos de lugares e visam dominá-los uns pelos outros. Privilegiam, portanto, as relações espaciais [...]. As táticas são procedimentos que valem pela persistência que dão ao tempo - às circunstâncias que o instante preciso de uma intervenção transforma em situação favorável, à rapidez de movimentos que mudam a organização do espaço, às relações entre os momentos sucessivos de um "golpe", aos cruzamentos possíveis de durações e ritmos heterogêneos, etc. ${ }^{3}$.

Entender o cotidiano das oficinas de teatro é, assim, um trabalho que busca compreender as táticas utilizadas pelos ministrantes para seu fazer pedagógico, penetrando astuciosamente e de modo particular em cada momento.

Pela multiplicidade das práticas cotidianas, as mesmas, segundo Certeau, devem ser entendidas com um número finito de procedimentos, que aplicam os códigos e normas existentes numa determinada "ocasião", que resulta de um certo número de formalidades, diz ele:

Em primeiro lugar, os 'jogos’ específicos de cada sociedade [...] dão lugar a espaços onde os 'lances' são proporcionais a situações [...] os jogos 'formulam' as 'regras' organizadoras dos lances e constituem também uma 'memória' (armazenamento e classificação) de esquemas de ações articulando novos lances conforme as ocasiões. ${ }^{4}$

Sendo assim, as táticas utilizadas em uma situação específica possuem uma formalidade própria, que não permite o desvelamento do jogo em sua totalidade. As regras são sempre as mesmas, mas os lances, que são múltiplos, serão escolhidos pelo participante.

Adentrar no cotidiano das oficinas é a possibilidade que temos de perceber

\footnotetext{
${ }^{2}$ ALVES, Nilda. Decifrando o pergaminho: o cotidiano das escolas nas lógicas das redes cotidianas. In: OLIVEIRA, Inês; ALVES, Nilda (Org). Pesquisa no/do cotidiano das escolas sobre redes de saberes. Rio de Janeiro: DP\&A, 2001. p. 17.

${ }^{3}$ CERTEAU, Michel de. A invenção do cotidiano: artes do fazer. Petrópolis: Vozes, 1999. p. 102

${ }^{4}$ CERTEAU, 1999 , p. 83-84
} 
as escolhas táticas de cada artista-docente para o ensino do teatro, assim como de compreender os lances dos participantes em cada trabalho proposto.

\section{O que chamamos de oficina?}

Um primeiro ponto a ser tratado concerne à utilização da oficina de teatro como recurso pedagógico. $\mathrm{O}$ dicionário $A$ linguagem da cultura, produzido pelo SESC-SP, define assim o termo:

Oficina $-{ }^{5}$ 2) curso informal de breve duração ministrado para o aprendizado de uma técnica ou disciplina artística, sem objetivos oficialmente profissionalizantes; 4) laboratório (local ou recinto); em francês ateliê, em inglês workshop'.

Workshop - 1) termo inglês correspondente a oficina ou ateliê; 2) curso intensivo ou condensado nas áreas artística e esportiva; 3) experimentação de uma técnica ou de uma estética, principalmente nas áreas teatral e coreográfica, com a função de 'laboratório', ou seja, de pesquisa formal. Com esse sentido foram constituídas escolas de renome no séc. XX, como a Dramatic Workshop de NY, na qual trabalhou Erwin Piscator, o Theatre Workshop, da encenadora inglesa Joan Litlewoad ou o American Lyric Theatre Workshop, do centro de aprendizado e de criação de dança do coreógrafo Jerome Robbins. ${ }^{7}$

A oficina de teatro é um recurso amplamente utilizado nas atividades artístico-pedagógicas. Caracterizada como uma ação pedagógica ativista, em que o professor/oficineiro direciona as atividades de forma a estabelecer um exercício dialético entre o seu conhecimento e o que os participantes trazem de seu universo sociocultural. Nesta medida, a oficina torna-se um momento de experimentar, refletir e elaborar um conhecimento das convenções teatrais, buscando instrumentalizar os participantes de um conhecimento teatral básico, vivência de uma atividade artística que permite uma ampliação de suas capacidades expressivas e consciência de grupo. No caso dos grupos teatrais, valemos da observação de Argelander:

Historicamente, os workshops (oficinas) de teatro foram organizados dentro de uma estrutura flexível de atuação do grupo; o workshop em si mesmo funcionava com duas capacidades básicas: a primeira e mais importante, como um lugar para se livrar das classes dogmáticas de atuação no sentido de explorar novas idéias e, segunda, como forma prática de fazer produções que poderiam refletir mais os valores pessoais do grupo do que os valores padronizados do teatro comercial ${ }^{8}$.

As oficinas são estruturadas, quase sempre, por exercícios de voz, corpo, jo-

\footnotetext{
${ }^{5}$ Ateliê - estúdio, recinto ou local de aprendizado de técnicas e de criação de obras artísticas, equipado com ferramentas, máquinas e materiais adequados a uma ou várias expressões. CUNHA, Newton (Coord.). Dicionário SESC. A linguagem da cultura. São Paulo: SESC: Perspectiva, 2003. p. 81.

${ }^{6}$ CUNHA, 2003, p. 474.

7 CUNHA, 2003, p. 677.

8 ARGELANDER, Ron. Performance workshops: three types. Tradução de Zeca Ligiéro. TDR: The Drama Review, New York, v. 22, n. 4, p. 4, dez. 1978.
} 
gos e improvisação. Os jogos e as improvisações, elementos básicos no ensino do teatro, são utilizados nestes trabalhos, pois permitem que o material colhido na trajetória do grupo ou do artista seja apropriado e canalizado para o desenvolvimento da criatividade e expressão cênica dos participantes.

As oficinas de teatro oferecidas têm o objetivo de socializar elementos ideológicos e técnicos adquiridos e trabalhados pelo artista-docente em sua práxis artística ao longo de sua carreira. Nelas o pensamento ético e estético são incorporados às atividades pedagógicas e atores e encenadores vão assumindo o papel de artistas-docentes e assim, configurando uma pedagogia teatral.

\section{Alguns exemplos}

A Oficina de Experimentação e Pesquisa Teatral, desenvolvida pelo Oi Nóis Aqui Traveiz, objetiva descobrir novas formas de linguagem e elaborar encenações de intervenção social no cotidiano da cidade. Tal proposta surgiu da necessidade de experimentação e desmistificação da atividade teatral, enquanto especialidade de poucos, e da necessidade de discussão da própria realidade. Trabalha-se contínua e sistematicamente na elaboração de improvisações coletivas que serão apresentadas em ruas e parques da cidade.

Um outro exemplo, a oficina de despressurização do Grupo Tá na Rua, é assim descrita pela atriz e professora Ana Carneiro:

[...] as pessoas chegam, e o material já está na sala, disposto de modo a ser visto e encontrado com facilidade: máscaras, panos, roupas, perucas e outros objetos que favorecem a transformação, material já usado, doado ao grupo e que constitui seu patrimônio. São cores, brilhos, texturas que modificam os corpos, contribuem para a liberação dos sentimentos e estabelecem um estado de teatro, de representação, em relação a tudo que ali acontece, transformando em teatralidade/teatro os amores, as paixões, os ódios, os medos, a violência e tudo mais que aflora'.

Normalmente, as atividades artístico-pedagógicas de um grupo ficam a cargo de um membro específico, que terá a função de organizar pedagogicamente os materiais técnicos trabalhados por todos os integrantes ao longo de sua carreira. Em alguns casos, cada membro torna-se um especialista num determinado instrumental técnico e sua oficina será conduzida a partir dele. Desta forma, acreditamos que a dissociação entre a prática artística e a prática docente, muito comum no meio acadêmico, não alcança a mesma dimensão nas práticas pedagógicas dos grupos. Nestes, as esferas artística e pedagógica encontram-se interligadas, num processo recíproco de aperfeiçoamento.

A educadora e dançarina Isabel Marques, ao tecer considerações sobre a relação entre prática artística e prática pedagógica, propõe o conceito de artista-docente como uma prática educacional de integração entre estes dois universos, colocados como distintos, tanto por artistas como por educadores, mas integrados em sua

\footnotetext{
${ }_{9}$ CARNEIRO, Ana. Espaço cênico e comicidade: a busca de uma definição para a_linguagem do ator: Grupo Tá na Rua 1981. 1998. p. 66. Dissertação (Mestrado em Teatro) - Centro de Letras e Artes, UNIRIO, Rio de Janeiro, 1998.
} 
práxis na construção de um trabalho artístico-educativo, "não abandonando suas possibilidades de criar, interpretar, dirigir, [que] tem também como função e busca explícita a educação em seu sentido amplo"10.

\section{Considerações finais}

É nesta direção que trabalhamos na disciplina Prática de Ensino 3, com alunos do curso de teatro, modalidade licenciatura, da Universidade Federal de Uberlândia, discutindo, problematizando e experenciando a organização e feitura de uma oficina de teatro com conteúdos variados e para um público diversificado. Cada graduando apresenta seu pré-projeto de trabalho, que é discutido por todos, e que gradativamente vai se constituindo como um projeto final de execução. A única exigência que faço é que este projeto seja feito a partir do interesse pessoal do aluno sobre alguma técnica, escola ou procedimento teatral e esteja, de preferência, vinculado à sua prática artística ${ }^{11}$. Com isto, procuramos uma articulação entre a produção artística do licenciando e os procedimentos pedagógicos a serem acionados numa futura relação de ensino-aprendizagem, procurando romper com o velho chavão "quem sabe faz, quem sabe ensina" para uma nova perspectiva na formação do artista-educador "quem sabe faz e ensina".

\section{REFERÊNCIAS}

${ }_{10}$ MARQUES, Isabel. Ensino de dança hoje: textos e contextos. São Paulo: Cortez, 2001. p.112. 11 Cf. TELLES, Narciso; MASCARENHAS, Márcia. Trilhando os caminhos do menino-navegador: Ilo Krugli e o ensino de teatro. In: SANTANA, Arão Paranaguá (Coord.). Visões da Ilha: apontamentos em teatro e educação. São Luís: Grupo de Pesquisa em Ensino do Teatro \& Pedagogia Teatral, 2003. p. 61-74. 
ALVES, Nilda. Decifrando o pergaminho: o cotidiano das escolas nas lógicas das redes cotidianas. In: OLIVEIRA, Inês; ALVES, Nilda (Org.). Pesquisa no/do cotidiano das escolas sobre redes de saberes. Rio de Janeiro: DP\&A, 2001. p. 13-38.

ARGELANDER, Ron. Performance workshops: three types. Tradução de Zeca Ligiéro. TDR: The Drama Review, New York, v. 22, n. 4, p. 3-18, dez. 1978.

CARNEIRO, Ana. Espaço cênico e comicidade: a busca de uma definição para a_linguagem do ator: Grupo Tá na Rua 1981. 1998. 241p. Dissertação (Mestrado em Teatro) - Centro de Letras e Artes, UNIRIO, Rio de Janeiro, 1998.

CERTEAU, Michel de. A invenção do cotidiano: artes do fazer. Petrópolis: Vozes, 1999.

CUNHA, Newton (Coord.). Dicionário SESC. A linguagem da cultura. São Paulo: SESC: Perspectiva, 2003.

FERNANDES, José Nunes. Oficinas de música no Brasil. História e metodologia. Teresina: Fundação Cultural Monsenhor Chaves, 2000.

MARQUES, Isabel. Ensino de dança hoje: textos e contextos. São Paulo: Cortez, 2001.

SANTANA, Arão Paranaguá (Coord.). Visões da Ilba: apontamentos em teatro e educação. São Luís: Grupo de Pesquisa em Ensino do Teatro \& Pedagogia Teatral, 2003.

TELLES, Narciso; MASCARENHAS, Márcia. Trilhando os caminhos do menino-navegador: Ilo Krugli e o ensino de teatro. In: SANTANA, Arão Paranaguá (Coord.). Visões da Ilha: apontamentos em teatro e educação. São Luís: Grupo de Pesquisa em Ensino do Teatro \& Pedagogia Teatral, 2003. p. 61-74. 


\section{Jogo dRAmÁtico SEgundo JeAn-PierRe RyngaERT}

Só há idéias burguesas no que a escola da burguesia divulga. É burguês catapultar Victor Hugo em "pára-quedas" para crianças que ninguém preparou para acolher, é burguês interpretar Victor Hugo de maneira puramente formalista deixando na sombra as suas tomadas de posição essenciais: já não é burguês iniciar as crianças em Victor Hugo levando-as pouco a pouco a ir além do seu Tintin habitual. E é a melhor das oportunidades para que finalmente sejam eles próprios a extrair, quer dos seus livros, quer da sua experiência, aquilo que irá alimentar uma tomada de consciência criadora do mundo de hoje. (George Snyders)

A mudança, ou como diz Snyders, "a purificação revolucionária entre os contributos que a escola burguesa se compraz precisamente em amalgamar”, decorrerá de uma demanda de fora para dentro. É a convite dos alunos que a pedagogia do professor tenderá mais ou menos para a "escola progressista" que, no que diz respeito à arte, deve buscar "separar as exigências efetivamente fundadas da cultura e as mistificações, os disfarces a que essa mesma cultura dá lugar”.

Como relacionar a importância desta demanda dos alunos, sob a perspectiva de uma escola progressista, com a teoria e prática do jogo dramático de Jean-Pierre Ryngaert?

Seu primeiro livro, Le Jeu dramatique en milieu scolaire, datado de 1977, é portador de um capítulo exclusivo para definir o jogo dramático para o qual devemos dedicar uma leitura cuidadosa e investigativa. Em linhas gerais, o autor preocupa-se em delimitar as fronteiras entre o jogo dramático, o psicodrama e o teatro, ampliando largamente o universo teórico que até então enfocava o jogo dramático de forma generalizada, a partir de pressupostos que não lhe diziam respeito diretamente.

Neste artigo, vamos nos limitar a tratar desta definição em dois momentos distintos e entrelaçados no intuito não só de provocar a leitura da obra de Jean-Pierre Ryngaert, como também de proporcionar material para atividade de reflexão em sala de aula do Curso de Licenciatura/Formação de Professores em Artes 
Cênicas (Ensino do Teatro). No primeiro momento, nossa preocupação principal recairá sobre alguns aspectos que tratam da relação entre jogo dramático e teatro contemporâneo.

Ao afirmar que o jogo é um meio de conhecimento da realidade, Ryngaert não deixa de se questionar sobre que realidade se reproduz no jogo e que relações o jogo mantém com a arte - "um outro instrumento de modelização do mundo":

O jogo dramático deve ser simultaneamente um meio concreto de criação de situações e de aquisição de técnicas, e um meio de reflexão destas situações a fim de fazê-las tender para a invenção. É a coexistência do modelo abstrato e do modelo lúdico que permite avançar e escapar ao impasse que representa a reprodução de clichês ${ }^{1}$.

Sendo esta uma das abordagens mais importantes para definição do jogo dramático, importa deixá-la explicitada de forma que não se criem idéias falsas. Cabe também acrescentar que o que se tenta aqui não exclui a leitura do desenvolvimento integral dos argumentos selecionados pelo autor. A necessidade de abrir um debate por este enfoque reside no fato de encontrar na proposta de Ryngaert um deslocamento da preocupação com a expressão para aquela que recai sobre a comunicação. A relação entre a forma e o conteúdo, a importância que a Escola atribui ao significado, à sua compreensão, ao fato de tudo ser racionalmente entendido e explicado, adquire no jogo dramático uma particularidade:

É por isto que não colocamos a aquisição de uma técnica anterior à elaboração de um discurso. O fundo só poderia estar subordinado à forma ou só poderia visar a sua clarificação. A invenção de formas originais mais adaptadas a qualquer novo discurso é o objetivo determinante em direção do qual tendemos².

As mistificações e os disfarces, a que Snyders se refere, ora se realizam sob enfoque exclusivo da forma, ora sob enfoque exclusivo do conteúdo. Assim, "a pesquisa da expressão está estreitamente ligada às exigências do conteúdo, e o trabalho sobre a forma a uma crítica do conteúdo", explicita Ryngaert quando se refere diretamente ao que ele chama de comportamento lucidamente elaborado. O jogo dramático se dá sempre numa situação de comunicação, na medida em que busca a inventividade, o questionamento dos modelos culturais, a aproximação com a estética teatral. Um instrumento que, desta maneira, evita as armadilhas da imitação estéril. "É por isto que se torna não somente um instrumento de análise do mundo, mas também uma arma diante do mundo"3.

A improvisação tem, assim, de se preocupar lucidamente com as formas que serão convocadas para explicitar a situação que se quer mostrar aos observadores. São estes que vão retornar aos jogadores os comentários pertinentes à melhoria de sua expressão, tendo como referência à clareza quanto ao teatro de que se fala.

\footnotetext{
RYNGAERT, Jean-Pierre. Le jeu dramatique en milieu scolaire. Paris: CEDIC, 1977. 175 p.

2 RYNGAERT, 1977.

${ }^{3}$ RYNGAERT, 1977.
} 
Da mesma forma, a noção de distância do ponto de vista brechtiano é fundamental no nosso trabalho, não só para evitar uma abordagem exclusivamente psicológica do fenômeno teatral, mas também para familiarizar os futuros espectadores com as técnicas de jogo contemporâneas ${ }^{4}$.

O analfabetismo teatral e estético, apontado por Richard Monod em suas aulas no Institut d'Etudes Théâtrales e em seus artigos, refere-se, entre outros aspectos, às manifestações teatrais recentes, aos autores dramáticos contemporâneos, aos diretores e ao conceito de direção propriamente dito. Quando não se tem claro de que teatro se fala, é quase sempre comum se ter em mente o teatro burguês, canastrão, bem "arrumadinho", detentor de mensagens bem comportadas, no qual há inexistência de ousadia ou de ruptura. A imagem cultural por ele transmitida, entretanto, não pode ser confundida com o Teatro, na medida em que não passa de uma das concepções as mais comuns de uma forma de teatro. A contemporaneidade no teatro, se tomada como ponto de referência, pode trazer para o universo da sala de aula a noção de ruptura que lhe cabe e que convém aos alunos tomar conhecimento e dela se apropriar no jogo. Neste sentido, o jogo dramático se define como uma arma diante do mundo. Para reforçar esta idéia, atentemo-nos para o que diz George Snyders:

A escola atual não sente o mínimo escrúpulo em funcionar segundo perspectivas temporais a longo prazo, que só actuam a longo prazo e que esmagam o presente. Isto de dois modos: 'Trabalhem bem para que mais tarde triunfes'. Mas a sua expansão presente, a plenitude da sua existência juvenil, serão realmente objecto de preocupação? E por outro lado, a actualidade tem enorme dificuldade em se introduzir como objeto de estudo: a classe dominante teme-a, prefere guardar silêncio - e falar doutra coisa. Com isto condena todos os alunos à apatia ${ }^{5}$.

O jogo dramático vai tentar caminhos, assim como fez o teatro no século XX, mais particularmente as experiências cênicas e performáticas do teatro, a partir dos anos 1960, em que se opera uma ruptura com o compromisso de reproduzir de forma fiel a realidade. A fragmentação, a coexistência do verbal, da imagem e do som sem prioridade de um sobre o outro, a noção de grupo minimizando, a estrutura hierárquica e a escala de valores, a preocupação com o processo são, dentre outros, novos compromissos estéticos para, em lugar de reproduzir, analisar a realidade. À escuta deste teatro, o jogo dramático estrutura-se e organiza seus conteúdos.

Através do enfoque estético e da adoção de novos compromissos em relação à forma que realize a ruptura com o naturalismo, torna-se possível a aquisição de novos hábitos na prática do jogo capazes de colocar em questão tanto os modelos culturais estandardizados quanto as formas estereotipadas de leitura do real. Uma mudança de qualidade na investigação do mundo passa obrigatoriamente por uma mudança de qualidade no modo de fazê-la. Assim, o jogo dramático determina um comportamento político e uma opção pedagógica.

${ }^{4}$ RYNGAERT, 1977, p. 45.

${ }^{5}$ SNYDERS, Georges. Escola, luta e luta de classes. Lisboa: Moraes Editores, 1981. p. 395. 
Os bons sentimentos podem tirar suas vantagens num jogo que fala do racismo de forma geral e bombardeado de clichês. Mas o jogo só oferece real interesse quando ela fala do racismo através da experiência que os jogadores têm, com as dúvidas, as contradições, as interrogações (e também a imaginação) que lhes pertencem. O jogo torna-se produtivo na medida em que ele é preciso, que deixa falar as subjetividades e que leva em consideração os desejos profundos dos participantes. O que é em princípio uma condição indispensável para que haja prazer ${ }^{6}$.

A garantia do jogo ser produtivo passa por esta concepção de engajamento e investimento pessoal determinada pelo jogar a partir de seus próprios interesses. $\mathrm{O}$ que se coloca em jogo são situações que, enfocadas sob expressiva oscilação de seu significado, polemizando-se a partir de diferentes pontos de vista, podem ser trabalhadas esteticamente através das senhas de jogo, dadas pelo animador, que ajudam a dizer, a melhor dizer. Segundo Ryngaert, as senhas vão favorecer a "ginástica do imaginário", quando formuladas levando em consideração, por exemplo, o acaso e o aleatório:

A situação a mais banal, recolocada num espaço previsto, adquire às vezes uma cor nova. A confrontação insólita de personagens não esperados com antecedência permite renovar o estoque de invenções dos participantes, de trazer um pouco de fantasia a um imaginário limitado ou fechado nas convenções ${ }^{7}$.

O mágico, o não-lógico, não só é permitido como através dele se pode chegar a projetar sobre o real um novo olhar, rompendo com a "bem rígida mímesis que eles procuram em vão reencontrar através das vias convencionais". Provocando constantemente o aumento da capacidade de jogo, deixa-se ao jogador a decisão de assumir ou não os riscos, garante-se a autonomia dos grupos e dos indivíduos. Através do vai-e-vem do jogo ao seu questionamento pelos observadores ativos, o processo pedagógico avança em ritmo próprio.

A referência que se quer ao teatro contemporâneo é a fonte para instrumentalizar o professor e ajudar o aluno a dizer, a comunicar de outra forma:

Um contato sólido com o teatro contemporâneo é indispensável, a fim de que os jogadores construam para si pontos de referência, quiçá modelos contraditórios. Ler/ escrever é uma dupla que faz parte da aprendizagem do francês. Jogar/olhar deveria ser uma dupla também natural, as experiências do espectador retroalimentando aquelas do jogador, e vice-versa. A dupla experiência se impõe para que sejam extrapolados os exemplos simplistas de sketches impostos pela televisão, para que seja possível ousar confrontar-se às formas contemporâneas de escrita e de jogo. Uma real relação ao teatro parece-me indispensável ao professor ${ }^{8}$.

\footnotetext{
${ }^{6}$ RYNGAERT, Jean-Pierre. Le jeu dramatique en milieu scolaire (anexe). In QUATRE articles sur art, créativité, expression et jeux dramatiques mis en relation avec ces pratiques. Paris: Institut d’Etudes Théâtrales, Sorbonne Nouvelle, 1984. p. 32. Traduzido por Renan Tavares. Relatório de pesquisa: anexo artigos traduzidos. CNPQ, 1990.

7 RYNGAERT, 1984, p. 33.

8 RYNGAERT, Jean-Pierre. Jouer, représenter. Paris: CEDIC, 1985. p. 40.
} 
A intervenção do professor é bastante delicada, há riscos de manipulação, de omissão, de dirigismo. A atividade pedagógica do professor difere daquela do diretor de teatro, ainda que ambos se preocupem com a teatralidade e com a pesquisa sistemática nos códigos culturais de seus elementos para a construção de produtos - jogos ou espetáculos.

$\mathrm{Na}$ escola, não cabe trabalhar a diversidade de interpretação com relação direta às diversas formações de ator, nem a aquisição de alguns elementos de códigos de jogo e relação à história da arte. O jogo da farsa, da commedia dell'arte, do palhaço, assim como o jogo interessado em elementos de outra cultura, a oriental, por exemplo, não podem ser apreendidos no tempo restrito da programação curricular. Da mesma forma, evita-se entender o jogo teatral, como comumente se faz, como o alargamento do gesto e seu exagero, o tratamento grosseiro que se dá ao traço.

Meus objetivos, mais modestos, orientam-se para a tomada de consciência do que funda o teatro enquanto tal, independentemente do texto e do diálogo. A identificação de alguns sistemas de convenções já é uma etapa satisfatória, que pode ser atingida no interior do jogo, através de algumas "bricolagens artísticas". Elas não conduzem à mestria absoluta das convenções, mas permitem a consciência de sua existência9.

O trabalho pedagógico em relação à teatralidade também não se define pela separação entre forma e conteúdo. Não se trata nem de realizar uma teatralização vazia de sentido, nem de utilizar um código como conjunto de truques só para embelezar uma idéia. A pesquisa de um código acompanha a elaboração do discurso, num mesmo movimento e determinadas pela mesma necessidade.

Segundo Ryngaert, a tomada de consciência dos diversos códigos se realiza pela opção jogo/não-jogo. A aprendizagem de regras simples que marcam a passagem do estado de disponibilidade ao estado de jogo significa o questionamento da transparência em teatro. Ela remete a não mais fazer a diferença entre a pessoa e a personagem, a falar dela como se fosse verdade, a falar do jogo como se tratasse do mundo. $O$ jogo inscrito num sistema determinado se realiza como reconhecimento da "mentira". A aprendizagem desta passagem do não-jogo ao jogo assinala a existência das convenções e que a seleção de uma delas é necessária para "mentir verdadeiramente".

$\mathrm{Na}$ medida em que a teatralização não é encarada como um molde para vestir um significado a priori estabelecido, o jogo dramático procura se realizar a partir de senhas concretas que provoquem a teatralidade no momento da produção dos signos. São elas que relativizam a anterioridade ou posteridade da forma em relação ao conteúdo e vice-versa.

Todas estas senhas trabalham sobre a materialidade do jogo e, em primeiro lugar, as senhas espaciais que impõem convenções rigorosas. Limitar-me-ei ao exemplo de jogadores que devem considerar o espaço imposto, que não corresponde ao lugar real, onde se desenvolve a situação que escolheram. Tomando consciência da metáfora espacial, descobrem também que a teatralização não se limita ao exagero ou ao efeito.

$\overline{9}$ RYNGAERT, 1985, p. 58. 
Ela começa com a derrapagem, o deslocamento do sentido, a metáfora. Quando as senhas provocam estas derrapagens, elas caminham na direção de uma teatralização que brota do coração da invençãa ${ }^{10}$.

O autor acrescenta ainda que a teatralidade deve ser identificada no jogo, nascida involuntariamente do lugar real, das atitudes sem jeito dos jogadores, de um efeito de luz fortuito, de uma situação ligeiramente insólita. Uma teatralidade do cotidiano que independe de artifícios, de palco. Trata-se de uma educação do olhar que trabalha sobre a observação do jogo em relação ao ambiente em que se realiza. "A teatralidade do espaço não começa no teatro, assim como a do gesto ou da mímica, ela intervém no cotidiano" $"$.

A solidariedade, que se reivindica ao realizar o jogo dramático entre jogadores e observadores, explicita uma atividade estético-pedagógica que faz interagir dialeticamente: a realidade cotidiana e a criação estética, a inventividade em sala de aula e os processos criativos na arte. Assim, ela não exclui a pressão que o grupo, o coletivo de alunos, possa fazer no sentido de avanços reais. Esta pressão se traduz por uma demanda explícita de fazer a cultura escolar manter uma relação com os problemas da vida. A cultura passa a ser um meio de ação sobre o real e de modificação: não mais se revela na escola através de evasivas, gratuidades nem simplesmente se restringe a exercícios puramente formais.

A educação estética poderia contribuir para a construção de uma escola progressista se ela realmente der conta da desmistificação do ilusório e da mentira que uma determinada classe social atribui à estética adequada e aos produtos difusores de sua ideologia.

Quanto mais obras-primas se conhecerem, mais o peso da verdade e da realidade se sobreporá ao artificial burguês. As exigências dos alunos proletários, tomadas em conta e interpretadas por professores progressistas, correspondem à passagem da classe de André Theuriet a Eluard. A cultura operária carece da escola não para se renegar, mas para se realizar. A escola precisa de que a pressão operária seja forte: de outro modo corre o risco de se esquecer de tirar das obras culturais sua substância revolucionária ${ }^{12}$.

No segundo momento, propomo-nos a, através de duas reflexões com base nas idéias de Ryngaert, interrogar nossa prática pedagógica no Ensino Fundamental e Médio, nos quais o jogo marca presença cotidianamente.

Em primeiro lugar, vamos tratar de sua desconfiança em relação aos "exercícios” e à transmissão simplista de técnicas de interpretação para o ator. Mesmo sabendo como é difícil para a maioria dos grupos se lançar de imediato em um trabalho aprofundado, sem esta espécie de "aquecimento", ou "tempo de relacionamento", ou ainda "limpeza do espaço", lembra-nos que os jogos e exercícios difundidos por Augusto Boal, entre outros existentes, retirados de seu contexto, de sua significação ideológica (como no caso do Teatro do Oprimido), correm o risco de

${ }^{10}$ RYNGAERT, 1985, p. 60.

${ }^{11}$ RYNGAERT, 1985.

12 SNYDERS, 1981, p. 403. 
se reduzirem a momentos superficiais, mecânicos. Sua desconfiança no tocante aos exercícios se faz acompanhar do desejo de abrir polêmica contra o "não importa o quê" proposto aos alunos, simplesmente porque havíamos feito ou teríamos visto fazer em algum lugar. É necessário ser mais prudente neste sentido. É necessário refletir sobre os objetivos da expressão dramática no meio escolar antes de decidir sobre a escolha destas "entradas" - propostas ou impostas - antes do jogo dramático propriamente dito. Elas podem se dar por elas mesmas.

Sem dúvida alguma, é necessário colocar os indivíduos e os grupos em relação, mas que seja permitido o direito à utopia. Pois estas formas de criar condições para o jogo são inevitavelmente dirigidas por um emissor único (o animador/o professor), que decide no lugar dos participantes o estado que eles devem atingir para produzir "bons jogos". E se os indivíduos tivessem direito a estados diferentes? Ou ainda, se fosse o caso de, ao final do caminho, serem capazes, por eles mesmos, de chegar como bem entendessem a este estado? Para Jean-Pierre Ryngaert, a autonomia dos indivíduos e dos grupos permanece o objetivo maior de seu trabalho. Neste sentido, ele preconiza que estas seqüências iniciais ou "entradas" não se caracterizem como bengalas (a aprendizagem de truques desgastados, ou o esconde-esconde da imaginação) de propriedade única do professor/animador.

Em segundo lugar, acredito ser interessante trazer à tona algumas reflexões de Jean-Pierre Ryngaert sobre seu insistente interesse em “jogar o mundo”, fortemente presente em seu primeiro livro, O Jogo dramático no meio escolar, de 1977. Apesar de ser mal compreendido, como, por exemplo, a necessidade de provar no jogo uma boa vontade ideológica um pouco inocente ou uma certeza política qualquer, o jogo dramático, correndo o risco de ser ou não didático, não escaparia dos "grandes temas" - quer renovados pela moda ou pela necessidade: a poluição, a violência, a miséria, a família, as drogas, a mídia. Ryngaert nos revela que, ao propor aos jogadores de se investir pessoalmente no jogo, como uma alternativa, corre-se o risco de sermos considerados suspeitos de favorecer o olhar voltado para seu próprio umbigo, a confissão íntima ou o psicodrama pirateado.

É bem verdade que o que os participantes jogam não apresenta interesse algum (nem para eles, nem para os outros), a não ser quando coloca em questão uma imagem do mundo que lhes diz respeito diretamente, em que eles podem se incluir. O jogo dramático, assim, torna-se produtivo, pois deixa falar as individualidades e leva em consideração o desejo profundo dos jogadores. Torna-se, assim, fonte de prazer.

O prazer reside também no interesse que cada um adquire em jogar o que lhe atrai e a fazer comungar seus interesses. Ryngaert nos lembra que é preciso nos encorajar a ter paciência, quando as situações abordadas não nos agradam pessoalmente. Por que diabos um grupo ou indivíduos aceitariam, da noite para o dia, lançar sobre a área de jogo preocupações que lhes pertencem ou às vezes lhes questionam? Por que estas preocupações seriam expostas diante dos outros, do professor/animador, nos quais eles, em princípio, não vêem razão para depositar confiança? Em nome do quê este professor/animador decidiria bem rapidamente o que é importante e o que não o é? As situações impostas ou caídas de pára-quedas não se revelam produtivas; são as senhas que ajudam a dizer, afirma Ryngaert. 
No sentido de trazer mais clareza a esta reflexão, vejamos o exemplo que ele nos dá com uma turma de $2^{a}$. Série do Ensino Médio: foi proposto se trabalhar em torno de Mãos Sujas, de Jean-Paul Sartre, peça estudada em sala de aula de literatura. Os adolescentes decidiram jogar as cenas não escritas, simplesmente mencionadas no texto de Sartre, as quais tinham uma relação com a infância ou a adolescência do personagem Hugo. A máscara do personagem serviu para que eles falassem daquilo que lhes dizia respeito: situações imediatas que eles tinham dificuldade de ver claramente, que os confrontavam com suas próprias famílias. O jogo encontra uma formidável alegria, quando introduz no aqui e agora imagens concretas de um algum lugar que diz respeito diretamente aos jogadores, reafirma Ryngaert. Assim, duas jovens da Martinica, recém-chegadas no Liceu de um subúrbio de Paris, jogam com delícia e um certo alívio, uma cena em que camponeses de seu país chegam em casa ao final de uma jornada de trabalho. Falando em crioulo aos personagens turistas e se movimentando de forma que ninguém da turma jamais as viu se movimentar, elas afirmam, com uma força tranqüila, uma identidade que elas não tinham ainda podido (ou querido) assumir no espaço escolar. Ryngaert acrescenta ainda que num momento posterior ao jogo, as jovens o resumiram como o desejo de jogar "lá", fazendo este "lá" entrar na turma simplesmente porque lhes dizia respeito, porque elas se incluíam na imagem do mundo que apresentavam e da qual se apropriaram ao jogá-la.

Sendo assim, ele volta a nos falar da paciência, pois, às vezes, são necessários dez jogos sobre situações desgastadas ou falsamente imitadas para que nasça uma imagem forte. Aprender a dizer leva tempo, mas, segundo Ryngaert, este tempo nunca é inutilmente perdido.

\section{Concluindo}

O jogo dramático na educação prioriza colocar em tensão o jogo espontâneo e aquele regido por códigos teatrais. Não se trata de negar a "livre expressão", mas de provocá-la em relação às formas e estruturas nas quais se realizam as inúmeras possibilidades da representação teatral. A provocação visa o deslocamento da livre-expressão para um encaminhamento lúcido, ainda que de experimentação das formas de representação da arte teatral, da apropriação das possibilidades expressivas realizáveis segundo códigos precisos. Do ponto de vista pedagógico, há que ser não-diretivo e saber respeitar o direito do aluno à sua autonomia e à sua opção pelos riscos que quer assumir no jogo.

Quando Jean-Pierre Ryngaert coloca em questão as longas séries de jogos ou exercícios que precedem o jogo dramático (comum a muitas práticas), ele, ao mesmo tempo, elabora a crítica à manutenção do espontaneísmo no jogo que, em geral, esta fase preparatória opera. $\mathrm{O}$ comportamento lúcido e autônomo que se espera do aluno entra em tensão como o que se entende ser espontâneo, natural, próprio, livre. $\mathrm{Na}$ nossa prática pedagógica, percebemos em crianças, adolescentes e adultos uma reduplicação de modelos culturais, do "déjà vu" que colocam radicalmente em questão a possibilidade de se entender o jogo espontâneo como expressão inocente, imaculada, não adulterada.

O comportamento lúcido passa por uma apropriação da expressão estética, 
colocando em questão os inevitáveis estereótipos que acompanham qualquer manifestação de livre expressão. A viabilidade deste comportamento lúcido só pode ser garantida pela relação que o jogo dramático estabelece com a estética teatral.

Os professores de arte deveriam de fato mostrar a seus alunos que o inconsciente não deve ser reprimido, que ele pode tornar-se a fonte de uma grande vitalidade [...] mas somente quando dominado pelas forças do ego e enriquecido por ele. O que é necessário é um trabalho disciplinado do material inconsciente caótico; é necessário que ele seja transformado e moldado em formas que sejam significativas tanto para o artista quanto para os outros. Nossos alunos deveriam aprender que o inconsciente, quando utilizado como uma fonte natural, pode enormemente dar vida ao conjunto da personalidade; enquanto que a expressão livre e desenfreada do inconsciente é um passo em direção à desintegração da personalidade ${ }^{13}$.

Bruno Bettelheim acrescenta à preocupação com o espontaneísmo, ao fazer não importa o quê, ao não ter nenhuma postura crítica face à reprodução de modelos culturais, os riscos da livre-expressão desenfreada, inconsciente, na educação. Chama a atenção dos professores sobre o fato de que os riscos podem ser evitados, ao levar em conta o trabalho lúcido do artista, da arte, como referência central e prioritária para um trabalho de educação estética.

Não se pode esquecer da importância da relação entre jogadores e observadores no jogo dramático no sentido de determinar os avanços do grupo e de cada indivíduo no tocante à lucidez e à autonomia. Não cabe ao professor nem acelerar, nem atrasar o processo que o grupo desenvolve, mas saber usar de paciência para evitar diretividade neste processo. A referência à arte, de forma constante e oportuna, é uma garantia para uma pedagogia não-diretiva, para o aumento gradativo da capacidade de jogo dos estudantes e não devemos jamais nos esquecer de que o produto artístico é polissêmico, abre possibilidades de caminhos, opções e recusas. $\mathrm{O}$ que, sem dúvida, favorece uma educação estética associada à "tomada de consciência criadora do mundo de hoje".

${ }^{13}$ BETTELHEIM, Bruno. Pontos de vista pessoais sobre a arte e a educação artística. In: QUA$T R E$ articles sur art, créativité, expression et jeux dramatiques mis en relation avec ces pratiques. Paris: Institut d'Etudes Théâtrales, Sorbonne Nouvelle, 1984. p. 3. 


\section{REFERÊNCIAS}

BETTELHEIM, Bruno. Pontos de vista pessoais sobre a arte e a educação artística. In: QUATRE articles sur art, créativité, expression et jeux dramatiques mis en relation avec ces pratiques. Paris: Institut d'Etudes Théâtrales, Sorbonne Nouvelle, 1984.

RYNGAERT, Jean-Pierre. Le jeu dramatique en milieu scolaire. Paris: CEDIC, 1977.

RYNGAERT, Jean-Pierre. Le jeu dramatique en milieu scolaire (anexe). In QUATRE articles sur art, créativité, expression et jeux dramatiques mis en relation avec ces pratiques. Paris: Institut d'Etudes Théâtrales, Sorbonne Nouvelle, 1984. p. 31-35. Traduzido por Renan Tavares. Relatório de pesquisa: anexo artigos traduzidos. CNPQ, 1990.

RYNGAERT, Jean-Pierre. Jouer, représenter. Paris: CEDIC, 1985.

SNYDERS, Georges. Escola, luta e luta de classes. Lisboa: Moraes Editores, 1981. 


\section{GATO\&RATOS: ATIVIDADE TEATRAL NA PRÉ-ESCOLA}

Ricardo Ottoni Vaz Japiassu

\section{O problema da formação de Teatro-Educadores para a educação infantil e séries iniciais do ensino fundamental $\left(1^{\mathrm{a}}\right.$ a $4^{\mathrm{a}}$ série $)$}

A inserção obrigatória do Teatro como "área do conhecimento" no currículo oficial da educação básica nacional deu-se a partir da entrada em vigor da Lei de Diretrizes e Bases da Educação - LDB 5692/71 e consolidou-se com a promulgação da Lei de Diretrizes e Bases da Educação Nacional - LDBEN 9394/96. Pode-se constatar, por exemplo, que tanto os Parâmetros Curriculares Nacionais - PCNS ${ }^{1}$ quanto o Referencial Curricular Nacional da Educação Infantil - RCNEI ${ }^{2}$ recomendam o desenvolvimento do trabalho pedagógico com as Artes Cênicas respectivamente nas séries iniciais do ensino fundamental e na educação infantil ${ }^{3}$.

Seria redundante aqui um exame crítico do tratamento didático-pedagógico dispensado ao Teatro por estes documentos, porque isso já foi feito em publicações anteriores ${ }^{4}$. A principal questão que emerge com a problemática da "disciplinarização” do Teatro no Brasil, hoje, no meu entendimento, é a do locus da formação docente dos Teatro-Educadores que irão atuar na educação infantil e séries iniciais do ensino fundamental ( $1^{\mathrm{a}}$ a $4^{\mathrm{a}}$ série).

Sabe-se que a "licença" para ensinar nestes níveis da escolarização é prerrogativa do pedagogo. Mas o fato é que os currículos dos cursos de formação de professores e de Pedagogia não têm oferecido aos seus cursistas um programa educacional com o Teatro que satisfaça as necessidades formativas do Teatro-Educador, ou seja, preparando-o para intervir pedagogicamente na educação infantil e

\footnotetext{
${ }^{1}$ Orientações oficiais dos conteúdos a serem trabalhados pelas várias áreas do conhecimento no ensino fundamental ( $1^{\mathrm{a}}$ a $8^{\mathrm{a}}$ série).

2 Orientações oficiais dos conteúdos a serem trabalhados na educação infantil.

3 Cf. BRASIL. Ministério da Educação. Secretaria de Educação Fundamental. Referencial curricular nacional de educação infantil. Brasília, DF, 1998. v. 1-3; BRASIL. Ministério da Educação. Secretaria de Educação Fundamental. Parâmetros curriculares nacionais. Brasília, DF, 1997. v. 1-10. 4 PENNA, Maura (Org.). É este o ensino de arte que queremos? Uma análise das propostas dos parâmetros curriculares nacionais. João Pessoa: Universitária UFPB, 2001; JAPIASSU, Ricardo. O lugar do lúdico na educação infantil brasileira. Revista da FAEEBA: Educação e contemporaneidade, n. 16, p. 191-199, jul./dez. 2001a.
} 
séries iniciais do ensino fundamental (fundamental menor) ${ }^{5}$. O problema agrava-se em razão de as licenciaturas em Teatro não chamarem para si a responsabilidade de formarem, também, Teatro-Educadores habilitados para atuar nestes níveis de escolaridade.

Tanto a educação infantil quanto os níveis inicias do ensino fundamental $\left(1^{\mathrm{a}}\right.$ a $4^{\mathrm{a}}$ série) possuem, cada um, no que tange à atividade dramática e cênica, especificidades ludopedagógicas próprias (na educação infantil a ênfase é no "faz-de-conta" ou "jogo com regras implícitas"; nas séries iniciais do ensino fundamental, focaliza-se mais o jogo com regras explícitas) ${ }^{7}$.

Há nitidamente uma lacuna na formação docente de Teatro-Educadores porque nem os cursos de Pedagogia nem as licenciaturas em Teatro preparam os profissionais habilitados para a organização da atividade pedagógica com as Artes Cênicas na educação infantil e fundamental menor. Isto preocupa.

Sou da opinião de que as licenciaturas em Teatro devam também oferecer a habilitação profissional para esses níveis da escolarização - sem prejuízo da formação dos professores generalistas responsáveis pela transposição pedagógica dos conteúdos das diferentes áreas do conhecimento que ocorre nos cursos de Pedagogia ${ }^{8}$.

Se os cursos de Pedagogia não têm sido capazes de atender à demanda formativa de Teatro-Educadores para a educação infantil e para o fundamental menor, então, que as licenciaturas em Teatro ousem fazê-lo. O que não se justifica, de modo algum, é fechar os olhos para essa problemática e fingir que ela não existe. Talvez a formação de Teatro-Educadores para atuarem nestes níveis da escolarização, no âmbito das licenciaturas em Teatro, possa ser, com efeito, um caminho para a solução do problema, porque precisamos de pessoal capacitado para organizar a atividade dramática e cênica na educação infantil e no fundamental menor - se de fato queremos o desenvolvimento do Teatro-Educação.

Em resumo: sou da opinião de que não devemos confiar unicamente aos cursos de Pedagogia a tarefa de formar Teatro-Educadores para os primeiros níveis da escolaridade. A realidade educacional brasileira demonstra que as faculdades de Educação e Institutos Normais Superiores têm falhado no atendimento à expectativa dos Artistas Cênicos, Pedagogos e Pais conscientes da relevância do papel do Teatro na perspectiva de uma educação infantil emancipadora na contemporaneidade?.

\footnotetext{
${ }^{5}$ JAPIASSU, Ricardo. Desafios da (in)formação docente: o trabalho pedagógico com as artes na escolarização. Eccos Revista Científica do Centro Universitário Nove de Julho: Escola Básica e Sociedade, São Paulo, v. 6, n. 1, p. 65-83, jun. 2004.

${ }^{6}$ VYGOTSKY, Liev S. O papel do brinquedo no desenvolvimento. In: da mente. São Paulo: Martins Fontes, 1996. cap. 7, p.121-137. A formação social

7 PIAGET, Jean. A classificação dos jogos e sua evolução, a partir do aparecimento da linguagem. In: . A formação do símbolo na criança: imitação, jogo e sonho, imagem e representação. Rio de Janeiro: Guanabara Koogan, 1978. cap. 5, p. 137-180; PIAGET, Jean. As regras do jogo. In: _. O juízo moral na criança. São Paulo: Summus, 1994. cap. 1, p. 23-91.

${ }^{8}$ Há uma interessante discussão a respeito da formação de professores generalistas $\mathrm{x}$ especialistas para a educação infantil e fundamental menor. Cf. SAYÃO, Rosely. Qual o melhor, generalista ou especialista? Presente! Revista de Educação, Salvador, CEAP, n. 48, ano 13, p. 25-26, mar./ maio 2005; SAMPAIO, Teresa C. F. de M. Polivalência ou ...? Presente! Revista de Educação, Salvador, ano 13 , n. 48 , p. 27-28, mar./maio 2005.

9 ADORNO, Theodor W. Educação e emancipação. Rio de Janeiro: Paz e Terra, 2000.
} 
Adiante passarei a expor alguns resultados obtidos com uma pesquisa-intervenção realizada em 1998 numa pré-escola da rede municipal de São Paulo ${ }^{10}$. O objetivo do que será exposto a seguir é unicamente o de compartilhar descobertas a respeito de alguns aspectos didático-pedagógicos específicos da atividade cênica lúdica na educação infantil que possam (in)formar Teatro-Educadores desejosos de atuarem neste nível da escolarização.

\section{A pesquisa-intervenção}

(1) Pré-escolares podem interagir mediados pela linguagem teatral?

(2) Quais as principais características da atividade teatral dos pré-escolares?

(3) Como se aprende a jogar o jogo teatral na pré-escola?

Buscando responder a estas questões eu realizei uma pesquisa-intervenção pedagógica que tinha por objetivo promover o desenvolvimento da capacidade estética em pré-escolares. É preciso, no entanto, esclarecer que não tive - nem tenho - a pretensão de encontrar respostas definitivas para as questões apresentadas acima. Os resultados da pesquisa aqui apresentados devem ser considerados tendo-se em mente (1) o contexto sociocultural da intervenção pedagógica; (2) aspectos idiossincráticos da atuação do coordenador de jogos teatrais e (3) os processos de crescimento pessoal e desenvolvimento cultural únicos dos sujeitos acompanhados pela pesquisa.

O relatório completo da observação participante que se expõe neste artigo foi formalmente apresentado à Faculdade de Educação da Universidade de São Paulo -FEUSP como tese de doutoramento sob a rigorosa orientação da professora doutora Marta Kohl de Oliveira. O projeto desenvolveu-se na Escola Municipal de Educação Infantil - Emei Prof ${ }^{a}$ Jonise Máximo da Fonseca, como proposta de intervenção pedagógica com a linguagem teatral ao longo de um ano letivo. A pesquisa-intervenção foi implementada após ser aprovada pelo Colegiado da escola e contou com o engajamento espontâneo de Claudia Fuga (professora regular da Emei) na investigação.

Todos os jogos teatrais propostos às crianças foram coordenados por Claudia, sob minha orientação. As sessões de jogos foram exaustivamente áudio-foto-vídeo registradas por mim. Entre uma e outra sessão Claudia e eu nos encontrávamos, na sala de vídeo da Emei, para consultarmos os registros do encontro anterior com os pré-escolares, refletirmos conjuntamente sobre o processo do nosso trabalho, discutirmos e planejarmos as próximas propostas para atividade teatral que seriam apresentadas às crianças nas sessões subseqüentes. Foram colocadas 12 crianças juntas em uma classe experimental multisseriada (4 a 6 anos) com o objetivo de praticarem - semana sim, semana não - jogos teatrais. Ocorreram ao todo 14 sessões de trabalho com os pré-escolares ao longo do ano letivo.

Os sujeitos foram selecionados considerando-se (1) o desejo da criança de fazer parte do grupo, (2) a autorização de seus pais e (3) indicação justificada da professora de sua classe regular. Todos os pais concordaram com a participação de

10 JAPIASSU, Ricardo. Jogos teatrais na pré-escola: o desenvolvimento da capacidade estética na educação infantil. 2003. Tese (Doutorado em Educação) - Faculdade de Educação, Universidade de São Paulo, São Paulo, 2003. 
seus filhos no projeto, inclusive autorizando-me, por escrito, a utilizar, com objetivos estritamente acadêmicos, as imagens e nomes verdadeiros das crianças. Ao encerramento de cada sessão de trabalho, uma cópia em vídeo invariavelmente era logo providenciada e permanecia em poder da Emei, para que pudesse ser examinada pelos pais e pela equipe pedagógica da pré-escola.

Claudia e eu participamos ainda de reuniões regulares com os pais das crianças nas quais eram (1) apresentados os registros em vídeo das sessões de jogos; (2) coletados depoimentos sobre o comportamento dos pré-escolares em suas casas ao longo do desenvolvimento do projeto e (3) expostos e discutidos os fundamentos acadêmicos da pesquisa.

\section{O contexto social da investigação}

A Emei Jonise localiza-se no Jardim Cabuçu - um bairro da zona norte de São Paulo atravessado pela movimentada rodovia Fernão Dias, próximo à divisa da capital com Guarulhos. Jardim Cabuçu é uma zona suburbana periférica que apresenta grandes contrastes sociais e econômicos. Por exemplo, ao lado de grandes fábricas e prédios comerciais luxuosos, existem muitas ilhas de pobreza (inúmeras ocupações irregulares de terrenos e grandes conjuntos habitacionais populares).

Grande parte das crianças atendidas pela pré-escola (30\%) morava nos conjuntos habitacionais Cingapura Jaçanã e Mutirão. Dados coletados, em meados dos anos noventa, por uma pesquisa que examinou as condições de moradia das crianças da EMEI, revelaram que: (1) $86 \%$ das crianças viviam em habitações feitas de alvenaria; (2) 59\% delas dividiam o lar com mais de cinco pessoas; e (3) em 59\% de suas famílias apenas uma pessoa tinha alguma ocupação remunerada com renda mensal variando entre um e dois salários mínimos.

A Emei Prof Ja Jonise Maximo da Fonseca foi aberta ao público em março de 1988. Em 1998 (ano em que se desenvolveu a pesquisa de que trata este artigo), existia um total de 407 crianças matriculadas, distribuídas nos três turnos diários de seu funcionamento: três classes no primeiro período ( $7 \mathrm{~h}-11 \mathrm{~h})$; outras três no segundo período (11h-15h) e mais três no último período (15h-18h). Cada classe era constituída por aproximadamente 30 crianças, que ficavam sob os cuidados de uma única professora. As crianças eram separadas em grupos por idade: quatro anos ( $1^{\circ}$ estágio); cinco anos ( $2^{\circ}$ estágio) e seis anos ( $3^{\circ}$ estágio).

A Emei possuía então 14 professoras. Todas haviam ingressado na pré-escola através de concurso público e recebiam entre dois a quatro salários mínimos, de acordo com seu nível de qualificação profissional e jornada de trabalho. Apenas duas professoras eram graduadas em curso superior de Pedagogia. As demais possuíam habilitação para o magistério de nível médio.

Além das professoras, trabalhavam na Emei seis auxiliares de serviço geral, três vigias e quatro pessoas na equipe administrativa (diretora, assessora da diretora, coordenador pedagógico e secretário). Todas as crianças da turma multisseriada experimental constituída para a pesquisa eram filhas de (1) trabalhadores autônomos, (2) trabalhadores assalariados ou (3) pequenos comerciantes do Jardim Cabuçu. 


\section{A atividade teatral da criança na pré-escola}

A proposta metodológica de Viola Spolin ${ }^{11}$ para a atividade teatral ludopedagógica tem sido exaustivamente estudada por pesquisadores da dimensão educativa do Teatro no Brasil desde final dos anos setenta ${ }^{12}$. O sistema de jogos teatrais de Spolin, do modo como vem sendo aplicado na escolarização brasileira, hoje, serviu de ponto de apoio para a intervenção pedagógica com a linguagem teatral desenvolvida na $\mathrm{Emei}^{13}$. Isso equivale dizer que ao lado dos quatro procedimentos operacionais que estruturam a ludopedagogia cênica de Spolin (foco, instrução, platéia e avaliação), utilizou-se outros três novos procedimentos: (1) o círculo de discussão - importado da pedagogia do oprimido de Paulo Freire; (2) a noção de área de jogo - construída sobre as idéias do teatro invisível de Boal; e (3) os protocolos de sessão - com base na teoria da peça didática de Brecht e na prática terapêutica psicodramática de Moreno.

A proposta metodológica para a atividade teatral na escolarização da qual se fala aqui costuma ser emoldurada pela seguinte "rotina" ou ritual: (1) círculo inicial de discussão - quando o protocolo da sessão anterior é apresentado à turma e eleito o jogador que se responsabilizará pela redação do protocolo daquela sessão; (2) proposição e delimitação da área de jogo; (3) divisão do grupo em equipes; (4) apresentação de propostas para a atividade teatral; (5) avaliação logo após a apresentação de uma equipe na área de jogo; (6) novo círculo de discussão para o encerramento dos trabalhos do dia.

Alguns ajustes na "rotina" descrita acima foram necessários para que esta proposta metodológica pudesse ser implementada na pré-escola: (1) ao término de uma sessão as crianças sempre faziam desenhos da sua atividade teatral naquele dia e (2) os protocolos de sessão eram invariavelmente orais e apoiados no vídeo-registro, fotos e desenhos da sessão anterior (recordação estimulada). Outra coisa que precisa ser dita aqui é que a maioria das propostas para atividade teatral apresentada aos pré-escolares baseava-se em jogos tradicionais infantis brasileiros adaptados ao sistema de jogos teatrais ${ }^{14}$.

$\overline{11}$ SPOLIN, Viola. Jogos teatrais: o fichário de Viola Spolin. São Paulo: Perspectiva, 2001; SPOLIN, Viola. O jogo teatral no livro do diretor. São Paulo: Perspectiva, 1999; SPOLIN, Viola. Improvisação para o teatro. São Paulo: Perspectiva, 1992.349 p.

${ }^{12}$ KOUDELA, Ingrid D. Brecht na pós-modernidade. São Paulo: Perspectiva, 2001. 152 p.; KOUDELA, Ingrid D. Texto e jogo. São Paulo: Perspectiva: Fapesp, 1996. 130 p.; KOUDELA, Ingrid D. Um vôo brechtiano. São Paulo: Perspectiva, 1992b. 130 p.; KOUDELA, Ingrid D. Jogos teatrais. São Paulo: Perspectiva, 1992a. 155 p.; KOUDELA, Ingrid D. Brecht: um jogo de aprendizagem. São Paulo: Perspectiva: Edusp, 1991; PUPO, Maria Lucia de S. B. Palavras em jogo: textos literários e teatro-educação. 1997. 230 p. Tese (Livre Docência) - Escola de Comunicação e Artes, Universidade de São Paulo, São Paulo, 1997; VAZ, Beatriz A. C. Teatro ou recreação? 1984. Dissertação (Mestrado em Artes) - Escola de Comunicação e Artes, Universidade de São Paulo, São Paulo, 1984; COELHO, Ana Flora F. de C. Introdução do texto literário ou dramático no jogo com crianças. 1989. Dissertação (Mestrado em Artes) - Escola de Comunicação e Artes, Universidade de São Paulo, São Paulo, 1989; CHAGAS, Amara. A brincadeira prometida... o jogo teatral e os folguedos. 1992. Dissertação (Mestrado em Artes) - Escola de Comunicação e Artes, Universidade de São Paulo, São Paulo, 1992; JAPIASSU, Ricardo. Ensino do teatro nas séries iniciais da educação básica: a formação de conceitos sociais no jogo teatral. 1999. Dissertação (Mestrado em Artes) Escola de Comunicação e Artes, Universidade de São Paulo, São Paulo, 1999.

${ }^{13}$ JAPIASSU, Ricardo. Metodologia do ensino de teatro. Campinas, SP: Papirus, 2001b. 224 p.

${ }_{14}$ Vários jogos tradicionais infantis brasileiros adaptados ao sistema formulado por Spolin podem ser encontrados em Japiassu (2001b). 
A seguir, descrevo como as crianças do projeto interagiram ao longo da implementação do jogo denominado Gato\&Ratos, respectivamente durante a $1^{\mathrm{a}}$ e $4^{\mathrm{a}}$ sessões de trabalho do/com o grupo. A descrição é útil para que se possa entender melhor a proposta ludopedagógica para a atividade teatral na pré-escola que se apresenta aqui:

Claudia pede para que as crianças retirem os sapatos e as meias e os coloquem em um determinado canto da sala próximo à porta de entrada. Risos. Algumas interações verbais entre os pré-escolares. As crianças vão se sentindo, literalmente, mais à vontade. Claudia solicita então que formem um círculo em torno a um tapete retangular posicionado no centro do ambiente. Emoldurando o tapete, encontram-se colchonetes empilhados um sobre o outro, dois a dois. As crianças sentam-se sobre eles.

Claudia - Bom... O jogo que nós vamos fazer primeiro chama-se GatoERatos.

Raphael (4 anos / $1^{\circ}$ estágio) - Quem vai ser o Gato?

Gutierre (4 anos / $1^{\circ}$ estágio) - Eu sou o Gato!

Jéssica (6 anos / $3^{\circ}$ estágio) - E eu sou o Rato!

Claudia - Vamos saber primeiro quais são as regras deste jogo?

Alguns - Vamos...

Claudia - Então nós vamos escolher uma criança, que é o Gato. E as outras, serão os Ratos... Ai, o Gato, ele vai pegar uma criança. Quando ele pegar nessa criança (segura no braço de Gutierre que está a seu lado) ela [a criança] vai ficar parada. Tá bom?

Todos - Tá!

Claudia - O Gato pega o Rato, aí, o Rato fica parado. Os outros Ratos poderão tocá-lo $e$ aí ele volta a brincar. Tá?

Todos-Tá.

Claudia pede para as crianças posicionarem os colchonetes nos quais estão sentadas em apenas um lado da sala. Após a (re) significação (co) laborativa do espaço físico da sala de aula, a professora volta a se dirigir aos pré-escolares.

Claudia-Pronto?

Alguns - Pronto!

Claudia - Então, quem quer ser o Gato?

Todos - (Com o braço elevado e dedo indicador em riste, saltitantes) Eu! Eu!

Claudia - Então, vamos escolher.. Como que nós vamos escolher?

Camila ( 5 anos $/ 3^{\circ}$ estágio) - (Referindo-se a uma parlenda de escolba muito conbecida das crianças da Emei) Minha mãe!

Claudia - Então, levanta a mão quem quiser ser o Gato. Vamos lá!

Claudia "canta" a parlenda" e Gilvan (5 anos / $2^{\circ}$ estágio) é escolbido para ser o Gato.

Não há divisão do grupo em equipes ou explicitação da área de jogo nem tampouco indicação da área de observação (platéia).

Claudia - Então, ele (toca em Gilvan) é o...?

Todos - Gato!

Claudia - E vocês são os...?

Uns - (Ao mesmo tempo em que outros) Rato!

Outros - Ratos!

O jogo tradicional infantil GatoERatos tem início.

$\overline{15}$ O texto da parlenda é o seguinte: Minha mãe mandou eu escolher este daqui, mas como eu sou teimoso (a) eu escolho este daqui! 
Aqui será feita uma interrupção no relato da $1^{\mathrm{a}}$ sessão de jogos com os pré-escolares para se expor a descrição deste jogo - adaptado por mim ao sistema de jogos teatrais de Spolin - conforme foi apresentado à professora Claudia no encontro de planejamento daquela $1^{a}$ sessão de trabalho:

\section{Gato\&Ratos}

Pré-condição:

Platéia de jogadores.

Foco:

Tentar agir como "gato" e "ratos" mantendo as regras que enquadram o desenvolvimento da atividade.

Descrição:

Divide-se o grupo em equipes. Define-se a equipe que iniciará a atividade na área de jogo. Um dos sujeitos da primeira equipe toma o papel de "gato". Todos os demais da mesma equipe são os "ratos". O "gato" precisa pegar todos os "ratos". Os "ratos" precisam escapar do "gato". A um sinal determinado pelo(a) professor (a) tem início o jogo. Os "ratos" alcançados pelo "gato" ficam imóveis, como se estivessem congelados, na posição em que foram tocados pelo "gato".

Instruções do(a) professor(a) durante a atividade da equipe na área de jogo:

Como um gato se move? Como um gato fala? Como se movem os ratos? Como falam os ratos? Procurem deixar a gente ver como um rato se move! Tentem deixar a gente ver como um gato fala! Procure ficar na posição em que você estiver quando for tocado pelo "gato"! Tentem se manter nos limites da área de jogo!

Nota:

Deixar a atividade prosseguir até que todos os jogadores da primeira equipe, se possivel, tenham sido "gato". Solicitar o revezamento das equipes na área de jogo (a primeira equipe assiste agora à segunda equipe jogar). Fazer avaliação coletiva e auto-avaliação logo após a apresentação de uma equipe na área de jogo. Só após todas as equipes terem desenvolvido a atividade deve ser introduzida nova regra. A nova regra a ser acrescentada pode ser a de que os "ratos" paralisados poderão ganhar movimento e se libertarem da "paralisia", desde que outros companheiros "ratos" os toquem, libertando-os do "congelamento". Propor novamente o jogo incorporando nova regra.

Observar:

As crianças conseguem cumprir todas as regras do jogo? Conseguem permanecer "congeladas" após terem sido tocadas pelo "gato"? Elas interagem verbalmente durante a atividade? O que dizem? Elas agem como "gato" e "ratos"? Falam como "gato" e "ratos"? Lembram-se de "salvar" os companheiros imobilizados pelo "toque" do "gato"? Conseguem se manter nos limites da área de jogo?

Avaliação coletiva e auto-avaliação:

Conduzir a avaliação logo após a apresentação de uma equipe na área de jogo. Formular perguntas, inicialmente, às crianças que se encontram na área de observação ou platéia, em seguida, aos jogadores da equipe que se apresentou na área de jogo:

1) Os jogadores desta equipe cumpriram as regras do jogo?

2) Quais são as regras deste jogo? 
3) Os jogadores se mantiveram na área de jogo?

4) Onde começa e onde termina a área de jogo?

5) O que cada um descobriu jogando este jogo?

6) Como você se sentiu quando era "gato"?

7) Como você se sentiu quando era "rato"?

8) O que é melhor: ser "gato" ou "rato"? Por quê?

9) Os que eram "gato" se moviam como um gato? Falavam como um gato?

10) Os jogadores que eram "ratos" se moviam como ratos?

11) O que acontece quando o "gato" toca em alguém que é "rato"?

12) Como um "rato" que ficou "congelado" pode voltar a se mover?

13) É difícil a gente ficar parado como uma estátua? Por quê?

De volta ao relato da $1^{\text {a }}$ sessão de trabalho:

As crianças se divertem com Gilvan no papel de Gato tentando alcançá-las: correria, gritaria, risos. Wellington (6 anos / $3^{\circ}$ estágio) é "tocado" por Gilvan, mas não consegue permanecer imóvel. Claudia intervém verbalmente.

Claudia - (Pára Wellington) Fica duro!

Wellington a obedece. Gilvan pára de correr atrás das outras crianças, põe o dedo polegar na boca e volta-se para a professora. Alguns permanecem muito excitados ainda, movendo-se por todo o espaço da sala. Outros interagem verbalmente. Todos, porém, invariavelmente, permanecem a alguma distância de Gilvan.

Claudia - (Para Gilvan) Agora vai atrás de outra criança!

Gilvan sai em disparada. Logo alcança Jéssica. Jéssica (6 anos / $3^{\circ}$ estágio), como Wellington, também não consegue ficar imóvel. As outras crianças parecem não se lembrarem da regra que possibilita a um Rato ser "salvo" por outro e esquecem de tocar em Wellington para "libertá-lo”. Nova intervenção verbal de Claudia. Nova interrupção da ação na área de jogo.

Claudia - (Para Jéssica) Ele [Gilvan] pegou, tem que ficar... (Simula estar "congelada") na hora! (As crianças, ofegantes, conversam animadamente) Gente, tem uma regra que vocês tão esquecendo: vocês podem tocar nele (referindo-se a Wellington) pra ele voltar a se mexer.

O jogo prossegue. Novas intervenções de Claudia e novas interrupções da atividade. As crianças saltitam de contentamento durante o desenvolvimento do jogo. As ações não se limitam ao tapete (que deveria ter sido explicitado como área de jogo pela professora).

Observa-se no decorrer da atividade que algumas crianças-Ratos já conseguem ficar imóveis - não exatamente na posição em que se encontravam na hora da "pegada" da criança-Gato. Também, pode-se constatar o fato de crianças-Ratos serem "libertadas" da "paralisação" a que estavam condenadas por outros jogadores-Ratos.

O relato deste fragmento da primeira sessão revela alguns problemas ocorridos durante a condução do jogo Gato\&Ratos. Abordá-los aqui é importante para o esclarecimento de certos procedimentos necessários ao funcionamento adequado desta proposta para a atividade teatral, conforme a dinâmica do sistema de Spolin.

Claudia, por exemplo, esquece - em razão daquele nervosismo típico da "primeira vez" - de explicitar a área de jogo (no caso, o tapete). Embora a professora 
dê início à (re)configuração do espaço físico a partir do momento em que pede às crianças para ajuntarem os colchonetes numa das laterais do ambiente, constata-se que ela "salta" as instruções que delimitariam, com rigor e clareza, o local destinado a ser área de jogo e, conseqüentemente, também o espaço reservado à área de observação.

A ansiedade típica de uma "estréia" não lhe permite dividir o grupo em equipes para o necessário revezamento das crianças na área de jogo. E mais, as regras (1) de agir cenicamente como gato e ratos e (2) de os jogadores se manterem nos limites físicos da área de jogo foram, ambas, totalmente ignoradas pela professora. Além disso, Claudia introduz - já de início - a regra de os jogadores-Ratos poderem libertar seus companheiros alcançados pelo pegador-Gato.

Eu poderia tê-la "corrigido", mas considerei inoportuna qualquer intervenção de minha parte naquele momento que me parecia ser "difícil” para ela. Afinal, era seu "début" na condução do trabalho com jogos teatrais na Emei. Julguei que uma manifestação de minha parte, no sentido de retificar sua atuação, a deixaria ainda mais nervosa. Preferi aguardar o encontro de avaliação-planejamento para podermos então analisar, com calma - e algum distanciamento crítico - o vídeo-registro da sessão: "Claudia - Eu tava tensa e acabei me esquecendo".

A par dos problemas identificados acima é preciso reconhecer alguns pontos muito positivos da atuação de Claudia. Refiro-me particularmente à sua habilidade em problematizar a escolha da criança que seria o "primeiro" Gato: "Como que nós vamos escolher?”.

Ora, ela poderia ter determinado arbitrariamente quem seria primeiramente o Gato, ou ter definido qual o procedimento para a escolha da criança que tomaria este papel no jogo. No entanto, observa-se que Claudia prefere colocar nas mãos do grupo de pré-escolares esta "decisão”. A solução encontrada pelas crianças é o uso de uma conhecida parlenda de escolha sugerida por Camila: "Minha mãe!” A sugestão de Camila é aceita pela professora, que democratiza assim a "eleição" - aleatória - de quem seria, inicialmente, o Gato.

Outro ponto positivo da atuação de Claudia, no meu entendimento, são as suas intervenções deliberadas durante o desenvolvimento da atividade, buscando levar as crianças a cumprirem as regras do jogo: "Gente, tem uma regra que vocês tão esquecendo: vocês podem tocar nele (referindo-se a Wellington) pra ele voltar a se mexer.”.

É bem verdade que a introdução desta regra, complicadora do comportamento da criança, deveria apenas ter sido apresentada após os pré-escolares terem se exercitado em permanecerem imóveis ao "toque" do jogador-Gato. Mas a idéia de o coordenador dos trabalhos intervir, deliberadamente, fornecendo instruções aos jogadores - que os ajudem a (re)ativarem a atenção no foco e nas regras da atividade proposta foi, em parte, apropriada por Claudia.

Um olhar atento à performance das crianças de quatro a seis anos durante suas ações na área de jogo, ao longo do desenvolvimento desta proposta de atividade, revela, com nitidez, a dificuldade que elas experimentam ao terem que permanecer imóveis ao serem "tocadas" pelo jogador-Gato. Percebe-se que o controle voluntário sobre seus movimentos, que é solicitado pela regra, exige grande esforço físico - e mental - por parte dos pré-escolares. 
Permanecer imóvel logo após o "toque” do pegador-Gato requer o "descolamento" do pensamento da criança das ações físicas ao seu redor, isto é, solicita que haja uma "separação" do pensamento do sujeito em relação ao seu campo perceptivo concreto. "Fugir" do jogador-Gato, neste jogo, constitui o objetivo dominante dos jogadores-Ratos. A esse "fugir" acabam sendo subordinadas todas as ações físicas da criança durante o desenvolvimento da atividade lúdica.

O contágio emocional dos gritos e movimentos dos companheiros em fuga "desesperada" do jogador-Gato é de tal magnitude, que se torna muito árdua, sobretudo para crianças de quatro a seis anos, a tarefa de "suspender" os movimentos pessoais ao "toque" do pegador.

Permanecer parado, neste jogo é uma ação auto-regulada e não dependente do campo perceptivo concreto do sujeito. Ficar sem se mexer ao mesmo tempo em que se percebe outros companheiros em movimento ao redor não é tarefa fácil. Trata-se de uma "convenção" que exige uma ação voluntária, ou seja, uma "regra" que implica subjugar o impulso de "mover-se", gerado, no caso, pelo contágio cinético-afetivo das ações dos outros companheiros que se encontram em "fuga” do pegador-Gato.

É preciso, no entanto, que o leitor tenha conhecimento de que o jogo Gato\&Ratos foi retomado outras vezes ao longo do processo de trabalho com os pré-escolares. A retomada de um mesmo jogo é fundamental para o aperfeiçoamento das ações na área de jogo por parte dos jogadores. E, em se tratando de crianças de quatro a seis anos, a repetição de propostas para atividade lúdica com a linguagem teatral torna-se extremamente necessária para uma posse genuína das regras do jogo e real compreensão do foco da atividade cênica sugerida ao jogadores.

Durante os encontros de avaliação-planejamento, diante da constatação das dificuldades experimentadas pelas crianças em (1) permanecerem imóveis ao toque do pegador-Gato e (2) de se recordarem de "libertar" os companheiros-Ratos imobilizados, Claudia e eu decidimos (re)apresentar esse jogo ao grupo enfatizando, desta vez, apenas a regra de os sujeitos permanecerem "parados" ao toque do pegador-Gato.

Só após fosse observado por nós um desempenho satisfatório dos pré-escolares no sentido de controlarem voluntariamente suas ações - introduziríamos a regra de os jogadores-Ratos poderem "salvar" os outros companheiros imobilizados pelo toque do pegador-Gato.

Veja-se abaixo o que conversamos, Claudia e eu, logo após termos assistido ao vídeo-registro de sua atuação na condução das propostas para atividade lúdica com a linguagem teatral durante a primeira sessão:

Claudia - Eles não tinham assimilado a regra de tocarpara voltar a ser Rato [para voltar a se moverem no papel de Ratos]... Eu tive que fazer uma intervenção... Tanto que eu falo: - Vocês estão esquecendo de uma regra que é tocar no amigo para ele voltar a brincar... Algumas crianças queriam ser o Gato. Foram todas, né? Quando começaram a jogar não houve discriminação quanto à idade: todos brincaram juntos sem se ater a pegar apenas os que eles já conbeciam... O jogo foi assimilado [pelas crianças] no decorrer da brincadeira e o que parece é que, no início, as ações são individuais e só depois há uma interação entre eles para que o jogo seja possível de ser realizado. 
Eu - Você observa que a gente geralmente inicia o trabalho com um jogo tradicional infantil teatralizado... No jogo GatoERatos, por exemplo, sobre as regras que emolduram essa atividade lúdica são propostas novas regras, novos desafios: agir como gato, agir como rato... Quer dizer: além das regras que tradicionalmente instalam esse jogo há um complicador... há a superposição de novas regras... essas novas regras vão ativar o foco da criança, do jogador, na atividade cênica que lhe é proposta: mover-se e atuar como gato e ratos... Então, há a introdução desse dado novo... Com isso, a gente está acentuando, ressaltando, grifando aspectos de teatralidade presentes - de maneira latente - nesses jogos... E o que ocorre com isso? A criança começa a trabalhar intuitivamente a noção de papel, de personagem, do que seja a interpretação de um papel, do que é a construção de uma personagem, projeção vocal, dicção, entonação, expressão corporal, jeito de se mover etc. E de uma maneira absolutamente lúdica, sem estar ensaiando, sem que se fale em Teatro, sem que a gente esteja prescrevendo como a criança deve se movimentar, falar, agir.

O enunciado da professora Claudia de que "no início, as ações são individuais e só depois há uma interação entre eles para que o jogo seja possível de ser realizado" traduz a grande dificuldade experimentada pelas crianças em coordenarem as ações de (1) se colocarem em fuga do pegador-Gato e, ao mesmo tempo, (2) buscarem "salvar" os jogadores-Ratos imobilizados pelo toque do pegador. Mas Claudia levanta a possibilidade de existir uma outra interpretação deste desempenho "errático" da criança ao levar em consideração a subjetividade de cada uma delas:

Clándia - O que eu fiquei pensando... Algumas questões que esse jogo nos coloca em relação à individualidade de cada um... No começo, ele quer ser o Gato... Então é uma coisa individual. Depois é que ele percebe que ele pode tá jogando com os outros... Então eu, Rato, também sou ativo como o Gato... Talvez seja por isso que eles não tocavam uns nos outros a princípio... Será que não é por isso?

No meu entendimento, o "esquecimento" dos companheiros-Ratos imobilizados ocorre em função da sobreposição de regras. Essa sobreposição solicita um comportamento mais complexo por parte da criança: recordar-se de "salvar" os companheiros-Ratos imobilizados é um complicador do desempenho da criança neste jogo por exigir a coordenação das ações de (1) colocar-se em fuga do pegador-Gato e, paralelamente, (2) buscar libertar os companheiros-Ratos de seu eventual “imobilismo". Além disso, (3) o jogador precisa mostrar agir como gato ou rato; (4) necessita manter-se nos limites da área de jogo e, finalmente, (5) deve permanecer, sem se mexer, na posição em que foi alcançado pelo pegador-Gato.

Vejamos a seguir como se deu a retomada desta proposta de atividade durante o quarto encontro do grupo. 


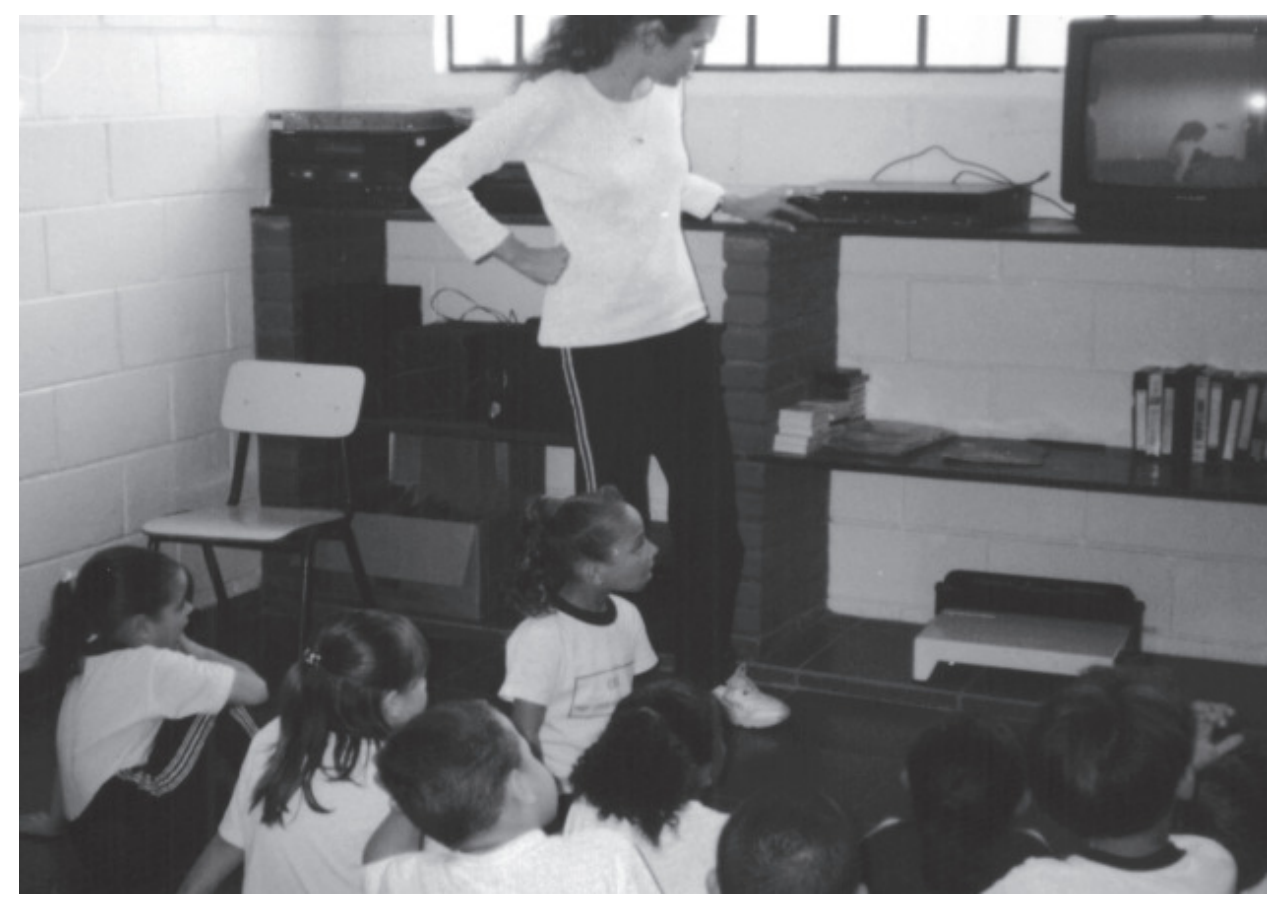

Figura 1. Vídeo-registro do jogo Gato\&Ratos: recordação estimulada

Inicialmente, o vídeo-registro do jogo Gato ERatos, realizado durante a primeira sessão, foi exibido para as crianças durante o círculo de discussão (círculo da memória). Observou-se que os pré-escolares demonstraram acompanhar as imagens na TV com grande interesse.

Há um momento em que Claudia, no vídeo, pergunta: - Quem quer ser o Gato? E Raphael (4 anos / $1^{\circ}$ estágio), que assiste à $T V$, levanta o braço em resposta à pergunta feita pela professora no vídeo. Mas, logo em seguida, ele abaixa o braço. As demais crianças permanecem sentadas muito atentas à exibição da gravação. Após assistirem ao vídeo-registro, a professora solicita a retomada do círculo de discussão e formula algumas questões ao grupo.

Claudia-Quem já viu um gato?

As crianças falam todas ao mesmo tempo, e com entusiasmo, de suas experiências com gatos.

Claudia - Como que é um gato?

Jéssica (6 anos / $3^{\circ}$ estágio) - Ele é loiro, tem orelba, tem boca, tem nariz, tem tudo!

Claudia - Os gatos falam?

Quase todos - Não!

Luis Ramon (6 anos / $3^{\circ}$ estágio) - Falam: (Contendo o riso) falam miau...

Algumas crianças prontamente começam a miar.

Jéssica ( 6 anos $/ 3^{\circ}$ estágio) - Os gatos falam. Só que eles miam quando estão com fome...

Claudia - Eles miam quando estão com fome?

Gutierre ( 4 anos $/ 1^{\circ}$ estágio) - Eles miam porque... Eles miam porque eles não acham a comida deles...

Claudia sorri.

Claudia - Os gatos têm casa?

Alguns - Não!

Outros - Têm! 
As crianças discutem animadamente seus pontos de vista a respeito do local de moradia dos gatos.

Claudia - Quem tem gato em casa?

Alguns - (Levantando o braço com o dedo indicador em riste) Eu!...

Claudia - (Para Gutierre) Você tem gato? Como que é seu gato?

Gutierre (4 anos / $1^{\circ}$ estágio) - O nome dele é Cinza, mas ele morreu.

Claudia - Ab, você tinha...

Gutierre (4 anos / $1^{\circ}$ estágio) - É a Juli que matou ele...

Claudia-Ah, é?

Gutierre (4 anos / $1^{\circ}$ estágio) - Ela pulou... ele pulou... embaixo dele, a Juli.

Luis Ramon (6 anos / $3^{\circ}$ estágio) - Que bicho é essa [Juli]... que bicho é esse?

Gutierre (4 anos / $1^{\circ}$ estágio) - Não é bicho, é cachorro. Daí, é...

Claudia - É um cachorro? Não é um gato?!

Gutierre (4 anos / $1^{\circ}$ estágio) - É um cachorro que matou ele... Daí, a Fernanda foi e internou ele...

Claudia - O gatinho ou o cachorro?

Gutierre (4 anos / $1^{\circ}$ estágio) - O gatinho. O cachorro também tá internado...

Claudia - Ab! O cachorro que chama Juli...

As crianças falam com entusiasmo dos seus animais de estimação (gatos, cachorros, periquitos, passarinhos e hamsters).

Raphael (4 anos / $1^{\circ}$ estágio) - (Para Claudia) Deixa eu falar! Não quer deixar eu falar?! Claudia - Agora é a vez da Bruna. Você teve sua vez de falar. Agora, é a vez da Bruna, não é?

Raphael (4 anos / $1^{\circ}$ estágio) - Mas é que eu tenho outra coisa [para dizer]...

Claudia - (Para Raphael) Então, deixa a Bruna falar. Depois é você. Tá bom assim?

Gutierre (4 anos / $1^{\circ}$ estágio) - (Para Claudia) Não! Depois da Bruna é ele! (Aponta

para Luis Ramon) Depois dele, sou eu.

Claudia - (Para todos) Então, deixa a Bruna falar agora, tá bom?

Bruna ( 5 anos $/ 2^{\circ}$ estágio) - Meu gato é laranja e o nome dele é Tim.

Claudia - O que que os gatos gostam de comer?

Jéssica ( 6 anos / $3^{\circ}$ estágio) - Ração!

Claudia - Ração. O que mais?

Luis Ramon (6 anos / $3^{\circ}$ estágio) - Rato!

Claudia - Rato. O que mais os gatos gostam de comer?

Gutierre (4 anos / $1^{\circ}$ estágio) - É: cachorro!

Jéssica (6 anos / $3^{\circ}$ estágio) - Lixo!

Raphael ( 4 anos / $1^{\circ}$ estágio) - Barata!

Edvana ( 5 anos $/ 2^{\circ}$ estágio) - Mosquito!

Claudia - De que jeito os gatos andam?

As crianças rapidamente respondem: - Assim! E se põem a engatinhar pelo espaço.

Claudia - Quem já viu um rato?

Todos - Eu!

As crianças contam, todas ao mesmo tempo, suas experiências com ratos.

Claudia - Peraí! Vamos falar para que todo mundo escute: todo mundo senta na roda e cada um fala de uma vez... 
Após esse “aquecimento" verbal e cognitivo, o jogo Gato\&Ratos é retomado com apenas a regra de o jogador permanecer imóvel após o toque do pegador-Gato. A área de jogo é explicitada e, também, a área de observação. Claudia enfatiza a necessidade de as crianças mostrarem como gatos e ratos se movem e falam durante o desenvolvimento da atividade. $\mathrm{O}$ grupo é dividido em duas equipes: uma equipe de meninas e outra de meninos, espontaneamente formadas pelas crianças.

A primeira equipe a se apresentar é composta por Edvana (5 anos / $2^{\circ}$ estágio), Bruna (5 anos / $2^{\circ}$ estágio), Marcela ( 4 anos $/ 1^{\circ}$ estágio), Jéssica ( 6 anos $/ 3^{\circ}$ estágio), Camila (5 anos / $3^{\circ}$ estágio) e Bianca ( 6 anos $/ 2^{\circ}$ estágio).

Camila é escolhida para ser, primeiramente, o Gato. As crianças não se mantêm na área de jogo, apesar de reiteradas instruções da professora lembrando-as para permanecerem dentro dela. Em alguns momentos, na fuga do pegador-Gato, as meninas invadem a área de observação (platéia). As que são tocadas pelo jogador-Gato, no entanto, conseguem permanecerem "paradas". Todas se revezam no papel de Gato. Algumas, no papel de pegador-Gato, mostram agir como gato. Outras, no papel de jogadores-Ratos, mostram agir como ratos.

A segunda equipe a se apresentar na área de jogo é composta por Luis Ramon (6 anos / $3^{\circ}$ estágio), Raphael (4 anos / $1^{\circ}$ estágio) e Gutierre (4 anos / $1^{\circ}$ estágio). O desempenho da equipe dos meninos é bem melhor. Eles demonstram maior apropriação das regras do jogo e do foco da atividade cênica proposta: (a) todos se mantêm na área de jogo; (b) todos conseguem permanecer paralisados após o toque do pegador-Gato e (c) todos mostram agir como gato e ratos.

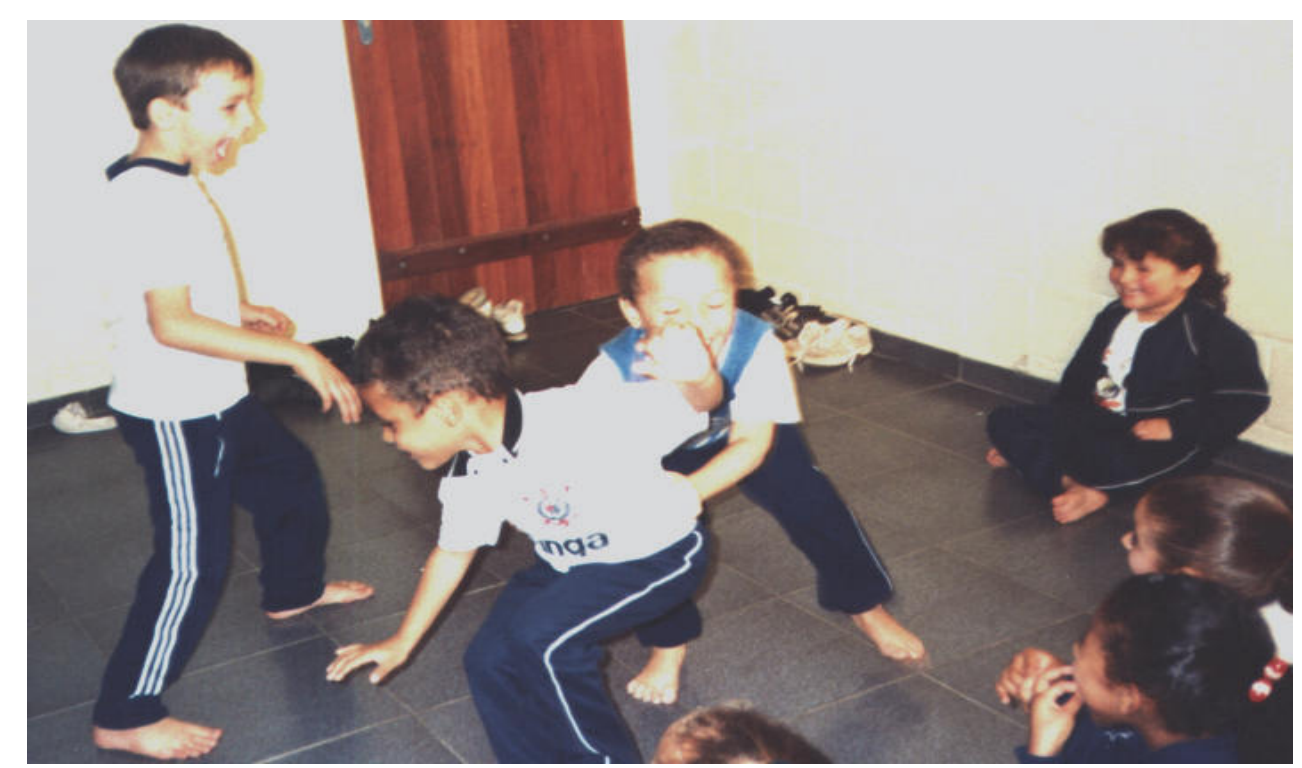

Figura 2. Equipe na área de jogo

Raphael (4 anos $/ 1^{\circ}$ estágio) no papel de pegador-Gato, alcança Gutierre (4 anos $/ 1^{\circ}$ estágio). Luis Ramon (6 anos $/ 3^{\circ}$ estágio) encontra-se imobilizado, de pé. Vê-se a platéia de observadores intragrupo.

Note-se, na foto, a postura de Luis Ramon e Gutierre, ambos no papel de ratos. Eles movem-se sobre dois pés, porém mostram possuírem garras nas mãos. Já Ra- 
phael, no papel de gato, inicia a perseguição engatinhando e "miando", mas só toma a postura bípede quando está muito próximo de alcançar algum parceiro de jogo.

A retomada do jogo Gato\&Ratos, no quarto encontro, deu-se a partir da exibição do vídeo-registro desta proposta para atividade teatral ocorrida na primeira sessão. A discussão que se seguiu à recordação estimulada deste jogo - das ações desenvolvidas pela criança no jogo - ofereceu a real possibilidade de que as regras e o foco da atividade pudessem ser mais bem entendidos pelos pré-escolares.

Os comentários e observações feitos pelas crianças sobre o vídeo-registro do jogo Gato\&Ratos, ocorrido na primeira sessão, foram inicialmente solicitados através de perguntas semelhantes às que se encontram relacionadas no item "avaliação coletiva" e "auto-avaliação" da descrição desta proposta de atividade apresentada anteriormente.

As interações verbais que foram transcritas aqui ocorrem logo após os comentários dos pré-escolares sobre o vídeo-registro do jogo que lhes foi exibido. Elas se dão a partir do momento em que Claudia pede às crianças para que falem de suas experiências pessoais com gatos e ratos.

Esse procedimento revelou-se eficaz no sentido de auxiliar os pré-escolares a agirem efetivamente como gato e ratos durante o jogo. Paralelamente, a supressão da regra que possibilitava "libertar" os companheiros-Ratos da imobilidade contribuiu para o desempenho satisfatório das crianças nesta atividade.

É importante destacar o papel decisivo que possui o revezamento das equipes na área de jogo para maior apropriação, por parte das crianças, do foco e regras da atividade proposta. Além do revezamento do grupo nos papéis de observadores e jogadores, a avaliação coletiva e auto-avaliação, que se dá logo após a apresentação de uma equipe na área de jogo, sinaliza claramente os caminhos a serem percorridos pelos sujeitos rumo ao desenvolvimento de desempenho adequado às regras do jogo e à manutenção do foco da atividade cênica proposta. Não foi por acaso que os integrantes da segunda equipe demonstraram atuar de maneira correta na perspectiva do cumprimento das regras do jogo e de atenção ao foco da atividade proposta.

A condução da quarta sessão por Claudia foi plenamente satisfatória do meu ponto de vista. E a cada novo encontro com o grupo de crianças sua atuação como coordenadora de jogos se aprimorava mais e mais. A transcrição das interações verbais revela ainda sua habilidade na animação de uma roda de conversas com pré-escolares. Note-se também as intervenções da professora no sentido de assegurar o direito democrático da palavra no círculo de discussão: "Deixa a Bruna falar. Depois é você. Tá bom assim?" e "Peraí! Vamos falar para que todo mundo escute: todo mundo senta na roda e cada um fala de uma vez...”.

Considero necessário destacar, uma vez mais, a importância pedagógica da retomada de propostas para a atividade teatral durante o desenvolvimento do trabalho com a ludopedagogia de Spolin na educação infantil. A repetição do jogo Gato\&Ratos, na quarta sessão, demonstra exemplarmente a dialética processo-produto que caracteriza, em geral, as práticas teatrais de natureza lúdica na escolarização, ou seja, explicita o caráter sempre provisório dos resultados obtidos junto ao grupo de jogadores e sinaliza a permanente (re)orientação da práxis do coordenador(a) de jogos em função de uma reflexão pessoal na/sobre sua ação pedagógica. 
Eu - Fundamental você ter percebido a importância da repetição das propostas para atividade... Que elas não se esgotam em uma sessão... Que a sessão não é apenas um "desfile" de jogos... Porque, às vezes, é difícil para a criança de quatro anos entender logo as regras de um jogo... Esse é um processo lento em que, a cada vez que se joga, o desempenho da criança se torna sempre melhor.

Claudia - Eu acho que essa revisão que a gente faz depois [nos encontros de avaliação] é muito importante. Para a gente estar avaliando o que está sendo bom, e o que não tá. Então, esta avaliação, ela nos dá a oportunidade de estar revendo as propostas, de avaliar o que é melhor, o que funciona mais... As coisas que eles gostam, eles querem repetir várias vezes... E é aquela coisa mesmo: cada vez que eles repetem, é alguma coisa que eles resolvem - e que não se esgota porque nunca é resolvido tudo, né? Acho isso bárbaro! Eu acho que esse tempo de 15 dias é um tempo super bom para a gente tá refletindo. E para as crianças, também. Eu penso que esse tempo é importante porque eles [as crianças] resolvem as questões postas pelos jogos teatrais em casa, na hora do parque... Quer dizer, eles continuam fazendo os jogos teatrais em outros momentos, né? E a gente tem esse tempo de 15 dias para tá avaliando, tá repensando. [...] [Sobre o revezamento das equipes na área de jogo] Eu acho isso super interessante, principalmente porque eles se situam em duas perspectivas: como observadores e como jogadores. Então eles experimentam os dois lados do jogo teatral: a hora de assistir, de observar; a hora de atuar, de agir, de verificar se as regras do jogo estão sendo cumpridas pelos colegas - $e$ de se exercitarem, eles mesmos, no cumprimento das regras de um jogo. E isso é muito importante para a criança assimilar mais o funcionamento de uma atividade. Em uma sala com um numero maior de crianças, isso faz com que todos realmente tenham a possibilidade de estar atuando em um papel "principal" ou como uma personagem "principal". Isso é uma coisa muito importante: todos podem brincar, todos podem ser aquela personagem. Percebi que é importante ter todos aqueles momentos: de você sentar, de você conversar com eles, de perguntar o quê que eles acharam dos colegas na área de jogo... Minha postura mudou bastante: estar observando mais certas coisas neles; deixar a espontaneidade deles fluir... Porque, às vezes, a gente é muito... a gente quer dirigir o tempo todo as ações da criança e essa era uma conduta que eu tinha mesmo - antes do início desse nosso trabalho. Essa postura minha mudou bastante: Bastante!

Eu - Bacana... Agora, em relação à tomada de depoimentos no sentido borário e anti-horário, no círculo da memória, acho que você deixa muito solto e ai, o que que acontece? Os mais verbalizadores dominam absolutamente o círculo da memória, e há também um certo caos, porque todos querem falar ao mesmo tempo, todos têm muito a dizer, querem espaço para se comunicar, para se colocar... E o que ocorre? A gente deixa de trabalhar a auto-regulação da criança... Essa coisa dos progressos na auto-regulação... O círculo da memória ajuda muito nisso... Em alguns momentos você exigiu o cumprimento das regras [ordem horária ou anti-horária dos depoimentos], você fez isso, você falou: - Raphael, agora é a vez de fulano... Você já falou! Então, a criança vai se tocando e acaba esperando a sua vez de falar... Eu considero muito importante este bábito de tomar os depoimentos no sentido horário e anti-horário, porque pode ser uma regra do funcionamento do sistema de jogos [do funcionamento do círculo de discussão]... Isso ajuda a criança a se exercitar na escuta do colega... 
Claudia - Eu sinto assim: Começa a Bianca, depois a Julianne e então a Jéssica. Daí a Jéssica fala, fala, fala... O que vem após a Jéssica, se é uma criança tímida, ela repete o que a Jéssica falou... Então, eu acho que a gente poderia também tá fazendo isso: Colocando pra falar, de alguma forma, na roda, primeiro, as crianças que menos se comunicam e, por último, as mais verbalizadoras...

Eu - Sim... Acho que este pode ser um caminho, uma tentativa de solucionar o problema de todos estarem falando ao mesmo tempo... Outra possibilidade seria não repetir a mesma pergunta para todos... Mas, a cada criança que vai sendo solicitada a falar, no círculo, pode-se perguntar algo novo, diferente... Então, foi nesse sentido que eu cheguei a propor algumas perguntas que se estaria fazendo a elas... Mas não são só aquelas perguntas... Elas são apenas algumas perguntas para provocar a intuição do coordenador dos jogos... Deixe sua intuição fluir... Deixe-se levar pela corrente das interações verbais, tentando exercitar a maiêutica, fazendo sempre novas perguntas... Claro, é uma sabedoria elaborar perguntas que podem levar o aluno a uma reflexão... $E$ isso só vem com a prática. Então, é preciso a gente estar se exercitando nisso... E isso que você está sentindo, eu também sinto quando estou iniciando um trabalho com jogos teatrais... No início, a gente trava mesmo... Depois flui...

Claudia - É verdade. Eu sinto que fica muito repetitivo [fazer as mesmas perguntas para todos e ater-se unicamente às perguntas do planejamento da sessão] E fiquei pensando, desde a última sessão, por que que as crianças estão respondendo as mesmas coisas? Porque talvez a pergunta que eu fiz para todas, a primeira criança já respondeu o que ela, a próxima criança, queria responder... Então é uma hora de eu tá pensando, da gente tá pensando, quais são as boas intervenções ou as boas perguntas para fazer para a próxima criança...

Outra coisa que vale a pena ser assinalada aqui é o papel do vídeo-registro como ferramenta útil na (re)orientação da atuação dos jogadores e do desempenho do(a) próprio(a) coordenador(a) do trabalho pedagógico com jogos teatrais. Vejamos o que diz Claudia a esse respeito:

Claudia - Antes, era uma coisa que eu não percebia. E o vídeo, ele nos traz a prática... Eu acho que todos os professores deveriam filmar uma aula sua pra depois estarem se analisando. Aquela coisa do "Não!", do "Peraí!", sabe, de dar um breque na criança? Eu parei pra pensar sobre isso e modifiquei. Também acho, assim, importante o respeito do espaço da criança. Porque a gente quando está em sala de aula-por exemplo, eu tenho 38 alunos - então, você fica muito preocupada de estar perdendo o controle, de ficar aquela agitação e toda hora estar retomando as coisas. Isso eu também modifiquei na minha sala de aula: deixar eles falarem no momento em que eles realmente querem e precisam falar, né? Ouvi-los!

A recordação estimulada - através do vídeo, no caso - oferece a possibilidade de um distanciamento crítico das nossas ações, necessário à uma reflexão desapaixonada sobre a própria performance. Trata-se de um recurso poderoso no sentido de possibilitar aos jogadores algum retorno sobre o que acreditam estar cenicamente mostrando aos observadores de suas ações na área de jogo, e que complementa os processos de avaliação coletiva e auto-avaliação subjacentes à dinâmica dos jogos teatrais. 
Claudia - Quando eles [as crianças] aparecem no vídeo, eles param e prestam mais atenção... Eu acho que eles fazem nesse momento uma auto-análise de si mesmos... Quanto a eu me ver, muitas coisas eu descobri sobre mim... Assim: a postura, a entonação de voz, o jeito de falar, o olhar... Eu refleti sobre bastante coisas... Contribuiu... É muito importante você estar revendo um trabalho com imagens, porque aquilo realmente aconteceu... Então, muitas coisas não são percebidas durante a ação da gente. Com o vídeo, há oportunidade de a gente estar falando: - Puxa, isso foi bacana! Já, aquilo lá, não foi legal, eu poderia ter feito de uma outra maneira. Da próxima vez vai ser melhor! Nossa, para mim, o uso do vídeo é uma auto-reflexão!

É preciso que se diga uma vez mais que o jogo GatoERatos foi retomado também em outras sessões - e não apenas só no quarto encontro do grupo. A repetição desta proposta para atividade lúdica com a linguagem teatral conduziu a (co) laboração de um desempenho satisfatório do pré-escolar na perspectiva do cumprimento das regras do jogo e de manutenção do foco da atividade cênica proposta.

A retomada de propostas para a atividade com a linguagem teatral sinaliza caminhos a serem percorridos pelo(a) professor(a), objetivando-se a superação da dicotomia processo x produto que tem caracterizado as propostas para a educação estética, em geral, na escolarização. A avaliação do desempenho do pré-escolar, no sistema de jogos teatrais, ocorre prospectivamente, ou seja, tendo-se em mente a apropriação progressiva, por parte do sujeito, do foco da atividade proposta e das regras do jogo.

Essa visão prospectiva do desenvolvimento da capacidade estética cênica do sujeito solicita uma intervenção deliberada do(a) professor(a) ou coordenador(a) de jogos no sentido de estar desafiando cenicamente os jogadores a solucionarem problemas de atuação cada vez mais complexos.

Quanto mais se joga, melhor se joga e mais se quer jogar. Esse entendimento da provisoriedade dos resultados obtidos ao longo do processo de trabalho liberta $\mathrm{o}(\mathrm{a})$ professor(a) e os(as) alunos(as) da valorização excessiva de apenas um determinado produto, ou seja, da ênfase em um produto que se relaciona apenas a um determinado momento da trajetória desenvolvimental da capacidade estética cênica dos sujeitos.

\section{Algumas descobertas}

Ampliação do repertório de jogos e maior incidência da atividade lúdica foram observados em todos os sujeitos do grupo multisseriado. Verificou-se também que crianças de diferentes estágios da Emei passaram a se relacionar socialmente, apresentados uns aos outros pelos sujeitos da turma experimental. Isso reforça a idéia de promoção da cultura infantil a partir das intervenções pedagógicas baseadas em grupos multisseriados.

Os resultados obtidos apontam ainda para um impacto positivo da dinâmica operacional desta proposta metodológica para a atividade teatral (particularmente do círculo de discussão) na quantidade e qualidade das interações verbais das crianças do 
projeto.

O uso instrumental do sistema de jogos teatrais de Spolin para a promoção do autocontrole e organização mais complexa do comportamento da própria criança se revelou eficaz de acordo com os resultados obtidos pela pesquisa. Verificou-se que este tipo de intervenção ludopedagógica, ancorada no conceito cotidiano de jogo com regras (jogo com regras explícitas), é uma poderosa ferramenta para levar as crianças a uma maior apropriação da cultura escolar e de comportamento socialmente desejável.

O modo "ativo" com o qual as regras dos jogos são apresentadas pelo sistema de jogos teatrais preenche as necessidades de "pensament(o)ação" por parte da criança pré-escolar. Apenas uma exposição verbal das regras dos jogos por parte do professor seria insuficiente para o desempenho cada vez melhor da criança na área de jogo, em razão da complexidade subjacente à coordenação das ações solicitadas por algumas propostas para a atividade teatral e das características do tipo de pensamento predominante nesta faixa etária.

Espero ter demonstrado e destacado aqui - ainda que muito brevemente - a importância fundamental de alguns procedimentos absolutamente necessários à dinâmica do sistema de jogos teatrais na pré-escola: (1) definição da área de jogo e da área de observação; (2) divisão do grupo em equipes; (3) revezamento das equipes na área de jogo; (4) explicitação do foco da atividade proposta e das regras do jogo; (5) instruções durante a apresentação das equipes na área de jogo; (6) avaliação coletiva e auto-avaliação logo após a apresentação de uma equipe; (7) formação do círculo de discussão (roda de conversas ou círculo da memória) para apresentação dos protocolos orais da sessão anterior.

Esses procedimentos revelaram-se essenciais ao pleno funcionamento do método proposto por Spolin e extremamente importantes para o trabalho com a linguagem teatral junto aos pré-escolares. A promoção de avanços no desenvolvimento da capacidade estética cênica da criança pré-escolar, através do sistema de jogos teatrais, solicita redobrada atenção aos sete procedimentos enumerados acima.

Afinal, acredito ter exposto aqui algumas razões para a promoção da capacidade estética cênica de pré-escolares através de jogos teatrais:

(1) Jogos teatrais constituem uma modalidade de atividade lúdica que requer um funcionamento mental complexo na perspectiva do desenvolvimento cultural;

(2) Jogos teatrais redimensionam o faz-de-conta infantil enquanto atividade conscientemente dirigida para observadores;

(3) Jogos teatrais são ferramentas úteis para promover o desenvolvimento da capacidade estética cênica da criança na pré-escola; 


\section{REFERÊNCIAS}

ADORNO, Theodor W. Educação e emancipação. Rio de Janeiro: Paz e Terra, 2000.

BRASIL. Ministério da Educação. Secretaria de Educação Fundamental. Parâmetros curriculares nacionais. Brasília, DF, 1997. v. 1-10.

BRASIL. Ministério da Educação. Secretaria de Educação Fundamental. Referencial curricular nacional de educação infantil. Brasília, DF, 1998. v. 1-3.

COELHO, Ana Flora F. de C. Introdução do texto literário ou dramático no jogo com crianças. 1989. Dissertação (Mestrado em Artes) - Escola de Comunicação e Artes, Universidade de São Paulo, São Paulo, 1989.

CHAGAS, Amara. A brincadeira prometida... o jogo teatral e os folguedos. 1992. Dissertação (Mestrado em Artes) - Escola de Comunicação e Artes, Universidade de São Paulo, São Paulo, 1992.

JAPIASSU, Ricardo. Desafios da (in)formação docente: o trabalho pedagógico com as artes na escolarização. Eccos Revista Científica do Centro Universitário Nove de Julho: Escola Básica e Sociedade, São Paulo, v. 6, n. 1, p. 65-83, jun. 2004.

JAPIASSU, Ricardo. Ensino do teatro nas séries iniciais da educação básica: a formação de conceitos sociais no jogo teatral. 1999. Dissertação (Mestrado em Artes) - Escola de Comunicação e Artes, Universidade de São Paulo, São Paulo, 1999.

JAPIASSU, Ricardo. Jogos teatrais na pré-escola: o desenvolvimento da capacidade estética na educação infantil. 2003. Tese (Doutorado em Educação) - Faculdade de Educação, Universidade de São Paulo, São Paulo, 2003.

JAPIASSU, Ricardo. O lugar do lúdico na educação infantil brasileira. Revista da FAEEBA: Educação e contemporaneidade, n. 16, p. 191-199, jul./dez. 2001a.

JAPIASSU, Ricardo. Metodologia do ensino de teatro. Campinas, SP: Papirus, $2001 \mathrm{~b}$.

KOUDELA, Ingrid D. Brecht: um jogo de aprendizagem. São Paulo: Perspectiva: Edusp, 1991.

KOUDELA, Ingrid D. Brecht na pós-modernidade. São Paulo: Perspectiva, 2001.

KOUDELA, Ingrid D. Jogos teatrais. São Paulo: Perspectiva, 1992a.

KOUDELA, Ingrid D. Texto e jogo. São Paulo: Perspectiva: Fapesp, 1996.

KOUDELA, Ingrid D. Um vôo brechtiano. São Paulo: Perspectiva, $1992 \mathrm{~b}$. 
PENNA, Maura (Org.). É este o ensino de arte que queremos? Uma análise das propostas dos parâmetros curriculares nacionais. João Pessoa: Universitária UFPB, 2001.

PIAGET, Jean. A classificação dos jogos e sua evolução, a partir do aparecimento da linguagem. In: - A formação do símbolo na criança: imitação, jogo e sonho, imagem e representação. Rio de Janeiro: Guanabara Koogan, 1978.

PIAGET, Jean. As regras do jogo. In: . O juízo moral na criança. São Paulo: Summus, 1994.

PUPO, Maria Lucia de S. B. Palavras em jogo: textos literários e teatro-educação. 1997. 230 p. Tese (Livre Docência) - Escola de Comunicação e Artes, Universidade de São Paulo, São Paulo, 1997.

SAMPAIO, Teresa C. F. de M. Polivalência ou ...? Presente! Revista de Educação, Salvador, ano 13, n. 48, p. 27-28, mar./maio 2005.

SAYÃO, Rosely. Qual o melhor, generalista ou especialista? Presente! Revista de Educação, Salvador, CEAP, n. 48, ano 13, p. 25-26, mar./maio 2005.

SPOLIN, Viola. Improvisação para o teatro. São Paulo: Perspectiva, 1992.

SPOLIN, Viola. O jogo teatral no livro do diretor. São Paulo: Perspectiva, 1999.

SPOLIN, Viola. Jogos teatrais: o fichário de Viola Spolin. São Paulo: Perspectiva, 2001.

VAZ, Beatriz A. C. Teatro ou recreação? 1984. Dissertação (Mestrado em Artes) - Escola de Comunicação e Artes, Universidade de São Paulo, São Paulo, 1984.

VYGOTSKY, Liev S. La imaginación y el arte em la infância. Madrid: Akal, 2000.

VYGOTSKY, Liev S. O papel do brinquedo no desenvolvimento. In: . A formação social da mente. São Paulo: Martins Fontes, 1996.

VYGOTSKY, Liev S. Psicologia pedagógica. São Paulo: M. Fontes, 2001. 


\section{SOBRE A VOZ EM SUA FUNÇÃO POÉTICA}

Sara Lopes

\section{Um conceito, uma função...}

A compreensão do papel da voz como objeto da arte faz pressentir a existência de um plano mais profundo em suas funções e características, quando utilizada como material da linguagem de representação. Esse nível de comunicação oral, do qual emerge a função poética da vocalidade, constrói seu significado entre a materialidade das vibrações sonoras de uma voz e a sonoridade - melódica e rítmica - de uma fala. Entenda-se, por vocalidade, o uso imediato de uma voz que pede por uma expressão que somente se concretiza na co-presença intérprete/espectador: ela só se realiza no encontro entre aquilo que o intérprete exterioriza com o interior do ouvinte.

Por poética, como adjetivo, fica denominada a função que tem uma voz de ir além de seu uso utilitário na linguagem, da transmissão de idéias ligadas ao significado das palavras, criando o gesto vocal, gerando impressões, dizendo de si mesma e se comentando enquanto comenta e diz, mantendo o movimento interno ao procedimento técnico que leva à expressão diferenciada.

É pela vocalidade poética que os signos se tornam coisas. Porque as palavras não são as coisas; são representações convencionadas, abstrações. A coisa da palavra falada são as formas dos sons. No exercício da vocalidade poética, o revestimento constituído por um texto se rompe e, pelas aberturas, um outro discurso é proposto. Um discurso que, de maneira específica, marcada e diferente a cada tempo e lugar, transgride os esquemas discursivos comuns: nas vibrações de uma voz se desenrola um fio que liga, às palavras, os sinais vindos da experiência. $O$ que permanece, como força referencial, põe em destaque o contato entre os sujeitos corporalmente presentes: o que tem a voz e o que a recebe. Os valores que a vocalidade poética torna relevantes fundamentam-se sobre as qualidades da voz, sobre a técnica vocal do ator ou cantor, tanto ou mais que sobre o conteúdo da mensagem. Ela faz emergir, da linguagem, tudo o que não serve à informação, tudo o que define a situação de comunicação.

Os pressupostos da vocalidade poética enraízam-se e extraem sua validade da tradição oral, na qual toda palavra se liga ao corpo por meio desse atributo físico que é a voz. Seus significados mantêm a integridade da arte vocal, e podem ser construídos 
na busca de uma experiência diferenciada de linguagem. Uma linguagem que esteja viva no corpo, em que o pensamento seja experienciado no corpo, as emoções tenham existência física. $\mathrm{Na}$ qual, plenas de pensamento e emoções, as ondas sonoras fluam através de um corpo e sejam percebidas, sensorialmente, por outros corpos que experimentem o(s) pensamento/emoções contido(s) nas vibrações do som.

Esse momento supõe competência: saber fazer, saber dizer, saber ser no espaço e na duração - o corpo dando forma ao vazio, a voz dando forma ao silêncio, e o movimento de ambos recriando o tempo.

Corporifica-se então, uma ação vocal que oferece, a quem ouve, uma palavra na qual não há lugar para dúvidas ou indecisões: uma publicação oral não tem rascunho; não permite ao ouvinte qualquer possibilidade de volta - independente do efeito buscado, a comunicação é imediata. É assim que o texto, publicado oralmente, apóia-se sobre um efeito de presentificação instantânea: mesmo que a audição aconteça muito depois de ter sido composto, ela só pode ser imediata.

À medida que o intérprete canta, declama, diz, limitações mais ou menos fortes, decorrentes do momento, geram sua ação. Esta, em qualquer caso, empenha uma totalidade pessoal: o conhecimento, a inteligência, a sensibilidade, os nervos, os músculos, a respiração e o talento para reelaborar tudo isso num espaço de tempo muito breve. O sentido da representação advém dessa unidade, resultado de um procedimento que a orienta e da posse de uma técnica expressiva particular, que é a arte da voz. Desse modo, os valores que emergem da ação vocal estão muito além das determinações lingüísticas e derivam da própria faculdade da linguagem, tornando a vocalidade poética.

Esta palavra poética é intensa, arquivo sonoro das vozes cotidianas; sua finalidade é representar o todo existente, revelando o que há por trás do grande discurso social. Garantindo uma identidade, a transmissão, a tradição, e dando início a transformações, à criação, à diferença, a palavra poética é, ao mesmo tempo, memória e invenção: a palavra que liberta o canto, que dá vida às narrativas, a palavra que significa o teatro.

No teatro, o discurso sempre se estrutura por um artifício que abrange a totalidade de uma situação e põe em jogo uma qualidade própria da voz: em sua função primeira, anterior à influência da escrita, a voz não descreve; ela age e deixa que o gesto indique as circunstâncias. Dada essa amplitude, é em torno do gesto que se organiza a cena inteira, subordinando a palavra. Mas ele, em vez de sufocá-la, vai valorizá-la, enquanto ela explicita seu significado, pois, ao que o olhar registra, falta a espessura concreta da voz, a percepção do sopro, a urgência da respiração; falta a condição de retomar, sempre, o jogo de presentificar um objeto ausente, pelo som da palavra.

O trabalho vocal que se estrutura sobre esse conceito busca a condição que tem uma voz, ao apropriar-se de um texto ou canção, de atualizá-los, por um momento, ao assumir a imediatez e a instantaneidade da "performance" mantendo, ao mesmo tempo, a memória do enunciado e da sonoridade, assegurando o espaço da criação.

O intérprete pode assumir a instantaneidade da "performance" e integrá-la na forma de seu discurso. Isso implica uma capacidade particular de eloqüência, fluência de frase e dicção, poder de sugestão, domínio dos tons e dos ritmos, todo 
um saber técnico, além do conhecimento das formas: a posse de um vocabulário e das regras para sua combinação, numa espécie de gramática poética. Então, mais que de procedimentos literários, a estruturação da palavra poética resulta do discurso; mais que em termos de gramática, as normas se definem em termos de dramaturgia.

A opção por esse percurso vai determinar o papel que, na representação, atribui-se ao desempenho vocal, assumindo que a magia pressupõe a perfeição da técnica e que o acaso tem muito pouco a ver com a arte.

\section{... alguns princípios...}

Interferir na natureza e transformar a matéria faz parte da vocação cultural humana. Presente na arte, por definição, essa tarefa é desempenhada sempre no limite do sagrado e da magia, manipulando a matéria conhecida para dar-lhe outro significado, fazendo com que uma coisa se torne outra, mesmo continuando a ser ela mesma.

Se a matéria é carne, emoções e pensamento, um corpo fabricado pela cultura que o cerca vai recriar a sua própria substância, superar limites e imposições, extrair outras configurações de seu todo, potencializar ao máximo suas funções para elaborar, como um mágico, na perfeição da técnica, a representação. Um corpo que não é uma obviedade física é um devir simbólico no qual se articulam, a cada instante, as imagens dadas pelo meio em que vive e podem se rearticular tantas imagens quantas ele for capaz de imaginar, buscar, observar, exercitar. Vencendo as imposições da gravidade, a parte mais flexível do corpo é livre para transpor e mover-se no espaço. $\mathrm{E}$, no entanto, mantém sua realidade física, constituindo-se em matéria concreta ${ }^{1}$.

Este princípio abre a voz à interferência determinada e consciente em sua construção, como a tela e as tintas se oferecem a um pintor: o suporte material, a substância que permite a manifestação da forma, transformando o abstrato em concreto, tornando visível o invisível, fazendo, do ausente, presença. Assim, uma voz responde mais propriamente à sua função, na representação, quando se desprende dos significados abstratos contidos na palavra para se ligar à concretude da materialidade sonora.

A geração dessa voz está diretamente ligada à identificação e ao reconhecimento de sua corporalidade, e a um redimensionamento físico pela expansão do corpo, essa unidade psicofísica que decididamente se organiza para uma função específica, poética, harmonizando seus movimentos internos e externos, reunindo pensamento, emoção, fisicalidade.

O trabalho vocal que se desenvolve pela adoção e imitação de um modelo, por meio da repetição de formas acabadas, fórmulas prontas, soluções permanentes, é limitado e torna-se limitador, quer seja proposto sobre si mesmo, quer seja na relação com uma linguagem. Percorrer esta via é admitir que uma técnica existe por si mesma, sem depender de um organismo vivo, consciente e dotado de imaginário,

1 O som é resultado de um fenômeno físico que só acontece num meio onde exista matéria, e acontece por meio de uma seqüência periódica de compressão e descompressão dela. Quando um som é produzido, alterações ocorrem no meio. $\mathrm{O}$ mesmo se dá com a voz. A vibração das pregas vocais altera o fluxo de ar que passa por elas, e este meio material, ar, alterado, é o som vocal. Um som, produzido, multiplica a alteração da matéria: uma porção alterada modifica a que lhe está mais próxima, e essa seqüência de alterações, através da matéria, é a propagação do som. 
que adote seus procedimentos e a construa em seu corpo, a seu modo, criando, pela matéria que lhe é própria, a individuação da forma.

A identificação, o reconhecimento e a apreensão física do funcionamento dos mecanismos do corpo levam, mesmo que mais lentamente, a um aprendizado diferenciado: relaciona a estrutura corporal interna à existência e à ocorrência da sensação, da emoção, do movimento e libera uma voz pronta para revelar essas relações. É um percurso que permite organizar o saber para além das formas, incorporando os conteúdos: aquilo que existe em termos de estrutura, função e energia. O que se aprende, então, é estar disponível a um processo constante, pessoal, de elaboração e reelaboração de um repertório técnico individual, ancorado na adoção de procedimentos que se organizam pela apreensão de princípios e fundamentos apoiados na absorção de um conceito sobre a voz, que se estabelece a partir da definição de sua função como elemento integrante da atuação. É a apropriação física de um trajeto que busca a autonomia: um saber que se sedimenta de forma única, pela memória e de coração, que é propriedade privada do artista, uma "tradição de si mesmo", para dispor como quiser.

Uma distinção qualitativa emerge do trabalho com a fisicidade e a percepção corporal: a noção de tridimensionalidade do corpo, por exemplo, torna-o mais envolvido no movimento e otimiza sua capacidade de utilização tridimensional do espaço; ao mesmo tempo, cria-se um estímulo à imaginação e um impulso individualizado para a ação, dotando-a de origem, autoria.

Fica estabelecido, então, que voz é corpo, num corpo vivo em cada uma de suas partes, capacitado a estabelecer relações funcionais entre o espírito, a mente e a matéria. E se a voz é físico, é possível concebê-la como ação, ambas originadas num mesmo impulso de respiração. O som vocal gera sensações e impressões, pela vibração, e as mantêm presentes, em emoção, no movimento. É o princípio da voz como materialização da ação física, permeando da pele ao sistema nervoso, sendo percebida através dos poros e dos ossos, e não apenas pelos ouvidos; esse atributo que estabelece o contato físico entre seres humanos distantes um do outro: a manifestação de uma interioridade livre para invadir outros corpos, provocando respostas fisiológicas internas, profundas.

$\mathrm{Na}$ função poética da voz, é assim que se dá a comunicação: corpo-ar-corpo, que vibra em conjunto, que sofre alterações simultaneamente, e que forma um todo unificado pelo som. Tratada assim, a voz é concreta, um prolongamento físico que, pelo toque, estabelece a comunicação.

A voz, pois, é a coordenação de muitas coisas, a começar de uma coordenação funcional que se dá pela conexão de todo o corpo tecendo seu mecanismo e de todo o ser tramando seu sentido.

Estabelecer a ligação entre a realidade física e todo o simbólico a ser trabalhado e representado por ela é função do imaginário, essa ponte entre a concretude e a abstração.

O som é invisível. A tendência, então, é entender a voz como algo abstrato, sobretudo porque nos chega ligada às palavras e seus significados. Saber como tudo se organiza, fisicamente, para produzir o som vocal, é esclarecedor quanto à sua

\footnotetext{
${ }^{2}$ O termo foi utilizado por Franco Ruffini em Conferência durante o Seminário Internacional "Teatro em fim de milênio". Tradução e transcrição da fala por Ricardo Ponti, Maria Lucia Raimundo e Nair d'Agostini.
} 
concretude e revelador quanto à convivência entre o universo dos símbolos e as determinações da matéria sonora.

Como o mecanismo de produção do som vocal não é aparente, é necessária uma estrutura imaginária para entender o que acontece: um processo mental que combina imagens e sensações, dotando a voz de concretude e plasticidade, disponível à interferência proposital em sua elaboração.

\section{... e outros tantos procedimentos.}

Visualizar a ossatura para construir sua imagem como estrutura de sustentação do corpo é um procedimento que libera a musculatura para os movimentos, desde os mais simples e evidentes até os mais complexos e sutis. Recuperar, alongando, os espaços que a tensão rouba entre as articulações, especialmente entre as vértebras, inicia o redimensionamento corporal que pode ser percebido como sensação nascida de uma alteração física real. O peso do corpo se apóia no chão, direcionando a gravidade, numa dispersão aberta e equilibrada, tendo os pés como raízes que se espalham e se aprofundam para sustentar a pélvis, o sacro e o encaixe das coxas. Esta é uma boa base para o som desenvolver grande extensão, sobretudo se a coluna vertebral estiver realmente aberta, em constante energia ascendente, adaptando-se à troca de peso da respiração, "muscularmente" equilibrada e neurologicamente sensível, pronta para responder. Os músculos livres, em torno do torso, tornam-se sensiveis à percepção do movimento tridimensional do diafragma, na respiração, ampliando o espaço ocupado pelo corpo. Na mesma medida, incrementa-se a capacidade de experimentar sensações e impressões mais sutis a serem incorporadas na construção de uma imagem corporal.

Visualizar a imagem que o próprio corpo recorta no espaço traz a consciência de sua tridimensionalidade, numa percepção para ser explorada e incorporada à memória e ao pensamento físico.

A ossatura, pela resistência de seu material é, ainda, condutora das vibrações do som, através das articulações, aos limites corporais mais distantes do seu ponto inicial, expandindo, amplificando, e projetando o corpo, em sua sonoridade, para além de seus limites.

Quando o corpo, como um todo, se compromete na manifestação da sonoridade, os esforços são divididos por uma área muscular e óssea muito mais extensa, se comparada àquela envolvida na adoção da voz como elemento dotado de existência autônoma.

O som inaugural, produzido por um corpo organizado em sua ossatura e musculatura, tem a amplitude de um suspiro de alívio, e está sujeito à passagem da respiração através das pregas vocais, na garganta, para criar as vibrações que são reconhecidas como uma voz individual. A respiração depende dos pulmões, que se estendem até a metade do dorso. A musculatura da respiração é entretecida em torno da caixa das costelas, continuando por baixo dos pulmões, no diafragma, conectando-se com a coluna vertebral e enraizando-se profundamente na pélvis. Não é metafórico dizer que o corpo respira.

O reconhecimento da respiração deve identificar o movimento que se inicia no centro do diafragma e expande o corpo em seis direções, na inspiração, permi- 
tindo a sensação de tridimensionalidade do tronco que é, então, um invólucro em torno do ar. O movimento inverso, de retorno das seis direções para o centro, na expiração, dá uma primeira noção de apoio, resultado da pressão da musculatura do torso, em torno do ar, para voltar à sua posição inicial.

A coluna vertebral é parte fundamental da respiração. O eixo central da coluna é indispensável para prover a força do movimento para a respiração, nas direções alto e baixo. A pressão negativa do ar, na pélvis, cria uma troca com a parte superior do corpo, no enchimento dos pulmões, dando suporte à respiração. Se a coluna permanecer rígida, se as vértebras perderem sua ação seqüencial, isso vai afetar a respiração e, por conseqüência, a qualidade do som.

Esta respiração consciente integra a representação como um elemento visual e espacial, quando é concebida e utilizada dessa forma ativa, tridimensional. Configurada assim, amplia as possibilidades de significação ao propor a percepção da vida no corpo, revelando como se faz, enquanto faz, como pensamento físico.

A respiração é o início do som vocal, tanto quanto da ação e do movimento, e funde esses esforços num impulso único; voz, ação e movimento terão a amplitude que tiver o impulso interno, inicial, da respiração num corpo sensível para reconhecê-lo e dar-lhe forma.

A opção por somar o corpo ao trabalho sonoro torna a respiração consciente indispensável e faz necessário aprender um modo de respirar que sustente a ação e o som encontrando, no corpo, o impulso que vai criar a coordenação entre os dois.

Trabalhar dessa forma alinha a presença e a abertura estrutural do corpo, que se torna suporte para um som claro e aberto. A qualidade do som reflete o estado do corpo e o que, nele, está vivo. Se houver tensão, o som vai refleti-la. Se o corpo estiver aberto nas articulações, respirando livre e sem tensão na musculatura, a voz vai refletir este estado.

A respiração age sobre a percepção. Cria, no corpo, uma tendência fisicamente mais receptiva, "muscularmente" mais suscetível.

A respiração consciente e a percepção diferenciada do corpo são procedimentos fundamentais para a produção do som vocal na perspectiva de sua fisicidade. É a respiração que determina como se cria o som no corpo porque seu percurso e espaço abrem, antes, o caminho da sensação e da percepção.

É fundamental, para o imaginário, buscar ver além do mecanismo funcional da respiração. Há uma energia respiratória, no corpo, que está além do simples ato de respirar, num nível mais profundo, numa experiência corporal total.

O elo entre a respiração e a energia interna é dado pela sensibilidade e depende dela para o desenvolvimento de uma capacidade de expressão ampliada. Alguns atributos podem ser ligados à voz do ator: extensão, variedade, beleza, clareza, poder, intensidade. Mas é a sensibilidade que valida todos estes atributos, que permanecem nebulosos se não refletirem a extensão das sensações, a variedade do pensamento, a beleza do conteúdo, a clareza da imaginação, o poder das emoções, a intensidade do desejo de se comunicar. Se a comunicação do interior para o exterior pretende ser verdadeira, as energias que abastecem os músculos da voz precisam estar afinadas, com extrema sensibilidade, às energias ainda mais refinadas da criação.

Nessa opção de trabalho vocal, é preciso partir do entendimento de que cada corpo tem seu próprio ritmo e pode encontrar sua própria respiração. O corpo 
pode usar mais de si mesmo do que apenas a superfície muscular.

Nossa primeira relação com o som é através da respiração. Assim, o trabalho com a respiração deve ter improvisação, atividade, estímulos, consciência, sensação física e atenção à percepção.

O corpo quer respirar plena e confortavelmente. A tentativa de se manter dentro de padrões familiares restringe a respiração. Respirar traz vitalidade, que traz sensações, que podem trazer o novo e, às vezes, há a tentativa de evitá-las. O trabalho deve, então, instalar um espaço diferenciado, dedicado à construção de elementos que se destinam a uma finalidade específica, a representação, permitindo a liberdade do corpo para que as sensações aconteçam. Trabalhar estas relações permite e propicia que a respiração se torne multidimensional.

A voz se organiza com a ação do diafragma, num trabalho de coordenação seqüencial entre os músculos abdominais e torácicos, na inspiração e expiração. Esse arranjo se equilibra com o aparato vocal, que permite a saída do ar para a produção do som.

A ação do diafragma, que se contrai ativamente na inspiração, expandindo o corpo, descontrai-se na expiração. Os dois movimentos são coordenados à força da liberação do ar através do laringe e das pregas vocais, resultado da pressão exercida pela musculatura do tronco no retorno à sua posição original. A intensidade do som depende desta relação. Manter a imagem de um centro, do qual parte e para o qual retorna o movimento da respiração e do som, traz o benefício fisiológico do equilíbrio da pressão do ar sobre as pregas vocais, apurando o timbre: ar demais força uma separação sustentada das pregas, provocando sopro. No entanto, equilíbrio não quer dizer contenção. A imagem do suspiro de alívio é proposta exatamente para afastar a idéia de resistência, de restrição.

A cada tom, as pregas vocais vibram - para cima e para baixo e de lado a lado - numa freqüência específica. Um tom alto tem freqüência de vibração mais rápida do que um tom baixo. O tom também depende da espessura das pregas: se grossas - baixo - ou delgadas - alto. A abertura e o fechamento das pregas criam uma fenda no meio do laringe: se ela se alarga, o tom é baixo; se ela se estreita, o tom é alto.

Há mais do corpo envolvido nessa relação de respiração, voz e tom.

O diafragma pode ser considerado apenas nesse trabalho com os músculos abdominais e torácicos na respiração. Há, porém, uma outra imagem que o visualiza como uma camada estendida entre duas regiões de órgãos - a de cima, contendo pulmões, coração, esôfago; e a de baixo, sobre a qual o diafragma descansa, contendo estômago, intestino, rins e fígado. Os órgãos e seu peso têm mobilidade, dentro do tronco, movimentando-se para cima e para baixo com a ação do diafragma. Se os órgãos não estiverem rigidamente tensos, em seus lugares no torso e, sim, mais sensíveis, respondendo à ação do diafragma, ele pode trabalhar de forma mais plena e efetiva. Para isso, contribui o alongamento e a liberação da coluna, articulações e musculatura do tronco, ampliando os espaços internos do corpo e tornando a possibilidade de ressonância do diafragma mais aberta e livre para se expandir por entre os órgãos, incrementando a intensidade do som.

A emissão do som é muscular e sua anatomia ganha contornos nas alterações dos canais por onde fluem livremente suas vibrações, na abertura e posicionamento da boca, nas possibilidades de encontros entre a língua e o palato, no desenho dos lábios, 
ajudando a criar texturas, cores, timbres, em formas que a fonética chama de vogais, cujas características individuais decorrem de uma acomodação dos sons nas cavidades de ressonância do corpo. Tonicidade e plasticidade em toda a musculatura que forma a boca, liberdade de movimentos para os maxilares, na prática, aumentam e refinam a emissão do som em sutilezas na revelação de emoções, impressões e sensações através do som.

O som que emerge de sua fonte profunda, no corpo, projeta-se no espaço como um jorro contínuo, em torno do qual a boca recorta e esculpe formas sonoras. A boca é tridimensional e seu formato e espaço de ressonância conduzem o som para o espaço externo.

A articulação e suas possibilidades de experimentação põem a voz em movimento, estabelecendo a ligação entre os sons numa ação coordenada de resistência e adesão dos lábios, língua, palato, dentes, maxilar, à saída do ar, definindo os ruídos nomeados como consoantes.

Um procedimento muito comum no trabalho vocal utiliza a criação de sons que, escutados, são guias para ajustes feitos sobre sua forma externa, sobre a matéria que já não está mais no corpo, dispersando a integridade do trabalho interno. Mas há uma outra escuta possível, com o corpo, fundamental quando se trabalha, primeiro, a sensação do som. É um ouvir sensível; sentir/ouvir e promover ajustes nas bases internas para alterar os resultados. Apenas escutar e manipular o resultado sonoro é fazer duas coisas separadas, quebrando a unidade que deve presidir o desempenho.

Este trabalho não é para ser realizado com o pensamento crítico, buscando aquilo que soa bem. Ele deve acontecer num nível mais puro, focado, antes de tudo, na expressão do corpo, na sensação do som e na resposta, no corpo, a esta sensação. Esta atitude isenta da obrigação de tentar soar bem antes de estar apto a se expressar com a voz. Há, aí, uma orientação diferenciada, menos avaliadora, que muda a qualidade do som: ele se torna mais pessoal.

O som que, em sua produção, contém um corpo, é mais enraizado nas emoções e soa diferente, tem outra textura. Os tons se tornam mais plenos, mais ricos, com mais harmônicos, que vão caracterizar melhor o som. Caracterizá-lo a partir daquilo que é dado pelas sensações geradas pela vibração, mais do que a partir daquilo que o som parece ou deve ser, inicialmente. A partir daí, o desenvolvimento pode se dar pelo uso do ritmo no corpo, do espaço, das dinâmicas do movimento e seu peso na criação do som. Este é um tipo de orientação particularizada na construção da voz poética.

A associação do movimento físico ao som não supõe uma sincronicidade nem uma imitação. $\mathrm{O}$ corpo não se limita a duplicar o som e o som não fica preso à reiteração do corpo: eles interagem.

Alinhando o impulso, a intenção da fisicalidade com o som, é possível encontrar a fonte comum com o movimento, no corpo. A interação traz algo consigo que revela não serem, ambos, um único elemento. $\mathrm{O}$ impulso criado no corpo não precisa ser sempre sonorizado; nem todos os sons têm de ser refletidos no movimento. Também há silêncio e imobilidade. Corpo e som podem interagir num percurso mais vital e menos previsível.

O potencial do trabalho com movimento - mesmo que em alguns momentos 
este não aconteça - desenvolve a habilidade de imaginar o movimento do corpo no espaço, o que é importante para a produção sonora como ação; se o som existe como um pressuposto, no movimento, a concentração e o movimento serão diferenciados, mesmo que os sons não se concretizem.

Procedimentos ancorados em princípios definidos e conceitos claros abrem a prática a uma experimentação sem restrições: o que deve ser preservado é a concepção que, construída pela experiência de cada um, sustenta a atitude do artista no confronto com os desafios de seu ofício. 


\section{REFERÊNCIAS}

BANU, Georges (Org.). De la parole aux chants. Paris: Actes SUS - Papiers, 1995. (Apprendre, n. 4).

BERRY, Cicely. The actor and the text. London: Virgin Books, 1993.

BERRY, Cicely. Voice and the actor. New York: Macmillan, 1973.

BEUTTENMÜLLER, Maria da Glória; LAPORT, Nelly. Expressão vocal e expressão_corporal. Rio de Janeiro: Forense Universitária, 1974.

BLOCH, Pedro. Falar é viver. Rio de Janeiro: Nórdica, 1980.

BLOCH, Pedro. Você pode falar bem: problemas de comunicação oral. São Paulo: Nacional, 1986.

BRASIL. Ministério da Educação. Normas para a língua falada no teatro. Rio de Janeiro, 1958.

CONGRESSO DA LÍNGUA NACIONAL CANTADA, 1., 1937, São Paulo. Anais... São Paulo: DCPM, 1937.

DUARTE, F. J. C. A fala e o canto no Brasil: dois modelos de emissão vocal. ArteUNESP, São Paulo, n. 10, p. 87-97, 1994.

É PRECISO juntar de novo palavra e corpo. Estado de São Paulo, São Paulo, 30 abr. 1995. Caderno 2.

FERREIRA, Leslie Piccolotto (Org.). Trabalhando a voz. São Paulo: Summus, 1988.

FERREIRA, Leslie Piccolotto (Org.). Voz profissional: o profissional e a voz. Carapicuíba: Pró-Fono Departamento Editorial, 1995.

FERREIRA, Leslie Piccolotto et al. Temas de fonoaudiologia. São Paulo: Loyola, 1984.

FORTUNA, Marlene. A performance da oralidade teatral. São Paulo: Annablume, 2000.

FOUCAULT, Michel. As palavras e as coisas. São Paulo: M. Fontes, 1999. (Coleção tópi$\cos )$.

FRY, Dennis. Homoloquens: o homem como animal falante. Rio de Janeiro: Zahar, 1978.

GAYOTTO, Lucia Helena. Voz partitura da ação. São Paulo: Summus, 1997.

GROTOWSKI, Jerzy. La Voix. Le Théâtre: Cahiers dirigés pour Arrabal, n. 1, p. 87-131, 1971. 
HAROCHE, Claudine. Da palavra ao gesto. Campinas, SP: Papirus, 1998.

LINKLATER, Kristin. Freeing Shakespeare's voice. New York: Theatre Communications Group, 1992.

LINKLATER, Kristin. Freeing the natural voice. New York: Drama Book Publishers, 1976.

MAIA, Eleonora Motta. No reino da fala: a linguagem e seus sons. São Paulo: Ática, 1985.

MAMMI, Lorenzo. João Gilberto e o projeto utópico da bossa nova. Novos Estudos CEBRAP, São Paulo, n. 34, p. 63-70, 1992.

MATOS, Cláudia N. de; MEDEIROS, Fernanda T. de; TRAVASSOS, Elizabeth (Org.). Ao encontro da palavra cantada: poesia, música e voz. Rio de Janeiro: 7 letras, 2001.

MELLO, E. B. de Souza. Educação da voz falada. Rio de Janeiro: Atheneu, 1984.

MURCE, Newton. O ator, a vocalidade poética e uma escritura no corpo. 2002. Monografia (Graduação) - Universidade Estadual de Campinas, Campinas, SP, 2002.

NUNES, Lília. Manual de voz e diç̧ão. Rio de Janeiro: SNT, 1972. (Série Cartilhas de teatro).

PALAVRA tem volume, cor, temperatura e sabor. Estado de São Paulo, São Paulo, 30 abr. 1995. Caderno 2.

ONG, Walter. Oralidade e cultura escrita. Campinas, SP: Papirus. 1998.

ORLANDI, Eni P. As formas do silêncio no movimento dos sentidos. Campinas, SP: Unicamp, 2002. (Coleção Repertórios).

QUINTERO, Eudósia Acuña. Estética da voz: uma voz para o ator. São Paulo: Summus, 1989.

ROUSSEAU, Jean-Jacques. Ensaio sobre a origem das línguas. Campinas, SP: Unicamp, 1998. (Coleção Repertórios).

SALZSTEIN, Sonia. O moderno como problema. Folha de São Paulo, São Paulo, 09 ago. 1997. Jornal de Resenhas, p. 8.

SOARES, R. M. Freire; PICCOLOTTO, Leslie. Técnicas de impostação e comunicação_oral. São Paulo: Loyola, 1977.

VALENTE, Heloísa de A. D. Os cantos da voz. Entre o ruído e o silêncio. São Paulo: Annablume, 1999. 
LA VOZ. Mascara, México, ano 2, n. 4/5, 1991.

ZUMTHOR, Paul. Introduction à la poésie orale. Paris: Édition du Seuil, 1983.

ZUMTHOR, Paul. A letra e a voz. São Paulo: Companhia das Letras, 1993.

ZUMTHOR, Paul. Performance, recepção, leitura. São Paulo: Educ, 2000. 


\section{O ENSINO DO TEATRO DE ANIMAÇÃO}

Valmor Nini Beltrame

O teatro de animação constitui um campo artístico que compreende as linguagens do teatro de máscaras, sombras e bonecos/objetos. Cada uma destas linguagens possui técnicas e especificidades que obedecem a regras e a um vocabulário próprio. $\mathrm{O}$ ensino dessa arte deve contemplar alguns eixos fundamentais: o estudo de sua história; o conhecimento do Mamulengo, teatro de bonecos popular brasileiro; a confecção de bonecos e a montagem de cenas, nas quais os princípios técnicos dessa linguagem sejam utilizados.

A inclusão do ensino de teatro de animação em universidades brasileiras é bastante recente. Iniciou-se por volta de 1980 e deve ser creditada principalmente a duas instituições: a Escola de Belas Artes da Universidade Federal de Minas Gerais e a Escola de Comunicações e Artes da Universidade de São Paulo. Hoje, a atividade se expandiu para outras universidades brasileiras, principalmente junto aos cursos de Licenciatura em Artes Cênicas.

O estudo que segue pretende discutir alguns dos eixos a serem contemplados no ensino do teatro de animação no âmbito acadêmico, com ênfase na linguagem do teatro de objetos/bonecos. A idéia é formular uma proposta que possa contribuir na formação acadêmica do artista professor interessado em trabalhar com essa linguagem.

\section{As vanguardas históricas e o teatro de animação}

Os últimos anos do século XIX e os primeiros do século XX são marcados pelo crescente interesse de dramaturgos e encenadores pela marionete. A marionetização do ator, a substituição do ator por bonecos, por formas, e a humanização de objetos são discussões que animam a produção teatral. Em torno dessa discussão, estão artistas que negam a estética do romantismo, do melodrama e do realismo enquanto correntes artísticas, e se abrigam sob o movimento simbolista. Tal interesse aparece de forma visível em duas direções: a marionete como referência para o comportamento do ator em cena e o teatro de marionetes como gênero artístico. Destaca-se, desse modo, o fascínio pela marionetização do trabalho do ator e experimentações em torno da humanização de objetos. 
Encenadores e dramaturgos, decepcionados com a atuação dos atores, seu histrionismo, excessos, caretas e condicionamentos psicofísicos, expressam a necessidade de o ator assumir outro comportamento em cena e apontam a marionete como referência para seu trabalho. Na raiz dessa discussão está a defesa do controle sobre o trabalho do ator, a ser efetuado pelo diretor; a negação do espontaneísmo e do vedetismo (predominantes no comportamento dos atores naquela época); a teatralização do teatro; a necessidade de consolidar a função do diretor como o maior responsável e criador do espetáculo teatral.

Hoje, o ator marionetizado pode ser visto como o "ator perfeito", o ator que com seus gestos e movimentos precisos, refinados, atingiu o ideal de beleza. Trata-se do ator que abandona a condição de vedete e uma atuação pautada na gestualidade cotidiana. Ele deixa de lado as características de seu comportamento diário, os traços marcantes da sua personalidade para realizar uma outra experiência, distanciada das propostas de interpretação realista e naturalista. É o ator que atingiu a capacidade de representar a personagem sem mesclar suas emoções e personalidade. Esse aparente "desumanizar-se" revela a essência humana. No seu trabalho, utiliza recursos técnicos comuns ao trabalho do ator-animador: a economia de meios, a precisão de gestos e movimentos, o olhar como indicador da ação, o foco, a triangulação, a partitura de ações, o subtexto; a idéia de que o movimento é frase, além de outros aspectos técnicos utilizados na animação de bonecos e objetos ${ }^{1}$.

A proposta de interpretação tendo a marionete como referência foi construída com a colaboração de diversos pensadores, dentre os quais se destacam Heinrich Von Kleist, Maurice Maeterlinck, Alfred Jarry, Edward Gordon Craig e Vsévolod Meyerhold. Ao estudar o pensamento desses dramaturgos e encenadores, é importante evidenciar pontos comuns e divergências em relação à idéia de marionetização do ator e, ao mesmo tempo, destacar que essas idéias vão influenciar o trabalho de marionetistas na produção de espetáculos cada vez mais heterogêneos.

O ator perfeito de Kleist - Heinrich Von Kleist (1777-1811) foi um dos pioneiros nessa discussão ao publicar o ensaio Sobre o Teatro de Marionetes, em 1810, cujas idéias passaram a animar polêmicas entre encenadores.

No diálogo estabelecido entre a personagem Senhor C e o primeiro bailarino da Ópera da cidade, Kleist diz que a marionete é o verdadeiro artista, porque dispõe de qualidades como euritmia, mobilidade e leveza. Ela pode realizar movimentos com graça, impossíveis de serem conseguidos pelo ser humano, porque o homem não tem controle sobre o centro de gravidade do movimento. E outra vantagem decisiva é que a marionete não é "afetada", como ocorre com a maioria dos atores e bailarinos.

Depois de discorrer sobre o movimento, sobre os deslocamentos e sua relação com o centro de gravidade, e de afirmar que estes devem ser conseguidos pelo controle externo, Kleist evoca um ator meio máquina, meio deus, capaz de realizar os desejos da alma e encarnar o homem como criador do mundo.

\footnotetext{
${ }^{1}$ Diversos espetáculos teatrais brasileiros utilizam esse procedimento: $U B U$, do Grupo Sobrevento; Buster, do Grupo XPTO; espetáculos dirigidos por Gerald Thomas, como Electra com Creta, Trilogia Kafka, M.O.R.T.E. No teatro europeu e norte-americano, destacam-se espetáculos dirigidos por Mnouchkine, Bob Wilson, Leszek Madzik. No cinema recente, são notáveis as atuações das atrizes Kati Outinem, em O Homem sem Passado, de Aki Kaurismaki; e Scarllet Johansson, em A Moça com Brinco de Pérola, de Peter Weber.
} 
O ator desencarnado de Maeterlinck - Maurice Maeterlinck (1862-1949), dramaturgo simbolista, apelava para a palavra pura, em que a verbalização o ator seria quase uma estátua falante, adquirindo uma sobriedade gestual com movimentos que obedeceriam a princípios de economia, contenção e elegância, imobilidade e face congelada, explorando silêncios. Insistia em que o espectador, ao ver homens materialmente representados e personagens se expressando em linguagem comum, percebia na cena um caso e um indivíduo e não o ser humano universal. E afirmava:

Talvez fosse necessário suprimir totalmente o ser humano da cena... Ou - quem sabe - o ser humano poderá ser substituído por uma sombra, um reflexo, projeções numa tela de formas simbólicas ou por um ser com toda a aparência da vida, sem ter vida. Eu não sei, mas a ausência do homem me parece indispensável².

Fica evidente que o que contrariava o autor era a presença física do ator - se mexendo, falando -, porque acreditava que isso destruía a ficção e impunha a realidade concreta, e limitada, de homens em seu cotidiano. Como se a realidade não conseguisse dar conta da verdade da existência. E tudo o que o ator fazia parecia ridículo, inadmissível, intolerável.

As indicações para a nova forma de interpretar são genéricas, mas fica claro que o ator precisa encontrar novos meios de expressão, cujas referências estariam, talvez, nas marionetes, nas figuras de cera, nos autômatos, nos andróides, nos reflexos, objetos, máscaras.

O ator boneco de Jarry - Alfred Jarry (1873 -1907) foi um dos precursores do retorno ao uso da máscara e pela busca de uma interpretação "despersonalizada", tendo como referência a marionete. Ele propôs um teatro no qual as máscaras substituem o retrato sociológico de uma pessoa pela "efígie da personagem". Na estréia da peça $U b u R e i$, em discurso para a platéia afirmava:

Nestas noites, os atores quiseram tornar-se impessoais e representar cobertos por máscaras demonstrando mais precisamente o homem interior e a alma das marionetes que vocês vão ver [...]. Estarão cobertos por uma máscara com o caráter da personagem: o avarento, fraco, sovina, criminoso ${ }^{3}$.

Jarry fazia a defesa da personagem tipificada, a negação da personagem psicologizada. Referindo-se ao boneco e ao ator que usa máscara, salientava que ambos devem se mover pouco e lentamente, com o fim de oferecer ao espectador uma imagem ambígua, afastada do contexto do qual surgiram.

As referências do teatro de marionetes presentes nas personagens da peça Ubu Rei são evidentes pelas mudanças bruscas das suas reações; pela rapidez com que mudam de atitudes e opiniões; pela coexistência de atitudes próximas da vulgaridade; pela proximidade entre o bom senso e a idiotice, entre a nobreza e a infâmia.

${ }^{2}$ MAETERLINCK, Maurice. Menus propus, le théâtre. In: PLASSARD, Didier. Les mains de lumière. Charleville-Mézières: Institut International de la Marionnette, 1996. p. 20.

${ }^{3}$ JARRY, Alfred. Todo ubú. Barcelona: Bruguera, 1980. p. 24. 
O ator máscara de Craig - Edward Gordon Craig (1872-1966) criticava a estética realista dando a impressão da impossibilidade de o ator estar em cena. Dentre as polêmicas afirmações do autor, destaca-se esta afirmativa: "A representação do ator não constitui uma arte; e é forçadamente que se dá ao ator o nome de artista. Porque tudo o que é acidental é contrário à arte" ${ }^{4}$.

A publicação do seu ensaio O Ator e a Supermarionete, em 1908, expressava sua rejeição ao teatro produzido na época. Negava a arte realista como imitação fotográfica da natureza, o teatro em que predomina a submissão ao texto, o teatro escrito, a interpretação submetida aos caprichos e emoções humanos. Dizia que os gestos do ator, a expressão de seu rosto, da sua voz, não obedecem a controles e se traem constantemente. E desafiava:

Suprima-se a árvore autêntica que se colocou em cena, suprima-se o tom natural, o gesto natural e chegar-se-á igualmente a suprimir o ator. [...]

O ator desaparecerá e em seu lugar veremos uma personagem inanimada que usará, se quereis, o nome de Sur-marionnette - até que tenha conquistado um nome mais glorioso 5 .

O pesquisador francês Plassard, ao manusear escritos de Craig dos anos 1905 e 1906, período em que este último formulou a idéia da Supermarionete, conclui:

Meus estudos constatam já nas primeiras páginas do Caderno A que a idéia de supermarionete não está separada do ator usando máscara, em parte inspirado no ator do teatro antigo grego. Notas e croquis demonstram o ator inteiramente coberto, despersonalizado, com máscara, tornando impossível ao intérprete mesclar suas emoções e personalidade na representação da personagem ${ }^{6}$.

Craig lançou as bases de uma tendência que se consolidaria mais tarde: a teatralização do teatro, instaurando o monopólio da figura do diretor na cena. Para ele, o ator é a Supermarionete, uma máscara cobrindo além do rosto, todo o corpo do ator.

A polifonia meyrholdiana - Para o diretor Vsévolod Meyerhold (1874 1940), o teatro de bonecos popular russo, o Petrushka, é referência importante na preparação do seu elenco. Ele via na síntese dos movimentos conquistas que seu elenco deveria fazer. $\mathrm{O}$ ator Igor Iliinski relata exercícios propostos pelo diretor:

Meyerhold apreciava altamente a expressividade do corpo. Fazia a demonstração com um boneco de guinhol: introduzindo os dedos, obtinha os efeitos mais diversos. Apesar da sua máscara parada, o boneco exprimia quer a alegria - os braços abertos, como a tristeza - a cabeça caída, ou ainda o orgulho - a cabeça inclinada para trás ${ }^{7}$.

\footnotetext{
${ }^{4}$ CRAIG, Edward Gordon. Da arte do teatro. Lisboa: Arcádia, 1973. p. 87.

${ }^{5}$ CRAIG, 1973, p. 108-109.

${ }^{6}$ PLASSARD, Didier. L'acteur en Effigie. Paris: L'Age D'Homme, 1992. p. 47-53.

7 ILIINSKI apud MEYERHOLD, Vsévolod. O teatro teatral. Lisboa: Arcádia, 1980. p. 189.
} 
O boneco é referência importante na superação da interpretação psicológica, colaborando para a expressividade do gesto, precisão e síntese do movimento.

Em seu estudo O Teatro de Feira (1912) recorre à marionete para marcar a diferença entre o "ator da interioridade" e o ator de uma linguagem cênica original. Para ele, o primeiro "só busca revelar seu estado de alma pessoal. Recusa-se a obrigar sua vontade a dominar os procedimentos técnicos". Ao segundo, perguntava: "ele deve substituir a marionete e perseguir esse papel auxiliar, que lhe recusa toda liberdade de criação pessoal, ou deve fundar um teatro análogo ao que a marionete soube conquistar, negando-se a se submeter à vontade do diretor de modificar a sua natureza?"8. Ele mesmo respondia dizendo:

A marionete não quer se identificar completamente ao homem, porque o mundo que ela representa é o maravilhoso mundo da ficção, porque o homem que ela representa é um homem inventado, porque o tablado onde ela evolui é o espaço de harmonia onde se encontram os fios de sua arte. Sobre seus tablados, é assim e não de outra maneira, não de acordo com as leis da natureza, mas porque essa é a sua vontade, e porque o que ela quer não é copiar, mas criar?

A idéia de marionetização em Meyerhold apresenta-se de maneira diferenciada, eventualmente o boneco é referência para que o ator elabore o que ele considera essencial: a construção de uma técnica particular fundada na expressividade do gesto e do corpo. $\mathrm{O}$ ator, criador dessa nova forma de interpretar, distancia-se da cópia pura e simples da natureza para chegar à harmonia plástica, à criação artística. Usa o boneco na cena com freqüência; porém, como alegoria, figuração, metáfora da personagem que representa. Conforme Krisinski1 ${ }^{10}$, "Meyerhold propõe um teatro sincrético e polifônico que integre o boneco, sem outorgar-lhe a função primordial de símbolo absoluto”.

Com Maeterlinck, Jarry, Craig e Meyerhold é possível perceber a existência de eixos, para analisar o trabalho do ator marionete. São tendências que por vezes se apresentam profundamente imbricadas e noutros momentos parecem tomar rumos distintos.

De acordo com Jarry, o ator é boneco com comportamento cênico e inclui uma gestualidade desconcertante. O boneco é referência tanto para a construção da personagem em seus textos dramáticos como para a interpretação.

Craig explora, através da marionete e suas múltiplas formas, as condições de reorganização do jogo teatral em linguagem única, numa homogeneidade plástica, em que o ator é tão somente parte integrante de uma totalidade mais ampla: o espetáculo. $\mathrm{O}$ ator inteiramente mascarado é quem pode concretizar essa forma de interpretar no novo teatro.

Já Maeterlinck desenha o perfil de um ator mediado pelo visível e o invisível. O ator é o ser desencarnado, símbolo do homem submetido ao servilismo absoluto de normas sociais estabelecidas.

\footnotetext{
${ }^{8}$ MEYERHOLD, Vsévolod. Le théâtre de foire. In: PLASSARD, Didier. Les mains de lumière. Charleville-Mézières: Institut International de la Marionnette, 1996. p. 232.

9 MEYERHOLD, 1996.

${ }^{10}$ KRISINSKI, Wladimir. Un desorden sofisticado. In: PUCK: el títere y las otras artes: cuerpos en el espacio. Bilbao: Institut International de la Marionnette: Centro de Documentación de Títeres de Bilbao, 1992. n. 4, p. 19.
} 
Para Meyerhold, o Petrushka eventualmente é referência tanto para a encenação quanto para a formação do elenco. $\mathrm{O}$ diretor buscava a teatralidade e assim torna relativa a função do boneco, integrando-o à simultaneidade de outros recursos, fazendo- o colaborar com a polifonia cênica em que se constituíam seus espetáculos.

Mas é possível perceber um eixo comum nos autores estudados: a marionete sempre aparece como síntese dessa nova forma de teatro, em que o espetáculo se aproxima do cálculo matemático, obedecendo a regras e normas de visibilidade cênica, compreendendo movimento, cores, gestos, sons, ritmo. Aí está a espetacularidade no teatro apoiada na marionete, num momento da história em que o teatro se rebela contra a encenação realista e a interpretação psicológica. Para esses dramaturgos e diretores, vale insistir, a marionete é referência, por vezes síntese da perfeição, rumo a essa nova forma de interpretar e conceber a arte do teatro.

No ensino do teatro de animação é relevante estudar as trajetórias desses dramaturgos e diretores, porque demonstram a importância do teatro de marionetes como caminho na formulação de propostas para um novo teatro, no qual as fronteiras entre diferentes linguagens artísticas já eram tênues; evidencia um período da história do teatro marcado pela inquietude, pela irreverência e pela rebeldia contra as distintas formas de um teatro comercial.

Mamulengo - Em alguns estados do Nordeste brasileiro e mais especialmente no estado de Pernambuco, existe uma forma de teatro de bonecos conhecida como mamulengo ${ }^{11}$. É uma arte praticada por artistas do povo, homens simples, vivendo em difíceis condições materiais, quase todos analfabetos, mas conhecidos como "Mestres". São artistas, homens que fazem a "brincadeira do mamulengo", criam e detêm o conhecimento sobre como se faz essa arte; são os portadores do patrimônio técnico, artístico e cultural do mamulengo.

O mamulengo consiste em um teatro do riso, como o são tantas outras formas dramáticas populares: “[...] no mamulengo todas as inverossimilhanças são permitidas porque nada é real e todo o prazer decorre das convenções, atingindo um realismo superior, mais verdadeiro que o verdadeiro, porque é poético" ${ }^{12}$.

A estruturação dramática obedece a um sistema de pequenas peças ou passagens não escritas, entremeadas por números de dança e por improvisações feitas pela personagem apresentadora, conhecida como Simão, Tiridá, João Redondo. Tratam-se de espetáculos de estruturação arbitrária, as passagens acontecendo de modo independente, sem muita preocupação de ligação lógica entre si. Embora se constituindo de peças ou passagens não escritas, o mamulengo pode ser considerado próximo ao "gênero revista", ou teatro de variedades, em que uma sucessão de pequenas passagens com assuntos cômicos, sociais, morais, religiosos se sucedem como esquetes, incorporando elementos que pertencem aos gêneros dos musicais e ao gênero do circo $^{13}$.

\footnotetext{
11 Em Pernambuco a manifestação é conhecida como Mamulengo, porém no Rio Grande do Norte é denominada João Redondo ou Calunga; na Paraíba, Babau; na Bahia, Mané Gostoso. BORBA FILHO, Hermilo. Fisionomia e espirito do mamulengo. Rio de Janeiro: Minc, Inacen, 1987. p. 55; PIMENTEL. Altimar de Alencar. O mundo mágico de João Redondo. Rio de Janeiro: Minc, Fundacen, 1988. p. 7.

12 BORBA FILHO, 1987, p. 227.

13 SANTOS, Fernando Augusto. Mamulengo: um povo em forma de bonecos. Rio de Janeiro: Mec: Funarte, 1987. p. 142.
} 
Por constituir uma tradição cuja prática vem desde a época do Brasil-Colônia, predominantemente agrário e escravocrata, o mamulengo representa simultaneamente uma dramaturgia e uma história de transmissão oral, em que foram sintetizadas personagens típicas, temas, fórmulas e estruturas, as quais têm inspirado desde então inúmeras adaptações, e formas de expressão artística. Os mestres das várias brincadeiras pernambucanas são também responsáveis pela criação de inúmeros versos e cantigas, expressões e ditos que freqüentemente se tornam populares e podem persistir, tornando-se típicos ${ }^{14}$.

A continuidade e preservação da arte do mamulengo estão intimamente ligadas à transmissão oral, na relação que se estabelece entre mestre e aprendiz, sobretudo a observação da prática, a forma de apresentar e "brincar" do mestre, pois estas são as características que preservam e sustentam a continuidade da brincadeira. $\mathrm{O}$ que é transmitido pelo mestre pode ser compreendido como "técnicas"15 ou "estruturas materiais ou imaginárias", ou ainda, "técnicas codificadas de longa duração". Para Eugenio Barba ${ }^{16}$, técnica é a "utilização extracotidiana do corpo", e para falar das técnicas codificadas refere-se a "princípios que retornam”. Os estudos de Barba concentram-se no treinamento corporal, na preparação psicofísica do ator, cuja história vai construindo um acervo composto de técnicas incorporadas por mestres do ofício, ao qual o aprendiz e seu seguidor recorrem e que as utilizam.

Os mamulengueiros vivem processos bastante semelhantes. Por isso, relacionar os estudos dessa arte com conceitos da antropologia teatral trabalhados por Barba ampliará a compreensão dessa manifestação. $O$ ensino do teatro de animação no Brasil deve estabelecer como prioridade o estudo dessa arte, apoiando-se em pesquisas, bem como na leitura e encenação de textos dramáticos do repertório do Mamulengo recolhido por pesquisadores ${ }^{17}$.

Nomenclaturas - É freqüente o uso de expressões como "teatro de marionetes", "teatro de bonecos", "teatro de formas animadas", "teatro de objetos", "teatro de animação" para designar essa linguagem. Muitas vezes essas nomenclaturas são usadas como sinônimos, mas existem diferenças entre elas. Atualmente a expressão mais aceita no Brasil é "teatro de animação", por se tratar de uma arte com a peculiaridade de animar a forma inanimada. É, de fato, a arte na qual a relação com a platéia é mediada pela presença do objeto animado.

14 DUTRA, Patrícia Angélica. Trajetórias de criação do mamulengo do professor Benedito em Chão de estrelas e mais além: ato, ritual arte e cultura popular. 1998. p. 180. (Dissertação) Programa de Pós-Graduação em Antropologia Social, Universidade Federal de Santa Catarina, Florianopólis, 1998. É possível registrar não só no Nordeste Brasileiro, mas em outras regiões do Brasil, a trajetória de grupos teatrais que têm sua base de inspiração no mamulengo. Observando sua estrutura e elementos presentes na brincadeira recriam o mamulengo, apresentando espetáculos originais, cujas referências são a arte dos mamulengueiros.

${ }^{15} \mathrm{Em} A$ arte secreta do ator, Barba e Savarese escrevem: "O modo como usamos nossos corpos na vida cotidiana é substancialmente diferente de quando usamos em situações de representação. $\mathrm{Na}$ vida cotidiana usamos uma técnica corporal que foi condicionada pela nossa cultura, nossa posição social e profissão. Mas, numa situação de representação, o uso do corpo é completamente diferente. Portanto, é possível diferenciar entre a técnica cotidiana e a técnica extracotidiana." BARBA, Eugenio; SAVARESE, Nicola. A arte secreta do ator. Dicionário de antropologia teatral. Campinas, SP: UNICAMP, 1995. p. 227.

${ }_{16}$ BARBA; SAVARESE, 1995 , p. 27-58.

17 Refiro-me a BORBA FILHO, 1987; CANELLA, Ricardo Elias Ieker. A construção da personagem no João Redondo de Chico Daniel. 2004. 178 p. (Dissertação) - Programa de Pós-Graduação em Ciências Sociais, Universidade Federal do Rio Grande do Norte, Natal, 2004; DUTRA, 1998; PIMENTEL, 1988; SANTOS, 1987. 
Também existem diferentes nomenclaturas para definir quem é o profissional que se expressa com a linguagem do teatro de animação. Historicamente, "titeriteiro" e "marionetista" foram as expressões mais utilizadas. No entanto, a partir de 1975 já se faziam rupturas estéticas visíveis em relação ao teatro de bonecos tradicional, e com o teatro geralmente produzido em escolas, bastante conhecido como "teatro de fantoches". E "bonequeiro" passou a ser a nomenclatura corrente. Mas logo apareceram outras designações, com a justificativa de que "bonequeiro" é a expressão mais adequada para quem trabalha com o boneco do tipo antropomorfo e, por isso, não aglutina tendências mais contemporâneas da linguagem.

A denominação mais aceita foi "manipulador", porque creditava a este artista a responsabilidade da encenação. No entanto, muitos profissionais da área passaram a considerá-la inadequada, porque pressupõe uma relação verticalizada do ator sobre o boneco ou objeto. Tal visão não contempla um aspecto fundamental no trabalho desse artista: o diálogo entre a matéria de que é feito o títere, os mecanismos de articulação e animação, assim como as intenções do ator-animador. Ou seja, a relação que se estabelece entre o artista que se expressa com bonecos e objetos ou formas animadas é mais complexa do que o sentido da palavra "manipulador" confere a este artista. Certamente por essa razão, mais recentemente é comum o uso de nomenclaturas como "ator-bonequeiro", "ator-animador". Isso evidencia a intenção de reafirmar a concepção de que o artista em questão é ator, é intérprete.

No entanto, ainda persistem as dúvidas que pairam sobre a denominação mais adequada ao trabalho desse profissional. Há o entendimento de que o ator-animador é um artista que encena espetáculos expressando-se com bonecos. E na realização desse trabalho, normalmente, concebe o texto: é dramaturgo; confecciona os bonecos, os objetos, o que lhe exige competências para esculpir, pintar, costurar: é escultor, pintor e figurinista; concebe e executa o cenário e materiais de cena: é cenógrafo e aderecista; seleciona a trilha sonora e, às vezes, compõe músicas para o espetáculo: é músico; interpreta utilizando bonecos e objetos para representar e, atualmente, é comum extrapolar os limites da "tenda" ou "palquinho" tradicional dos bonecos e atua numa relação direta com o público: é ator; dirige o próprio espetáculo: é diretor; concebe a iluminação para o espetáculo: é iluminador; levanta os recursos financeiros e as condições materiais para a realização do trabalho, além de divulgar e vender o espetáculo: é produtor; define o material gráfico, tais como programa e cartaz: assim, também é artista gráfico.

Como se vê, trabalhar com teatro de animação é atividade que envolve o conhecimento das práticas de outras profissões, exigindo a realização de tarefas que, mesmo não tendo formação na área, os atores-animadores precisam executar.

Os tipos mais comuns na confecção de bonecos são o boneco de fio, mais conhecido como marionete; boneco de luva, popularizado como fantoche; boneco de vara; marote; boneco à tringle, boneco de mesa ou balcão.

Boneco de fio, mais conhecido no Brasil como "marionete", é um boneco de confecção e manipulação complexa, porque, além de ter entre cinco e 30 fios, é um gênero que exige movimentos lentos e delicados, quase sempre próximos dos movimentos humanos ou animais. Boneco de luva, também chamado de fantoche, é sem dúvida o gênero mais popular do teatro de animação. A luva é a roupa do boneco, 
a mão e os dedos do marionetista constituem o corpo e fazem os movimentos do boneco. É conhecido como guignol (França), Don Cristóbal (Espanha), punch (Inglaterra), karspel (Alemanha), pulcinella (Itália), petrushka (Rússia) e mamulengo (Brasil), para citar apenas algumas das formas mais conhecidas. No Oriente também é uma arte muito praticada, sobretudo na China, local onde existem grandes virtuoses no gênero. Boneco de vara, derivado do Wayang, é o boneco tradicional da ilha de Java, na Indonésia, que é sustentado por uma vara principal que fixa sua cabeça e manipulado de baixo para cima. Normalmente, o boneco possui uma segunda vara em uma das mãos. Marote é uma variação simplificada do boneco de vara. Trata-se de um boneco montado em torno de uma única vara principal, presa na cabeça. Não possui varas que controlem as mãos, mas um bom marionetista sempre consegue tirar muitos efeitos, principalmente em cenas de dança e figurações. Boneco à tringle: originário do francês tringle, tem uma vara, haste de metal fixada na cabeça e também aparece com varas de manipulação fixas num pé ou mão. Geralmente apresenta movimentos bruscos e rápidos. Boneco de mesa ou balcão: manipulado por trás do corpo do boneco, o marionetista o apóia numa mesa ou balcão. Derivado do bunraku japonês, é um boneco que exige até três animadores para sua atuação. Difundiu-se amplamente no Ocidente a partir da segunda metade do século XX, originando diversas variantes. A mais conhecida é a forma de teatro em que os marionetistas se vestem de preto, atuam à vista do público e se tornam quase invisíveis devido ao jogo de luz.

A expressão do boneco - inerte, o boneco é um objeto, e o que o transforma em elemento teatral é a ação dramática, a interpretação diante do espectador. Ao animar o boneco, o ator-bonequeiro também atua. É equivocado pensar que quando o ator é deficiente em seu trabalho de intérprete, pode se realizar profissionalmente no campo do teatro de animação, porque ali se trabalha só com as mãos. "Dificilmente alguém pode ser um bom titeriteiro se não for bom ator"18.

Animar é transformar o objeto em personagem, e o que caracteriza o teatro de animação não é apenas o objeto em si, tampouco seu desenho, forma, peso, volume e material de que é construído, embora esses elementos sejam determinantes na sua animação e no processo de encenação do espetáculo. É a animação que faz com que ele exista, e só a ação justifica sua presença na cena. A vida presente nos bonecos cria uma outra realidade, e isso se deve ao trabalho do bonequeiro. Por isso, é possível afirmar que o boneco é a extensão do corpo do ator-animador.

A animação não pode ser confundida com a realização de qualquer movimento do objeto em cena e não tem obrigatoriamente relação com quantidade e intensidade de movimentos. O movimento sutil, mínimo, bem como o ampliado, brusco, ou seja, todo tipo de movimento pode fazer parte da animação, desde que tenha uma intenção. A ausência de movimento também pode ser uma ação da personagem. A animação dá a impressão de que o boneco tem autonomia, possui consciência, age por vontade própria. Como afirma Niculescu, "[...] é importante que as marionetes pensem. Uma marionete que não pensa é uma marionete manipulada"19.

\footnotetext{
${ }^{18}$ ERULI, Brunella. Le dernier pas dépend du premier. In: PUCK: la marionnette et les autres arts. Charleville-Mézières: Institut International de le Marionnette, 1994. n. 7, p. 85.

${ }_{19}$ Margareta Niculescu, então diretora da École Supérieure National des Arts de la Marionnette em Charleville-Mézières, França, em entrevista ao autor em 07 de dezembro de 1998.
} 
$\mathrm{O}$ ator-bonequeiro define e ordena a seqüência de gestos e ações que qualificam a presença do objeto/personagem. O desafio é produzir a impressão de vida num corpo que se encontra fora do seu próprio corpo. $\mathrm{O}$ que qualifica a animação é, portanto, a adequação dos movimentos, dos gestos, das ações selecionadas pelo ator-animador e pela direção do espetáculo com o conjunto da obra.

Atualmente, os espetáculos de teatro de animação têm utilizado com muita freqüência a presença visível do ator-animador no espaço de atuação, na cena. É comum ver espetáculos em que ele interpreta uma personagem e contracena com o boneco; às vezes é neutro em cena, atuando de modo a valorizar a performance do boneco. Registra-se ainda outra maneira, na qual, enquanto atua, estabelece uma relação de cumplicidade com o boneco.

Assim, quando se toma como referência o teatro de bonecos com a estética $\mathrm{da}$ manifestação popular, ou aquele pertencente às grandes tradições, como o Mamulengo, é possível constatar que o teatro feito atualmente usa variados meios de expressão, abandona o boneco do tipo antropomorfo, rompe com o palquinho do tradicional teatro de bonecos e se torna um teatro de animação bastante heterogêneo. Sua proximidade com outras linguagens artísticas, incluindo a dança, a mímica, o circo, o teatro de atores, as arte plásticas e o espetáculo multimídia torna esta arte reconhecidamente mais contemporânea, porém heterogênea, distanciada dos códigos e registros que historicamente a tornaram conhecida do grande público.

A heterogeneidade não elimina as especificidades próprias desse campo artístico, ao contrário, ela merece destaque no ensino dessa arte. Como afirma Jurkowski, “[...] o teatro de títeres é uma arte diferenciada do teatro de atores pela sua característica mais fundamental, ou seja, o sujeito que fala, que atua, [o boneco] faz uso temporal de fontes de poderes vocais e motoras que estão fora dele, não são seus atributos próprios”20. Essa diferença aparentemente simples se reveste de complexidade à medida que o desafio do ator-animador consiste em animar a forma inanimada, em transpor suas emoções ao títere.

Princípios da linguagem - outro aspecto a ser priorizado no ensino dessa arte é o conhecimento de princípios técnicos para a animação de bonecos e objetos. Existem "normas", que vistas em conjunto e de forma interligada, definem princípios da linguagem artística em estudo, como as listadas abaixo.

A “economia de meios” - princípio que se utiliza do mínimo de recursos para realizar determinada ação. Implica em selecionar os gestos mais expressivos, o movimento preciso, limpo, sem titubeios e claramente definido. É como compreender que "menos vale mais", ou seja, não é a quantidade de gestos que garante a qualidade da ação.

O "foco" é a definição do centro das atenções de cada ação. A noção de foco pode ser exemplificada em momentos em que o boneco projeta seu olhar para o objeto ou personagem com que contracena. Quando existem diversos bonecos em cena e apenas um está realizando alguma ação, todos dirigem seu olhar ao que age. Isso dá a noção de foco, define o lugar para onde o público deve concentrar seu olhar.

O "olhar como indicador da ação" - princípio que se realiza quando o boneco, antes do início de determinadas ações, olha para o ponto exato de deslocamento.

${ }^{20}$ JURKOWSKI, Henryk. Sobre el teatro de titeres. Bilbao: Concha de la Casa, 1990. p. 39. 
Este princípio também serve para destacar a presença de um objeto em cena. A precisão do seu olhar é determinante e indica ao espectador o que deve ser observado. Isso requer um movimento da cabeça amplo e definido, para dar a sensação de que o boneco olha. É comum ouvir de atores-bonequeiros experientes que "o boneco olha com a cabeça e não apenas com o olho".

A "triangulação" - recurso que se realiza com o olhar e colabora para "dialogar" com o espectador, fazendo-o "entrar" na cena. Trata-se de um "truque" efetuado com o olhar para mostrar ao espectador o que acontece na cena, evidenciar a reação de uma personagem, destacar a presença de um objeto. $O$ boneco interrompe a ação com o objeto (congela), dirige o seu olhar ao público, volta a olhar para o objeto e reinicia a ação ${ }^{21}$.

A "partitura de gestos e ações" - é a escrita cênica que detalha a seqüência de movimentos, ações e gestos de cada personagem no espaço, em cada uma das cenas do espetáculo. A construção da partitura é criação do ator-animador em parceria com o diretor, obedecendo a determinações das técnicas de animação, à matéria com a qual foram confeccionados os bonecos, às articulações da sua estrutura física e à conduta da personagem. Vale destacar ainda a vinculação existente entre os gestos e ações do boneco com os princípios estéticos do espetáculo. Portanto, a criação da partitura de gestos e ações não é criação aleatória do ator-bonequeiro: sua construção mantém estreitos vínculos com a concepção do espetáculo teatral.

O "subtexto" é uma criação interna do ator, pautada nas intenções de cada personagem, e que apóia a construção e apresentação da partitura de gestos e ações. Conforme Pavis, é "[...] aquilo que não é dito explicitamente no texto dramático, mas que se salienta na maneira pela qual o texto é interpretado pelo ator. O subtexto é uma espécie de comentário efetuado pela encenação e pelo jogo do ator, dando ao espetáculo a iluminação necessária à boa recepção do espetáculo"22. A construção do subtexto pode funcionar como guia ao ator-bonequeiro para sustentar a atuação da marionete.

"O eixo do boneco e sua manutenção" - consiste em respeitar a estrutura corporal e sua coerência com a coluna vertebral do ser humano, ou obedecer à postura animal quando a personagem é dessa origem. É importante aproximar o boneco da forma "natural" da personagem que representa. Exige observar a posição das pernas, coluna vertebral, verticalidade do corpo do boneco quando se trata de boneco do tipo antropomorfo. Quando o ator-bonequeiro não mantém o eixo corporal do boneco, colabora para a perda da credibilidade da personagem em cena, porque evidencia que ela está sendo manipulada.

"Relação frontal" - mantê-la é atuar de forma que o público não perca de vista a face (máscara) do boneco. Quando o boneco realiza ações que escondem totalmente seu rosto por tempo prolongado é difícil manter o foco e a atenção do espectador na cena. Assim, a personagem perde força e dá a impressão de que volta a ser o objeto ou a matéria da qual o boneco é confeccionado.

\footnotetext{
${ }^{21}$ Quando existem dois bonecos dialogando em cena, uma das maneiras mais comuns de realizar a triangulação é fazer com que o boneco que age e fala, olhe para o público enquanto é observado pelo outro boneco, que permanece imóvel. Ao terminar sua fala ou ação, devolve o olhar para o segundo e os papéis se invertem. Ou seja, o que age e fala, olha para o público enquanto é observado pelo outro boneco. Faz-se o triângulo: a personagem que atua, o público e a segunda personagem. Isso também define o foco da cena e capta a atenção do espectador.

${ }_{22}$ PAVIS, Patrice. Dicionário de teatro. São Paulo: Perspectiva, 1999. p. 368.
} 
"Movimento é frase" - trabalhar com essa noção supõe ultrapassar a idéia de movimentar aleatoriamente ou sacudir o boneco em cena. Implica em dissecar os movimentos, fazendo a "pontuação" adequada, incluindo "ponto" e "vírgulas”. Cada ação tem seus movimentos realizados numa seqüência que implica em finalizá-las para depois iniciar o movimento subseqüente. Remete à necessidade de cuidar da finalização de cada gesto ou ação. Ajuda a definir os diferentes ritmos presentes em cada ação. Binômios como ação-reação, imobilidade-movimento, silêncio-ruído, podem ser referências importantes para o ator-bonequeiro realizar esse trabalho.

A "respiração do boneco" - fazer com que o boneco "respire" complementa a noção de estar em movimento, de estar vivo. Encontrar o movimento justo para dar a idéia de que o boneco respira exige a ampliação desse movimento, uma vez que o boneco "respira" com o corpo inteiro Por isso, o ator-animador busca encontrar o movimento justo, para dar veracidade a essa respiração. Muitas vezes o boneco "respira" em sintonia com a respiração do seu animador. Muitos gestos são impulsionados pelo ato de inspirar. As emoções vividas pela personagem-boneco também estão relacionadas com a inspiração/expiração: reagir com raiva implica em respirar de forma distinta à que ocorre ao receber um afago. É necessário longo tempo de "convivência” com o boneco para encontrar o movimento justo. Trata-se de um movimento dilatado, diferente do ato de respirar humano, mas fundamental para dar qualidade à sua atuação. Quando a respiração é feita adequadamente, o boneco parece vivo e sua atuação torna-se convincente.

A “'neutralidade' do ator-bonequeiro em cena" - Este princípio tem gerado muitas controvérsias, porque é difícil conceber a idéia de presença neutra na cena, uma vez que tudo o que está no palco adquire significado. A "neutralidade” é aqui concebida como predisposição do ator-animador para estar a serviço da forma animada, tornar-se "invisível” em cena, atenuar sua presença para valorizar a do boneco. Supõe eliminar caretas, suspiros, olhares e economizar gestos do ator-animador para evidenciar as ações do boneco. Trata-se de trabalhar com a noção de consciência de estar em cena, o que exige movimentos comedidos, discretos, elegantes, suficientes para que se remeta o foco das atenções ao boneco presente na cena e não ao seu animador. Quando os gestos do ator-bonequeiro e sua presença são mais eloqüentes que a presença do boneco, cria-se um duplo foco que desvaloriza a cena ${ }^{23}$.

Quando o ator-animador conhece esses elementos, certamente realiza melhor o seu trabalho. Isso ocorre quando o ator-manipulador está imbuído do que diz Brecht: "[...] há muitos objetos num só objeto"24. Ou seja, ver além do aparente, olhar mais profundamente e ver a possibilidade do movimento, o "vir a ser" contido em cada objeto ou boneco. A técnica e a qualidade da animação nascem desse tipo de concepção, aliada, naturalmente, ao exercício diário, ao trabalho paciente e prolongado.

\footnotetext{
${ }_{23}$ Em $O$ ator e seus $d u p l o s$, Amaral discute esse tema e propõe uma série de exercícios para a compreensão e domínio desses princípios técnicos. AMARAL, Ana Maria. O ator e seus duplos. São Paulo: Senac: Edusp, 2001. 159 p.

${ }^{24}$ BRECHT apud KOUDELA, Ingrid. Brecht: um jogo de aprendizagem. São Paulo: Perspectiva, 1991. p. 80.
} 


\section{Considerações finais}

O ensino do teatro de animação deve privilegiar o aprendizado da mais peculiar característica dessa arte, ou seja, a interpretação, a representação mediada pelo objeto-boneco. Ainda que seja indispensável para sua atuação, o conhecimento necessário ao trabalho de ator não é suficiente. Ser ator não significa, necessariamente, ser ator-animador. A animação do objeto, incumbência principal desse artista, exige o domínio de técnicas e saberes que não são necessariamente do conhecimento do ator. Ao mesmo tempo, é preciso salientar que se o ator-bonequeiro se confinar nas especificidades dessa linguagem, dissociando-se do trabalho do ator, terá uma atuação incompleta e inadequada. Ou seja, o ator-animador não pode prescindir dos conhecimentos que envolvem a profissão de ator.

É possível considerar o teatro de animação como uma linguagem com regras próprias, que estão em permanente processo de transformação, podendo ser atualizadas, recriadas ou superadas. Os acontecimentos mais recentes nos distintos campos das artes revelam mudanças, evidenciando um movimento em direção à ampliação das formas de atuação que se mesclam com outras linguagens artísticas. O ensino do teatro de animação precisa, obviamente, considerar essa realidade.

Eis algumas das proposições a serem consideradas no ensino do teatro de animação. Mas é preciso repetir: essa atividade é relativamente nova nas universidades brasileiras e as diversas experiências que vêm sendo realizadas em distintas regiões do país certamente contribuem para o enriquecimento do ensino dessa arte. 


\section{REFERÊNCIAS}

ABIRACHED, Robert. La crisis del personage en el teatro moderno. Madrid: Asociación de Directores de Escena de España, 1997.

AMARAL, Ana Maria. O ator e seus duplos. São Paulo: Senac: Edusp, 2001.

AMARAL, Ana Maria. Teatro de formas animadas. São Paulo: Edusp, 1991.

BARBA, Eugenio; SAVARESE, Nicola. A arte secreta do ator. Dicionário de antropologia teatral. Campinas, SP: UNICAMP, 1995. p. 23-63, p. 227-243.

BELTRAME, Valmor. Animar o Inanimado: a formação profissional no teatro de bonecos. 2001. 303 p. Tese (Doutorado) - Escola de Comunicações e Artes, Universidade de São Paulo, São Paulo, 2001.

BORBA FILHO, Hermilo. Fisionomia e espírito do mamulengo. Rio de Janeiro: Minc, Inacen, 1987. p. 55-86.

CANELLA, Ricardo Elias Ieker. A construção da personagem no João Redondo de Chico Daniel. 2004. 178 p. (Dissertação) - Programa de Pós-Graduação em Ciências Sociais, Universidade Federal do Rio Grande do Norte, Natal, 2004.

CAVALIERE, Arlete. O inspetor geral de Gógol/Meyerhold. São Paulo: Perspectiva, 1996.

CRAIG, Edward Gordon. Da arte do teatro. Lisboa: Arcádia, 1973.

DUTRA, Patrícia Angélica. Trajetórias de criação do mamulengo do professor Benedito em Chão de estrelas e mais além: ato, ritual arte e cultura popular. 1998. 205 p. (Dissertação) - Programa de Pós-Graduação em Antropologia Social, Universidade Federal de Santa Catarina, Florianopólis, 1998.

ERULI, Brunella. Le dernier pas dépend du premier. In: PUCK: la marionnette et les autres arts. Charleville-Mézières: Institut International de le Marionnette, 1994. n. 7.

HORMIGÓN, Juan Antonio. Meyerhold: textos teóricos. Madrid: Asociación de Directores de Escena de España, 1992.

JARRY, Alfred. Todo ubú. Barcelona: Bruguera, 1980.

JURKOWSKI, Henryk. Sobre el teatro de titeres. Bilbao: Concha de la Casa, 1990.

KLEIST, Heinrich von. Sobre o teatro de marionetes. Rio de Janeiro: Sette Letras, 1997. 
KRISINSKI, Wladimir. Un desorden sofisticado. In: PUCK: el títere y las otras artes: cuerpos en el espacio. Bilbao: Institut International de la Marionnette: Centro de Documentación de Títeres de Bilbao, 1992. n. 4, p. 13-20.

KOUDELA, Ingrid. Brecht: um jogo de aprendizagem. São Paulo: Perspectiva, 1991.

MANGANI, Adelaida. Taller escuela de titiriteros del teatro general San Martin. Buenos Aires: Mimeografado, 1998.

MAETERLINCK. Maurice. Menus propus, le théâtre. In: PLASSARD, Didier. Les mains de lumière. Charleville-Mézières: Institut International de la Marionnette, 1996. p. 196-201. MEYERHOLD, Vsévolod. O teatro teatral. Lisboa: Arcádia, 1980.

MEYERHOLD, Vsévolod. Le théâtre de foire. In: PLASSARD, Didier. Les mains de lumière. Charleville-Mézières: Institut International de la Marionnette, 1996. p. 231-232.

NICULESCU, Margareta. L'Ecole Supérieure Nationale des Arts de la marionnette. Charleville-Mézières: Institut International de la Marionnette, 1998.

PIMENTEL. Altimar de Alencar. O mundo mágico de João Redondo. Rio de Janeiro: Minc, Fundacen, 1988.

PAVIS, Patrice. Dicionário de teatro. São Paulo: Perspectiva, 1999.

PLASSARD, Didier. L'acteur en Effigie. Paris: L’Age D`Homme, 1992.

SANTOS, Fernando Augusto. Mamulengo: um povo em forma de bonecos. Rio de Janeiro: Mec: Funarte, 1987. 


\section{JOGO TEATRAL E CRIAÇÃO LITERÁRIA}

Vilma Campos dos Santos Leite

O sistema dos jogos teatrais de Viola Spolin (1906-1994) está entre as abordagens de aprendizagem teatral que trabalha com a noção de que todos são capazes de atuar e pressupõe que a habilidade de comunicação cênica pode ser aprendida, em contraposição à noção de talento inato.

Tal estrutura, ao propor uma ruptura com a noção de dom, é pertinente para a inclusão da escrita literária enquanto habilidade que também pode ser desenvolvida. Ao incluir o papel do jogador-escritor, ponho em foco as intersecções e similaridades entre a esfera criativa do escrever e do fazer teatral.

Originalmente nos jogos teatrais, os participantes são revezados em dois papéis: "jogadores do palco" e da "platéia". Todos passam por eles sucessivamente, mas não simultaneamente, ou seja, enquanto os jogadores do palco estão preocupados em resolverem determinado problema cênico ou "foco", os jogadores da platéia, durante o jogo, estão atentos ao mesmo para a "avaliação" posterior.

É a partir das observações da platéia, da interação entre ela e os jogadores do palco, bem como do revezamento entre os dois papéis, que a aprendizagem teatral acontece.

Em A criação literária e o jogo teatral ${ }^{1}$, acrescento ao sistema de Spolin a figura do jogador-escritor como terceiro papel. O conceito de dialogismo do pensador russo Bakhtin (1895-1975) fundamenta o trabalho enquanto interação entre os sujeitos e os textos, considerando o ponto de vista do outro para uma construção própria.

Como para os “jogadores do palco" e "da platéia”, há uma troca sucessiva, só que neste caso, enquanto alguns jogam na área de jogo e outros na platéia avaliam, uma ou mais pessoas trabalham com a imagem do jogo como sugestão de escrita. Em um outro jogo ou sessão de trabalho, aquele que escreveu se torna jogador da platéia e palco, enquanto que um outro que assumira estes dois papéis experimenta a escrita.

O papel do jogador-escritor é estimulado a partir da disponibilidade inicial de um ou mais jogadores em experimentar esta nova posição do jogo. O texto ou textos produzidos, a avaliação e o tornar o texto escrito objeto de novos jogos impulsionam outros jogadores a escrever.

${ }^{1}$ LEITE, Vilma Campos dos Santos. A criação literária e o jogo teatral. 2003. Dissertação (Mestrado) - Escola de Comunicações e Artes, Universidade de São Paulo, São Paulo, 2003. 
Destaco o protocolo como procedimento fundamental durante todas as fases do processo. O protocolo é o instaurador do exercício da escrita. A materialização dele como ato criativo e como instrumento dialógico numa prática simultânea revela-nos possibilidades iniciais de gêneros de texto em determinado grupo e a transformação desses textos no decorrer das sessões.

Podemos estabelecer pelo menos três fases de trabalho nesse processo: jogos e protocolos com ponto de partida, textos de autores alheios ao grupo e a introdução do terceiro papel, o do jogador-escritor, ao jogo teatral.

\section{Jogos teatrais e protocolos como ponto de partida}

O protocolo é um procedimento que Brecht já incorporara ao jogo como instrumento de avaliação estética. A prática desse instrumento como propósito da aprendizagem teatral tem se mostrado também como um exercício de apropriação do ato da escrita. Cada jogador tem possibilidades de partir de gêneros que lhe são mais convenientes na escrita, sem se afastar da avaliação na linguagem teatral.

Como nos informa Koudela ${ }^{2}$ durante a fase de experimentação dos Versuche, Brecht protocolava as reações dos participantes com preocupação científica de compará-las e como subsídios de avaliação, porque ele concebia as peças didáticas como ponto de partida ou como experimentos escritos em elos de uma mesma cadeia.

Tenho procurado utilizar o protocolo como avaliação estética dos jogos e textos em jogo, bem como oportunizar o ato como exercício de escrita criativa. Todos os jogadores avaliam cada sessão de trabalho. Relatando ou ficcionando. Em prosa ou verso. Ao focar cada protocolo, coloco a materialidade de cada texto escrito para dialogar e interagir.

Se inicialmente os jogadores não querem escrever, eles desenham ou produzem imagens gráficas. $O$ intuito nessa fase é deixar cada membro o mais "livre" possível para uma criação pessoal. A diferença é acolhida e bem-vinda.

É fundamental fomentar o exercício constante, independente de aparecer mais ligado a uma descrição contextual, ou de ser trabalhado esteticamente.

Emissão oral, recepção auditiva e até a troca de textos escritos têm sido ações que garantem o não encaminhamento para um diário íntimo, principalmente porque é necessário incentivar a interação e o diálogo entre os participantes.

Enquanto orientadora de uma sessão de trabalho, tenho me deparado com a prática de incentivar o jogador a dizer ou mostrar o seu texto, encorajando a socialização. Mas, por outro lado, cada enunciador do protocolo pode optar por uma enunciação oral e feita por ele, selecionando os trechos que quer comunicar ao grupo. É uma condução que preza o papel ativo de cada membro.

No decorrer do processo, quando os participantes ficam mais seguros de sua enunciação pessoal, socializam os protocolos também por escrito. A cooperação vai se fazendo presente. Escrever e dizer protocolos passa também a fazer parte do jogo, embora num momento distinto e não simultâneo com o jogo teatral.

${ }^{2}$ KOUDELA, Ingrid Dormien. Brecht: um jogo de aprendizagem. São Paulo: Edusp: Perspectiva, $1991.176 \mathrm{p}$. 
Para cada um dos jogadores é um dos aspectos de cada sessão que chama a atenção. Cria-se uma expectativa quando alguém vai dizer o seu protocolo porque há um diálogo entre eles. Esse olhar do "outro" alimenta o "eu” de cada jogador:

Ao olhar para trás do caminho, percebo o quanto me confundi, me embaracei nas linhas dos textos escritos no início da caminhada. Havia uma preocupação em escrever. Só. Mais nada. Acho que todos assim pensavam. Depois, gradativamente, isso foi se tornando necessário, imprescindível. As experiências, vivências e sensações precisavam ser registradas; na memória se perderiam. Os textos fluíam, dançavam, se soltavam com uma maior 'facilidade'. A preocupação não era mais escrever [...], mas como escrever [...], como expressar tantas emoções [...]. Como, na tela, saber as cores que se vai usar. Chegar para trás, olhar a tela, comparar, fechar um pouquinho os olhos para perceber as nuanças, formas, linhas, a composição! A escrita agora era uma pintura. Cuidadosamente pensada, analisada e reescrita (jogador 12 - auto-avaliação em 23 de abril de 2002).

No relato anterior, é perceptível a trajetória do jogador. A natureza estética ganhou importância. A diversidade de protocolos e os diálogos provocados configuram-se em parâmetros dentro do próprio grupo, preparando o objetivo final, que é a criação de textos de natureza literária a partir dos próprios jogos.

\section{Apropriação lúdica de textos}

Escrever ainda aqui é um hábito que vai sendo exercitado no processo de avaliação estética da linguagem teatral (protocolo), mas que vai também se alimentando pelos textos de autores alheios ao grupo, que passam a ser objeto de jogo. Estes textos podem ser de natureza diversa: em prosa ou verso, em diálogos ou não.

Os jogadores são levados a familiarizar-se com procedimentos de sensibilização do texto em jogo. Para tal apropriação, utilizo os procedimentos de $\mathrm{Pupo}^{3}$ : todos caminham e lêem ao mesmo tempo; um pára, todos param de caminhar e de ler; um caminha, todos continuam a ler e caminhar; caminhar e a um sinal enunciar para alguém: próximo ou distante; ler para jogadores com olhos fechados etc.

Outros procedimentos de leitura e experimentação com o texto das práticas da Prof ${ }^{a}$. Dra. Maria Lúcia de Barros Pupo e da Prof ${ }^{a}$. Dra. Ingrid Dormien Koudela ${ }^{4}$ são exemplares, entre eles: todos os jogadores numa roda virada para fora, cada um escolhe uma passagem do texto e a retoma não simultaneamente, mas sucessivamente, em diferentes entonações.

A instrução nesse ou em outros procedimentos é a emissão "ao outro". A enunciação para alguém. Na escuta ou no olhar. Cada enunciação como reação à ação anterior, provocando o diálogo e auxiliando os participantes a saírem do "eu" enquanto grupo e irem a um "outro" mais distante, presente na materialidade da leitura do texto.

3 PUPO, Maria Lúcia de Souza Barros. Palavras em jogo. Textos literários e teatro educação. 1997. 160 p. Tese (Livre-Docência) - Escola de Comunicações e Artes, Universidade de São Paulo, São Paulo, 1997.

${ }^{4}$ Professoras e pesquisadoras da linha Teatro e Educação da Escola de Comunicações e Artes da Universidade de São Paulo - ECA-SP. 
A opção por trabalhar em um determinado momento do processo com textos que podem ser também de autores consagrados é um elemento a mais para alimentar o papel do jogador-escritor que será introduzido na terceira fase do trabalho.

Quando os textos de autores diversos passam a ser objeto de jogo, percebe-se uma transformação na silhueta dos protocolos. A escrita vem acrescida dos elementos lúdicos vivenciados na área do jogo. Há jogadores que arriscam protocolos em versos ou outros elementos literários da prosa que não se manifestavam quando estava em foco o jogo sem estímulos de fragmentos ou textos escritos. As aliterações, rimas, enunciação de nomes próprios que não correspondem aos verdadeiros dos jogadores, clamando por personagens passam a ser recorrentes. É uma transposição para o universo ficcional. Os protocolos manifestam imagens, analogias e metáforas, anunciando o momento de introduzir o terceiro papel ao jogo: o do jogador-escritor.

\section{O papel do jogador-escritor}

Finalmente, jogadores da platéia são convidados a fazer algo distinto da avaliação do jogo. O foco dos voluntários é registrar imagens por escrito, enquanto um determinado jogo teatral acontece ou logo após a sua ocorrência, ao mesmo passo que os jogadores da platéia o avaliam do ponto de vista da linguagem cênica.

A instrução dada aos participantes é: não escreva um texto inteiro, pronto, acabado. Parta de uma imagem, metáfora ou analogia que você faça com o presente desse jogo. Não ofereça uma reprodução do real. Não de um o quê, onde ou personagem real que envolve os jogadores do palco, mas das sensações ou imagens que tal foco em jogo provoca em você.

Os jogadores utilizam o jogo como uma imagem geradora no sentido que lhe dá Salles enquanto processo de criação artística: "As imagens geradoras que fazem parte do percurso criador funcionam, na verdade, como sensações alimentadoras da trajetória, pois são responsáveis pela manutenção do andamento do processo e, conseqüentemente, pelo crescimento da obra"5.

Essas imagens são trabalhadas pelo jogador-escritor até a sessão seguinte (dois dias, duas semanas, enfim, de acordo com a periodicidade de encontro do grupo). De posse do texto escrito, este é copiado para todos os jogadores, a fim de que a enunciação não fique apenas no nível da oralidade e para que se possa experimentar o texto em um novo jogo, similarmente aos textos de autores alheios que são trabalhados na fase anterior.

Para exemplificar o percurso do jogador-escritor no terceiro papel, reproduzo e analiso a seguir o texto Inquietação, escrito a partir da imagem "carrossel" de um parque de diversões, no jogo Um objeto move os jogadores ${ }^{6}$.

\footnotetext{
${ }^{5}$ SALLES, Cecília Almeida. Gesto inacabado. Processo de criação artística. São Paulo: Anna Blume, 1998. p. 57.

${ }^{6}$ SPOLIN, Viola. Improvisação para o teatro. São Paulo: Perspectiva, 1987. p.64; SPOLIN, Viola. Jogos teatrais. O fichário de Viola Spolin. São Paulo: Perspectiva, 2001. p. A46.
} 
Sabrina, inquieta com tanto calor, levanta do sofá e vai até o seu armário, revira as gavetas sem sucesso. Corre para o quarto do irmão e também revira suas gavetas, mas não acha o que procura. Vai até o banheiro e o acha pendurado e molhado. Não se importa, afinal está quente e ela quer se refrescar. Então veste seu lindo e ensopado biquíni verde, corre até o playground e mergulha com satisfação na minúscula piscina de plástico (jogador-escritor - 19/03).

É importante informar que a personagem Sabrina (que não corresponde a nenhum nome de jogador da turma) já vinha se fazendo presente enquanto nome nos últimos protocolos da jogadora-escritora em questão, mas lá evidenciando avaliações estéticas de elementos reais da sessão de trabalho.

Os jogadores da turma trabalharam na sessão posterior com o texto Inquietação nas mãos, de acordo com os procedimentos de apropriação sensível do texto como os apontados em $\mathrm{Pupo}^{7}$, já utilizados em textos de autores terceiros.

Nesse exemplo, como em outros, o protocolo continua realizando a sua função de avaliação estética da linguagem teatral e também contribui para o desenvolvimento sensorial e poético, estabelecendo diálogo entre o texto Inquietação e os jogos. Evidenciam diálogo de relações e sensações entre o jogo e o texto:

Com o corpo, 3 Sabrinas a representar

Euforia, inquietação, sensação de bem-estar

Levanta, corre, revira a procurar

Em um espaço livre a brincar.

(jogador 11- protocolo 14 de 26 de março)

Ah! É você inquietação?

Que avança como um furacão

Que vem em minha direção

Que abala minha emoção

Que explode meu coração

De tanta perturbação.

(jogador 13 - protocolo 14 de 26 de março)

Sabrina? ou Sabrinas? Os lugares? Onde? Inquietações? Ações? Quem? Surgiu a irmã de Sabrina? A piscina? E o sofá que voa? Quanta coisa um texto trás... E agora que a autora viu o seu texto dramatizado, ela vai reescrever a nossa Sabrina.

(jogador 3 - protocolo 14 de 26 de março)

Os protocolos dialogam inclusive com o poema de Cecília Meireles, que fora trabalhado por esse grupo, quando enunciam a movimentação física: "Levanta, corre, revira a procurar/em um espaço livre a brincar”. Os objetos também tomam os movimentos emprestados: "E o sofá que voa”.

7 PUPO, 1997. 
O “eu” vai tão em direção ao "outro" (“O coração explode”), tanto quanto o "outro" invade o "eu”: "Ah! É você inquietação? Que avança como um furacão, Que vem em minha direção”.

Sabrina não é mais criação única de um jogador. Ela se materializa, se fisicaliza e se transforma na "nossa Sabrina". O dialogismo, ou a interação entre os jogos e textos, permite que outros jogadores apropriem-se de Sabrina.

Os pontos de vista evidenciados ou compartilhados por esse dialogismo fazem com que o jogador-escritor reescreva seu texto:

Uma típica tarde de um domingo de verão; a alta umidade do ar, o suor a escorrer sobre a pele já úmida, a roupa grudada no corpo...

O calor é tanto que até o sofá parece ter calor próprio.

Sabrina, que ali está deitada, revira-se tentando achar uma posição mais confortável, mas o contato direto da pele com o sofá plastificado produz pequenas piscinas de suor que se espalham entre ele e ela.

Então levanta-se, vai em direção à sacada e abre a porta de vidro que dá para o playground.

Uma brisa suave entra pela porta, passeia pela sala e envolve Sabrina em uma deliciosa sensação de frescor e liberdade, conduzindo-a para fora.

Recostando-se no parapeito, volita entre brisas e ruídos infantis, procurando em gavetas antigas algo que faltava ou talvez que não chegara a ter.

Vozes, gritos, risadas e choros sempre se calavam com água, fosse de uma lágrima ou de um mergulho, de saliva ou de mercúrio.

A brisa agora ecoa dentro de gavetas vazias, passando de uma a outra, silenciosa, confusa e perdida.

De repente: um ruído, e um chamado a traz de volta, e Sabrina finalmente percebe que o que procurava estava todo tempo ali. Com um lindo sorriso no rosto, um biquíni fofo a combinar com seus olhinhos de esmeralda, molhadinha a pingar toda a sala, ela entra e corre em direção a Sabrina.

Carinhosamente as duas se abraçam e, em meio à água e ao suor que ali se misturavam, o frescor e o calor se fundem em um único e verdadeiro sentimento (jogador-escritor 2 - segunda versão de Inquietação).

O encontro acontece não só na narrativa ("carinhosamente as duas se abraçam. [...] se fundem em um único e verdadeiro sentimento”), mas também enquanto realidade de trabalho. $O$ jogador-escritor teve percepção para interagir com os elementos surgidos nos jogos teatrais, retrabalhando-os no texto. Os jogadores do palco e da platéia também continuam a interagir, por meio dos protocolos, com o texto do jogador-escritor: "Sabrina ficou mais legal onde estava mais viva a presença da irmã. O texto era mais detalhista. Foi um texto um pouco diferente, mas ainda era a Sabrina." (jogador 4 - protocolo 16 em 9 de abril).

A Sabrina não é mais "o eu” ou "o outro", ela é "o nosso", mas não como uma massa indistinta. Importa menos a autoria, importa mais a contribuição pessoal e única de cada jogador.

O dialogismo aconteceu na situação de jogo e também com a situação de escrita e reescrita, sobretudo porque o jogador-escritor pôde ouvir diferentes versões 
sobre a sua criação, sensibilizada pelo exercício do jogo e do protocolo. O protocolo ampliou o repertório dos jogadores, avançou a produção escrita.

No jogo, a interação entre os sujeitos leva à aprendizagem da linguagem teatral porque contribui para a solução do problema ou foco. No presente processo, o protocolo foi ponto de partida para a interação entre os textos e tornou-se objeto de aprendizagem escrita, na medida em que incentivou o exercício simultâneo e sistemático com a criação literária.

Os jogadores puderam sentir-se mais capazes e interessados em escrever. Detalhamentos sensoriais dos jogos também aconteceram na escrita. Elementos poéticos e narrativos foram se fortalecendo nessa troca de protocolos.

Podemos ter jogadores na platéia cuja função é escrever a partir de uma imagem, metáfora ou analogia do jogo. O texto Inquietação, por exemplo, surgiu da imagem de jogo. O texto não simplesmente sublinha, descreve ou relata o jogo. Ele é uma imagem ou uma analogia que a jogadora fez. Esse processo foi “aquecido" e "preparado" com o protocolo constante em todas as sessões de trabalho.

Quando o texto criado pelo jogador-escritor volta para o jogo, os jogadores descobrem novos elementos ao brincar e trabalhar com o texto. Percebem que o texto de um colega é tão rico de possibilidades quanto o texto de um autor consagrado. Pontos de vista são visíveis no jogo. Esses pontos de vista diversos levam o jogador-escritor a reescrever o texto, numa manutenção do dialogismo entre os textos e entre os próprios interlocutores.

A segunda versão de Inquietação é mais detalhada e aprofundada do que a primeira porque pôde dialogar com os jogos e com outros textos. Os elementos sensoriais, por exemplo, tornam-se mais intensos, assim como deve acontecer num jogo teatral. A personagem do texto não se levanta do sofá aleatoriamente, são os efeitos da alta temperatura descritos de maneira minuciosa que a levam a agir. A autora desta versão nos leva a enxergar, ouvir, cheirar, pegar e sentir o gosto.

Destaco, também desta segunda versão, elementos simbólicos que foram trabalhados pela autora a partir das imagens de jogo. O elemento líquido é reiterado seja pela água da piscina, seja pelo calor que quase dissolve os elementos sólidos, como o sofá. Outro elemento simbólico é o biquíni. Sabrina o procura, mas talvez nem "chegara a ter" o traje. A busca é pelo que o objeto biquíni representa.

Real e imaginário misturam-se em Sabrina e essa ambigüidade é outro elemento interessante que o jogador-escritor consegue alcançar. Sabrina abraça a imagem do passado, ela mesma ou a irmã?

Esses resultados não teriam sido possíveis se não tivessem o protocolo como ponto de partida. Ele foi importante recurso de interação, uma que por meio dele transformações textuais aconteceram, como, por exemplo, a utilização do texto poético e depois a utilização do personagem de ficção. O protocolo revelou que o instrumento instaurado por Brecht para o jogo em muito se ajusta à concepção dialógica. "Ao almejar como função mais nobre dar conta do caráter estético do experimento com modelo de ação (imagem e/ ou texto), o protocolo promove a dialética como método de pensamento"8.

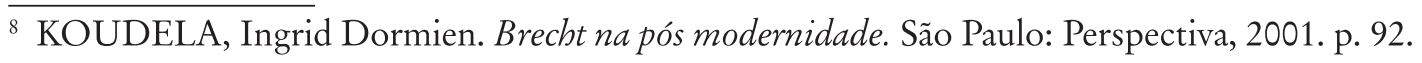




\section{REFERÊNCIAS}

BAJARD, Elie. Ler e dizer. São Paulo: Cortez, 1994.

BAKHTIN, Mikhail. Estética da criação verbal. 3. ed. São Paulo: M. Fontes, 2000.

BAKHTIN, Mikhail. Marxismo e filosofia da linguagem. 4. ed. São Paulo: Hucitec, 1988.

BAKHTIN, Mikhail. Questões de literatura e de estética. A teoria do romance. 3. ed. São Paulo: Hucitec, 1993.

BARROS, Diana Luz Pessoa de; FIORIM, José Luiz (Org.). Dialogismo, polifonia, intertextualidade em torno de Bakbtin. São Paulo: Edusp, 1994.

BAUNE, Jean; GROSJEAN, Bernard. Petites formes... grands enjeux. Cahiers Pédagogiques, Paris, n. 337, p 47-49, oct. 1995.

BRAIT, Beth (Org). Bakbtin, dialogismo e construção do sentido. São Paulo: Unicamp, 1997.

BRECHT, Bertolt. Diário de Brecht. Porto Alegre: L\&PM, 1995.

CALKINS, Lucy McCormick. A arte de ensinar a escrever. O desenvolvimento do discurso escrito. Porto Alegre: Artmed, 1989.

DOLZ, Joaquim; SCHNEUWLY, Bernard. Gêneros e progressão em expressão oral e escrita. Elementos para reflexões sobre uma experiência suíça (francófona). Tradução de Roxane $\mathrm{H}$. R. Rojo. [S.l.]: Enjeux, [19--?]. p. 31, 49. Mimeografado.

GAMA, Joaquim Cesar Moreira. Produto teatral: a velha-nova história. Experimento com alunos do Ensino Médio. 2000. 262 p. Dissertação (Mestrado em Artes) - Escola de Comunicação e Artes, Universidade de São Paulo, São Paulo, 2000.

KOUDELA, Ingrid Dormien. Brecht: um jogo de aprendizagem. São Paulo: Edusp: Perspectiva, 1991.

KOUDELA, Ingrid Dormien. Brecht na pós modernidade. São Paulo: Perspectiva, 2001.

KOUDELA, Ingrid Dormien. Texto e jogo. São Paulo: Fapesp: Perspectiva, 1996.

KOUDELA, Ingrid Dormien. Um vôo brechtiano. Teoria e prática da peça didática. São Paulo: Fapesp: Perspectiva, 1992.

OLIVEIRA, Ulisses Ferraz de Oliveira. Veredas do estranhamento. Pedagogia do teatro e produção de texto. 2001. 265 p. Tese (Doutorado em Educação da Faculdade de Educação) - Universidade de São Paulo, São Paulo, 2001. 
PAIS, Marco Aurélio Vieira. A aquisição da competência semiótica para a atuação Teatral. 2000. 190 p. Dissertação (Mestrado em Artes Cênicas) - Escola de Comunicações e Artes, Universidade de São Paulo, São Paulo, 2000.

PAVIS, Patrice. Dicionário de teatro. São Paulo: Perspectiva, 1997.

PUPO, Maria Lúcia de Souza Barros. Palavras em jogo. Textos literários e teatro educação. 1997. 160 p. Tese (Livre-Docência) - Escola de Comunicações e Artes, Universidade de São Paulo, São Paulo, 1997.

SALLES, Cecília Almeida. Gesto inacabado. Processo de criação artística. São Paulo: Anna Blume, 1998.

SPOLIN, Viola. Improvisação para o teatro. São Paulo: Perspectiva, 1987.

SPOLIN, Viola. O jogo teatral no livro do diretor. São Paulo: Perspectiva, 1999.

SPOLIN, Viola. Jogos teatrais. O fichário de Viola Spolin. São Paulo: Perspectiva, 2001. 


\section{DOIS ECOS LONGÍNQUOS DE TAMBORES NA NOITE}

ou

exercícios livres (ou seja, tratados com humor) em torno das ações e lições de dois dramas modernos pedagógicos, escritos por alemães da ex-RDA antes da queda do muro de Berlim

Walder Gervásio Virgulino de Souza

\section{Uma parábola-diálogo com a infância do teatro}

Um dia, numa Alemanha dividida, conheci um espectador que era cego. Apreciava o teatro de rua, mas não suportava o teatro que se fazia em espaços fechados. Porque amava o fato de poder deslocar seu olhar, em liberdade, de um lado para outro, pelas praças em que os espetáculos de rua aconteciam; porque amava deslocar-se guiado por sua mulher, espectadora como ele, atraídos os dois pelas canções que os atores cantavam, por suas vozes múltiplas que surgiam ora daqui, ora dali, vindas do alto ou de baixo, da direita ou da esquerda.

Meu amigo cego (tornamo-nos amigos) revelou-me, então, que as imagens cênicas se formavam diante dele, em torno dele - ele as "via"! - e se sentia, ao mesmo tempo, participando não somente com os outros espectadores, mas também com os atores de um único jogo teatral, do espetáculo de rua. Era um jogo coletivo, contou-me, emocionante demais, ao qual se sentia completamente integrado.

\section{O jogo teatral do ponto de vista do espectador ou olhares sobre aqueles que olham}

- [...] Eu sempre vou amaldiçoá-lo [o teatro] por perturbar a paz de minha casa por tua paixão imoderada por este prazer. [...] disse a mãe.

-Mas que diferença quando estamos sentados diante dela (a cortina do teatro)! Mesmo se tivermos que esperar muito tempo, sabemos que ela se levantará e veremos as coisas mais variadas que nos distraem, nos instruem e nos elevam ${ }^{1}$.

Gostaria sempre de falar (enquanto ator e professor) ou de escrever textos

1 GOETHE. Les années d'apprentissage de Wilhelm Meister. Traduit de l'allemand par Jeanne Ancelet-Hustache. Paris: Aubier-Montaigne, 1983. p. 44. 
teóricos que pudessem fazer mexer meus espectadores, alunos ou leitores, o que não quer dizer, necessariamente, que desejo fazer com que pulem para a cena, incitando-os a se levantarem de suas cadeiras e agirem. Mas, simplesmente, fazer-lhes (fazer-me) refletir um pouco mais sobre nossa condição de indivíduos e dar-nos consciência do papel ativo que representamos em qualquer tipo de fazer teatral.

Uma situação particular de minha vida profissional, no entanto, leva-me, neste texto, a iniciar minha viagem a partir da lembrança do instante em que retomo, a cada semestre, minhas atividades de professor do Departamento de Teoria da Escola de Teatro da Uni-Rio e tenho de escolher os textos teatrais que trabalharemos juntos, eu, na posição de professor-ator-teórico, e eles, quase meia centena de rapazes e moças, de idades as mais variadas, todos ingressantes na Universidade, como alunos-atores, teóricos, diretores, cenógrafos ou licenciandos em teatro. Desenvolverei aqui exercícios em torno de dois textos alemães exemplares, que tratarei como modelos do trabalho mais amplo de conscientização profissional que realizamos em atividades coletivas, numa sala de aula vista sempre como espaço dramático, e em que nos revezaremos, professor ou alunos, ora como atores, ora como espectadores de um jogo teatral específico, que exigirá, de cada um de nós, uma preparação em total liberdade e uma legítima atitude lúdica.

Poderia, certamente, centrar minha reflexão, desde o início, sobre a maneira como atores e espectadores participam juntos do jogo teatral, mas preferi privilegiar, como objeto de minhas primeiras observações, apenas a conduta e as reações isoladas dos que observam o jogo desempenhado pelo ator. Em dois livros que teorizam sobre o assunto: Les jeux et les hommes (Os jogos e os bomens), de Roger Caillois, e Le jeu (O Jogo), de Jacques Henriot, esses autores se interessaram pela definição e classificação das coisas denominadas "jogos” ou pela atividade de "jogar", considerando-os principalmente do ponto de vista do jogador (ou do ator, no que se refere aos jogos de simulacro) e esqueciam ou só atribuíam uma função secundária ao jogo do espectador, que é, por sua vez, ele também um “jogador”.

Para Caillois, o sistema dos jogos apresenta quatro tipos diversos, na medida em que neles predomine a função de competição, de acaso, de simulacro ou de vertigem. No jogo teatral, segundo o autor, predomina o simulacro. Para designá-lo, escolheu a expressão inglesa mimicry, que corresponde a "mimetismo":

Encontramo-nos, então, diante de uma série variada de manifestações que têm por caráter comum apoiar-se no fato de que o sujeito acredita ser ou faz os outros acreditarem que ele é um outro que não ele [...] e [nestas manifestações] ele inventa um mundo fictícioº .

[Tais jogos de simulacro] aparecem na criança sob a forma do jogo simbólico e, no adulto, em todas as condutas psico-sociais que são a máscara, o papel que representa socialmente, o personagem ${ }^{3}$.

\footnotetext{
CAILLOIS, Roger. Les jeux et les hommes. Paris: Gallimard, 1967. p. 61, 103.
}

${ }^{3}$ HENRIOT, Jacques. Le jeu. Paris: Synonyme, 1983. p. 46. 
De saída, uma distinção se impõe. Apesar de o ator e a criança proporem uma conduta associada a imagens, o ator, ao contrário da criança, sabe que ele representa para os outros. E assim, de imediato, surgem elementos que são regras, limites, convenções do jogo, embora atuados com relativa liberdade. Em princípio, sente-se obrigado a apresentar condutas identificáveis, na medida em que pretende comunicar-se com os outros. A partir daí, outros elementos vêm compor esta compreensão do que seja um jogo teatral. Atualmente, este tipo específico de encontro de seres humanos está dividido em dois subgrupos: espectadores e atores, que juntos vão participar de uma atividade prática de ruptura com a realidade quotidiana, em que imagens de representação mental são construídas e começam a circular da maneira mais econômica possível entre eles. Trata-se de um imaginário comum simbólico que, num dado grupo social, pode tomar toda espécie de formas e de significações sucessivas. $\mathrm{O}$ jogo teatral vai se dar, exatamente, no ponto de tensão entre a comunicação totalmente codificada e a mais livre invenção. O que um espectador percebe do jogo do ator e vice-versa? Quais são os signos que percebem e o que constroem a partir do que percebem?

\section{A atitude lúdica: uma visão de jogo como êxtase dinâmico do homem}

[...] Cada homem traz em si a sua dose de ópio natural, incessantemente segregada e renovada; e do nascimento à morte, quantas horas podemos contar cheias pelo verdadeiro prazer, pela ação feliz e resoluta? Viveremos jamais, conheceremos algum dia esse quadro que o meu espírito pintou, esse quadro que se parece contigo? $[\ldots]^{4}$.

Mais uma vez deve ser lembrado que essa missão [do ator] é a de recrear os filhos de uma era científica [os espectadores] proporcionando-lhes o prazer dos sentidos e a alegria. [...] Do prazer sexual, extraímos deveres conjugais; o prazer artístico está ao serviço da cultura, e aprender não significa conhecer aprazivelmente, mas, sim, aferrar o nariz ao objeto do conhecimento. Nada do que fazemos representa um esforço aprazível, e, para justificarmos os nossos atos, não invocamos o que gozamos com isto ou com aquilo, mas, sim, quanto suor nos custou ${ }^{5}$.

Torna-se necessário que os atores e espectadores tenham consciência do fato de estarem juntos e jogarem juntos ao longo do "espetáculo" teatral. Na verdade, só há troca teatral quando estes dois sujeitos, o ator e o espectador, podem compreender e aceitar a dimensão de seu próprio jogo e do jogo do outro. O ator é, evidentemente, o primeiro a agir, cabendo-lhe a iniciativa de jogar, mas o jogo teatral só se completará após a inclusão das reações do público.

No entanto, em nossos espaços de jogo, estarão sempre incrustradas e pressupostas, nos gestos e atitudes do ator ou do espectador, as chances de desenvolverem aspectos secretos e misteriosos de todos os participantes, que poderão e deverão utilizar sutilezas de suas livres associações, provenientes do foro particular e do mais

${ }^{4}$ BAUDELAIRE, Charles. O convite à viagem. In: Pequenos poemas em prosa. Tradução de Aurélio Buarque de Hollanda. Rio de Janeiro: J. Olympio, 1950. p. 58-59. (Coleção Rubáiyat).

${ }^{5}$ BRECHT, Bertolt. Pequeno organon para o teatro (fragmento 75). In: teatro. Tradução de Fiama Pais Brandão. Rio de Janeiro: Nova Fronteira, $\overline{978 . ~ p .} 133$. 
íntimo de cada um. A entrada no jogo é, portanto, este momento em que o ator ou o espectador ficcionalizam o mundo real, isto é, aquele momento em que vivem atos que aparentemente não pertencem ao real quotidiano, mas a um mundo fictício, separado. Para analisarmos o teatro enquanto jogo, devemos nos colocar sempre nesta espécie de entre-dois, nesta evidente zona de fronteira, de um real que pode ser visto como ficção, que pode ser vivido como falso, mas que se admite, mesmo assim, como um pseudo-real (ou um verdadeiro real).

Uma outra característica da atitude lúdica é a incerteza. Segundo J. Henriot, aquela margem de indeterminação, que tornaria o comportamento dos jogadores totalmente imprevisível. Na minha opinião, o fundamento mesmo do ato teatral enquanto expressão coletiva de um grupo de pessoas, de uma turma de alunos de uma dada sociedade.

Expliquemos. Quando um aluno ou um ator entra em cena, nos exercícios de cada aula ou de cada ensaio, propõe ao espectador o resultado parcial de um trabalho paciente de preparação de sua leitura de uma obra. Como se trata de um artista em ensaio, vivendo uma situação experimental, o público presume que este ator, ao qual teria delegado seu poder de representar, está aprendendo a dominar técnicas de sua arte e que ele lhe mostrará, com seu corpo e movimentos, imagens cujos pormenores estarão sendo objeto de sua pesquisa em cena.

Trata-se, assim, de uma aventura coletiva vivenciada por atores e espectadores, durante a qual se constituirão imagens comuns. Uma aventura que deve ser qualificada, segundo o fenomenologista Jankélévitch, como "aventurosa”, o que não tem nada a ver com uma mera aventura "aventureira". Os atores e espectadores aventurosos representam "[...] um verdadeiro estilo de vida, enquanto que os aventureiros não passariam de meros profissionais das aventuras. [...] As baixas e inferiores aventuras aventureiras não passariam de caricaturas das aventuras aventurosas"6.

Esta aventura implicaria, na verdade, numa oscilação da consciência entre o jogo e o sério. Continua o fenomenologista:

Suprimam um dos contrários - o jogo ou o sério - e a aventura deixa de ser aventurosa. Optando pela supressão do elemento lúdico, a aventura torna-se tragédia; suprimindo o sério, a aventura vira jogo de cartas, passatempo derrisório, aventura fingidora ${ }^{7}$.

\section{Da pseudopassividade do espectador à ocupação dos espaços Anda, Luzia, pega o pandeiro e vem pro Carnaval... Anda, Luzia, que esta tristeza lhe vai muito mal.}

O trabalho de fato começa quando digo aos alunos que o semestre em que nos conhecemos será marcado por uma enorme aventura aventurosa pelo mundo das possibilidades do teatro contemporâneo. Proponho que a escolha dos textos seja feita, então, de acordo com a necessidade de cada turma e com a possibilidade de cada um de nós descobrir e experimentar, em nossas vidas e em nossos corpos, que o teatro pode não

\footnotetext{
6 JANKÉLÉVITCH, Vladimir. L'aventure, l'ennui, le sérieux. Paris: Aubier-Montaigne, 1963. p. 10.

7 JANKELÉVITCH, 1963, p. 13.
} 
ser nada do que conhecemos até agora; que houve muitos experimentadores de formas novas, que abalaram e propuseram saídas, ao longo do século XX, tanto no mundo da dramaturgia tradicional como no mundo da pesquisa de soluções (e revoluções) da própria cena. Falo muito das novas formas de representação e não só das teorias da representação de Aristóteles ou das formas de um teatro psicológico, que Antonin Artaud enxergava como partindo das tragédias de influência jansenista de Jean Racine. Mostro o mundo das peças didáticas de Bertolt Brecht, da explosão crítica de seu teatro nas mãos e na sensibilidade de Heiner Müller. Encorajo-os para que leiam muito sobre as experiências de Artaud e de sua busca consciente de um corpo sem órgãos, de como suas teorias foram retomadas e sistematizadas, na segunda metade do século XX, por homens de teatro como Jerzy Grotowski, Bob Wilson, Peter Brook. Incentivo meus alunos para que entrem em contato com as obras críticas contemporâneas de brasileiros e estrangeiros e que comprem muitos livros (não só peças) e discutam todas as formas do fazer teatral. Que leiam, se possível, como me recomendou um dia o diretor Amir Haddad, uma peça (ou um texto teórico) por dia. Que questionem bastante o que lhes ensinamos em nossa Universidade, que sejam capazes de dialogar com nossas diferenças e tomem, por favor, sempre por base o lema da leitura infinita, que considero a arma mais eficaz para determinar a escolha do teatro que querem fazer. Divido a turma (refiro-me, ao longo deste texto, sempre aos 50 alunos que ingressam na Uni-Rio por semestre) em grupos menores com sete ou oito integrantes e digo-lhes: "Cada grupo deve buscar sua leitura particular, saindo de sua pseudo-passividade de espectador, experimentando com base no que vêm aprendendo nos palcos do 'mundo', nas salas de aula, em que talvez sejam também professores e, principalmente, a partir da bela ou triste história de vida múltipla de cada um”. Imaginei esta longa introdução como um exemplo da necessidade de que haja, além das experiências de cada grupo, uma proposta de leitura e experimentação, ao longo do semestre, das peças oferecidas como temas e formas de discussão teatrais possíveis. Na presente análise, ilustrando a questão "O texto dramático na sala de aula”, forneço algum material para reflexão a partir de minha leitura pessoal - integrado às descobertas de cada grupo isolado - destes dois autores alemães fundamentais. Ao longo de minha vida, descobri as linhas centrais de meu interesse de estudo, as oferecidas pela cena alemã e as imaginadas pelo teatro brasileiro a partir da dramaturgia de Nelson Rodrigues, bem como pelo teatro desenvolvido na França em todos os tempos.

\section{O diálogo possível entre Mauser, de Heiner Müller, e $A$ Decisão (Die Massnabme), de Bertolt Brecht, duas peças didáticas do século XX}

Nosso exercício tentará estar atento ao diálogo imaginário entre os textos de duas peças didáticas do teatro alemão moderno.

A Decisão, de Brecht, é nosso ponto de partida. Escrita entre 1929 e 1930, após o suicídio de Maïakovski, esta peça teve o mérito de descrever o problema fundamental do socialismo "de que sejam sempre os melhores, em suas próprias fileiras - a elite intelectual, portanto - que tenham de ser eliminados" ". A Decisão tem a força destes grandes textos, destes tambores eloqüentes que, começando a ressoar já no final dos anos vinte do

${ }^{8}$ GOTSCHEFF, Dimiter. Nous maintiendrons le virus en vie. In: confessions, mémoires, analyses. Paris: L'Arche, 1993. p. 28.

. Brectht après la chute: 
século XX, vão tornar-se documentos essenciais à compreensão dos anos hitleristas que virão a seguir e dos julgamentos sumários que ocorrerão ao longo dos anos stalinistas de construção da República Democrática da Alemanha - RDA, esta então nova República socialista européia.

Mauser é um eco longínquo deste tambor brechtiano que bate na noite, ou seja, da teoria e da prática de suas peças didáticas. Escrita em 1970 por Heiner Müller, ela é a terceira de uma série experimental, "sendo a primeira Philoktet (Filocteto) e a segunda Der Horatier (O Horaciano)" " e pode, talvez, ser considerada como uma variação em torno de aspectos formais e temáticos de $A$ Decisão. Existe, na Alemanha, esta tendência a se trabalhar, de forma experimental, temas tratados anteriormente por outros escritores, a retomar criticamente o que chamam de "antigas situações-modelo". Aliás, é o próprio Müller que nos adverte, a propósito de Mauser, que não se trata de uma "peça de repertório", mas de uma peça experimental. "Escrevi uma peça que, pelo assunto, é uma variação de $A$ Decisão, ou uma continuação. [...] Prossigo com esta peça a partir do momento em que $A$ Decisão foi interrompida"10. O conteúdo das duas peças.

BRECHT - "A Decisão mostra um tribunal do Partido Comunista. A comissão de controle, encarnada pelo Coro, deve julgar quatro agitadores que trabalham na clandestinidade. No interesse da causa, foram obrigados a suprimir um quinto companheiro, um jovem militante que, sensível e indisciplinado demais, ameaçava o partido com uma catástrofe" ${ }^{\prime 1}$.

O CORO DE CONTROLE - (...) também nesse país a revolução está em marcha, e as fileiras estão organizadas. Estamos de acordo com vocês.

OS QUATRO AGITADORES - (...) Queremos comunicar a morte de um camarada.

O CORO DE CONTROLE - Quem o matou?

OS QUATRO AGITADORES - Nós o matamos. Atiramos nele e o jogamos numa mina de cal.

O CORO DE CONTROLE - O que ele fez para que vocês o matassem?

OS QUATRO AGITADORES - Muitas vezes fez o que era certo, algumas vezes o que era errado, mas por último colocou em risco o movimento. Ele queria o certo e fez o errado. Exigimos sua sentença.

O CORO DE CONTROLE - Mostrem-nos como e por que aconteceu e ouvirão nossa sentença ${ }^{12}$.

(Uma passagem do julgamento de Brecht pela Comissão de Defesa do governo dos Estados Unidos).

\footnotetext{
9 MÜLLER, Heiner. Quatro textos para teatro: Mauser, Hamlet-máquina, a missão, quarteto. Apresentação de Fernando Peixoto. São Paulo: Editora Hucitec: Associação Cultural Bertolt Brecht, 1987. p. 21.

10 Apud MAIER-SCHAFFER, F. Heiner Müller et la Lebrstück. Berne: P. Lang, 1992. p. 86.

11 Apud BETZ, Albrecht et al. L'état d'urgence chez Carl Schmitt et La décision chez Bertolt Brecht. In: STORCH, Wolfgang (Dir.). Brecht après la chute. Confessions, mémoires, analyses. Paris: L'Arche, 1993. p. 36-37.

12 BRECHT, Bertolt. A decisão (1929-1930). In:

Dormien Koudela. Rio de Janeiro: Paz e Terra, 1988. v. 3, p. 237.
} 
BRECHT - Esta peça [A Decisão] é uma adaptação de uma antiga peça religiosa japonesa, e é uma "peça didática". Segue fielmente a narrativa original e mostra alguém que se sacrifica por um ideal, chegando ao ponto de morrer por ele.

STRIPLING - Então, senhor Brecht, poderia confirmar à Comissão se é exato que um dos personagens de A Decisão foi assassinado por seus camaradas pelo bem do Partido, do Partido Comunista...

BRECHT - De forma alguma. (...) Este rapaz, ao morrer, estava persuadido de ter colocado em risco a causa em que acreditava, e aceitava morrer para não prejudicar ainda mais o movimento. Por este motivo, pede a seus camaradas que o ajudem a morrer. Ele se atira num precipício, depois de ter sido levado até lá. É esta a história ${ }^{13}$.

O JOVEM CAMARADA - Meu coração bate pela Revolução. Ela está aqui (...). Mas agora seria melhor se eu não existisse. (...) No interesse do comunismo/ De acordo com o avanço das massas proletárias/ De todos os países,/ Afirmando a revolução mundial. $(\ldots)^{14}$.

\section{CANÇÃO DA MERCADORIA}

(...) O que é um homem, afinal?

Eu lá sei o que é um homem?

(...) Não sei o que é um homem.

Eu só conheço o seu preço.

MAS QUEM É O PARTIDO? (...)

OS 3 AGITADORES - O Partido somos nós.

Você e eu e vocês - nós todos. (...).

O CORO DE CONTROLE

ELOGIO AO PARTIDO

$\mathrm{O}$ indivíduo tem dois olhos.

O Partido tem milhares de olhos. (...).

O CORO DE CONTROLE - Não foram vocês que pronunciaram a sua sentença, mas sim a realidade. (...).

OS QUATRO AGITADORES - Então perguntamos: você está de acordo?

Pausa.

O JOVEM CAMARADA - Sim. Vejo que sempre agi erradamente. (...).

O CORO DE CONTROLE - Compreensão da parte e compreensão do todo:

Só ensinados pela realidade é que podemos

Transformar a realidade ${ }^{15}$.

HEINER MÜLLER - “Mauser, por sua vez, expõe também um "processo judicial”

${ }_{13}$ BRECHT, 1988, p. 45-49.

${ }^{14}$ BRECHT, 1988, p. 260-265.

15 BRECHT, 1988, p. $254-266$. 
em que "A", um revolucionário experiente, ao contrário do Jovem Camarada, um jovem militante, é acusado diante de um tribunal, no qual deve se dizer de acordo com sua própria condenação à morte. A última cena de Mauser, a execução de "A", corresponderia ao ponto de partida da peça de Brecht" ${ }^{16}$.

CORO - (...) Você aplicou a morte na cidade de Witebski

Aos inimigos da revolução, por nosso encargo

Sabendo que o pão de cada dia da revolução

$\mathrm{Na}$ cidade de Witebski como em outras cidades

É a morte de seus inimigos, sabendo que ainda

Precisamos arrancar a relva para que o verde permaneça (...)

A - Cumpri a minha missão.

CORO - Cumpra agora a sua derradeira

A - Eu matei pela revolução.

CORO - Morra agora por ela.

A - Cometi um erro.

CORO - Você é o erro.

A - Sou um ser humano.

CORO - O que é isso?

A - Não quero morrer.

CORO - $\quad$ (...) A revolução não precisa mais de você. Ela precisa da sua morte. Mas antes de dizer SIM ao NÃO que foi sentenciado contra você,

Não terminou a sua tarefa ${ }^{17}$.

$\mathrm{O}$ "Coro" e "A" se tratam por "você" e ficam assim mais à vontade para explicar os motivos de suas ações e decisões. Estão todos num plano de igualdade, ao contrário de $A$ Decisão, em que os Quatro Agitadores falavam a uma instância suprema, o Coro de Controle. Esta modificação formal vai tornar possível a "A" se mostrar como indivíduo, no sentido psicológico ou mesmo psicanalítico do termo. Se o personagem quer fazer referência a sua ação enquanto membro de um coletivo, enquanto instrumento do Partido Comunista, de imediato passa a utilizar o tratamento "nós".

A - (...) Contra a dúvida quanto à revolução, não havia

Nenhum outro remédio senão a morte do cético.

E eu não tinha olhos para suas mãos

Quando estava diante de meu revólver, de rosto virado para a pedreira

Se elas estavam ou não arruinadas pelo trabalho

Estavam, sim, bem amarradas com cordas

E o matamos com a minha mão

Sabendo que o pão de cada dia da revolução

É a morte de seus inimigos, sabendo que ainda

Temos que arrancar a relva para que o verde fique ${ }^{18}$ ( grifos nossos).

A repetição deste refrão: "Sabendo que o pão de cada dia da revolução [...],

\footnotetext{
16 Apud MAIER- SCHAFFER, 1992, p. 86.

17 Müller, 1987, p. 3-4.

${ }_{18}$ Müller, 1987, p. 9.
} 
sabendo que ainda temos que arrancar a relva para que o verde fique" remete às soluções formais sugeridas pelo compositor Hanns Eisler para $A$ Decisão que, segundo Albrecht Betz, deveria ser uma espécie de anti-oratório, uma inversão de uma Paixão de Bach, principalmente da Paixão segundo São Mateus. "Tudo que tem valor positivo no modelo cristão, isto é, a fé, a compaixão, o sacrifício, etc. mostra-se falso", (perigoso) para o Jovem Camarada e motivo para sua condenação à morte pelo Coro de Controle de A Decisão. Em Mauser, o "pão de cada dia" da oração cristã torna-se o refrão que anuncia na peça esta espécie de anti-Parábola do Julgamento Final, em que o ensinamento, a lição que não deve ser esquecida, consiste em aceitar a condenação à morte de todos os inimigos da revolução, mesmo na hipótese de o inimigo ser ele próprio.

O "Coro" e "A" repetirão esta lição doutrinária oito vezes em três ou quatro páginas do conjunto do texto, justamente nas páginas destinadas ao acontecimento externo, isto é, ao processo judicial. O restante das páginas, em torno de umas dez aproximadamente, tratará de tudo que se passa no interior do indivíduo, referente às dúvidas do ser humano "A".

A - Mas no clamor da batalha, que havia crescido

E crescia ainda mais, estava eu com as mãos ensangüentadas

Eu soldado e baioneta da revolução

E procurava com a minha voz por uma certeza ${ }^{19}$.

A (CORO) - A mim, no entanto, os meus semelhantes conduzem agora ao paredão

E eu que entendo isso não o entendo

Por quê? ${ }^{20}$.

Neste particular, devem ser lembradas as razões pelas quais Müller decidiu-se pela retomada do tema de $A$ Decisão. Mauser é uma peça em que ele se interroga justamente sobre a necessidade da violência a serviço da Revolução. Em suas três peças experimentais - Filocteto, O Horaciano e Mauser - investiga a relação, no interior do marxismo, entre humanismo e terror. Mauser, conforme o próprio Müller o diz, é “a práxis do comunismo que Brecht naturalmente não poderia conhecer em 1920, que ele se recusa a considerar durante sua luta contra o nazismo, mas que ele tem de encarar de frente, em 1953, em seu retorno à RDA".

\section{A peça didática brechtiana, uma forma revista por Müller}

A peça didática é um exercício formal cumprido por um Heiner Müller em busca de uma forma adequada para suas peças. Müller escreve Mauser num momento de crise, em que desconfia da reação passiva demais do seu sonhado "novo público", cuja participação ativa durante a experiência do espetáculo era, naqueles anos, sua preocupação maior. Ele queria que este "novo público" se tornasse seu co-autor, conforme declarou no Prólogo de sua peça $O$ Achatador de Salários, assumindo assim a tarefa de encontrar a solução do "conflito entre o Antigo e o Novo que o escritor é

19 MÜLLER, 1987, p. 14.

${ }^{20}$ MÜLLER, 1987, p. 16-17. 
incapaz de resolver”21. Com Mauser, Heiner Müller colocava à prova, em 1970, a prática brechtiana. Segundo Mayer-Schaffer, esta peça, a última "do ciclo de experiências destaca-se igualmente como a primeira de uma outra trilogia”. Primeira etapa de uma recepção ativa, ela terá prosseguimento numa crítica mais veemente, em 1977, com a peça Hamlet-Máquina, que o levará, em 1979, até $A$ Missão, uma peça que se poderia qualificar como mais tipicamente mülleriana.

Por outro lado, não se deve esquecer que, também em 1977, dois anos antes de $A$ Missão, Heiner Müller encenou o Fragment-Fatzer a partir de fragmentos da peça Declínio do egoísta Johann Fatzer, que Brecht começara a escrever nos anos 1929-1930, mas não chegara a concluir. O Fragment-Fatzer contém elementos de toda a obra de Brecht ou, pelo menos, de toda sua utopia e, para Müller, este trabalho significou a realização de uma montagem que se situa num momento decisivo de sua carreira, em que se encontrava diante da alternativa: "desenvolver uma nova dramaturgia ou renunciar à escritura de peças teatrais. Não consigo enxergar outra saída"22. Müller se sentia num impasse provocado pelo "período de estagnação" que reinava em seu país.

Müller, por esta época, perdera para sempre sua crença em peças com um fim e revelara a importância do interesse do fragmentário:

Existe ainda quem escreva peças com uma conclusão. Estas peças me entediam, talvez menos ao público. [...] Mas nesta hora que estamos vivendo, torna-se necessário utilizar este instrumento para fazer o que lhe interessa, sem levar em conta o que possa estar interessando ao público ${ }^{23}$.

Nesta mesma fonte citada, Müller retoma o tema do eterno retorno, ou seja, de que, para um texto ser eficaz, torna-se necessário que se retrabalhe nele algumas situações-modelo do passado. Segundo o dramaturgo, os Nibelungos são um esboço de Fausto; Os Bandoleiros, de Schiller; de A morte de Danton, de Büchner etc. Por este motivo, a fábula do Fragment-Fatzer, a deserção de quatro homens durante a primeira guerra mundial, que acreditam na iminência da revolução que não virá jamais, será citada por Brecht em $A$ peça didática de Baden-Baden sobre o Acordo. E a morte do Jovem Camarada será o ponto de partida de Mauser.

Se o Jovem Camarada destrói sua máscara e os clássicos (“é tudo uma merda”) e se decide a partir logo para a ação ("pois o homem, o homem vivo, urra e sua miséria rompe todos os diques da doutrina”), "A”, por sua vez, em Mauser, não hesitará também em urrar e revelar suas dúvidas com relação às ordens do Partido. Ele se dirá um homem e recusará a condenação à morte que lhe é imposta. São "atos de loucura" de dois personagens que se identificavam com o Partido e a atitude de "A" ganha peso maior na medida em que é descrito como um seguidor incondicional do Partido que conhece o preço da Revolução.

Esses dois personagens, no entanto, chegarão à mesma conclusão de Fatzer:

\footnotetext{
${ }^{21}$ MÜLLER apud MAYER-SCHAFFER, 1992, p. 83.

22 Apud MAIER-SCHAFFER, 1992, p. 128.

${ }^{23}$ MÜLLER, 1987, p. 7.
} 
Para mim a guerra acabou,

volto correndo para casa.

Estou cagando para a ordem do mundo.

Estou perdido.

Curiosamente, a situação é a mesma da peça $A$ verdadeira história de $A b Q$, de Christoph Hein, outro autor contemporâneo alemão, em que Wang e AhQ, dois prisioneiros, estão também esperando por uma revolução iminente que virá, mas que, ironicamente, não os convidará para integrar o novo governo revolucionário.

Fatzer, como o Jovem Camarada, será assassinado por seus companheiros por se tratar de um homem que tem visões, de alguém que luta contra o quotidiano. "Um ser ativo", segundo Dimiter Gotscheff, o diretor búlgaro que, em 1993, montou Fatzer no Schauspiel de Colônia, em quem ele vê uma representação do grande

[...] dilema tragicômico do socialismo. Tudo começou com Maïakovski [Não esqueçamos que Brecht escreve $A$ Decisão em homenagem a Maïakovski] e Babel para atingir, em seguida, engenheiros, médicos, militares. Os indivíduos mais fortes foram massacrados, pois a sociedade não podia suportar que alguém pudesse formular as coisas de forma diferente, pudesse entrever outras soluções, etc. ${ }^{24}$.

Em contrapartida, se Fatzer e o Jovem Camarada são liquidados por suas reações espontâneas, por erros sucessivos atribuídos à sua juventude e inexperiência, que colocarão em perigo outras pessoas, "A" e o personagem de $A$ Missão serão escolhidos, justamente, por deterem uma grande experiência.

\section{CORO}

Você ["A"] lutou na frente da guerra civil

$\mathrm{O}$ inimigo não encontrou fraqueza alguma em você.

Nós não havíamos encontrado fraqueza alguma em você² .

A partir de um texto de janeiro de 1977, Adeus à peça didática, Müller se diz a favor do "derrotismo construtivo" e nega a eficácia da lição. Para ele, o apocalipse de $A$ Decisão teria "caducado, a história devolveu o processo para a rua, mesmo os coros sabidos de cor não cantam mais, o humanismo quando se manifesta é através do terrorismo, o coquetel Molotov é o último acontecimento educativo burguês"26.

Mas, em 1988, Müller retorna curiosamente à peça didática. Escreve $A$ Estrada de Wolokolamsk (em francês, traduzida como La Route des chars [A Estrada dos Tanques]), em que um personagem, o Comandante, obrigado a matar um "traidor", concretiza seu desejo de libertar o condenado num sonho que ele tem, e que consi-

${ }^{24}$ GOTSCHEFF, 1993, p. 28.

25 MÜLLER, 1987, p. 3.

26 MÜLLER, Heiner. Hamlet-machine, Horace-Mauser-Héraclès 5 et autres pièces. Traduits de l'allemand par Jean Jourdeuil et Heinz Schwarzinger. Paris: Les Éditions de Minuit, 1985. p. 68. 
dera um "movimento espontâneo de seu outro eu”.

Em seu uniforme meu outro eu

Queria pedir perdão ao morto,

Desta morte que tinha sido meu trabalho ${ }^{27}$.

\section{Conclusão: para que serve uma peça didática?}

Para Brecht, peças didáticas são aquelas a serem interpretadas

[...] de forma idêntica a alunos numa escola, através de uma elocução voluntariamente marcada, revendo sem cessar as passagens difíceis, para descobrir seus significados ou fixá-los na memória. Não são peças para serem "vistas" pelo público habitual dos teatros - o público burguês - mas autênticos exercícios dramáticos destinados às crianças das escolas, aos membros de grupos de jovens, de grupos leigos, de associações proletárias e principalmente aos corais de trabalhadores.

É para instruir os participantes dessas coletividades que ele propõe suas peças didáticas, "na esperança de que eles possam ser socialmente influenciados pela execução de modos bem precisos de ação" 28 .

Segundo Bernard Dort, em seu ensaio Exercícios didáticos, Bertolt Brecht estava radiante com estes corais operários que chegaram a ter, na Alemanha, meio milhão de participantes, e insistia em que se deveria chamar a atenção para a "forma de atingir o resultado, para sua execução, e não para o resultado deste novo trabalho teatral"29. Tornava-se necessário oferecer a esses corais um novo repertório.

No que se refere à Decisão, por exemplo, Brecht dizia que esta peça nunca deveria ser representada, pois, insistia, "só o intérprete do Jovem Camarada pode aprender com ela alguma coisa e, mesmo assim, se tiver representado também um dos agitadores e tiver cantado no Coro de Controle" 30 .

Quando, em nossos dias, autores contemporâneos do teatro alemão continuam a utilizar este tipo de teatro épico por excelência, centrado na interrupção constante da ação dramática por intérpretes que se perguntam sobre o significado de certas passagens de um texto ou de uma canção, podemos pensar na grande atualidade desta forma didática, longe de estar definitivamente esgotada.

Para Müller, a peça didática é um trabalho entre outros, "organizado pelo coletivo e organizando o coletivo”, cuja representação diante de um público só é possível na medida em que esse público tem a possibilidade de controlar o jogo com respeito ao texto e o texto com respeito ao jogo.

Voltamos, então, a esta preocupação constante do teatro mülleriano, de um teatro em que o público possa chegar a uma participação ativa, de um espetáculo em que o público torna-se ator e em que todos atuam juntos.

\footnotetext{
27 Apud MAYER-SCHAFFER, 1992, p. 115.

${ }_{28}$ BRECHT, Bertolt. Sur la pièce didactique. In: 1972. p. 341.

29 DORT, Bernard. Des exercices didactiques. In: et forme épique. Paris: Seuil, 1960. p.76.

${ }_{30}$ DORT, 1960, p. 351. Écrits sur le théâtre I. Paris: L’Arche, . Lectures de Brecht, suivi de pédagogie
} 
Chegar-se-ia, assim, a uma repartição do texto proposta a partir de um esquema variável.

A exemplo de Brecht, Müller sugeriu uma multiplicidade de variantes possíveis na distribuição de papéis: 1) o coro põe à disposição do protagonista um intérprete do protagonista (A1);2) Todos os membros do coro, sucessiva ou simultaneamente, atuam como protagonista; 3 ) o protagonista fica encarregado de algumas partes corais, enquanto A1 o representa.

O jogo, consistindo, principalmente, em tornar possível a todos os membros do grupo uma transmissão coletiva das várias experiências.

Para transformar uma sociedade, é preciso compreendê-la em sua unicidade e, ao mesmo tempo, em seu movimento, o que permitirá "analisar esta sociedade [...] como o produto instável de situações individuais e de condições objetivas" ${ }^{31}$.

A comparação entre os dois textos revelou-nos um fenômeno que nos interessa particularmente: a conexão vital entre um texto que cita e um texto que se descobre citado. O prazer de descobrir em Müller o eco longínquo de idéias sugeridas originariamente por Brecht, a emoção de descobrir no discípulo a possibilidade de fazer reviver, em textos novos, uma intenção oculta, não explícita do texto anterior.

$\mathrm{Da}$ ascese religiosa do Jovem Camarada às dúvidas de "A", em suas dificuldades individuais para estar de acordo, podemos ouvir, enquanto leitores, um grito de vida que passa de um indivíduo ao outro. E foi este grito de vida que nos contaminou a todos, professor e alunos (atores e espectadores), nas apresentações de nossas leituras das duas peças didáticas alemãs.

${ }^{31}$ DORT, 1960, p. 91. 


\section{REFERÊNCIAS}

BAUDELAIRE, Charles. O convite à viagem. In: Pequenos poemas em prosa. Tradução de Aurélio Buarque de Hollanda. Rio de Janeiro: J. Olympio, 1950. (Coleção Rubáiyat).

BETZ, Albrecht et al. L'état d'urgence chez Carl Schmitt et La décision chez Bertolt Brecht. In: STORCH, Wolfgang (Dir.). Brecht après la chute. Confessions, mémoires, analyses. Paris: L'Arche, 1993.

BRECHT, Bertolt. A decisão (1929-1930). In: . Teatro completo. Tradução de Ingrid

Dormien Koudela. Rio de Janeiro: Paz e Terra, 1988. v. 3.

BRECHT, Bertolt. Pequeno organon para o teatro (fragmento 75). In: Estudos sobre teatro. Tradução de Fiama Pais Brandão. Rio de Janeiro: Nova Fronteira, 1978.

BRECHT, Bertolt. Sur la pièce didactique. In: .Écrits sur le théâtre I. Paris: L’Arche, 1972.

CAILLOIS, Roger. Les jeux et les hommes. Paris: Gallimard, 1967.

DORT, Bernard. Des exercices didactiques. In: Lectures de Brecht, suivi de pédagogie et forme épique. Paris: Seuil, 1960.

GOETHE. Les années d'apprentissage de Wilhelm Meister. Traduit de l'allemand par Jeanne Ancelet-Hustache. Paris: Aubier-Montaigne, 1983.

GOTSCHEFF, Dimiter. Nous maintiendrons le virus en vie. In: Brectht après la chute: confessions, mémoires, analyses. Paris: L'Arche, 1993.

HECHT, Werner. Devant la commission d'enquête sur les activités antiaméricaines. Entretiens avec Brecht. Traduit de l'allemand par François Mathieu. Paris: Éditions Messidor, 1988.

HENRIOT, Jacques. Le jeu. Paris: Synonyme, 1983.

JANKÉLÉVITCH, Vladimir. L'aventure, l'ennui, le sérieux. Paris: Aubier-Montaigne, 1963.

MAIER-SCHAFFER, F. Heiner Müller et la Lebrstück. Berne: P. Lang, 1992.

MÜLLER, Heiner. Hamlet-machine, Horace-Mauser-Héraclès 5 et autres pièces. Traduits de l'allemand par Jean Jourdeuil et Heinz Schwarzinger. Paris: Les Éditions de Minuit, 1985.

MÜLLER, Heiner. Quatro textos para teatro: Mauser, Hamlet-máquina, a missão, quarteto. Apresentação de Fernando Peixoto. São Paulo: Editora Hucitec: Associação Cultural Bertolt Brecht, 1987. 


\section{SOBRE OS AUTORES}

AdiLSON FlORENTINO, professor, pesquisador, mestre em Educação (1992) pela UERJ, doutor em Teatro (2006) pela UNIRIO. É professor no Departamento de Interpretação Teatral da Escola de Teatro e do Programa de Pós-Graduação em Artes Cênicas da Universidade Federal do Estado do Rio de Janeiro - UNIRIO.

Antonia Pereira, dramaturga, diretora teatral, pesquisadora, mestre (1995) e doutora em Letras Modernas (1999) pela Universidade de Toulouse II. É professora no Departamento de Artes Cênicas e no Programa de Pós-graduação em Artes Cênicas, na Universidade Federal da Bahia - UFBA.

Arão Paranaguá de Santana, professor, pesquisador, mestre em Educação pela UnB (1983), doutor em Artes (1999) pela ECA-USP. É professor do Departamento de Artes da Universidade Federal do Maranhão. Líder de grupo de pesquisa Ensino do Teatro \& Pedagogia Teatral (UFMA-CNPq). Autor do livro Teatro $e$ formação de professores (EDUFMA, 2000) e coordenador do livro Visões da ilhaapontamentos sobre teatro e educação (UFMA, 2003).

Beatriz Cabral (Biange), diretora teatral, mestre em Artes (1984) pela ECA-USP, doutora em Teatro (1994) pela University of Central England. É professora no Departamento de Artes Cênicas e no Programa de Pós-graduação em Teatro, na Universidade do Estado de Santa Catarina - UDESC. Autora do livro O drama como método (Hucitec, 2006) e organizadora do livro Ensino do Teatro: experiências interculturais (CAPES/UFSC, 1999).

Carmela SoARes, professora, atriz, mestre em Teatro (2003) pela UNIRIO. É professora no Departamento de Interpretação Teatral da Escola de Teatro da Universidade Federal do Estado do Rio de Janeiro - UNIRIO onde atua na licenciatura.

EleONORA FABIÃo, atriz, performer, mestre em História da Cultura pela PUC-Rio (1997), doutora em Estudos da Performance pela New York University (2006). É professora do Curso de Direção Teatral da Escola de Comunicação da Universidade Federal do Rio de Janeiro (UFRJ).

EIZA DE ANDRADE, diretora teatral, mestre (1996) e doutora em Teatro (2005) pela UNIRIO. É professora no Departamento de Interpretação e no Programa de Pós-graduação em Artes Cênicas, na Universidade Federal do Estado do Rio de Janeiro - UNIRIO.

Flavio Desgranges, diretor teatral, professor, mestre em Educação pela UFF (1995) e doutor em Educação (2001) pela USP. É professor no Departamento de Artes Cênicas e no Programa de Pós-Graduação em Artes Cênicas da ECA-USP. Autor dos livros Pedagogia do Espectador (Hucitec, 2003) e a Pedagogia do Teatro: provocação e dialogismo (Hucitec, 2006). 
GiLBERTO ICLE, ator, mestre (2000) e doutor (2004) em Educação pela UFRGS. É professor no Departamento de Ensino e Currículo, da Faculdade de Educação da UFRGS. É diretor do Núcleo de Investigação Usina do Trabalho do Ator, em Porto Alegre, e autor de diversos artigos no Brasil e exterior, além dos livros Teatro e construção de conhecimento (Mercado Aberto, 2003) e O ator como xamã (Perspectiva, 2006).

GiLson MotTA, cenógrafo, pesquisador, mestre (1995) e doutor (2000) em Filosofia pela UFRJ. É professor no Departamento de Artes da Universidade Federal de Ouro Preto.

INGRID DORMIEN KoUdELA, diretora teatral, professora, pesquisadora, mestre (1983) e doutora (1988) e livre-docente (1997) em Artes pela ECA-USP. É professora colaboradora no Programa de Pós-Graduação em Artes Cênicas da ECA-USP. Autora dos seguintes livros, entre outros, Jogos Teatrais (Perspectiva, 1990), Brecht: um jogo de aprendizagem (Perspectiva, 1991) e Brecht na pós-modernidade (Perspectiva, 2001).

JosÉ DA CosTA, diretor teatral, pesquisador, mestre em Teatro pela UNIRIO (1997), doutor em Literatura Comparada (2003) pela UERJ. É professor no Departamento de Teoria do Teatro e no Programa de Pós-graduação em Artes Cênicas, na Universidade Federal do Estado do Rio de Janeiro - UNIRIO.

José Luiz Ribeiro, ator, diretor de teatro, mestre em Teatro pela UNIRIO (1992), doutor em Comunicação e Cultura pela UFRJ (2001). É professor do Departamento de Comunicação e Artes da Universidade Federal de Juiz de Fora (UFJF).

José ToNEZZI, ator, professor, mestre em Educação pela UNICAMP (2003), doutor em Teatro pela UNIRIO (2008). É professor do Departamento de Artes da Universidade Federal da Paraíba (UFPB). Autor do livro Distúrbios de linguagem e teatro: o afásico em cena (Plexus, 2007).

Lucia Helena de Freitas (Gyata), professora, mestre em Educação pela UERJ (1995), doutora em Teatro pela UNIRIO (2005). É professora no Departamento de Interpretação Teatral da Escola de Teatro da Universidade Federal do Estado do Rio de Janeiro - UNIRIO onde atua na licenciatura.

Luiz Humberto Martins Arantes, historiador, dramaturgista, mestre (1999) e doutor (2003) em História da Cultura pela PUC-SP. É professor no Departamento de Música e Artes Cênicas e do Programa de Pós-Graduação em Artes, na Universidade Federal de Uberlândia - UFU. Autor do livro O teatro da memória: história e ficção na dramaturgia de Jorge Andrade (Annablume/FAPESP, 2001) e organizador do livro Perspectivas Teatrais (EDUFU, 2005). 
Marcia Pompeo Nogueira, professora, mestre em Artes (1993) pela ECA/USP, doutora em Teatro na Universidade de Exeter, Inglaterra (2002). É professora no Departamento de Artes Cênicas e no Programa de Pós-graduação em Teatro, na Universidade do Estado de Santa Catarina - UDESC - onde atua, tanto na graduação como no mestrado, na área do Teatro para o Desenvolvimento de Comunidades. Coordenou o Grupo de Trabalho nesta área nos dois últimos Congressos da Associação Internacional de Drama e Teatro na Educação - IDEA. Autora do livro Teatro com meninos e meninas de rua (Perspectiva, 2008).

Maria Beatriz Mendonça (Bya Braga), atriz e diretora cênica, mestre em Estudos Literários pela UFMG (1995), doutoranda em Teatro pela UNIRIO. É professora no Departamento de Fotografia, Cinema e Teatro da Escola de Belas Artes, na Universidade Federal de Minas Gerais - UFMG. Coordenadora artística do GRUPA (Grupo de Pesquisa-prática em atuação) na UFMG. Coordenadora Adjunta do FIT-BH 2004.

Maria Lucia Souza de Barros Pupo, professora, pesquisadora, mestre em Artes pela ECA-USP (1981), doutora em Teatro pela Universidade de Paris III (1985), pós-doutora pela Escola Normal Superior de Paris-França (1996). É professora no Departamento de Artes Cênicas e Mariana Oliveira, atriz, professora, mestre em Teatro pela UNIRIO (2006). É professora de Teatro do Colégio de Aplicação da Universidade do Estado do Rio de Janeiro - UERJ.

Mona Magalhã ES, atriz, caracterizadora, mestre em Ciência da Arte (2004) pela UFF, doutoranda em Letras - Semiótica Plástica pela UFF. Especialista pela Los Angeles School of Make-Up. É professora no Departamento de Interpretação da Escola de Teatro na UNIRIO. Caracterizadora do Grupo Galpão.

NARA KeISERMAn, preparadora corporal, atriz, diretora teatral, mestre em Artes pela ECA-USP (1986), doutora em Teatro pela UNIRIO (2004). É professora no Departamento de Interpretação e no Programa de Pós-graduação em Artes Cênicas, na Universidade Federal do Estado do Rio de Janeiro - UNIRIO.

Narciso Telles, ator, professor e diretor, mestre (1999) e doutor (2007) em Teatro pela UNIRIO. É professor no Departamento de Música e Artes Cênicas e do Programa de Pós-graduação em Artes, na Universidade Federal de Uberlândia - UFU. Autor do livro Pedagogia do teatro e o teatro de rua (Mediação, 2008) e organizador dos livros Teatro: ensino, teoria e prática (EDUFU, 2004) e Teatro de Rua: olhares e perspectivas (E-PAPERS, 2005).

Renan Tavares, professor, mestre em Comunicação e Cultura (1980) pela ECO-UFRJ, doutor (1985) e pós-doutor (1997) em Teatro pela Universidade de Paris III. É professor na Escola de Enfermagem e no Programa de Pós-graduação, Mestrado em Enfermagem, na Universidade Federal do Estado do Rio de Janeiro - UNIRIO. Autor do livro Teatro Oficina de São Paulo: seus 10 primeiros anos (Yendis, 2006) e organizador do livro Entre Coxias e recreios - recortes da produção carioca sobre ensino do teatro (Yendis, 2006). 
RICARDO JAPIASSU, professor, pesquisador, mestre em Artes pela ECA-USP (1999) e doutor em Educação pela USP (2003). É professor do Departamento de Educação da Universidade do Estado da Bahia, em Valença. Autor dos livros Metodologia do Ensino de Teatro (Papirus, 2005) e A linguagem teatral na escola ( Papirus, 2007).

SARA LOPES, preparadora vocal, diretora de cena de óperas e musicais, mestre em Artes pela UNICAMP (1993), doutora em Artes pela ECA-USP (1997). É professora no Instituto de Artes e no Programa de Pós-Graduação em Artes da UNICAMP.

Valmor Níni Beltrame, bonequeiro, diretor teatral, mestre (1995) e doutor em Artes (2001) pela ECA-USP. É professor no Departamento de Artes Cênicas e no Programa de Pós-graduação em Teatro, na Universidade do Estado de Santa Catarina - UDESC. Pesquisa distintas formas de teatro de animação.

Vilma Campos dos Santos Leite, diretora teatral, atriz e professora, mestre em Artes (2003) pela ECA-USP e doutoranda no Programa de Pós-Graduação em História da UFU. É professora no Departamento de Música e Artes Cênicas, na Universidade Federal de Uberlândia - UFU.

Walder Gervasio Virgulino de Souza, professor, pesquisador, mestre em Letras pela UFRJ (1992), mestre (1995) e doutor (2002) em Teatro pela Universidade de Paris III. É professor no Departamento de Teoria do Teatro e no Programa de Pós-graduação em Artes Cênicas, na Universidade Federal do Estado do Rio de Janeiro - UNIRIO. 
Sobre o livro

$\begin{array}{cl}\text { Formato } & 18,5 \mathrm{~cm} \times 28,5 \mathrm{~cm} \\ \text { Tipologia } & \text { Times New Roman }\end{array}$

LV Imprensa Universitária/Gráfica UFU 